Florida International University FIU Digital Commons

$8-27-1998$

\title{
Sorption measurements and behavior of monosodium methanearsonate and arsenic $(+5)$ in aqueous suspensions of floridian soil fractions
}

George William Di Carlo

Florida International University

DOI: $10.25148 /$ etd.FI14062267

Follow this and additional works at: https://digitalcommons.fiu.edu/etd

Part of the Environmental Engineering Commons

\section{Recommended Citation}

Di Carlo, George William, "Sorption measurements and behavior of monosodium methanearsonate and arsenic $(+5)$ in aqueous suspensions of floridian soil fractions" (1998). FIU Electronic Theses and Dissertations. 2797.

https://digitalcommons.fiu.edu/etd/2797 
FLORIDA INTERNATIONAL UNIVERSITY

Miami, Florida

SORPTION MEASUREMENTS AND BEHAVIOR OF MONOSODIUM

METHANEARSONATE AND ARSENIC (+5) IN AQUEOUS SUSPENSIONS OF

FLORIDIAN SOIL FRACTIONS

A thesis submitted in partial fulfillment of the

requirements for the degree of

MASTER OF SCIENCE

in

ENVIRONMENTAL ENGINEERING

by

George William Di Carlo

1999 
To: Dean Gordon R. Hopkins

College of Engineering

This thesis, written by George Di Carlo, and entitled Sorption Measurements and Behavior of Monosodium Methanearsonate and Arsenic $(+5)$ in Aqueous Suspensions of Floridian Soil Fractions, having been approved in respect to style and intellectual content, is referred to you for judgement.

We have read this thesis and recommend that it be approved.

Yong Cai

Walter Z. Tang

Héctor R. Fuentes, Major Professor

Date of Defense: August 27, 1998

The thesis of George Di Carlo is approved.

Dean Gordon R. Hopkins College of Engineering

Dean Richard L. Campbell Division of Graduate Studies

Florida International University, 1999 


\section{DEDICATION}

I would like to dedicate this thesis to my mother, Georgia Belle Di Carlo, and my father, John Joseph Di Carlo. After my mother lost her battle with lung cancer, my father was faced with raising a 12 year-old by himself. I cannot begin to understand what he went through. By dedicating this work to my parents, I hope that I can show just how much I appreciate all their hard work, love, and support. 


\section{ACKNOWLEDGMENTS}

I would like to express my deepest thanks to Dr. Héctor R. Fuentes for his unparalleled guidance and support during my graduate studies and the completion of this thesis. Dr. Fuentes provided me the unique opportunity to work on a subject that holds great potential for further research important to the quality of Florida's environment.

I would like to thank Dr. Rudolf Jaffe for his guidance with my thesis and vast support for all chemical analysis in conjunction with the Southeast Environmental Research Program.

I would also like to thank Dr. Yong Cai for his guidance with my thesis and his much-needed assistance with the use of the equipment in his laboratory. I would like to thank Dr. Walter Tang for always making time to assist me with this thesis.

Funding was provided by Dr. H. R. Fuentes under an EPA sponsorship grant and is greatly appreciated, as this project would not have been possible without financial support.

I would like to thank Dr. Jackson Ellington from the U.S. EPA Ecosystems Research Division, Process Modeling Branch in Athens, Georgia, for his support and guidance as my mentor during my internship in the summer of 1997; Mr. Carlos Riverode Aguilar, Director - Florida Department of Environmental Protection (FDEP) Southeast District (SED); Ms. Melissa Meeker FDEP-SED; and Ms. Leslie Smith, point of contact on collaborative research activities from FDEP.

In addition, I would like to thank my family and Christy Combs for their patience, love, and motivation to do my best. 


\title{
ABSTRACT OF THE THESIS \\ SORPTION MEASUREMENTS AND BEHAVIOR OF MONOSODIUM \\ METHANEARSONATE AND ARSENIC (+5) IN AQUEOUS SUSPENSIONS OF \\ FLORIDIAN SOIL FRACTIONS
}

by

\section{George William Di Carlo}

Florida International University, 1999

\author{
Miami, Florida \\ Professor Héctor R. Fuentes, Major Professor
}

Adsorption experiments using both monosodium methanearsonate (MSMA) and its inorganic degradation by-product species $\mathrm{As}(+5)$, as sodium arsenate $\mathrm{Na}_{2} \mathrm{AsO}_{4}$, were conducted to evaluate the sorptivity of these constituents to various fractions of soil samples taken from the West Palm Beach Country Club. Adsorption data were analyzed with common isotherm equations (i.e., Linear, Freundlich, Langmuir) to determine $\mathrm{K}_{\mathrm{d}}$ for each arsenic (As) species/soil fraction. Simulations using a one-dimensional pesticide transport model, PRZM 2.0, were completed to evaluate possible dissolved concentrations of arsenic at the water table interface under 8 different application scenarios for the soil profile found at the sample site.

All contaminant/soil systems displayed a linear sorptivity relationship ( $\mathrm{R}^{2}$ ranging from 0.8262 to 0.9779 ) with $\mathrm{K}_{\mathrm{d}}$ values (units of $\mathrm{L} / \mathrm{g}$ ) ranging from 0.0102 to 0.2295 . Results also indicate $\mathrm{As}(+5)$ had a higher affinity for the soil fractions than MSMA. PRZM-2.0 predicted concentrations of dissolved arsenic at the water table interface from 0.04 to $1018 \mathrm{ppb}$ within 1 month from only 1 application. Florida's MCL for dissolved as in groundwaters is $50 \mathrm{ppb}$.

It is recommended that the registration and use of MSMA be re-evaluated as it may impact ground water quality at golf courses or other sandy aquifer systems. 


\section{TABLE OF CONTENTS}

CHAPTER

PAGE

1.0 INTRODUCTION

1

1.1 Background 2

1.2 Objective 3

2.0 LITERATURE REVIEW 4

2.1 Adsorption 4

2.1.1 Adsorption Mechanisms 5

2.1.2 Adsorption Models and Mathematics 6

2.1.2.1 Langmuir $\quad 6$

$\begin{array}{ll}\text { 2.1.2.2 Freundlich } & 8\end{array}$

2.2 Arsenic Chemistry 9

$\begin{array}{ll}\text { 2.2.1 Organoarsenical Herbicides } & 10\end{array}$

$\begin{array}{ll}\text { 2.2.1.1 MSMA } & 10\end{array}$

$\begin{array}{ll}\text { 2.2.2 Inorganic Arsenate } & 12\end{array}$

$\begin{array}{lll}2.3 & \text { PRZM-2.0 } & 17\end{array}$

$\begin{array}{lll}2.3 .1 & \text { Theory } & 20\end{array}$

$\begin{array}{ll}\text { 2.3.2 } & \text { Limitations } \\ & 22\end{array}$

$\begin{array}{lll}2.3 .3 & \text { Algorithms } & 24\end{array}$

$\begin{array}{lll}3.0 & \text { METHODS } & 28\end{array}$

$\begin{array}{lll}3.1 & \text { Equipment } 28\end{array}$

$\begin{array}{lll}3.2 & \text { Materials } & 29\end{array}$ 
$\begin{array}{lll}3.3 & \text { Preliminary Work } & 30\end{array}$

$\begin{array}{lll}3.3 .1 & \text { Kinetics } & 30\end{array}$

3.3.2 Atomic Adsorption Analysis 34

3.4 Experimental Protocol 34

$\begin{array}{lll}\text { 3.4.1 Sampling } & 34\end{array}$

$\begin{array}{lll}3.4 .2 & \text { Soil Sieving } & 36\end{array}$

$\begin{array}{lll}\text { 3.4.3 Soil Characterization } & 37\end{array}$

$\begin{array}{ll}\text { 3.4.4 Standards and Solutions } & 37\end{array}$

$\begin{array}{ll}3.4 .5 & \text { Adsorption }\end{array}$

$\begin{array}{lll}3.4 .6 & \text { Modeling } & 40\end{array}$

3.4.6.1 Soil Parameters $\quad 43$

3.4.6.2 Hydrology Parameters $\quad 44$

3.4.6.3 Chemical Parameters $\quad 45$

$\begin{array}{lll}3.5 & \mathrm{QA} / \mathrm{QC} & 48\end{array}$

3.5.1 Sampling, Storage, and Documentation $\quad 48$

3.5.2 General Experimentation $\quad 49$

3.5.3 Statistical Data Analysis $\quad 49$

$\begin{array}{lll}3.5 .4 & \text { Replicability } & 51\end{array}$

3.6 Experimental Design $\quad 55$

$\begin{array}{lll}4.0 & \text { RESULTS AND DISCUSSION } & 60\end{array}$

$\begin{array}{lll}4.1 & \text { Experiments } 1 \text { and } 5 & 60\end{array}$

4.2 Experiments 2 and $3 \quad 64$ 
$4.3 \quad$ Experiments 4

$\begin{array}{lll}4.4 & \text { Computer Simulations } & 81\end{array}$

$\begin{array}{ll}\text { 4.4.1 Predictions } & 82\end{array}$

$\begin{array}{lll}4.5 & \text { Limitations } & 102\end{array}$

5.0 CONCLUSIONS AND RECOMMENDATIONS 104

$\begin{array}{lll}5.1 \text { Conclusions } & 104\end{array}$

$\begin{array}{lll}5.2 & \text { Recommendations } & 105\end{array}$

$\begin{array}{ll}\text { LIST OF REFERENCES } & 106\end{array}$

$\begin{array}{ll}\text { APPENDICES } & 112\end{array}$ 


\section{LIST OF TABLES}

TABLE

PAGE

1 Known Physical, Chemical, and Toxicological Properties MSMA

$2 \quad \mathrm{pH}$ Based Equilibria of Arsenic Acid and Arsenious

Acid

3 Replicability and Recovery of As(+3) Atomic Adsorption Standard and MSMA

$4 \quad$ Experimental Matrix Table

57

$5 \quad$ Matrix of Modeling Scenarios

6 Summary of Vital Soil Characteristics

63

7 Summary of $\mathrm{K}_{\mathrm{d}}$ Values for Each Isotherm Type, As $(+5)$

66

8 Summary of $K_{d}$ Values for Each Isotherm Type, MSMA

75

9 Q-Test Applied to $\mathrm{pH}$ of Equilibrated As(+5) Samples

10 Q-Test Applied to $\mathrm{pH}$ of Equilibrated As(+5) Samples and Standards

11 Q-Test Applied to $\mathrm{pH}$ of Equilibrated MSMA Samples and Standards

12 Q-Test Applied to $\mathrm{pH}$ of Equilibrated MSMA Samples

13 Analysis for Control Soil Blanks and Control DD-Water Blanks

14 Q-Test Applied to Total Organic Carbon Data

15 Comparison of FDEP versus FIU Analysis, Kinetics Data

16 Comparison of FDEP versus FIU Analysis, Experiment 2

17 Q-Test Applied to Sieve Data 
19 Q-Test Applied to Equilibrium Concentrations from All As $(+5)$ Experiments

20 Mass of As(+5) Adsorbed to Each Soil at Each Initial Concentrations

21 Q-Test Applied to MSMA Equilibrium Concentrations

22 Tabulated Predictions, Concentration versus Time for Scenarios 1, 2 and 3 (Comparing varying $D$ values)

23 Tabulated Predictions, Concentration versus Time for Scenarios 4 and 5 (Comparing varying $\mathrm{K}_{\mathrm{d}}$ values)

24 Tabulated Predictions, Concentration versus Time for Scenarios 2, 6, 7, and 8 (Comparing Varying Irrigation)

25 Tabulated Predictions, Concentration versus Time for Fractional Dissolved MSMA, As(+5), and Total Dissolved As at Groundwater Interface After One Application of MSMA 


\section{LIST OF FIGURES}

FIGURE

PAGE

1 Formulae of Organic Arsenical Herbicides

2 Transformational Pathways for MSMA in the Natural

Environment

3 Eh-pH Diagram for the As- $\mathrm{H}_{2} 0$ System

4 Physicochemical Parameters Modeled by PRZM-2.0

5 Illustration of Chemical Movement and Transformations

6 Plot of Equilibrium Concentrations vs. Time, Soil 1

Kinetics Experiments No. 1

7 Plot of Control minus Equilibrium Concentration vs. Time, Soil 1,2, and 5 from Kinetics Experiments No. 2

8 A Hyetograph for the Year 1990

9 Differences of Corrected FIU Arsenic Analysis from FDEP Arsenic Analysis on Initial Kinetics Experiments

10 Observed Concentrations of FIU Standards by FDEP Analysis

11 Percentage of Particle Sizes for all 5 Soils 62

$12 \quad$ As $(+5)$ Adsorption to all 5 Soils $\quad 65$

13 Langmuir Isotherm for the As(+5), Soil 1 System 68

14 Linear Isotherm for the As(+5), Soil 2 System 69

15 Langmuir Isotherm for the As(+5), Soil 3 System 70

16 Langmuir Isotherm for the As(+5), Soil 4 System 71

17 Linear Isotherm for the As(+5), Soil 5 System 72 
19 Langmuir Isotherm for the MSMA, Soil 1 System 76

20 Langmuir Isotherm for the MSMA, Soil 2 System 77

21 Linear Isotherm for the MSMA, Soil 3 System 78

22 Linear Isotherm for the MSMA, Soil 4 System 79

23 Langmuir Isotherm for the MSMA, Soil 5 System 80

24 Plot of Concentration versus Time for Scenario 1 83

25 Plot of MSMA and As(+5) as a Fraction of Total As versus Time, Scenario 1

26 Plot of Concentration versus Time for Scenario 2

27 Plot of MSMA and As( +5$)$ as a Fraction of Total As versus Time, Scenario 2

28 Plot of Concentration versus Time for Scenario 3

29 Plot of MSMA and As( +5$)$ as a Fraction of Total As versus Time, Scenario 3

30 Plot of Concentration versus Time for Scenario 4

31 Plot of MSMA and As( +5$)$ as a Fraction of Total As versus Time, Scenario 4

32 Plot of Concentration versus Time for Scenario 5

33 Plot of MSMA and As( +5$)$ as a Fraction of Total As versus Time, Scenario 5

34 Plot of Concentration versus Time for Scenario 6

35 Plot of MSMA and As(+5) as a Fraction of Total As versus Time, Scenario 6 
37 Plot of MSMA and As $(+5)$ as a Fraction of Total As versus Time, Scenario 7

38 Plot of Concentration versus Time for Scenario 8

39 Plot of MSMA and As( $(+5)$ as a Fraction of Total As versus Time, Scenario 8

$40 \quad$ Plot of $\mathrm{pH}$ versus Equilibrium Concentrations of $\mathrm{As}(+5)$ Adsorption Experiments

41 Plot of $\mathrm{pH}$ versus Equilibrium Concentrations of MSMA Adsorption Experiments

42 Linear Isotherm for the MSMA, Soil 1 System

43 Linear Isotherm for the MSMA, Soil 2 System 116

44 Langmuir Isotherm for the MSMA, Soil 3 System 117

45 Langmuir Isotherm for the MSMA, Soil 4 System 118

46 Linear Isotherm for the MSMA, Soil 5 System 119

47 Linear Isotherm for the As(+5), Soil 1 System 120

48 Langmuir Isotherm for the As(+5), Soil 2 System 121

49 Linear Isotherm for the As $(+5)$, Soil 3 System 122

50 Linear Isotherm for the As(+5), Soil 4 System 123

51 Langmuir Isotherm for the As(+5), Soil 5 System 124

52 Freundlich Isotherm for the MSMA, Soil 1 System 125

53 Freundlich Isotherm for the MSMA, Soil 2 System 126

54 Freundlich Isotherm for the MSMA, Soil 3 System 127

$55 \quad$ Freundlich Isotherm for the MSMA, Soil 4 System 128 
56 Freundlich Isotherm for the MSMA, Soil 5 System

57 Freundlich Isotherm for the As(+5), Soil 1 System

58 Freundlich Isotherm for the As $(+5)$, Soil 2 System

59 Freundlich Isotherm for the As(+5), Soil 3 System

132

60 Freundlich Isotherm for the As(+5), Soil 4 System

133

61 Freundlich Isotherm for the As(+5), Soil 5 System

134

62 Differences of Corrected FIU Arsenic Analysis from FDEP Arsenic Analysis on As(+5) Experiment 2

63 Observed Concentrations of $2^{\text {nd }}$ FIU Standards by FDEP Analysis

64 Hyetograph and Input Scheme of MSMA, Water Year 1988

65 Hyetograph and Input Scheme of MSMA, Water Year 1989

66 Hyetograph and Input Scheme of MSMA, Water Year 1991

139

67 Hyetograph and Input Scheme of MSMA, Water Year 1992

68 Hyetograph and Input Scheme of MSMA, Water Year 1993

69 Plot of MSMA and As (+5) as a Fraction of Total As versus Time After 1 Application of MSMA

70 Plot of Total As versus Time after 1 Application of MSMA

71 Graphical Representation of $154 \mathrm{~cm}$ Modeled Soil Core 


\subsection{INTRODUCTION}

The application of herbicides to turf grass is common at golf courses throughout the United States. Most golf courses follow an Integrated Pest Management (IPM) program - a multidisciplinary, ecologically-based pest management system that uses all available methods to keep pests at acceptable levels while minimizing effects on people, the environment, and turf (Bruneau et al., 1995). Thus, the IPM program is a method that reduces reliance on herbicides and pesticides in an effort to manage golf course water quality. However, IPM programs must be tailored to accommodate each unique environmental condition and circumstance. Effective IPM programs established in one geographical area may not be environmentally acceptable in others.

The state of Florida regulates herbicide usage through the Department of Agriculture \& Consumer Services (FDACS) by establishing a Ranking Index (RI) to evaluate every new herbicide. The RI is part of the Florida Pesticide Registration Guideline. Some herbicides registered before FDACS' use of the RI are still in the process of being re-evaluated with the RI. The RI is an indicator of the active ingredient's (ai) leaching potential and is calculated using the following chemodynamic parameters: vapor pressure, molecular weight, temperature $(\mathrm{K})$, solubility, Henry's constant, partition coefficient, and degradation half-life in soils. These values are entered into a computer program using a reference Tavares soil, 10 meters $(\mathrm{m})$ depth to ground water table, and 28 centimeters $(\mathrm{cm})$ recharge rate. If the RI value is calculated above 499 , then the department may decide to grant full registration of the active ingredient. If the RI is 499 or below, the department requires the registrant to submit additional information for further evaluation of the active ingredient. In the case of the organic arsenical herbicide monosodium methanearsonate (MSMA), FDACS has 
estimated a RI of 935.02 and granted registration without additional restrictions other than those stated on the label. MSMA is primarily used at golf courses for the post-emergence control of grassy weeds and is typically sprayed onto turf grasses and various agricultural crops spatially at $0.5-2.2 \mathrm{~kg}$ ai/hectare (ha).

The Florida Department of Environmental Protection has initiated a study on arsenic and its occurrence in the Biscayne aquifer as a result of organic arsenical herbicide use at golf courses. The state of Florida limits the concentration of As in groundwaters at $50 \mu \mathrm{g} / \mathrm{L}$ (Florida Statutes, FAC, 62-550). Recent characterizations undergone in Dade County, Florida, found dissolved arsenic concentrations up to $12 \mathrm{mg} / \mathrm{L}$ in the groundwater at certain golf courses (Buckner et al., 1997). This high arsenic concentration is believed to be attributed to the following:

- South Florida has a very porous subsurface environment consisting mostly of sands and limestone;

- The average depth to the ground water table is approximately less than $10 \mathrm{feet}$; and

- MSMA is a highly soluble herbicide (104 g/100 mL) (Farm Chemicals Handbook 1997).

\subsection{Background}

The phenomenon of pollutant fixation (i.e., MSMA) from solution onto soil particles is a direct function of the pollutant's affinity towards the soil fraction (Valsaraj et al., 1995). As one of the many factors that control pollutant fate and transport, sorption (i.e., adsorption and/or sorption) is a measure of this affinity for the solid phase. Pollutant sorption 
characteristics, vital to predicting fate and transport, can be expressed by the variable $\mathrm{K}_{\mathrm{d}}$. This study focuses on the $K_{d}$ of MSMA to soil fractions found at golf courses and uses a one-dimensional solute transport code to estimate dissolved As levels at the vadose zone/water table interface.

\subsection{Objectives}

The main objective of this work is to:

- $\quad$ Experimentally determine the $\mathrm{K}_{\mathrm{d}}$ values of both MSMA and its expected predominant inorganic by-product, arsenate $(\mathrm{As}(+5))$, to Floridian soil fractions sampled from the West Palm Beach Country Club (WPBCC).

A secondary objective is to also:

- Illustrate the potential impact that MSMA usage on drinking water aquifers in southern Florida, using a simple analytical water model to estimate dissolved concentrations at the vadose zone/water table interface. 


\subsection{LITERATURE REVIEW}

Extensive literature searches were conducted on the adsorption of chemicals to soils and sediments, one-dimensional analytical pesticide transport codes, arsenical herbicides, and environmental arsenic chemistry. Adsorption mechanisms, mathematics, in addition to environmental arsenic chemistry are important components of this study and emphasized in this review.

\subsection{Adsorption}

In the unsaturated zone, soil and sediments can be generally characterized by a solid phase composed mainly of mineral matter, organic macromolecules (i.e., humic and fulvic acids) attached to the minerals, and sedimentary porewater. Minerals typically consist of oxides of $\mathrm{Al}, \mathrm{Si}, \mathrm{Fe}$, and other metals (Valsaraj, 1995). In southern Florida, especially in engineered strata found at golf courses, sand is the predominant fraction with less than $1 \%$ attributed to total organic matter. The various components of a soil column can accumulate contaminants which are controlled mainly by the contaminants' affinity for the physical/chemical makeup of the sediments. Valsaraj (1995) confirms that the most important process involving the fate and transport of organics and metal ion species in the subsurface is the process called sorption. Sorption can include both the adsorption to the surface of a solid (chemical) or absorption within the solid (Pignattelo et al., 1996) through molecular diffusion into micro pores or cavities (physical).

Sediments such as sands can accumulate coatings of dissolved organic matter or $\mathrm{Fe}$ and $\mathrm{Al}$ oxides which greatly enhance the sorptive capacities of an otherwise relatively inert component (Lindsay, 1979; Valsaraj, 1995). These "enhanced" sands will establish 
sorptive equilibria with any organic or inorganic contaminant which are controlled by various diffusion rates through the macro and micropores. However, diffusion into the sand particle itself is not expected to be a major influential factor.

\subsubsection{Adsorption Mechanisms}

Stumm et al. (1987) states that adsorption of a contaminant to a soil or sediment fraction occurs through various mechanisms. Each mechanism operates independently of each other and the energy involved can be quantified by:

$$
\Delta \mathrm{G}_{\mathrm{ads}}=\sum_{\mathrm{T}} \Delta \mathrm{G}_{\mathrm{I}}
$$

Where $\Delta \mathrm{G}_{\mathrm{I}}$ is the energy associated with each mechanism. Valsaraj (1995) categorizes the various mechanisms:

(i) interactions with the electrical double layer,

(ii) ion exchange including protonation followed by ion exchange,

(iii) coordination with surface metal cations,

(iv) ion-dipole interactions,

(v) hydrogen bonding, and

(vi) hydrophobic interactions.

For adsorption of MSMA and arsenate, the first two mechanisms may apply as they relate 
to ionizable species. However, the first mechanism, stated by Roy et al., (1987) as the coulombic-electrostatic-chemical mechanism, is the most important. In this mechanism, an electrostatic force results from a surface charge (due to protonation of surface oxygen or $\mathrm{OH}$ groups) and an oppositely charged species, which maintains the electro-neutrality of the surface. Since these substitutions are usually done by lower valence cations, a net negative excess charge results. This excess charge creates a second diffuse layer of positively charged atoms or molecules. This type of reaction is important in adsorption of inorganic ions and ionized organic molecules.

\subsubsection{Adsorption Models and Mathematics}

Sorption is a partitioning from the soluble/insoluble phase in solution onto the solid sediment phase for which there are many partitioning descriptors. In studies concerned with the adsorption of gases by solids, more than 40 equations have been used to describe the data (Krapac et al., 1987). However, most of these gas/solid derived sorption equations can be easily applied towards liquid/solid sorption (Sparks et al., 1986). Mathematical representations of adsorption traditionally have been accomplished using isotherms, such as Langmuir and Freundlich (Fuentes et al., 1993).

\subsubsection{Langmuir}

Initially, the Langmuir equation was derived to explain the adsorption of gases on solid surfaces (Sparks, 1986). The most commonly used Langmuir isotherm can be mathmematically expressed as: 


$$
\frac{\mathrm{x}}{\mathrm{m}}=\frac{\mathrm{K}_{\mathrm{L}} \mathrm{MC}}{1+\mathrm{K}_{\mathrm{L}} \mathrm{C}}
$$

where $\mathrm{x}$ is the mass of the solute adsorbed $(\mu \mathrm{g}), \mathrm{m}$ is the mass of the adsorbent $(\mathrm{g})$, if $\mathrm{C}$ is the equilibrium concentration of the solute as $\mu \mathrm{g} / \mathrm{L}$, then the constants $\mathrm{K}_{\mathrm{L}}$ and $\mathrm{M}$ have units of $\mathrm{L} / \mu \mathrm{g}$ and $\mu \mathrm{g} / \mathrm{g}$ respectively (Krapac et al., 1987). The Langmuir constant $\mathrm{K}_{\mathrm{L}}$ is related to the bonding energy between the adsorbed ion and the adsorbent, whereas $M$ represents the maximum monolayer adsorption (Gutierrez et al., 1993). Sparks (1986) states that the Langmuir equation is based on the following assumptions:

1) The adsorbed entity is attached to the surface at definite, homogeneous, localized sites forming a monolayer.

2) The heat of adsorption, $Q$ is constant over the entire monolayer.

3) There is no lateral interaction between the adsorbed species.

4) Equilibrium is reached.

5) The volume of a monolayer and the energy of adsorption are independent of temperature.

Two linearized expressions of equation (2) can be used to calculate the constants after a simple linear regression is performed:

$$
\frac{C}{x / m}=\frac{1}{K_{L} M}+\frac{C}{M}
$$




$$
\frac{1}{x / m}=\frac{1}{K_{L} M C}+\frac{1}{M}
$$

From these equations, the distribution coefficient, $K_{d}$, can be determined by dividing $x / m$ by the corresponding C. Since equations (3) and (4) imply linear behavior, the following relationship can be used to find $\mathrm{K}_{\mathrm{d}}$ for either of the two equations; as $\mathrm{C} \rightarrow 0$, then

$$
\frac{\mathrm{C}}{\mathrm{x} / \mathrm{m}} \rightarrow \frac{1}{\mathrm{~K}_{\mathrm{L}} \mathrm{M}}
$$

Thus, $K_{d}(L / g)$ can be found as the product of $K_{L} M(L / \mu g)(\mu g / g)$. Langmuir isotherm equations have been successfully used to describe the adsorption characteristics of arsenate/sandy soil systems (Lindsay, 1979; Aly et al.,1983; Stumm et al., 1987, 1981; Krapac et al., 1987; Masscheleyn et al., 1991; Patrick et al., 1991; Allen, 1995).

\subsubsection{Freundlich}

Krapac (1987) states that the Freundlich equation is the most widely used one for solid-liquid systems. This equation was first developed as an empirical expression without a theoretical foundation. Later, some investigators referred to the Freundlich constant $\mathrm{K}_{\mathrm{f}}$ as a relation to the affinity of a contaminant to the adsorbent. The Freundlich equation can be expressed as: 


$$
\frac{\mathrm{x}}{\mathrm{m}}=\mathrm{K}_{\mathrm{f}} \mathrm{C}^{1 / \mathrm{n}}
$$

where $1 / \mathrm{n}$ is also a constant that describes how the capacity of the adsorbent varies with the equilibrium solute concentration (Krapac et al., 1987). The simplicity of this equation is shown with a simple linear regression in the following logarithmic form:

$$
\log (\mathrm{x} / \mathrm{m})=\log \mathrm{K}_{\mathrm{f}}+1 / \mathrm{n} \log \mathrm{C}
$$

When using equation (6), the constant $\mathrm{K}_{\mathrm{f}}$ and the exponent $1 / \mathrm{n}$ can be solved for by using a power regression. However, the simplest case is where the adsorption of the solute conforms to a Freundlich equation isotherm and the $1 / \mathrm{n}$ term is unity,

$$
\mathrm{x} / \mathrm{m}=\mathrm{S}=\mathrm{K}_{\mathrm{f}} \mathrm{C}^{1 / \mathrm{n}}=\mathrm{K}_{\mathrm{f}} \mathrm{C}
$$

This isotherm equation should produce a linear plot, where the slope $\mathrm{K}_{\mathrm{f}}$ is numerically equal to $\mathrm{K}_{\mathrm{d}}$ with units of $\mathrm{L} / \mathrm{g}$ if $\mathrm{x} / \mathrm{m}$ is expressed as $\mu \mathrm{g} / \mathrm{g}$ and $\mathrm{C}$ as $\mu \mathrm{g} / \mathrm{L}$ ( Sparks et.al., 1986; Krapac et al., 1987; Fuentes et al., 1988).

\subsection{Arsenic Chemistry}

Arsenic is a naturally occurring element that ranks $20^{\text {th }}$ in abundance in the earth's crust. Both inorganic and methylated forms can be found in soil/sediment and aquatic systems. However, the inorganic form is the most abundant of the two species. Cullen 
et al. (1989) states that As is associated mostly with igneous and sedimentary rocks, particularly with iron, copper, cobalt and sulfidic ores, and coal. Natural and anthropogenic release of As into the environment occurs through the weathering, burning or smelting of these materials and may be deposited in soils, fresh and salt water, and in sediments (Onken et al., 1995). Therefore, the presence of As in a sample is almost considered to be insignificant, unless it is compared with a value normally expected for that sample and found to be excessive. In the state of Florida, arsenic is limited to $50 \mathrm{ppb}$ in groundwaters (FAC 62-550).

\subsubsection{Organoarsenical Herbicides}

For the past 35 years, organic arsenical herbicides have been used extensively. Hiltbold (1974) states that the more commonly used compounds are sodium and ammonium salts of methanearsonic acid (MAA), monosodium methanearsonate (MSMA), disodium methanearsonate (DSMA), and monoammonium methanearsonate (MAMA). Unlike the inorganic orthoarsenate compounds, methanearsonates have a methyl substitution of one of the hydroxyl groups linked to the arsenic atom. Addition of a second methyl group produces methylarsinic or cacodylic acid (See Figure 1).

\subsubsection{MSMA}

Monosodium methanearsonate $\left(\left(\mathrm{CH}_{3}\right) \mathrm{O}_{3} \mathrm{AsOHNa}\right.$; CAS No. 2163-80-6), commonly referred to as MSMA, is known as an organic arsenical because is contains a methyl group $\left(-\mathrm{CH}_{3}\right)$ (U.S. EPA et al., 1995). MSMA is a highly water soluble crystalline solid and is used as an herbicide for the postemergent control of grassy weeds in cotton, sugercane, 
nonbearing orchards, citrus groves, lawns, turf, and in noncrop areas. Applications to turf grass at golf courses range from $0.5 \mathrm{~kg}$ ai/ha to $2.2 \mathrm{~kg}$ ai $/ \mathrm{ha}(0.45 \mathrm{lbs}$ MSMA/acre $-1.96 \mathrm{lbs}$ MSMA/acre).

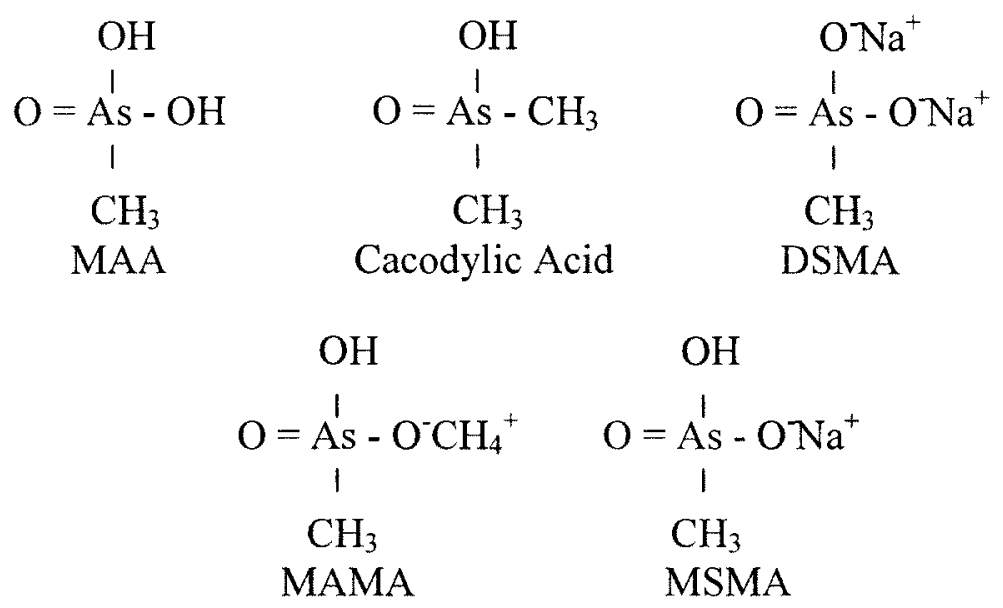

Figure 1. Formulae of organic arsenical herbicides (Hiltbold, 1974).

Hiltbold (1974) states that MSMA is typically applied to foliage as a spray. Much of the spray that is not intercepted by foliage is deposited directly onto the soil. In addition, a fraction of the MSMA that is intercepted by the foliage does reach the soil via washoff from plant surfaces. This is referred to as the foliar washoff extract coefficient, where the suggested typical value is 0.10 (Carsel et al., 1984). In the environment, MSMA will undergo chemical and biochemical transformations that include oxidation, reduction, and methylation. All of these transformations are largely controlled by microbial, soil, and sediment adsorption/desorption processes which affect the overall environmental distribution of arsenic-containing constituents (U.S. EPA et al., 1995). However, when considering the predominant species of As over time, the issue of understanding the fate 
and transport of MSMA transforms into understanding the fate of the inorganic species.

Monosodium methanearsonate can bind, reversibly, to ferrous and aluminum oxides which may be contained on the surfaces of clay particles and sand. While unbound, MSMA may undergo oxidative demethylation to arsenate $\left(\mathrm{H}_{2} \mathrm{AsO}_{4^{-}}\right)$, an inorganic form of arsenic, and reductive methylation to cacodylic acid (U.S. EPA et al., 1995), all of which are reversible (See Figure 2). MSMA is considered to be a possible carcinogen to humans (U.S. EPA et al., 1995). Table 1 illustrates some of the physiochemical properties of MSMA.

\subsubsection{Inorganic Arsenate}

In most environments, As occurs in an inorganic form in aqueous systems as a result of the dissolution of solids phases such as $\mathrm{As}_{2} \mathrm{O}_{3(\mathrm{~s})}$ (arsenolite), and $\mathrm{As}_{2} \mathrm{O}_{5(\mathrm{~s})}$ (arsenic anhydride) and $\mathrm{AsS}_{2(\mathrm{~s})}$ (realgar)(Aly et al., 1993). Aly (1983) comments that the two predominant aqueous forms are weak acids: arsenic acid (i.e., arsenate, +5 oxidation state), and arsenious acid (i.e., arsenite, +3 oxidation state). Table 2 illustrates the acidbase $\mathrm{pH}$ dependent equilibria.

The oxides of Table 2 are all very soluble. As a result, As is found mostly in the anionic form which is dependent upon the $\mathrm{pH}$ of the water. Microbial activity, in conjunction with the right $\mathrm{pH}$ and redox potential, can produce naturally occuring methylated As forms. However, most aquatic systems in Florida are oxidizing conditions which do not allow a stable environment for the methylated forms to remain for very long. Figure 3 shows the effect of redox potential and $\mathrm{pH}$ has on the prevailing species of As in a given soil system. Masscheleyn et al., (1991) found that the solubility, 


\section{Volatilizes to Atmosphere}

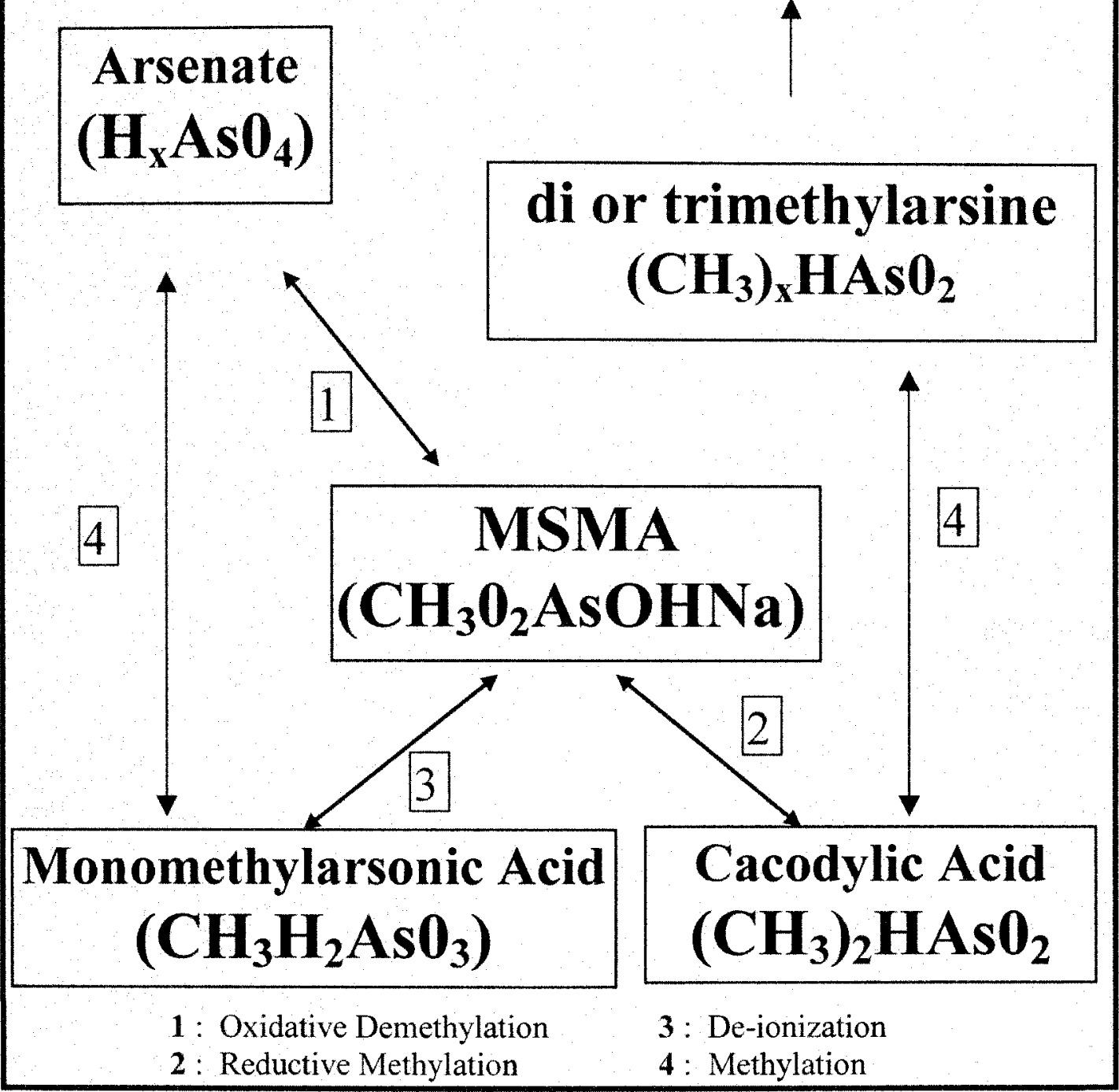

Figure 2. Transformational Pathways for MSMA in the Natural Environment (U.S. E.P.A. ,1995; and Hiltbold (1974). 
TABLE 1. KNOWN PHYSICAL, CHEMICAL, AND TOXICOLOGICAL PROPERTIES OF MSMA (FEDERAL REGISTER, 4/20/95; FARM CHEMICALS HANDBOOK, 1997).

Property

MSMA

Molecular Formula/Weight

$\mathrm{CH}_{4} \mathrm{AsO}_{3} \mathrm{Na} /$

161.95 grams

Water Solubility

$104 \mathrm{~g} / 100 \mathrm{ml}$ water

Vapor Pressure/Henry's Constant

$<7.5 \mathrm{E}-08 \mathrm{~mm} \mathrm{Hg}$ /

$6.2 \mathrm{E}-15$

Color

White crystalline solid

Melting Point /Boiling Point

$132-139^{\circ} \mathrm{C} / 110^{\circ} \mathrm{C}$

Density

$1.55 \mathrm{~g} / \mathrm{ml}$

Herbicide Use

Postemergent control of grassy weeds in turf. Preplant in cotton, nonbearing orchards.

Half-life $\mathrm{DT}_{\varsigma_{0}}$ (days)

$\sim 100$

Binding Substrate

Aluminum oxide (clay)

Ferrous oxide (coating)

SDWA limits in drinking water

$0.05 \mathrm{mg} / \mathrm{L}$ 
TABLE 2. PH BASED EQUILIBRIA OF ARSENIC ACID AND ARSENIOUS ACID (ALY ET.AL., 1983).

\section{Reaction}

$$
\begin{gathered}
\quad \begin{array}{l}
+3 \\
\mathrm{AsO}^{+}+\mathrm{H}_{2} \mathrm{O}=\mathrm{HAsO}_{2}+\mathrm{H}^{+} \\
\mathrm{HAsO}_{2}=\mathrm{AsO}_{2}{ }^{-}+\mathrm{H}^{+}
\end{array} \\
\quad+\mathbf{5} \\
\mathrm{H}_{3} \mathrm{AsO}_{4}=\mathrm{H}_{2} \mathrm{AsO}_{4}{ }^{-}+\mathrm{H}^{+} \\
\mathrm{H}_{2} \mathrm{AsO}_{4}{ }^{-}=\mathrm{HAsO}_{4}{ }^{2-}+\mathrm{H}^{+} \\
\mathrm{HAsO}_{4}{ }^{2-}=\mathrm{AsO}_{4}{ }^{3-}+\mathrm{H}^{+}
\end{gathered}
$$

$\log \mathrm{Ka}$

0.34

$-9.21$

$-3.60$

$-7.26$

$-12.47$ 


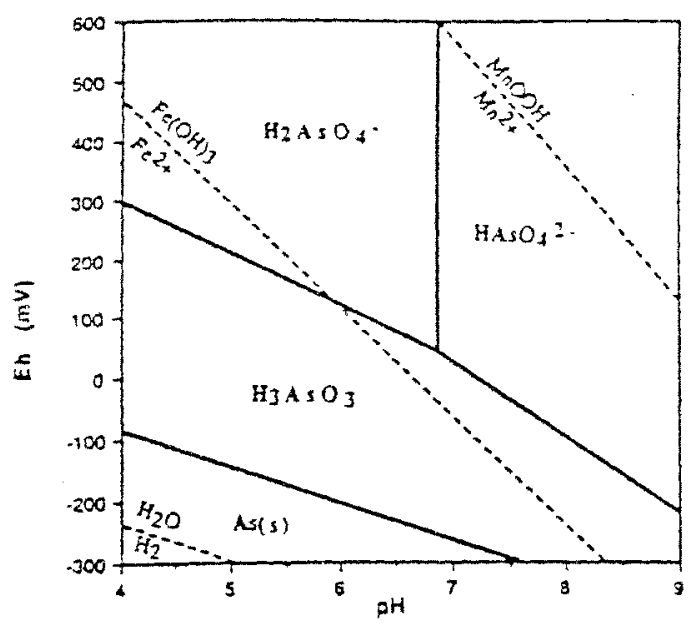

Figure 3. Eh-pH diagram for the $\mathrm{As}-\mathrm{H}_{2} \mathrm{O}$ system (Masscheleyn et al., 1991). 
mobility, bioavailability, and toxicity of arsenic depends on its oxidation state and $\mathrm{pH}$. His studies indicate that under higher soil redox levels $(+200$ to $+500 \mathrm{mV})$ with $\mathrm{pH}$ values ranging from 5 to 7.5 , the solubility of arsenic was low and the major species present (up to $87 \%$ ) in solution was $\mathrm{As}(+5)$. Another study concluded that the solubility of arsenate was controlled by the adsorption to soils rather than precipitation of arsenate compounds (Raven et al., 1998).

In southern Florida the subsurface is very porous, aerated, with soil pH ranging from 6.5-7.5. As a result, the predominant species of inorganic arsenic would be expected to be of the +5 valence state. Thus, arsenate $(\operatorname{As}(+5))$ would not be expected to be as mobile as would arsenite (As(+3)). This is significant when determining which As species to conduct sorption studies on. Masscheleyn (1991) also found that amorphous $\mathrm{Fe}$ and $\mathrm{Al}$ hydroxides, clay content, and $\mathrm{pH}$ are the soil properties most related to As sorption.

\subsection{PRZM-2.0}

Herbicides and pesticides that leach from agricultural fields as nonpoint sources can lead to groundwater contamination. Non-point source contamination can be described as highly variable in terms of loadings. Parameters such as rainfall and irrigation events control the timing and magnitude of the herbicides leaching below the root zone (the root zone is the uppermost layer of soil where the roots of the crop or, in this case, the roots of the turf grass penetrate). Non-point sources are widespread by nature and, as a result, are very difficult to remediate. However, efforts must be made to prevent this type of contamination since herbicide use has affected Florida's Biscayne 
aquifer (DERM et al., 1997). The first, and most important, step in preventing groundwater contamination is understanding the relationships between chemical properties, soil system properties, and the climatic and turf management variables that combine to induce leaching.

According to Carsel et al. (1994), many investigators have shown that chemical solubility in water, sorptive properties, volatility, formulation, and soil persistence determine the tendency of pesticides to leach through soil. In addition, the hydrologic cycle interacts with the chemical characteristics to transform and transport pesticides within and out of the root zone.

There are many numerical models available that predict contaminant movement in porous media for steady-state, transient, homogenous, and multi-layered components. These models require large amounts of detailed data since modelers generally use what is called finite segment modeling (finite differences). This is where site specific data is entered into smaller segments of known finite volume and characteristics, within the desired area, instead of using field averages found over the whole area. Mass balances are then performed about each segment assuming homogeneity (or "pseudohomogeneity") (Thomann et al., 1987). Thus, finite element modeling allows more accurate predictions in highly variable (heterogeneous) areas that do not share the same characteristics throughout. Unfortunately, as Carsel (1994) points out, each spatial segment modeled must be properly characterized - a task which is sometimes either too expensive to perform or too overwhelming to accomplish within a project's time limits. Therefore, the use of modeling for this work should be viewed as the possibility or potential of groundwater contamination via use of MSMA at typical golf course 
environments in southern Florida, and not as a modeled scenario that has undergone extensive (and expensive) verification and calibration of model parameters and conditions.

Once the critical components necessary to reasonably simulate modeling scenarios have been determined, a suitable unsaturated flow and transport computer code will be used to predict the fate and transport of MSMA and its predominant degredation product, arsenate, in the vadose zone. The computer code will estimate concentration profiles as a function of depth and time. Unsaturated zone transport models include:

$\begin{array}{ll}\Rightarrow & \text { VLEACH } \\ \Rightarrow & \text { VS2D } / \mathrm{T} \\ \Rightarrow & \text { SESOIL } \\ \Rightarrow & \text { CHEMFLO } \\ \Rightarrow & \text { ONE }-\mathrm{D} \\ \Rightarrow & \text { PESTRUN } \\ \Rightarrow & \text { PESTAN } \\ \Rightarrow & \text { PRZM } 1.0-3.0\end{array}$

PRZM-2.0, an EPA approved computer code, was designed to address the above problems and was chosen for this study. PRZM-2.0 is available through the U.S. EPA Center for Environmental Assessment Modeling internet website, and is free to the public. It has been used by investigators for over 10 years with some success. For the 
purposes of estimating the impact of MSMA use at golf courses, this model is acceptable despite its' development for agronomic systems. However, the author also recognizes that this model has limitations which will be discussed later in this chapter.

\subsubsection{Theory}

PRZM-2.0 is a one-dimensional, dynamic, compartmental model that is able to estimate chemical movement in unsaturated soil systems within and immediately below the plant root zone (see Figure 4) (Carsel et al., 1994). PRZM-2.0 allows the consideration of pulse loads, prediction of peak events, and estimation of time-varying concentration profiles, which overcomes the limitations in steady-state models. Timedependent transport by both advective and dispersive mechanisms in the dissolved phase or diffusion in the gas phase are also estimated in this program.

PRZM's two major components are hydrology and chemical transport. The hydrologic component estimates runoff and erosion and is based on the Soil Conservation Service curve number technique and the Universal Soil Loss Equation (Carsel et al., 1994). Water movement is simulated through use of the following soil parameters including field capacity, wilting point, and saturation water content. Evapotranspiration is estimated from pan evaporation data, or by an empirical formula if input pan data are unavailable. Evapotranspiration is divided among evaporation from crop interception, evaporation from soil, and transpiration by the crop. Irrigation may also be considered.

All three phases of the MSMA/As(+5) system (dissolved, adsorbed, and gaseous) are moderated by plant uptake, surface runoff, erosion, decay, volatilization, foliar washoff, advection, dispersion, and retardation. PRZM-2.0 solves the transport equation 


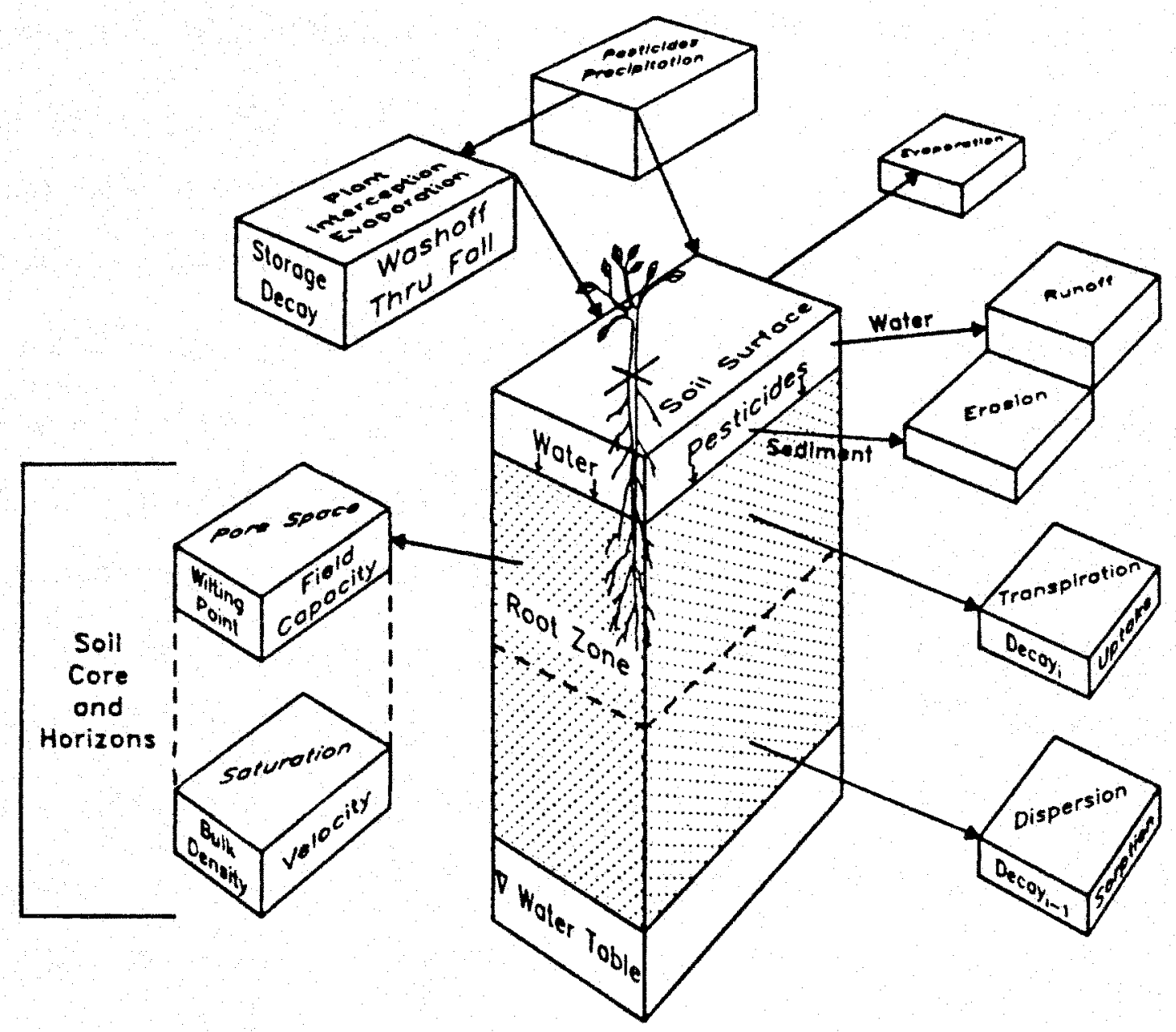

Figure 4. Illustration of Chemical Movement as Modeled by PRZM- 2.0 (Carsel, 1994). 
with one of two finite-difference numerical solutions; the backwards-difference implicit scheme, or a Method of Characteristics (MOC) algorithm that greatly reduces numerical dispersion (Carsel et al., 1994). The hydrologic components of pesticide transport equations (i.e., moisture content and soil-water velocities) are solved separately and then numerically integrated into the equation in succeeding time steps. Output can be summarized as daily, monthly, annually, or a daily time series value for various fluxes or storages can be written to sequential files during program execution (Carsel et al., 1994)

PRZM-2.0 also links another transport code, VADOFT. VADOFT is also a onedimensional solute transport code that only models the vadose zone. The two models, PRZM and VADOFT, are the two major components of PRZM-2.0. In addition, PRZM2.0 includes a Monte Carlo pre- and post- processor, that can perform probability-based exposure assessments. However, the predominant focus of this research effort precludes the use of these modeling compartments. Therefore, only the PRZM code, without the use of the Monte Carlo processor, will be used and discussed further.

\subsubsection{Limitations}

Limitations associated with PRZM-2.0 have been well documented. Carsel et al. (1994) states the four major categories:

- Hydrology

- Soil hydraulics
- Method of solution of the transport equation

- Deterministic nature of the model

Hydraulic computations are performed in PRZM on a daily time step, therefore 
parameters that vary throughout the day (i.e., evaporation, runoff, etc.) could be overestimated or underestimated. This has the effect, especially in larger soil cores, of inducing a greater-than-anticipated movement of chemical through the profile. For shorter soil cores, PRZM-2.0 can obviously be used to represent the entire vadose zone. PRZM-2.0 retained its daily time step due to the relative availability of daily meteorological data. Evapotranspiration is calculated using Hamon's formula, in the absence of evaporation data. When Hamon's formula was compared against field data at an irrigated citrus crop in Florida, PRZM-2.0 substantially underestimated evapotranspiration (Dean et al., 1985). However, the author suspects the gap would be closed when compared to a much less dynamic system such as turf grass with an extremely shallow, sandy aquifer.

PRZM-2.0 is unable to calculate the heat loss through the soil profile as a result from evaporation of water. The energy associated with changing water from liquid to vapor phase is enough to have a cooling effect in the soil column. The upward movement of water in response to gradients induced by evapotranspiration cannot be simulated by PRZM-2.0 as it only considers the advective, downward movement of water. For chemicals with a low vapor pressure, hence low volatization, this process is important for renewing the chemical concentration at the surface.

If the user does not solve for transport with the MOC method, especially for advection-dominated systems, PRZM tends to produce a high degree of numerical dispersion in such systems. This results in overprediction of downward movement due to smearing of the peak and subsequent overestimation of loadings to groundwater (Carsel et al., 1994). In low-advection systems, the MOC approach reduces to the original 
backwards-difference solution scheme, which is exact for velocities approaching zero.

The input file which contains the pesticide partition coefficient parameter for each contaminant modeled, only allows for the input of $\mathrm{K}_{\mathrm{d}}$. Use of the Freundlich isotherm cannot be used if the contaminant exhibits nonlinear sorption as the exponent $1 / \mathrm{n}$ has not been incorporated into the model. Thus, only chemicals with linear type adsorption characteristics can be modeled with PRZM-2.0, leaving only the use of Langmuir and Linear adsorption parameters for this modeling effort.

\subsubsection{Algorithms}

Because the use of PRZM-2.0 is a secondary goal of this work, the reader is advised to refer to the detailed listing of the various solutions that can be found in PRZM2.0, "A Model for Predicting Pesticide Fate in the Crop Root and Unsaturated Soil Zones: User Manual for Release 2.0". However, the two major equations, chemical and water transport, will be briefly reviewed in order to explain how the developers chose the driving mechanisms for this program. Figure 5 illustrates the mass balances between each phase for a single contaminant.

Both the surface and subsurface zones will use the following partial differential equations to simulate transport in soil for each of the dissolved, adsorbed, and vapor phases respectively:

$$
\frac{A \Delta z \partial\left(C_{w} \theta\right)}{\partial t}=J_{D}-J_{V}-J_{D W}-J_{U}-J_{Q R}+J_{A P P}+J_{F O F} \pm J_{T R N}
$$

$$
\frac{\mathrm{A} \Delta \mathrm{z} \partial\left(\mathrm{C}_{\mathrm{S}} \rho_{\mathrm{S}}\right)}{\partial \mathrm{t}}=\mathrm{J}_{\mathrm{DS}}-\mathrm{J}_{\mathrm{ER}}
$$




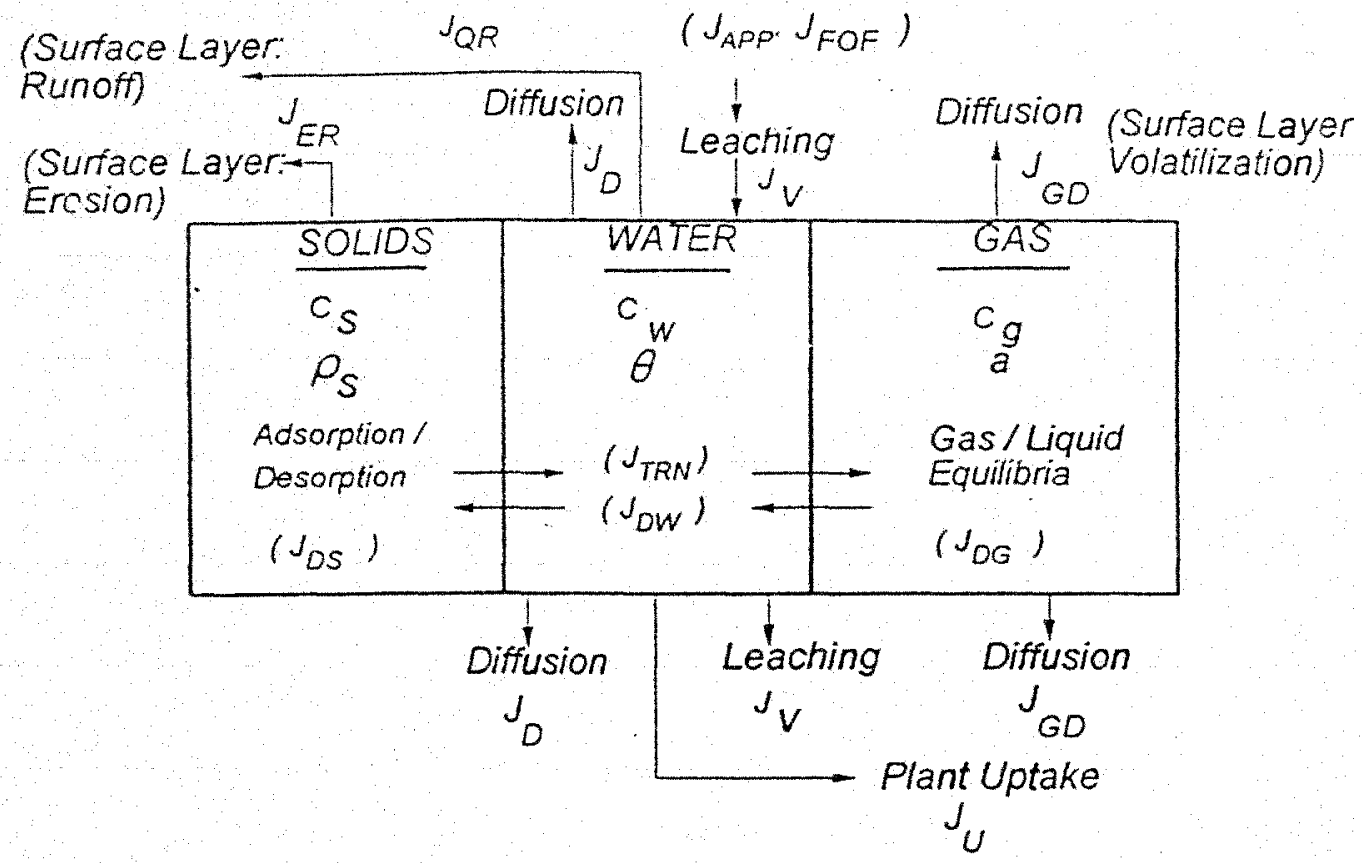

Figure 5. . Illustration of chemical movement and transformations (Carsel, 1994) 


$$
\frac{\mathrm{A} \Delta \mathrm{z} \partial\left(\mathrm{C}_{\mathrm{g}} \mathrm{a}\right)}{\partial \mathrm{t}}=\mathrm{J}_{\mathrm{GD}}-\mathrm{J}_{\mathrm{DG}}
$$

where
A $=$ cross-sectional area of soil column $\left(\mathrm{cm}^{2}\right)$
$\Delta \mathrm{z}=$ depth dimension of compartment $(\mathrm{cm})$
$\mathrm{C}_{\mathrm{w}}=$ dissolved concentration of pesticide $\left(\mathrm{g} \mathrm{cm}^{-3}\right)$
$\mathrm{C}_{\mathrm{s}} \quad=$ sorbed concentration of pesticide $\left(\mathrm{g} \mathrm{g}^{-1}\right)$
$\mathrm{C}_{\mathrm{g}}=$ gaseous concentration of pesticide $\left(\mathrm{g} \mathrm{cm}^{-3}\right)$
$\theta=$ volumetric water content of soil $\left(\mathrm{cm}^{3} \mathrm{~cm}^{-3}\right)$
a $=$ volumetric air content of the soil $\left(\mathrm{cm}^{3} \mathrm{~cm}^{-3}\right)$
$\rho_{\mathrm{s}} \quad=$ soil bulk density $\left(\mathrm{g} \mathrm{cm}^{-3}\right)$
$\mathrm{t}=\operatorname{time}(\mathrm{d})$
$J_{\mathrm{D}} \quad=$ represents effect of dispersion/diffusion of dissolved phase $\left(\mathrm{g} \mathrm{day}^{-1}\right)$
$\mathrm{J}_{\mathrm{V}} \quad=$ represents the effect of advection of dissolved phase $\left(\mathrm{g} \mathrm{day}^{-1}\right)$
$\mathrm{J}_{\mathrm{GD}} \quad=$ represents effect of dispersion and diffusion in vapor phase $\left(\mathrm{g} \mathrm{day}^{-1}\right)$
$\mathrm{J}_{\mathrm{DW}}=$ mass loss due to degradation in the dissolved phase $\left(\mathrm{g} \mathrm{day}^{-1}\right)$
$\mathrm{J}_{\mathrm{DG}} \quad=$ mass loss due to degradation in the vapor phase $\left(\mathrm{g} \mathrm{day}^{-1}\right)$
$\mathrm{J}_{U} \quad=$ mass loss by plant uptake of dissolved phase $\left(\mathrm{g} \mathrm{day}^{-1}\right)$
$\mathrm{J}_{\mathrm{QR}} \quad=$ mass loss by removal in runoff $\left(\mathrm{g} \mathrm{day}^{-1}\right)$
$\mathrm{J}_{\mathrm{APP}}=$ mass gain due to pesticide deposition on the soil surface $\left(\mathrm{g} \mathrm{day}^{-1}\right)$
$\mathrm{J}_{\mathrm{FOF}}=$ mass gain due to washoff from plants to soil $\left(\mathrm{g} \mathrm{day}^{-1}\right)$
$\mathrm{J}_{\mathrm{DS}} \quad=$ mass loss due to degradation of sorbed phase chemical $\left(\mathrm{g} \mathrm{day}^{-1}\right)$
$\mathrm{J}_{\mathrm{ER}} \quad=$ mass loss by removal on eroded sediments $\left(\mathrm{g} \mathrm{day}^{-1}\right)$
$\mathbf{J}_{\mathrm{TRN}}=$ mass gain or loss due to parent/daughter transformations

In the application of equations (9), (10), and (11), the variables $\mathrm{J}_{\mathrm{QR}}, \mathrm{J}_{\mathrm{FOF}}$, and $\mathrm{J}_{\mathrm{ER}}$ would not be included in the subsurface zones. $J_{A P P}$ is used only when the 
herbicide/pesticide is applied below the surface and $\mathrm{J}_{\mathrm{U}}$ is also only used for surface layers below the root zone.

The transport of water is a combination of Darcy's law and the continuity equation which yields the Richards differential equation as follows:

$$
\frac{\partial \theta}{\partial t}=\frac{\partial}{\partial z}\left[K(\theta) \frac{\partial h}{\partial t}\right]
$$

where

$$
\begin{aligned}
& \mathrm{K}(\theta)=\text { hydraulic conductivity at various heads }\left(\mathrm{cm} \mathrm{sec}^{-1)}\right. \\
& \theta \quad=\text { soil water content }\left(\mathrm{cm}^{3} \mathrm{~cm}^{-3}\right)
\end{aligned}
$$

The water balances for each of the 3 zones (surface zone, root zone, and unsaturated zone) are solved separately.

There are four other major categories of algorithms including chemical application and foliar washoff, chemical runoff, soil erosion, and volatization. The variables representing the solutions to these other categories are included in equations (9), (10), (11), and (12). Again, the reader is advised to refer to the PRZM-2.0 user's manual for all the detailed solutions to the above equations. 


\subsection{METHODS}

This section describes the materials, methods, equipment, protocols, and documentation used throughout this work.

\subsection{Equipment}

This section is intended to provide a list of each major piece of equipment and a brief description of the purpose it was used for.

Field sampling at the West Palm Beach Golf Course required the use of a hand operated auger (Environmental Sampling Kit, Art's Manufacturing \& Supply, American Falls, ID, 83211; 1/4 "Stainless Steel Rods). All samples were homogenized (mixed) in a $5 "$ " $5 "$ " 3 " stainless steel tray and subsequently placed in a plastic storage bag, Soils were dried overnight in a Fisher Scientific Isotemp Oven Model 725F. Soil samples were split, and poured into a set of ASTM brass sieves (\#'s 16, 30, 40,60, 140, and 200), and shaken with a mechanical shaker (Baker, 1/2HP).

All kinetics tests were conducted in $33 \mathrm{~mL}$ Fisher Scientific glass flat-bottomed tubular reactors with teflon coated screw caps. Subsequent adsorption tests were conducted in $130 \mathrm{~mL}$ glass bottles with teflon coated septas and aluminum caps. All weighings of soil and contaminants were performed with a microbalance (range $400 \mathrm{~g}$ $0.0001 \mathrm{~g}$, calibrated through May, 1998). Centrifugation of all experimental reactors was performed in a Marathon $6 \mathrm{~K}$ Centrifuge $(33 \mathrm{~mL}$ reactor bottles) or an IEC Model $\mathrm{K}$ Centrifuge (130 mL reactor bottles). Mixing of samples for both kinetics and adsorption tests was accomplished with a mechanical rotator (Environmental Services, tumbling 
motion, 30 rotations per minute). Glassware (Kimax and Pyrex) used: volumetric pipettes (1-50 mL, class A), $400 \mathrm{~mL}$ beakers, disposable pipettes, volumetric flasks (5$500 \mathrm{~mL}$, class A), and crucibles (Coors, Inc). pH readings were performed with a Corning pH Meter 245 which was calibrated for each use with Fisher Scientific pH Buffer Solutions (pH's of 4,7, and 10). A Fisher Isotemp Muffle Furnace was used to ignite the soil for Total Organic Carbon (TOC) measurements. All atomic adsorption (AA) analyses for arsenic were performed on a Perkin Elmer $5100 \mathrm{C}$ fitted with an AS-60 autosampler and a graphite furnace equipped with a L'vov platform for good replicability. Computer simulations were modeled on a Hitachi Visionbook 4000 Series, 32 MB RAM, 133MHz, with PRZM-2.0 (Pesticide Root Zone Model). Daily laboratory room temperatures were monitored using a mercury thermometer and recorded into a notebook.

\subsection{Materials}

All kinetics and adsorption tests were conducted with distilled de-ionized water (dd-water) supplied from the Department of Southeast Environmental Restoration Program at Florida International University (FIU). MSMA 6.6 (Lesco, Inc.) was purchased from Lesco, Inc. (Ft. Lauderdale, FL) with a registered purity of $6.6 \mathrm{lbs}$ MSMA per gallon $(23.8 \%$ by wt. as elemental As). Inorganic arsenic $(+5)$ was studied using sodium arsenate $\left(\mathrm{Na}_{2} \mathrm{HASO} \mathrm{S}_{4} \cdot 7 \mathrm{H}_{2} \mathrm{O}\right.$, analytical grade, Aldrich Chemical Company, Milwaukee, WI). Trace metal grade nitric acid $\left(\mathrm{HNO}_{3}\right.$, Fisher Scientific), and hydrogen peroxide $\left(30 \% \mathrm{H}_{2} \mathrm{O}_{2}\right.$, Fisher Scientific) were used in the digestion procedures, and nickel nitrate (nickelous (II) nitrate, $\mathrm{Ni}\left(\mathrm{NO}_{3}\right) 2 * \mathrm{H}_{2} \mathrm{O}$, Fisher Scientific) was used as a modifier 
for As analysis. Soap (Laboratory Soap with Calgon, Fisher Scientific) was used to clean glassware.

\subsection{Preliminary Work}

Final experimental adsorption and analytical methods will require preliminary work to determine at least two important issues: (1) established equilibrium conditions, and (2) maximized analytical methods for the determination of arsenic.

\subsubsection{Kinetics}

Prior to any equilibrium adsorption tests, it was necessary for the contaminant mixture to have reached a point of equilibrium between the adsorbed phase and the dissolved phase. Though previous research illustrated that most inorganic As species need approximately 48 hours to reach equilibrium, it was critical for this study to conduct kinetics tests to eliminate any unforeseen deviations from the norm in either the equipment, procedures, or analysis (Goldberg et al., 1988; Masscheleyn et al., 1991, 1991, 1993; Aurillo et al., 1994; Darland et al., 1997).

Kinetics testing began by preparing the soil solution ratios which were based on previous studies (Roy et al., 1987). A $10 \mathrm{ppm}$ solution of $\mathrm{As}(+5)$ (as sodium arsenate) was mixed with the five different soil fractions while keeping the same soil to solution ratio identical for all replicates. The reactors were mixed in a rotator and removed for analysis at the following intervals: $2,4,8,16,24,48,96$, and 168 hours. Samples were then digested for Total Recoverable As as listed in Standard Methods (1995). 
Equilibrium was considered to be established when there was a less than $2 \%$ difference in the mass of As removed between 2 consecutive intervals. The following formula shows the calculation necessary to determine when the system reached equilibrium:

$$
\left\{\left(\mathrm{C}_{1}-\mathrm{C}_{2}\right) * \mathrm{~V}_{\mathrm{sol}}\right\} * 100 \%=\% \text { Difference }
$$

where,

$$
\begin{aligned}
& \mathrm{C}_{1}=\text { Concentration of sample at interval } 1 \\
& \mathrm{C}_{2}=\text { Concentration of sample at interval } 2 \\
& \mathrm{~V}_{\text {sol }}=\text { Volume of liquid in reactor }
\end{aligned}
$$

Figures 6 and 7 illustrate the results from two sets of kinetic experiments. Figure 6 shows the kinetics for the $\mathrm{As}(+5)$ :Soil 1 system, from which a 48 hour equilibration period was determined. However, the system exhibited a non-linear approach towards equilibrium. The same pattern occurred for the other soils as well (See Appendix A). To verify that no experimental errors were made, a second kinetics test was conducted. From the second set of kinetics, it was determined that the systems do require 48 hours to reach equilibrium (See Appendix A) as indicated by Roy (1987). The equilibration for MSMA was extrapolated from the sodium arsenate tests since both are ionizable As species.

\subsubsection{Atomic Adsorption Analysis}




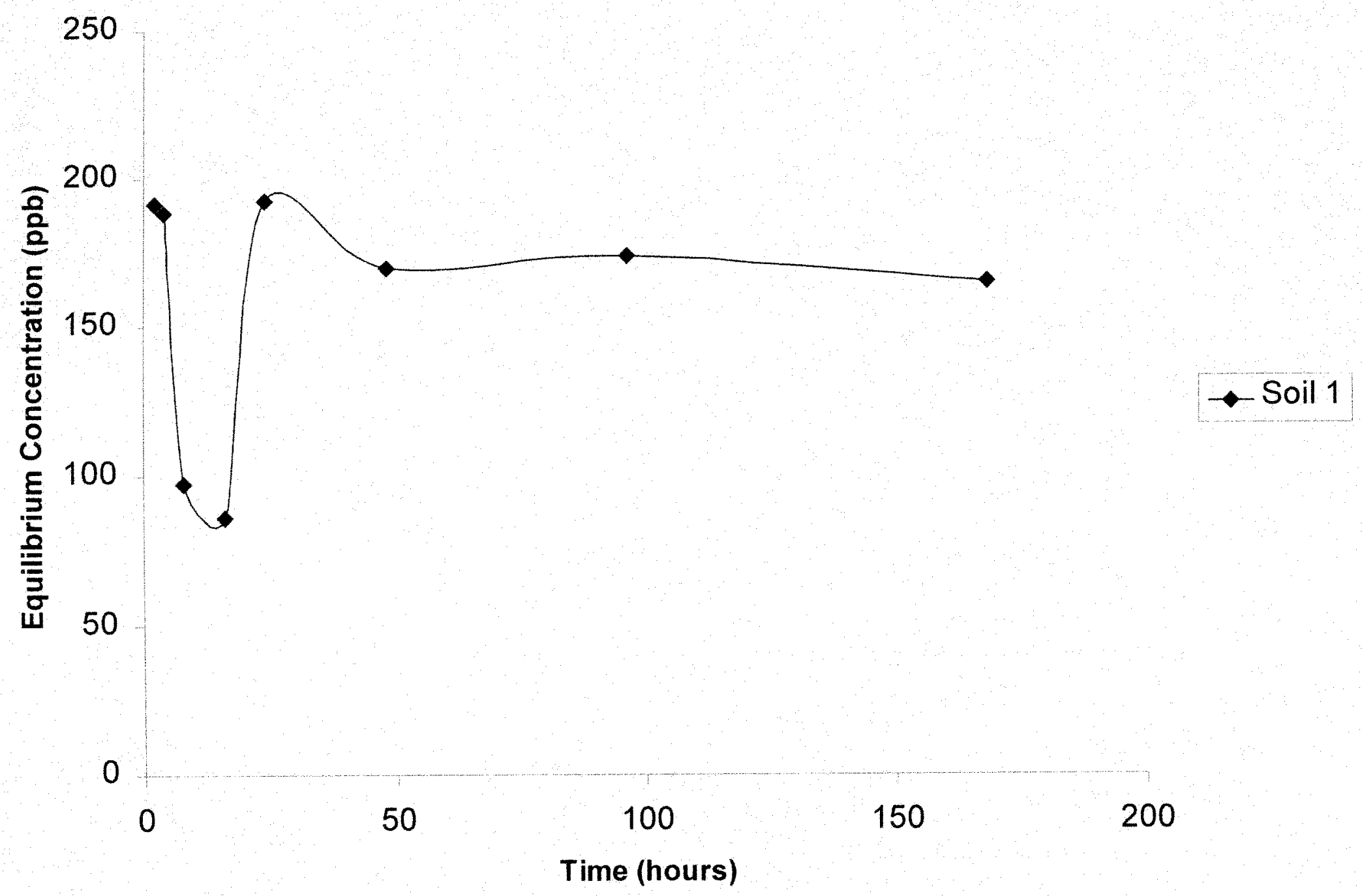

Figure 6. Plot of Equilibrium Concentration vs. Time, Soil 1 from Kinetics Experiments \#1. 


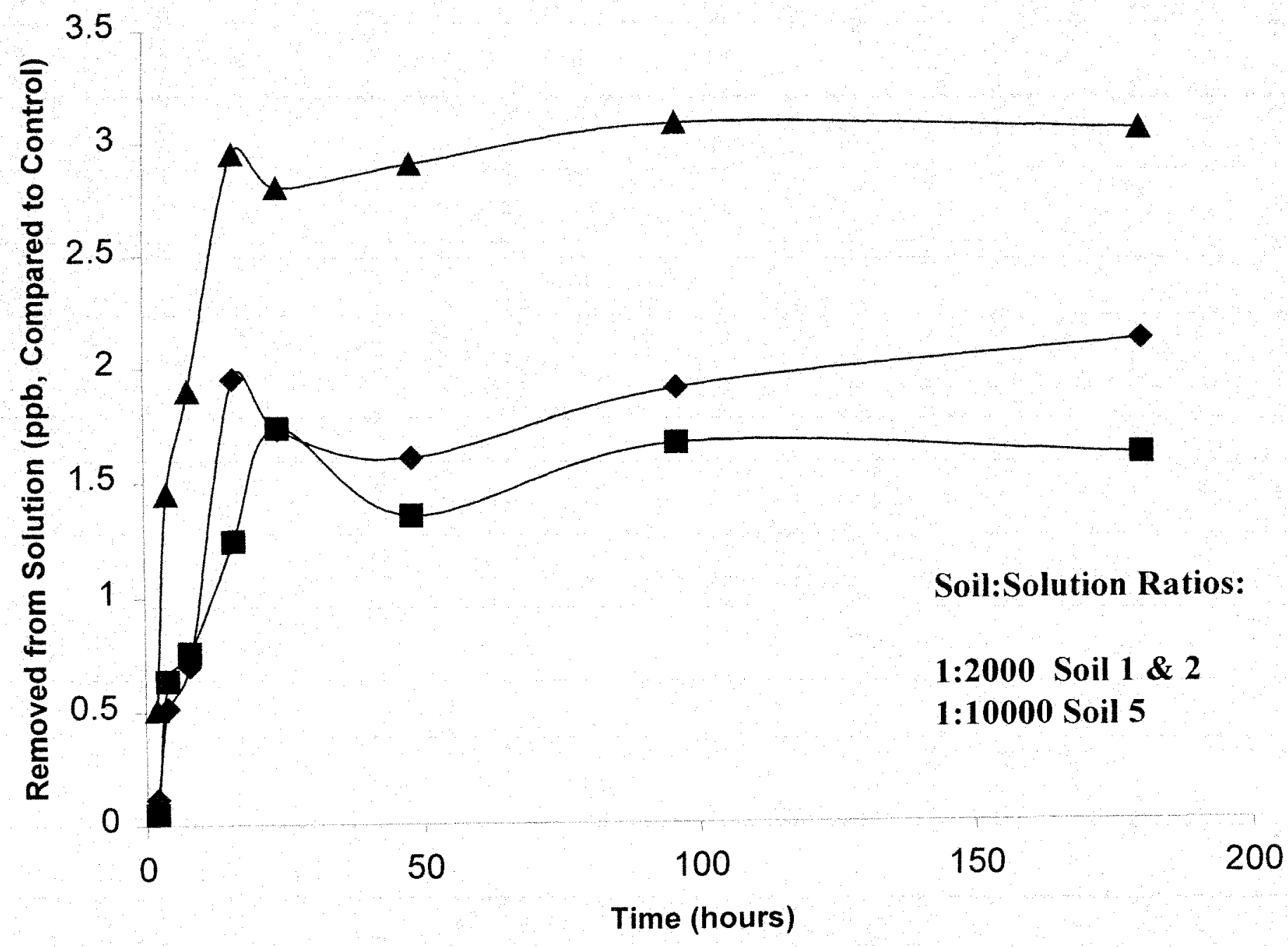

Figure 7. Plot of Control - Equilibrium Concentration vs. Time, 3 soils from Kinetics Experiments \#2. 
The graphite furnace atomic adsorption (GFAA) method is an EPA accepted method for the determination of As (US Army Corps of Engineers, 1995). The optimum range for analyzing arsenic concentrations is from $1-200 \mathrm{ppb}$ for the Perkin Elmer 5100C. However, interference from other dissolved minerals or metals can either reduce the sensitivity of the instrument, or the replicability of a given set of samples. Therefore, it is important to use a matrix modifier during the analysis for As. Nickel nitrate, when added to a sample as a matrix modifier, will allow modifications to the temperature program in optimizing the instrument's response to a sample. The Perkin Elmer 5100C is controlled using WINLAB v. 4.0 software that allowed modifications to the analytical procedures (i.e., adding a matrix modifier, changing temperature). This software, in conjunction with a matrix modifier, maximized both the sensitivity and precision for each analysis. Consequently, sample replicability was greatly improved.

\subsection{Experimental Protocol}

Where applicable, all experimental procedures were followed in strict accordance to accepted methods and protocols. This section outlines all field and laboratory procedures performed during this study and the source of each method will accompany its' description.

\subsubsection{Sampling}

A soil sample was taken from the West Palm Beach Country Club (WPBCC) located at 7001 Parker Avenue, West Palm Beach, Florida, on the 4th of November 1997 
(See Appendix A for map of area). All methods were followed according to strict Quality Assurance (QA) procedures as defined by the Florida Department of Environmental Protection (FDEP) Standard Operating Procedures (SOP's) for Laboratory Operations and Sample Collecting Activities Manual (DEP - QA-001/92). FDEP personnel - Leslie Smith (Waste Cleanup Section) and Terry Davis (Environmental Specialist) - and Dr. Hector R. Fuentes were present to coordinate sampling activities.

Upon reviewing reports of previous field studies at the WPBCC (Ardaman \& Associates, Inc. et.al., 1996), it was decided to take a sample from an area that was untended (i.e. area where MSMA had not been applied). Thus, the likelihood of acquiring a soil sample, from any depth above the ground water table, containing arsenic at levels above the anticipated background of $\sim 5 \mathrm{ug} / \mathrm{kg}$ would be greatly reduced. All samples were retrieved using a hand-operated auger which was cleaned using an in-field cleaning method for field equipment (DEP - QA-001/92).

Sampling began by clearing away the top 4 inches of soil (mostly root material) using a stainless steel spade. An extension from the auger equipment was placed across the prepared area to be used as a reference point in measuring the depth of the samples taken. The auger bucket was 12 inches in length and 4 inches in diameter and, thus, was able to retrieve a maximum of 150.8 cubic inches of soil each sampling. When the samples were brought to the surface, the bucket was emptied into a precleaned stainless steel pan for immediate observations. Samples were mixed for homogeneity and placed into a sealed plastic bag. Five samples were taken at the following depth ranges: (1) 4" 9", (2)1'2" - 1'11", (3) 3'6" - 4'6", (4)5'6" - 6'6", (5)7'6-8'6", and labeled, at the time 
of sampling, Surficial 4" $-9 ", \mathrm{gd}-2, \mathrm{gd}-3$, gd -4 , and gd -5 respectively. Samples were immediately stored in a cooler of ice and brought back to Florida International University (FIU) for storage at $4^{\circ} \mathrm{C}$.

\subsubsection{Soil Sieving}

After sampling the soil from the West Palm Beach Golf Course, a portion of each soil sample was placed out on a clean sheet of plastic and allowed to air dry at room temperature in a contaminant free environment for 1 week. A portion of the air dried samples (approximately 300 grams) was used for sieve analysis. The remainder $(<700$ grams) was placed in a sealed plastic bag for use in all batch kinetic and adsorption experiments.

Sieving was performed using the following ASTM brass sieves: \#16, \#30, \#40, $\# 60$, \#140, and \#200. After each soil sample was prepared, approximately $400 \mathrm{~g}$ was partitioned for sieve analysis. The following procedure (ASTM D1140-54) was used for each sieving:

1) Determine weight of sample to be sieved.

2) Assemble sieves in numerical order so that the sieve $\# 200$ is on the bottom. Place a pan beneath sieve $\# 200$, pour sample in the uppermost sieve. Place a cover on sieve \#16.

3) Insert sieve arrangement into a mechanical shaker, and shake $5 \mathrm{~min}-10 \mathrm{~min}$.

4) Remove from mechanical shaker and weigh each sieve noting the weight of 
sample that each sieve retained.

5) Carefully transfer all sample portions to the original beaker (using various brushes to remove particles caught in the mesh).

6) Repeat steps 1-5 twice, so that each sample is sieved a total of three times.

\subsubsection{Soil Characterization}

A fraction of each soil sample was sent to the FDEP Chemistry Laboratory for analysis of background levels of Total Phosphorus, and Total Recoverable Arsenic and Iron. These background concentrations are important to know when evaluating adsorption isotherms and determining if the presence of other constituents influence arsenic's mobility and sorptivity to the soils obtained from the WPBCC.

In addition to this, the soils were analyzed for Total Organic Carbon at FIU. After the soils were oven dried $\left(104^{\circ} \mathrm{C}\right)$ overnight, they were placed in a crucible, weighed, and ignited at $450^{\circ} \mathrm{C}$ for 48 hours. Once samples were removed from the crucible and cooled to room temperature in a dessicator, they were re-weighed to determine how much organic matter was removed. Jaffe (1998) stated that all organic matter is completely destroyed at these temperatures and should give a good estimate of the TOC for each soil.

\subsubsection{Standards and Solutions}

All solution preparation methodologies have been followed in strict accordance to those outlined in the Standard Methods for the Examination of Water and Wastewater 
(19th ed.). To prevent trace level As cross-contamination when preparing standards and solutions, laboratory glassware were washed with a soap solution (10:1, dd-water:soap) and rinsed with acidified dd-water $(\mathrm{pH}<2$,$) and dd-water. All standards were created$ using either stock As(+3) Atomic Adsorption, MSMA, or sodium arsenate solutions.

\subsubsection{Adsorption}

Adsorption tests were conducted to evaluate the sorptivity of both $\mathrm{As}(+5)$ and MSMA towards each soil fraction (5). The soil fractions, from this point on, are renamed as follows: Surficial 4" - 9" to Soil 1, gd-2 to Soil 2, gd-3 to Soil 3, gd-4 to Soil 4, gd5 to Soil 5. Each soil fraction was tested with 4 to 6 different concentrations ( 3 replicate attempts per concentration), plus one soil blank (dd-water), one water blank (dd-water), and one control (with the original As(+5) or MSMA concentration for comparison). Thus, a total of 18 to 21 samples were created per soil per contaminant. The soil to solution ratios mentioned previously, were modified so that approximately 30 of the original total As will remain in the equilibrated solution. This allowed for a statistically valid comparison of replicate versus controls, and a value that can be more easily reproduced. Soil:solution ratios were then set at 1:250 (0.5000 $\mathrm{g}$ of soil/125 $\mathrm{mL}$ solution) for soils $1-4$ and $1: 500$ for soil 5 ( $0.2500 \mathrm{~g}$ of soil/125 $\mathrm{mL}$ of solution).

Unlike the kinetics experiments, both adsorption trials used $125 \mathrm{~mL}$ of solution in $140 \mathrm{~mL}$ glass reactors with teflon coated septas capped with aluminum rings. The $15 \mathrm{~mL}$ of headspace was designed to maintain oxidizing conditions within the reactor during the experiment. Thus, the predominant species in the $\mathrm{As}(+5)$ experiments were assumed to 
be $\mathrm{As}(+5)$. However, the fraction of $\mathrm{As}(+5)$ remaining in solution at the end of the equilibration period was not expected to exceed the $87 \%$ as found in Masscheleyn's study (1991). Once the samples were prepared, they were wrapped in protective cloth and placed into the rotator for 48 hours of mixing/equilibration time. After 48 hours, each sample was centrifuged for 10 minutes at $1,100 \mathrm{rpm}$ in the IEC Model $\mathrm{K}$ centrifuge. Applying the following formula, an estimate of the largest particle remaining in solution can be made:

$$
\mathrm{t}=\frac{9 \eta \ln \left(\mathrm{R}_{\mathrm{b}} / \mathrm{R}_{\mathrm{t}}\right)}{2 \omega^{2} \mathrm{r}^{2}\left(\rho_{\mathrm{p}} / \rho\right)}
$$

where,

$$
\begin{array}{ll}
\omega & =4 \pi^{2}\left(\mathrm{rpm}^{2}\right) / 60 \\
\rho & =\text { density of solution }(\mathrm{g} / \mathrm{cu} . \mathrm{cm}) \\
\eta & =\text { viscosity of water }(8.95 \mathrm{E}-03 \mathrm{~g} / \mathrm{sec}-\mathrm{cm} @ 25 \mathrm{C}) \\
\mathrm{t} & =\text { time }(\mathrm{min}) \\
\rho_{\mathrm{p}} & =\text { particle density }(\mathrm{g} / \mathrm{cu} . \mathrm{cm}) \\
\mathrm{R}_{\mathrm{b}} & =\text { distance }(\mathrm{cm}) \text { from center of centrifuge rotor to top of solution. } \\
\mathrm{R}_{\mathrm{r}} & =\text { distance }(\mathrm{cm}) \text { from center of centrifuge rotor to bottom of tube. }
\end{array}
$$

Thus, particles larger than 0.3 microns have settled during centrifugation. A $100 \mathrm{~mL}$ aliquot of each sample was then digested, in accordance with Standard Methods (1995) method 3113 for Total Recoverable As (atomic adsorption electrothermal furnace). Once 
digestion was complete, each sample was split into two; (1) for analysis at the Florida Department of Environmental Protection - Chemistry Lab, and (2) for analysis at Florida International University.

\subsubsection{Modeling}

The value of computer simulations are largely based on the quantity and quality of data and the inevitable necessary assumptions. However, all data that was estimated for simulations came from recommendations from the PRZM-2.0 user's manual (gained through years of trial and error), from peer review sources, or was determined experimentally. It is recognized that a complete calibration and verification of the model should be performed before results are considered as fact. Because this study has focused largely on other issues (i.e., laboratory derived $\mathrm{K}_{\mathrm{d}}$ values for both MSMA and arsenate to a set of sampled soils), simulations should be viewed as preliminary work towards understanding the possible fate and transport of MSMA.

Using the sources mentioned above and experimental data on the partitioning of MSMA and arsenate to all five soil fractions, a simulation of MSMA transformation and transport was conducted to estimate dissolved arsenic concentrations in the soil profile down to the water table interface. The entire vadose zone was categorized into 5 horizons (154 $\mathrm{cm}$ total depth), each representing the different soil types found at the WPBCC sample site (see Figure 71, Appendix A). At the WPBCC sample site, the depth to the water table was estimated at 8 feet, but records show that the water table was found at depths as little as 5 feet (Ardaman \& Associates, Inc. et.al., 1996). 
The method of solving for the transport equations by PRZM-2.0 was performed using the backward-difference scheme. Another important issue is whether to link PRZM-2.0 to the VADOFT model. Since the simulated soil core is so short ( 5 feet), it was not deemed necessary to utilize the VADOFT model. This assumption is based on the likelihood of the drainage of field capacitance in one day. One of the parameters used for determining the actual water velocity in any media is known as the hydraulic conductivity or coefficient of permeability (de Marsily et.al., 1986). Under saturated conditions, the hydraulic conductivity for fine sands is $2.5 \mathrm{~m}$ /day (Gupta et.al., 1989). However, under unsaturated conditions the hydraulic conductivity is found to be smaller (even when saturated during rain events) and should be determined experimentally (de Marsily et.al., 1986). To find the estimated maximum pore water velocity or seepage velocity for fine sands under saturated conditions, the Darcy's velocity must first be found (de Marsily et.al., 1986):

$$
\mathrm{V}_{\mathrm{D}}=\mathrm{Ki}
$$

where, $\quad V_{D}$ is the Darcy's velocity $\left(\mathrm{L} \mathrm{T}^{-1}\right)$

$\mathrm{K}$ is the saturated hydraulic conductivity $\left(\mathrm{L} \mathrm{T}^{-1}\right)$

$\mathrm{i}$ is the hydraulic gradient $(\Delta \mathrm{h} / \mathrm{L}$, Dimensionless)

For the conditions in this simulation, the hydraulic gradient is equal to 1 when considering that the head differential $(5 \mathrm{ft})$ is equal to the length along which it is 
measured $(5 \mathrm{ft})$. Thus, the maximum Darcy's velocity is equal to the saturated hydraulic conductivity. The actual pore water velocity, which would be slower in the vadose zone to some degree, is related to the Darcy's velocity in this soil using the following relationship discussed by Gupta (1989):

$$
v=\frac{\mathrm{V}_{\mathrm{D}}}{\eta}
$$

where, $\quad v$ is the seepage or pore water velocity $\left(\mathrm{L} \mathrm{T}^{-1}\right)$

$\mathrm{V}_{\mathrm{D}}$ is the Darcy's velocity $\left(\mathrm{L} \mathrm{T}^{-1}\right)$

$\eta$ is the porosity (Dimensionless)

Assuming a porosity range of 0.20 to 0.40 for the fine sands, then the seepage velocity would range from $6.25-12.5 \mathrm{~m} /$ day. Since the simulated soil core is only $1.54 \mathrm{~m}\left(5^{\prime}\right.$ $5 / 8 ")$, the drainage of field capacity in one day can be accomplished under maximum, saturated conditions. Thus, the assumption must be made that the seepage velocity in the vadose zone during rain events must be at least $12-25 \%$ of the velocities found in the saturated zone under similar hydraulic gradients.

Other parameters necessary for simulations can be summarized into three major categories: soil characteristics, hydrology and meteorology, and herbicide characteristics and application. Simulations were performed so that comparisons can be made against results derived from ranges of certain input parameters instead of just single values. By increasing and decreasing the values of certain input parameters, this study would 
illustrate which parameters may have the strongest impact (aside from increasing MSMA applications and/or rates) on the resulting soil concentration profiles. The input parameters that will be varied are: (1) $\mathrm{K}_{\mathrm{d}}$ values , (2) Irrigation, and (3) Hydrodynamic Dispersion. The values for these parameters are discussed in section 3.6. The other parameters that will not vary throughout the simulations will be discussed in the following sections and will be referred to as the "Reference Parameters". Since there are over 120 different input parameters, only the more important ones will be listed.

\subsubsection{Soil Parameters}

Based on the particle size characterization study of the five soils (all classified as sand), and the PRZM-2.0 user's manual recommendations of soil parameters for this type of soil group, the following major soil parameters were used:

$\underline{\text { Parameter }}$

- Total depth of soil core:

- Plant uptake factor:

- Irrigation:

- Fraction of water capacity triggering irrigation:

- Soil surface albedo:

- Reflectivity:

- Ave Temp at water table: $\underline{\text { Value }}$

$154.0 \mathrm{~cm}$

0.2 (ranges are 0.2-0.4 for very soluble herbicides)

Yes, over the canopy, max. rate of $1 \mathrm{~cm} / \mathrm{hr}$ (recommended value)

0.55 (recommended range $0.45-0.55$ )

0.21 (recommended value)

0.96 (recommended value)

$25^{\circ} \mathrm{C}$ (recommended value) 
- Horizons:

- Thickness per horizon:

- Bulk density:

- Initial soil water content:

- Adsorbed, dissolved, vapor decay rate:

- Field capacity:

- Wilting point:

- Organic carbon:
5,1 for each soil type

Top layer first (cm) 14, 42, 30, 40, 28

1.45 (g/cu.cm, recommended value)

0.1 (cu. cm/ cu. cm, recommended value)

0.1 for MSMA, 0.0 for arsenate

0.1 (recommended value)

0.05 (recommended value)

Top Lyr (\%) 0.43, 0.23, 0.01, 0.74, 1.15

\subsubsection{Hydrology Parameters}

The following major hydrology parameters were used for this simulation:

Parameter

- Pan factor:

- Maximum depth evaporation is extracted:

- Maximum interception storage: $0.03 \mathrm{~cm}$ (recommended value)

- Maximum rooting depth:

- Runoff curve number:

- Maximum canopy height:
Value

0.72 (recommended value)

$15 \mathrm{~cm}$
$3 \mathrm{~cm}$

30 (recommended value)

$4 \mathrm{~cm}$

Because the model is based on agronomic systems, the dates of crop emergence, 
maturation and harvest were required. All applications and simulations were performed during maturation of the crop (grass).

Daily meteorological data such as temperature, wind speed, and precipitation were downloaded from the National Climatic Data Center (NCDC, 1998) for the most recent 5 year period without any missing data points; January 1 water year 1988 to December 31 water year 1993. Other parameters such as albedo and evaporation were estimated and calculated respectively (via PRZM-2.0) based on temperatures and daylight hours for the WPBCC (based on longitude). Figure 8 illustrates the hyetograph (from the West Palm Beach International Airport weather station) and MSMA timing and application rates for the water years 1990 (See Appendix A for water years 1988-1993).

\subsubsection{Chemical Parameters}

Chemical parameters necessary for model execution are as follows:

Parameters

- Application dates:

- Application rate:

- Names of Herbicides:

- Depth of application:

- Filtration of herbicide off foliage:

- Henry's Coefficient: $\underline{\text { Values }}$

For each year there are 2 applications (i.e., 3/1/88 and 9/1/89). These dates were chosen since they are the approximate dates used at the WPBCC. Choosing the $6 / 1 / \mathrm{xx}$ application date was important.

$1.85 \mathrm{~kg}$ MSMA/ ha, $0.0 \mathrm{~kg}$ Arsenate $/ \mathrm{ha}$

MSMA, daughter product - arsenate.

$0.0 \mathrm{~cm}$

linear application, nonlinear filtration.

$1.5 \mathrm{E}-14$, calculated: vapor pressure/water solubility 


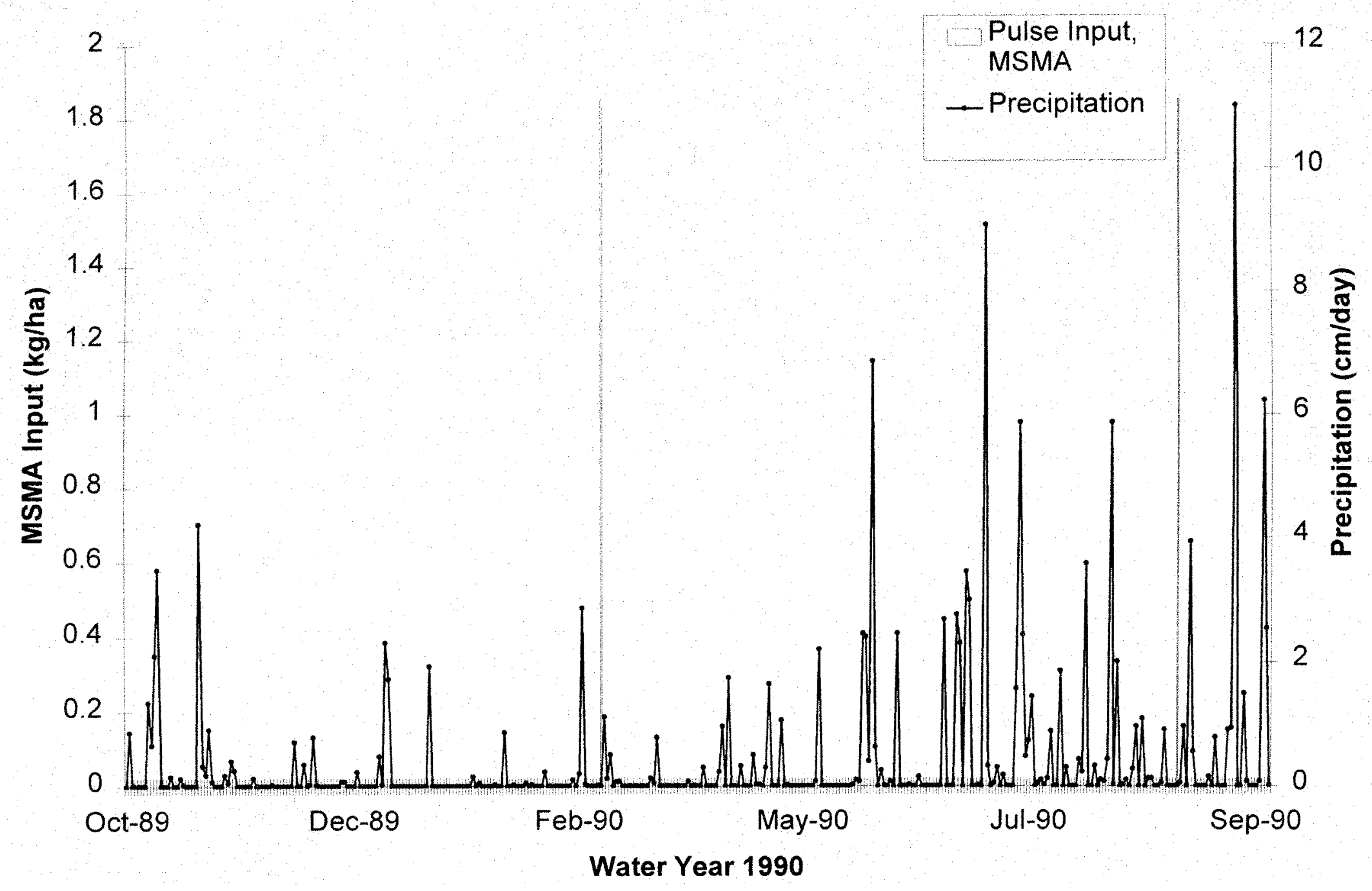

Figure 8. Hyetograph and Input Scheme of MSMA for Water Year 1990. 
- MSMA decay rate:

In summary, the following list presents the major assumptions and conditions that were used for this modeling effort:

- Soil horizons in simulated soil column (water table depth of 5 feet) are proportional and spatially identical to sample site (water table depth of 8 feet).

- Drainage of field capacitance in 24 hours. Thus, seepage velocities are at least $1 / 10-1 / 4$ the theoretical seepage velocities under completely saturated conditions.

- Range of effective dispersion values represent what may happen in field as follows (de Marsily et.al., 1986):

1. Low Dispersion $-100 \mathrm{~cm}^{2} /$ day

2. Medium Dispersion $-1,000 \mathrm{~cm}^{2} /$ day

3. High Dispersion $-10,000 \mathrm{~cm}^{2} /$ day

- MSMA applied twice annually (March, September) at a rate of $1.85 \mathrm{~kg} / \mathrm{ha}$.

- 5 water years (January 1988 to December 1993) of precipitation, daily temperature, and wind speed were acquired from the NCDC.

- Field data was estimated from US EPA PRZM-2.0 User's Manual. Data in manual was compiled based on Soil Conservation Society (SCS) soil hydrologic groups and regional characteristics.

- Laboratory derived $\mathrm{K}_{\mathrm{d}}$ values represent the likely interactions of MSMA and $\mathrm{As}(+5)$ in the sampled soils. 
- $\mathrm{K}_{\mathrm{d}}$ values, irrigation and dispersion coefficients are inputted using a range of values instead of single field average estimates.

\subsection{QA/QC}

All protocols were followed in strict accordance to procedures outlined in Standard Methods (1995) and Batch-Type Procedures for Estimating Soil Adsorption of Chemicals (EPA/530-SW-87-006-F). The various precautionary steps followed for minimum compliance with $\mathrm{QA} / \mathrm{QC}$ requirements are given in this section.

\subsubsection{Sampling, Storage, and Documentation}

- For every sample obtained, field data such as date, depth, sample number, weather conditions, odor, and color were reported (Appendix B).

- For every sample obtained in the field, proper soil storage bags were placed in a cooler for shipment back to the University for long-term storage at $4^{\circ} \mathrm{C}$.

- Duplicates of every sample were sent to FDEP's Chemistry Laboratory located in Tallahassee, Florida via common carrier. Each shipment of samples, both soil and aqueous, were accompanied with chain-of-custody forms, FDEP Laboratory Service request forms, sample description forms, and properly labeled sample containers as listed in FDEP's QA manual mentioned previously (DEP - QA-001/92). (Appendix C).

- Best sample containers (either TFE or polypropylene) were washed with $10 \%$ nitric acid and clearly labeled. 
- Laboratory samples containers were properly labeled with ID \# and stored acidified at $4^{\circ} \mathrm{C}$.

- All arsenic laboratory sample documentation was entered into laboratory notebooks with carbon copies.

- A detailed report will be submitted to the Principle Investigator (US EPA) at the end of the experimentation.

\subsubsection{General Experimental}

- Standard solutions were prepared daily.

- Sorbates were preconditioned before experiments.

- Calibrations for AA analysis were conducted for every set of 18 samples $\left(\mathrm{R}^{2} \geq 0.9800\right.$ for all calibrations) with either sodium arsenate (see materials) or Fisher Scientific As (+3) Atomic Adsorption Standard.

- The microscale was calibrated within the past year (6/97).

- All pH readings were performed after calibrations with buffer solutions (slopes ranged within 58.01-60.11)

- All experiments were conducted in accordance with minimum safety standards, including wearing laboratory coats, gloves, protective eyewear, and long pants.

- All use of acids was performed under a fume hood, and any hazardous material was disposed of properly.

- The following phone number was to be called in case of emergency: (305) 348-2621. 


\subsubsection{Statistical Data Analysis}

All replicates for one sample point were statistically analyzed for purposes of eliminating outliers. An ideal minimum number of replicates necessary for a statistical analysis is three. In some cases, however, experimental error prevented having three replicates for each data point, thus statistical analysis could not be performed for those sets of replicates. Depending upon the number of replicates, Day et al. (1986) states that at least two tests can be applied to remove outliers for the following situations: for the rejection of a single data value from a set of data points, the Q-test can be applied to data sets of 3-5 replicates, and the $4 d$ rule applies to data sets from $4-8$ replicates.

The Q-test will be applied to all data sets containing three replicates, an example of this methodology follows:

1) Calculate the range of the results

2) Find the difference between suspect and nearest neighbor.

\begin{tabular}{|c|c|}
\hline Replicate 1 & 81.03 \\
Replicate 2 & 85.67 \\
Replicate 3 & 92.28 \\
\hline Range & $\mathbf{1 1 . 2 5}$ \\
Diff. from highest value & 6.61 \\
Q value & 0.59 \\
Diff. from lowest & $\mathbf{4 . 6 4}$ \\
Q value & 0.41 \\
\hline Modified Mean & 86.33 \\
\hline
\end{tabular}

3) Divide the difference obtained from step 2 by the range in step 1 to obtain rejection quotient, $\mathrm{Q}$.

\begin{tabular}{|c|c|}
\hline Replicate 1 & 81.03 \\
Replicate 2 & 85.67 \\
Replicate 3 & 92.28 \\
\hline Range & 11.25 \\
Diff. from highest value & 6.61 \\
Q value & $\mathbf{0 . 5 9}$ \\
Diff. from lowest & 4.64 \\
Q value & 0.41 \\
\hline Modified Mean & 86.33 \\
\hline
\end{tabular}


4) If the $Q$ value is $>0.94$, then the result can be discarded with $90 \%$ confidence that there was some factor that did not operate on the other results.

For the case of rejecting one outlier from a group of 4 to 8 using the $4 d$ rule, the method is outlined below, Day et al. (1986):

1) Compute the mean and the standard deviation of the "good" data.

2) Find the deviation of the suspected result from the mean of the "good" ones.

3) If the deviation of the suspected result from the mean of the good data is larger than 4 standard deviations (calculated from the good data) away, then the result must be rejected.

\begin{tabular}{|c|c|}
\hline Replicates & Sample Data set \\
\hline 1 & $*$ \\
2 & 47.88 \\
3 & 50.94 \\
4 & 51.22 \\
5 & 52.35 \\
\hline Suspect value & $\mathbf{4 7 . 8 8}$ \\
Mean "good" data & $\mathbf{5 1 . 5 0}$ \\
Std. Deviation & $\mathbf{0 . 7 5}$ \\
\# of standard & $\mathbf{4 . 8 5}$ \\
deviations away & discard \\
Actions (4d rule) & 51.50 \\
Modified Mean & \\
\hline
\end{tabular}

* Denotes a known experimental error, thus can be discarded.

See Appendix C for sample calculations.

\subsubsection{Replicability}

Replicability is an important experimental factor. The ability to verify laboratory 
or field data confirms that the experimental conditions involved do not vary enough to bias or scatter the data. Replicability needs to be established for two areas - in the experimental design and procedure and the analytical methods and procedures. The replicability of the data, based on the experimental design, has been satisfactorily established and confirmed through the use of the Q-Test and the $4 d$ rule.

The replicability of the analysis and all associated analytical methods, such as digesting a sample for Total Recoverable As, must be determined. Smith et al. (FDEP, 1997) found that the analysis of arsenic can be variable from laboratory to laboratory.

The FDEP Laboratory also analyzed the FIU samples to help establish the replicability of the analytical methods associated with determining Total Recoverable As. Fifty-seven of the samples were compared against the same analyses performed at FIU. Figure 9 illustrates that approximately $84 \%$ of the data ( 26 samples from $2^{\text {nd }}$ kinetics data) was within $\pm 6.34 \%$ of each other once the correction was made for the minor differences in analyzing FIU's standards. Corrections to the FDEP values were accomplished by adding the difference between FDEP and FIU analysis of the same standard used for FIU analysis. The small, but noticeable, shift in sensitivity most likely would have been negligible if the FDEP Laboratory used the FIU standards to calibrate their equipment or visa versa. The same standard was analyzed by both laboratories (Figure 10) and was extremely comparable ( $R^{2}$ of 0.9996 versus 0.9958 ). Another set of samples (31 samples from experiment 2, See Appendix A) were analyzed for replicability and found that approximately $71 \%$ of the samples were within $\pm 6.95 \%$ of each other after corrections, as stated earlier were made to differences in analysis of FIU standard. The standard used 


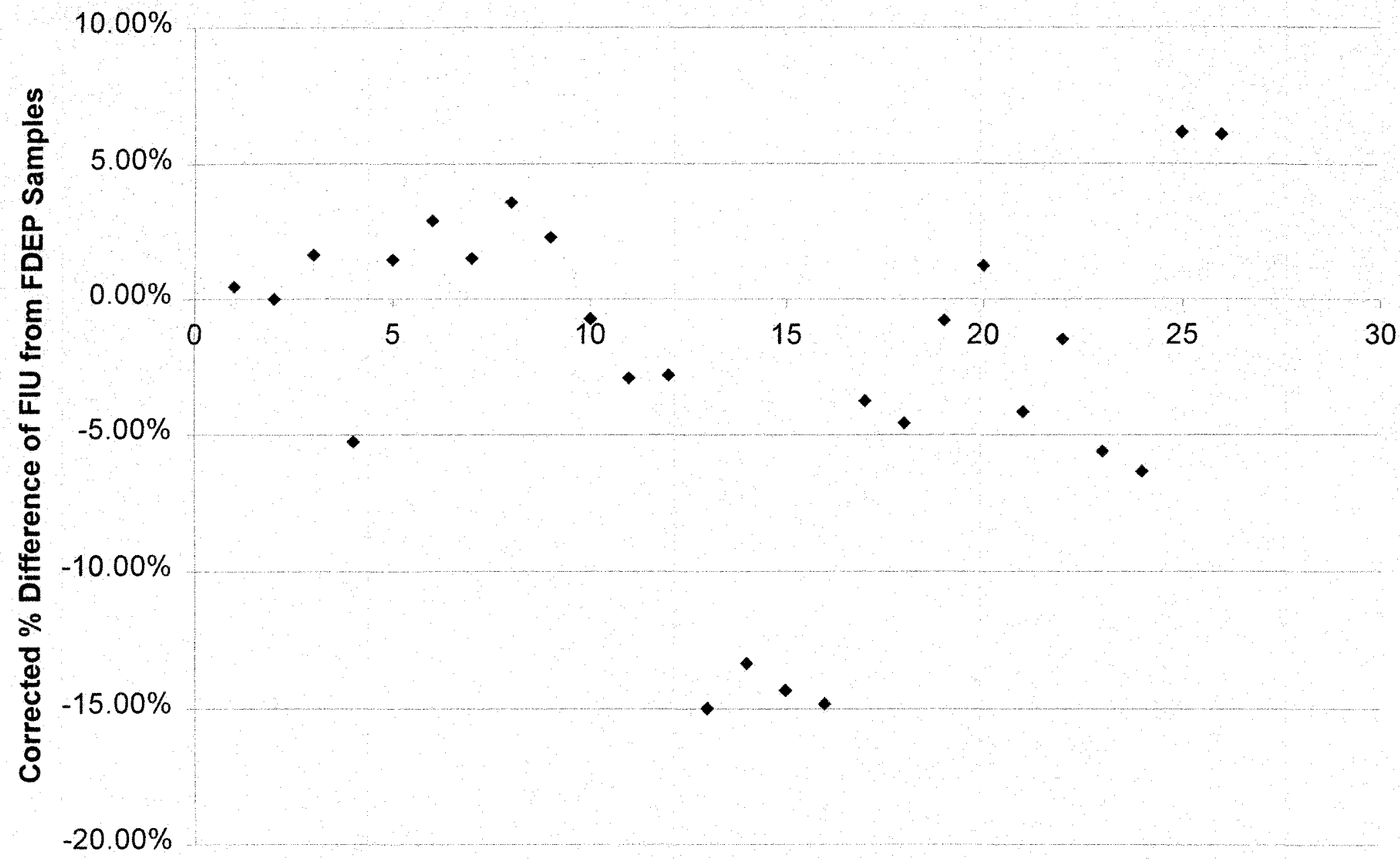

Number of Samples, Kinetics Experiments

Figure 9. Difference of Corrected FIU Arsenic Analysis from FDEP Arsenic Analysis on Initial Kinetics Experiments. 


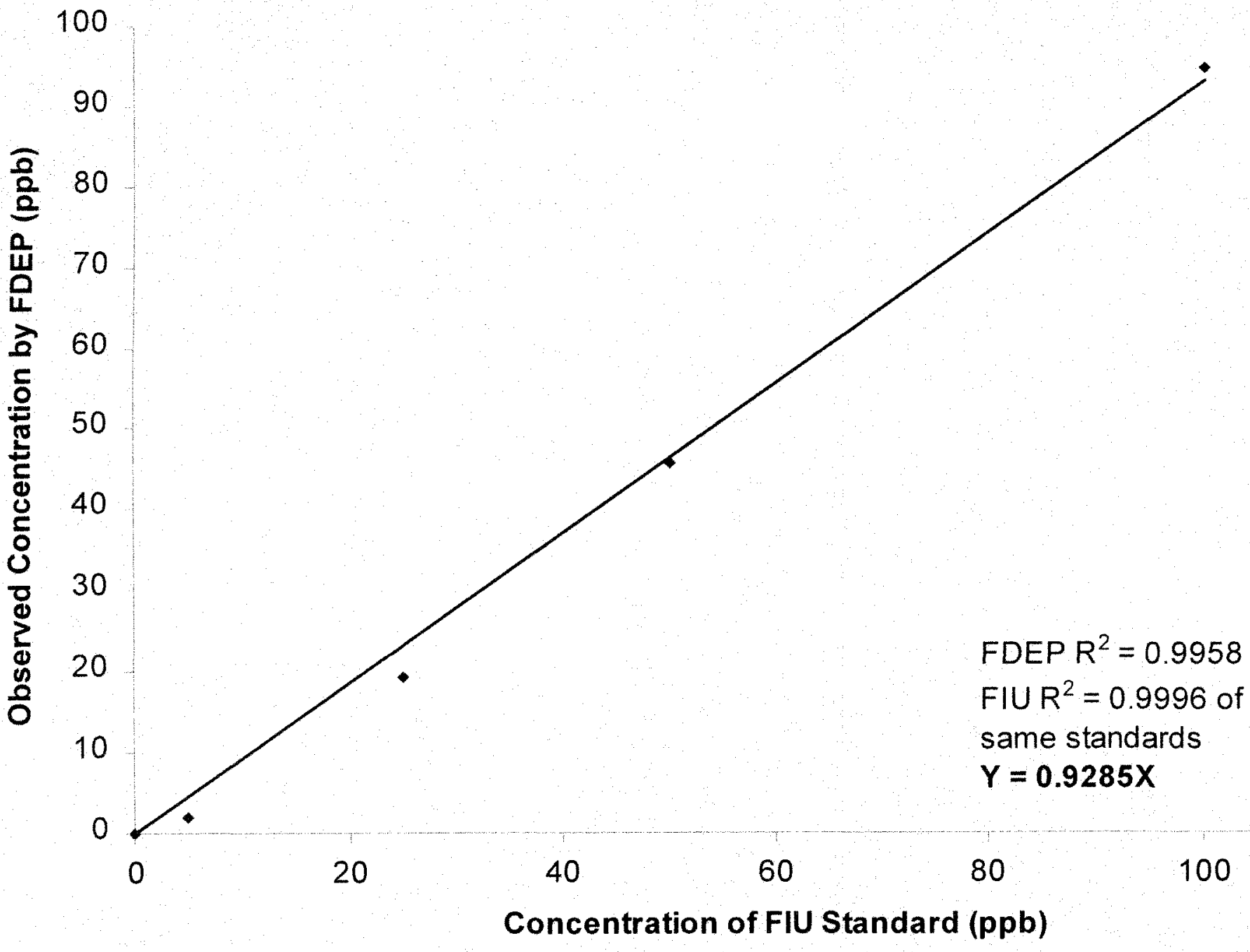

Figure 10. Observed Concentrations of FIU Standards by FDEP Analysis. 
for FIU analysis of experiment 2 samples was analyzed by the FDEP Laboratory and found to comparable ( $R^{2}$ of 0.9987 versus 0.9902$)$. Thus, the replicability of the analytical procedures for this work have been satisfactorily established and confirmed by an outside laboratory. Recovery measurements of the inorganic form of arsenic (using As +3, AA standard), as seen in Table 3 when comparing column 1 versus 2 , show that a loss in sample occurred during digestion. Since each sample was transferred to several different pieces of glassware, an average of $3.8 \%$ in recovery loss was observed. The calibration for all analysis in Table 3 were performed using As +5 , as sodium arsenate, thus an additional $3 \%$ of sample recovery was lost (by comparing the recovered As +3 average to the $50 \mathrm{ppb}$ As +5 standard) due to the incomplete conversion of $\mathrm{As}+5$ to As +3 resulting in lowered instrument sensitivity. When comparing the recovery of MSMA against As +3 , column 3 versus column 1 , the values are within $1.6 \%$ of each other, and can be considered negligible.

\subsection{Experimental Design}

Five (5) sets of laboratory experiments were conducted to accomplish the major goal of this thesis. Table 4 presents a detailed matrix of the experimental work performed. The following is a summary of the major experimental categories:

- Experiments 1 and 5 characterize the soils for particle size distribution, and TOC. Analysis of Total Phosphorus, and Total Recoverable As and Fe were conducted by

- the FDEP-SED. This data helped establish background As levels and parameter 
TABLE 3. REPLICABILITY AND RECOVERY OF As(+3) ATOMIC ADSORPTION STANDARD AND MSMA.

\begin{tabular}{|c|c|c|c|}
\hline Replicates & $\begin{array}{c}\text { Equilibrium } \\
\text { concentration after } \\
\text { initial at } 50 \mathrm{ppb} \\
\text { digested } \mathrm{As}(+3) \\
\text { reference solution }\end{array}$ & $\begin{array}{c}\text { Equilibrium } \\
\text { concentration after } \\
\text { initial at } 50 \mathrm{ppb} \\
\text { undigested } \mathrm{As}(+3) \\
\text { reference solution }\end{array}$ & $\begin{array}{c}\text { Equilibrium } \\
\text { concentration after } \\
\text { initial at 50ppb } \\
\text { digested MSMA }\end{array}$ \\
\hline 1 & $*$ & 45.06 & 48.71 \\
\hline 2 & 47.88 & 52.96 & 51.90 \\
\hline 3 & 50.94 & 52.98 & 52.14 \\
\hline 4 & 51.22 & 53.99 & 53.14 \\
\hline 5 & 52.35 & 54.23 & 55.54 \\
\hline Suspect value & 47.88 & 45.06 & 55.54 \\
\hline Mean "good" data & 51.50 & 53.54 & 51.47 \\
\hline Std. Deviation & 0.75 & 0.67 & 1.92 \\
\hline \# of ave dev. away & 4.85 & 12.74 & 2.12 \\
\hline Actions (4d rule) & discard & discard & retain \\
\hline Modified Mean & 51.50 & 53.54 & 52.29 \\
\hline
\end{tabular}

* Denotes a known experimental error, thus can be discarded. 
TABLE 4. EXPERIMENTAL MATRIX TABLE.

\begin{tabular}{|c|c|c|c|}
\hline Experiment & Variables & $\begin{array}{l}\text { Other variables } \\
\text { tested }\end{array}$ & Purpose \\
\hline 1 & All 5 soils & & $\begin{array}{l}\text { 1) Sampling } \\
\text { 2) Characterize all } 5 \text { soils: } \\
\text { particle size } \\
\text { distributions. }\end{array}$ \\
\hline 2 & As $(+5)$ & Temperature & $\begin{array}{c}\text { Adsorption tests, } 5 \text { soils } \\
\text { and with } 6 \text { concentrations: } \\
(10,50,100,200) \text { ppb \& } \\
(1,5) \text { pppm }\end{array}$ \\
\hline 3 & As $(+5)$ & $\begin{array}{c}\text { Temperature, } \\
\mathrm{pH}\end{array}$ & $\begin{array}{l}\text { Perform replicates of } \\
\text { experiment } 2\end{array}$ \\
\hline 4 & MSMA & $\begin{array}{c}\text { Temperature, } \\
\text { pH }\end{array}$ & $\begin{array}{l}\text { Adsorption tests, } 5 \text { soils } \\
\text { and with } 4 \text { concentrations: } \\
(10,50,100,200) \mathrm{ppb}\end{array}$ \\
\hline 5 & All 5 soils & & $\begin{array}{l}\text { Characterize all } 5 \text { soils: } \\
\text { Total Organic Carbon }\end{array}$ \\
\hline
\end{tabular}


- estimations for use in PRZM-2.0

- Experiments 2,3, and 4 develop the partitioning coefficients, $K_{d}$, for each soil. Partitioning coefficients were used in the modeling simulations with PRZM-2.0.

- These partitioning coefficients will also be able to be used for similar soils (that match in particle size, mineral, and organic content) when modeling MSMA or $\operatorname{As}(+5)$.

In addition to the experimental work, computer modeling was performed to simulate the impact of MSMA at the vadose zone/water table interface under conditions where it may be used. Modeling will attempt to simulate fate and transport in subsurface zones using the physicochemical parameters determined in the laboratory for MSMA, As(+5), and the soil characteristics found at the West Palm Beach Country Club sample site. Table 5 shows the matrix for all computer simulations. All Reference Parameters are those defined in sections 3.4.6.1 - 3.4.6.3, and the other parameters that vary are defined in the matrix table. 
TABLE 5. MATRIX OF MODELING SCENARIOS ${ }^{1}$.

\begin{tabular}{|c|c|c|c|c|}
\hline \multirow{2}{*}{ Scenario } & \multirow{2}{*}{ Input Mode } & \multicolumn{2}{|c|}{ Parameters } & \multirow[t]{2}{*}{ Purpose/Comments } \\
\hline & & Reference & \begin{tabular}{|l|} 
Variable \\
\end{tabular} & \\
\hline 1 & $\begin{array}{c}\text { 2 Chemicals: } \\
\text { MSMA/As(+5) } \\
\text { (Input/Metabolite), } 5 \\
\text { Horizons, Irrigation, } \\
\text { Precipitation }\end{array}$ & $\begin{array}{c}\text { See Chapter } \\
3\end{array}$ & $\begin{array}{l}100 \% \mathrm{~K}_{\mathrm{d}} ; \mathrm{D}=1.0 \\
\mathrm{~m}^{2} / \mathrm{day} ; \text { irrigate } \\
\text { @ } 50 \% \theta\end{array}$ & $\begin{array}{l}\text { Illustrates the effect of } \\
\text { an average } \mathrm{K}_{\mathrm{d}}^{2}, \\
\text { irrigate }^{3} \text {, and a high } \mathrm{D}^{4} .\end{array}$ \\
\hline 2 & $\begin{array}{l}2 \text { Chemicals: } \\
\text { MSMA/As(+5) } \\
\text { (Input/Metabolite), } 5 \\
\text { Horizons, Irrigation, } \\
\text { Precipitation }\end{array}$ & $\begin{array}{c}\text { See Chapter } \\
3\end{array}$ & $\begin{array}{l}100 \% \mathrm{~K}_{\mathrm{d}} ; \mathrm{D}=0.1 \\
\mathrm{~m}^{2} / \text { day; irrigate } \\
\text { @ a } 5 \theta \% \theta\end{array}$ & $\begin{array}{l}\text { Illustrates the effect of } \\
\text { an average } K_{d} \text {, Irrigate, } \\
\text { and } D .\end{array}$ \\
\hline 3 & $\begin{array}{c}2 \text { Chemicals: } \\
\text { MSMA/As }(+5) \\
\text { (Input/Metabolite), } 5 \\
\text { Horizons, Irrigation, } \\
\text { Precipitation } \\
\end{array}$ & $\begin{array}{c}\text { See Chapter } \\
3\end{array}$ & $\begin{array}{c}100 \% \mathrm{~K}_{\mathrm{d}} ; \mathrm{D}= \\
0.01 \mathrm{~m}^{2} / \text { day; } \\
\text { irrigate @ } 50 \% \theta\end{array}$ & $\begin{array}{l}\text { Illustrates the effect of } \\
\text { an average } K_{d} \text {, irrigate, } \\
\text { and a low D. }\end{array}$ \\
\hline 4 & $\begin{array}{c}2 \text { Chemicals: } \\
\text { MSMA/As }(+5) \\
\text { (Input/Metabolite), } 5 \\
\text { Horizons, Irrigation, } \\
\text { Precipitation } \\
\end{array}$ & $\begin{array}{c}\text { See Chapter } \\
3\end{array}$ & $\begin{array}{c}150 \% \mathrm{~K}_{\mathrm{d}} ; \mathrm{D}=0.1 \\
\mathrm{~m}^{2} / \mathrm{day} ; \text { irrigate } \\
@ 50 \% \theta\end{array}$ & $\begin{array}{l}\text { Illustrates the effect of } \\
\text { an average D, irrigate, } \\
\text { and a high Kd. }\end{array}$ \\
\hline 5 & $\begin{array}{c}\text { 2 Chemicals: } \\
\text { MSMA/As(+5) } \\
\text { (Input/Metabolite), } 5 \\
\text { Horizons, Irrigation, } \\
\text { Precipitation }\end{array}$ & $\begin{array}{c}\text { See Chapter } \\
3\end{array}$ & $\begin{array}{l}25 \% \mathrm{~K}_{\mathrm{d}} ; \mathrm{D}=0.1 \\
\mathrm{~m}^{2} / \text { day; irrigate } \\
\text { @ a } 50 \% \theta\end{array}$ & $\begin{array}{l}\text { Illustrates the effect of } \\
\text { an average } D \text {, irrigate, } \\
\text { and a low } K_{d} \text {. }\end{array}$ \\
\hline 6 & $\begin{array}{c}\text { 2 Chemicals: } \\
\text { MSMA/As(+5) } \\
\text { (Input/Metabolite), } 5 \\
\text { Soil Horizons, Irrigation, } \\
\text { Precipitation }\end{array}$ & $\begin{array}{c}\text { See Chapter } \\
3\end{array}$ & $\begin{array}{l}100 \% \mathrm{~K}_{\mathrm{d}} ; \mathrm{D}=0.1 \\
\mathrm{~m}^{2} / \text { day; irrigate } \\
\text { @ } 85 \% \theta\end{array}$ & $\begin{array}{l}\text { Illustrates the effect of } \\
\text { an average } K_{d}, D \text {, and } \\
\text { high irrigate. }\end{array}$ \\
\hline 7 & $\begin{array}{c}2 \text { Chemicals: } \\
\text { MSMA/As }(+5) \\
\text { (Input/Metabolite), } 5 \\
\text { Horizons, Irrigation, } \\
\text { Precipitation }\end{array}$ & $\begin{array}{c}\text { See Chapter } \\
3\end{array}$ & $\begin{array}{c}100 \% \mathrm{~K}_{\mathrm{d}}: \mathrm{D}=0.1 \\
\mathrm{~m}^{2} / \text { day; irrigate @ } \\
15 \% \theta\end{array}$ & $\begin{array}{l}\text { Illustrates the efffect of } \\
\text { an average } K_{d}, D \text { and a } \\
\text { low irrigate. }\end{array}$ \\
\hline 8 & $\begin{array}{c}\text { 2 Chemicals: } \\
\text { MSMA/As }(+5 \text { ) } \\
\text { (Input/Metabolite), } 5 \\
\text { Horizons, Precipitation }\end{array}$ & $\begin{array}{c}\text { See Chapter } \\
3\end{array}$ & $\begin{array}{c}100 \% \mathrm{~K}_{\mathrm{d}}: \mathrm{D}=0.1 \\
\mathrm{~m}^{2} / \text { day; No } \\
\text { irrigation }\end{array}$ & $\begin{array}{l}\text { Illustrates the efffect of } \\
\text { an average } K_{d}, D \text { no } \\
\text { irrigation. }\end{array}$ \\
\hline
\end{tabular}

${ }^{1}$ Average monthly temperature of bottom boundary soil $=25^{\circ} \mathrm{C}$

${ }^{2} \mathbf{K}_{\mathbf{d}}=$ Chemical Soil-Water Partitioning Coefficient.

${ }^{3}$ Irrigate @ 50\% $\theta$ = Irrigation triggerred when soil moisture content is [.5(field capacity - wilting point)]

${ }^{4} \mathbf{D}=$ Effective dispersion, (molecular dispersion + hydrodynamic dispersion) 
There are 4 major sections of this chapter that are intended to present the findings, compare results against other published studies (if any), and to discuss any significant correlations. In this order, the four sections are:

\section{$\S 4.1$ - Experiments 1 and 5 \\ $\$ 4.2$ - Experiments 2 and 3 \\ $\S 4.3-$ Experiment 4 \\ $\S 4.4$ - Computer Simulations}

\subsection{Experiments 1 and 5}

Soil samples were successfully acquired from the West Palm Beach Country Club, located at 7001 Parker Avenue, West Palm Beach, FL on November $4^{\text {th }}$, 1997 (See Appendix A for Map). The samples were taken 100 feet NW from the $1^{\text {st }}$ hole green, in between the edge of the $1^{\text {st }}$ hole rough and a small forest-type area. There appeared to be 4 distinct soil horizons from which 5 representative samples were taken at even intervals. Each horizon consisted predominantly ( $99 \%$ by wt) of sands (See Appendix A). The uppermost sample $\left(4^{\prime \prime}-9^{\prime \prime}\right)$ consisted of a grayish colored sand with small pieces of decaying root material. The second sample (1'2" - 1'11") appeared to be identical in color and composition to the uppermost sample, except much less root material. Soil 3 (3'6'$\left.4^{\prime} 6^{\prime \prime}\right)$ had a light cream colored appearance, void of organic matter or any other mineral coating (by inspection) and root material. Soil $4\left(5^{\prime} 6^{\prime \prime}-7^{\prime} 0^{\prime \prime}\right)$ was dark brown with a 
strong humic smell. Soil $5\left(7^{\prime} 6^{\prime \prime}-8^{\prime} 10^{\prime \prime}\right)$ appeared to be a rusty orange color. Part of this sample was actually at or below the water table. Water could be seen at the bottom of the core which was approximately $8^{\prime} 0^{\prime \prime}-8^{\prime} 6^{\prime \prime}$. Samples were immediately packed for transport back to FIU (Refer to Appendix C for Field Sample Data Sheets).

Results from the particle size analysis by sieving are presented in Figure 11. The majority of the sand particles (from $50.6 \%$ to $58.05 \%$ ) for each soil fraction were between $0.25 \mathrm{~mm}$ and $0.425 \mathrm{~mm}$, which can be classified as a fine sand. Soil 5 had the highest percentage $(0.4 \%)$ of particles less than $0.075 \mathrm{~mm}$ which was twice as much as the next closest, soil $1(0.2 \%)$.

According to the FDEP chemical analysis of the soils used in this study, it is clear that As levels are below detection limits (See Table 6). These As background concentrations also compare well against experimental results (Appendix A - Table 13). Thus, arsenic is not considered present in enough quantity to influence the results presented in this thesis. For all intents and purposes As concentrations in the soil are classified as negligible. Though the samples expired according to FDEP QA/QC standards (ice melted in shipping coolers before arrival to FDEP Laboratory), the reported concentrations increased with depth within the soil profile (Table 6). This increase is significant in that arsenic behaves in the natural environment much like $\mathrm{P}$ does. If there are large amounts of $\mathrm{P}$ lower in the soil column, then arsenic mobility would be enhanced the lower it travels vertically. There is also a large concentration of Iron $(\mathrm{Fe})$ in soil 5 . This may be attributed to iron oxides that are rather soluble and have accumulated due the close proximity of the fluctuating water table. This layer of Fe may actually act as barrier to As( +5$)$ transport since it may bind strongly to iron oxides. 


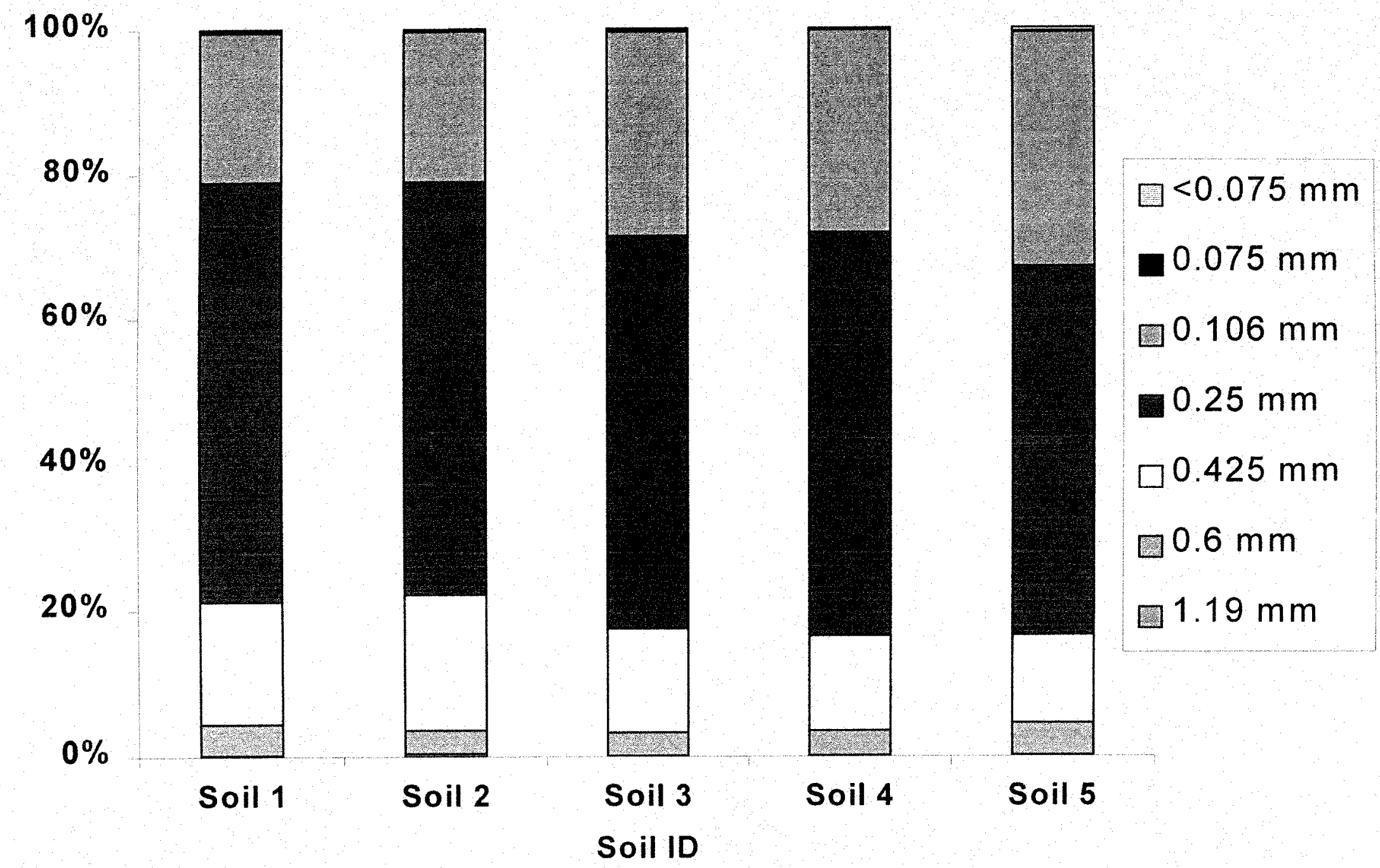

Figure 11. Bar Graph of Percentages For Each Range of Particle Sizes For All 5 Soils. 
TABLE 6. SUMMARY OF VITAL SOIL CHARACTERISTICS.

\begin{tabular}{|c|ccccc|}
\hline Analysis & Soil 1 & Soil 2 & Soil 3 & Soil 4 & Soil 5 \\
\hline Arsenic & $0.5 \mathrm{mg} / \mathrm{kg}{ }^{* *}$ & $0.5 \mathrm{mg} / \mathrm{kg} * *$ & $0.4 \mathrm{mg} / \mathrm{kg}^{*}$ & $0.7 \mathrm{mg} / \mathrm{kg} * *$ & $0.7 \mathrm{mg} / \mathrm{kg}^{* *}$ \\
Iron $^{1}$ & $233 \mathrm{mg} / \mathrm{kg}$ & $237 \mathrm{mg} / \mathrm{kg}$ & $43.5 \mathrm{mg} / \mathrm{kg}$ & $34.5 \mathrm{mg} / \mathrm{kg}$ & $1530 \mathrm{mg} / \mathrm{kg}$ \\
$\begin{array}{c}\text { Total-P } \\
\text { OOC }^{2}\end{array}$ & $32 \mathrm{mg} / \mathrm{kg}$ & $32 \mathrm{mg} / \mathrm{kg}$ & $4.8 \mathrm{mg} / \mathrm{kg}$ & $120 \mathrm{mg} / \mathrm{kg}$ & $390 \mathrm{mg} / \mathrm{kg}$ \\
$\begin{array}{c}\text { Aluminum } \\
\text { Equilibrated }\end{array}$ & $0.43 \%$ & $0.23 \%$ & $0.01 \%$ & $0.74 \%$ & $1.15 \%$ \\
$\begin{array}{c}\text { pH of Soil } \\
\text { Blank }\end{array}$ & 6.77 & 6.72 & 6.24 & 6.85 & 6.57 \\
$\begin{array}{c}\text { Equilibrated As } \\
\text { concentration } \\
\text { of Soil Blank }\end{array}$ & BDL & BDL & BDL & BDL & BDL \\
\hline
\end{tabular}

* Material was analyzed for but not detected. The value reported is the minimum detection limit (FDEP Chemical Analysis Report, see Appendix E).

** Value reported is less than the minimm quantitation limit, and greater than or equal to the minimum detedtion limit (FDEP Chemical Analysis Report, see Appendix E).

$x \quad$ Aluminum analysis not available at time of thesis write up.

1 Analysis (Total Recoverable - As \& Fe) performed by FDEP.

2 Analysis performed by FIU.

BDL Below Limit of Detection $(1.0 \mu \mathrm{g} / \mathrm{L})$. 
Table 6 and the following summarize soil characteristics:

- High P levels which may enhance inorganic arsenic transport (Davenport et.al., 1991). However, high Fe content in the lowermost horizon may influence sorption at the water table interface (Stumm et.al., 1987, Aly et. al., 1993, Masscheleyn et.al., 1991, Onken et.al., 1995, Raven et.al., 1998).

- Soils are very low in organic matter content (values range from $0.01 \%$ to $1.15 \%$ ) which may be a controlling factor in the fate and transport of MSMA (organic contaminants) and As(+5) (Valsaraj et. al., 1995).

- Total Recoverable As was not detected higher than the anticipated background levels of $5 \mathrm{mg} / \mathrm{kg}$. The site of the sampling may have been in an area where MSMA was probably never applied.

- The soil profile is mostly sand. It is very likely that the soil drains well, thus may enhance transport of contaminants.

\subsection{Experiments 2 and 3}

Adsorption tests were completed over two separate trials. Data was combined together so that the Q-test could be applied for statistical analysis. "Modified Means" (resulting statistical means after applying the Q-Test) for each data point were successfully used in applying Linear, Freundlich and Langmuir isotherms. Figure 12 summarizes the adsorption of $\mathrm{As}(+5)$ to all five of the soils using the Linear isotherm. It is apparent that soil 5 has the strongest affinity for arsenate. As mentioned in Chapter 2, iron and aluminum oxides, and organic matter control the solubility of arsenate in aqueous systems via sorption. From this data, soil 5 would have the strongest tendency 


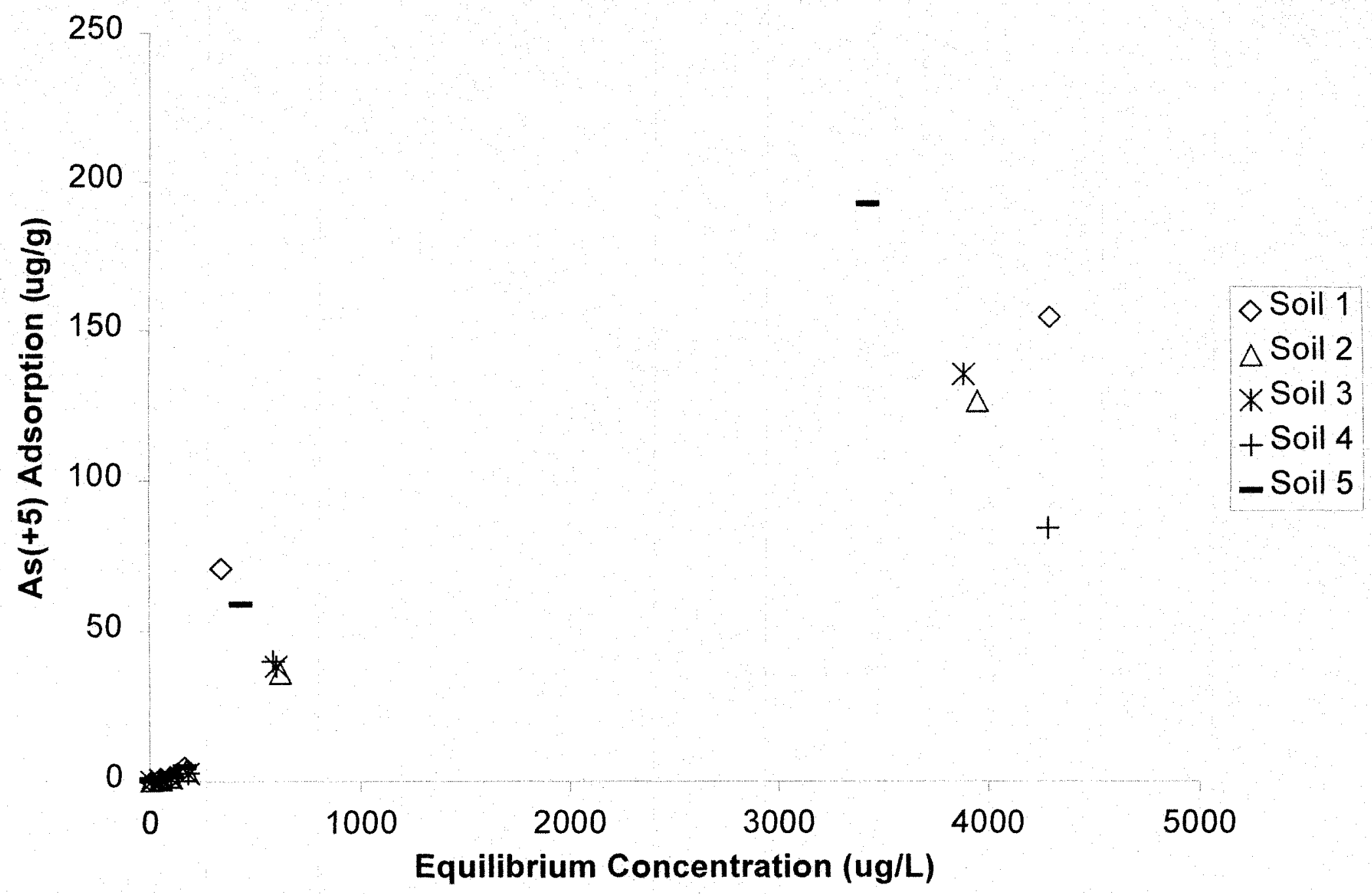

Figure 12. As(+5) Adsorption @ $22.48^{\circ} \mathrm{C}$, Soil:pH: 1:6.37, 2:6.38, 3:6.07, 4:6.47, 5:6.52. 
TABLE 7. SUMMARY OF BEST-FITTED ISOTHERM PARAMETERS (22.48 gC).

\begin{tabular}{|c|cc|ccc|ccc|c|}
\hline \multicolumn{10}{|c}{ As (+5) } \\
\cline { 2 - 10 } & \multicolumn{4}{c|}{ Linear } & \multicolumn{4}{c|}{ Freundlich } & \multicolumn{4}{c|}{ Langmuir } \\
\hline Soil & $\mathrm{K}_{\mathrm{d}}$ & $\mathrm{R}^{2}$ & $\mathrm{~K}_{\mathrm{f}}$ & $1 / \mathrm{n}$ & $\mathrm{R}^{2}$ & $\mathrm{~K}_{\mathrm{L}}$ & $\mathrm{M}$ & $\mathrm{R}^{2}$ & $\mathrm{pH}$ \\
\hline 1 & 0.0741 & 0.8262 & 0.025 & 1.197 & 0.8943 & 0.00067 & 57.8 & 0.9988 & 6.37 \\
2 & 0.0652 & 0.9791 & 0.0257 & 1.1256 & 0.9623 & 0.0074 & 9.852 & 0.9677 & 6.38 \\
3 & 0.0709 & 0.9779 & 0.0133 & 1.2205 & 0.9626 & 0.00092 & 33.22 & 0.9982 & 6.07 \\
4 & 0.0410 & 0.8646 & 0.0303 & 1.0633 & 0.9265 & 0.0077 & 7.2 & 0.9561 & 6.47 \\
5 & 0.2295 & 0.9575 & 0.2318 & 0.9736 & 0.8721 & 0.0419 & 14.79 & 0.7143 & 6.52 \\
\hline
\end{tabular}

$$
\begin{aligned}
& \mathrm{K}_{\mathrm{d}} \text { units }=(\mathrm{L} / \mathrm{g}) \\
& \mathrm{K}_{\mathrm{f}} \text { units }=(\mathrm{L} / \mathrm{g}) \\
& \mathrm{K}_{\mathrm{L}} \text { units }=(\mathrm{L} / \mu \mathrm{g}) \\
& \mathrm{M} \text { units }=(\mu \mathrm{g} / \mathrm{g})
\end{aligned}
$$


to sorb arsenate. Table 7 confirms that soil 5 has the highest partitioning coefficient of all the soils.

In evaluating the best isotherm fit, it appears that the adsorption for both contaminants follows linearity ( $\mathrm{R}^{2}$ ranges from 0.7143 to 0.9988 for $\mathrm{As}(+5)$ ). Though, values for the Freundlich $1 / \mathrm{n}$ term ranges from 0.9736 to 1.2205 , the adsorption behavior can be said to be semi-linear $(1 / n=1$ implies linearity). Figures $13-17$ show the best fitting of the three isotherms for each soil (summarized from Table 7). For 3 of the 5 soils the Langmuir isotherm best described the partitioning of the arsenate:soil system. Langmuir implies monolayer accumulation and is usually driven by electrostatic forces (especially for ionized species). As a possible indicator of this behavior, soils 1 through 4 had approximately $3-5$ times less Fe content than soil 5 and consequently had $\mathrm{K}_{\mathrm{d}}$ values 3 to 5 times lower than soil 5 (comparing Tables 6, 7, and 8). Thus, the contaminant:soil system may in fact be electrostatically controlled. There appears to be no correlation between the soil TOC contents and their respective $K_{d}$ values.

In summary, $\mathrm{K}_{\mathrm{d}}$ values for arsenate adsorption to the five soils were successfully determined. The following summarizes the results of these experiments:

- Comparing another study, Darland et al. (1997) found the following Langmuir adsorption parameters of an arsenate/homogeneous single sand system in the presence of phosphorus:

$$
134 \mu \mathrm{M} \text { initial } \mathrm{P} \quad \mathrm{M}=112 \mu \mathrm{mol} / \mathrm{kg} \quad \mathrm{K}_{\mathrm{L}}=0.21 \mathrm{~L} / \mu \mathrm{mol}
$$

this study found a range of sorption parameters, primarily due to the heterogeneity of the sands types used, in the presence of phosphorus:

$$
3 \mu \mathrm{M} \text { initial } \mathrm{P} \quad \mathrm{M}=7.2-57.8 \mu \mathrm{mol} / \mathrm{kg} \quad \mathrm{K}_{\mathrm{L}}=0.0089-0.559 \mathrm{~L} / \mu \mathrm{mol}
$$




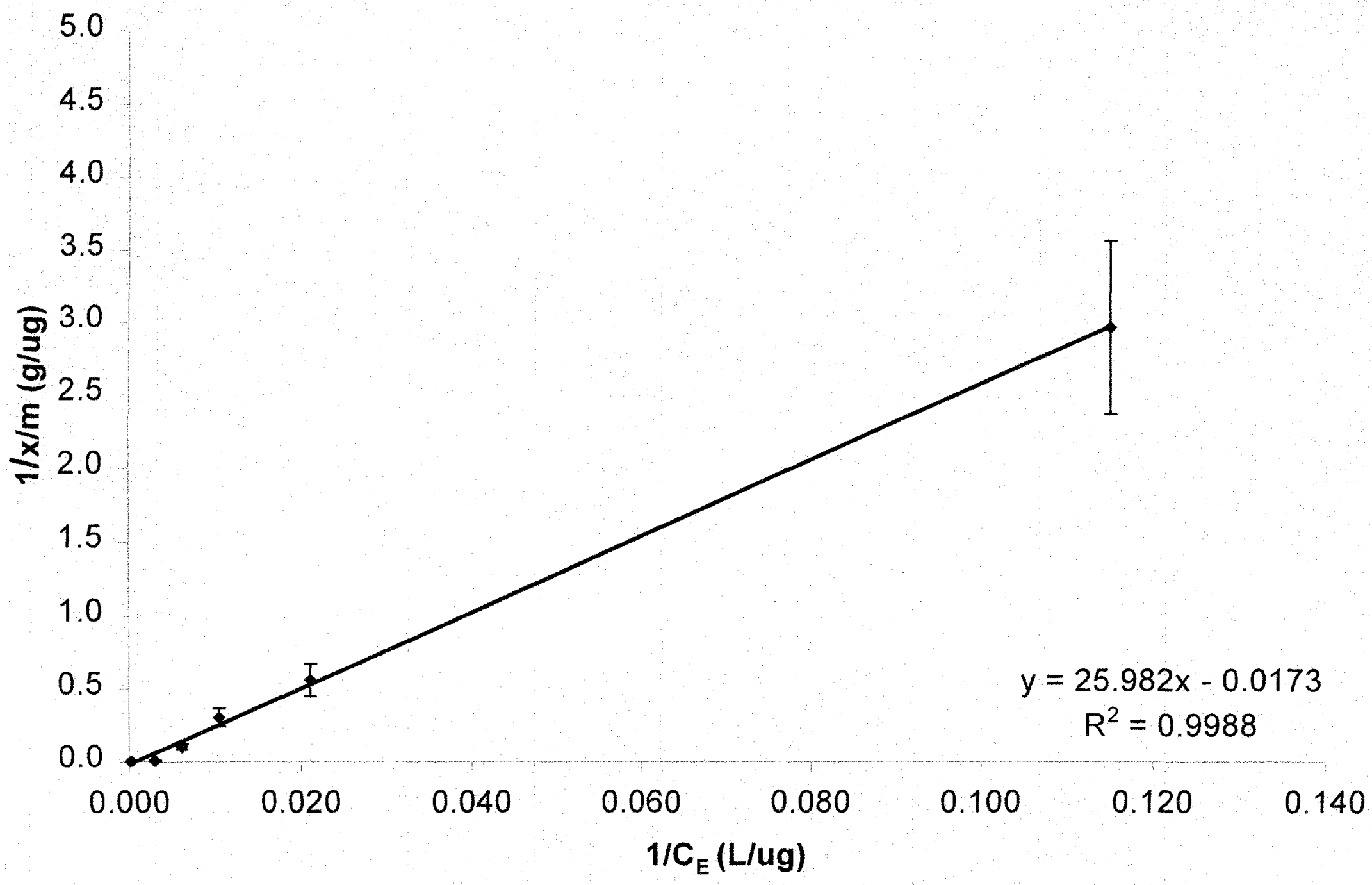

Figure 13. Langmuir Isotherm for the As( $(+5)$, Soil 1 System @ $22.48^{\circ} \mathrm{C}$ (Experimental error $\pm 20 \%$ ). 


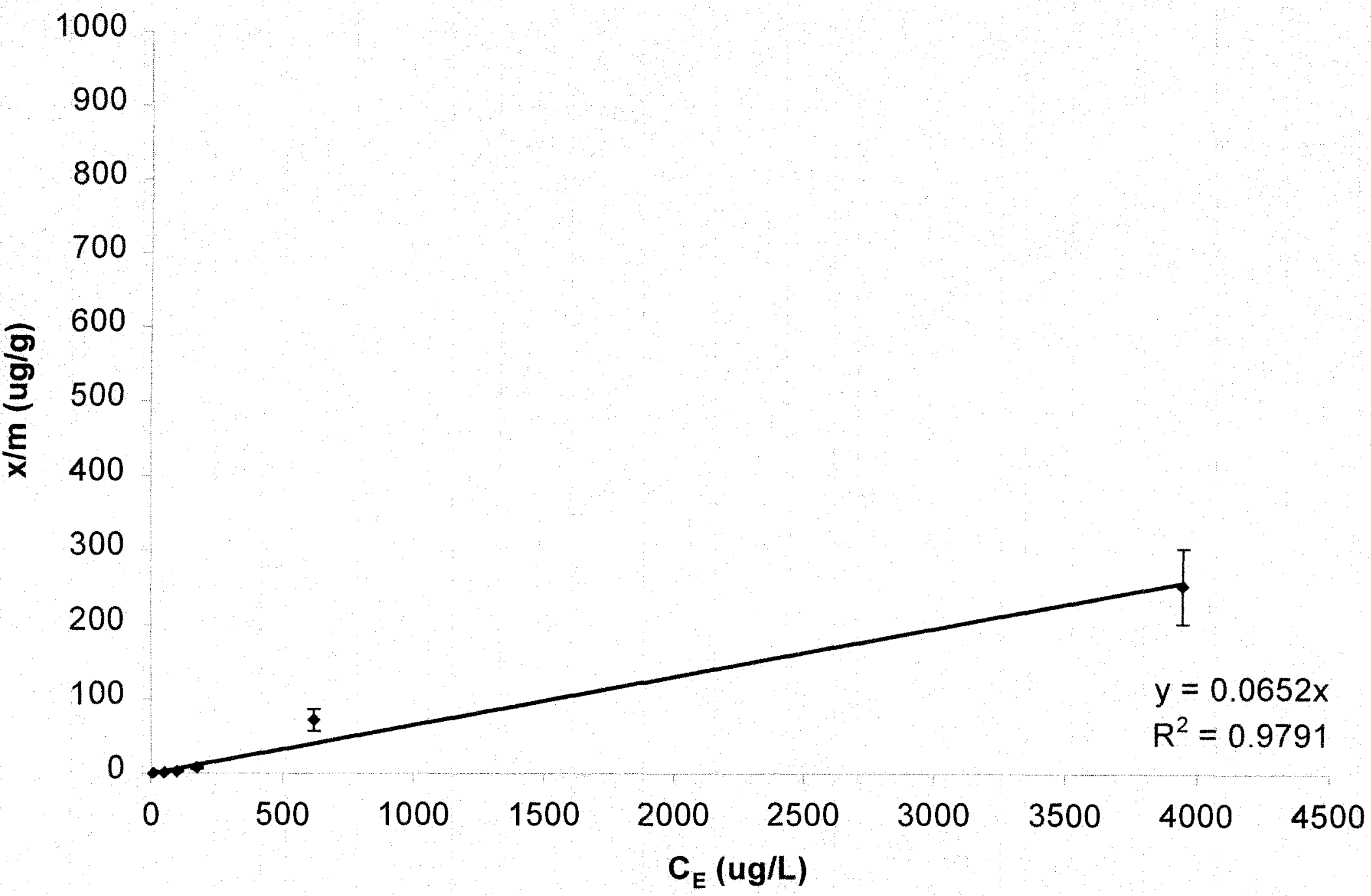

Figure 14. Linear Isotherm for the As(+5), Soil 2 System @ $22.48^{\circ} \mathrm{C}$ (Experimental error $\pm 20 \%$ ). 


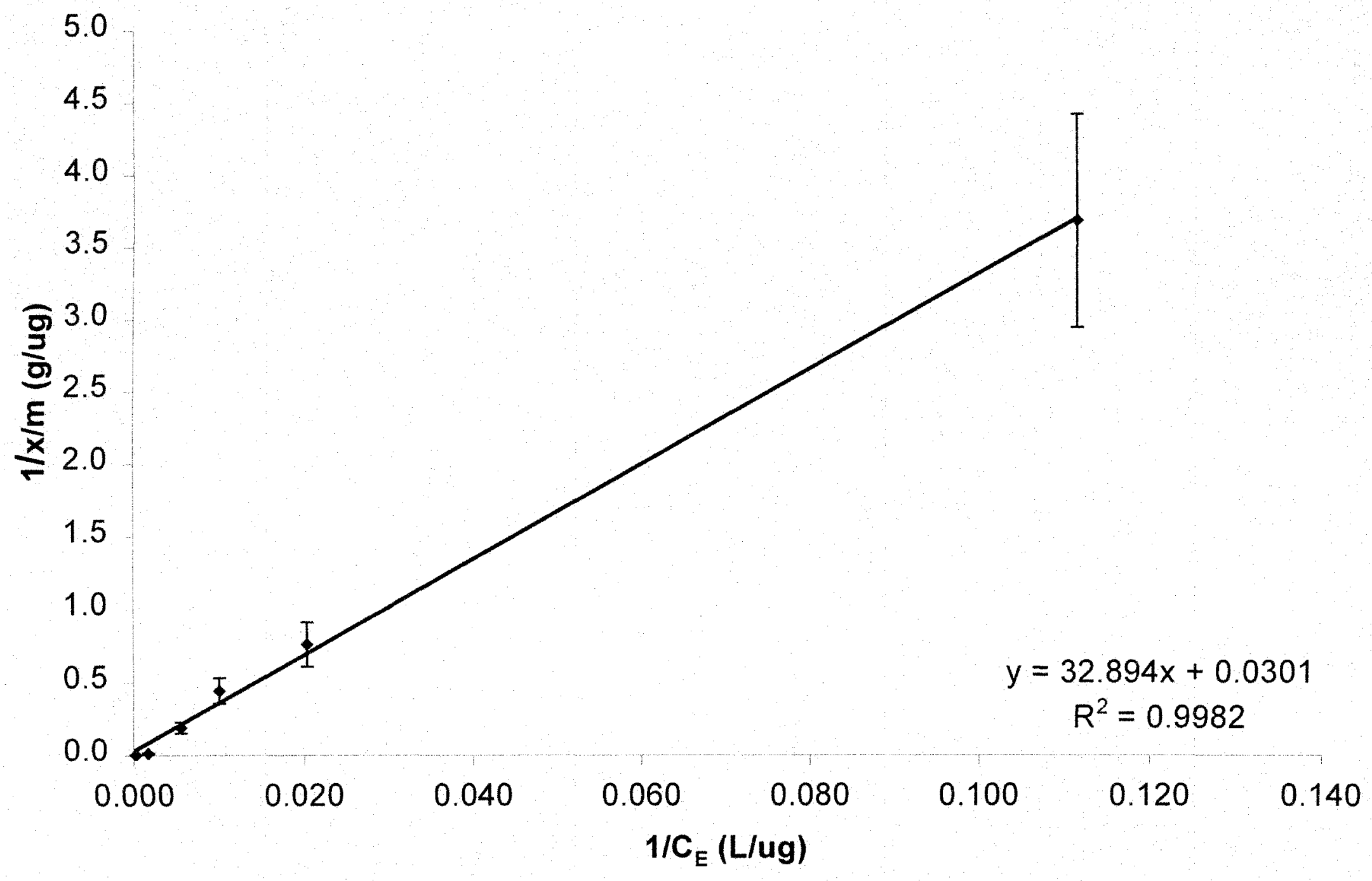

Figure 15. Langmuir Isotherm for the As $(+5)$, Soil 3 System @ $22.48^{\circ} \mathrm{C}$ (Experimental error $\pm 20 \%$ ). 


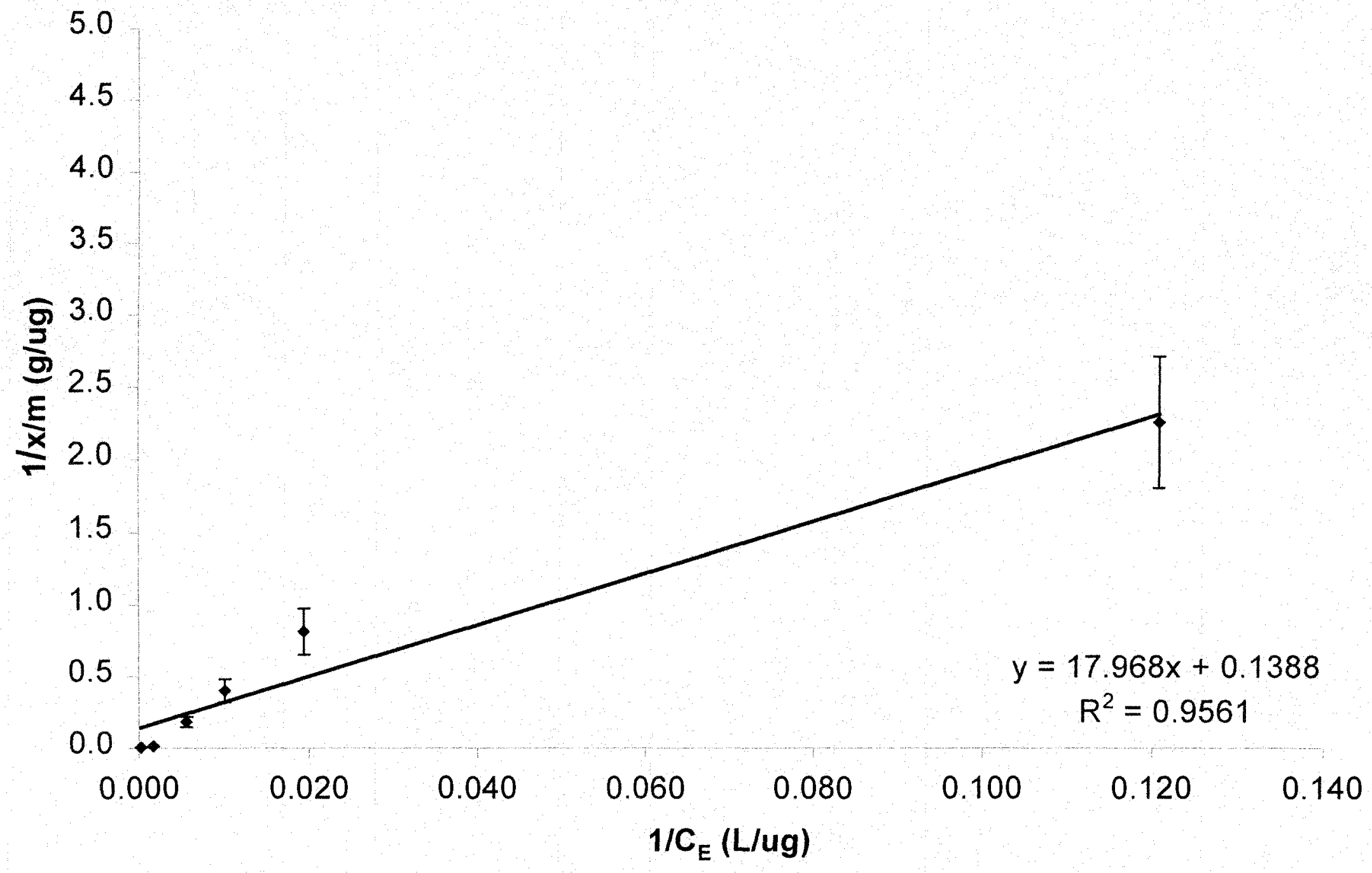

Figure 16. Langmuir Isotherm for the As(+5), Soil 4 System @ $22.48{ }^{\circ} \mathrm{C}$ (Experimental error $\left.\pm 20 \%\right)$. 


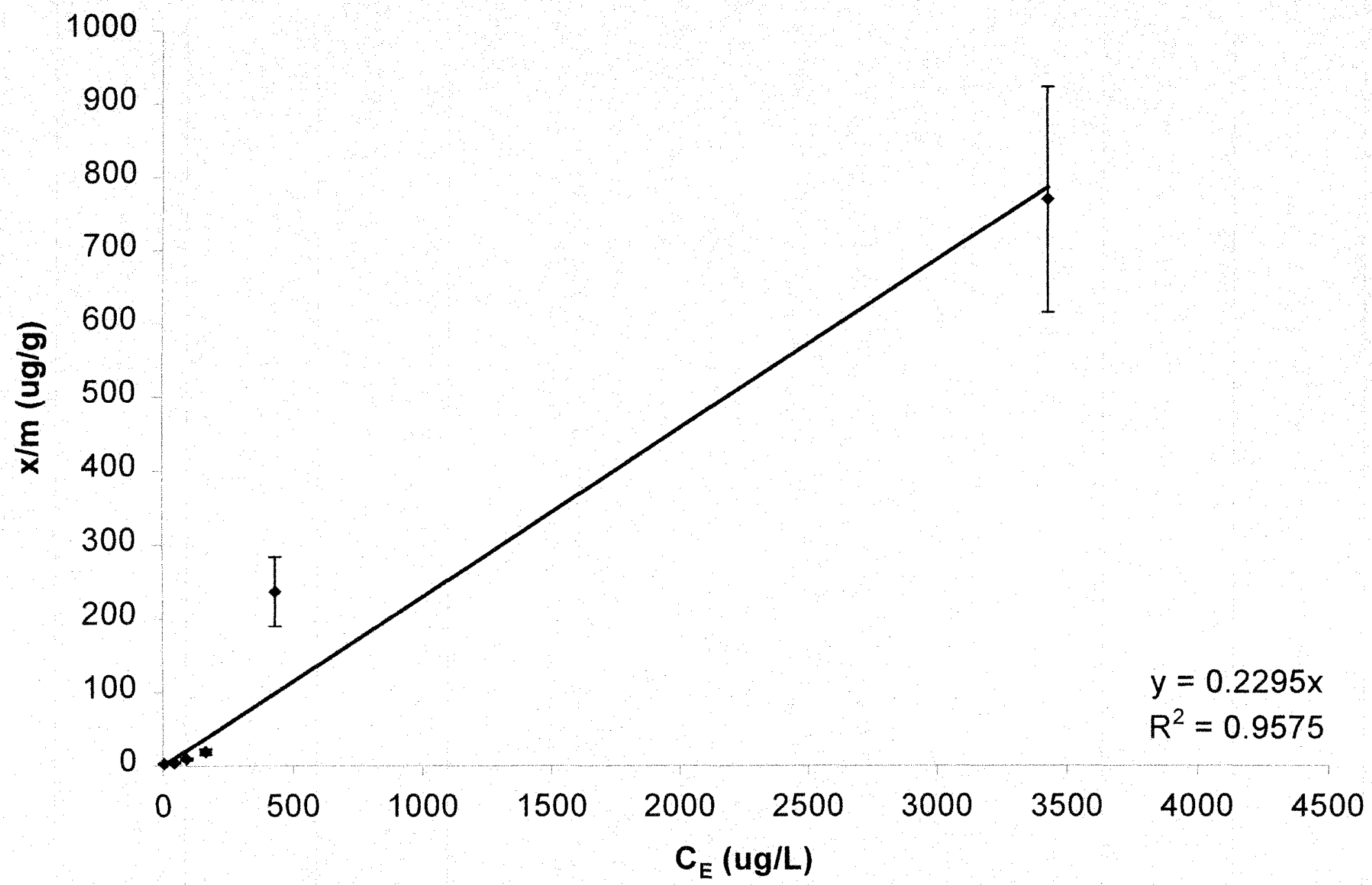

Figure 17. Linear Isotherm for the As(+5), Soil 5 System @ $22.48^{\circ} \mathrm{C}$ (Experimental error $\pm 20 \%$ ). 
- Soil 5 has the strongest affinity for arsenic.

- Iron oxides seem to be a controlling factor for arsenate solubility.

- Equilibrium $\mathrm{pH}$ is relatively close to that found in the environment.

- The experimental Linear Isotherm partitioning coefficients (in units of $\mathrm{L} / \mathrm{g}$ ) of the soils are as follows: Soil 1: $\mathrm{K}_{\mathrm{d}}=0.0385$; Soil 2: $\mathrm{K}_{\mathrm{d}}=.0652$; Soil 3: $\mathrm{K}_{\mathrm{d}}=0.0304$; Soil 4: $K_{d}=0.0557 ;$ Soil $5: K_{d}=0.2295$.

\subsection{Experiment 4}

Adsorption tests for all 5 soils with MSMA were completed and Q-tests were applied for statistical analysis of the data (Figure 18). Modified means for each data point were successfully used in applying Linear, Freundlich and Langmuir isotherms. Again, Freundlich $1 / \mathrm{n}$ terms ranged from 0.6775 to 1.1846 which imply linear adsorption. Both the Linear and Langmuir isotherms fit better than the Freundlich isotherms which also illustrates linear adsorption behavior (See Table 8). Soil 5 again demonstrated the strongest affinity towards MSMA.

Figures $19-23$ show the best fitting of the three isotherms for each soil. The Langmuir isotherm again, best described the partitioning of the MSMA:soil system for 3 of the 5 soils. The Fe content of soil 5 was many times higher than in the other soils yet had similar $\mathrm{Kd}$ values, thus indicating that the Fe content may not effect MSMA adsorption to these soils as it had on $\mathrm{As}(+5)$. However, the TOC content of the soils may have had an effect on MSMA sorption. Soils 4 and 5 had 2 to 5 times higher TOC than the other soils and had $\mathrm{K}_{\mathrm{d}}$ values approximately twice that of the others, respectively. The following summarizes the results of this experiment: 


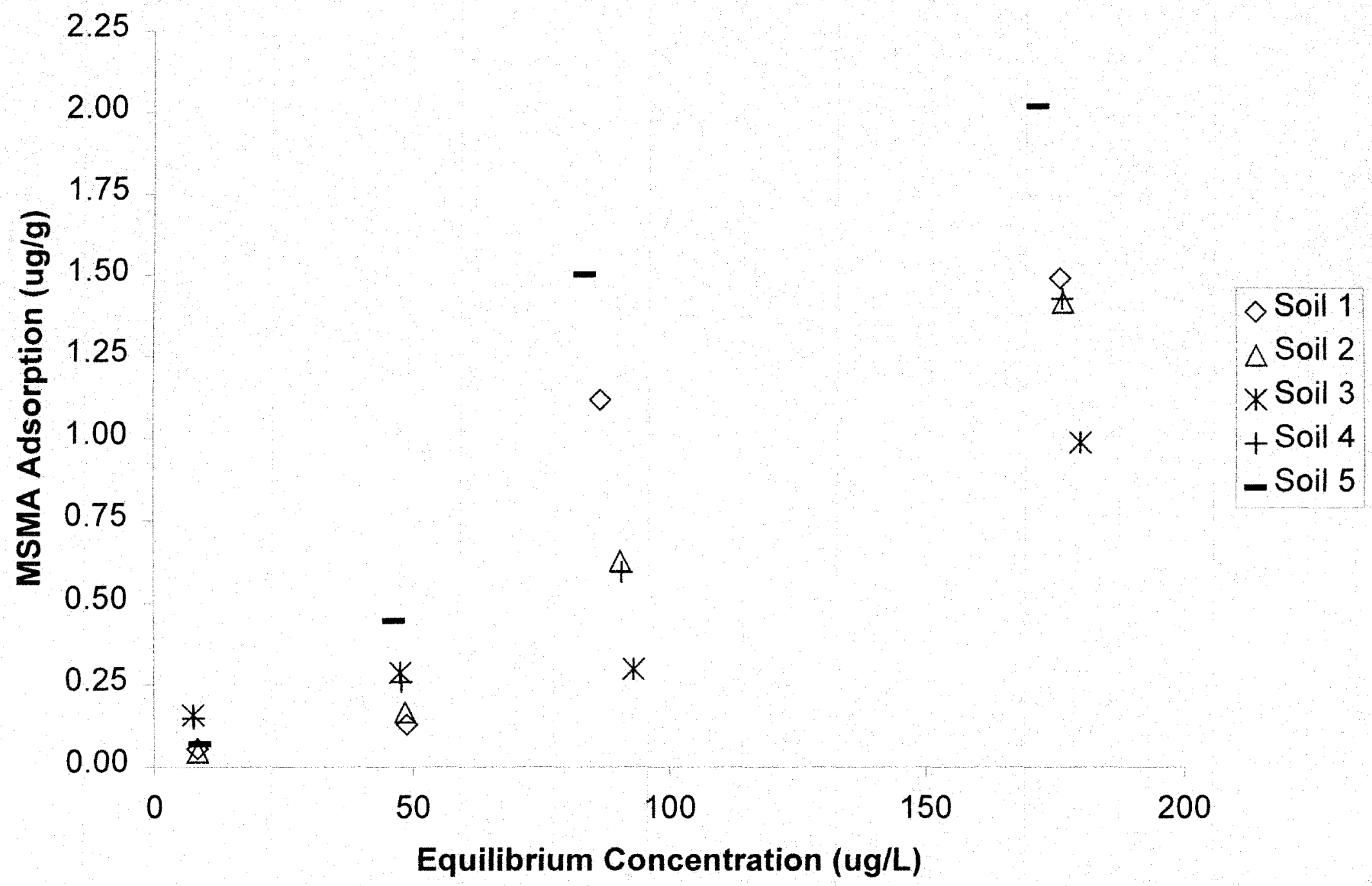

Figure 18. MSMA Adsorption, Soil:pH; 1:6.03, 2:6.00, 3:5.80, 4:6.29, 5:6.28@ $22.48{ }^{\circ} \mathrm{C}$ 
TABLE 8. SUMMARY OF BEST-FITTED ISOTHERM PARAMETERS $\left(22.48^{\circ} \mathrm{C}\right)$.

\begin{tabular}{|c|cc|ccc|ccc|c|}
\hline \multicolumn{10}{|c|}{ MSMA } \\
\cline { 2 - 10 } & \multicolumn{2}{c|}{ Linear } & \multicolumn{4}{c|}{ Freundlich } & \multicolumn{1}{c|}{ Langmuir } \\
\hline Soil & $\mathrm{K}_{\mathrm{d}}$ & $\mathrm{R}^{2}$ & $\mathrm{~K}_{\mathrm{f}}$ & $1 / \mathrm{n}$ & $\mathrm{R}^{2}$ & $\mathrm{~K}_{\mathrm{L}}$ & $\mathrm{M}$ & $\mathrm{R}^{2}$ & $\mathrm{pH}$ \\
\hline 1 & 0.0179 & 0.8562 & 0.0077 & 1.1386 & 0.8397 & 0.0237 & 1.7197 & 0.9070 & 6.03 \\
2 & 0.0151 & 0.9565 & 0.0067 & 1.1325 & 0.9523 & 0.0021 & 5.0302 & 0.9849 & 6.00 \\
3 & 0.0102 & 0.8747 & 0.1023 & 0.4863 & 0.7546 & 0.0632 & 0.9162 & 0.7921 & 5.80 \\
4 & 0.0153 & 0.9647 & 0.0609 & 0.6775 & 0.8633 & 0.0372 & 1.3212 & 0.8390 & 6.29 \\
5 & 0.0255 & 0.9010 & 0.011 & 1.1846 & 0.9722 & 0.0043 & 3.5945 & 0.9985 & 6.28 \\
\hline
\end{tabular}

$K_{d}$ units $=(L / g)$

$\mathrm{K}_{\mathrm{f}}$ units $=(\mathrm{L} / \mathrm{g})$

$\mathrm{K}_{\mathrm{L}}$ units $=(\mathrm{L} / \mu \mathrm{g})$

M units $=(\mu \mathrm{g} / \mathrm{g})$ 


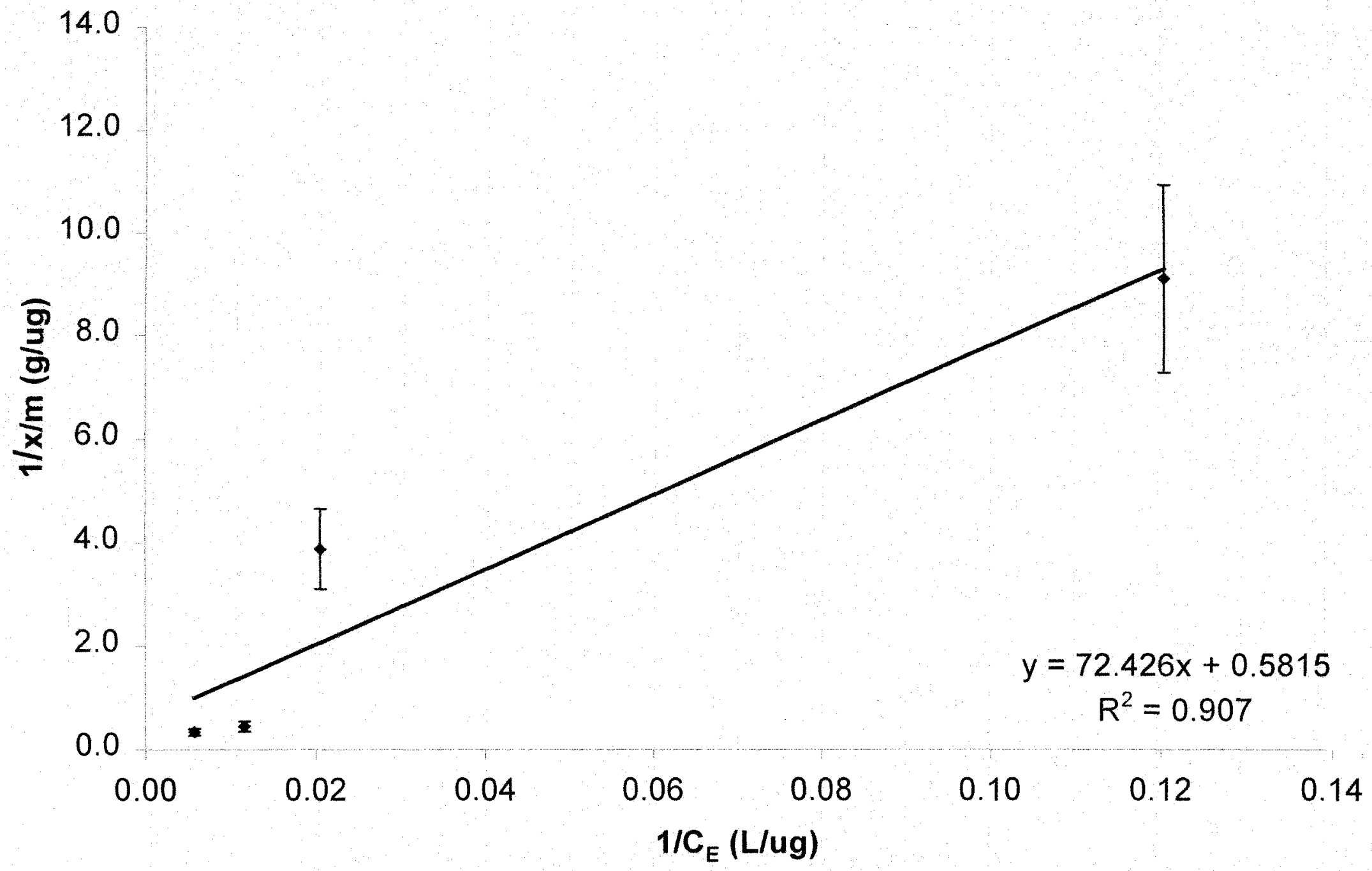

Figure 19. Langmuir Isotherm for the MSMA, Soil 1 System @22.48 ${ }^{\circ} \mathrm{C}$. 


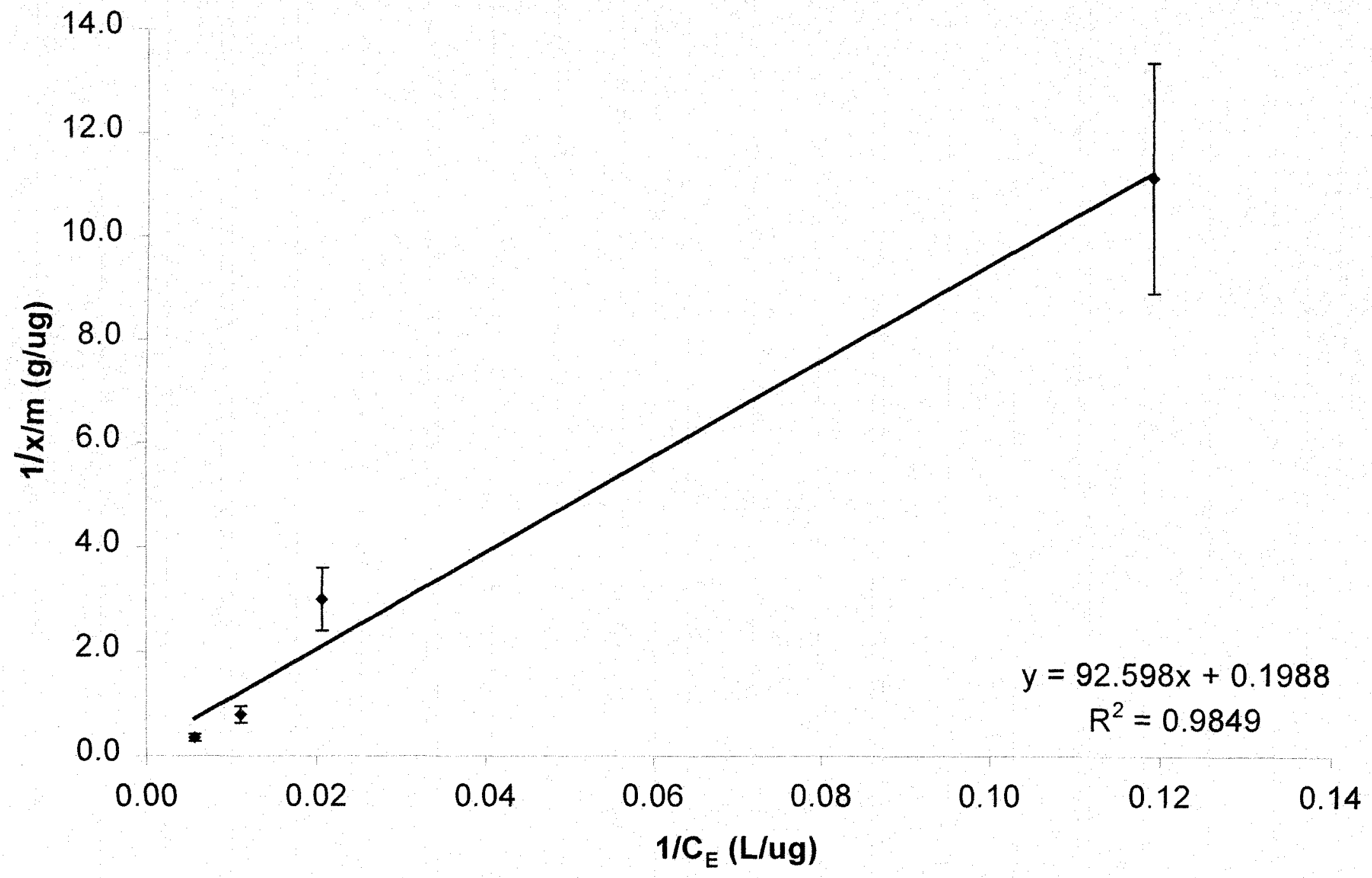

Figure 20. Langmuir Isotherm for the MSMA, Soil 2 System @ $22.48{ }^{\circ} \mathrm{C}$. 


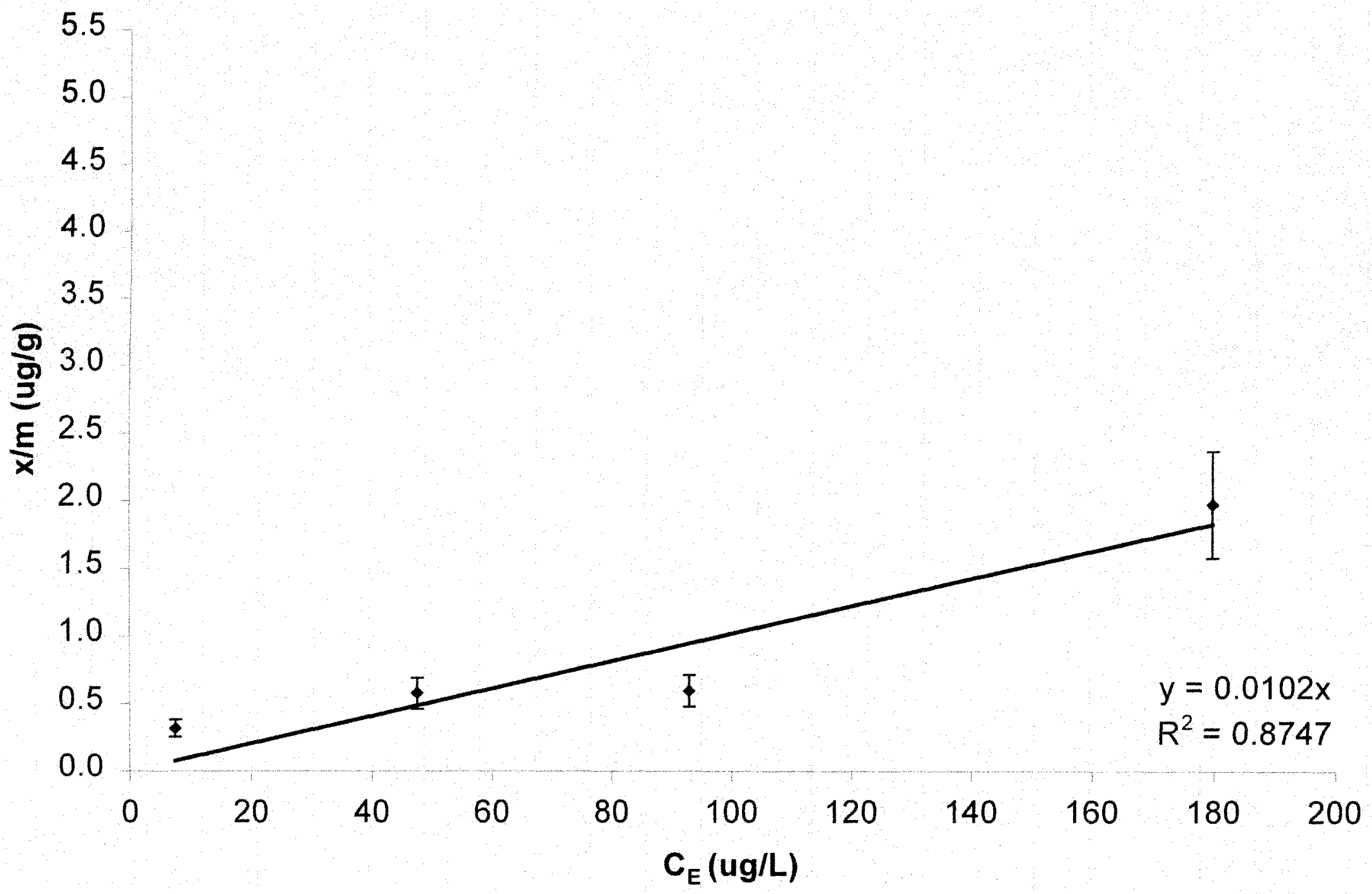

Figure 21. Linear Isotherm for the MSMA, Soil 3 System @ $22.48^{\circ} \mathrm{C}$. 


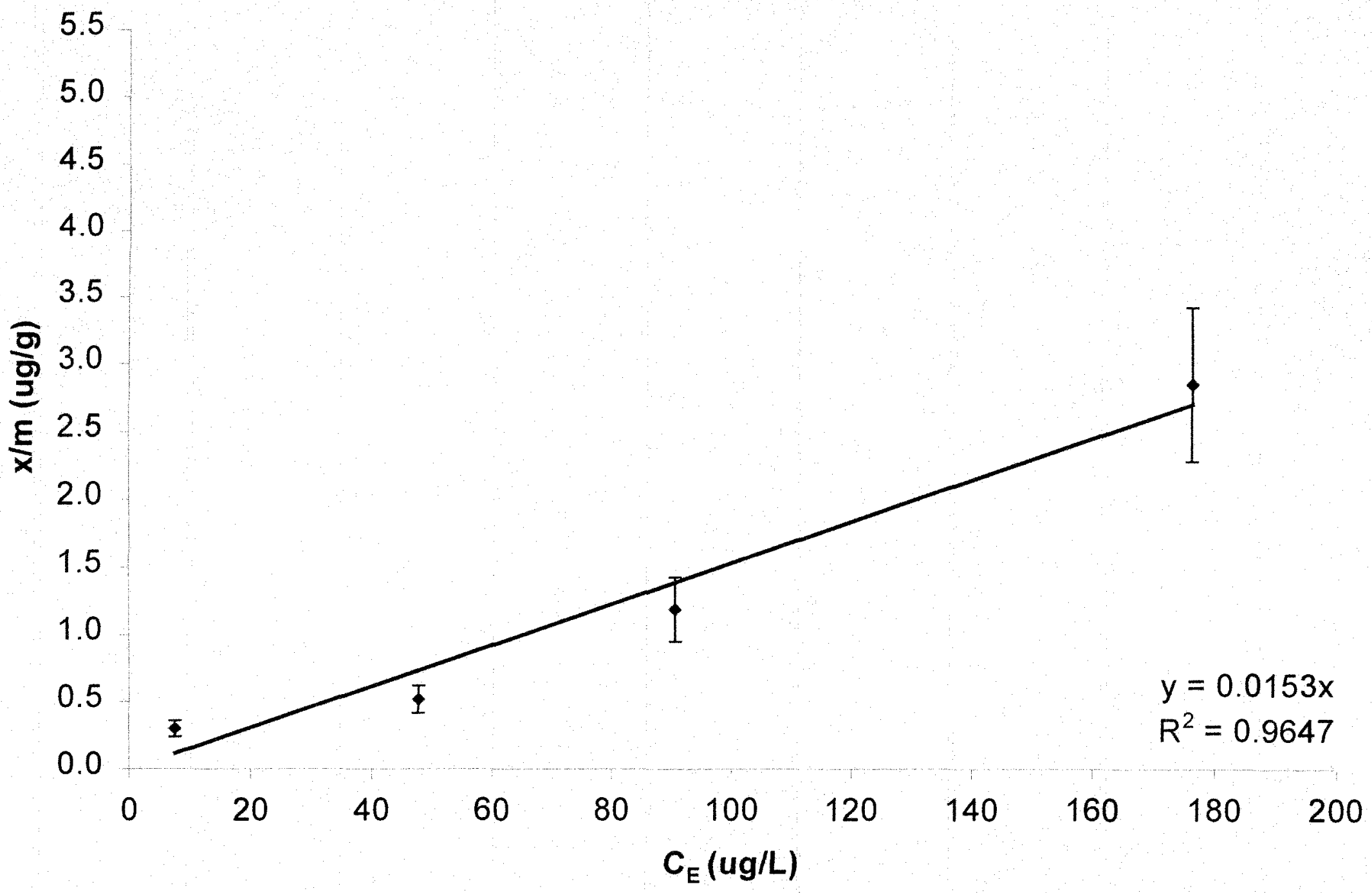

Figure 22. Linear Isotherm for the MSMA, Soil 4 System @ $22.48^{\circ} \mathrm{C}$. 


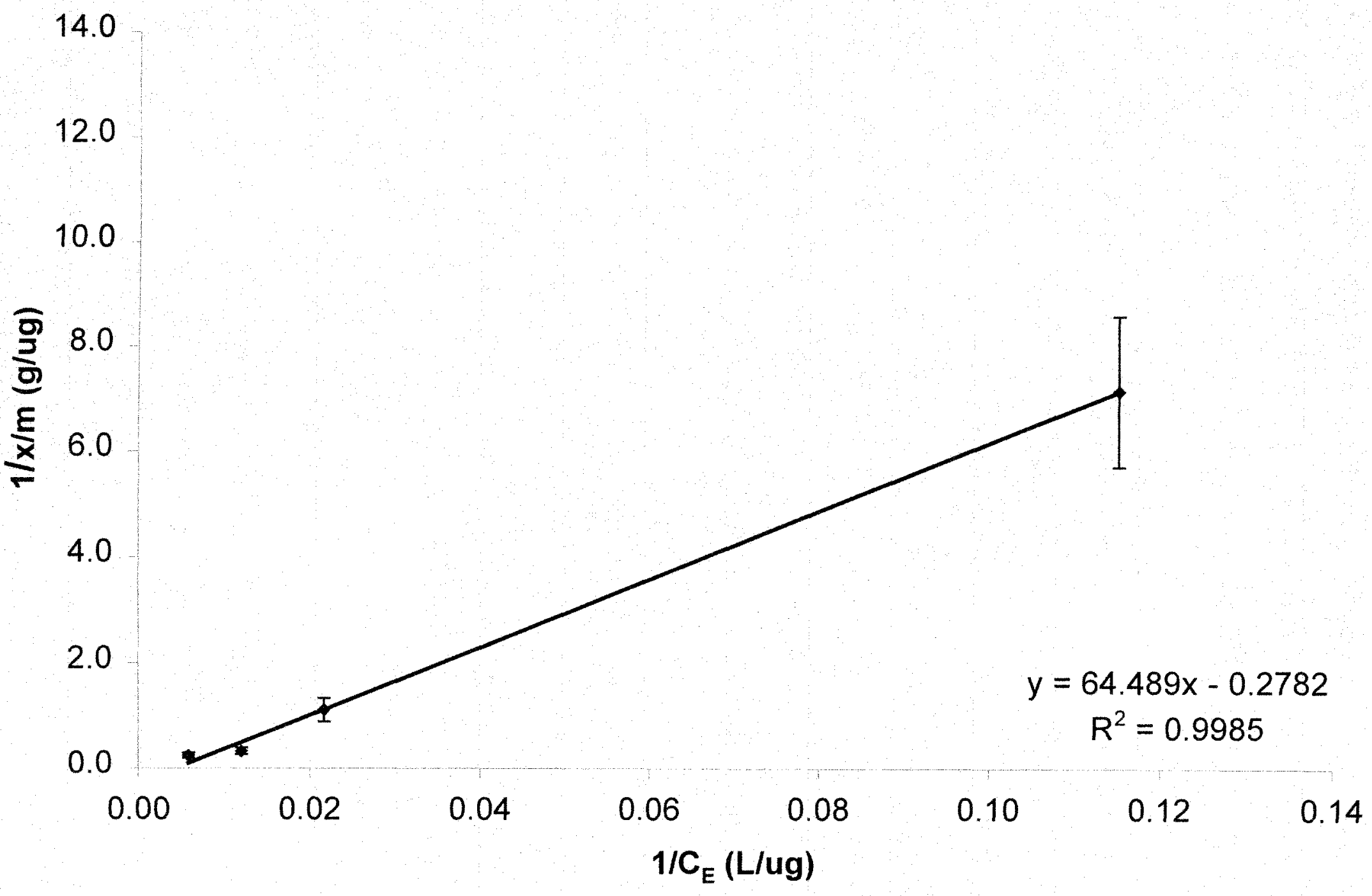

Figure 23. Langmuir Isotherm for the MSMA, Soil 5 System. @ $22.48^{\circ} \mathrm{C}$ 
- MSMA displayed linear adsorption behavior. Langmuir isotherms were the best fit method for 3 of the 5 soils. Electrostatic forces could be the anticipated driving force behind sorption in this system, based on the associated controlling mechanisms (Sparks et. al., 1986).

- MSMA equilibrium solutions were slightly lower in $\mathrm{pH}$ than the arsenate system.

- The following $\mathrm{K}_{\mathrm{d}}$ values $(\mathrm{L} / \mathrm{g})$ were determined: Soil 1: $\mathrm{K}_{\mathrm{d}}=0.0138$; Soil $2: \mathrm{K}_{\mathrm{d}}=$ 0.0108 ; Soil 3: $\mathrm{K}_{\mathrm{d}}=0.0102 ;$ Soil 4: $\mathrm{K}_{\mathrm{d}}=0.0153 ;$ Soil 5: $\mathrm{K}_{\mathrm{d}} 0.0155$.

- $\mathrm{K}_{\mathrm{d}}$ values for MSMA were 4 to 6 times less than arsenate for soils 1-4, and 22 times less than arsenate for soil 5 . This would imply that MSMA may be more likely to be flushed from the soil column than would its by-product, arsenate $(\mathrm{As}(+5))$.

- The TOC contents of the soils appear to have an effect on it's sorptivity to MSMA.

\subsection{Computer Simulations}

Computer simulations of MSMA use in environments that may be found in southern Florida were completed. Eight simulation scenarios were conducted with PRZM-2.0 to evaluate the fate and transport of MSMA for a period of 5 years (January 1 water year 1988 to December 31 water year 1993) with results showing predicted concentrations of Total Dissolved As and the two composing fractions, As +5 and MSMA, at the water table interface. PRZM-2.0 has the capability to determine the concentrations of any biodegradation product throughout the soil profile. Since MSMA is expected to under oxidative-demethylation in oxygenated environments like that found in shallow, sandy/limestone aquifers, As +5 is the expected daughter product. Results will also be discussed from the FDEP regulatory perspective of Total As with regards to 
dissolved As concentrations in the groundwater (or in this case, Total Dissolved As at the water table interface).

\subsubsection{Predictions}

Figures $24-37$ show the Total As and fractional concentrations of $\mathrm{As}(+5)$ and MSMA at the water table interface as a function of time over a 5 year interval (See Tables $22-24$ in Appendix A). Data points along the time line represent concentrations at intervals of 1 day, 1 week, and 1 month after each application of MSMA (total of 10 applications and 30 data points per scenario). Results from the model indicate that under conditions stated in Chapter 3, concentrations of Total Dissolved arsenic reached levels greater than $50 \mathrm{ppb}$ at the vadose zone/water table within 1 month of every application of MSMA. In fact, concentrations of Total Dissolved arsenic reached levels as high as 399 ppb (Scenarios 1 and 8, high dispersion and no irrigation respectively). Data shows that the predominant remaining species ( $>50$ percent) of arsenic at the water table interface is the organic form, MSMA. Significant quantities of the inorganic fraction were not present during the first year of application. However, in the second year of application, predictions showed that on average, from 53 to 87 percent of all the dissolved As present in every scenario was $\mathrm{As}(+5)$.

Results suggest that the higher dispersion coefficients influenced the mobility of MSMA transport (dispersive transportation). Concentrations of Total Dissolved As varied between scenarios 1,2, and 3 which simulated dispersion coefficients ranging from $100-10,000 \mathrm{~cm}^{2} /$ day (See Figures 24-29 and in Appendix A, Table 22). On the first day after the first application of MSMA, the Total Dissolved arsenic levels were the highest 


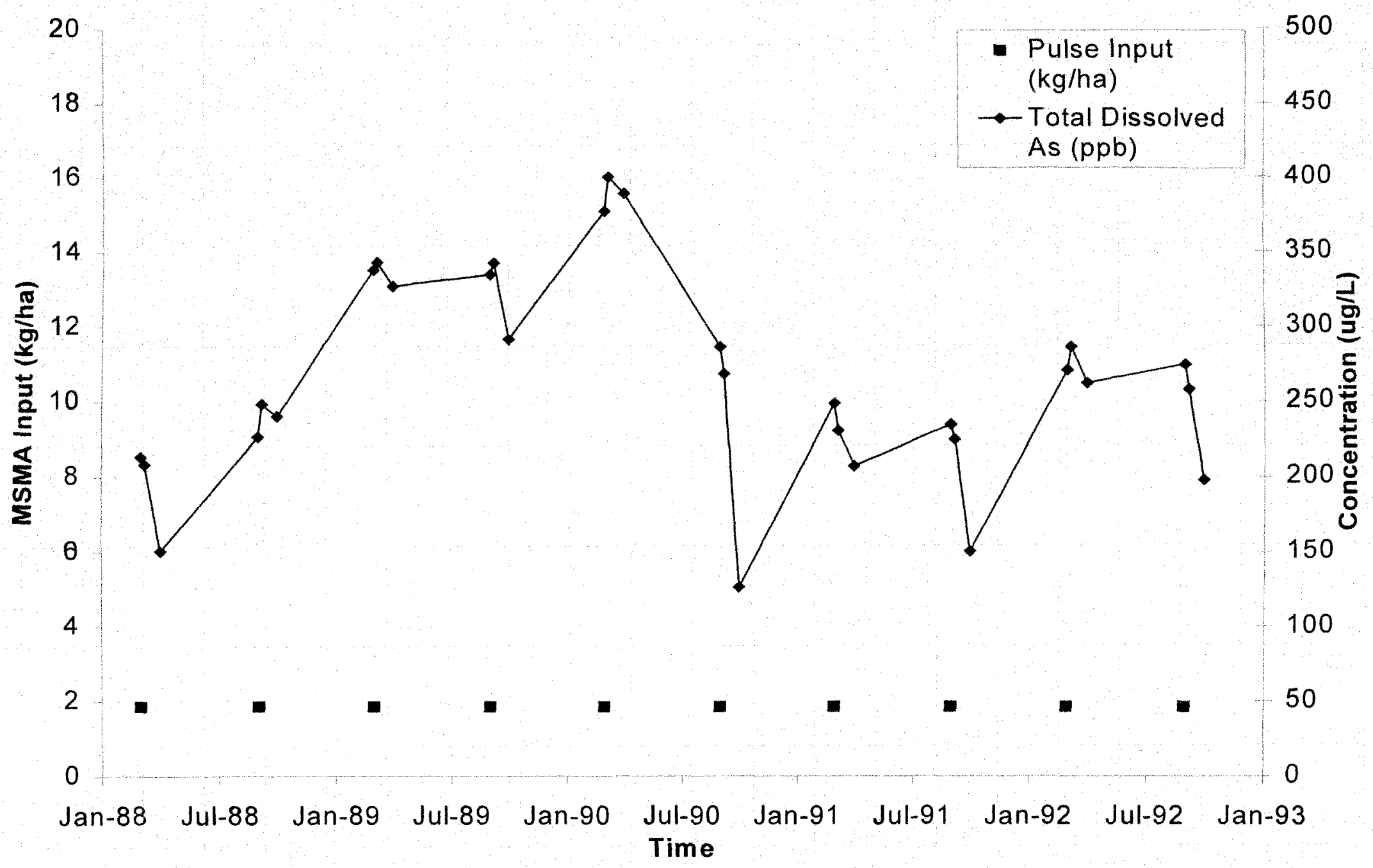

Figure 24. Plot of Concentration verses Time for Total Dissolved Arsenic at the Water Table Interface. Conditions: Laboratory $\mathrm{K}_{\mathrm{d}}$, Dispersion $=10,000 \mathrm{~cm}^{2} /$ day, Irrigation at $50 \%$ Field Capacity (Scenario 1 ). 


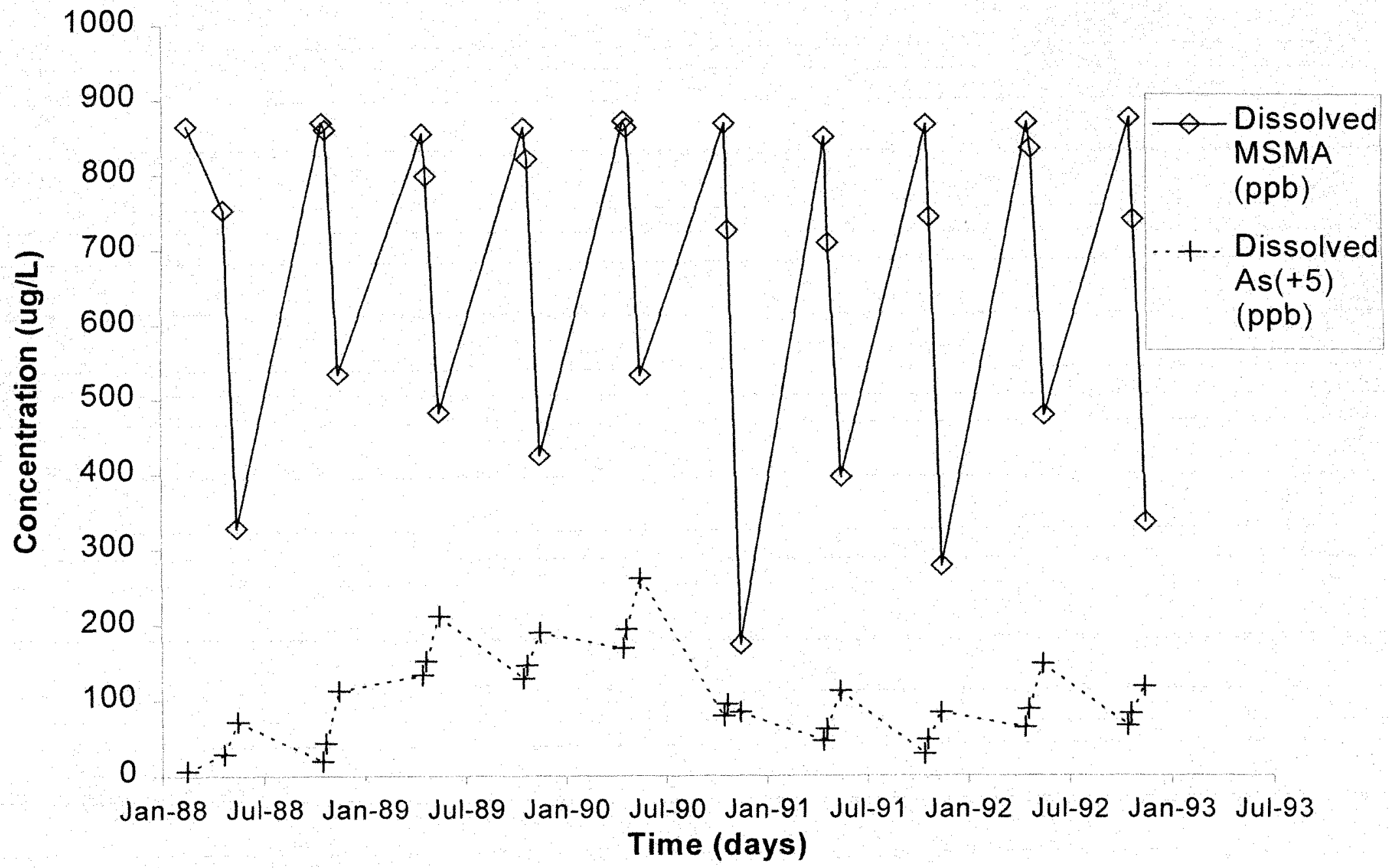

Figure 25. Plot of Concentration verses Time for Dissolved MSMA and Dissolved As $(+5)$ at the Water Table Interface. Conditions: Laboratory $\mathrm{K}_{\mathrm{d}}$, Dispersion $=10,000 \mathrm{~cm}^{2} /$ day, Irrigation at $50 \%$ Field Capacity. 


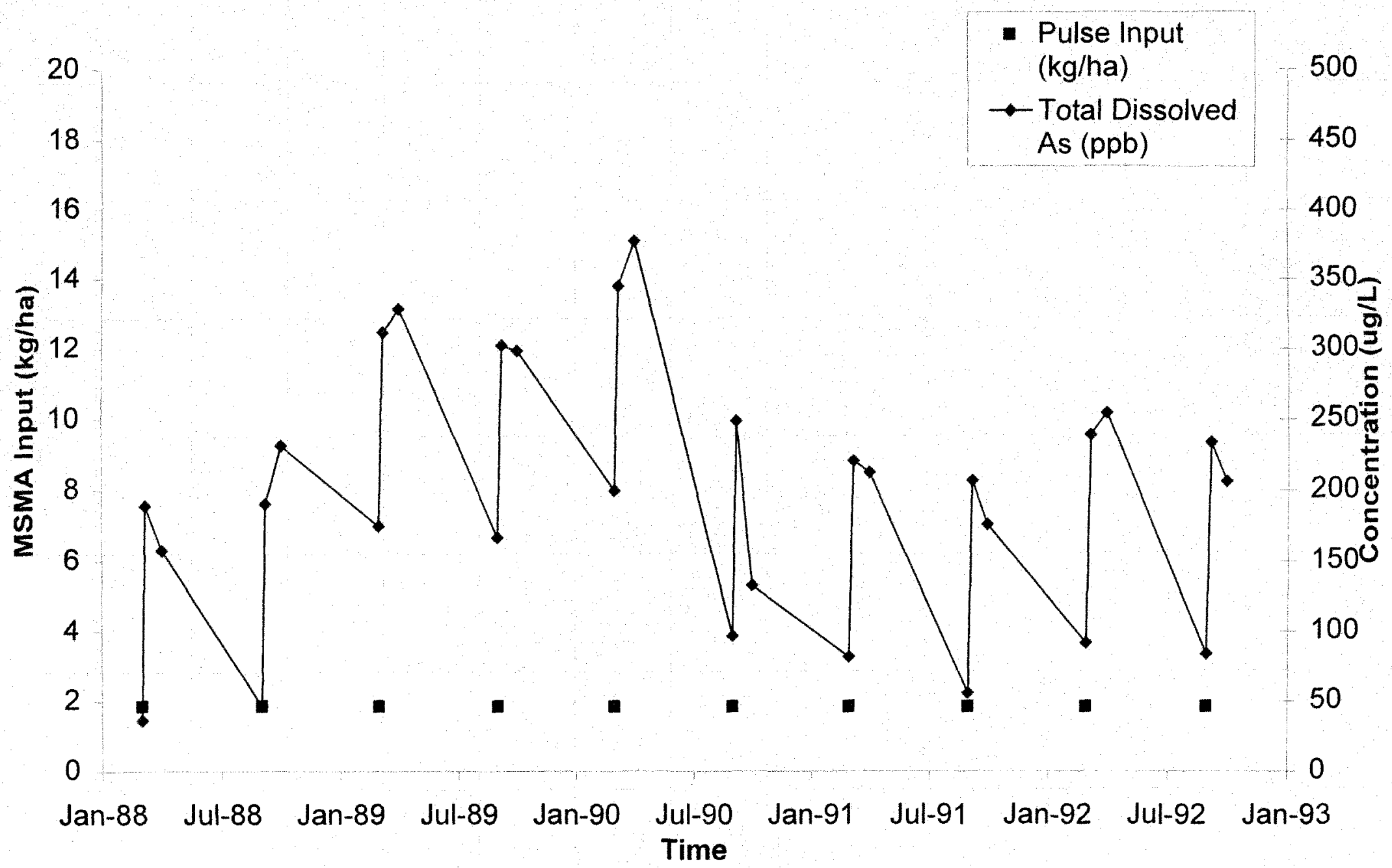

Figure 26. Plot of Concentration verses Time for Total Dissolved Arsenic at the Water Table Interface. Conditions: Laboratory $\mathrm{K}_{\mathrm{d}}$, Dispersion $=1,000 \mathrm{~cm}^{2} /$ day, Irrigation at $50 \%$ Field Capacity (Scenario 2 ). 


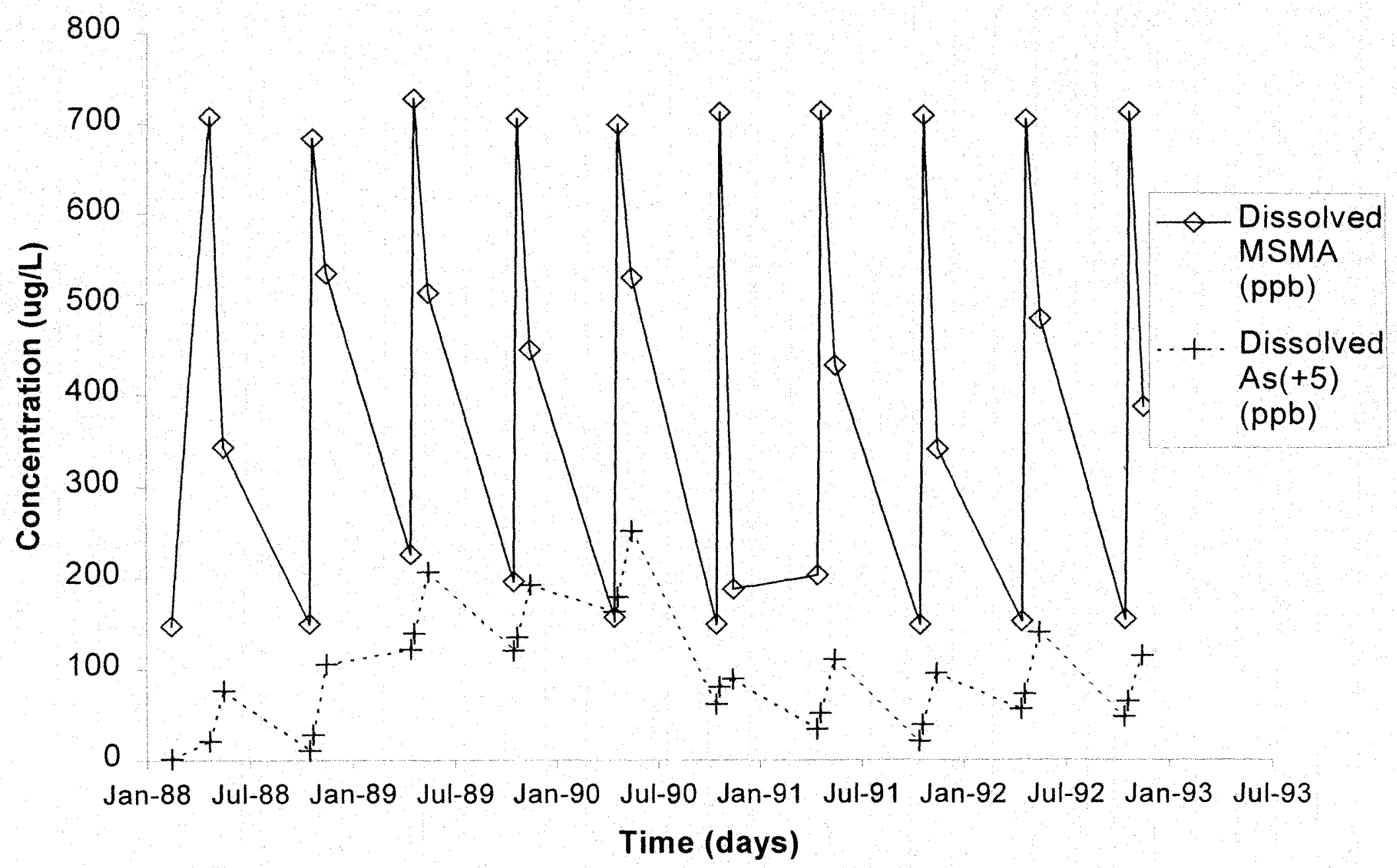

Figure 27. Plot of Concentration verses Time for Dissolved MSMA and Dissolved As $(+5)$ at the Water Table Interface. Conditions: Laboratory $\mathrm{K}_{\mathrm{d}}$, Dispersion $=1,000 \mathrm{~cm}^{2} /$ day, Irrigation at $50 \%$ Field Capacity. 


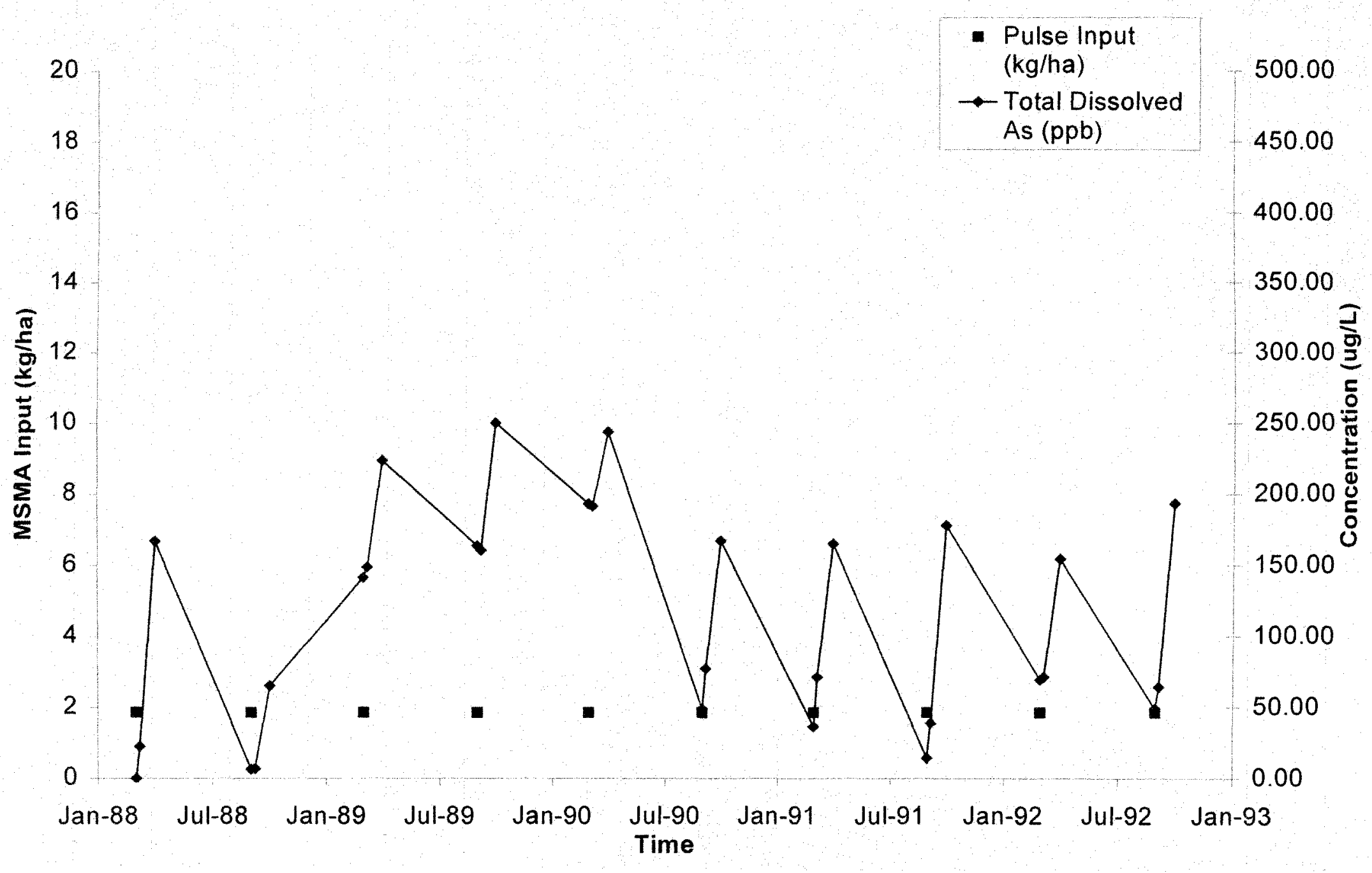

Figure 28. Plot of Concentration verses Time for Total Dissolved Arsenic at the Water Table Interface. Conditions: Laboratory $\mathrm{K}_{\mathrm{d}}$, Dispersion $=100 \mathrm{~cm}^{2} /$ day, Irrigation at $50 \%$ Field Capacity (Scenario 3 ). 


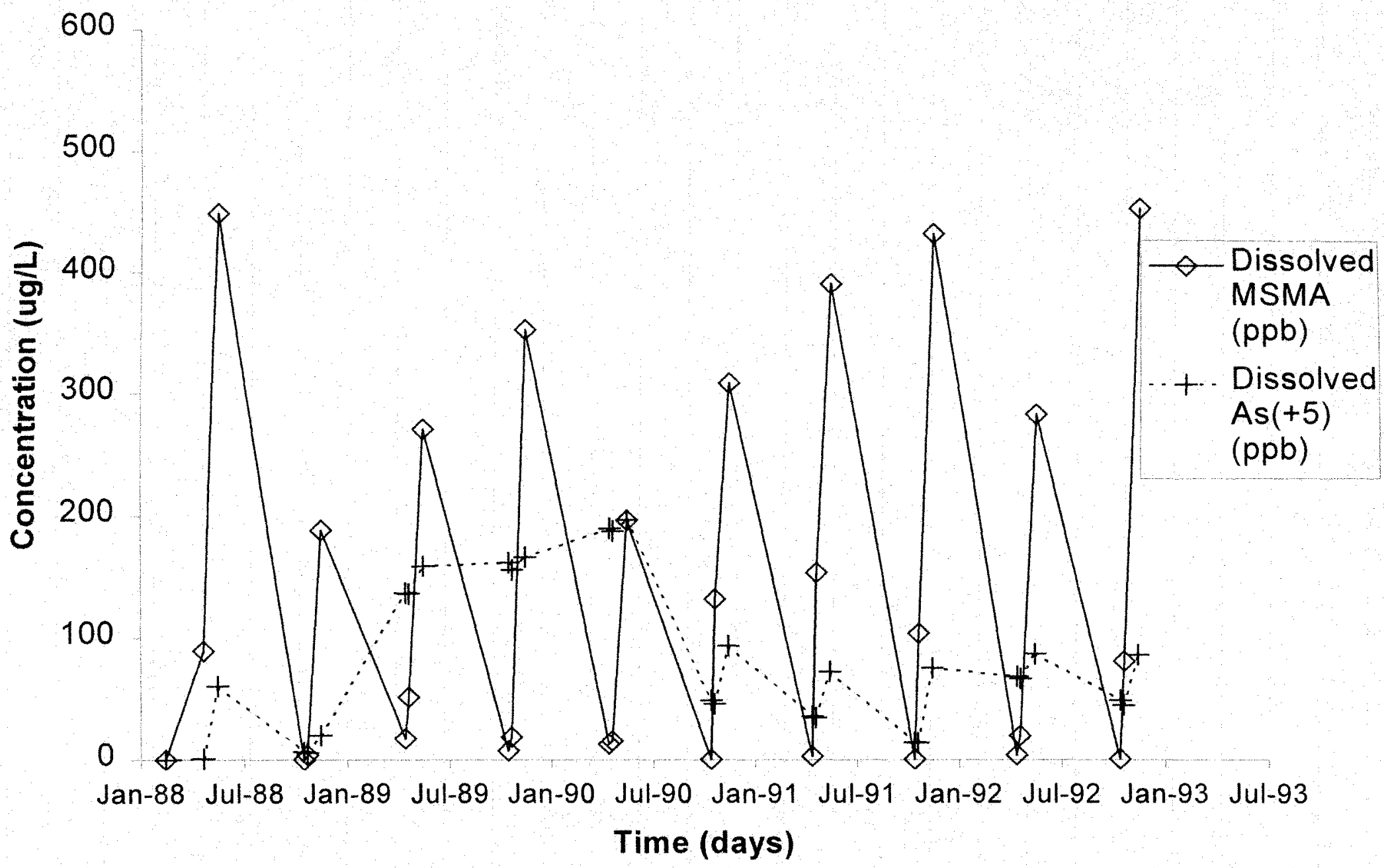

Figure 29. Plot of Concentration verses Time for Dissolved MSMA and Dissolved As $(+5)$ at the Water Table Interface. Conditions: Laboratory $\mathrm{K}_{\mathrm{d}}$, Dispersion $=100 \mathrm{~cm}^{2} /$ day, Irrigation at $50 \%$ Field Capacity. 


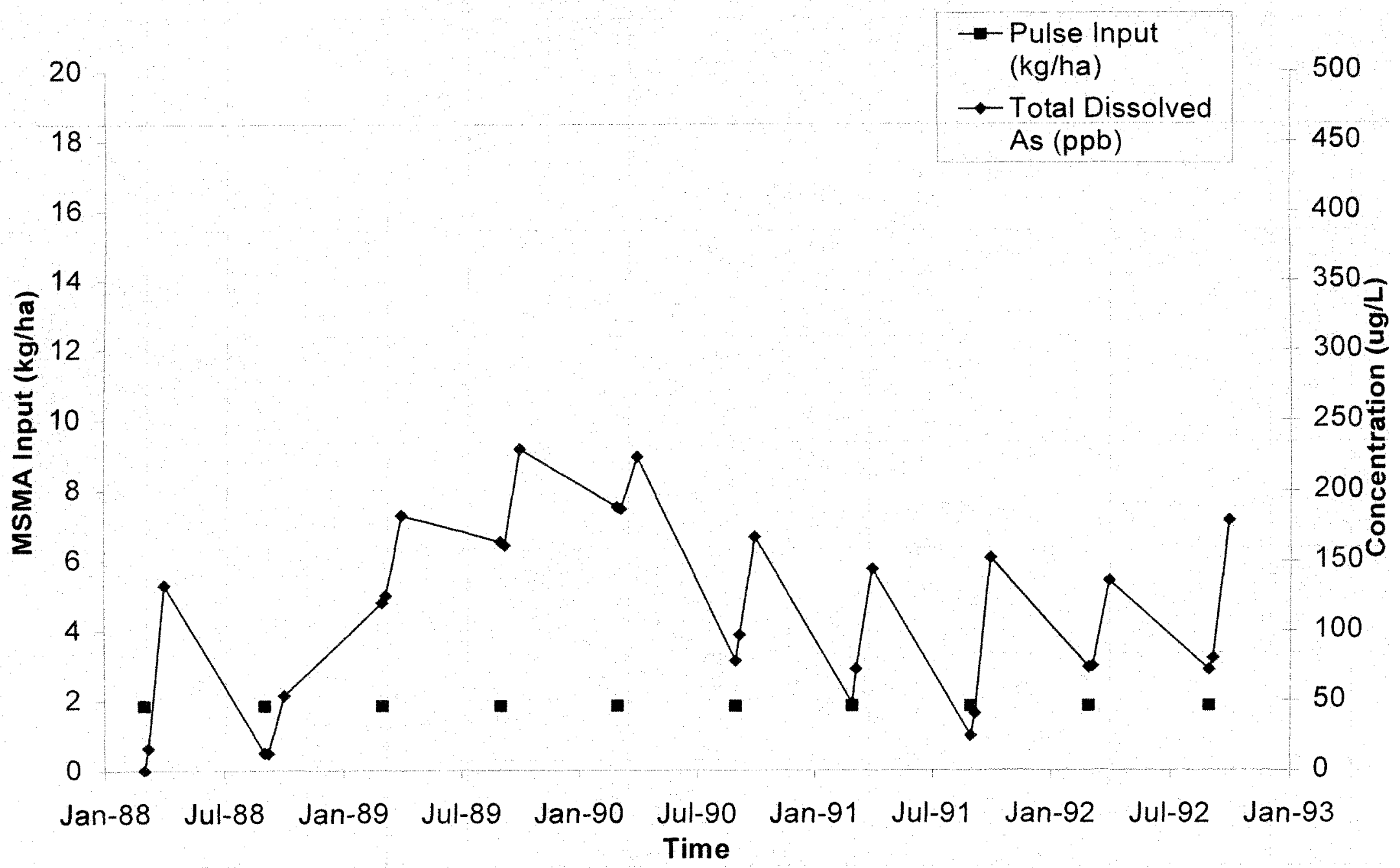

Figure 30. Plot of Concentration verses Time for Total Dissolved Arsenic at the Water Table Interface. Conditions: 150\% Laboratory $\mathrm{K}_{\mathrm{d}}$, Dispersion $=1,000 \mathrm{~cm}^{2} /$ day, Irrigation at $50 \%$ Field Capacity (Scenario 4 ). 


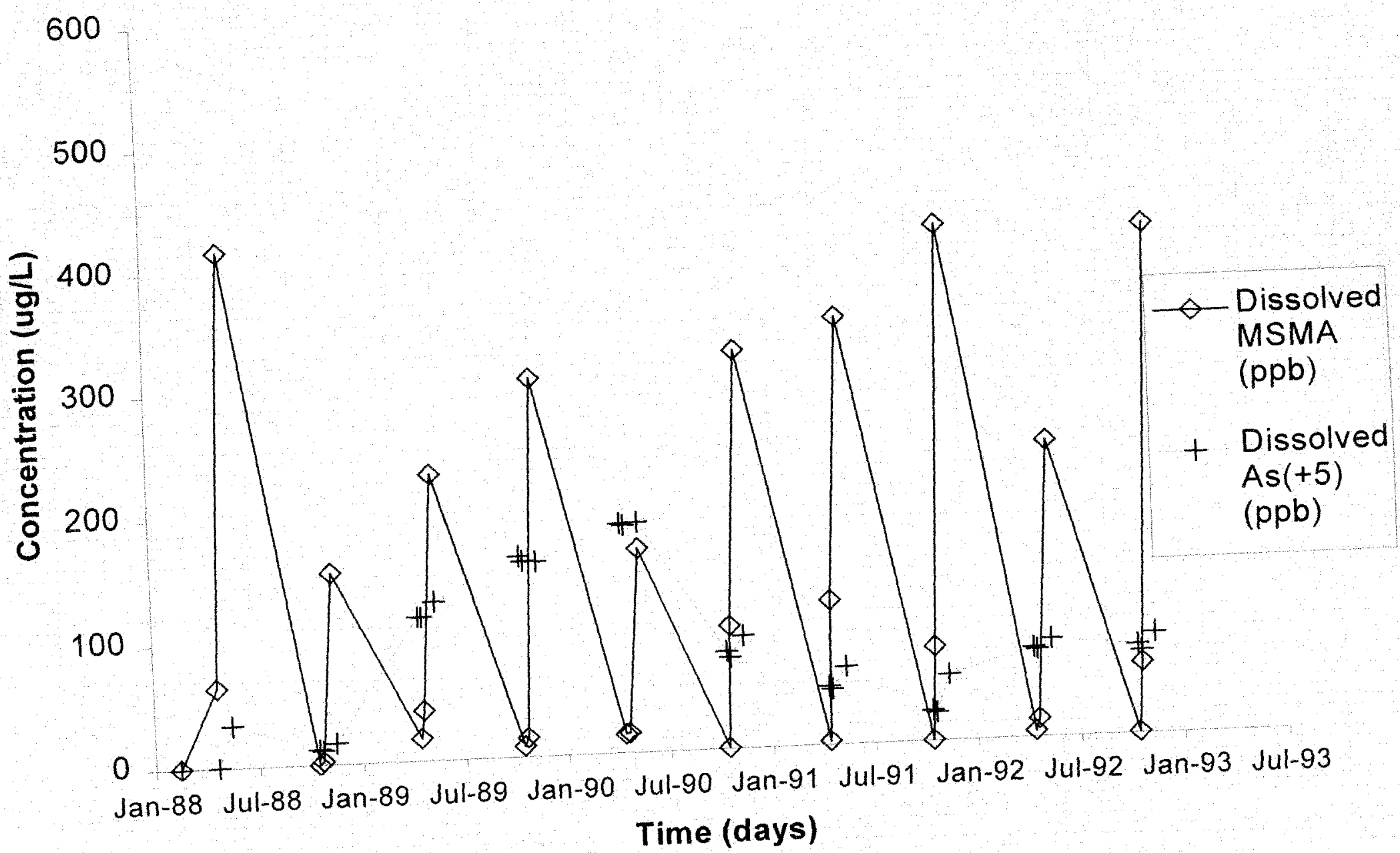

Plot of Concentration verses Time for Dissolved MSMA and Dissolved As $(+5)$ at the Water Table Interface. Conditions: $150 \%$ Laboratory $\mathrm{K}_{\mathrm{d}}$, Dispersion $=1,000 \mathrm{~cm}^{2} /$ day, Irrigation at $50 \%$ Field Capacity. 


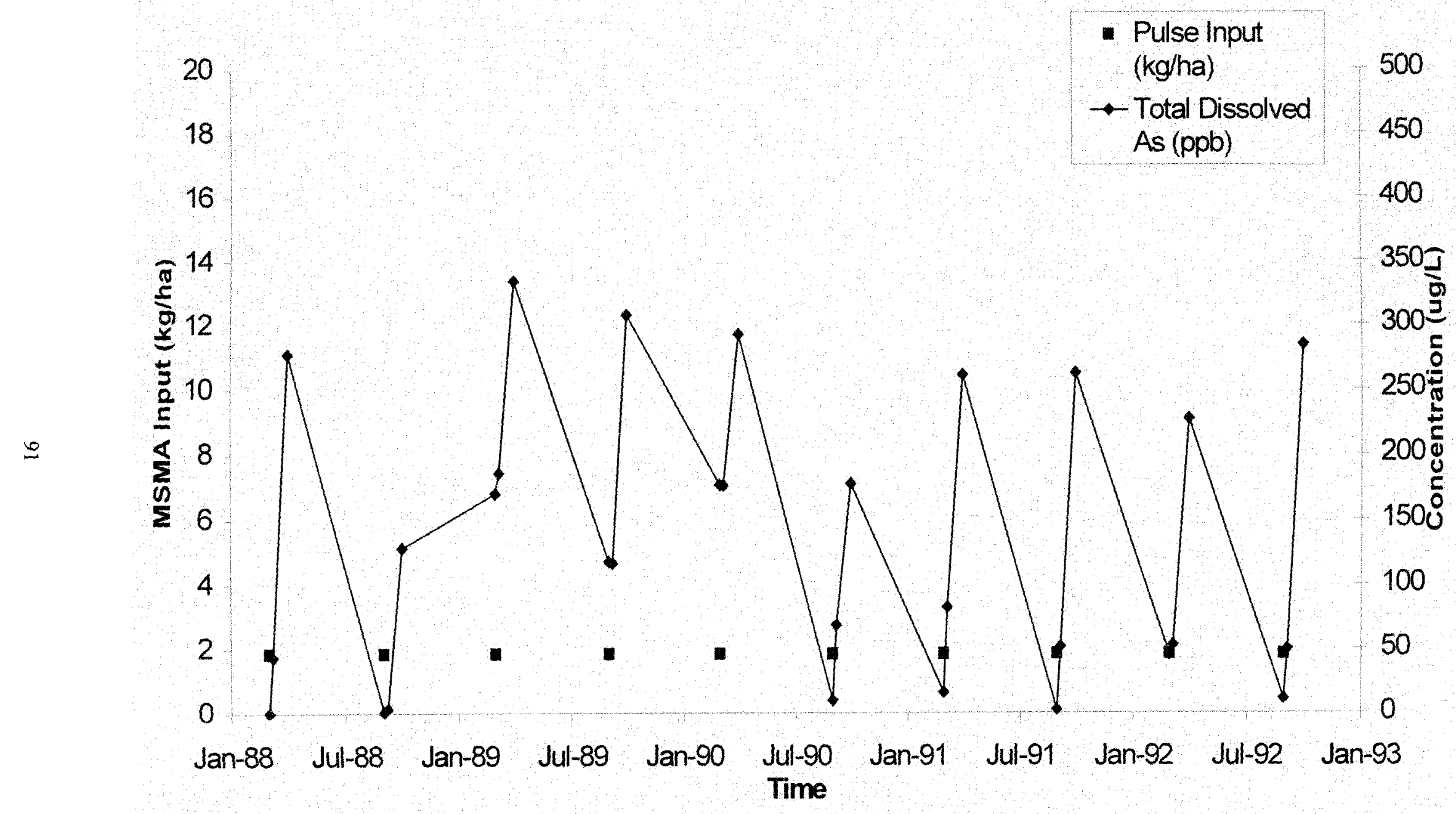

Figure 32. Plot of Concentration verses Time for Total Dissolved Arsenic at the Water Table Interface. Conditions: $25 \%$ Laboratory $\mathrm{K}_{\mathrm{d}}$, Dispersion $=1,000 \mathrm{~cm}^{2} /$ day, Irrigation at $50 \%$ Field Capacity (Scenario 5). 


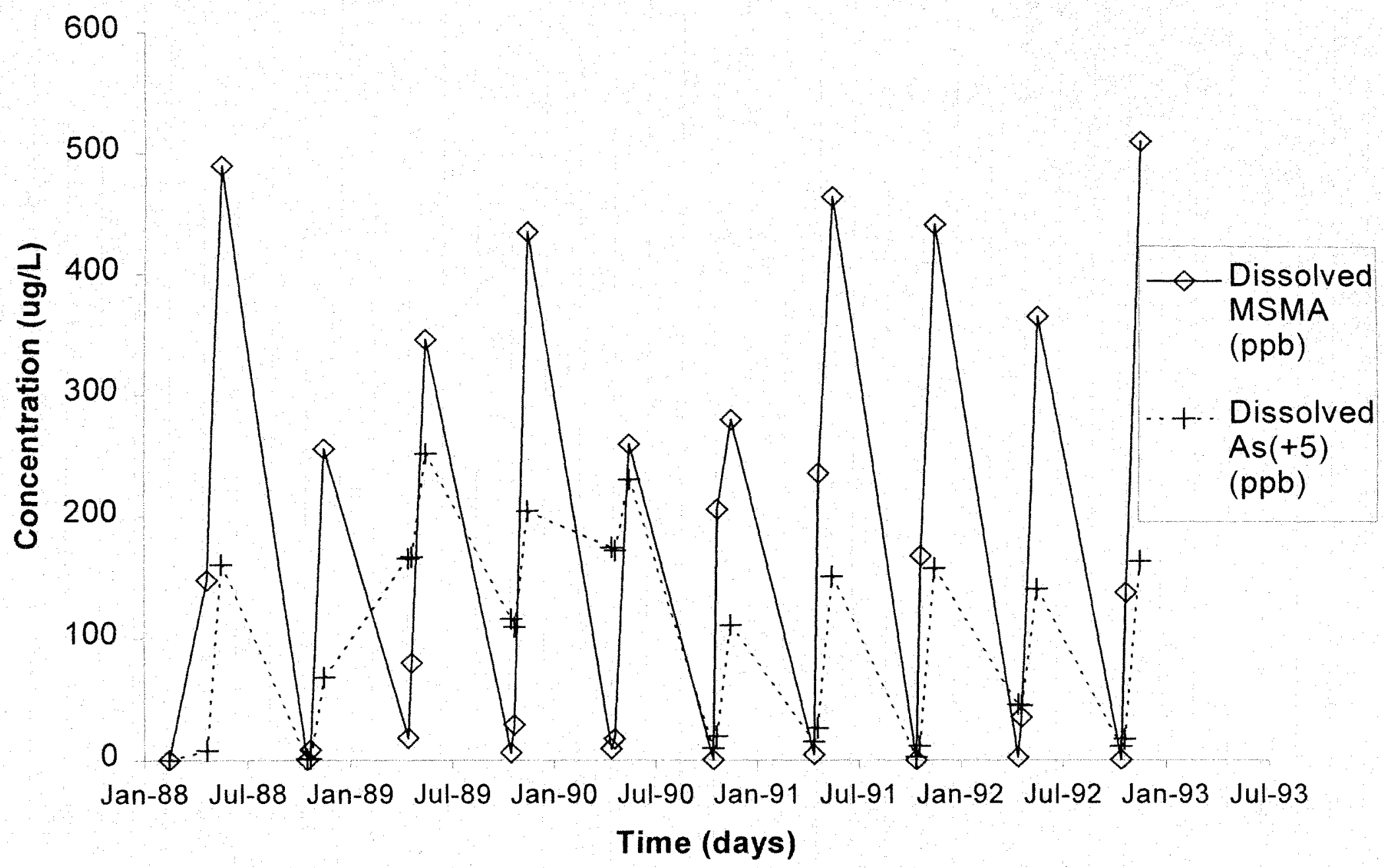

Figure 33. Plot of Concentration verses Time for Dissolved MSMA and Dissolved As $(+5)$ at the Water Table Interface. Conditions: $25 \%$ Laboratory $\mathrm{K}_{\mathrm{d}}$, Dispersion $=1,000 \mathrm{~cm}^{2} /$ day, Irrigation at $50 \%$ Field Capacity. 


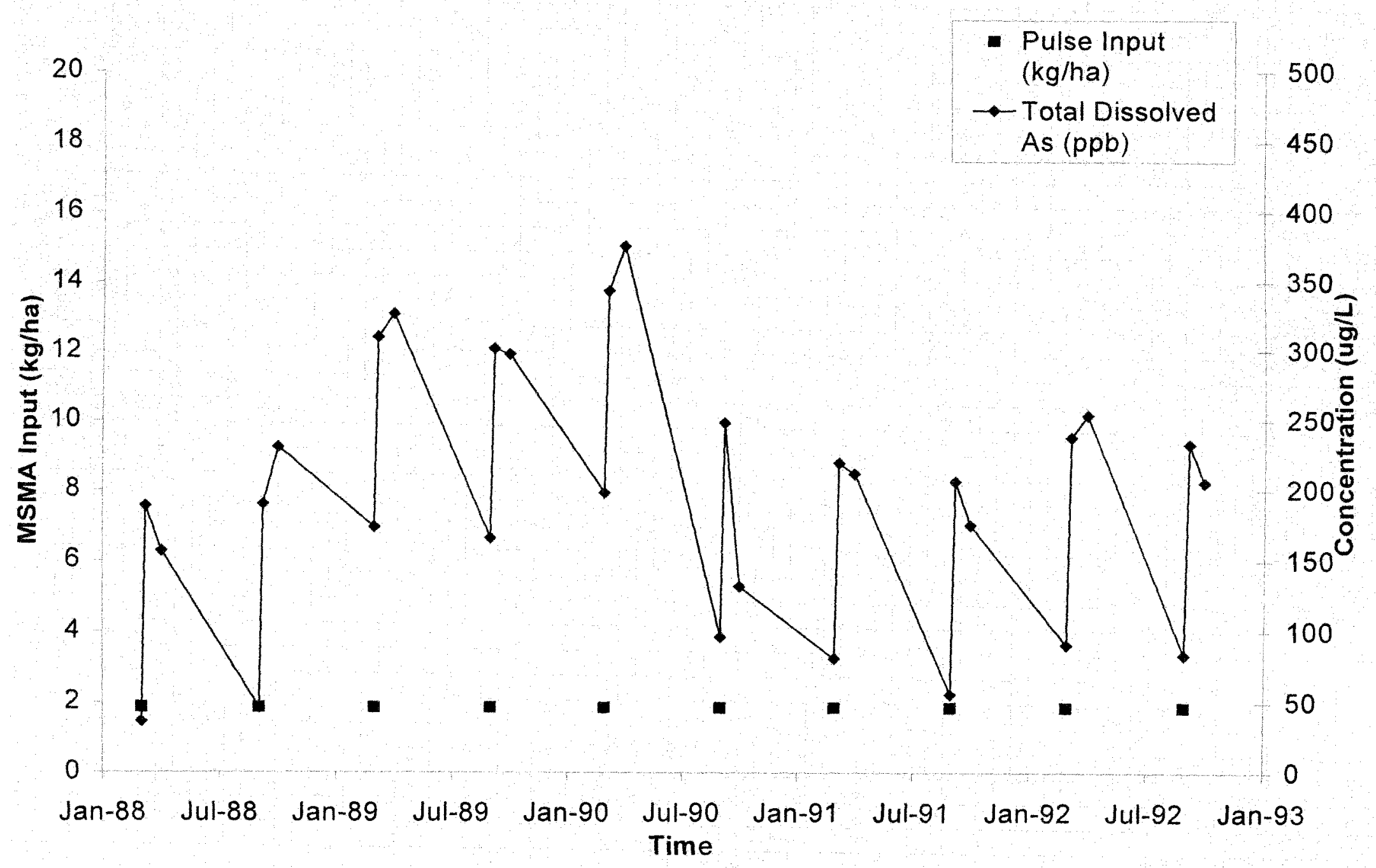

Figure 34. Plot of Concentration verses Time for Total Dissolved Arsenic at the Water Table Interface. Conditions: Laboratory $\mathrm{K}_{\mathrm{d}}$, Dispersion $=1,000 \mathrm{~cm}^{2} /$ day, Irrigation at $85 \%$ Field Capacity (Scenario 6). 


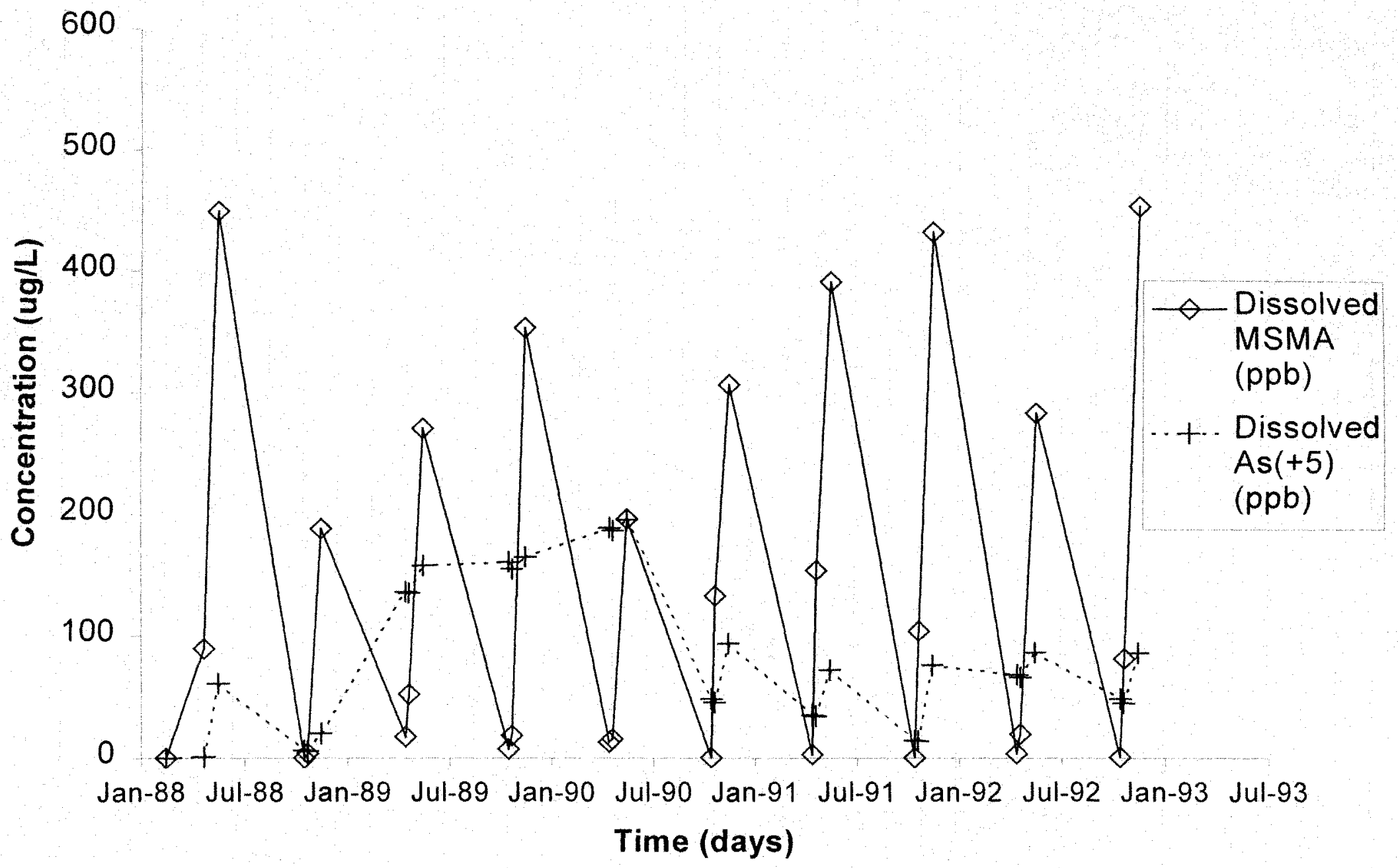

Figure 35. Plot of Concentration verses Time for Dissolved MSMA and Dissolved As $(+5)$ at the Water Table Interface. Conditions: Laboratory $\mathrm{K}_{\mathrm{d}}$, Dispersion $=1,000 \mathrm{~cm}^{2} /$ day, Irrigation at $85 \%$ Field Capacity. 


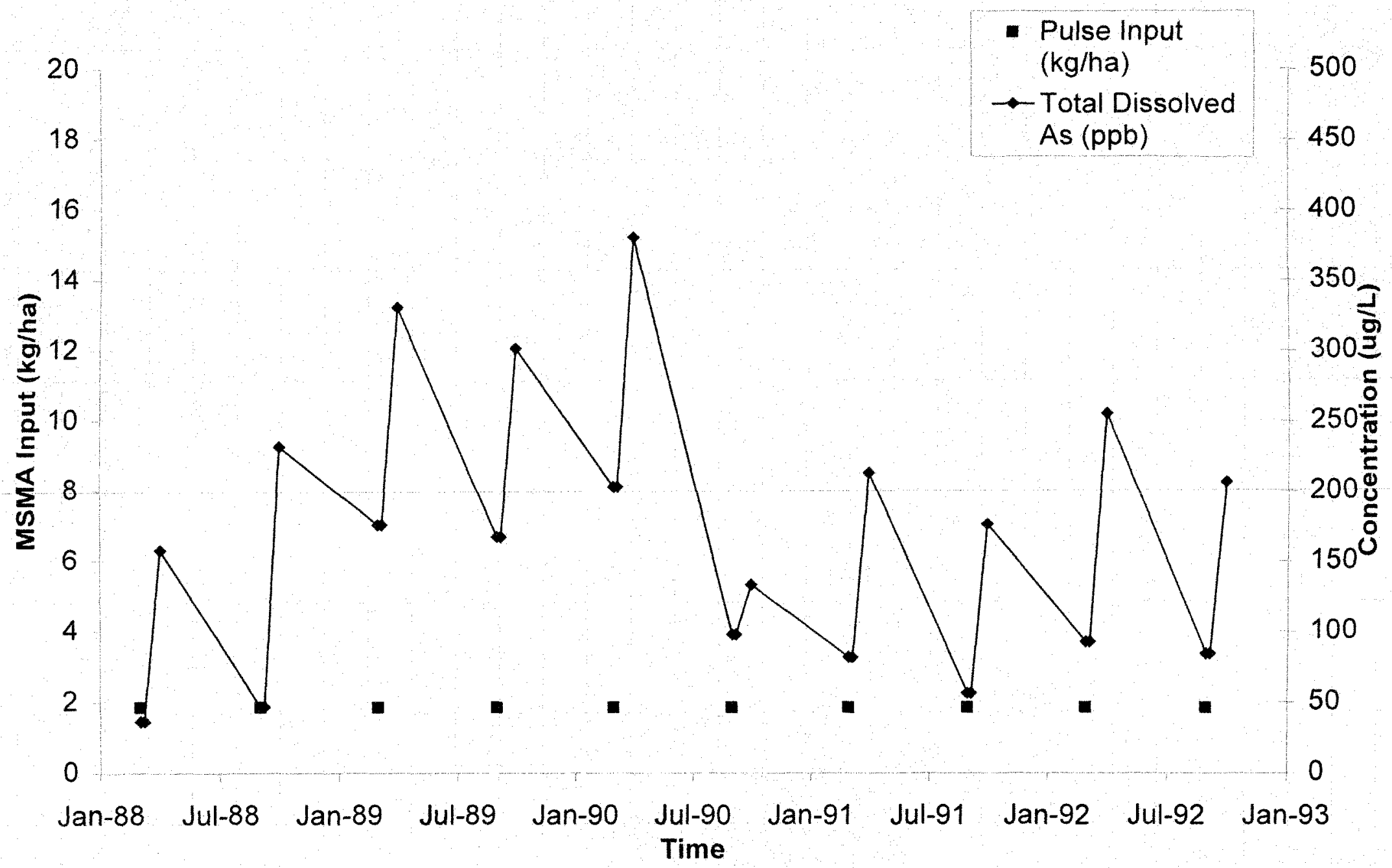

Figure 36. Plot of Concentration verses Time for Total Dissolved Arsenic at the Water Table Interface. Conditions: Laboratory $\mathrm{K}_{\mathrm{d}}$, Dispersion $=1,000 \mathrm{~cm}^{2} /$ day, Irrigation at $15 \%$ Field Capacity (Scenario 7). 


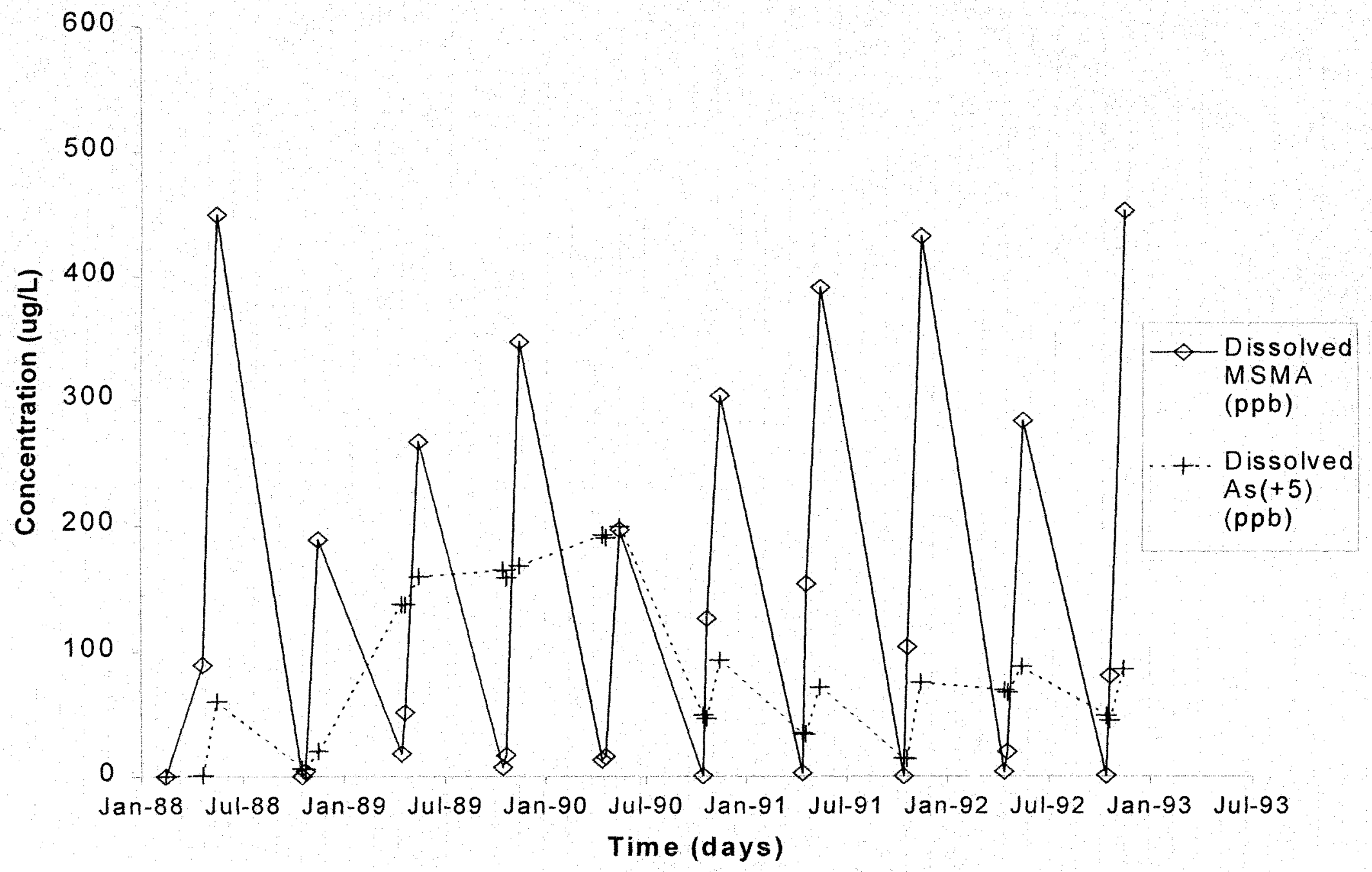

Figure 37. Plot of Concentration verses Time for Dissolved MSMA and Dissolved As $(+5)$ at the Water Table Interface. Conditions: Laboratory $\mathrm{K}_{\mathrm{d}}$, Dispersion $=1,000 \mathrm{~cm}^{2} /$ day, Irrigation at $15 \%$ Field Capacity. 


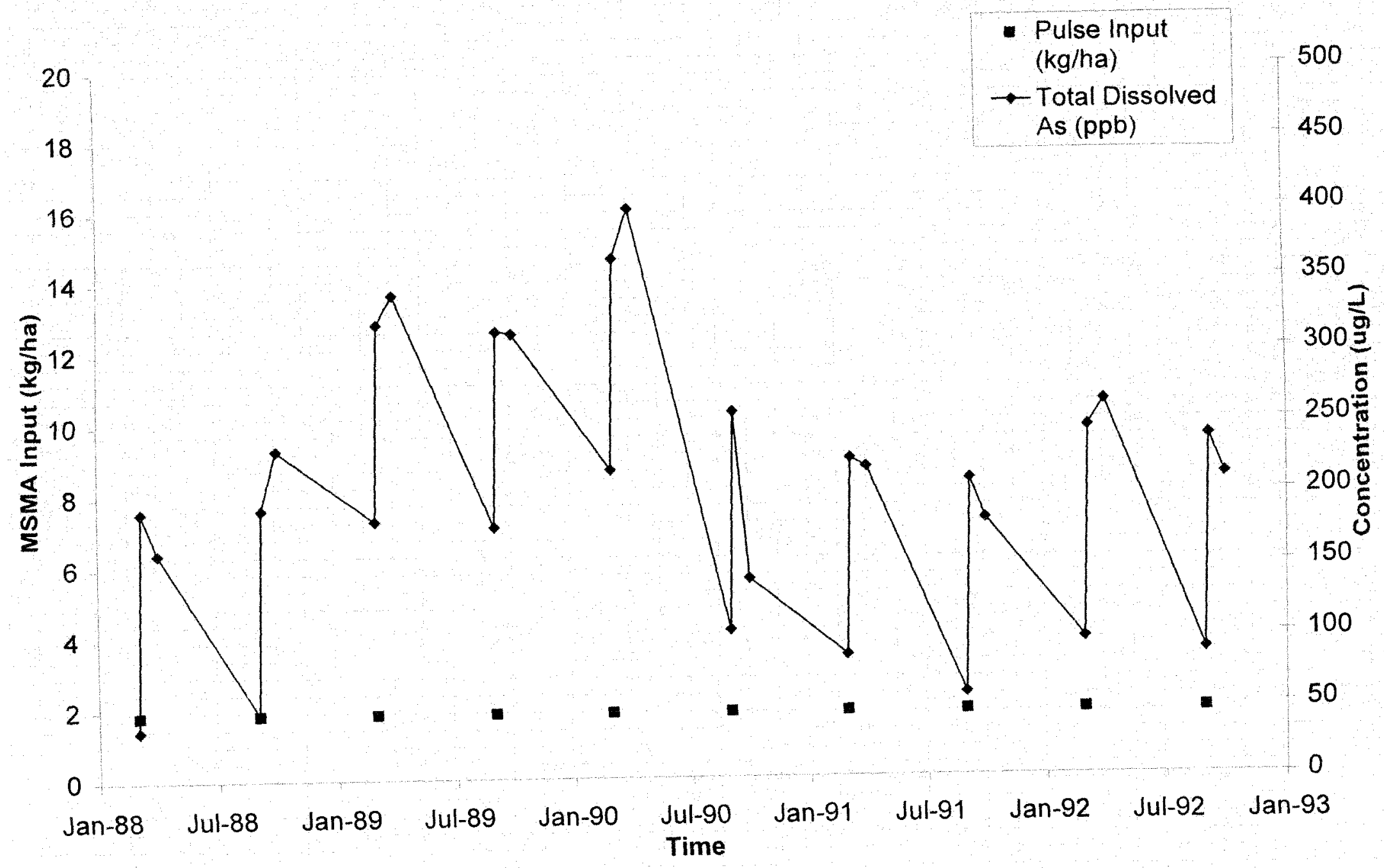

Figure 38. Plot of Concentration verses Time for Total Dissolved Arsenic at the Water Table Interface. Conditions: Laboratory $\mathrm{K}_{\mathrm{d}}$, Dispersion $=1,000 \mathrm{~cm}^{2} /$ day, No Irrigation (Scenario 8). 
1000

900

800

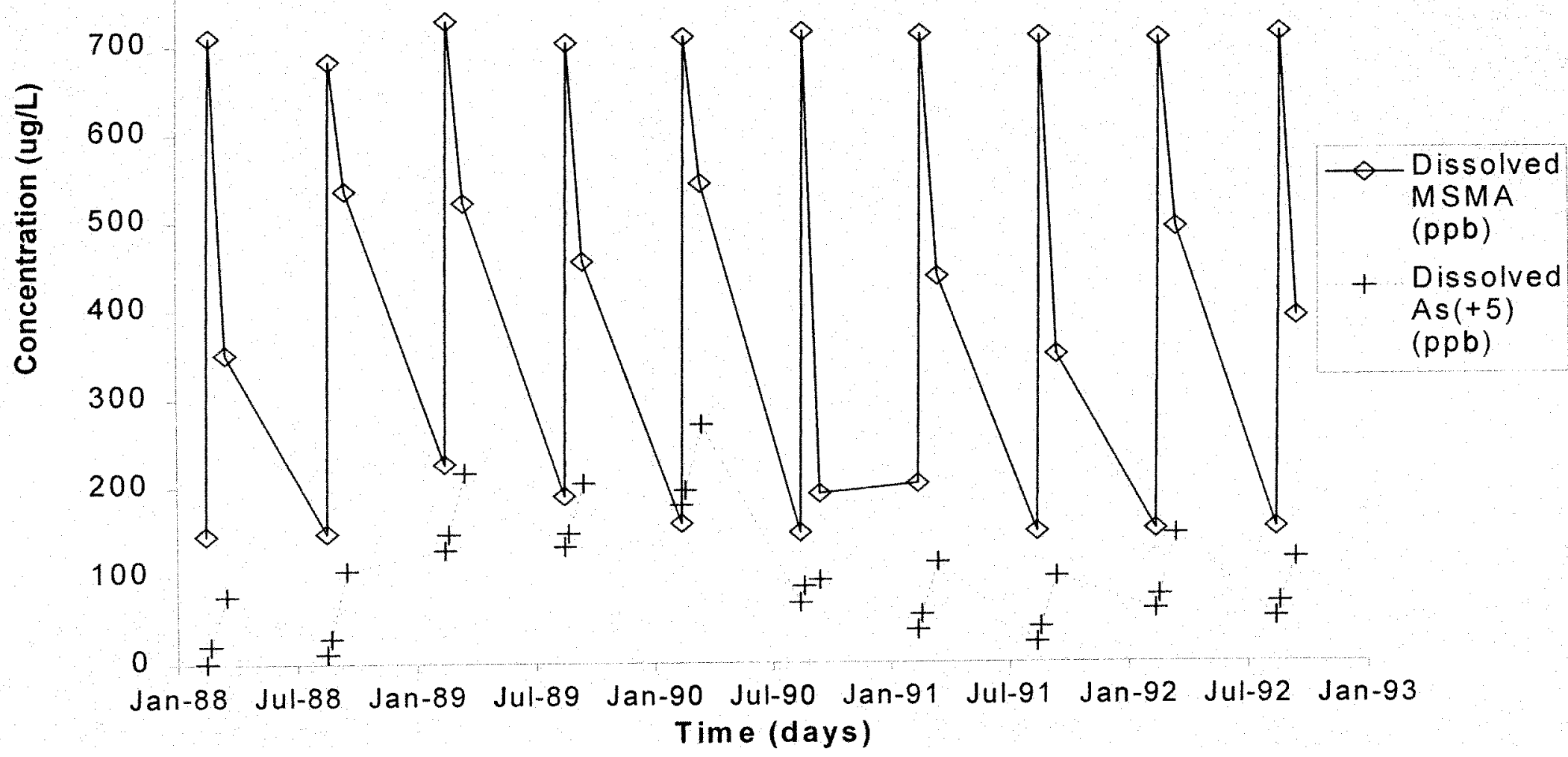

Figure 39. Plot of Concentration verses Time for Dissolved MSMA and Dissolved As(+5) at the Water Table Interface. Conditions: Laboratory $\mathrm{K}_{\mathrm{d}}$, Dispersion $=1,000 \mathrm{~cm}^{2} /$ day, No Irrigation. 
(213 ppb) when a $\mathrm{D}$ value of $10,000 \mathrm{~cm}^{2} /$ day was used in scenario 1 . Concentrations on that day for scenarios 2 and 3 ranged from 0.00 to $36.20 \mathrm{ppb}$ Total Dissolved As using D values of 1,000 and $10,000 \mathrm{~cm}^{2} /$ day respectively.

Another major influence of MSMA and $\mathrm{As}(+5)$ transport was precipitation (advective transportation). MSMA was present at the water table interface in concentrations of at least $50 \mathrm{ppb}$ within 1 month for every scenario (See Figures 24 - 37 and in Appendix A, Tables 22 - 24). This is significant in that PRZM-2.0 indicates that MSMA may have a high mobility within a very short time period. In addition, all the scenarios illustrated that the largest annual accumulation of As $(+5)$ at the vadose zone/water table interface occurred during the 1989 water year, the driest period of the simulation (See Appendix A). This time period appears to have allowed accumulation of $\mathrm{As}(+5)$ as a result of the low precipitation. However, in May of 1990 when rainfall values returned to normal, concentrations of dissolved $\mathrm{As}(+5)$ decreased and did not accumulate at those concentrations again for the remainder of the simulation period (May 1990 through December 1993).

Results also suggest that the irrigation regime of the soils had a minor effect on the transport of dissolved MSMA and As(+5) (See Figures 23-28 and in Appendix A, Table 24). Reports from Ardaman \& Associates, Inc (1996) indicated that the irrigation of the golf course may have influenced the movement of MSMA (and possibly its metabolites) in the soil column. For example, irrigation was triggered in scenario 7 when the water moisture content fell only $15 \%$ of the difference between 0.1 (initial water moisture content) and 0.05 (wilting point) which invoked irrigation more frequently. Therefore, when the water moisture content fell to 0.0925 , the surface was irrigated at a 
maximum rate of $1 \mathrm{~cm} / \mathrm{h}$. As a result, scenario 7 Total Dissolved arsenic concentrations were much lower at the 1 week intervals (148 to $349 \mathrm{ppb}$ ) than in the other 3 scenarios that varied irrigation (710 to $875 \mathrm{ppb}$ ). Since irrigation was triggered a lot more in scenario 7 due to the quicker time it took for the soil moisture to drop to $0.15 \theta$ resulting in a higher irrigation frequency, MSMA and As (+5) were flushed through the soil column more than in scenarios 2,6 , and $8(0.5 \theta, 0.85 \theta$ and no irrigation, respectively).

The effect of $\mathrm{K}_{\mathrm{d}}$ values on contaminant transport was another influential parameter. Figures 25, 28 and 30 illustrate that the lowest concentration of Total Dissolved As occurred when the partitioning coefficient was at $150 \%$ of the normal $\mathrm{K}_{\mathrm{d}}$ value. This high partitioning value retarded the movement of MSMA and As $(+5)$ and resulted in less contaminant migrating from the advective/dispersive forces. However, it appears that every scenario, at some interval during the 5 year simulation, resulted in a violation of Florida's MCL for Total arsenic in groundwater (50 ppb).

When comparing the simulated data to actual field data acquired by Ardaman \& Associates, Inc. (1996), PRZM-2.0 demonstrated reasonably close predictions. In the 1996 report (dated August 7, 1996) submitted to the FDEP, groundwater samples taken from the maintenance area (where MSMA is prepared for applications) at the WPBCC indicated that Dissolved As concentrations ranged from $<5$ to $372 \mathrm{ppb}$. Assuming that the last time MSMA was applied at the golf course was in April of that year, the interval between the handling and sampling may have been $31 / 2$ months. However, these groundwater samples were taken from sites that have varying water table depths (14.17 to 1.78 feet) and soil profiles. In addition, the amount of MSMA applied to these areas cannot be determined since it was probably never "dosed" analogous to this simulation. 
Thus, only generalizations can be made between the field data and PRZM-2.0 simulations. Total Dissolved arsenic concentrations predicted by PRZM-2.0 for time intervals of 1 month after every application under scenario 2 (average: $K_{d}$, Irrigation, and D values) indicate that the Total Dissolved As concentrations ranged from $132.91 \mathrm{ppb}$ to $376.94 \mathrm{ppb}$. Scenarios 6, and 7 also appears to have predicted concentrations closer to the actual field data for the 1 month intervals with ranges of Total Dissolved As values from $133.11 \mathrm{ppb}$ to $379.64 \mathrm{ppb}$. It thus appears that PRZM-2.0 predictions are within a reasonable proximity of actual field data.

When looking at how long it takes, under average simulating conditions (scenario 2), for the bulk of both MSMA and As( +5$)$ to pass through the soil core after only one application, it can be seen that MSMA peaks $(714.8 \mathrm{ppb})$ after 10 days from the application (See Figures 69, 70 and Table 25, Appendix A). As(+5) peaks (98.42 ppb) approximately 60 days from the application, and the maximum Total Dissolved arsenic peak of $200 \mathrm{ppb}$ occurs within 14 days after the application. Since As( +5$)$ has Kd values 20 times higher than MSMA in soil 5 (bottom of simulated core), this may explain why the migration out of the soil core is greatly extended in comparison. Hence, the migration of $\mathrm{As}(+5)$ would be expected to be much slower through soils of this type.

The losses of MSMA due to volatilization, which have not been accounted for in this model, may also be an important factor. The following summarizes the results of the computer modeling:

- There is significant transport of both MSMA and arsenate which results in: (1) MSMA and As(+5) migration into the water table; (2) Total Dissolved As 
concentrations persistently found at the water table interface that exceed $50 \mu \mathrm{g} / \mathrm{L}$ in every scenario.

- The dispersion coefficient was found to be the most influential means of transport for MSMA and arsenate other than precipitation (considered to have the greatest impact on contaminant transport). This can be seen by reviewing scenarios 1 through 3 which show that migration towards the water table interface was accelerated when using the highest dispersion coefficient (Scenario 1). Concentrations ranged from $0.014 \mathrm{ppb}$ (Scenario 3) to $871 \mathrm{ppb}$ Total Dissolved As on similar days from each simulation.

- Other variable tested also had an impact on the contaminants transport. Since MSMA is highly soluble and can be transported greater distances (via the initial wetting front), higher irrigation frequencies flushed MSMA out of soil column and into the groundwater. Conversely, peak As $(+5)$ concentrations at the water table interface occurred much later than MSMA due to its lower mobility (higher $\mathrm{K}_{\mathrm{d}}$ values in the lower part of the soil column retained As $(+5)$ better). Results also indicate that higher $\mathrm{K}_{\mathrm{d}}$ values also retarded the movement of MSMA.

- It can be extrapolated from this gross estimate, that the possible use of MSMA at the recommended rates may result in dissolved As concentrations that exceed the groundwater limits set forth in FAC 62-550.

\subsection{Limitations}

The followings lists the limitations of this study: 
- Although, care in minimum QA/QC protocols were used, the results from the analytical experimentation may have been influenced by: inaccurate preparation of standards, inaccurate spiking of experiments with MSMA and As(+5), variable and/or inaccurate readings from the Perkin Elmer $5100 \mathrm{C}$ due to age of equipment or operator error, loss of analyte from frequent handling of sample, or errors due to experimental design. As a result, and since this experimental data set may be the first developed based on actual field samples from a South Florida golf course, additional studies should be conducted to confirm the results before they are considered for other modeling exercises.

- Modeling results may have been possibly influenced by: assumptions of input applications, background conditions, selected boundaries, estimation of average field parameters, possible inherent nature of PRZM-2.0 that may not be applicable outside of agronomic systems, inaccurate representation of application rates and frequencies of MSMA. In addition, the process of model verification and calibration was not performed due to experimental data, time and financial constraints. Therefore, the results of this modeling exercise should be viewed as the potential of what may actually occur in the environment. 


\subsection{CONCLUSIONS AND RECOMMENDATIONS}

The objectives of this study were accomplished through experimental work and computer simulations.

\subsection{Conclusions}

The conclusions of this study are generalized as follows:

- Experimental work indicated that MSMA and arsenate adsorption may follow a linear-type behavior in the soils sampled from the West Palm Beach Country Club. Of the three isotherm equations used for comparison, the Linear equation best fit the adsorption characteristics for both MSMA and arsenate. Previous studies confirmed the sorptive characteristics of an arsenate:sand system in the presence of phosphorus.

- Simulations of MSMA and its byproduct arsenate, under the considered application scenarios, assumptions and limitations, indicate that dissolved concentrations at the vadose zone/Biscayne aquifer interface could exceed the state of Florida's groundwater limits on total arsenic (50 ppb) within lapplication. This study should point out that the registration of MSMA needs to be re-evaluated closely.

- According to PRZM-2.0 results, the predominant fraction of As over time is the organic fraction, MSMA. However, under different scenarios not simulated in this work, the concentrations of MSMA and As $(+5)$ at the water table interface may differ from these results.

- Simulations are considered to be a gross estimate of the fate and transport of MSMA 
and its byproduct, arsenate, for the various reasons mentioned in section 4.5.2. The procedure of calibration and verification of the model and inputted parameters were not part of this study.

\subsection{Recommendations}

Recommendations for further research in this area are as follows:

- A 3-Dimensional analytical computer model more suited for urban areas such as the Hydrologic Simulation Program-FORTRAN (HSPF) model would allow a more comprehensive approach to appropriately model the hydrology and hydraulics required. These two factors are ultimately the controlling mechanisms for transport of herbicides as soluble as MSMA.

- Of course, additional good information must be collected. Soil column or caisson experiments, which can more objectively simulate the vadose zone, should be used to verify the bench-scale batch $\mathrm{K}_{\mathrm{d}}$ values for the soils from this study. These experiments will improve the estimation of $\mathrm{K}$ values and the calibration and verification of any modeling simulations.

- The influence of phosphates and other fertilizers on the transport of arsenate should be researched. Other related studies (Hiltbolt et.al., 1974; Davenport et.al., 1991; Darland et.al., 1997) point out that this has already been observed in other situations.

- The registration of herbicides and pesticides, to date, use a very general method to quantify the effects that they may have over a wide variety of environments. 


\section{LIST OF REFERENCES}

Allen, H. E. 1995. Metal Contaminated Aquatic Sediments. Ann Arbor Press, Chelsea, Michigan.

Althaus, W., Kabash, S., Weinspach, P.M. 1996. Batch-Precipitation of Calcium Carbonate from Highly Supersaturated Solutions. Trans IChemE. v. 74. pp. 765772 .

Aly, O.M., Faust, S.d. 1983. Chemistry of Water Treatment. Butterworth. Woburn, Ma. pp. 493-501.

Ardaman \& Associates, Inc. 1996. Contamination Assessment Report, West Palm Beach Country Club.

Aurillio, A.C., Durant, J.L., Hemond, H.F., Knox, M.L. 1995. Sources and Distribution Of Arsenic in the Aberjono Watershed, Eastern Massachusetts. Water, Air, and Soil Pollution. 81, pp. 265-282.

Bruneau, A. H., Hodges, S.C., Powell, M.A., Lucas, L.T. Integrated Pest Management for Municipalities. URL: http://ipmwww.ncsu.edu/urban/cropsci/c01 intro/colntrol.html $7 / 11 / 97$.

Buckner, L. 1997. Dade County Environmental Resources Management (DERM). Phone Interview, July 8.

Cullen, W.R., Reimer, K. J. 1989. Arsenic Speciation in the Environment. Chemical Review. pp. 713-764.

Curreri, P., Onoda, G.Y. Jr., and Finlayson, B.. 1979. An electrophoretic study of calcium oxalate monohydrate. Journal of Colloid and Interface Science. 69, pp. 170-181.

Darland, J.E., Inskeep, W.P. 1997. Effects of $\mathrm{pH}$ and Phosphate Competition on the Transport of Arsenate. Journal of Environmental Quality. v 26. July -August. pp. 1133-1139.

Davenport, J.R., Peryea, F.J. 1991. Phosphate Fertilizers Influence Leaching of Lead and Arsenic in a Soil Contaminated with Lead Arsenate. Water, Air, and Soil Pollution. v. 57-58. pp. 101-110.

Davis, A., De Curnou, P., Eary, L. 1997. Discriminating between source of Arsenic in the Sediments of a Tidal Waterway, Tacoma, Washington. Environmental Science Technology. 31, pp. 1985-1991.

Day, R. A., Underwood, A. L. 1986. Quantitative Analysis, $5^{\text {th }}$ Edition. Prentice Hall. London. pp. 28-30.

de Marsily, G., 1986. Quantitative Hydrogeology: Groundwater Hydrology for Engineers. Academic Press, Inc. 
Delgado, A., Gonzalex-Caballero, F., and Bruque, J.M. 1986. On the electrophoretic Mobility and zeta potential of montmorillonite in non-aqueous media. Journal Of Colloid \& Polymer Science. 264, pp. 435-438.

Edwards M., ,McNeill, L.S. 1997. Predicting As removal during metal hydroxide precipitation. Journal of American Water Works Association. 89 (1), pp. 75-86.

Farm Chemicals Handbook, Pesticides Dictionary, 1997. pp. C254 -C255.

Florida Department of Agriculture \& Consumer Services. 1997. Florida Pesticide Registration Guidelines. Tallahassee, Fl.

Fuentes, H.R., Polzer, W.L. The Use of a Heterogeneity-Based Isotherm to Interpret the Transport of Radionuclides in Volcanic Tuff Media. Radiochimica Acta. 44/45, pp. $361-365$.

Fuentes, H.R., Rao, M.G., Polzner, W.L., and Essington, E.H. 1990. Modeling the Mass-Transfer Rate of Radioactive Cobalt from a synthetic Groundwater to Volcanic Tuff Media. Journal of Contaminant Hydrology. 6, pp. 69-84.

Fuentes, H.R., Polzer, W.L., Smith, J.L. Laboratory Measurements of Diffusion Coefficients for Trichlorethylene and Orthosylene in Undisturbed Tuff. Journal of Environmental Quality. v. 20, January-March.

Fuentes, H.R., Gutierrez, M. 1993. A Langmuir Isotherm-Based Prediction of Competitive Sorption of $\mathrm{Sr}, \mathrm{Cs}$, and $\mathrm{Co}$ in Ca-Montmorillonite. Waste Management. v. 13, pp. 327-332.

Gagdon, C., Arnac M., and J.R. Brindle. 1992. Sorption interactions between trace metals $(\mathrm{Cd}$ and $\mathrm{Ni}$ ) and phenolic substances on suspended clay materials. Water Resources. 26 (8), pp. 1067-1072.

Ghosh, M. M., Cox, C.D. 1994. Surface Complexation of Methylated Arsenates by Hydrous Oxides. Water Resources. v. 28, pp. 1181-1188.

Goldberg, S., Glaubig, R.A. 1988. Anion Sorption on a Calcareous, Montmorillonitic Soil-Arsenic. Soil Science Society America Journal. v. 52, pp. 1297-1300.

Gupta, R.S. Hydrology \& Hydraulic Systems. 1989. Waveland Press, Inc. Illinois.

Gutierrez, M. 1992. Competitive Adsorption Interactions of Strontium, Cobalt and Cesium in Suspensions of Calcium Montmorillonite: Electrochemical Behavior and Modeling. Dissertation-University of Texas at El Paso, Major Professor: Dr. H. R. Fuentes.

Harris, L.B. 1970. Simplified calculation of electrophoretic mobility of non-spherical particles when the electrical double layer is very extended. Journal of Colloid and Interface Science. 34 (2), pp. 322-325.

Harsh, J.B., Doner, H.E., and Fuerstenau, D.W.. 1988. Electrophoretic mobility of Hydroxy-Aluminum and Sodium Hectorite in aqueous solutions. Soil Science of the Society of Americal Journals. 52, pp. 1589-1592. 
Hidalgo-Alvarez, R., Delgado, A., Callejas, J., and Gonzalez-Caballero, F. 1985. Electrophoretic behavior of calcium oxalate monohydrate in liquid mixtures. Colloid and Polymer Science. 263, pp. 941-947.

Hiltbolt, A. E. 1974. Behavior of Oganoarsenicals in Plants and Soils. American Chemical Society Symposium Series. pp. 53-69.

Itano, M., Kezuka, T., Ishii M., Unemoto, T., and Kubo, M. 1995. Minimization of particle contamination during wet processing of Si wafers. Journal of the Electrochemical Society. 142 (2), pp. 971-978.

Jaffe, R. 1998. Department of Chemistry, Florida International University. Phone Interview, May 6.

Jensen, D.J., Radke, C.J. 1988. Cesium and strontium diffusion through sodium montmorillonite at elevated temperature. Journal of Soil Science. 39. pp. 53-64.

Jorgensen, P. R., Fredericia, J. 1992. Migration of Nutrients, pesticides and heavy metals in fractured clayey till. Geotechnique. v. 42, pp. 67-77.

Kachanoski, R.G., Tanji, K.K., Rollins, L.T., Whittig, L.D., Fujii, R. 1992. Dissolution kinetics of CaCO3: Carkin-1, A computer model. Soil Science. 153 (1), pp. 13-24.

Koelmans, A.A., de Lange, H.J., and Lijklema, L. 1993. Desorption of chlorobenzenes from natural suspended solids and sediments. Journal of Water Science Technology. 28 (8-9), pp. 171-180.

Lindsay, W.L. 1979. Chemical Equilibria in Soils. John Wiley \& Sons, N.Y.

Manning, B. A., Goldberg, S. 1997. Adsorption and Stability of Arsenic (III) at the Clay Mineral-Water Interface. Environment Science Technology. 31, pp. 20052011.

Masscheleyn, P.H., Delaune, R. D., Patrick W.H. 1991. Arsenic and Selenium Chemistry as affected by Sediment Redox Potential and $\mathrm{pH}$. Journal of Environmental Quality 1991. pp. 522-527.

Masscheleyn, P.H., Delaune, R.D., Patrick, W.H. 1991. Effect of Redox Potential and $\mathrm{pH}$ on Arsenic Solubility and Speciation in a Contaminated Soil. Environmental Science Technology. 25, pp. 1414-1419.

McLaughlin, R., 1994. Are golf Course handicapping Coastal Water Quality? Environment. July, pp. 21.

Miles, C.J., Leong, G., Dollar, S. 1992. Pesticides in Marine Sediments Associated with Golf Course Runoff. Bulletin of Environmental Contamination and Toxicology. 49, pp. 179-185.

Morel, F.M.M., Hering, J.G. 1993. Principles and Applications of Aquatic Chemistry. 
John Wiley \& Sons, N.Y.

Muhammad, S. 1997. Arsenic Chemistry in Soils: An Overview of Thermodynamic Predictions and Field Observations. Water, Air and Soil Pollution. v 93 (1-4), pp. 117-136

National Climatic Data Center. 1947 - 1997 Climatological Data Set, West Palm Beach International Airport. URL: http:// www.ncdc.gov/ 7/15/98.

Onken, B. M., Hossner, L. R. 1995. Heavy Metals in the Environment. Journal of Environmental Quality. 24, pp. 373-381.

Papadopoulos, P., Rowell, D.L. 1988. The reactions of cadmium with calcium carbonate surfaces. Journal of Soil Science. 39, pp. 23-36.

Papadopoulos, P., Rowell, D.L. 1988. The reactions of copper and zinc with calcium carbonate surfaces. Journal of Soil Sciences. 40, pp. 39-48.

Piatt, J.J., Backhus, D.A., Capel, P.D., Eisenreich, S.J. 1996. Temperature-Dependent Sorption of Napthalene, Phenanthrene, and Pyrene to Low Aquifer Sediments. Environmental Science and Technology. 30, pp. 751-760.

Pignatello, J.J., Xing, B. 1996. Mechanisms of slow sorption of organic chemicals to natural particles. Environmental Science and Technology. 30 (1), pp. 1-11.

Peible, D.D., and Savant-Malheit, S.A. 1993. Comparison of physical transport processes in non-cohesive river sediments. Journal of Environmental Engineering. 119(1), pp. 90-102.

Raven, K.P., Jain, A., Loeppert, Richard H. 1998. Arsenite and arsenate adsorption on ferrihydrite: Kinetics, equilibrium, and adsorption envelopes. Environmental Science Technology. v32 (3), pp. 344-349.

Rees, T.F., and Ranville, J.F. 1990. Collection and analysis of colloidal particles transported in the Mississippi River, U.S.A.. Journal of Contaminant Hydrology. 6, pp. 241-250.

Riddick, T.M. 1968. Control of colloid stability through zeta potential . Zeta-Meter, Inc. pp. 1-204.

Ross, R. and Morrison, I.D. 1988. Colloidal Systems and Interfaces. John Wiley and Sons, N.Y., pp. 2 - 255.

Roy, W.R., Krapac, I.G., Chou, S.F.J., and Griffin, R.A. 1987. Batch-type procedures for Estimating Soil Adsorption of Chemicals. EPA/530-SW-87-006-F.

Salingar, Y., Geifman, Y., Aronowich. 1993. Orthophosphate and calcium carbonate solubilities in the Upper Jordan Watershed Basin. Journal of Environmental Quality. 22, pp. 672-677.

Seamen, J.C., Bertsch, P.M., Miller, W.P. 1995. Chemical controls on colloid 
generation and transport in a sandy aquifer. Environmental Science and Technology. 29 (7), pp. 1808-1815.

Smith, L. 1998. Florida Department of Environmental Protection - South East District. Waste Management Program. Phone Interviews, March 1997 - February 1998.

Sparks, D.L. 1986. Soil Physical Chemistry. CRC Press, Inc. Boca Raton, FL.

Standard Methods. 1995. Standard Methods for the Examination of Water and Wastewater. WEF.

Stanitski, C.L., Slowinski, E.J., Masterton, W.L. 1986. Chemical Principles with Qualitative Analysis. CBS College Publishing.

Stotz, S. 1978. Field dependence of the electrophoretic mobility of particles suspended in low-conductivity liquids. Journal of Colloid and Interface Science $65(1)$, pp. 118-130.

Stumm, W. 1987. Aquatic Surface Chemistry: Chemical Processes at the ParticleWater Interface. John Wiley and Sons, N.Y.

Stumm, W., and Morgan, J. 1981. Aquatic Chemistry: An Introduction Emphasizing Chemical Equilibria in Natural Waters. John Wiley and Sons, N.Y.

Thomann, R.V., Mueller, J. A. 1987. Principles of Surface Water Quality Modeling and Control. Harper Collins Publishers.

U.S. Army Corps of Engineers. 1995. QA/QC Guidance for Sampling and Analysis of Sediments, Water, and Tissues for Dredged Material Evaluations, Chemical Evaluations. U.S. EPA, Office of Water. EPA 823-B-95-001.

U.S. Environmental Protection Agency. 1995. Monosodium Methanearsonate and Disodium Methanearsonate: Toxic Chemical Release Reporting; Community Right-to-Know. Federal Register. April 20.

U.S. Geological Survey. 1996. Water Quality, Pesticide Occurrence, and Effects of Irrigation with Reclaimed Water at Golf Courses in Florida. U.S. Department of the Interior.

Valsaraj, K.T. 1995. Elements of Environmental Engineering, Thermodynamics and Kinetics. CRC Press, Inc.

Wan, H. B., Wong, M.K. 1996. Pesticides in Golf Course Waters Associated with Golf Course Runoff. Environmental Contamination and Toxicology. v. 56, pp. 205209.

Woolson, E.A. 1974 Bioaccumulation of Arsenicals. American Chemical Society. pp. 
108-123. 
Appendix A - Tables, Figures, and Maps 


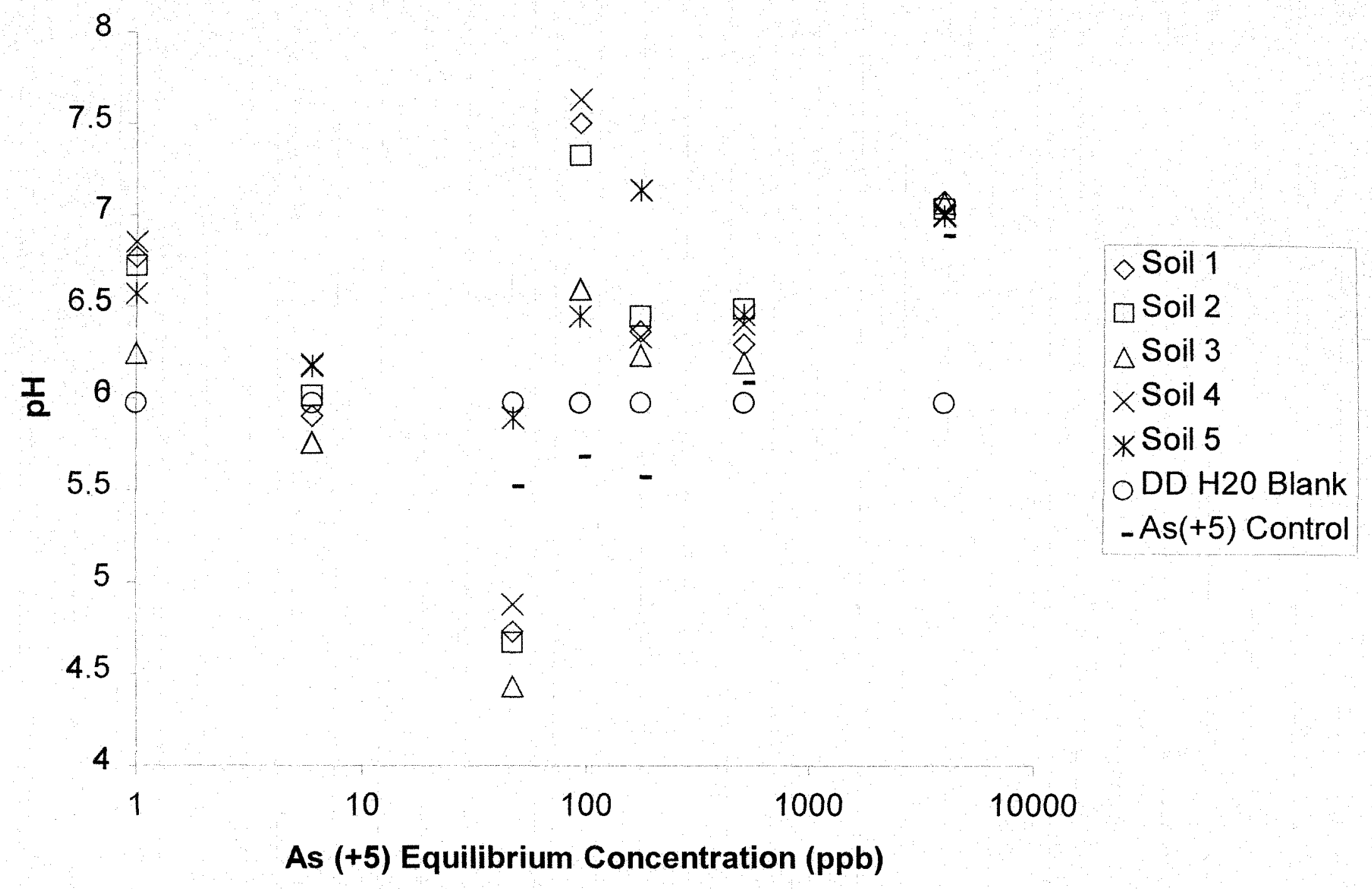

Figure 40. Plot of $\mathrm{pH}$ vs. Equilibrium Concentrations of As(+5) Adsorption Experiments @ $22.48{ }^{\circ} \mathrm{C}$ 


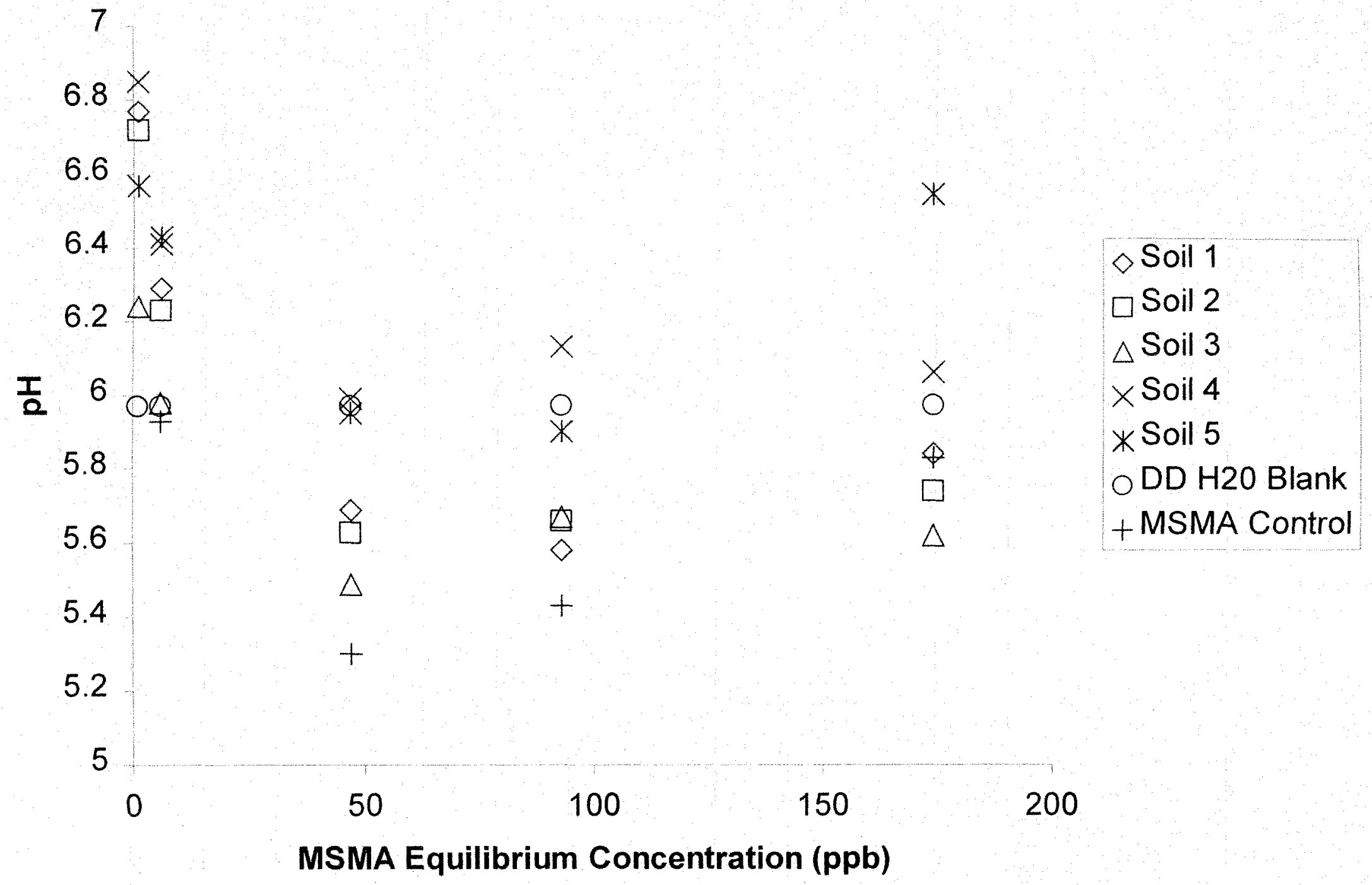

Figure 41. Plot of pH vs. Equilibrium Concentrations of MSMA Adsorption Experiments @ $22.48{ }^{\circ} \mathrm{C}$. 


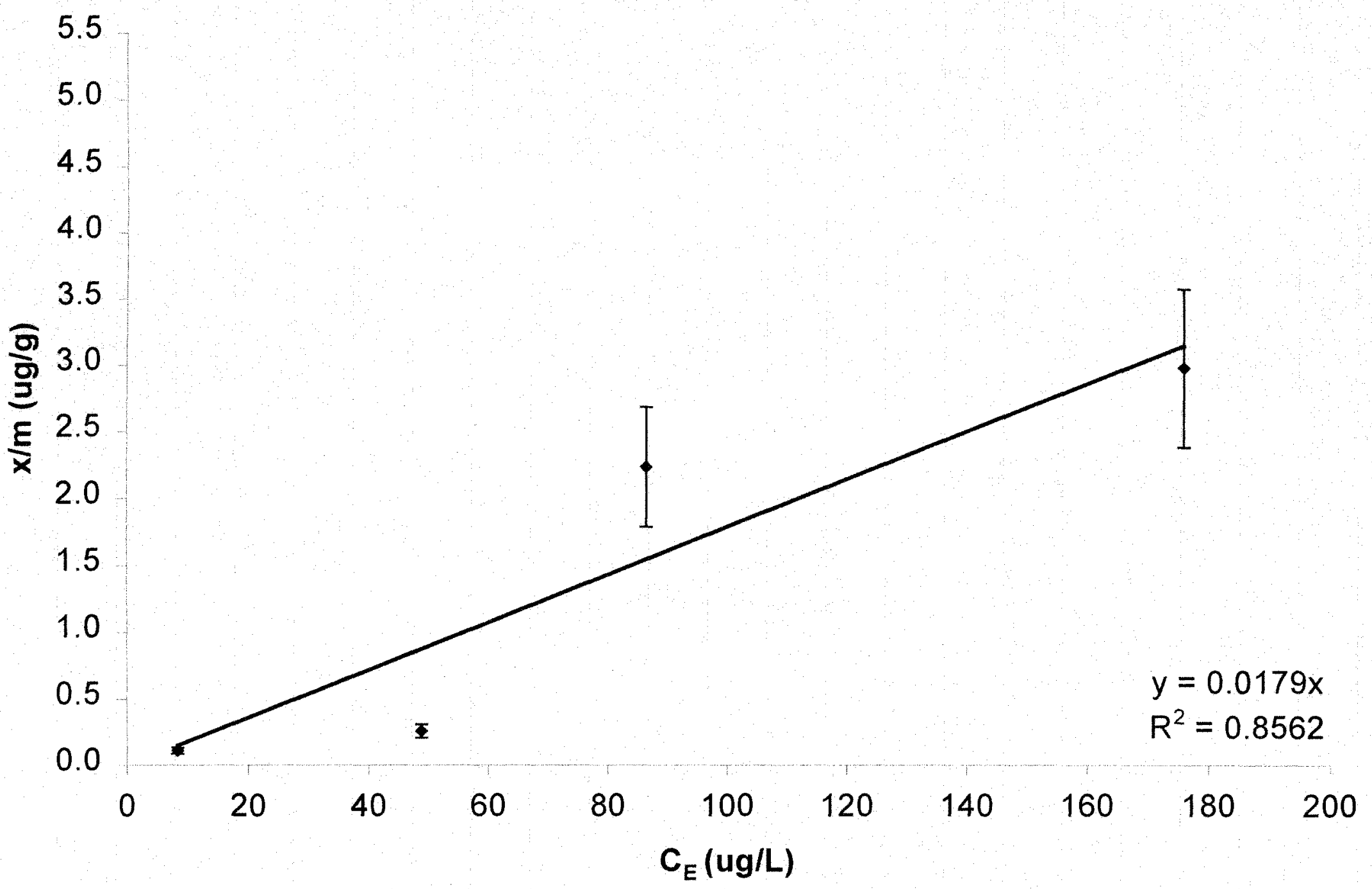

Figure 42. Linear Isotherm for the MSMA Soil $1 @ 22.48^{\circ} \mathrm{C}$. 


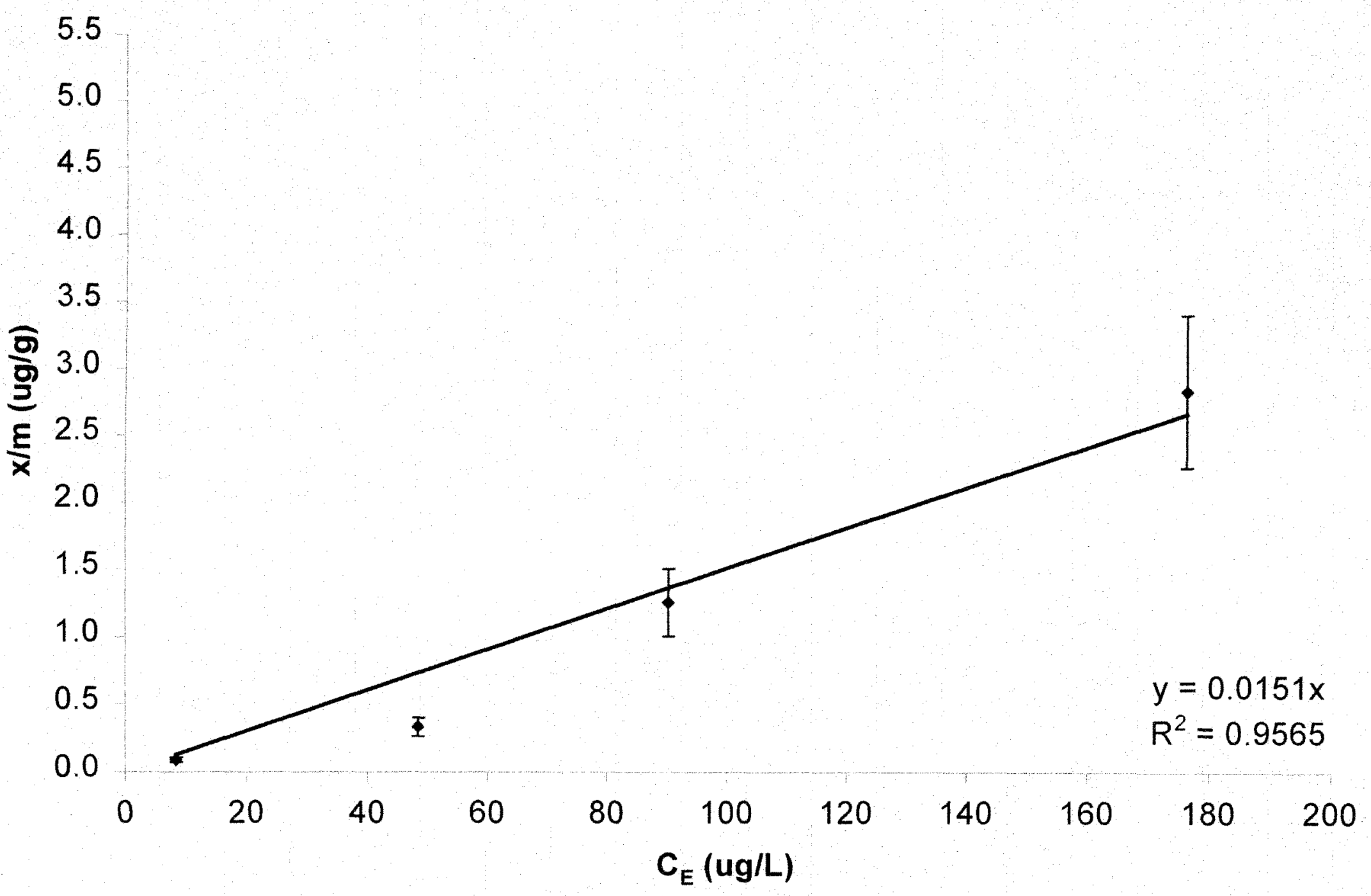

Figure 43. Linear Isotherm for the MSMA, Soil 2 System @ $22.48^{\circ} \mathrm{C}$. 


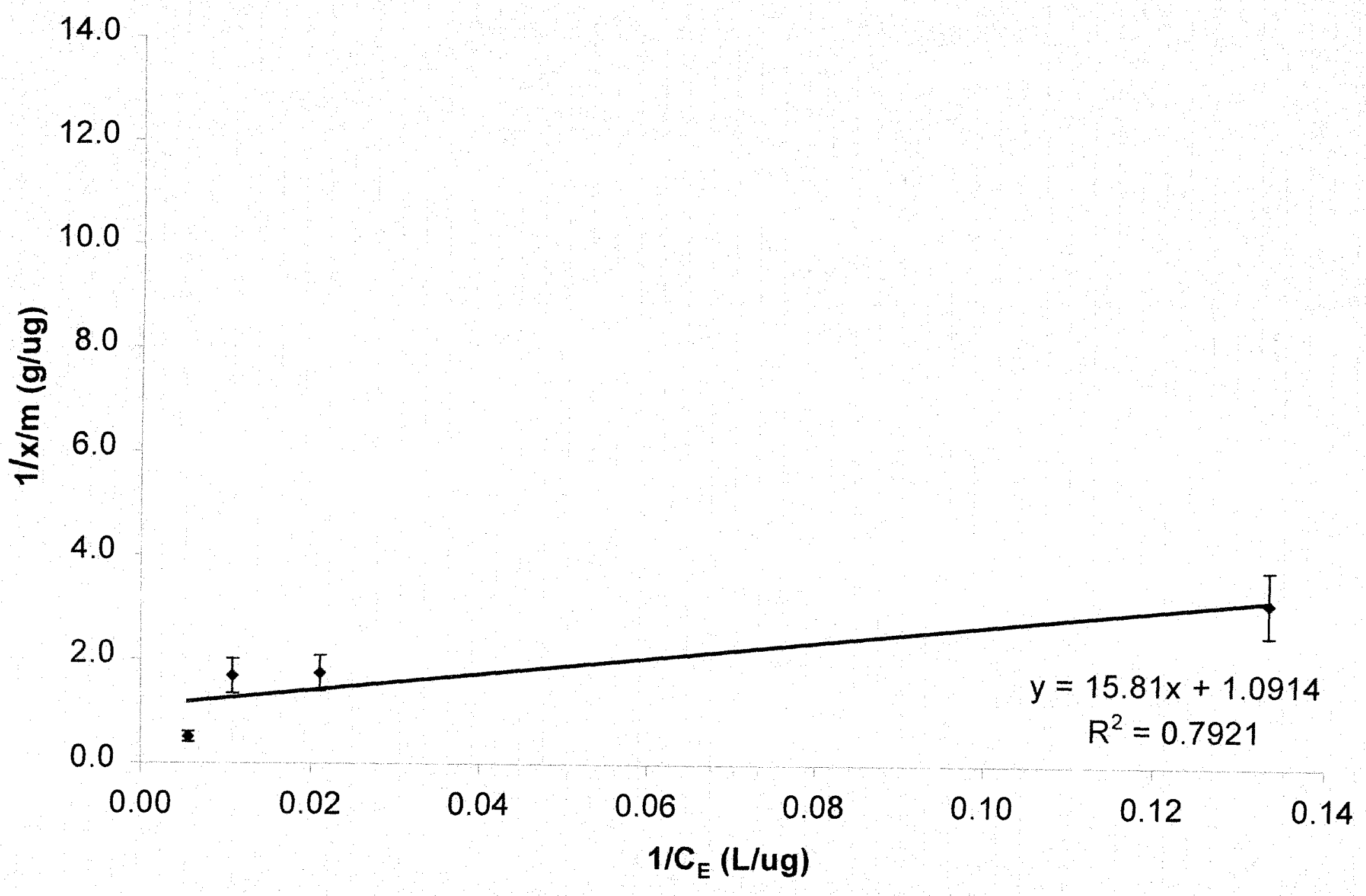

Figure 44. Langmuir Isotherm for the MSMA, Soil 3 System @ $22.48^{\circ} \mathrm{C}$. 


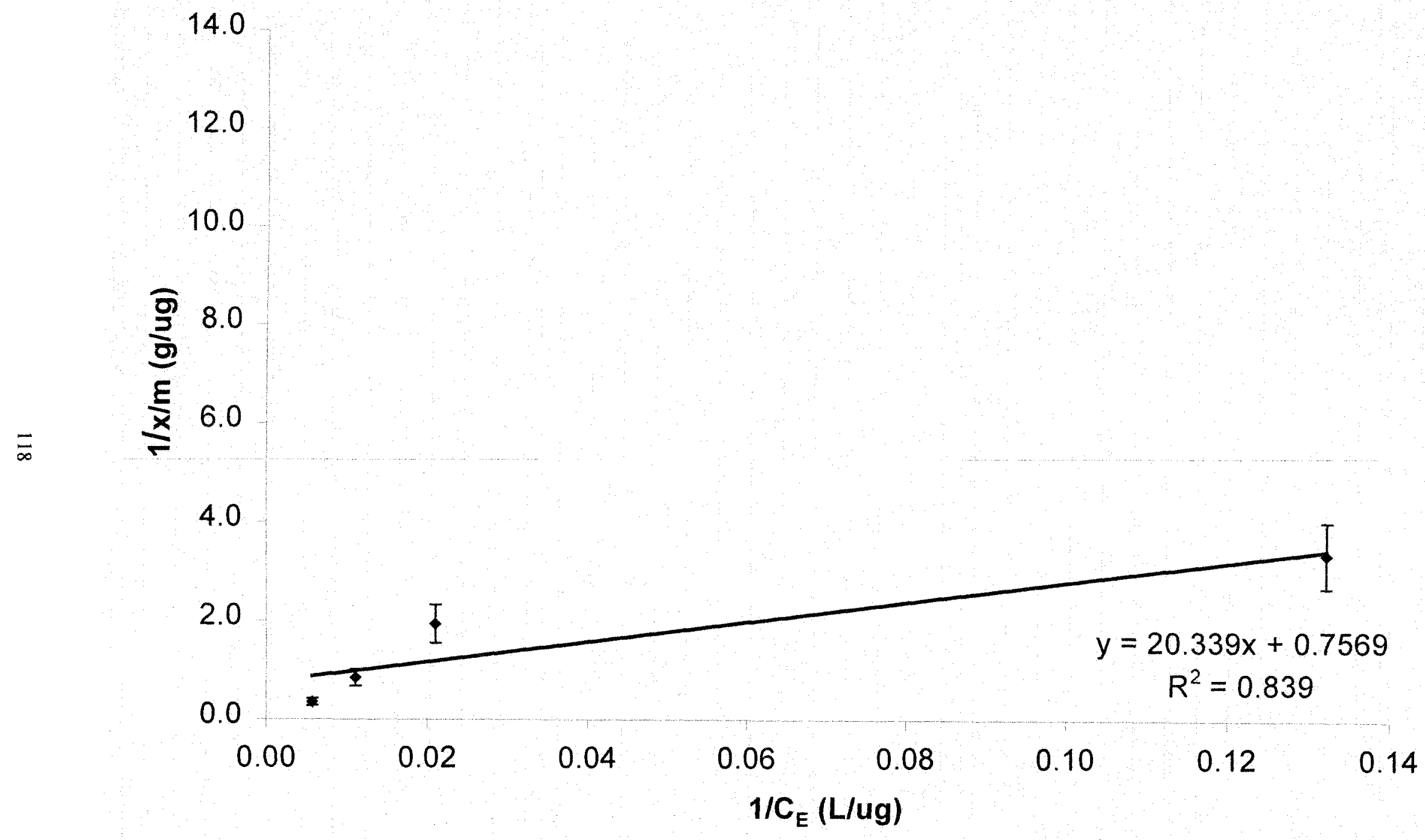

Figure 45. Langmuir Isotherm for the MSMA, Soil 4 System @ $22.48^{\circ} \mathrm{C}$. 


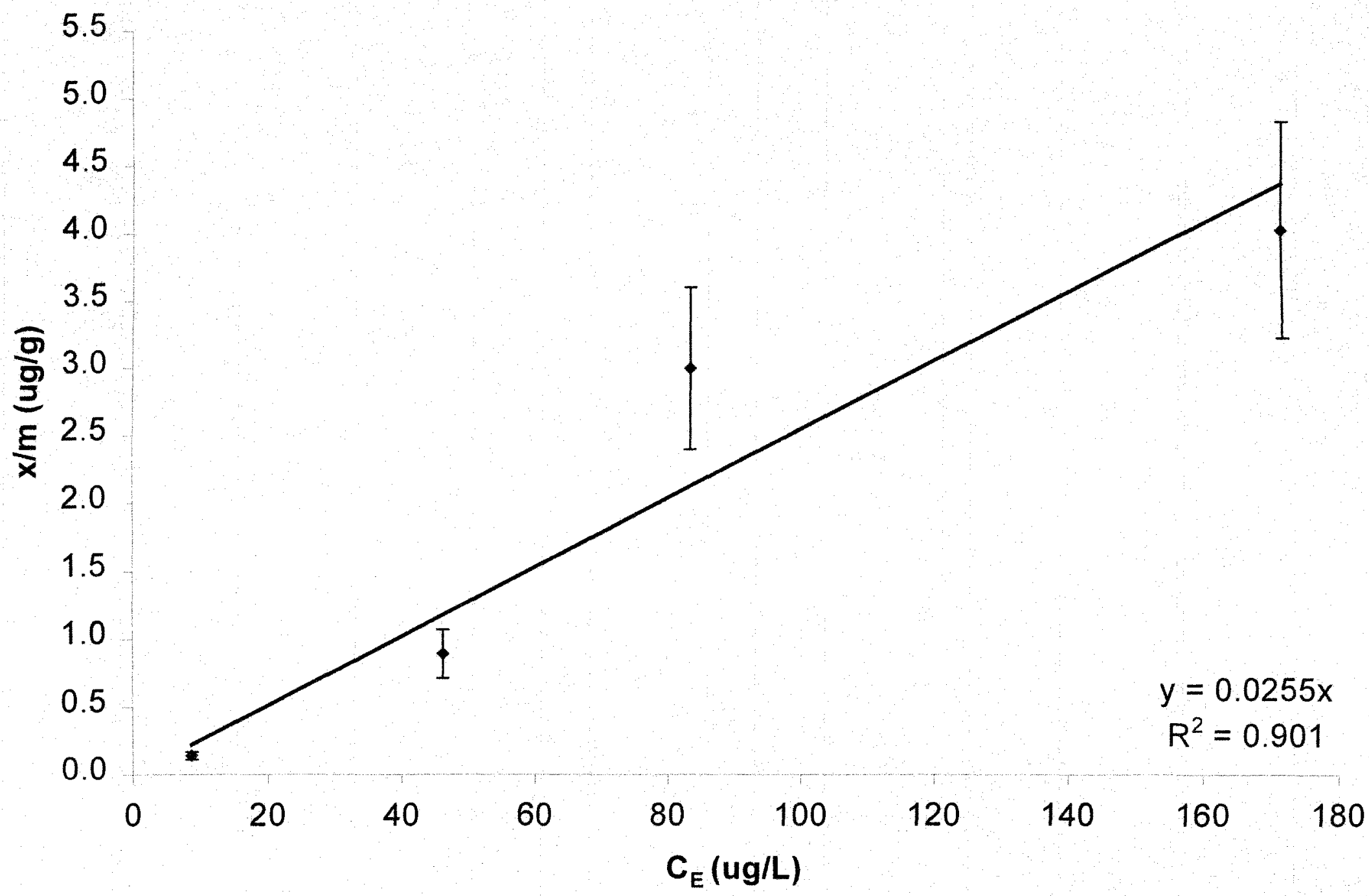

Figure 46. Linear Isotherm for the MSMA, Soil 5 System @ $22.48^{\circ} \mathrm{C}$. 


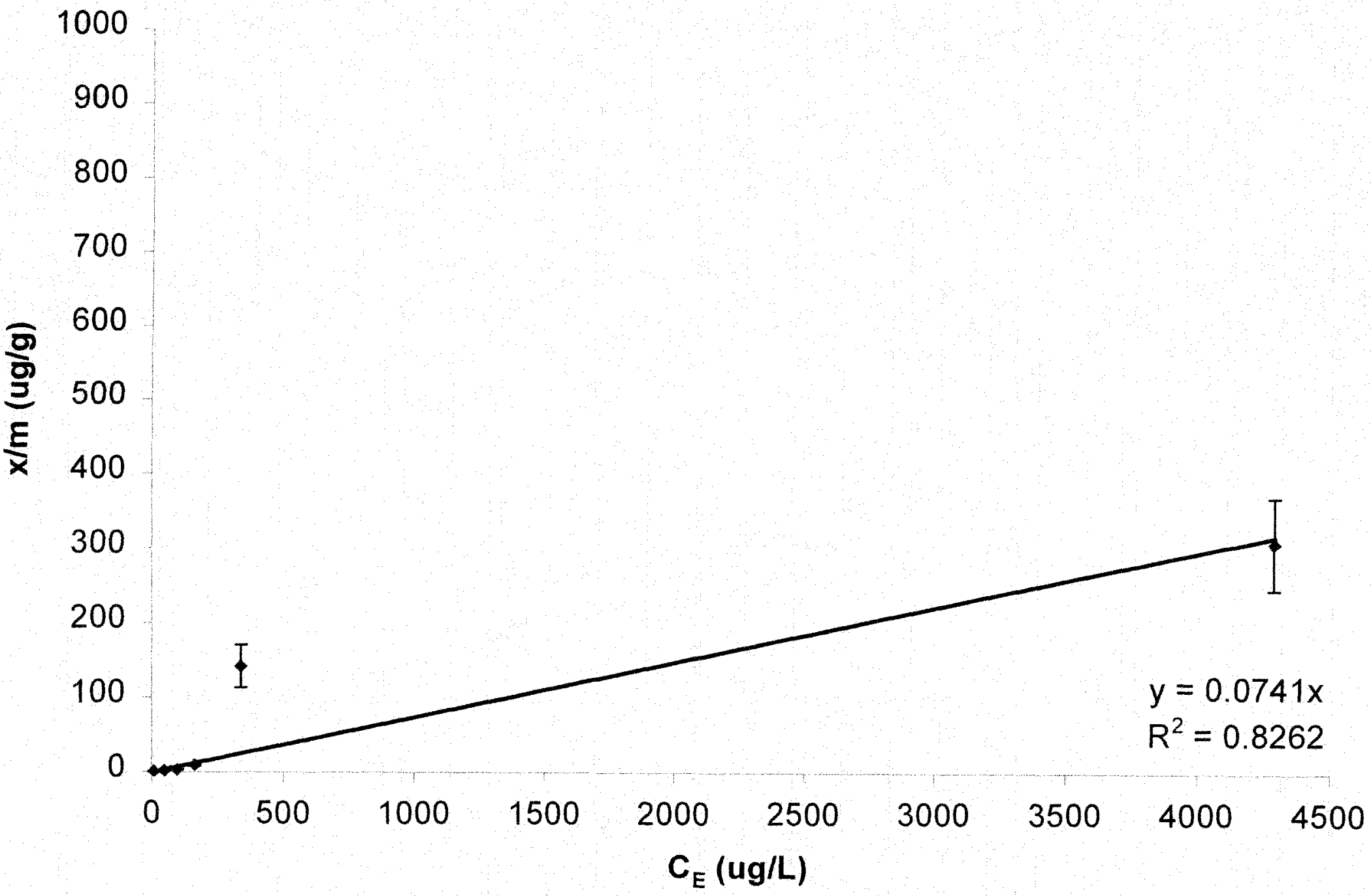

Figure 47. Linear Isotherm for the As $(+5)$, Soil 1 System $@ 22.48{ }^{\circ} \mathrm{C}$ (Experimental error $\pm 20 \%$ ). 


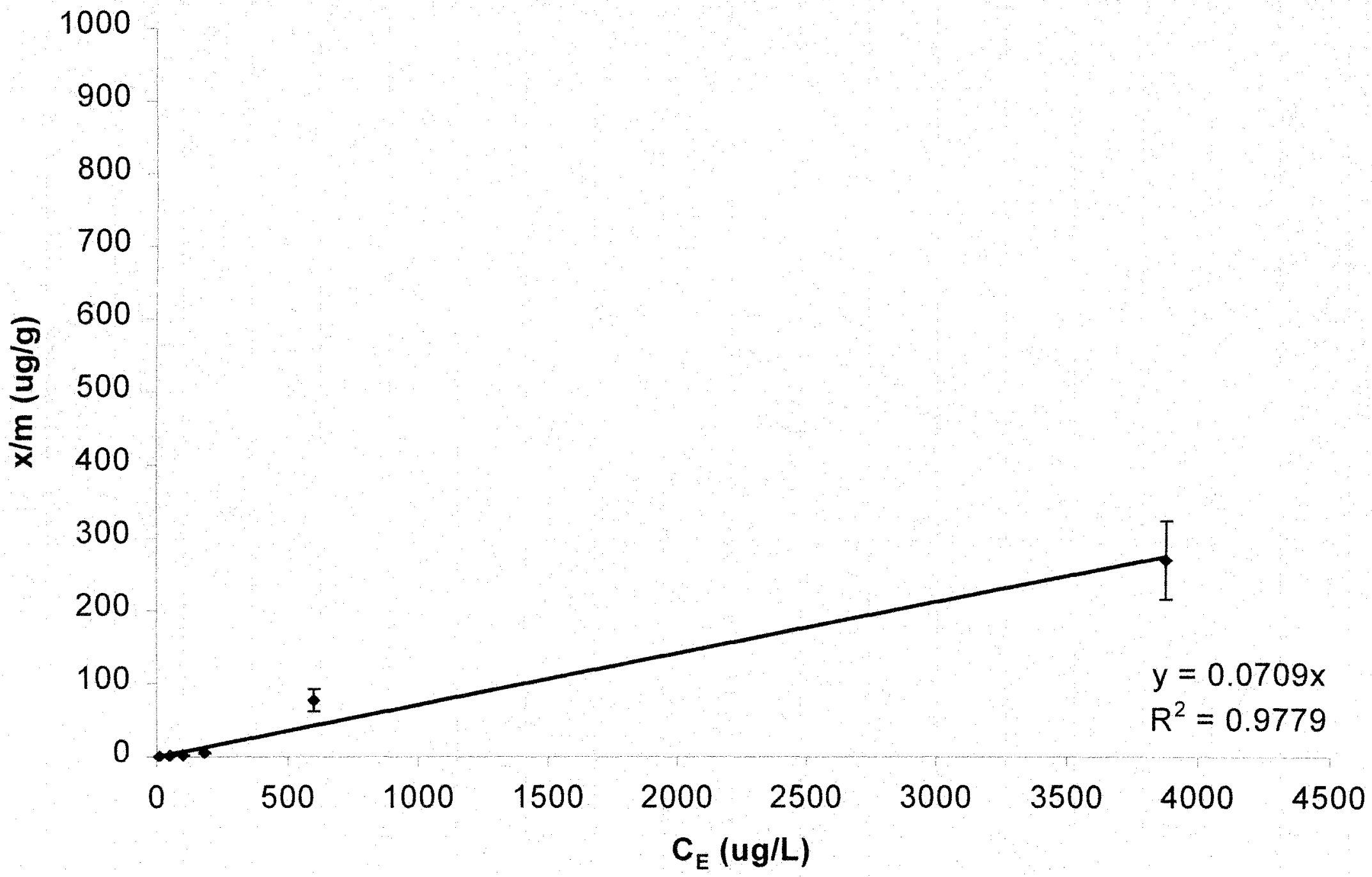

Figure 49. Linear Isotherm for the As $(+5)$, Soil 3 System @ $22.48^{\circ} \mathrm{C}$ (Experimental error $\pm 20 \%$ ). 


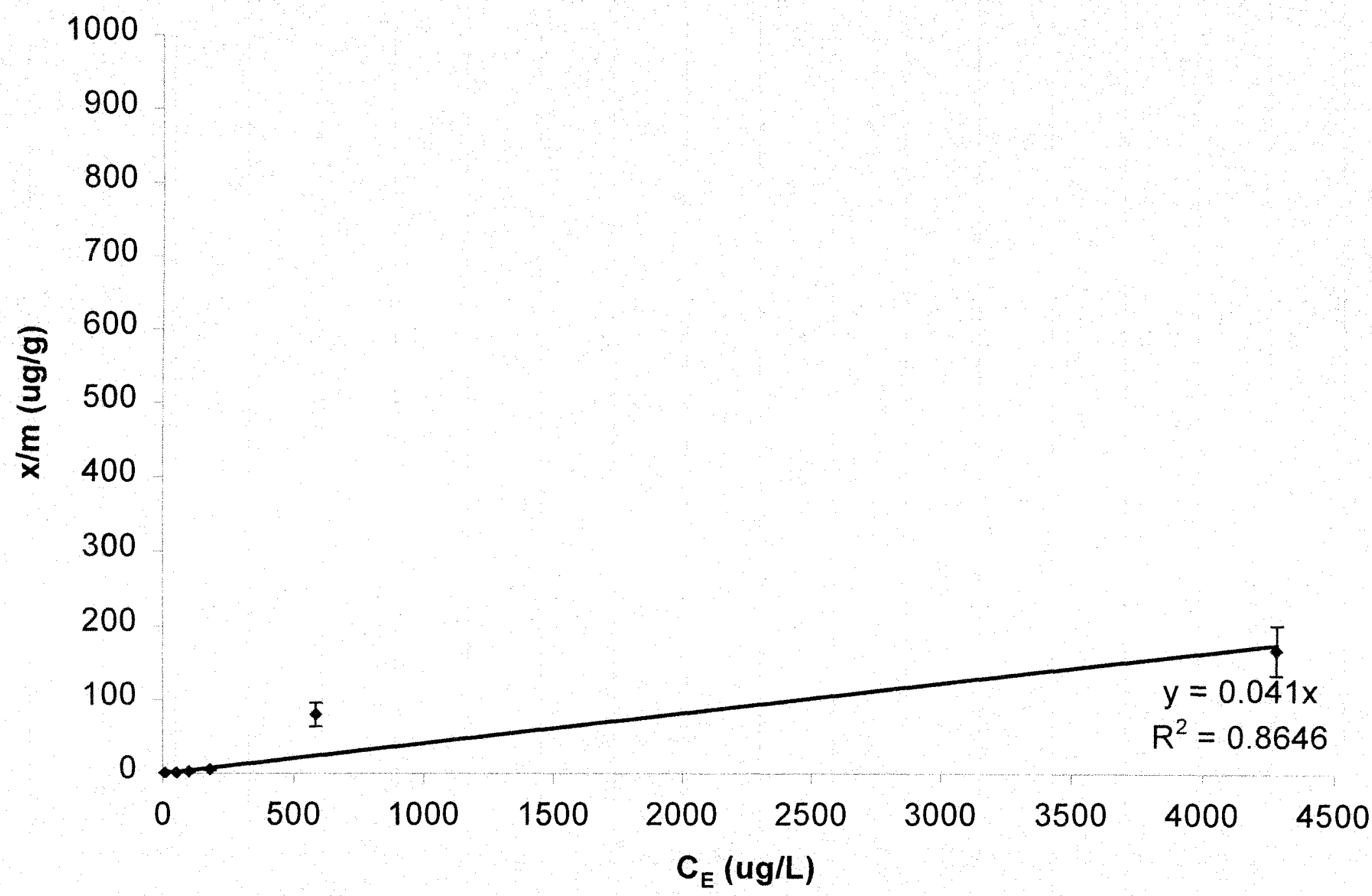

Figure 50. Linear Isotherm for the As(+5), Soil 4 System @ $22.48{ }^{\circ} \mathrm{C}$ (Experimental error $\pm 20 \%$ ). 


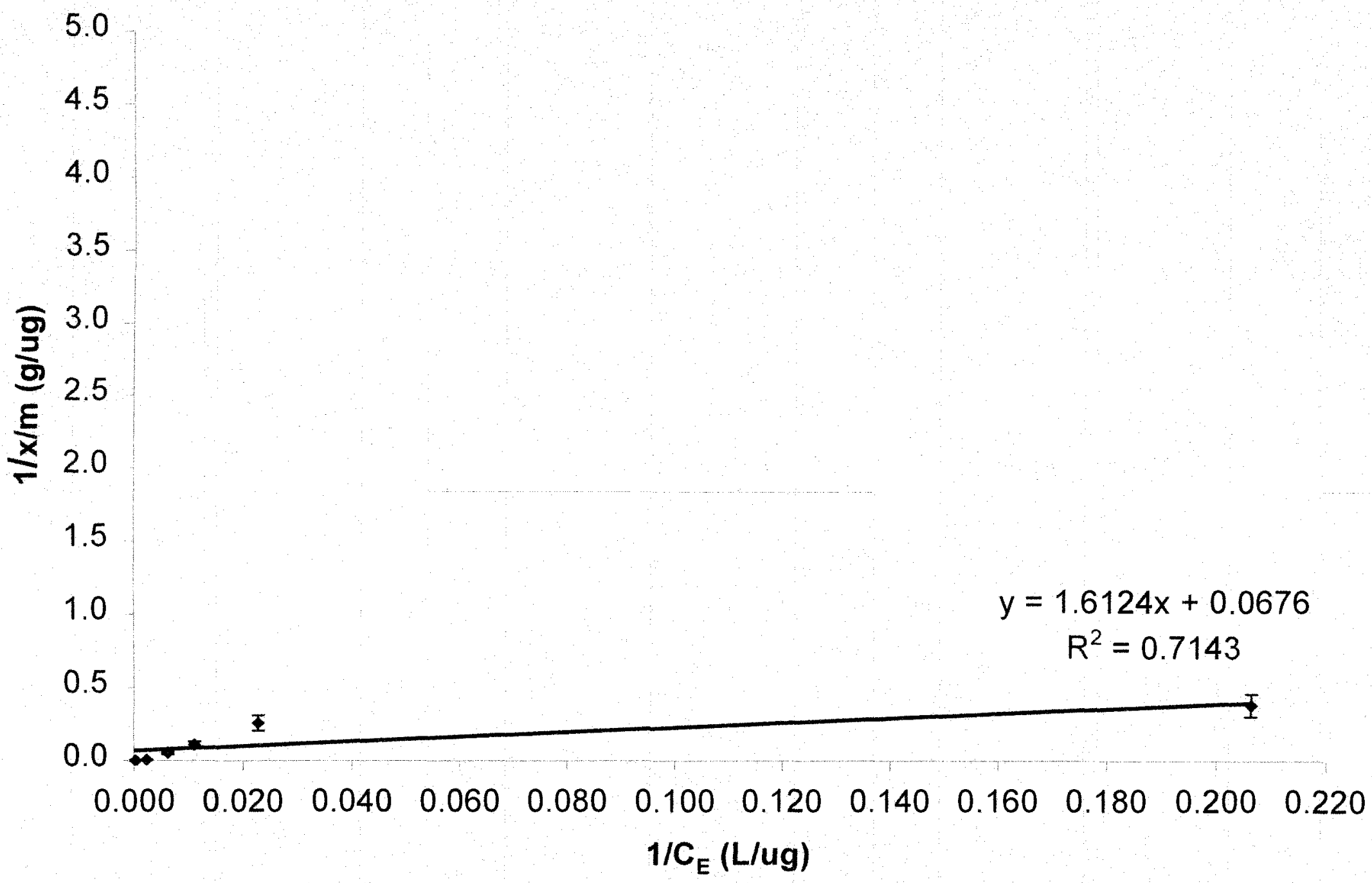

Figure 51. Langmuir Isotherm for the As( +5$)$, Soil 5 System @ $22.48{ }^{\circ} \mathrm{C}$ (Experimental error $\pm 20 \%$ ). 


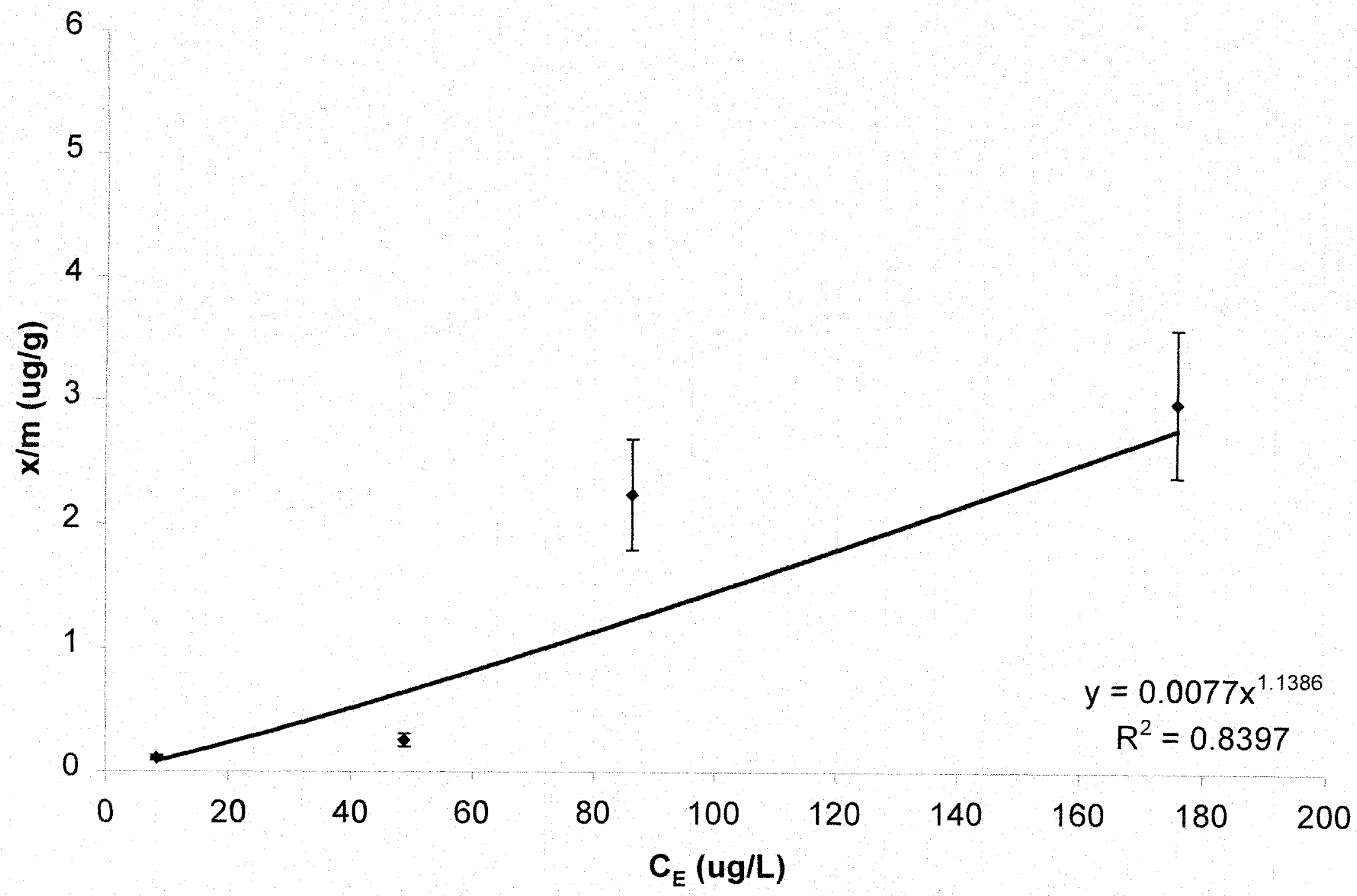

Figure 52. Freundlich Isotherm for the MSMA, Soil 1 System at $22.48^{\circ} \mathrm{C}$. 


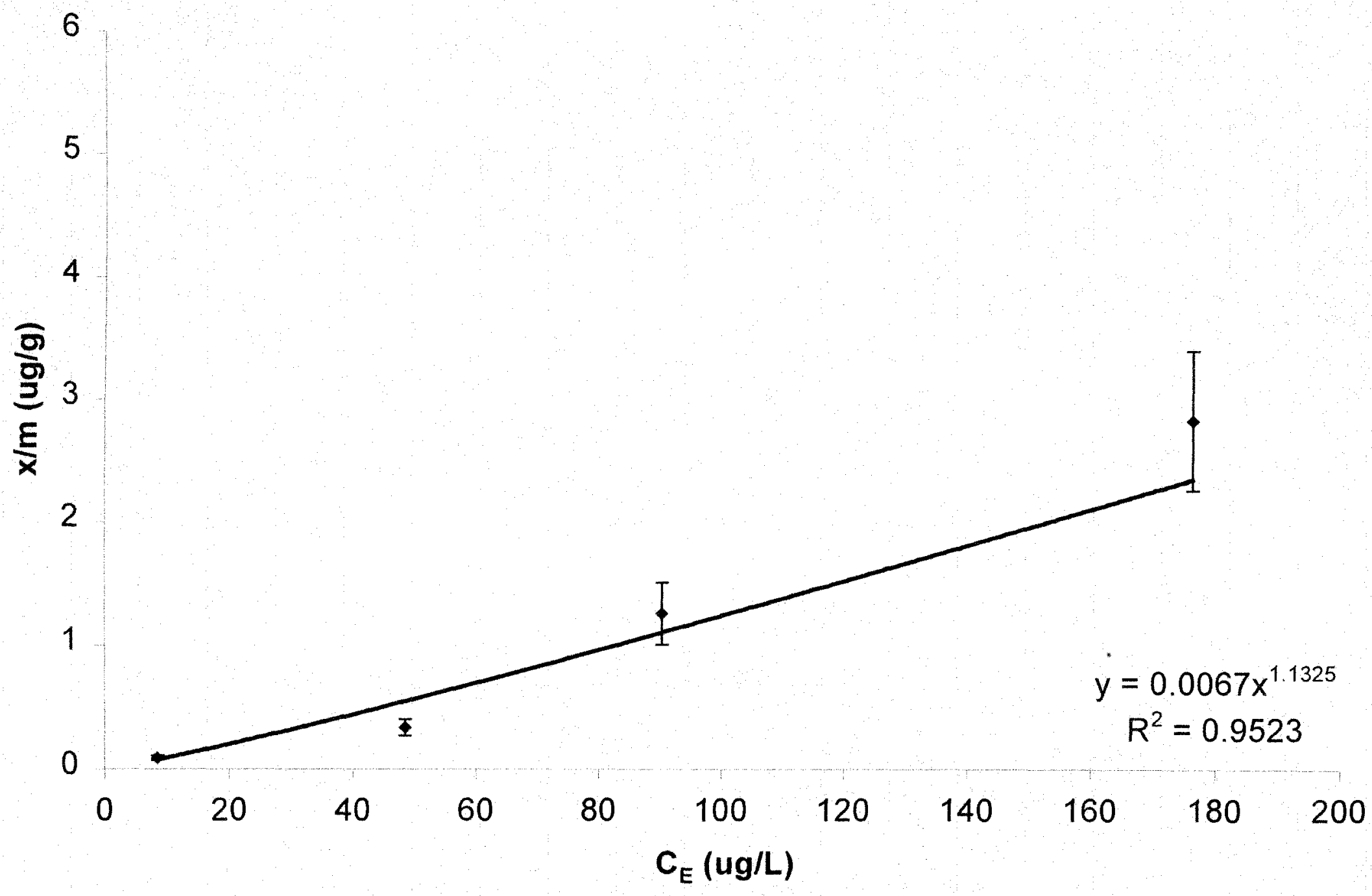

Figure 53. Freundlich Isotherm for the MSMA, Soil 2 System at $22.48^{\circ} \mathrm{C}$. 


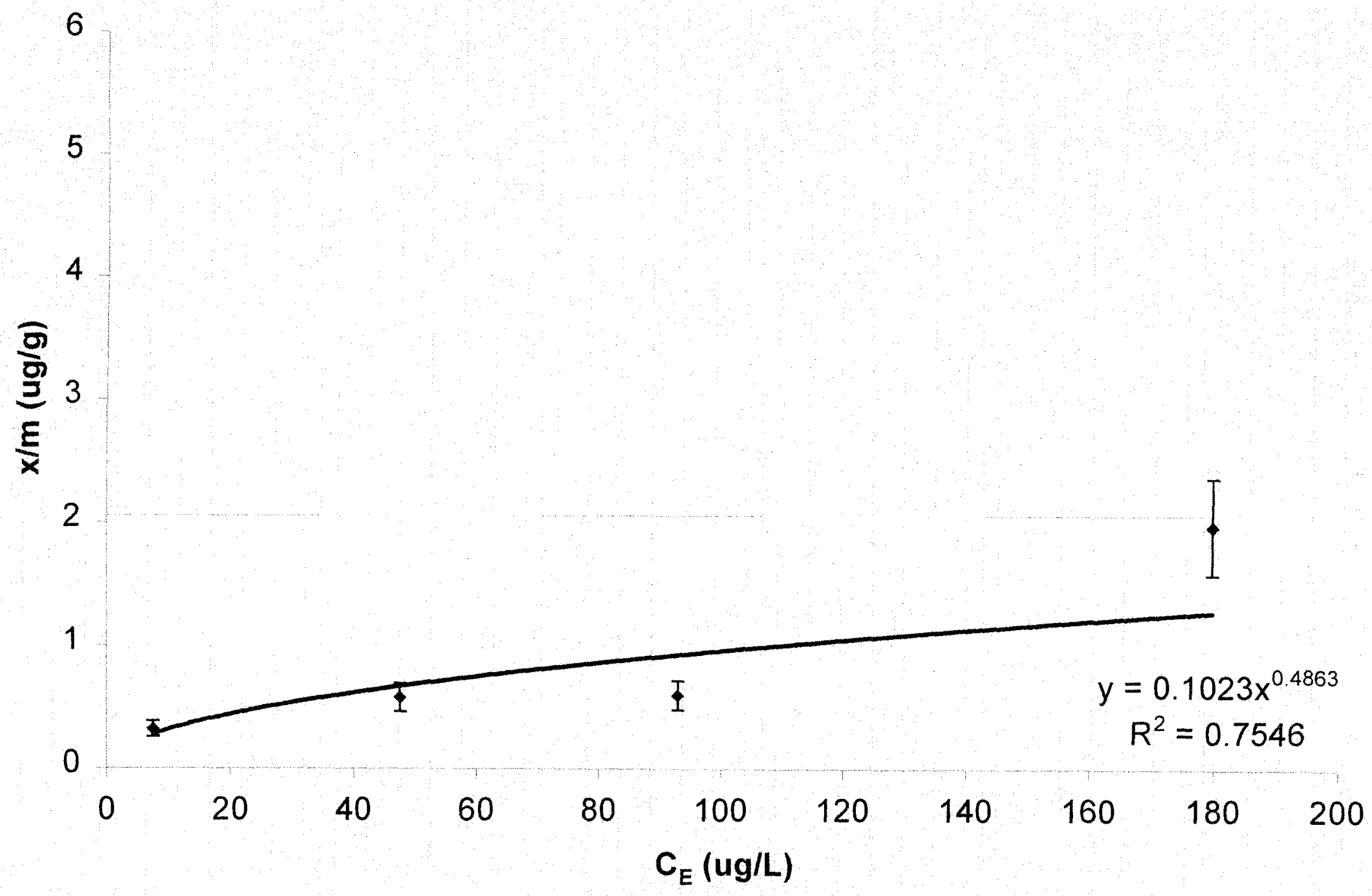

Figure 54. Freundlich Isotherm for the MSMA, Soil 3 System at $22.48^{\circ} \mathrm{C}$. 


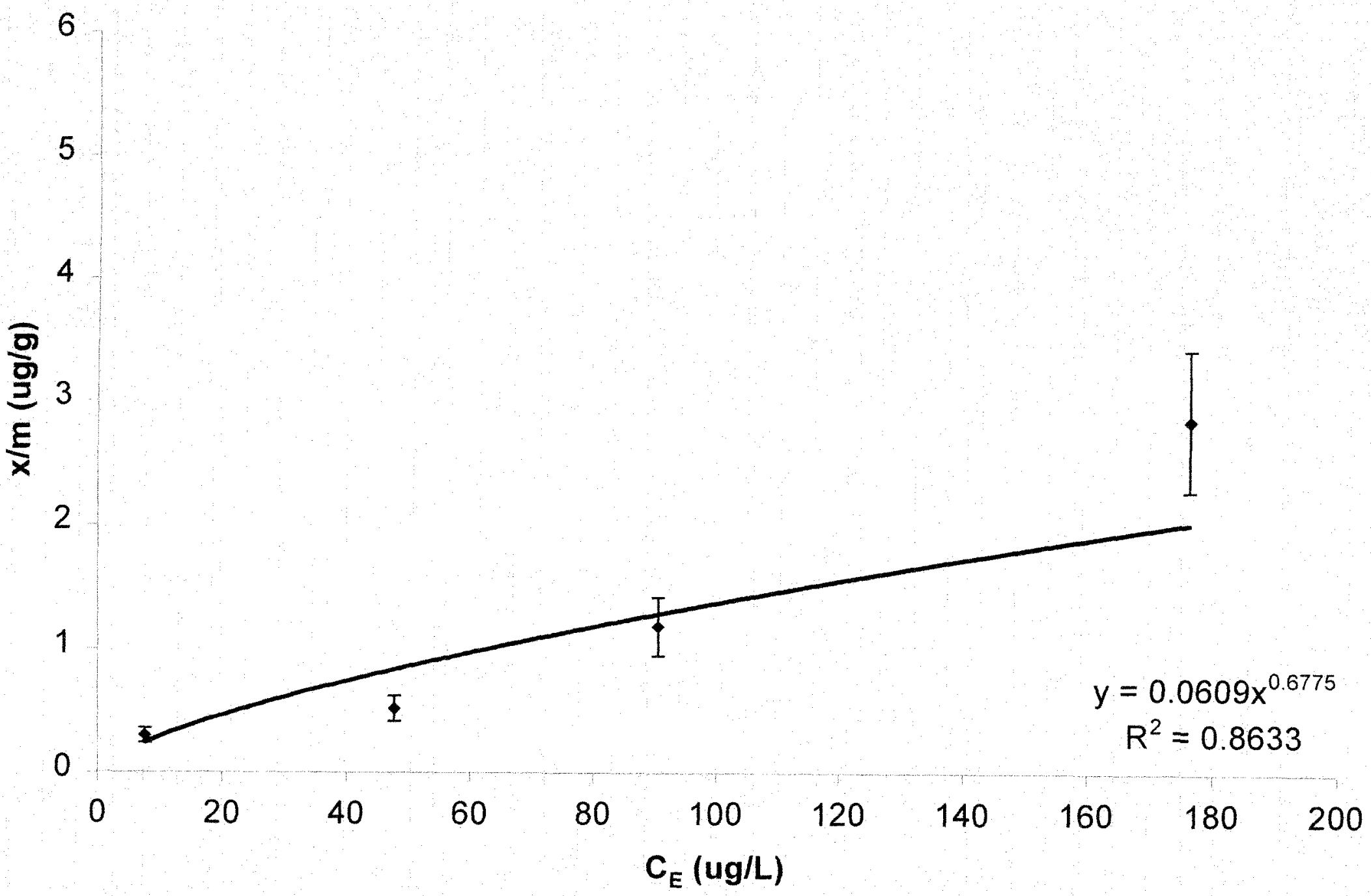

Figure 55. Freundlich Isotherm for the MSMA, Soil 4 System at $22.48^{\circ} \mathrm{C}$. 


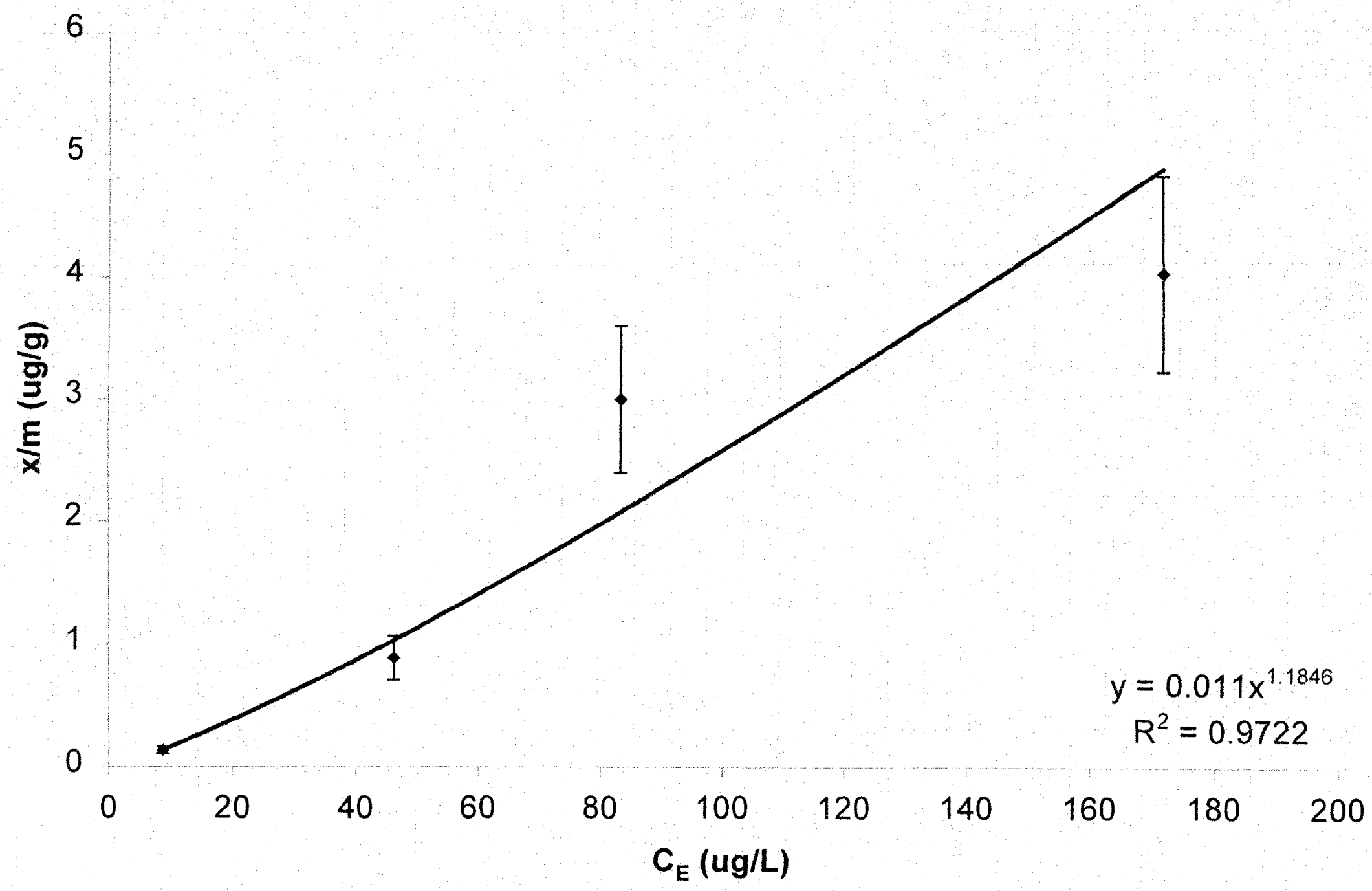

Figure 56. Freundlich Isotherm for the MSMA, Soil 5 System at $22.48^{\circ} \mathrm{C}$. 


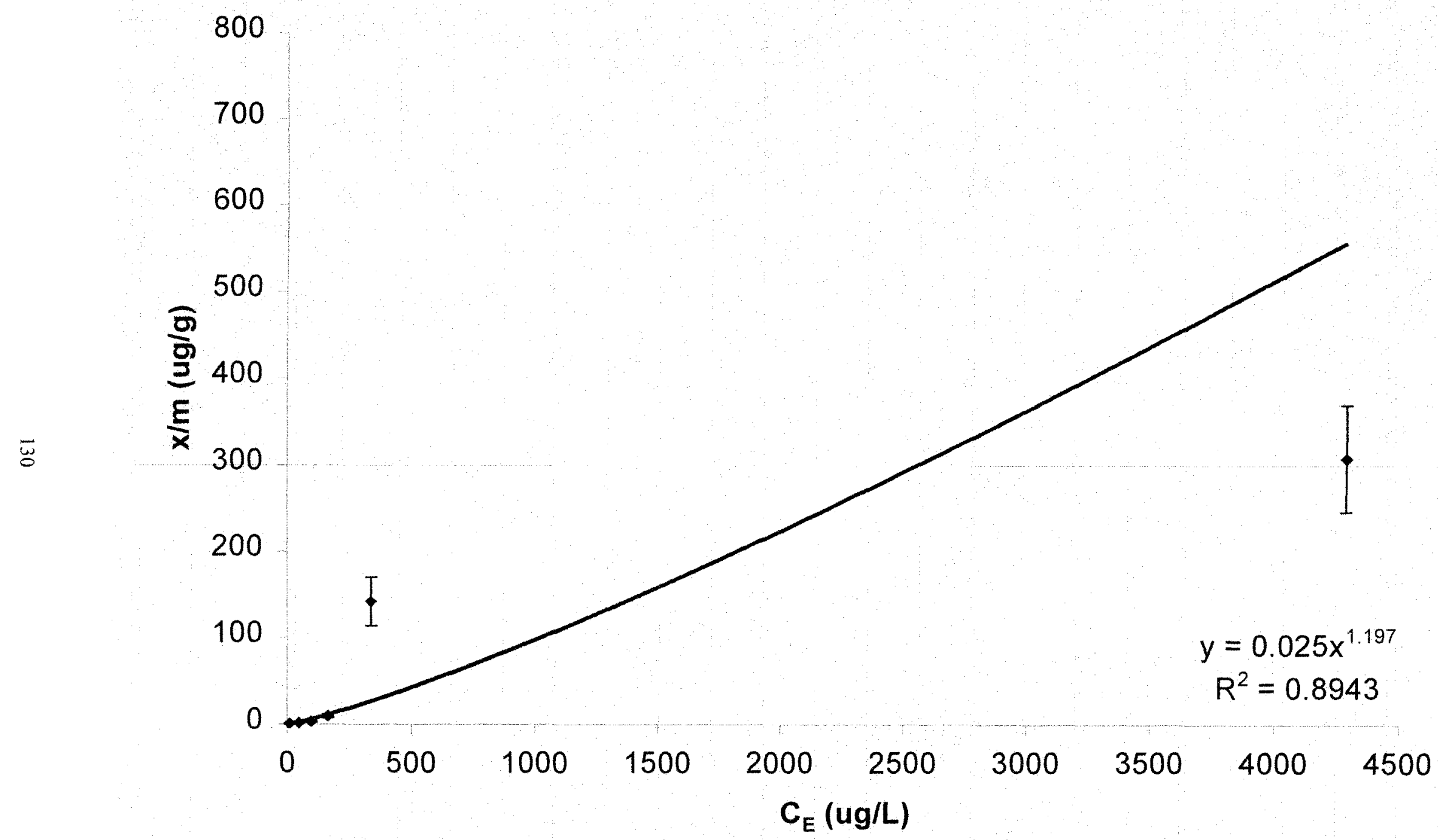

Figure 57. Freundlich Isotherm for the $\mathrm{As}(+5)$, Soil 1 System at $22.48^{\circ} \mathrm{C}$, 


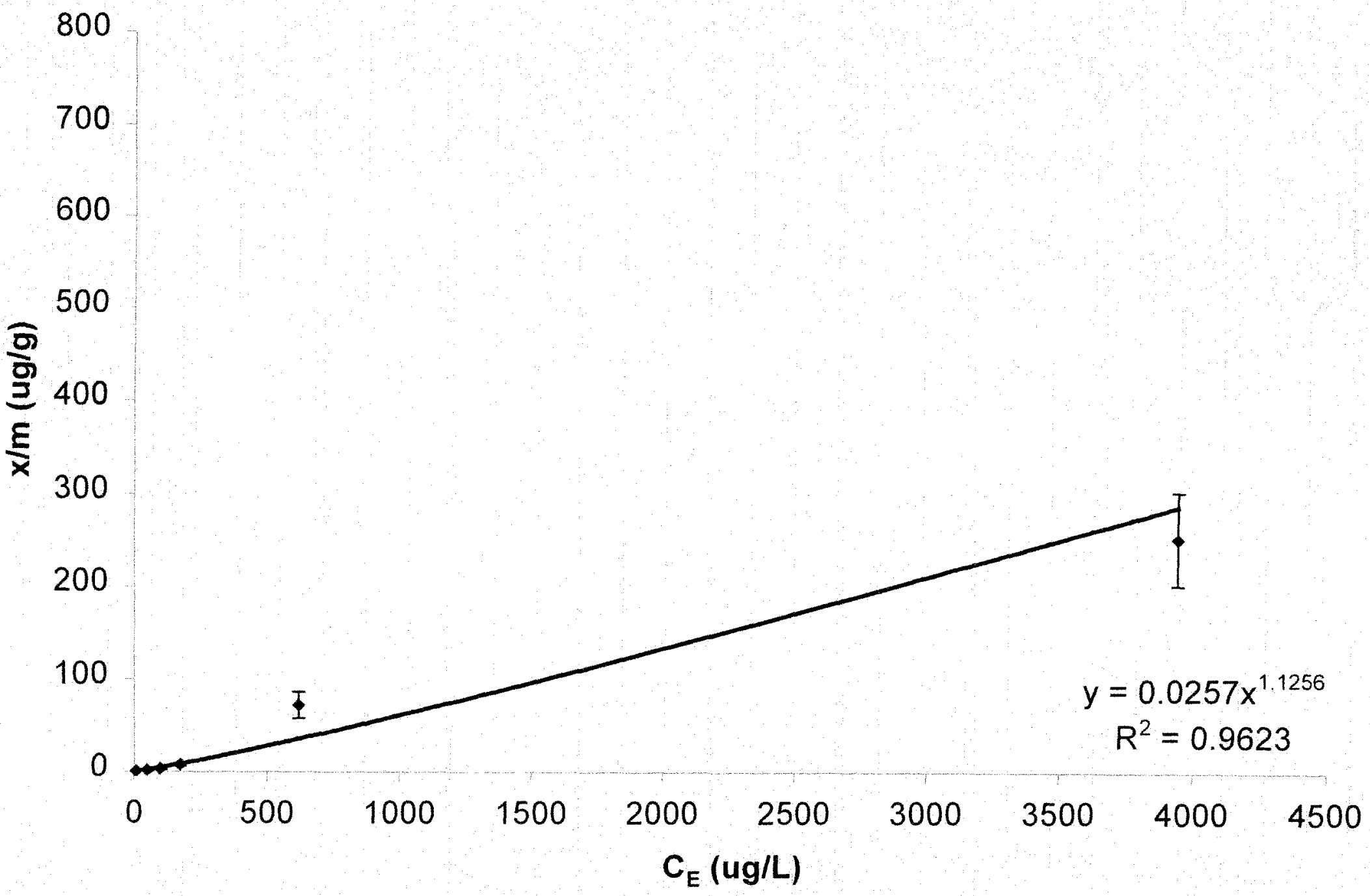

Figure 58. Freundlich Isotherm for the As $(+5)$, Soil 2 System at $22.48^{\circ} \mathrm{C}$. 


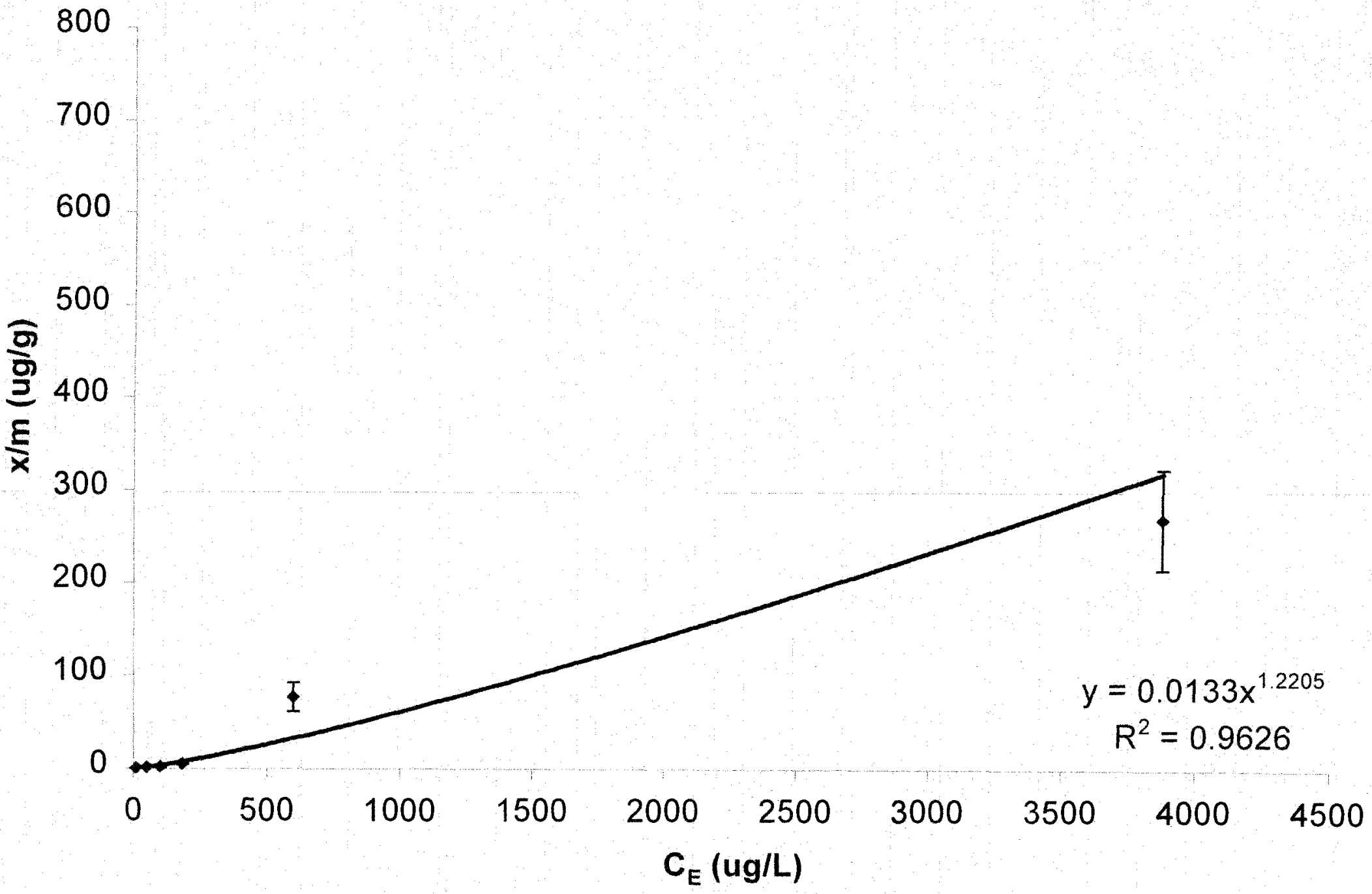

Figure 59. Freundlich Isotherm for the $\mathrm{As}(+5)$, Soil 3 System at $22.48^{\circ} \mathrm{C}$. 


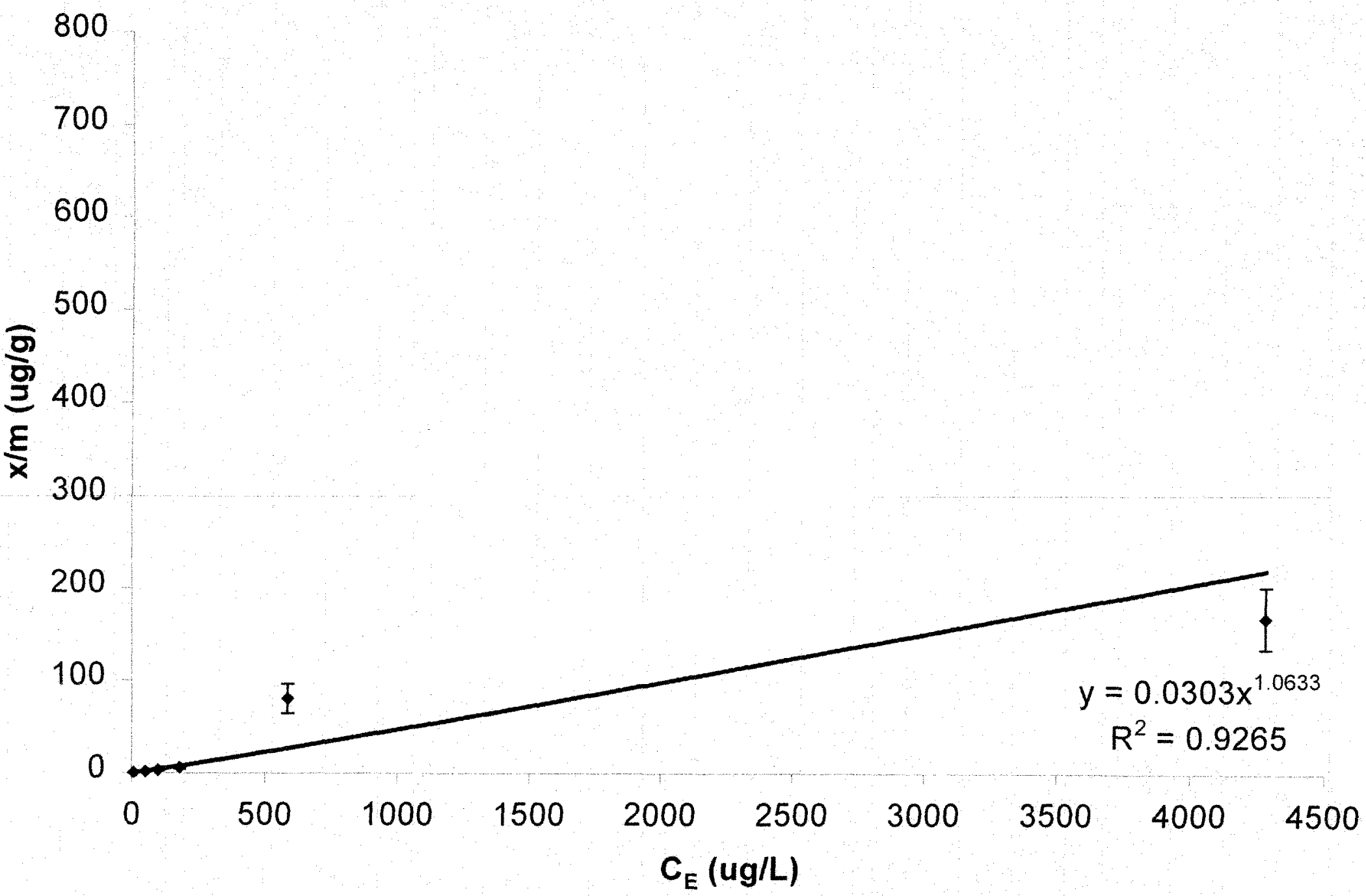

Figure 60. Freundlich Isotherm for the $\mathrm{As}(+5)$, Soil 4 System at $22.48^{\circ} \mathrm{C}$. 


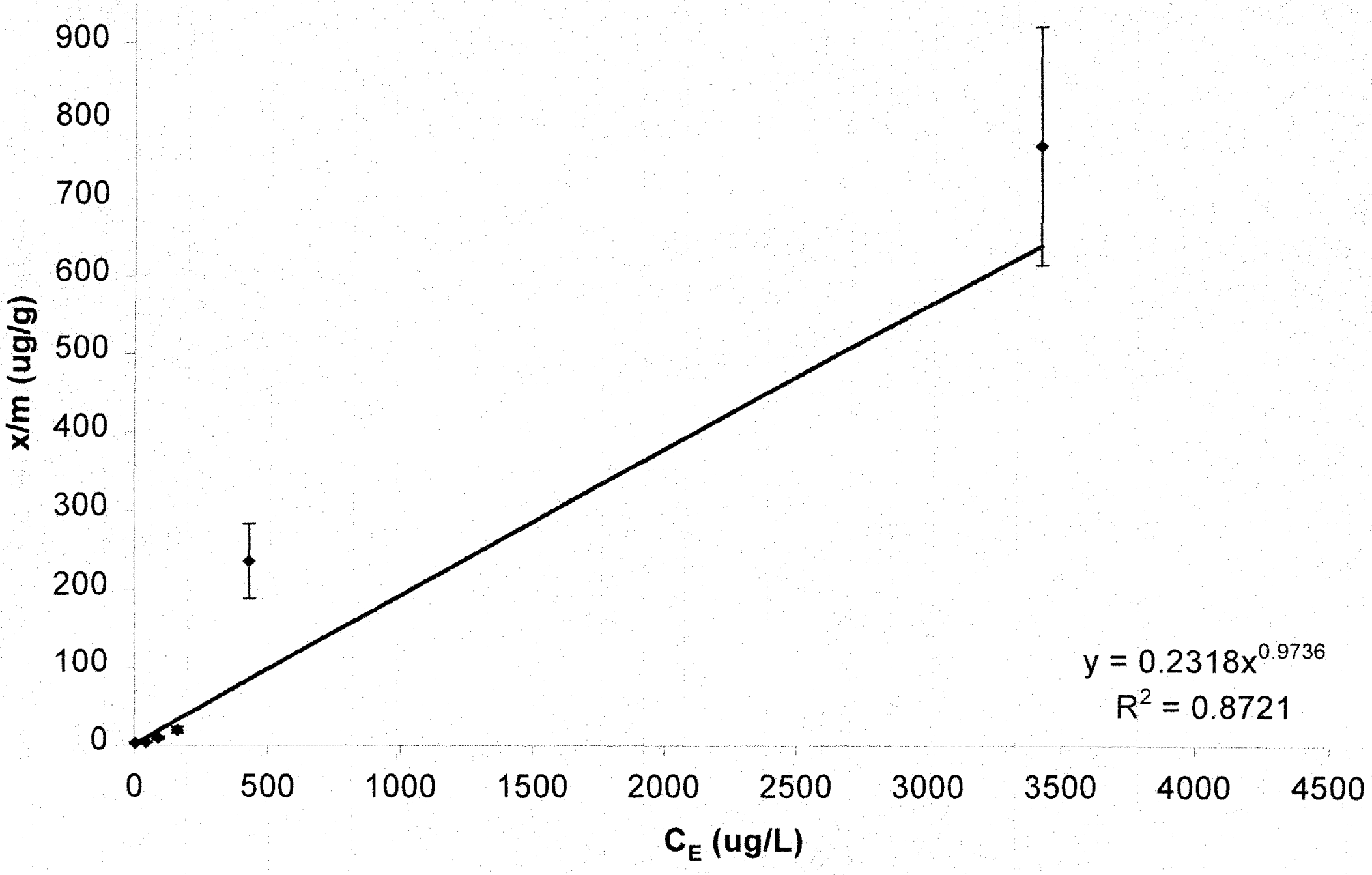

Figure 61. Freundlich Isotherm for the As(+5), Soil 5 System at $22.48^{\circ} \mathrm{C}$. 


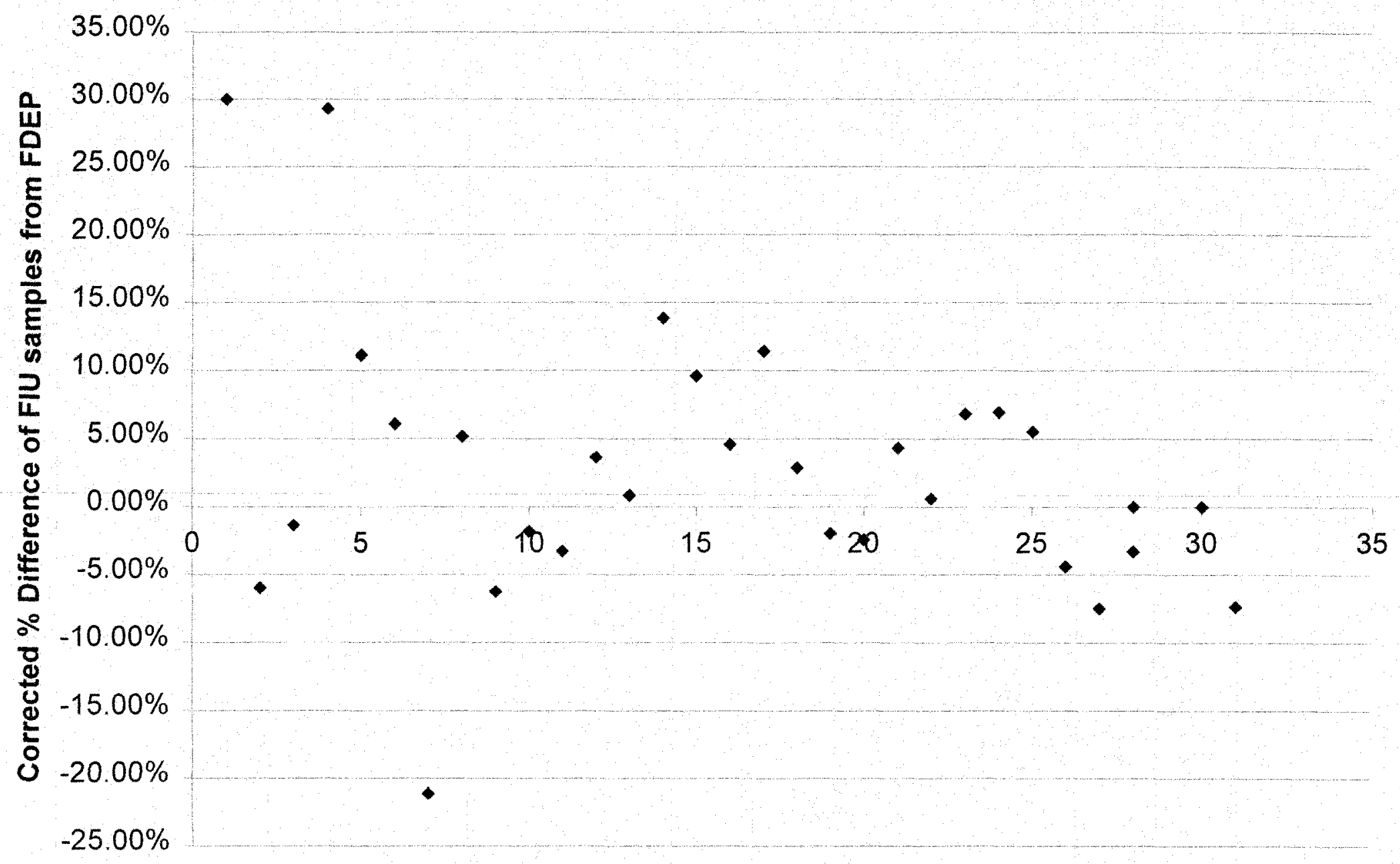

Number of Samples, Experiment 2

Figure 62. Corrected Difference of FIU Analysis from FDEP Analysis on As(+5) Experiment 2. 


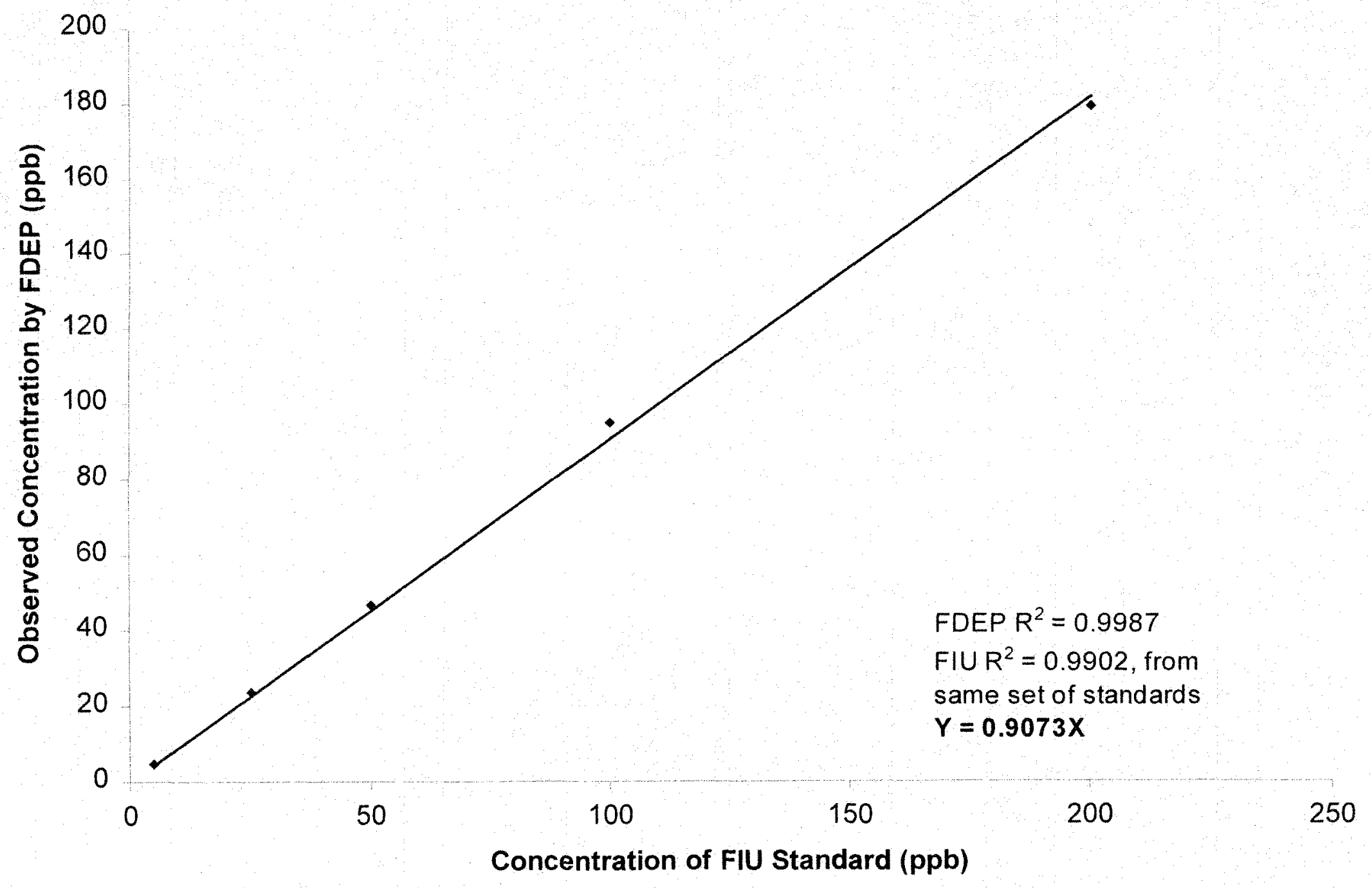

Figure 63. Observed Concentrations of a Second FIU Standard by FDEP Analysis. 


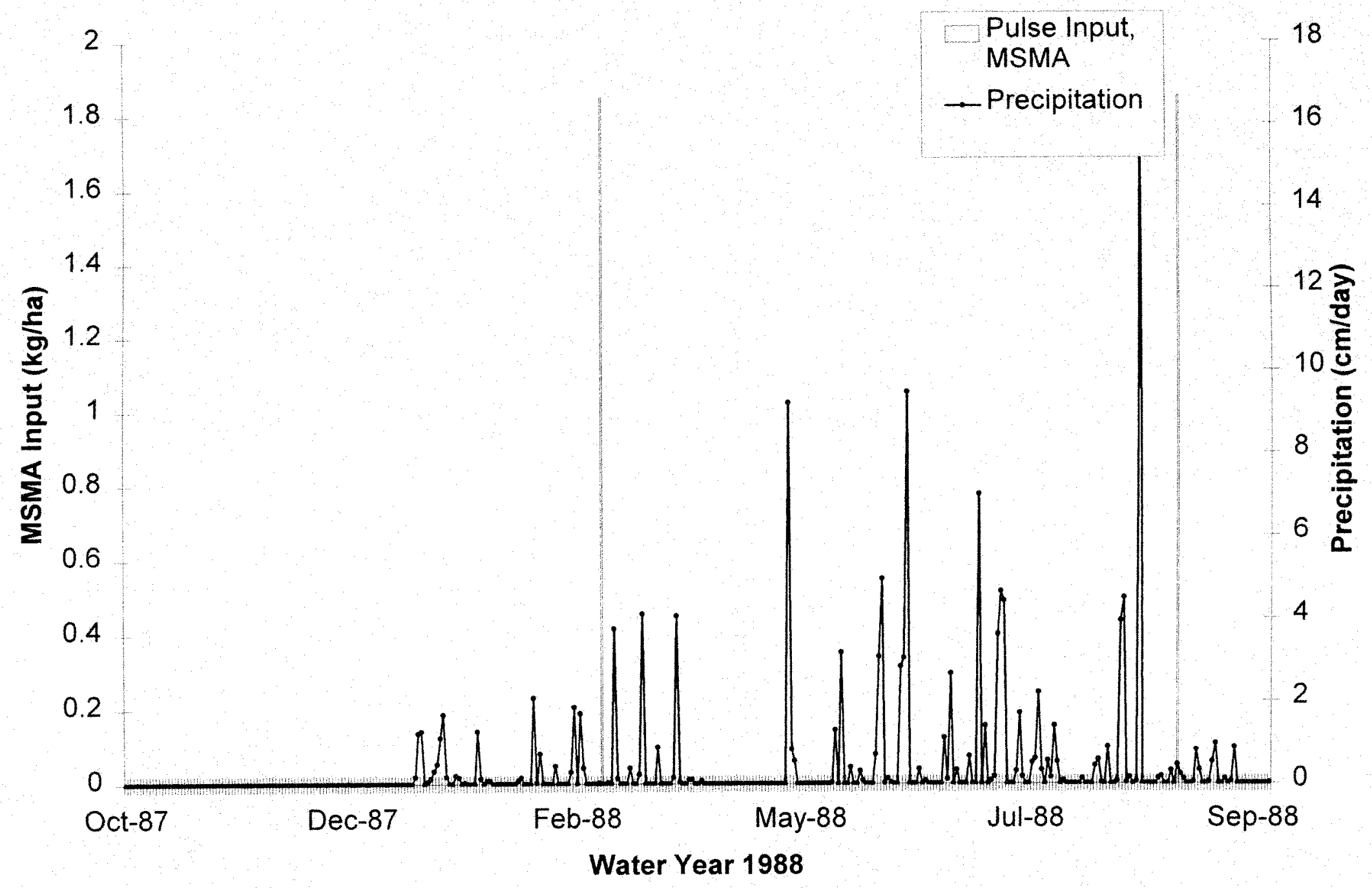

Figure 64. Hyetograph and Input Scheme of MSMA for Water Year 1988. 


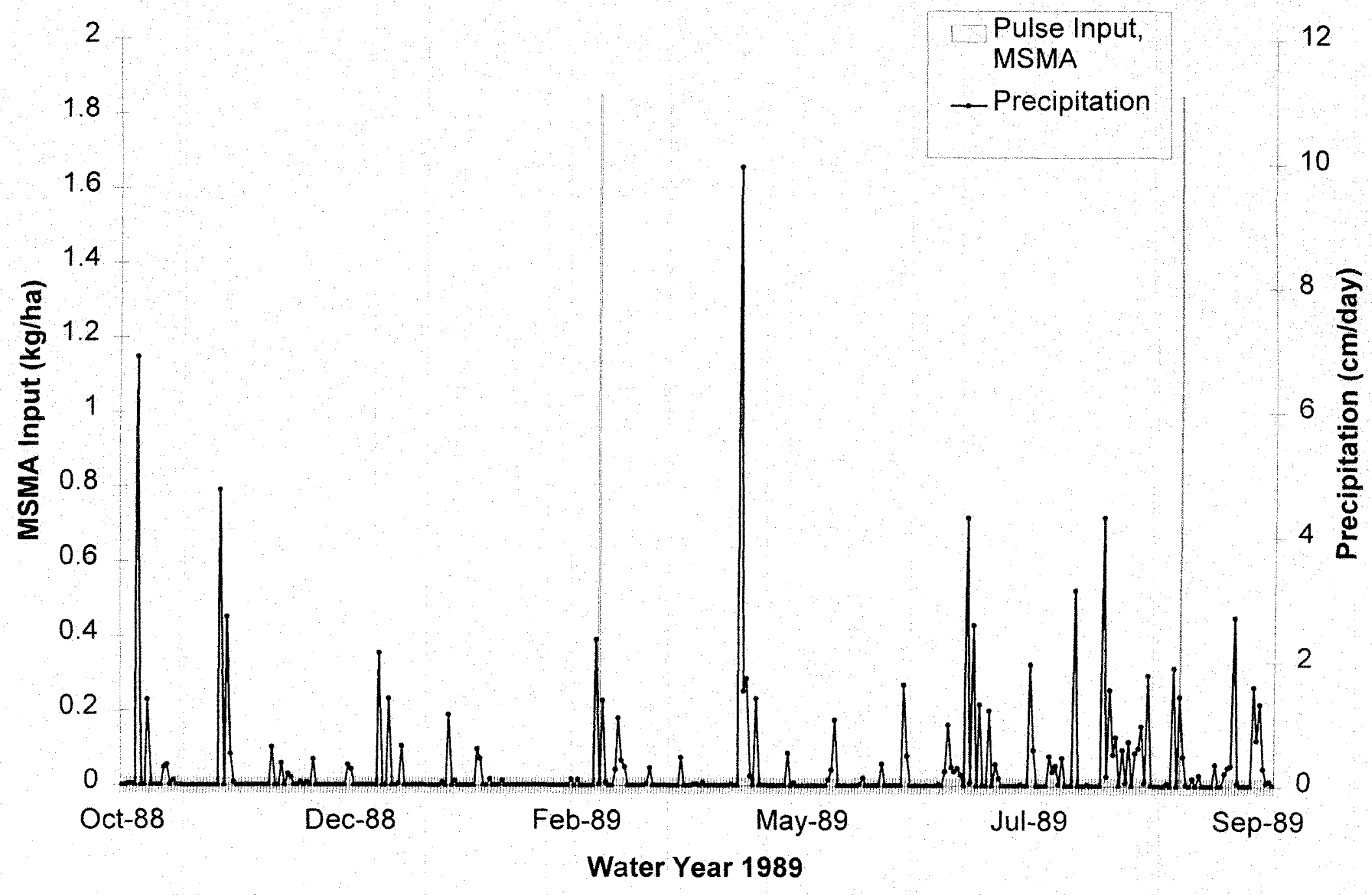

Figure 65. Hyetograph and Input Scheme of MSMA for Water Year 1989. 


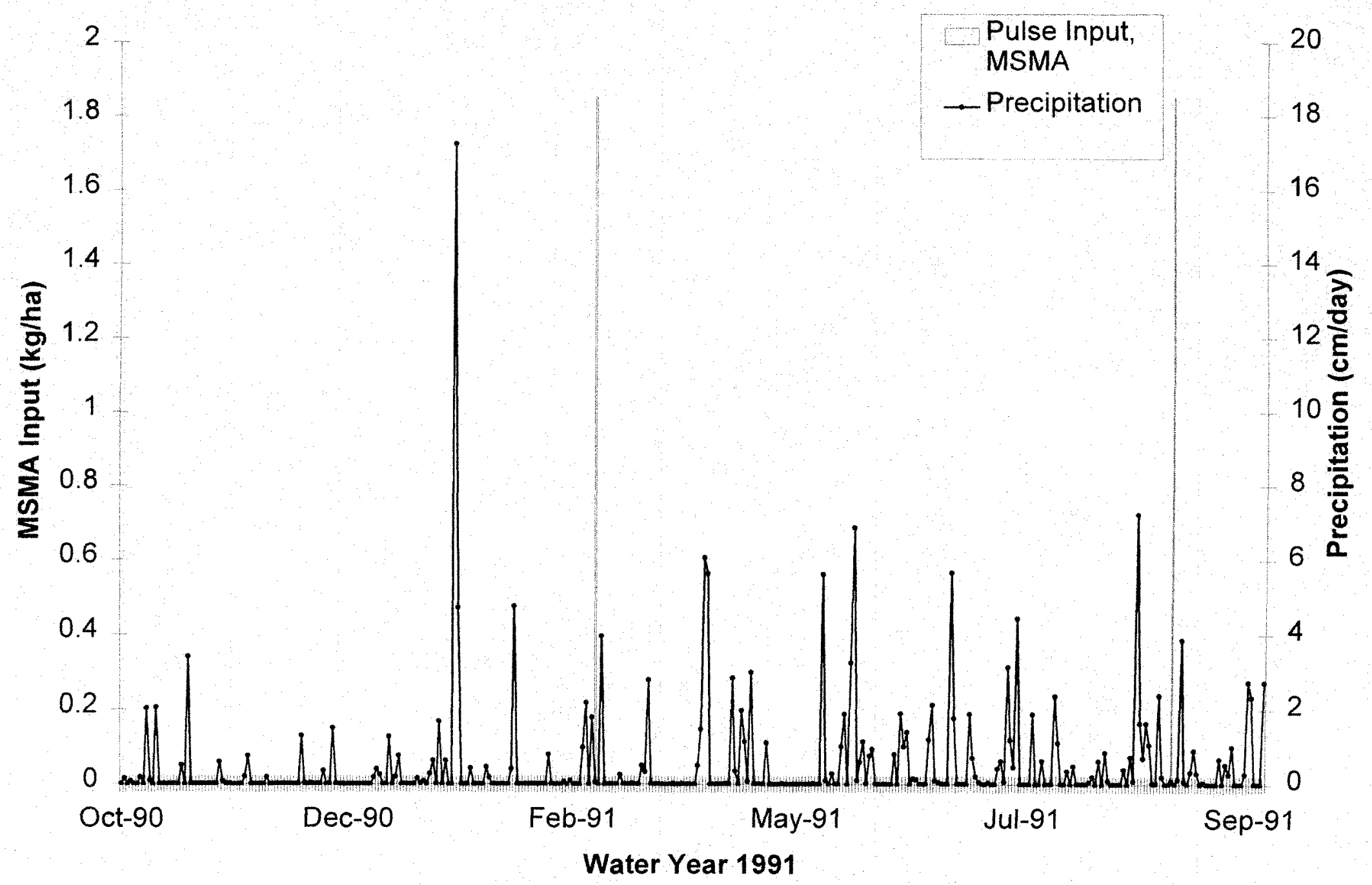

Figure 66. Hyetograph and Input Scheme of MSMA for Water Year 1991. 


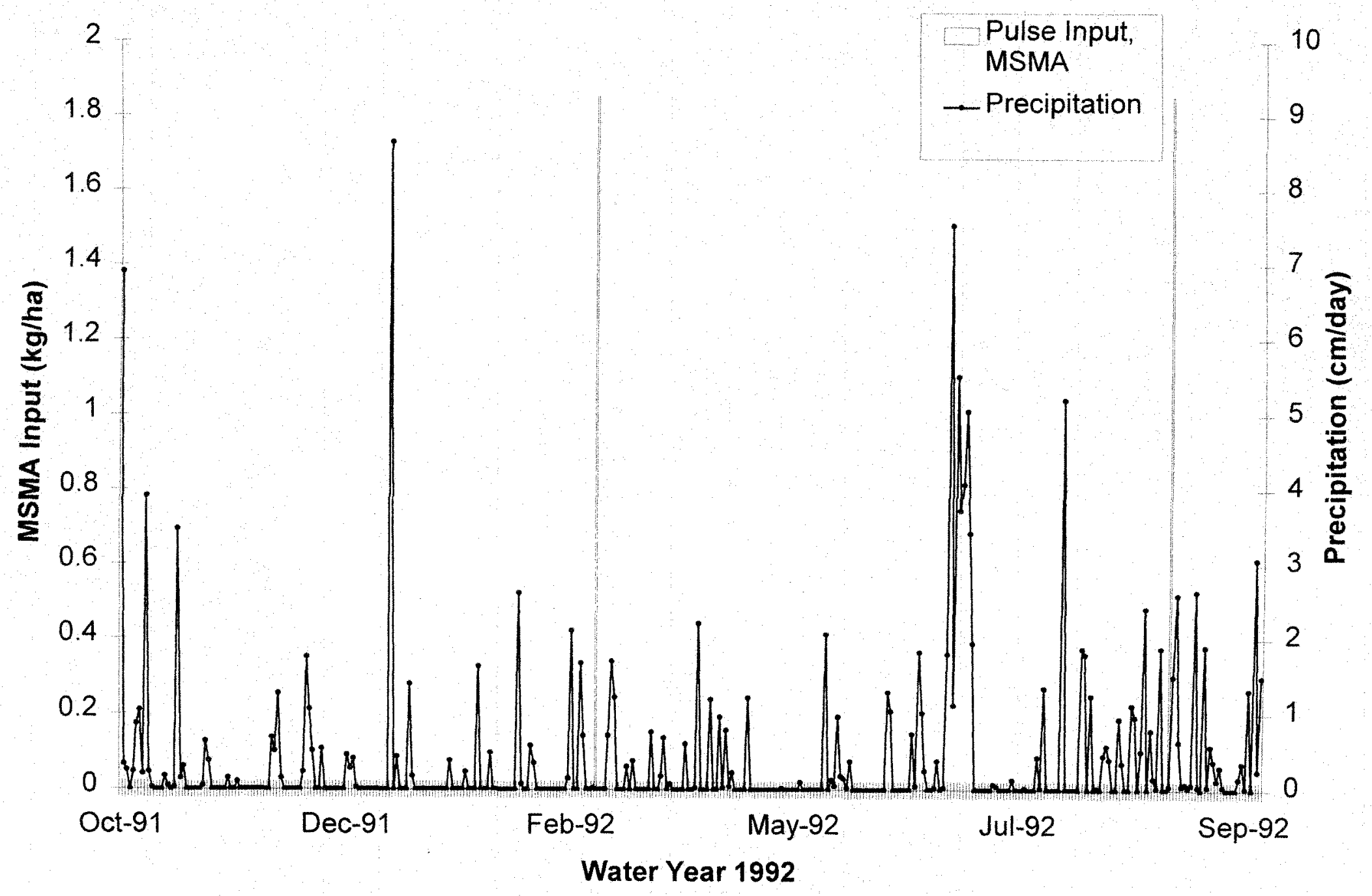

Figure 67. Hyetograph and Input Scheme of MSMA for Water Year 1992. 


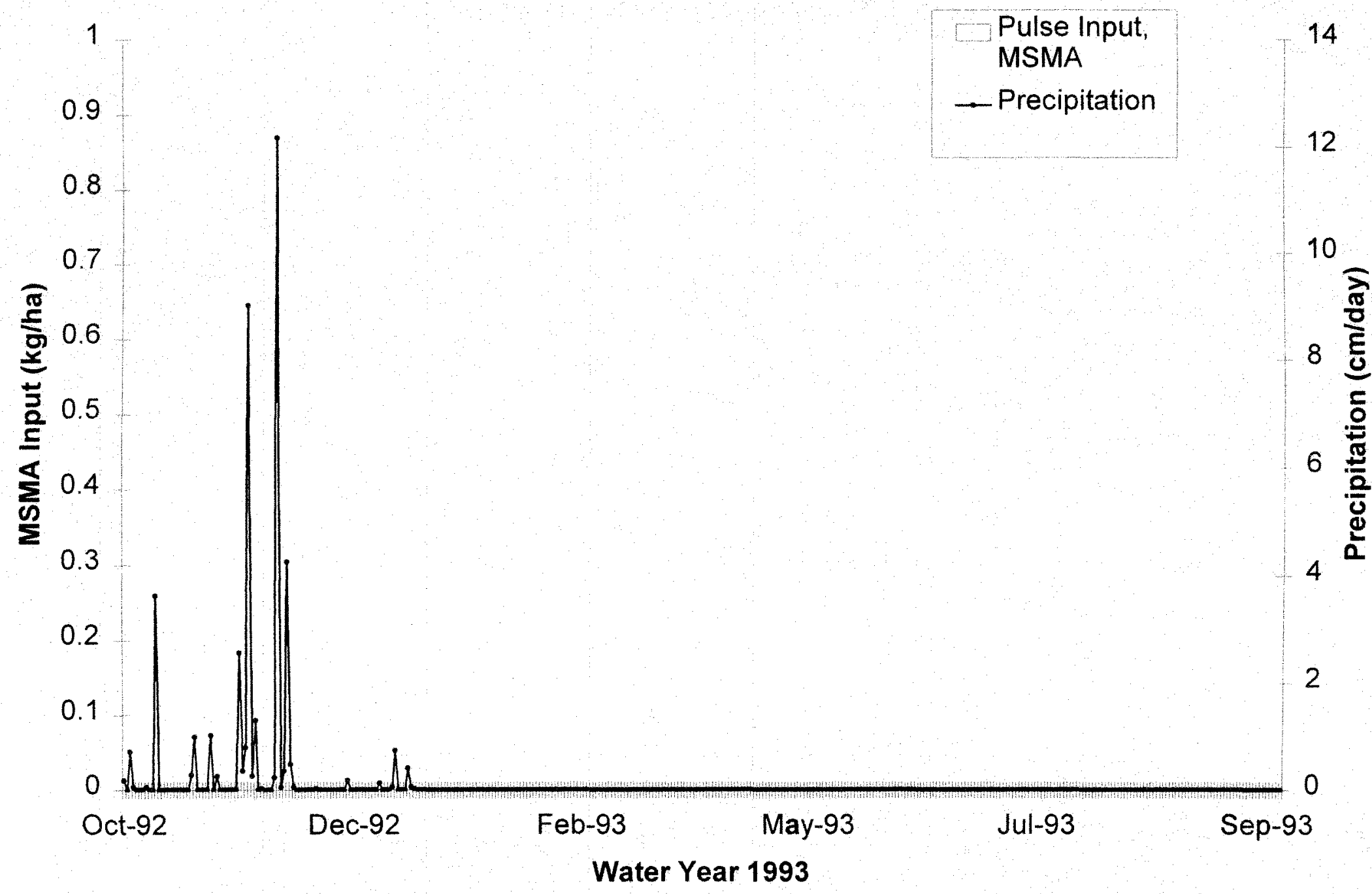

Figure 68. Hyetograph and Input Scheme of MSMA for Water Year 1993. 
Time Series After 1 Application of MSMA

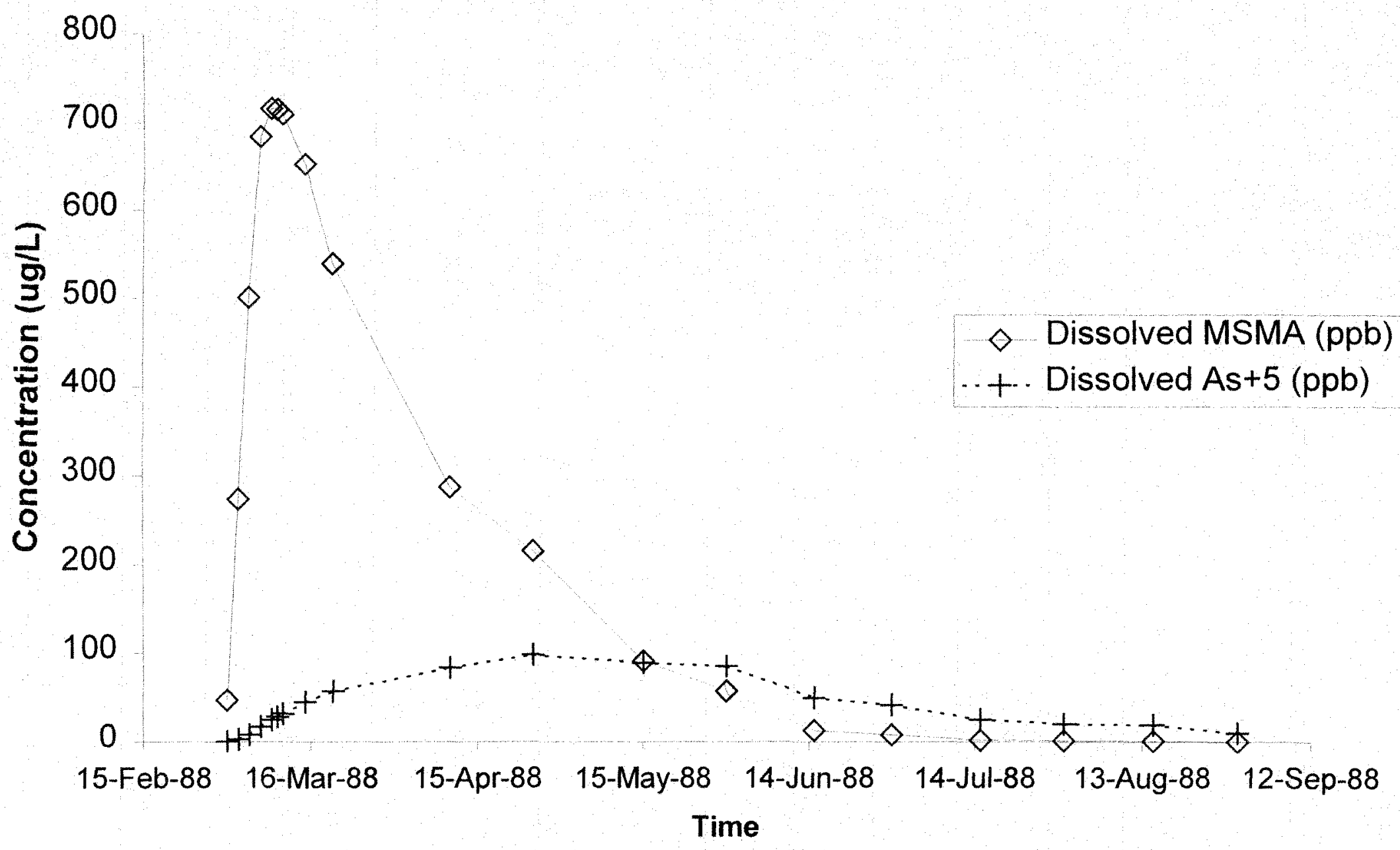

Figure 69. Plot of MSMA and As(+5) as a Fraction of Total As versus Time after 1 Application of MSMA. 


\section{Time Series After 1 Application of MSMA}

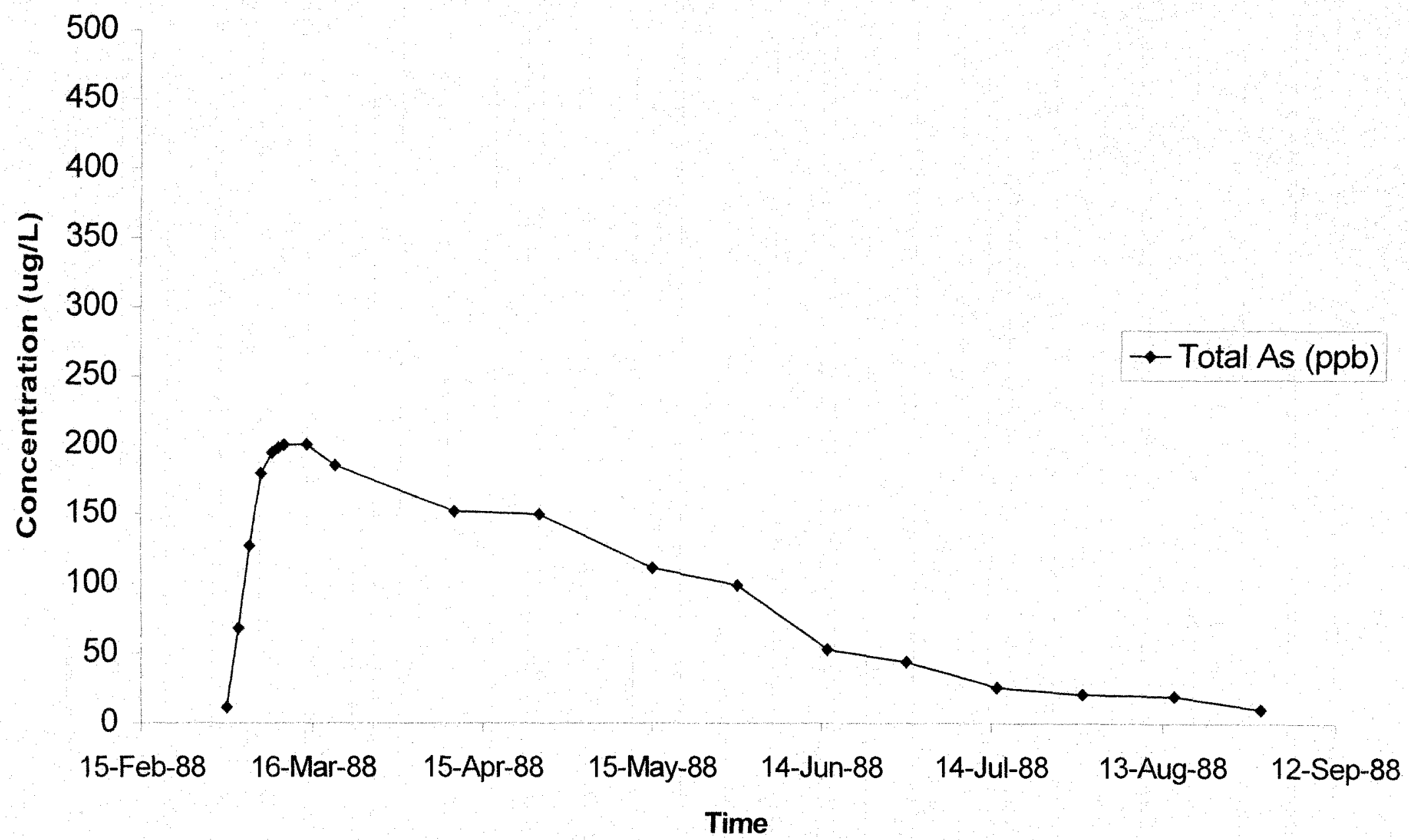

Figure 70. Plot of Total As versus Time after 1 Application of MSMA 


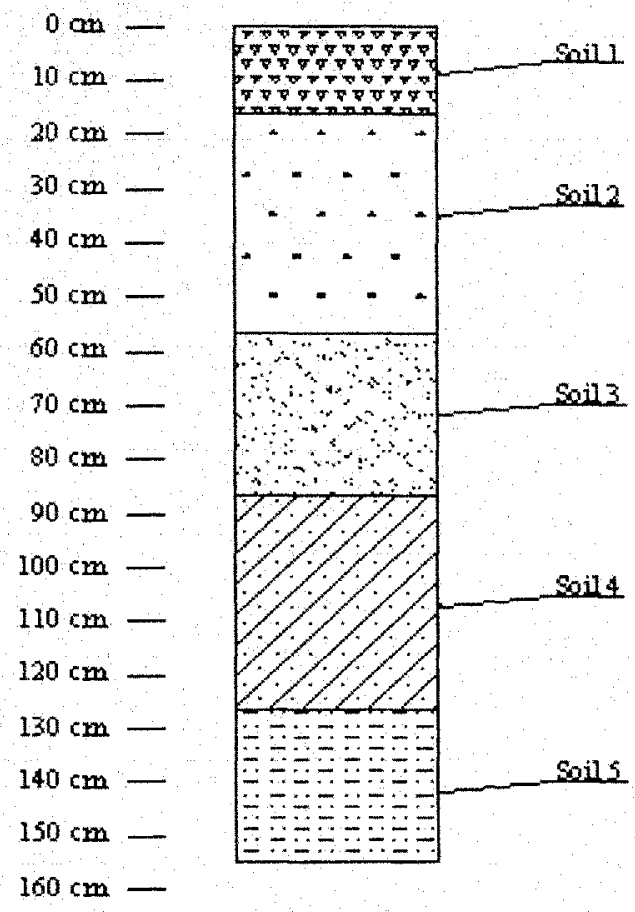

Figure 71. Graphical Representation of $154 \mathrm{~cm}$ Modeled Soil Core 
TABLE 9. Q-TEST APPLIED TO pH OF EQUILIBRATED As(+5) SAMPLES.

\begin{tabular}{|c|c|c|c|c|c|}
\hline Replicates & $\begin{array}{c}\text { Soil 1: } \\
\text { pH of } \\
\text { Equilibrated } \\
10 \mathrm{ppb} \\
\mathrm{As}(+5) \\
\text { Solution } \\
\end{array}$ & $\begin{array}{c}\text { Soil 2: } \\
\text { pH of } \\
\text { Equilibrated } \\
10 \mathrm{ppb} \\
\mathrm{As}(+5) \\
\text { Solution } \\
\end{array}$ & $\begin{array}{c}\text { Soil 3: } \\
\text { pH of } \\
\text { Equilibrated } \\
10 \mathrm{ppb} \\
\text { As }(+5) \\
\text { Solution }\end{array}$ & $\begin{array}{c}\text { Soil 4: } \\
\text { pH of } \\
\text { Equilibrated } \\
10 \mathrm{ppb} \\
\mathrm{As}(+5) \\
\text { Solution } \\
\end{array}$ & $\begin{array}{c}\text { Soil 5: } \\
\text { pH of } \\
\text { Equilibrated } \\
10 \mathrm{ppb} \\
\mathrm{As}(+5) \\
\text { Solution }\end{array}$ \\
\hline 1 & 5.90 & 6.01 & 5.76 & 6.18 & 6.17 \\
\hline Replicates & $\begin{array}{c}\text { Soil 1: } \\
\text { pH of } \\
\text { Equilibrated } \\
50 \mathrm{ppb} \\
\text { As }(+5) \\
\text { Solution }\end{array}$ & $\begin{array}{c}\text { Soil 2: } \\
\text { pH of } \\
\text { Equilibrated } \\
50 \mathrm{ppb} \\
\mathrm{As}(+5) \\
\text { Solution }\end{array}$ & $\begin{array}{c}\text { Soil 3: } \\
\text { pH of } \\
\text { Equilibrated } \\
50 \mathrm{ppb} \\
\text { As }(+5) \\
\text { Solution }\end{array}$ & $\begin{array}{c}\text { Soil 4: } \\
\text { pH of } \\
\text { Equilibrated } \\
50 \mathrm{ppb} \\
\mathrm{As}(+5) \\
\text { Solution }\end{array}$ & $\begin{array}{c}\text { Soil 5: } \\
\text { pH of } \\
\text { Equilibrated } \\
50 \mathrm{ppb} \\
\mathrm{As}(+5) \\
\text { Solution }\end{array}$ \\
\hline 1 & 3.85 & 4.00 & 3.46 & 4.15 & 4.35 \\
\hline $\begin{array}{l}2 \\
3\end{array}$ & $\begin{array}{l}4.28 \\
6.07\end{array}$ & $\begin{array}{l}4.17 \\
5.84\end{array}$ & $\begin{array}{l}4.00 \\
5.82\end{array}$ & $\begin{array}{l}4.39 \\
6.09\end{array}$ & $\begin{array}{l}5.85 \\
5.92\end{array}$ \\
\hline $\begin{array}{c}\text { Range } \\
\text { Diff Highest } \\
\text { Q value }\end{array}$ & $\begin{array}{l}2.22 \\
1.79 \\
0.81\end{array}$ & $\begin{array}{l}1.84 \\
1.67 \\
0.91\end{array}$ & $\begin{array}{l}2.36 \\
1.82 \\
0.77\end{array}$ & $\begin{array}{l}1.94 \\
1.70 \\
0.88\end{array}$ & $\begin{array}{l}1.57 \\
0.07 \\
0.04\end{array}$ \\
\hline $\begin{array}{c}\text { Diff Lowest } \\
Q \text { value }\end{array}$ & $\begin{array}{l}0.43 \\
0.19\end{array}$ & $\begin{array}{l}0.17 \\
0.09\end{array}$ & $\begin{array}{l}0.54 \\
0.23\end{array}$ & $\begin{array}{l}0.24 \\
0.12\end{array}$ & $\begin{array}{l}1.50 \\
\mathbf{0 . 9 6}\end{array}$ \\
\hline $\begin{array}{l}\text { Modified } \\
\text { Mean }\end{array}$ & 4.73 & 4.67 & 4.43 & 4.88 & 5.89 \\
\hline Replicates & $\begin{array}{c}\text { Soil 1: } \\
\text { pH of } \\
\text { Equilibrated } \\
100 \mathrm{ppb} \\
\text { As }(+5) \\
\text { Solution }\end{array}$ & $\begin{array}{c}\text { Soil 2: } \\
\text { pH of } \\
\text { Equilibrated } \\
100 \mathrm{ppb} \\
\text { As }(+5) \\
\text { Solution }\end{array}$ & $\begin{array}{c}\text { Soil 3: } \\
\text { pH of } \\
\text { Equilibrated } \\
100 \mathrm{ppb} \\
\text { As }(+5) \\
\text { Solution } \\
\end{array}$ & $\begin{array}{c}\text { Soil 4: } \\
\text { pH of } \\
\text { Equilibrated } \\
100 \mathrm{ppb} \\
\text { As }(+5) \\
\text { Solution } \\
\end{array}$ & $\begin{array}{c}\text { Soil 5: } \\
\text { pH of } \\
\text { Equilibrated } \\
100 \mathrm{ppb} \\
\text { As }(+5) \\
\text { Solution } \\
\end{array}$ \\
\hline $\begin{array}{l}1 \\
2\end{array}$ & $\begin{array}{l}7.59 \\
7.41\end{array}$ & $\begin{array}{l}7.60 \\
7.04\end{array}$ & $\begin{array}{l}6.41 \\
6.76\end{array}$ & $\begin{array}{l}7.95 \\
7.31\end{array}$ & $\begin{array}{l}6.56 \\
6.32\end{array}$ \\
\hline Mean & 7.50 & 7.32 & 6.59 & 7.63 & 6.44 \\
\hline
\end{tabular}

Box around data denotes known rejected values. * Symbol denotes known experimental error and was rejected. 
TABLE 9 (Continued). Q-TEST APPLIED TO pH OF EQUILIBRATED As(+5) SAMPLES.

\begin{tabular}{|c|c|c|c|c|c|}
\hline Replicates & $\begin{array}{c}\text { Soil 1: } \\
\text { pH of } \\
\text { Equilibrated } \\
200 \mathrm{ppb} \\
\text { As(+5) } \\
\text { Solution } \\
\end{array}$ & $\begin{array}{c}\text { Soil 2: } \\
\text { pH of } \\
\text { Equilibrated } \\
200 \mathrm{ppb} \\
\text { As }(+5) \\
\text { Solution }\end{array}$ & $\begin{array}{c}\text { Soil 3: } \\
\text { pH of } \\
\text { Equilibrated } \\
200 \mathrm{ppb} \\
\text { As }(+5) \\
\text { Solution } \\
\end{array}$ & $\begin{array}{c}\text { Soil 4: } \\
\text { pH of } \\
\text { Equilibrated } \\
200 \mathrm{ppb} \\
\text { As }(+5) \\
\text { Solution } \\
\end{array}$ & $\begin{array}{c}\text { Soil 5: } \\
\text { pH of } \\
\text { Equilibrated } \\
200 \mathrm{ppb} \\
\text { As }(+5) \\
\text { Solution } \\
\end{array}$ \\
\hline 1 & 5.99 & 6.05 & 5.57 & 6.07 & 6.02 \\
\hline 2 & 6.51 & 6.24 & 6.15 & 6.30 & 7.62 \\
\hline 3 & 6.58 & 7.03 & 6.96 & 6.61 & 7.76 \\
\hline Range & 0.59 & 0.98 & 1.39 & 0.54 & 1.74 \\
\hline Diff Highest & 0.07 & 0.79 & 0.81 & 0.31 & 0.14 \\
\hline $\mathrm{Q}$ value & 0.12 & 0.81 & 0.58 & 0.57 & 0.08 \\
\hline Diff Lowest & 0.52 & 0.19 & 0.58 & 0.23 & 1.60 \\
\hline $\mathrm{Q}$ value & 0.88 & 0.19 & 0.42 & 0.43 & 0.92 \\
\hline $\begin{array}{c}\text { Modified } \\
\text { Mean } \\
\end{array}$ & 6.36 & 6.44 & 6.23 & 6.33 & 7.13 \\
\hline Replicates & $\begin{array}{c}\text { Soil 1: } \\
\text { pH of } \\
\text { Equilibrated 1 } \\
\text { ppm As }(+5) \\
\text { Solution }\end{array}$ & $\begin{array}{c}\text { Soil 2: } \\
\text { pH of } \\
\text { Equilibrated } 1 \\
\text { ppm As }(+5) \\
\text { Solution }\end{array}$ & $\begin{array}{c}\text { Soil 3: } \\
\text { pH of } \\
\text { Equilibrated 1 } \\
\text { ppm As }(+5) \\
\text { Solution }\end{array}$ & $\begin{array}{c}\text { Soil 4: } \\
\text { pH of } \\
\text { Equilibrated } 1 \\
\text { ppm As }(+5) \\
\text { Solution }\end{array}$ & $\begin{array}{c}\text { Soil 5: } \\
\text { pH of } \\
\text { Equilibrated 1 } \\
\text { ppm As }(+5) \\
\text { Solution }\end{array}$ \\
\hline 1 & 6.16 & 6.03 & 5.43 & 6.40 & 6.22 \\
\hline 2 & 6.41 & 6.47 & 6.40 & 6.40 & 6.39 \\
\hline 3 & & 6.95 & 6.74 & 6.54 & 6.50 \\
\hline Range & & 0.92 & 1.31 & 0.14 & 0.28 \\
\hline Diff Highest & & 0.48 & 0.34 & 0.14 & 0.11 \\
\hline $\mathrm{Q}$ value & & 0.52 & 0.26 & 1.00 & 0.39 \\
\hline Diff Lowest & & 0.44 & 0.97 & 0.00 & 0.17 \\
\hline Q value & & 0.48 & 0.74 & 0.00 & 0.61 \\
\hline $\begin{array}{c}\text { Modified } \\
\text { Mean }\end{array}$ & 6.29 & 6.48 & 6.19 & 6.40 & 6.45 \\
\hline
\end{tabular}

Box around data denotes known rejected values. * Symbol denotes known experimental error and was rejected. 
TABLE 9 (Continued). Q-TEST APPLIED TO pH OF EQUILIBRATED As(+5) SAMPLES.

\begin{tabular}{|c|c|c|c|c|c|}
\hline Replicates & $\begin{array}{c}\text { Soil 1: } \\
\text { pH of } \\
\text { Equilibrated } 5 \\
\text { ppm As }(+5) \\
\text { Solution }\end{array}$ & $\begin{array}{c}\text { Soil 2: } \\
\text { pH of } \\
\text { Equilibrated } 5 \\
\text { ppm As }(+5) \\
\text { Solution }\end{array}$ & $\begin{array}{c}\text { Soil 3: } \\
\text { pH of } \\
\text { Equilibrated } 5 \\
\text { ppm As }(+5) \\
\text { Solution }\end{array}$ & $\begin{array}{c}\text { Soil 4: } \\
\text { pH of } \\
\text { Equilibrated } 5 \\
\text { ppm As }(+5) \\
\text { Solution }\end{array}$ & $\begin{array}{c}\text { Soil 5: } \\
\text { pH of } \\
\text { Equilibrated } 5 \\
\text { ppm As }(+5) \\
\text { Solution }\end{array}$ \\
\hline 1 & 6.84 & 7.02 & 7.04 & 6.55 & 6.98 \\
\hline 2 & 7.07 & 7.03 & 7.07 & 6.99 & 7.00 \\
\hline 3 & 7.07 & & & 7.01 & \\
\hline Range & 0.23 & & & 0.46 & \\
\hline Diff Highest & 0.00 & & & 0.02 & \\
\hline $\mathrm{Q}$ value & 0.00 & & & 0.04 & \\
\hline Diff Lowest & 0.23 & & & 0.44 & \\
\hline$Q$ value & 1.00 & & & 0.96 & \\
\hline $\begin{array}{c}\text { Modified } \\
\text { Mean }\end{array}$ & 7.07 & 7.03 & 7.06 & 7.00 & 6.99 \\
\hline $\begin{array}{l}\text { Control } \\
\text { Type }\end{array}$ & $\begin{array}{c}\mathrm{pH} \text { of } \\
\text { Equilibrated } \\
50 \mathrm{ppb} \\
\mathrm{As}(+5) \\
\text { Control }\end{array}$ & $\begin{array}{c}\mathrm{pH} \text { of } \\
\text { Equilibrated } \\
100 \mathrm{ppb} \\
\mathrm{As}(+5) \\
\text { Control } \\
\end{array}$ & $\begin{array}{c}\mathrm{pH} \text { of } \\
\text { Equilibrated } \\
200 \mathrm{ppb} \\
\mathrm{As}(+5) \\
\text { Control }\end{array}$ & $\begin{array}{c}\mathrm{pH} \text { of } \\
\text { Equilibrated } 1 \\
\text { ppm As }(+5) \\
\text { Control }\end{array}$ & $\begin{array}{c}\mathrm{pH} \text { of } \\
\text { Equilibrated } 5 \\
\text { ppm As }(+5) \\
\text { Control }\end{array}$ \\
\hline $\begin{array}{c}\mathrm{As}(+5) \\
\text { Control } 1\end{array}$ & 3.90 & 5.60 & 5.52 & 5.93 & 6.55 \\
\hline $\begin{array}{c}\mathrm{As}(+5) \\
\text { Control } 2\end{array}$ & 5.48 & 5.77 & 5.61 & 6.02 & 6.94 \\
\hline $\begin{array}{c}\mathrm{As}(+5) \\
\text { Control } 3\end{array}$ & 5.55 & 6.20 & 7.45 & 6.30 & 7.16 \\
\hline Range & 1.65 & 0.60 & 1.93 & 0.37 & 0.61 \\
\hline Diff Highest & 0.07 & 0.43 & 1.84 & 0.28 & 0.22 \\
\hline$Q$ value & 0.04 & 0.72 & 0.95 & 0.76 & 0.36 \\
\hline $\begin{array}{l}\text { Diff Lowest } \\
\text { Q value }\end{array}$ & $\begin{array}{l}1.58 \\
0.96\end{array}$ & $\begin{array}{l}0.17 \\
0.28\end{array}$ & $\begin{array}{l}0.09 \\
0.05\end{array}$ & $\begin{array}{l}0.09 \\
0.24\end{array}$ & $\begin{array}{l}0.39 \\
0.64\end{array}$ \\
\hline $\begin{array}{c}\text { Modified } \\
\text { Mean }\end{array}$ & 5.52 & 5.69 & 5.57 & 6.08 & 6.88 \\
\hline
\end{tabular}

Box around data denotes known rejected values. * Symbol denotes known experimental error and was rejected. 
TABLE 10. Q-TEST APPLIED TO $\mathrm{pH}$ OF EQUILIBRATED As(+5) SAMPLES AND STANDARDS

\begin{tabular}{|c|cccccc|}
\hline \multirow{2}{*}{ Replicate } & $\begin{array}{c}\text { Soil 1 } \\
\text { Water } \\
\text { Blank }\end{array}$ & $\begin{array}{c}\text { Soil 2 } \\
\text { Water } \\
\text { Blank }\end{array}$ & $\begin{array}{c}\text { Soil 3 } \\
\text { Water } \\
\text { Blank }\end{array}$ & $\begin{array}{c}\text { Soil 4 } \\
\text { Water } \\
\text { Blank }\end{array}$ & $\begin{array}{c}\text { Soil 5 } \\
\text { Water } \\
\text { Blank }\end{array}$ & $\begin{array}{c}\text { Water } \\
\text { Blank }\end{array}$ \\
\hline 1 & 4.25 & 4.36 & 4.23 & 5.36 & 5.1 & 3.68 \\
2 & 6.1 & 6.07 & 5.81 & 6.28 & 6.36 & 5.79 \\
4 & 7.68 & 6.89 & 6.52 & 6.56 & 6.78 & 5.95 \\
5 & 7.81 & 8.11 & 7.95 & 7.96 & 8.07 & 8.05 \\
& 8.03 & 8.18 & 6.68 & 8.08 & 6.53 & 6.36 \\
\hline Suspect pH & 4.25 & 4.36 & 4.23 & 5.36 & 5.1 & 3.68 \\
\hline $\begin{array}{c}\text { Mean "good" } \\
\text { data }\end{array}$ & 7.41 & 7.31 & 6.74 & 7.22 & 6.94 & 6.54 \\
\hline $\begin{array}{c}\text { Standard } \\
\text { Deviation }\end{array}$ & 0.88 & 1.02 & 0.89 & 0.93 & 0.78 & 1.04 \\
\hline \# of Deviations & & & & & & \\
Away From & 3.58 & 2.90 & 2.82 & 2.00 & 2.36 & 2.76 \\
Stand. Dev. & & & & & & \\
\hline Action (4d rule) & Retain & Retain & Retain & Retain & Retain & Retain \\
\hline Modified Mean & $\mathbf{6 . 7 7}$ & $\mathbf{6 . 7 2}$ & $\mathbf{6 . 2 4}$ & $\mathbf{6 . 8 5}$ & $\mathbf{6 . 5 7}$ & $\mathbf{5 . 9 7}$ \\
\hline
\end{tabular}

Box around data denotes known rejected values. * Symbol denotes known experimental error and was reiected. 
TABLE 12. Q-TEST APPLIED TO pH OF EQUILIBRATED MSMA SAMPLES.

\begin{tabular}{|c|c|c|c|c|c|}
\hline Replicates & $\begin{array}{l}\text { Soil 1: } \\
\text { pH of } \\
\text { Equilibrated } \\
10 \text { ppb } \\
\text { MSMA } \\
\text { Solution }\end{array}$ & $\begin{array}{c}\text { Soil 2: } \\
\text { pH of } \\
\text { Equilibrated } \\
10 \mathrm{ppb} \\
\text { MSMA } \\
\text { Solution }\end{array}$ & $\begin{array}{c}\text { Soil 3: } \\
\text { pH of } \\
\text { Equilibrated } \\
10 \mathrm{ppb} \\
\text { MSMA } \\
\text { Solution } \\
\end{array}$ & $\begin{array}{c}\text { Soil 4: } \\
\text { pH of } \\
\text { Equilibrated } \\
10 \mathrm{ppb} \\
\text { MSMA } \\
\text { Solution }\end{array}$ & $\begin{array}{c}\text { Soil 5: } \\
\text { pH of } \\
\text { Equilibrated } \\
10 \mathrm{ppb} \\
\text { MSMA } \\
\text { Solution }\end{array}$ \\
\hline 1 & 6.23 & 6.13 & 5.91 & 6.39 & 6.3 \\
\hline 2 & 6.28 & 6.24 & 6.01 & 6.41 & 6.41 \\
\hline 3 & 6.35 & 6.32 & 6.03 & 6.43 & 6.44 \\
\hline Range & 0.12 & 0.19 & 0.12 & 0.04 & 0.14 \\
\hline Diff Highest & 0.07 & 0.08 & 0.02 & 0.02 & 0.03 \\
\hline Q value & 0.58 & 0.42 & 0.17 & 0.50 & 0.21 \\
\hline Diff Lowest & 0.05 & 0.11 & 0.10 & 0.02 & 0.11 \\
\hline $\mathrm{Q}$ value & 0.42 & 0.58 & 0.83 & 0.50 & 0.79 \\
\hline $\begin{array}{c}\text { Modified } \\
\text { Mean } \\
\end{array}$ & 6.29 & 6.23 & 5.98 & 6.41 & 6.43 \\
\hline Replicates & \begin{tabular}{|c|} 
Soil l: \\
pH of \\
Equilibrated \\
$50 \mathrm{ppb}$ \\
MSMA \\
Solution
\end{tabular} & $\begin{array}{c}\text { Soil 2: } \\
\text { pH of } \\
\text { Equilibrated } \\
50 \mathrm{ppb} \\
\text { MSMA } \\
\text { Solution }\end{array}$ & $\begin{array}{c}\text { Soil 3: } \\
\text { pH of } \\
\text { Equilibrated } \\
50 \mathrm{ppb} \\
\text { MSMA } \\
\text { Solution }\end{array}$ & $\begin{array}{c}\text { Soil 4: } \\
\text { pH of } \\
\text { Equilibrated } \\
50 \mathrm{ppb} \\
\text { MSMA } \\
\text { Solution }\end{array}$ & $\begin{array}{c}\text { Soil 5: } \\
\text { pH of } \\
\text { Equilibrated } \\
50 \mathrm{ppb} \\
\text { MSMA } \\
\text { Solution }\end{array}$ \\
\hline 1 & 5.61 & 5.53 & 5.42 & 5.92 & 5.87 \\
\hline 2 & 5.72 & 5.62 & 5.49 & 5.99 & 5.92 \\
\hline 3 & 5.75 & 5.73 & 5.56 & 6.07 & 5.97 \\
\hline Range & 0.14 & 0.20 & 0.14 & 0.15 & 0.10 \\
\hline Diff Highest & 0.03 & 0.11 & 0.07 & 0.08 & 0.05 \\
\hline Q value & 0.21 & 0.55 & 0.50 & 0.53 & 0.50 \\
\hline Diff Lowest & 0.11 & 0.09 & 0.07 & 0.07 & 0.05 \\
\hline Q value & 0.79 & 0.45 & 0.50 & 0.47 & 0.50 \\
\hline $\begin{array}{l}\text { Modified } \\
\text { Mean }\end{array}$ & 5.69 & 5.63 & 5.49 & 5.99 & 5.95 \\
\hline
\end{tabular}

Box around data denotes known rejected values. * Symbol denotes known experimental error and was rejected. 
TABLE 12 (Continued). Q-TEST APPLIED TO pH OF EQUILIBRATED MSMA SAMPLES.

\begin{tabular}{|c|c|c|c|c|c|}
\hline \multirow{4}{*}{ Replicates } & $\begin{array}{l}\text { Soil 1: } \\
\text { pH of } \\
\text { Equilibrated }\end{array}$ & $\begin{array}{c}\text { Soil 2: } \\
\text { pH of } \\
\text { Equilibrated }\end{array}$ & $\begin{array}{c}\text { Soil 3: } \\
\text { pH of } \\
\text { Equilibrated }\end{array}$ & $\begin{array}{c}\text { Soil 4: } \\
\text { pH of } \\
\text { Equilibrated }\end{array}$ & $\begin{array}{c}\text { Soil 5: } \\
\text { pH of } \\
\text { Equilibrated }\end{array}$ \\
\hline & $100 \mathrm{ppb}$ & $100 \mathrm{ppb}$ & $100 \mathrm{ppb}$ & $100 \mathrm{ppb}$ & $100 \mathrm{ppb}$ \\
\hline & MSMA & MSMA & MSMA & MSMA & MSMA \\
\hline & Solution & Solution & Solution & Solution & Solution \\
\hline 1 & 5.46 & 5.63 & 5.62 & 6.02 & 5.82 \\
\hline 2 & 5.53 & 5.63 & 5.68 & 6.12 & 5.86 \\
\hline 3 & 5.74 & 5.73 & 5.70 & 6.24 & 5.93 \\
\hline Range & 0.28 & 0.10 & 0.08 & 0.22 & 0.11 \\
\hline Diff Highest & 0.21 & 0.10 & 0.02 & 0.12 & 0.07 \\
\hline Q value & 0.75 & 1.00 & 0.25 & 0.55 & 0.64 \\
\hline Diff Lowest & 0.07 & 0.00 & 0.06 & 0.10 & 0.04 \\
\hline Q value & 0.25 & 0.00 & 0.75 & 0.45 & 0.36 \\
\hline $\begin{array}{c}\text { Modified } \\
\text { Mean } \\
\end{array}$ & 5.58 & 5.66 & 5.67 & 6.13 & 5.90 \\
\hline Replicates & $\begin{array}{c}\text { Soil 1: } \\
\text { pH of } \\
\text { Equilibrated } \\
200 \text { ppb } \\
\text { MSMA } \\
\text { Solution }\end{array}$ & $\begin{array}{c}\text { Soil 2: } \\
\text { pH of } \\
\text { Equilibrated } \\
200 \text { ppb } \\
\text { MSMA } \\
\text { Solution }\end{array}$ & $\begin{array}{c}\text { Soil 3: } \\
\text { pH of } \\
\text { Equilibrated } \\
200 \mathrm{ppb} \\
\text { MSMA } \\
\text { Solution }\end{array}$ & $\begin{array}{c}\text { Soil 4: } \\
\text { pH of } \\
\text { Equilibrated } \\
200 \mathrm{ppb} \\
\text { MSMA } \\
\text { Solution } \\
\end{array}$ & $\begin{array}{c}\text { Soil 5: } \\
\text { pH of } \\
\text { Equilibrated } \\
200 \text { ppb } \\
\text { MSMA } \\
\text { Solution } \\
\end{array}$ \\
\hline 1 & 5.77 & 5.68 & 5.24 & 5.96 & 6.50 \\
\hline 2 & 5.79 & 5.75 & 5.80 & 6.07 & 6.52 \\
\hline 3 & 5.96 & 5.80 & 5.81 & 6.15 & 6.55 \\
\hline Range & 0.19 & 0.12 & 0.57 & 0.19 & 0.05 \\
\hline Diff Highest & 0.17 & 0.05 & 0.01 & 0.08 & 0.03 \\
\hline $\mathrm{Q}$ value & 0.89 & 0.42 & 0.02 & 0.42 & 0.60 \\
\hline Diff Lowest & 0.02 & 0.07 & 0.56 & 0.11 & 0.02 \\
\hline $\mathrm{Q}$ value & 0.11 & 0.58 & 0.98 & 0.58 & 0.40 \\
\hline $\begin{array}{c}\text { Modified } \\
\text { Mean } \\
\end{array}$ & 5.84 & 5.74 & 5.62 & 6.06 & 6.54 \\
\hline
\end{tabular}

Box around data denotes known rejected values. * Symbol denotes known experimental error and was rejected. 
TABLE 11. Q-TEST APPLIED TO $\mathrm{pH}$ OF EQUILIBRATED MSMA SAMPLES AND STANDARDS.

\begin{tabular}{|c|c|c|c|c|}
\hline Control Type & $\begin{array}{c}\mathrm{pH} \text { of } \\
\text { Equilibrated } 10 \\
\text { ppb MSMA } \\
\text { Control }\end{array}$ & $\begin{array}{c}\mathrm{pH} \text { of } \\
\text { Equilibrated } 50 \\
\text { ppb MSMA } \\
\text { Control }\end{array}$ & $\begin{array}{c}\text { pH of } \\
\text { Equilibrated } 100 \\
\text { ppb MSMA } \\
\text { Control }\end{array}$ & $\begin{array}{c}\text { pH of } \\
\text { Equilibrated } 200 \\
\text { ppb MSMA } \\
\text { Control }\end{array}$ \\
\hline $\begin{array}{l}\text { MSMA } \\
\text { Control } 1\end{array}$ & 5.80 & 5.26 & 5.32 & 5.78 \\
\hline $\begin{array}{c}\text { MSMA } \\
\text { Control } 2\end{array}$ & 5.81 & 5.31 & 5.43 & 5.81 \\
\hline $\begin{array}{c}\text { MSMA } \\
\text { Control } 3\end{array}$ & 6.18 & 5.33 & 5.54 & 5.90 \\
\hline Range & 0.38 & 0.07 & 0.22 & 0.12 \\
\hline Diff Highest & 0.37 & 0.02 & 0.11 & 0.09 \\
\hline Q value & 0.97 & 0.29 & 0.50 & 0.75 \\
\hline Diff Lowest & 0.01 & 0.05 & 0.11 & 0.03 \\
\hline Q value & 0.03 & 0.71 & 0.50 & 0.25 \\
\hline $\begin{array}{c}\text { Modified } \\
\text { Mean }\end{array}$ & 5.93 & 5.30 & 5.43 & 5.83 \\
\hline
\end{tabular}

Box around data denotes known rejected values. * Symbol denotes known experimental error and was rejected. 
TABLE 13. ANALYSIS OF CONTROL SOIL BLANKS AND CONTROL DD WATER.

\begin{tabular}{|c|c|c|c|c|c|c|}
\hline Replicate & $\begin{array}{l}\text { Control } \\
\text { Soil } 1, \\
\text { DD } \mathrm{H}_{2} 0 \\
\text { (ppb As) }\end{array}$ & $\begin{array}{l}\text { Control } \\
\text { Soil 2, } \\
\text { DD H }_{2} 0 \\
\text { (ppb As) }\end{array}$ & $\begin{array}{l}\text { Control } \\
\text { Soil } 3 \text {, } \\
\text { DD H }_{2} 0 \\
\text { (ppb As) }\end{array}$ & $\begin{array}{l}\text { Control } \\
\text { Soil 4, } \\
\mathrm{DD} \mathrm{H}_{2} 0 \\
\text { (ppb As) }\end{array}$ & $\begin{array}{l}\text { Control } \\
\text { Soil 5, } \\
\mathrm{DD} \mathrm{H}_{2} 0 \\
(\mathrm{ppb} \mathrm{As})\end{array}$ & $\begin{array}{l}\text { Control } \\
\text { no soil, } \\
\mathrm{DD} \mathrm{H}_{2} \mathrm{O} \\
\text { (ppb As) }\end{array}$ \\
\hline$T$ & -1.715 & -1.46 & -1.4 & -1.227 & -0.5 & -0.704 \\
\hline 2 & -0.579 & -0.777 & -0.948 & -0.74 & -0.355 & -0.1 \\
\hline 3 & -0.449 & -0.289 & -0.74 & 0.017 & -0.31 & -0.1 \\
\hline 4 & -0.187 & 0.052 & -0.3 & 0.068 & -0.138 & 0 \\
\hline 5 & -0.1 & 0.107 & -0.1 & 0.1 & 0.1 & 0.107 \\
\hline 6 & 0.227 & 0.421 & 0.2 & 0.2 & 0.129 & 0.223 \\
\hline 7 & 0.5 & 0.52 & 0.3 & 0.3 & 0.29 & 0.271 \\
\hline 8 & 0.578 & 0.7 & 0.419 & 0.327 & 0.616 & 0.5 \\
\hline 9 & 0.596 & 0.776 & 0.452 & 0.631 & 0.635 & 0.795 \\
\hline 10 & 0.692 & 0.842 & 0.821 & 1.01 & 0.74 & 0.9 \\
\hline 11 & 0.869 & 1.537 & 0.9 & 2.182 & 0.796 & 1.05 \\
\hline 12 & 1.96 & 1.672 & 1.365 & 2.521 & 1.073 & 1.285 \\
\hline 13 & 2.358 & 2.277 & 2.037 & 2.989 & 1.1 & 1.672 \\
\hline AVG & 0.37 & 0.49 & 0.23 & 0.64 & 0.32 & 0.45 \\
\hline STDEV & 1.06 & 1.01 & 0.95 & 1.24 & 0.55 & 0.66 \\
\hline
\end{tabular}


TABLE 14. Q-TEST APPLIED TO TOTAL ORGANIC CARBON DATA.

\begin{tabular}{|c|ccccc|}
\hline \multirow{2}{*}{ Replicate } & Soil 1 & \multicolumn{5}{c|}{ Percentage Organic Matter } \\
\hline 1 & 0.38 & 0.22 & 0.005 & 0.725 & 1.044 \\
2 & 0.434 & 0.23 & 0.01 & 0.73 & 1.075 \\
3 & 0.435 & 0.24 & 0.025 & 0.754 & 1.325 \\
& & & & & \\
Range & 0.06 & 0.02 & 0.02 & 0.03 & 0.28 \\
Diff Highest & 0.00 & 0.01 & 0.02 & 0.02 & 0.25 \\
Q value & 0.02 & 0.50 & 0.75 & 0.83 & 0.89 \\
& & & & & \\
Diff Lowest & 0.05 & 0.01 & 0.01 & 0.01 & 0.03 \\
Q value & $\mathbf{0 . 9 8}$ & 0.50 & 0.25 & 0.17 & 0.11 \\
Modified & $0.43 \%$ & $0.23 \%$ & $0.01 \%$ & $0.74 \%$ & $1.15 \%$ \\
Mean & & & & & \\
\hline
\end{tabular}

Box around data denotes known rejected values. * Symbol denotes known experimental error and was rejected. 
TABLE 15. COMPARISON OF FDEP VERSUS FIU ANALYSIS OF As(+5) KINETICS DATA AND STANDARDS.

\begin{tabular}{|c|c|c|c|c|c|}
\hline Sample ID & $\begin{array}{c}\text { Blank } \\
\text { Corrected } \\
\text { Signal } \\
\text { (FIU) }\end{array}$ & $\begin{array}{c}\text { FIU } \\
\text { Observed } \\
\text { Conc. } \\
\text { As }(+V) \\
\text { ppb's } \\
\end{array}$ & $\begin{array}{c}\text { FDEP } \\
\text { Observed } \\
\text { Conc. } \\
\text { As(+V) } \\
\text { ppb's } \\
\end{array}$ & $\begin{array}{c}\text { Actual } \% \\
\text { Away of } \\
\text { FIU from } \\
\text { FDEP }\end{array}$ & $\begin{array}{l}\text { Corrected } \\
\% \text { Using } \\
\text { Standards' } \\
\text { Average } \\
\text { Difference }\end{array}$ \\
\hline $8 \mathrm{a}: 168 \mathrm{k} 2$ & 0.683 & 159.8 & 154.4 & $3.50 \%$ & $0.45 \%$ \\
\hline $8 \mathrm{~b}: 168 \mathrm{k} 2$ & 0.725 & 169.5 & 164.8 & $2.85 \%$ & $0.00 \%$ \\
\hline $8 \mathrm{~d}: 168 \mathrm{k} 2$ & 0.803 & 187.8 & 180.2 & $4.22 \%$ & $1.61 \%$ \\
\hline $8 \mathrm{e}: 168 \mathrm{k} 2$ & 0.804 & 188.1 & 193.6 & $-2.84 \%$ & $-5.27 \%$ \\
\hline $8 \mathrm{~g}: 168 \mathrm{k} 2$ & 0.834 & 195 & 187.6 & $3.94 \%$ & $1.44 \%$ \\
\hline $8 \mathrm{i}: 168 \mathrm{k} 2$ & 0.828 & 193.6 & 183.6 & $5.45 \%$ & $2.89 \%$ \\
\hline $8 \mathrm{k}: 168 \mathrm{k} 2$ & 0.286 & 66.62 & 61 & $9.21 \%$ & $1.51 \%$ \\
\hline $81: 168 \mathrm{k} 2$ & 0.292 & 68.29 & 61.4 & $11.22 \%$ & $3.57 \%$ \\
\hline AR-168K2 & 0.904 & 211.3 & 202 & $4.60 \%$ & $2.28 \%$ \\
\hline AR-2K2 & 0.886 & 207.2 & 204 & $1.57 \%$ & $-0.74 \%$ \\
\hline $7 \mathrm{a}: 96 \mathrm{k} 2$ & 0.824 & 176.7 & 177.2 & $-0.28 \%$ & $-2.93 \%$ \\
\hline $7 \mathrm{~b}: 96 \mathrm{k} 2$ & 0.793 & 170.1 & 170.2 & $-0.06 \%$ & $-2.82 \%$ \\
\hline $7 \mathrm{~d}: 96 \mathrm{k} 2$ & 0.735 & 157.7 & 180 & $-12.39 \%$ & $-15.00 \%$ \\
\hline $7 \mathrm{e}: 96 \mathrm{k} 2$ & 0.739 & 158.4 & 177.4 & $-10.71 \%$ & $-13.36 \%$ \\
\hline $7 \mathrm{~g}: 96 \mathrm{k} 2$ & 0.766 & 164.2 & 186.2 & $-11.82 \%$ & $-14.34 \%$ \\
\hline $7 \mathrm{~h}: 96 \mathrm{k} 2$ & 0.756 & 162.1 & 184.8 & $-12.28 \%$ & $-14.83 \%$ \\
\hline $7 \mathrm{k}: 96 \mathrm{k} 2$ & 0.427 & 91.51 & 90.2 & $1.45 \%$ & $-3.76 \%$ \\
\hline $71: 96 \mathrm{k} 2$ & 0.438 & 94.01 & 93.6 & $0.44 \%$ & $-4.58 \%$ \\
\hline $6 \mathrm{a}: 48 \mathrm{k} 2$ & 0.676 & 169.2 & 165.8 & $2.05 \%$ & $-0.78 \%$ \\
\hline $6 \mathrm{~b}: 48 \mathrm{k} 2$ & 0.7 & 175.8 & 169 & $4.02 \%$ & $1.24 \%$ \\
\hline $6 \mathrm{~d}: 48 \mathrm{k} 2$ & 0.686 & 172.2 & 174.8 & $-1.49 \%$ & $-4.18 \%$ \\
\hline $6 \mathrm{e}: 48 \mathrm{k} 2$ & 0.73 & 183.2 & 181.2 & $1.10 \%$ & $-1.49 \%$ \\
\hline $6 \mathrm{~g}: 48 \mathrm{k} 2$ & 0.722 & 181.2 & 187 & $-3.10 \%$ & $-5.61 \%$ \\
\hline $6 \mathrm{i}: 48 \mathrm{k} 2$ & 0.707 & 177.4 & 184.4 & $-3.80 \%$ & $-6.34 \%$ \\
\hline $6 \mathrm{k}: 48 \mathrm{k} 2$ & 0.471 & 118.3 & 107 & $10.56 \%$ & $6.17 \%$ \\
\hline $61: 48 \mathrm{k} 2$ & 0.45 & 112.9 & 102 & $10.69 \%$ & $6.08 \%$ \\
\hline AS-0A & Standard & 0 & $<2$ & & \\
\hline AS-5A & Standard & 5 & 2 & $3 \mathrm{ppb}$ & Average \\
\hline AS-25A & Standard & 25 & 19.2 & $5.8 \mathrm{ppb}$ & Difference \\
\hline AS-50A & Standard & 50 & 45.6 & $5.4 \mathrm{ppb}$ & $4.7 \mathrm{ppb}$ \\
\hline $\mathrm{AS}-100 \mathrm{~A}$ & Standard & 100 & 94.4 & $5.6 \mathrm{ppb}$ & \\
\hline
\end{tabular}


TABLE 16. COMPARISON OF FDEP VERSUS FIU ANAYSIS OF EXPERIMENT 2.

\begin{tabular}{|c|c|c|c|c|}
\hline Sample ID & $\begin{array}{c}\text { FIU Observed } \\
\text { Conc. As(+V) } \\
\text { ppb's }\end{array}$ & $\begin{array}{c}\text { DEP } \\
\text { analysis }\end{array}$ & $\begin{array}{c}\text { Actual } \% \\
\text { Away from } \\
\text { DEP }\end{array}$ & $\begin{array}{c}\text { Corrected } \\
\% \text { Away } \\
\text { from DEP }\end{array}$ \\
\hline $12 ; 10$ & 10.14 & 7.7 & $31.69 \%$ & $30.00 \%$ \\
\hline $21 ; 10$ & 8.84 & 9.3 & $-4.95 \%$ & $-5.96 \%$ \\
\hline $22 ; 10$ & 10.36 & 10.4 & $-0.38 \%$ & $-1.33 \%$ \\
\hline $32 ; 10$ & 10.99 & 8.4 & $30.83 \%$ & $29.29 \%$ \\
\hline $41 ; 10$ & 9.89 & 8.8 & $12.39 \%$ & $11.12 \%$ \\
\hline $42 ; 10$ & 10.5 & 9.8 & $7.14 \%$ & $6.06 \%$ \\
\hline $51 ; 10$ & 5.6 & 7 & $-20.00 \%$ & $-21.13 \%$ \\
\hline $52 ; 10$ & 7.15 & 6.7 & $6.72 \%$ & $5.15 \%$ \\
\hline $11 ; 50$ & 47.72 & 47.5 & $0.46 \%$ & $-6.25 \%$ \\
\hline $12 ; 50$ & 50.18 & 47.7 & $5.20 \%$ & $-1.80 \%$ \\
\hline $21 ; 50$ & 48.28 & 46.5 & $3.83 \%$ & $-3.25 \%$ \\
\hline $22 ; 50$ & 49.74 & 44.6 & $11.52 \%$ & $3.63 \%$ \\
\hline $31 ; 50$ & 48.3 & 44.5 & $8.54 \%$ & $0.84 \%$ \\
\hline $32 ; 50$ & 49.98 & 40.5 & $23.41 \%$ & $13.85 \%$ \\
\hline $41 ; 50$ & 52.5 & 44.5 & $17.98 \%$ & $9.60 \%$ \\
\hline $42 ; 50$ & 52.28 & 46.6 & $12.19 \%$ & $4.56 \%$ \\
\hline $51 ; 50$ & 45.36 & 37.3 & $21.61 \%$ & $11.45 \%$ \\
\hline $11 ; 100$ & 95.16 & 87.3 & $9.00 \%$ & $2.88 \%$ \\
\hline $12 ; 100$ & 96.47 & 93.2 & $3.51 \%$ & $-1.96 \%$ \\
\hline $21 ; 100$ & 97.97 & 95.2 & $2.91 \%$ & $-2.42 \%$ \\
\hline $22 ; 100$ & 96.1 & 86.9 & $10.59 \%$ & $4.34 \%$ \\
\hline $31 ; 100$ & 99.48 & 93.7 & $6.17 \%$ & $0.59 \%$ \\
\hline $32 ; 100$ & 100.2 & 88.6 & $13.09 \%$ & $6.82 \%$ \\
\hline $42 ; 100$ & 100 & 88.3 & $13.25 \%$ & $6.95 \%$ \\
\hline $51 ; 100$ & 92.34 & 82.3 & $12.20 \%$ & $5.53 \%$ \\
\hline $11 ; 200$ & 153 & 139 & $10.07 \%$ & $-4.38 \%$ \\
\hline $12 ; 200$ & 149.9 & 141 & $6.31 \%$ & $-7.47 \%$ \\
\hline $21 ; 200$ & $*$ & 80.8 & * & $*$ \\
\hline $22 ; 200$ & 155.7 & 140 & $11.21 \%$ & $-3.29 \%$ \\
\hline $31 ; 200$ & $*$ & 82.9 & $*$ & $*$ \\
\hline $32 ; 200$ & 151 & 142 & $6.34 \%$ & $-7.36 \%$ \\
\hline $41 ; 200$ & 154.5 & 140 & $10.36 \%$ & $-4.04 \%$ \\
\hline $42 ; 200$ & $*$ & 92.3 & $*$ & $*$ \\
\hline $51 ; 200$ & 149.3 & 132 & $13.11 \%$ & $-2.42 \%$ \\
\hline $52 ; 200$ & $*$ & 74.8 & $*$ & $*$ \\
\hline Standard $5 \mathrm{ppb}$ & 5 & 4.9 & -0.1 & \\
\hline Standard $25 \mathrm{ppb}$ & 25 & 23.6 & -1.4 & \\
\hline Standard $50 \mathrm{ppb}$ & 50 & 46.6 & -3.4 & \\
\hline Standard $100 \mathrm{ppb}$ & 100 & 94.8 & -5.2 & \\
\hline Standard $200 \mathrm{ppb}$ & 200 & 179 & -21 & \\
\hline
\end{tabular}

* Symbol denotes known experimental/procedural error and was rejected. 
TABLE 17. Q-TEST APPLIED TO SIEVING DATA.

\begin{tabular}{|c|c|c|c|c|c|c|c|}
\hline \multicolumn{8}{|c|}{ Soil 1 } \\
\hline Sieve No. & Dia. (mm) & $\begin{array}{c}\text { \%Retained } \\
\text { Replicate \# } \\
1\end{array}$ & $\begin{array}{c}\% \text { Retained } \\
\text { Replicate \# } \\
2\end{array}$ & $\begin{array}{c}\% \text { Retained } \\
\text { Replicate \# } \\
3\end{array}$ & $\begin{array}{c}\text { Suspect } \\
\text { value }\end{array}$ & $Q$ value & $\begin{array}{l}\text { Corrected } \\
\text { Mean (\%) }\end{array}$ \\
\hline 16 & 1.190 & 0.30 & 0.20 & 0.20 & 0.30 & 1.00 & 0.20 \\
\hline 30 & 0.600 & 3.10 & 2.90 & 2.90 & 3.10 & 1.00 & 4.30 \\
\hline 40 & 0.425 & - & 16.70 & 16.90 & - & - & 16.80 \\
\hline 60 & 0.250 & - & 57.30 & 58.80 & - & - & 58.05 \\
\hline 140 & 0.106 & 19.30 & 22.40 & 20.70 & 22.40 & 0.55 & 20.80 \\
\hline 200 & 0.075 & 0.30 & 0.30 & 0.30 & - & - & 0.30 \\
\hline Pan & $<0.075$ & 0.20 & 0.20 & 0.20 & - & - & $\mathbf{0 . 2 0}$ \\
\hline \multicolumn{8}{|c|}{ Soil 3 } \\
\hline Sieve No. & Dia. $(\mathrm{mm})$ & $\begin{array}{c}\text { \%Retained } \\
\text { Replicate \# } \\
1\end{array}$ & $\begin{array}{c}\text { \%Retained } \\
\text { Replicate \# } \\
2\end{array}$ & $\mid \begin{array}{c}\text { \%Retained } \\
\text { Replicate \# } \\
3\end{array}$ & $\begin{array}{c}\text { Suspect } \\
\text { value }\end{array}$ & $Q$ value & $\begin{array}{l}\text { Corrected } \\
\text { Mean (\%) }\end{array}$ \\
\hline 16 & 1.190 & 0.10 & 0.10 & 0.10 & - & - & 0.10 \\
\hline 30 & 0.600 & 3.10 & 3.20 & 3.20 & 3.10 & 1.00 & 3.20 \\
\hline 40 & 0.425 & 14.10 & 14.60 & 14.00 & 14.60 & 0.83 & 14.23 \\
\hline 60 & 0.250 & 54.20 & 53.50 & 54.10 & 53.50 & 0.86 & 53.93 \\
\hline 140 & 0.106 & 28.10 & 28.30 & 28.30 & 28.10 & 1.00 & 28.30 \\
\hline 200 & 0.075 & 0.30 & 0.20 & 0.30 & 0.20 & 1.00 & 0.30 \\
\hline Pan & $<0.075$ & 0.20 & 0.10 & 0.10 & 0.20 & 1.00 & 0.10 \\
\hline \multicolumn{8}{|c|}{ Soil 5} \\
\hline Sieve No. & Dia. $(\mathrm{mm})$ & $\begin{array}{c}\text { \% Retained } \\
\text { Replicate \# } \\
1\end{array}$ & $\begin{array}{c}\text { \%Retained } \\
\text { Replicate \# } \\
2\end{array}$ & $\begin{array}{c}\% \text { Retained } \\
\text { Replicate \# } \\
3\end{array}$ & $\begin{array}{c}\text { Suspect } \\
\text { value }\end{array}$ & $Q$ value & $\begin{array}{l}\text { Corrected } \\
\text { Mean }(\%)\end{array}$ \\
\hline 16 & 1.190 & 0.30 & 0.10 & 0.00 & 0.30 & 0.67 & 0.13 \\
\hline 30 & 0.600 & 4.30 & 4.40 & 4.60 & 4.60 & 0.67 & 4.43 \\
\hline 40 & 0.425 & 12.10 & 12.00 & 11.90 & - & - & 12.00 \\
\hline 60 & 0.250 & 51.50 & 50.60 & 50.60 & 51.50 & 1.00 & 50.60 \\
\hline 140 & 0.106 & 31.40 & 32.30 & 32.30 & 31.40 & 1.00 & 32.30 \\
\hline 200 & 0.075 & 0.10 & 0.20 & 0.20 & 0.10 & 1.00 & 0.20 \\
\hline Pan & $<0.075$ & 0.40 & 0.40 & 0.40 & - & - & 0.40 \\
\hline
\end{tabular}


TABLE 17. Q-TEST APPLIED TO SIEVING DATA.

\begin{tabular}{|c|c|c|c|c|c|c|}
\hline \multicolumn{7}{|c|}{ Soil 2} \\
\hline Sieve \# & $\begin{array}{c}\% \text { Retained } \\
\text { Replicate \# } \\
1\end{array}$ & $\begin{array}{c}\text { \%Retained } \\
\text { Replicate \# } \\
2\end{array}$ & $\begin{array}{c}\% \text { Retained } \\
\text { Replicate \# } \\
3\end{array}$ & $\begin{array}{l}\text { Suspect } \\
\text { value }\end{array}$ & Q value & $\begin{array}{l}\text { Corrected } \\
\text { Mean (\%) }\end{array}$ \\
\hline 16 & \begin{tabular}{|l|}
0.50 \\
\end{tabular} & \begin{tabular}{|l|}
0.30 \\
\end{tabular} & 0.40 & - & - & 0.40 \\
\hline 30 & 3.40 & 3.30 & 3.20 & - & - & 3.30 \\
\hline 40 & 19.50 & 18.20 & 18.60 & 19.50 & 0.69 & 18.77 \\
\hline 60 & 59.60 & 56.80 & 56.30 & 59.60 & 0.85 & $\mathbf{5 7 . 5 7}$ \\
\hline 140 & 16.80 & 21.10 & 21.10 & 16.80 & 1.00 & 21.10 \\
\hline 200 & 0.10 & 0.20 & 0.20 & 0.10 & 1.00 & 0.20 \\
\hline pan & 0.10 & 0.10 & 0.10 & - & - & 0.10 \\
\hline \multicolumn{7}{|c|}{ Soil 4} \\
\hline Sieve \# & $\begin{array}{c}\% \text { Retained } \\
\text { Replicate \# } \\
1\end{array}$ & {$\left[\begin{array}{c}\% \text { Retained } \\
\text { Replicate \# } \\
2\end{array}\right.$} & $\mid \begin{array}{c}\% \text { Retained } \\
\text { Replicate \# } \\
3\end{array}$ & $\begin{array}{l}\text { Suspect } \\
\text { value }\end{array}$ & Q value & $\begin{array}{l}\text { Corrected } \\
\text { Mean }(\%)\end{array}$ \\
\hline 16 & 0.10 & 0.03 & 0.10 & 0.03 & 1.00 & 0.10 \\
\hline 30 & 3.40 & 3.50 & 3.40 & 3.50 & 1.00 & 3.40 \\
\hline 40 & 13.10 & 12.90 & 13.00 & - & - & 13.00 \\
\hline 60 & 55.90 & 54.90 & 55.00 & 55.90 & 0.90 & 55.27 \\
\hline 140 & 27.20 & 28.40 & 28.30 & 27.20 & 0.92 & 27.97 \\
\hline 200 & 0.10 & 0.10 & 0.10 & - & - & 0.10 \\
\hline pan & 0.10 & 0.10 & 0.10 & - & - & 0.10 \\
\hline
\end{tabular}


TABLE 18. RESULTS FROM ORIGINAL As(+5) EXPERIMENTS.

\begin{tabular}{|c|c|c|c|c|c|c|}
\hline $\begin{array}{c}\text { Soil; } \\
\text { Replicate }\end{array}$ & $\begin{array}{c}\text { Equilibrium } \\
\text { conc (ppb), } \\
\text { initial at } \\
\sim 10 \mathrm{ppb}\end{array}$ & $\begin{array}{c}\text { Equilibrium } \\
\text { conc (ppb), } \\
\text { initial at } \\
50 \mathrm{ppb}\end{array}$ & $\begin{array}{c}\text { Equilibrium } \\
\text { conc (ppb), } \\
\text { initial at } \\
100 \mathrm{ppb}\end{array}$ & $\begin{array}{c}\text { Equilibrium } \\
\text { conc (ppb), } \\
\text { initial at } \\
200 \mathrm{ppb}\end{array}$ & $\begin{array}{c}\text { Equilibrium } \\
\text { conc (ppb), } \\
\text { initial at } \\
\text { 1ppm }\end{array}$ & $\begin{array}{c}\text { Equilibrium } \\
\text { conc (ppb), } \\
\text { initial at } \\
5 \mathrm{ppm}\end{array}$ \\
\hline $1 ; 1$ & 12.25 & 47.72 & 95.16 & 153.8 & 330.4 & 3720 \\
\hline $1 ; 2$ & 10.14 & 50.18 & 96.47 & 149.9 & 343.9 & 4830 \\
\hline $2 ; 1$ & 8.84 & 48.28 & 97.97 & $*$ & 470.7 & 4104 \\
\hline $2 ; 2$ & 10.36 & 49.74 & 96.1 & 155.7 & 382.3 & 3773 \\
\hline $3 ; 1$ & 10.99 & 48.3 & 99.48 & $*$ & 439.7 & 3816 \\
\hline $3 ; 2$ & 11.54 & 49.98 & 100.2 & 151 & 381.6 & 3932 \\
\hline $4 ; 1$ & 9.89 & 52.5 & 97.77 & 154.5 & 361.0 & 4698 \\
\hline $4 ; 2$ & 10.5 & 52.28 & 100 & * & 425.3 & 3854 \\
\hline $5 ; 1$ & 5.58 & 45.36 & 92.34 & 149.3 & 391.7 & 3310 \\
\hline $5 ; 2$ & 7.15 & - & 88.31 & $*$ & 468.2 & 3524 \\
\hline$\left[\begin{array}{c}\text { Control 1 } \\
\text { (Initial) }\end{array}\right]$ & 11.37 & 57.31 & 108.9 & * & $*$ & 4950 \\
\hline $\begin{array}{c}\text { Soil; } \\
\text { Replicate }\end{array}$ & $\begin{array}{c}\text { Control - } \\
\text { EQ (ppb), } \\
\text { initial conc } \\
\sim 10 \mathrm{ppb} \\
\end{array}$ & $\begin{array}{c}\text { Control - } \\
\text { EQ (ppb), } \\
\text { initial conc } \\
\sim 50 \mathrm{ppb}\end{array}$ & $\begin{array}{l}\text { Control - } \\
\text { EQ (ppb), } \\
\text { initial conc } \\
\sim 100 \mathrm{ppb}\end{array}$ & $\begin{array}{l}\text { Control - } \\
\text { EQ (ppb), } \\
\text { initial conc } \\
\sim 200 p^{1} b^{1}\end{array}$ & $\begin{array}{c}\text { Control - } \\
\text { EQ (ppb), } \\
\text { initial conc } \\
\sim 1 \mathrm{ppm}^{2}\end{array}$ & $\begin{array}{c}\text { Control - } \\
\text { EQ (ppb), } \\
\text { initial conc } \\
\sim 5 \mathrm{ppm}\end{array}$ \\
\hline $1 ; 1$ & -0.88 & 9.59 & 13.74 & 48.0 & 574.4 & 1230 \\
\hline $1 ; 2$ & 1.23 & 7.13 & 12.43 & 51.9 & 560.1 & 120 \\
\hline $2 ; 1$ & 2.53 & 9.03 & 10.93 & $*$ & 433.0 & 846 \\
\hline $2 ; 2$ & 1.01 & 7.57 & 12.8 & 46.1 & 520.9 & 1177 \\
\hline $3 ; 1$ & 0.38 & 9.01 & 9.42 & $*$ & 463.9 & 1134 \\
\hline $3 ; 2$ & -0.17 & 7.31 & 8.7 & 50.8 & 522.3 & 1018 \\
\hline $4 ; 1$ & 1.48 & 4.81 & 11.13 & 47.3 & 542.9 & 252 \\
\hline $4 ; 2$ & 0.87 & 5.03 & 8.9 & $*$ & 478.4 & 1096 \\
\hline $5 ; 1$ & 5.79 & 11.95 & 16.56 & 52.5 & 512.1 & 1640 \\
\hline $5 ; 2$ & 4.22 & $*$ & 20.59 & $*$ & 435.5 & 1426 \\
\hline
\end{tabular}

* Symbol denotes known experimental/procedural error and was rejected.

${ }^{1}$ The corresponding $\sim 200 \mathrm{ppb}$ control from $2^{\text {nd }} \mathrm{As}(+5)$ experiments was used.

${ }^{2}$ The corresponding $-1 \mathrm{ppm}$ control from $2^{\text {nd }} \mathrm{As}(+5)$ experiment was used. 
TABLE 18 (Continued). RESULTS FROM SECOND SET OF As $(+5)$ EXPERIMENTS.

\begin{tabular}{|c|c|c|c|c|c|}
\hline Soil; Replicate & $\begin{array}{l}\text { Equilibrium } \\
\text { conc (ppb), } \\
\text { initial at } \\
\sim 10 \mathrm{ppb}\end{array}$ & $\begin{array}{l}\text { Equilibrium } \\
\text { conc. W/ } \\
\text { initial at } \\
50 \mathrm{ppb}\end{array}$ & $\begin{array}{l}\text { Equilibrium } \\
\text { conc. W/ } \\
\text { initial at } \\
100 \mathrm{ppb}\end{array}$ & $\begin{array}{l}\text { Equilibrium } \\
\text { conc. W/ } \\
\text { initial at } \\
200 \mathrm{ppb}\end{array}$ & $\begin{array}{c}\text { Equilibrium } \\
\text { conc. W/ } \\
\text { initial at } \\
1 \mathrm{ppm}\end{array}$ \\
\hline $1 ; 3$ & 3.742 & 44.2 & & 186.7 & \\
\hline $2 ; 3$ & 5.781 & 50.12 & & 188 & 997.5 \\
\hline $3 ; 3$ & 4.398 & 49.37 & & 210.4 & 971.5 \\
\hline $4 ; 3$ & 4.476 & 49.86 & & 204.9 & 966.5 \\
\hline $5 ; 3$ & 1.818 & 43.88 & & 176.4 & \\
\hline $5 ; 4$ & & 42.48 & & & \\
\hline $\begin{array}{l}\text { Control } 2 \\
\text { (Initial) }\end{array}$ & 7.85 & 48.5 & 99.5 & 192.1 & 828 \\
\hline $\begin{array}{c}\text { Control } 3 \\
\text { (Initial) }\end{array}$ & 7.048 & 49.11 & 99.17 & 211.4 & 984.5 \\
\hline $\begin{array}{l}\text { Control average } \\
\text { (Initial) }\end{array}$ & 7.449 & 48.805 & 99.335 & 201.75 & 906.75 \\
\hline Soil; Replicate & $\begin{array}{l}\text { Control - } \\
\text { EQ (ppb), } \\
\text { initial conc } \\
\sim 10 \mathrm{ppb}\end{array}$ & $\begin{array}{l}\text { Control - } \\
\text { EQ (ppb), } \\
\text { initial conc } \\
\sim 50 \mathrm{ppb}\end{array}$ & $\begin{array}{l}\text { Control - EQ } \\
\text { (ppb), initial } \\
\text { conc } \\
\sim 100 \mathrm{ppb}\end{array}$ & $\begin{array}{c}\text { Control - EQ } \\
\text { (ppb), initial } \\
\text { conc } \\
\sim 200 \mathrm{ppb}\end{array}$ & $\begin{array}{l}\text { Control - } \\
\text { EQ (ppb), } \\
\text { initial conc } \\
\sim 1 \mathrm{ppm}\end{array}$ \\
\hline $1 ; 3$ & 3.707 & 4.605 & & 15.05 & \\
\hline $2 ; 3$ & 1.668 & -1.315 & & 13.75 & -90.75 \\
\hline $3 ; 3$ & 3.051 & -0.565 & & -8.65 & -64.75 \\
\hline $4 ; 3$ & 2.973 & -1.055 & & -3.15 & -59.75 \\
\hline $5 ; 3$ & 5.631 & 4.925 & & 25.35 & \\
\hline $5 ; 4$ & & 6.325 & & & \\
\hline
\end{tabular}


TABLE 19. Q-TEST APPLIED TO EQUILIBRIUM CONCENTRATIONS FROM ALL As(+5) EXPERIMENTS.

\begin{tabular}{|c|c|c|c|c|c|}
\hline & $\begin{array}{c}\text { Soil 1 } \\
\text { Equilibrium } \\
\text { conc (ppb), } \\
\text { initial at } \\
\sim 10 \mathrm{ppb} \\
\end{array}$ & $\begin{array}{c}\text { Soil } 2 \\
\text { Equilibrium } \\
\text { conc (ppb), } \\
\text { initial at } \\
\sim 10 \mathrm{ppb} \\
\end{array}$ & $\begin{array}{c}\text { Soil } 3 \\
\text { Equilibrium } \\
\text { conc (ppb) } \\
\text { initial at } \\
\sim 10 \mathrm{ppb} \\
\end{array}$ & $\begin{array}{c}\text { Soil } 4 \\
\text { Equilibrium } \\
\text { conc (ppb), } \\
\text { initial at } \\
\sim 10 \mathrm{ppb} \\
\end{array}$ & $\begin{array}{c}\text { Soil } 5 \\
\text { Equilibrium } \\
\text { conc (ppb), } \\
\text { initial at } \\
\sim 10 \mathrm{ppb} \\
\end{array}$ \\
\hline Replicate 1 & 3.74 & 5.78 & 4.40 & 4.48 & 1.82 \\
\hline Replicate 2 & 10.14 & 8.84 & 10.99 & 9.89 & 5.58 \\
\hline Replicate 3 & 12.25 & 10.36 & 11.54 & 10.50 & 7.15 \\
\hline Range & 8.51 & 4.58 & 7.14 & 6.02 & 5.33 \\
\hline Diff Highest & 2.11 & 1.52 & 0.55 & 0.61 & 1.57 \\
\hline$Q$ value & 0.25 & 0.33 & 0.08 & 0.10 & 0.29 \\
\hline Diff Lowest & 6.40 & 3.06 & 6.59 & 5.41 & 3.76 \\
\hline Q value & 0.75 & 0.67 & 0.92 & 0.90 & 0.71 \\
\hline \multirow[t]{2}{*}{$\begin{array}{c}\text { Modified } \\
\text { Mean } \\
\end{array}$} & 8.71 & 8.33 & 8.98 & 8.29 & 4.85 \\
\hline & $\begin{array}{c}\text { Soil 1 } \\
\text { Equilibrium } \\
\text { conc (ppb), } \\
\text { initial at } \\
\sim 50 \mathrm{ppb} \\
\end{array}$ & $\begin{array}{c}\text { Soil } 2 \\
\text { Equilibrium } \\
\text { conc (ppb), } \\
\text { initial at } \\
\sim 50 \mathrm{ppb}\end{array}$ & $\begin{array}{c}\text { Soil } 3 \\
\text { Equilibrium } \\
\text { conc (ppb), } \\
\text { initial at } \\
50 \mathrm{ppb}\end{array}$ & $\begin{array}{c}\text { Soil } 4 \\
\text { Equilibrium } \\
\text { conc (ppb), } \\
\text { initial at } \\
\sim 50 \mathrm{ppb}\end{array}$ & $\begin{array}{c}\text { Soil } 5 \\
\text { Equilibrium } \\
\text { conc (ppb), } \\
\text { initial at } \\
\sim 50 \mathrm{ppb} \\
\end{array}$ \\
\hline Replicate 1 & 44.20 & 48.28 & 48.30 & 49.86 & 42.48 \\
\hline Replicate 2 & 47.72 & 49.74 & 49.37 & 52.28 & 43.88 \\
\hline Replicate 3 & 50.18 & 50.12 & 50.00 & 52.50 & 45.36 \\
\hline Range & 5.98 & 1.84 & 1.70 & 2.64 & 2.88 \\
\hline Diff Highest & 2.46 & 0.38 & 0.63 & 0.22 & 1.48 \\
\hline$Q$ value & 0.41 & 0.21 & 0.37 & 0.08 & 0.51 \\
\hline Diff Lowest & 3.52 & 1.46 & 1.07 & 2.42 & 1.40 \\
\hline Q value & 0.59 & 0.79 & 0.63 & 0.92 & 0.49 \\
\hline $\begin{array}{c}\text { Modified } \\
\text { Mean }\end{array}$ & 47.37 & 49.38 & 49.22 & 51.55 & 43.91 \\
\hline
\end{tabular}

Box around data points denotes known rejected values. * Symbol denotes known experimental error and was rejected. 
TABLE 19 (Continued). Q-TEST APPLIED TO EQUILIBRIUM CONCENTRATIONS FROM ALL As(+5) EXPERIMENTS.

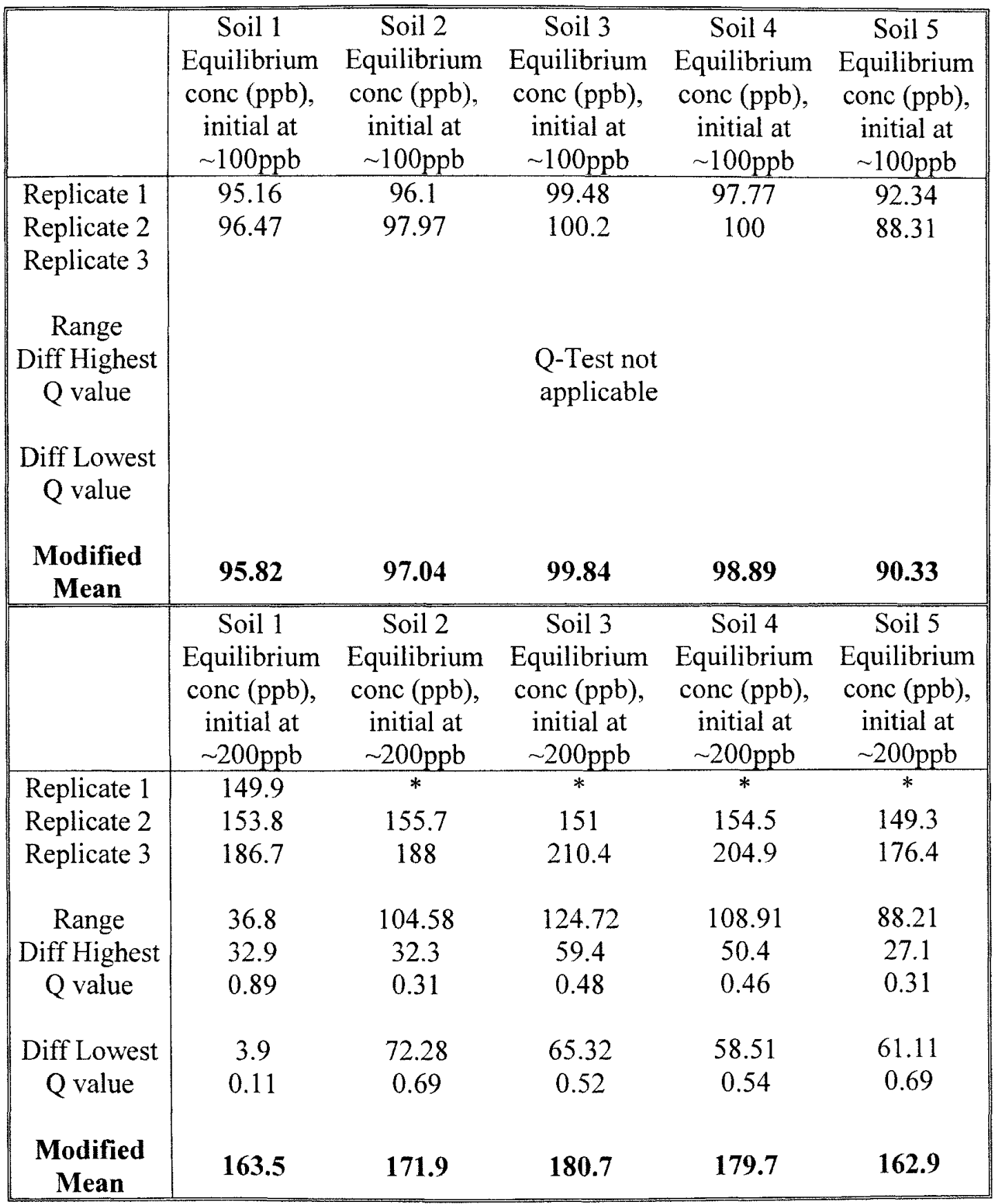

Box around data points denotes known rejected values. * Symbol denotes known experimental error and was reiected. 
TABLE 19 (Continued). Q-TEST APPLIED TO EQUILIBRIUM CONCENTRATIONS FROM ALL As(+5) EXPERIMENTS.

\begin{tabular}{|c|c|c|c|c|c|}
\hline & $\begin{array}{c}\text { Soil 1 } \\
\text { Equilibrium } \\
\text { conc (ppb), } \\
\text { initial at } \\
\sim 1 \mathrm{ppm}\end{array}$ & $\begin{array}{c}\text { Soil } 2 \\
\text { Equilibrium } \\
\text { conc (ppb), } \\
\text { initial at } \\
\sim 1 \mathrm{ppm}\end{array}$ & $\begin{array}{c}\text { Soil } 3 \\
\text { Equilibrium } \\
\text { conc (ppb), } \\
\text { initial at } \\
\sim 1 \mathrm{ppm}\end{array}$ & $\begin{array}{c}\text { Soil } 4 \\
\text { Equilibrium } \\
\text { conc (ppb), } \\
\text { initial at } \\
\sim 1 \mathrm{ppm}\end{array}$ & $\begin{array}{c}\text { Soil } 5 \\
\text { Equilibrium } \\
\text { conc (ppb), } \\
\text { initial at } \\
\sim 1 \mathrm{ppm}\end{array}$ \\
\hline Replicate 1 & 330.4 & 383.9 & 382.5 & 361.9 & 392.7 \\
\hline Replicate 2 & 344.7 & 471.8 & 440.9 & 426.4 & 469.3 \\
\hline Replicate 3 & & 997.5 & 971.5 & 966.5 & \\
\hline Range & & 613.6 & 589 & 604.6 & \\
\hline Diff Highest & & 525.7 & 530.6 & 540.1 & \\
\hline $\mathrm{Q}$ value & & 0.86 & 0.90 & 0.89 & \\
\hline Diff Lowest & & 87.9 & 58.4 & 64.5 & \\
\hline $\mathrm{Q}$ value & & 0.14 & 0.10 & 0.11 & \\
\hline \multirow[t]{2}{*}{$\begin{array}{c}\text { Modified } \\
\text { Mean }\end{array}$} & 337.6 & 617.7 & 598.3 & 584.9 & 431 \\
\hline & $\begin{array}{c}\text { Soil } 1 \\
\text { Equilibrium } \\
\text { conc (ppb), } \\
\text { initial at } \\
\sim 5 \mathrm{ppm} \\
\end{array}$ & $\begin{array}{c}\text { Soil } 2 \\
\text { Equilibrium } \\
\text { conc }(\mathrm{ppb}) \\
\text { initial at } \\
\sim 5 \mathrm{ppm}\end{array}$ & $\begin{array}{c}\text { Soil 3 } \\
\text { Equilibrium } \\
\text { conc (ppb), } \\
\text { initial at } \\
\sim 5 \mathrm{ppm} \\
\end{array}$ & $\begin{array}{c}\text { Soil } 4 \\
\text { Equilibrium } \\
\text { conc (ppb), } \\
\text { initial at } \\
\sim 5 \mathrm{ppm}\end{array}$ & $\begin{array}{c}\text { Soil } 5 \\
\text { Equilibrium } \\
\text { conc (ppb), } \\
\text { initial at } \\
\sim 5 \mathrm{ppm} \\
\end{array}$ \\
\hline Replicate 1 & 3720 & 3773 & 3816 & 3854 & 3310 \\
\hline $\begin{array}{l}\text { Replicate } 2 \\
\text { Replicate } 3\end{array}$ & 4830 & 4104 & 3932 & 4698 & 3524 \\
\hline $\begin{array}{c}\text { Range } \\
\text { Diff Highest } \\
\text { Q value }\end{array}$ & & & $\begin{array}{l}\text { Q-Test not } \\
\text { applicable }\end{array}$ & & \\
\hline \multicolumn{6}{|l|}{$\begin{array}{l}\text { Diff Lowest } \\
\text { Q value }\end{array}$} \\
\hline $\begin{array}{c}\text { Modified } \\
\text { Mean }\end{array}$ & 4275 & 3939 & 3874 & 4276 & 3417 \\
\hline
\end{tabular}

Box around data points denotes known rejected values. * Symbol denotes known experimental error and was rejected. 
TABLE 20. MASS OF As(+5) ADSORBED TO EACH SOIL AT EACH INITIAL CONCENTRATION.

\begin{tabular}{|c|c|c|c|c|c|}
\hline & $\begin{array}{c}\text { Soil 1: } \\
\text { Mass } \\
\text { adsorbed } \\
\text { (ug), initial } \\
\text { conc. } \sim 10 \mathrm{ppb}\end{array}$ & $\begin{array}{c}\text { Soil 2: } \\
\text { Mass } \\
\text { adsorbed } \\
\text { (ug), initial } \\
\text { conc. } \sim 10 \mathrm{ppb}\end{array}$ & $\begin{array}{c}\text { Soil 3: } \\
\text { Mass } \\
\text { adsorbed } \\
\text { (ug), initial } \\
\text { conc. } \sim 10 \mathrm{ppb} \\
\end{array}$ & $\begin{array}{c}\text { Soil 4: } \\
\text { Mass } \\
\text { adsorbed } \\
\text { (ug), initial } \\
\text { conc. } \sim 10 \mathrm{ppb}\end{array}$ & $\begin{array}{c}\text { Soil 5: } \\
\text { Mass } \\
\text { adsorbed } \\
\text { (ug), initial } \\
\text { conc. } \sim 10 \mathrm{ppb}\end{array}$ \\
\hline Replicate 1 & -0.110 & 0.126 & -0.020 & 0.109 & 0.528 \\
\hline Replicate 2 & 0.154 & 0.209 & 0.047 & 0.185 & 0.704 \\
\hline Replicate 3 & 0.463 & 0.316 & 0.382 & 0.372 & 0.724 \\
\hline Range & 0.463 & 0.190 & 0.382 & 0.263 & 0.196 \\
\hline Diff Highest & 0.310 & 0.108 & 0.334 & 0.187 & 0.020 \\
\hline $\mathrm{Q}$ value & 0.668 & 0.566 & 0.875 & 0.710 & 0.101 \\
\hline Diff Lowest & 0.154 & 0.082 & 0.047 & 0.076 & 0.177 \\
\hline $\mathrm{Q}$ value & 0.332 & 0.434 & 0.125 & 0.290 & 0.899 \\
\hline \multirow{2}{*}{$\begin{array}{c}\text { Modified } \\
\text { Mean } \\
\end{array}$} & 0.169 & 0.217 & 0.136 & 0.222 & 0.652 \\
\hline & $\begin{array}{c}\text { Soil 1: } \\
\text { Mass } \\
\text { adsorbed } \\
\text { (ug), initial } \\
\text { conc. } \sim 50 \mathrm{ppb} \\
\end{array}$ & $\begin{array}{c}\text { Soil 2: } \\
\text { Mass } \\
\text { adsorbed } \\
\text { (ug), initial } \\
\text { conc. } \sim 50 \mathrm{ppb} \\
\end{array}$ & $\begin{array}{c}\text { Soil 3: } \\
\text { Mass } \\
\text { adsorbed } \\
\text { (ug), initial } \\
\text { conc. } \sim 50 \mathrm{ppb} \\
\end{array}$ & $\begin{array}{c}\text { Soil 4: } \\
\text { Mass } \\
\text { adsorbed } \\
\text { (ug), initial } \\
\text { conc. } \sim 50 \mathrm{ppb}\end{array}$ & $\begin{array}{c}\text { Soil 5: } \\
\text { Mass } \\
\text { adsorbed } \\
\text { (ug), initial } \\
\text { conc. } \sim 50 \mathrm{ppb}\end{array}$ \\
\hline Replicate 1 & 0.576 & -0.160 & -0.070 & -0.130 & 0.616 \\
\hline Replicate 2 & 0.891 & 0.946 & 0.914 & 0.601 & 0.791 \\
\hline Replicate 3 & 1.199 & 1.126 & 1.126 & 0.629 & 1.494 \\
\hline Range & 0.623 & 1.196 & 1.196 & 0.759 & 0.878 \\
\hline Diff Highest & 0.308 & 0.210 & 0.213 & 0.028 & 0.703 \\
\hline Q value & 0.493 & 0.176 & 0.178 & 0.036 & 0.801 \\
\hline Diff Lowest & 0.316 & 0.986 & 0.984 & 0.731 & 0.175 \\
\hline$Q$ value & 0.507 & 0.824 & 0.822 & 0.964 & 0.199 \\
\hline $\begin{array}{c}\text { Modified } \\
\text { Mean }\end{array}$ & 0.889 & 0.637 & 0.657 & 0.615 & 0.967 \\
\hline
\end{tabular}

Box around data points denotes known rejected values. * Symbol denotes known experimental error and was rejected. 
TABLE 20 (Continued). MASS OF As(+5) ADSORBED TO EACH SOIL AT EACH INITIAL CONCENTRATION.

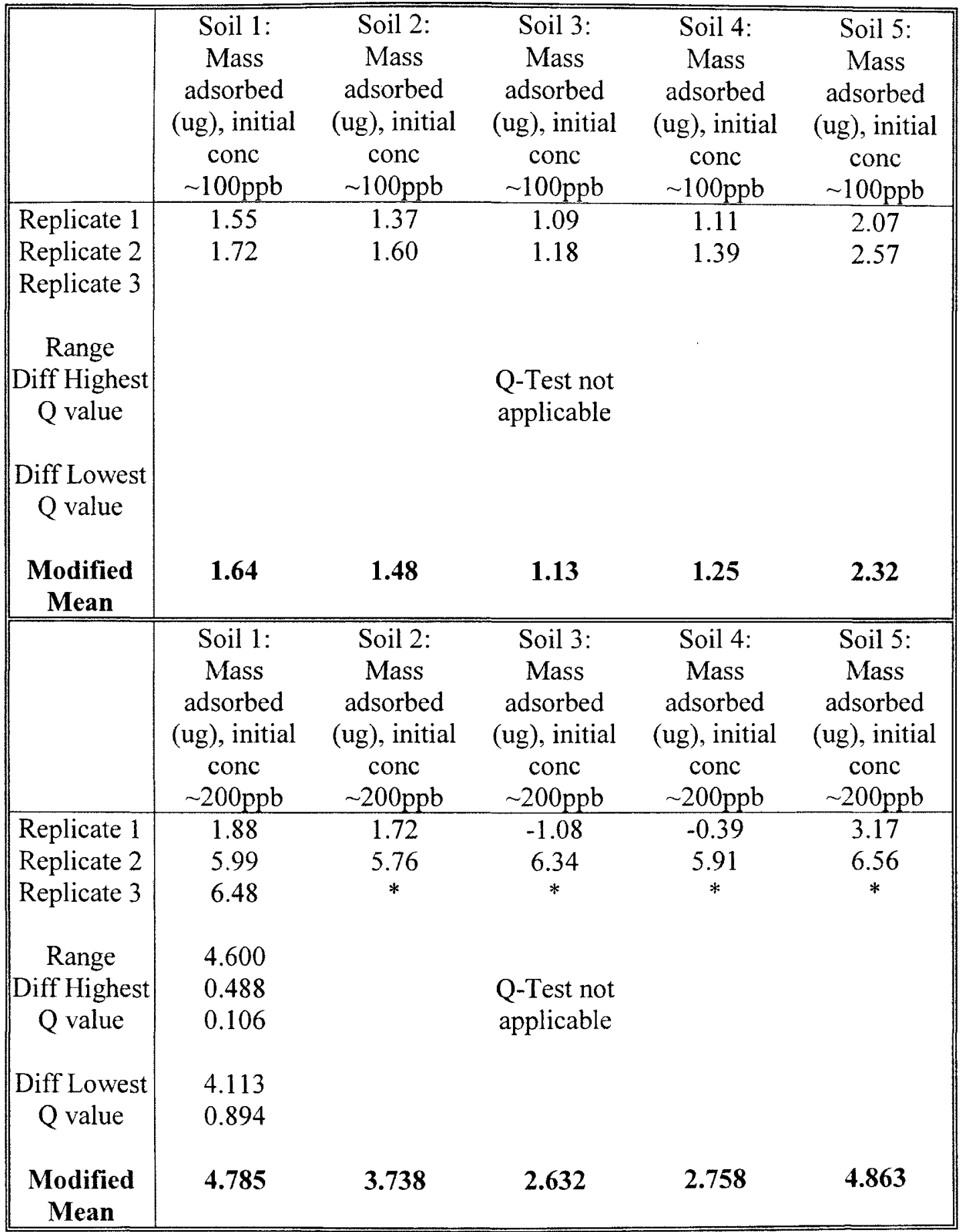

Box around data points denotes known rejected values. * Symbol denotes known experimental error and was rejected. 
TABLE 20 (Continued). MASS OF As(+5) ADSORBED TO EACH SOIL AT EACH INITIAL CONCENTRATION.

\begin{tabular}{|c|c|c|c|c|c|}
\hline & $\begin{array}{c}\text { Soil 1: } \\
\text { Mass As }(+5) \\
\text { adsorbed } \\
\text { (ug), initial } \\
\text { conc. } \sim 1 \text { ppm }\end{array}$ & $\begin{array}{c}\text { Soil 2: } \\
\text { Mass As }(+5) \\
\text { adsorbed } \\
\text { (ug), initial } \\
\text { conc. } \sim 1 \text { ppm }\end{array}$ & $\begin{array}{c}\text { Soil 3: } \\
\text { Mass As }(+5) \\
\text { adsorbed } \\
\text { (ug), initial } \\
\text { conc. } \sim 1 \mathrm{ppm}\end{array}$ & $\begin{array}{c}\text { Soil 4: } \\
\text { Mass As(+5) } \\
\text { adsorbed } \\
\text { (ug), initial } \\
\text { conc. } \sim 1 \text { ppm }\end{array}$ & $\begin{array}{c}\text { Soil 5: } \\
\text { Mass As }(+5) \\
\text { adsorbed } \\
\text { (ug), initial } \\
\text { conc. } \sim \text { lppm }\end{array}$ \\
\hline Replicate 1 & 70.01 & -11.59 & -8.34 & -7.72 & 54.43 \\
\hline Replicate 2 & 71.79 & 54.12 & 57.98 & 59.79 & 64.01 \\
\hline Replicate 3 & & 65.11 & 65.28 & 67.86 & \\
\hline Range & & 76.700 & 73.625 & 75.575 & \\
\hline Diff Highest & & 10.988 & 7.300 & 8.063 & \\
\hline$Q$ value & & 0.143 & 0.099 & 0.107 & \\
\hline Diff Lowest & & 65.71 & 66.33 & 67.51 & \\
\hline $\mathrm{Q}$ value & & 0.86 & 0.90 & 0.89 & \\
\hline \multirow{2}{*}{$\begin{array}{c}\text { Modified } \\
\text { Mean } \\
\end{array}$} & 70.90 & 35.88 & 38.31 & 39.98 & 59.22 \\
\hline & $\begin{array}{c}\text { Soil 1: } \\
\text { Mass As( }+5 \text { ) } \\
\text { adsorbed } \\
\text { (ug), initial } \\
\text { conc. } \sim 5 \mathrm{ppm}\end{array}$ & $\begin{array}{c}\text { Soil 2: } \\
\text { Mass As }(+5) \\
\text { adsorbed } \\
\text { (ug), initial } \\
\text { conc. } \sim 5 \text { ppm }\end{array}$ & $\begin{array}{c}\text { Soil 3: } \\
\text { Mass As }(+5) \\
\text { adsorbed } \\
\text { (ug), initial } \\
\text { conc. } \sim 5 \mathrm{ppm}\end{array}$ & $\begin{array}{c}\text { Soil 4: } \\
\text { Mass As }(+5) \\
\text { adsorbed } \\
\text { (ug), initial } \\
\text { conc. } \sim 5 \mathrm{ppm}\end{array}$ & $\begin{array}{c}\text { Soil 5: } \\
\text { Mass As }(+5) \\
\text { adsorbed } \\
\text { (ug), initial } \\
\text { conc. } \sim 5 \mathrm{ppm}\end{array}$ \\
\hline Replicate 1 & $14^{*}$ & 106 & 128 & 32 & 178 \\
\hline $\begin{array}{l}\text { Replicate } 2 \\
\text { Replicate } 3\end{array}$ & 154 & 147 & 142 & 137 & 205 \\
\hline $\begin{array}{c}\text { Range } \\
\text { Diff Highest } \\
\text { Q value }\end{array}$ & & & $\begin{array}{l}\text { Q-Test not } \\
\text { applicable }\end{array}$ & & \\
\hline \multicolumn{6}{|l|}{$\begin{array}{c}\text { Diff Lowest } \\
\text { Q value }\end{array}$} \\
\hline $\begin{array}{l}\text { Modified } \\
\text { Mean }\end{array}$ & 154 & 126 & 135 & 84 & 192 \\
\hline
\end{tabular}

Box around data points denotes known rejected values. * Symbol denotes known experimental error and was rejected. 
TABLE 21. Q-TEST APPLIED TO MSMA EQUILIBRIUM CONCENTRATIONS.

\begin{tabular}{|c|c|c|c|c|c|c|}
\hline & $\begin{array}{c}\text { Soil 1 } \\
\text { Equilibrium } \\
\text { conc (ppb), } \\
\text { initial at } \\
\sim 10 \mathrm{ppb} \\
\end{array}$ & $\begin{array}{c}\text { Soil } 2 \\
\text { Equilibrium } \\
\text { conc (ppb), } \\
\text { initial at } \\
\sim 10 \mathrm{ppb}\end{array}$ & $\begin{array}{c}\text { Soil } 3 \\
\text { Equilibrium } \\
\text { conc (ppb), } \\
\text { initial at } \\
\sim 10 \mathrm{ppb}\end{array}$ & $\begin{array}{c}\text { Soil } 4 \\
\text { Equilibrium } \\
\text { conc (ppb), } \\
\text { initial at } \\
\sim 10 \mathrm{ppb}\end{array}$ & $\begin{array}{c}\text { Soil } 5 \\
\text { Equilibrium } \\
\text { conc (ppb), } \\
\text { initial at } \\
\sim 10 \mathrm{ppb}\end{array}$ & $\begin{array}{c}\text { Control } \\
\text { Equilibrium } \\
\text { conc (ppb), } \\
\text { initial at } \\
\sim 10 \mathrm{ppb}\end{array}$ \\
\hline Replicate 1 & 7.941 & 7.992 & 5.588 & 6.175 & 6.937 & 7.185 \\
\hline Replicate 2 & 8.386 & 8.837 & 9.404 & 6.99 & 7.995 & 10.36 \\
\hline Replicate 3 & 8.667 & 8.952 & $*$ & 9.569 & 11.17 & $*$ \\
\hline Range & 0.726 & 0.960 & & 3.394 & 4.233 & \\
\hline Diff. High & 0.281 & 0.115 & & 2.579 & 3.175 & \\
\hline$Q$ value & 0.39 & 0.12 & & 0.76 & 0.75 & \\
\hline \multirow{4}{*}{$\begin{array}{c}\text { Diff. Low } \\
\text { Q value } \\
\text { Modified } \\
\text { Mean } \\
\end{array}$} & 0.445 & 0.845 & & 0.815 & 1.058 & \\
\hline & 0.61 & 0.880 & & 0.24 & 0.25 & \\
\hline & 8.33 & 8.41 & 7.50 & 7.58 & 8.70 & 8.77 \\
\hline & $\begin{array}{c}\text { Soil 1 } \\
\text { Equilibrium } \\
\text { conc (ppb), } \\
\text { initial at } \\
\sim 50 \mathrm{ppb}\end{array}$ & $\begin{array}{c}\text { Soil } 2 \\
\text { Equilibrium } \\
\text { conc (ppb), } \\
\text { initial at } \\
\sim 50 \mathrm{ppb}\end{array}$ & $\begin{array}{c}\text { Soil } 3 \\
\text { Equilibrium } \\
\text { conc (ppb), } \\
\text { initial at } \\
50 \mathrm{ppb}\end{array}$ & $\begin{array}{c}\text { Soil } 4 \\
\text { Equilibrium } \\
\text { conc (ppb), } \\
\text { initial at } \\
\sim 50 \mathrm{ppb}\end{array}$ & $\begin{array}{l}\text { Soil } 5 \\
\text { Equilibrium } \\
\text { conc (ppb), } \\
\text { initial at } \\
\sim 50 \mathrm{ppb}\end{array}$ & $\begin{array}{c}\text { Control } \\
\text { Equilibrium } \\
\text { conc (ppb), } \\
\text { initial at } \\
\sim 50 \mathrm{ppb}\end{array}$ \\
\hline Replicate 1 & 47.72 & 48.44 & 46.48 & 45.93 & 44.13 & 25.45 \\
\hline Replicate 2 & 48.12 & 48.48 & 47.59 & 48.48 & 45.24 & 49.65 \\
\hline Replicate 3 & 50.44 & 49.98 & 48.4 & 48.74 & 49.3 & 49.92 \\
\hline Range & 2.72 & 1.54 & 1.92 & 2.81 & 5.17 & 24.47 \\
\hline Diff. High & 2.32 & 1.5 & 0.81 & 0.26 & 4.06 & 0.27 \\
\hline$Q$ value & 0.85 & 0.97 & 0.42 & 0.09 & 0.79 & 0.01 \\
\hline Diff. Low & 0.4 & 0.04 & 1.11 & 2.55 & 1.11 & 24.2 \\
\hline$Q$ value & 0.15 & 0.03 & 0.58 & 0.91 & 0.21 & 0.99 \\
\hline $\begin{array}{l}\text { Modified } \\
\text { Mean }\end{array}$ & 48.76 & 48.46 & 47.49 & 47.72 & 46.22 & 49.79 \\
\hline
\end{tabular}

Box around data denotes known rejected values. * Symbol denotes known experimental error and was rejected. 
TABLE 21 (continued). Q-TEST APPLIED TO MSMA EQUILIBRIUM CONCENTRATIONS.

\begin{tabular}{|c|c|c|c|c|c|c|}
\hline & $\begin{array}{c}\text { Soil 1 } \\
\text { Equilibrium } \\
\text { conc (ppb), } \\
\text { initial at } \\
\sim 100 \mathrm{ppb} \\
\end{array}$ & $\begin{array}{c}\text { Soil } 2 \\
\text { Equilibrium } \\
\text { conc (ppb), } \\
\text { initial at } \\
\sim 100 \mathrm{ppb} \\
\end{array}$ & $\begin{array}{c}\text { Soil } 3 \\
\text { Equilibrium } \\
\text { conc (ppb), } \\
\text { initial at } \\
\sim 100 \mathrm{ppb}\end{array}$ & $\begin{array}{c}\text { Soil } 4 \\
\text { Equilibrium } \\
\text { conc (ppb), } \\
\text { initial at } \\
\sim 100 \mathrm{ppb}\end{array}$ & $\begin{array}{c}\text { Soil } 5 \\
\text { Equilibrium } \\
\text { conc (ppb), } \\
\text { initial at } \\
\sim 100 \mathrm{ppb}\end{array}$ & $\begin{array}{c}\text { Control } \\
\text { Equilibrium } \\
\text { conc (ppb), } \\
\text { initial at } \\
\sim 100 \mathrm{ppb}\end{array}$ \\
\hline Replicate 1 & 81.03 & 84.46 & 90.29 & 87.95 & 79.67 & 90.45 \\
\hline Replicate 2 & 85.67 & 91.71 & 92.34 & 89.84 & 83.62 & 95.16 \\
\hline Replicate 3 & 92.28 & 94.59 & 96.04 & 91.17 & 86.56 & 100.2 \\
\hline Range & 11.25 & 10.13 & 5.75 & 3.22 & 6.89 & 9.75 \\
\hline Diff. High & 6.61 & 2.9 & 3.7 & 1.33 & 2.94 & 5.04 \\
\hline Q value & 0.59 & 0.28 & 0.64 & 0.41 & 0.43 & 0.52 \\
\hline Diff. Low & 4.64 & 7.25 & 2.05 & 1.89 & 3.95 & 4.71 \\
\hline Q value & 0.41 & 0.72 & 0.36 & 0.59 & 0.57 & 0.48 \\
\hline $\begin{array}{l}\text { Modified } \\
\text { Mean }\end{array}$ & 86.33 & 90.25 & 92.89 & 90.51 & 83.28 & 95.27 \\
\hline & $\begin{array}{c}\text { Soil 1 } \\
\text { Equilibrium } \\
\text { conc (ppb), } \\
\text { initial at } \\
\sim 200 \mathrm{ppb}\end{array}$ & $\begin{array}{c}\text { Soil } 2 \\
\text { Equilibrium } \\
\text { conc (ppb), } \\
\text { initial at } \\
\sim 200 \mathrm{ppb}\end{array}$ & $\begin{array}{c}\text { Soil } 3 \\
\text { Equilibrium } \\
\text { conc (ppb), } \\
\text { initial at } \\
\sim 200 \mathrm{ppb}\end{array}$ & $\begin{array}{c}\text { Soil } 4 \\
\text { Equilibrium } \\
\text { conc (ppb), } \\
\text { initial at } \\
\sim 200 \mathrm{ppb} \\
\end{array}$ & $\begin{array}{c}\text { Soil } 5 \\
\text { Equilibrium } \\
\text { conc (ppb), } \\
\text { initial at } \\
\sim 200 \mathrm{ppb} \\
\end{array}$ & $\begin{array}{c}\text { Control } \\
\text { Equilibrium } \\
\text { conc (ppb), } \\
\text { initial at } \\
\sim 200 \mathrm{ppb}\end{array}$ \\
\hline Replicate 1 & 169.6 & 169.9 & 174.5 & 174.3 & 167 & 182.1 \\
\hline Replicate 2 & 177.6 & 178.8 & 181.2 & 176.5 & 170.1 & 184 \\
\hline Replicate 3 & 179 & 179.3 & 182.6 & 176.9 & 176.6 & 192.1 \\
\hline Range & 9.4 & 9.4 & 8.1 & 2.6 & 9.6 & 10 \\
\hline Diff. High & 1.4 & 0.5 & 1.4 & 0.4 & 6.5 & 8.1 \\
\hline $\mathrm{Q}$ value & 0.15 & 0.05 & 0.17 & 0.15 & 0.68 & 0.81 \\
\hline $\begin{array}{l}\text { Diff. Low } \\
\text { Q value }\end{array}$ & $\begin{array}{c}8.4 \\
0.85\end{array}$ & $\begin{array}{c}8.9 \\
0.936\end{array}$ & $\begin{array}{c}6.7 \\
0.83\end{array}$ & $\begin{array}{c}2.2 \\
0.85\end{array}$ & $\begin{array}{l}3.1 \\
0.32\end{array}$ & $\begin{array}{c}1.9 \\
0.19\end{array}$ \\
\hline $\begin{array}{l}\text { Modified } \\
\text { Mean }\end{array}$ & 175.4 & 176 & 179.4 & 175.9 & 171.2 & 186.1 \\
\hline
\end{tabular}

Box around data points denotes known rejected values. * Symbol denotes known experimental error and was rejected. 
TABLE 22. TABULATED RESULTS OF CONCENTRATION AS A FUNCTION OF TIME FOR SCENARIOS 1, 2, AND 3 (COMPARE VARYING DISPERSION VALUES).

\begin{tabular}{|cccc|}
\hline Date & $\begin{array}{c}\text { Scenario 1: } \\
\text { Total Dissolved } \\
\text { arsenic (ppb) }\end{array}$ & $\begin{array}{c}\text { Scenario 2: } \\
\text { Total Dissolved } \\
\text { arsenic (ppb) }\end{array}$ & $\begin{array}{c}\text { Scenario 3: } \\
\text { Total Dissolved } \\
\text { arsenic (ppb) }\end{array}$ \\
\hline 2-Mar-88 & 213.11 & 36.20 & 0.00 \\
8-Mar-88 & 208.13 & 188.98 & 22.33 \\
2-Apr-88 & 150.59 & 157.63 & 167.14 \\
2-Sep-88 & 226.53 & 46.31 & 6.35 \\
8-Sep-88 & 248.27 & 190.50 & 6.88 \\
2-Oct-88 & 240.35 & 231.63 & 64.97 \\
2-Mar-89 & 336.95 & 174.98 & 141.56 \\
8-Mar-89 & 342.04 & 311.58 & 149.00 \\
2-Apr-89 & 326.35 & 328.36 & 223.88 \\
2-Sep-89 & 334.03 & 166.65 & 163.85 \\
8-Sep-89 & 341.75 & 302.42 & 160.52 \\
2-Oct-89 & 291.02 & 298.59 & 250.17 \\
2-Mar-90 & 376.27 & 199.82 & 193.18 \\
8-Mar-90 & 399.14 & 344.41 & 191.62 \\
2-Apr-90 & 388.04 & 376.94 & 243.69 \\
2-Sep-90 & 285.94 & 96.69 & 48.67 \\
8-Sep-90 & 268.10 & 248.95 & 77.23 \\
2-Oct-90 & 126.09 & 132.91 & 167.25 \\
2-Mar-91 & 248.58 & 81.74 & 36.28 \\
8-Mar-91 & 230.64 & 220.51 & 71.15 \\
2-Apr-91 & 207.04 & 212.82 & 165.10 \\
2-Sep-91 & 234.74 & 55.99 & 14.35 \\
8-Sep-91 & 224.80 & 206.86 & 38.70 \\
2-Oct-91 & 150.32 & 176.04 & 178.19 \\
2-Mar-92 & 270.54 & 91.70 & 69.40 \\
8-Mar-92 & 285.91 & 239.11 & 71.27 \\
2-Apr-92 & 261.98 & 254.68 & 154.52 \\
2-Sep-92 & 274.15 & 83.95 & 48.76 \\
8-Sep-92 & 257.84 & 233.46 & 64.11 \\
2-Oct-92 & 197.92 & 205.93 & 193.58 \\
\hline
\end{tabular}


TABLE 23. TABULATED RESULTS OF CONCENTRATION AS A FUNCTION OF TIME FOR SCENARIOS 4 AND 5 (COMPARE VARYING $\mathrm{K}_{d}$ VALUES).

\begin{tabular}{|cccc|}
\hline Date & $\begin{array}{c}\text { Scenario 4: } \\
\text { Total Dissolved } \\
\text { arsenic (ppb) }\end{array}$ & $\begin{array}{c}\text { Scenario 2: } \\
\text { Total Dissolved } \\
\text { arsenic (ppb) }\end{array}$ & $\begin{array}{c}\text { Scenario 5: } \\
\text { Total Dissolved } \\
\text { arsenic (ppb) }\end{array}$ \\
\hline 2-Mar-88 & 0.00 & 36.20 & 0.01 \\
8-Mar-88 & 15.70 & 188.98 & 43.38 \\
2-Apr-88 & 132.78 & 157.63 & 277.40 \\
2-Sep-88 & 12.39 & 46.31 & 0.84 \\
8-Sep-88 & 12.17 & 190.50 & 3.24 \\
2-Oct-88 & 53.56 & 231.63 & 128.59 \\
2-Mar-89 & 120.26 & 174.98 & 170.17 \\
8-Mar-89 & 125.39 & 311.58 & 186.19 \\
2-Apr-89 & 182.59 & 328.36 & 333.96 \\
2-Sep-89 & 163.47 & 166.65 & 117.55 \\
8-Sep-89 & 160.97 & 302.42 & 116.32 \\
2-Oct-89 & 229.57 & 298.59 & 307.64 \\
2-Mar-90 & 188.32 & 199.82 & 176.76 \\
8-Mar-90 & 186.81 & 344.41 & 176.27 \\
2-Apr-90 & 224.26 & 376.94 & 292.38 \\
2-Sep-90 & 78.60 & 96.69 & 9.76 \\
8-Sep-90 & 97.16 & 248.95 & 68.61 \\
2-Oct-90 & 167.13 & 132.91 & 177.67 \\
2-Mar-91 & 47.85 & 81.74 & 16.11 \\
8-Mar-91 & 72.56 & 220.51 & 82.42 \\
2-Apr-91 & 144.39 & 212.82 & 261.08 \\
2-Sep-91 & 24.76 & 55.99 & 2.53 \\
8-Sep-91 & 40.91 & 206.86 & 51.45 \\
2-Oct-91 & 152.08 & 176.04 & 262.42 \\
2-Mar-92 & 73.75 & 91.70 & 45.95 \\
8-Mar-92 & 74.46 & 239.11 & 53.17 \\
2-Apr-92 & 135.70 & 254.68 & 227.31 \\
2-Sep-92 & 71.99 & 83.95 & 11.23 \\
8-Sep-92 & 80.51 & 233.46 & 49.84 \\
2-Oct-92 & 178.83 & 205.93 & 284.40 \\
\hline & & & \\
\hline
\end{tabular}


TABLE 24. TABULATED RESULTS OF CONCENTRATION AS A FUNCTION OF TIME FOR SCENARIOS 2, 6, 7, AND 8 (COMPARE VARYING IRRIGATION).

\begin{tabular}{|ccccc|}
\hline Date & $\begin{array}{c}\text { Scenario 7: } \\
\text { Total Dissolved } \\
\text { arsenic }(\mathrm{ppb})\end{array}$ & $\begin{array}{c}\text { Scenario 2: } \\
\text { Total Dissolved } \\
\text { arsenic }(\mathrm{ppb})\end{array}$ & $\begin{array}{c}\text { Scenario 6: } \\
\text { Total Dissolved } \\
\text { arsenic }(\mathrm{ppb})\end{array}$ & $\begin{array}{c}\text { Scenario 8: } \\
\text { Total Dissolved } \\
\text { arsenic (ppb) }\end{array}$ \\
\hline 2-Mar-88 & 36.20 & 36.20 & 36.20 & 35.85 \\
8-Mar-88 & 36.20 & 188.98 & 188.98 & 189.66 \\
2-Apr-88 & 157.78 & 157.63 & 157.03 & 160.61 \\
2-Sep-88 & 46.35 & 46.31 & 46.15 & 46.72 \\
8-Sep-88 & 46.35 & 190.50 & 190.44 & 190.98 \\
2-Oct-88 & 231.70 & 231.63 & 231.29 & 232.92 \\
2-Mar-89 & 175.96 & 174.98 & 173.97 & 182.68 \\
8-Mar-89 & 175.96 & 311.58 & 309.99 & 319.78 \\
2-Apr-89 & 330.05 & 328.36 & 326.47 & 340.41 \\
2-Sep-89 & 167.07 & 166.65 & 166.03 & 177.72 \\
8-Sep-89 & 167.07 & 302.42 & 301.69 & 314.20 \\
2-Oct-89 & 301.16 & 298.59 & 297.64 & 312.63 \\
2-Mar-90 & 202.89 & 199.82 & 198.39 & 217.19 \\
8-Mar-90 & 202.89 & 344.41 & 343.08 & 364.55 \\
2-Apr-90 & 379.64 & 376.94 & 375.08 & 399.95 \\
2-Sep-90 & 97.85 & 96.69 & 96.46 & 103.85 \\
8-Sep-90 & 97.85 & 248.95 & 248.51 & 256.82 \\
2-Oct-90 & 133.11 & 132.91 & 132.12 & 139.91 \\
2-Mar-91 & 81.69 & 81.74 & 81.13 & 85.37 \\
8-Mar-91 & 81.69 & 220.51 & 219.90 & 223.67 \\
2-Apr-91 & 212.91 & 212.82 & 212.07 & 217.70 \\
2-Sep-91 & 56.20 & 55.99 & 55.78 & 57.92 \\
8-Sep-91 & 56.20 & 206.86 & 206.66 & 208.84 \\
2-Oct-91 & 176.34 & 176.04 & 175.47 & 180.80 \\
2-Mar-92 & 92.47 & 91.70 & 90.97 & 96.22 \\
8-Mar-92 & 92.47 & 239.11 & 238.34 & 244.51 \\
2-Apr-92 & 255.40 & 254.68 & 254.06 & 262.62 \\
2-Sep-92 & 84.144 & 83.95 & 83.66 & 87.83 \\
8-Sep-92 & 84.144 & 233.46 & 233.18 & 237.70 \\
2-Oct-92 & 206.42 & 205.93 & 205.73 & 210.80 \\
\hline
\end{tabular}


TABLE 25. TABULATED RESULTS OF CONCENTRATION VERSUS TIME FOR FRACTIONAL DISSOLVED MSMA, As(+5), AND TOTAL DISSOLVED ARSENIC AT GROUNDWATER INTERFACE AFTER ONE APPLICATION OF MSMA.

\begin{tabular}{||cccc||}
\hline Date & $\begin{array}{c}\text { Dissolved } \\
\text { MSMA } \\
(\mathrm{ppb})\end{array}$ & $\begin{array}{c}\text { Dissolved } \\
\text { As(+5) } \\
(\mathrm{ppb})\end{array}$ & $\begin{array}{c}\text { Total } \\
\text { Dissolved } \\
\text { arsenic } \\
(\mathrm{ppb})\end{array}$ \\
\hline 1-Mar-88 & 46.92 & 0.2734 & 11.44 \\
3-Mar-88 & 273.3 & 2.773 & 67.81 \\
5-Mar-88 & 500.7 & 8.068 & 127.23 \\
7-Mar-88 & 683.1 & 16.91 & 179.48 \\
9-Mar-88 & 714.8 & 24.55 & 194.67 \\
10-Mar-88 & 714.1 & 28.14 & 198.09 \\
11-Mar-88 & 708.7 & 31.62 & 200.29 \\
15-Mar-88 & 651.9 & 45.31 & 200.46 \\
20-Mar-88 & 538.2 & 57.21 & 185.30 \\
10-Apr-88 & 286.7 & 83.66 & 151.89 \\
25-Apr-88 & 215.3 & 98.42 & 149.66 \\
15-May-88 & 91.03 & 89.49 & 111.15 \\
30-May-88 & 57.61 & 85.3 & 99.01 \\
15-Jun-88 & 12.83 & 49.85 & 52.90 \\
29-Jun-88 & 8.136 & 41.96 & 43.89 \\
15-Jul-88 & 2.059 & 25.35 & 25.84 \\
30-Jul-88 & 1.234 & 20.59 & 20.88 \\
15-Aug-88 & 0.8676 & 19.38 & 19.58 \\
30-Aug-88 & 0.1864 & 10.07 & 10.11 \\
\hline \hline
\end{tabular}


Appendix B - Supporting Documents 


\section{Florida International University \\ Field Sample Data Sheet}

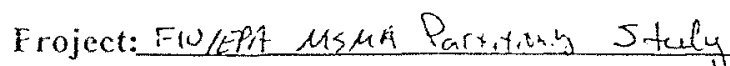

Approximate Location: Loft of green of 1 st Lole

Sampling Date: $11 / 4 / 97$

Sample \#: Surviral $4.9^{-}$

Sampling Type and Equipment: Shout, Ayger,

Visual Fixes: Appoximatery $100^{\prime} \mathrm{NW}$ of prom, as indizatod by map below

Depth of Sample: From

Photos - Roll:

Picture: $1-6$

Sample Description: Sondy soi!

Observed Weather Conditions: Clocly, $84^{\circ} \mathrm{F} ; 808$ hemictity, Very light wivd

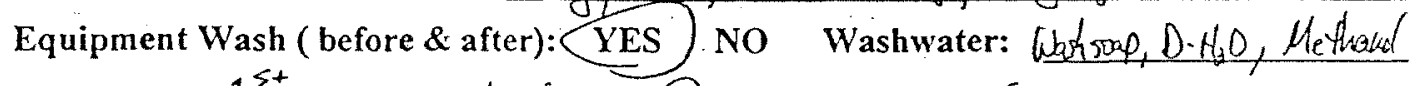
Comments: $1^{\text {st }}$ sample of thiday. Removed top $4=$ off $-a$

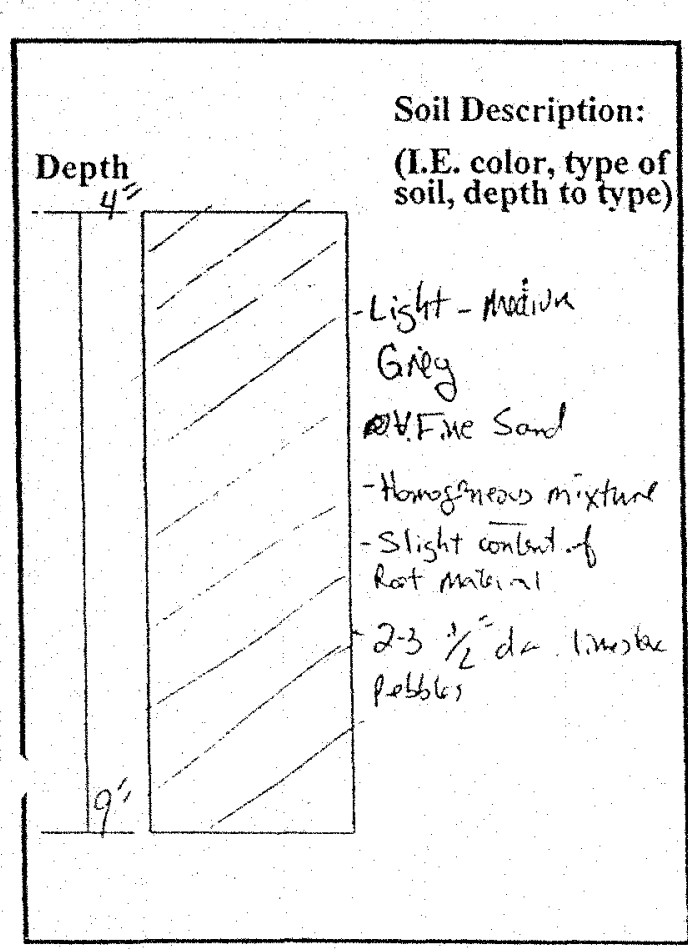

Sample taken by: Tem Davis

Witness(es) Present: Leslik Smith FOEP-scD,

Terg DuB FDP-Bot stlucie, George Dlal. D. Tutor Fuenter, Bomand Kimmel.

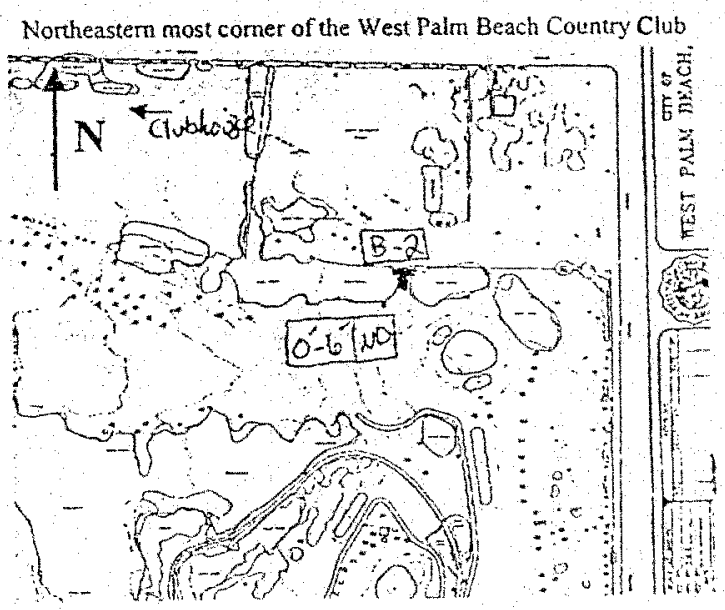




\section{Florida International University \\ Field Sample Data Sheet}

Froject: Fulepit MSMA Partition Stuly

Approximate Location. Left of greon of 1 st lole

Sampling Date: $11 / 4 / 97$

Sample $\begin{aligned} & \text { Suret } \\ & 49^{-}\end{aligned}$

Sampling Type and Equipment: Shoud, Ayger,

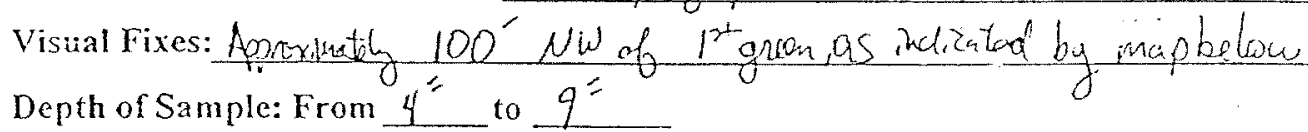

Photos-Roll:

Picture: $1-6$

Sample Description: Sondy so.i

Observed Weather Conditions: Clody, $84^{\circ} \mathrm{F}, 80 \%$ humidit, Very light wivel

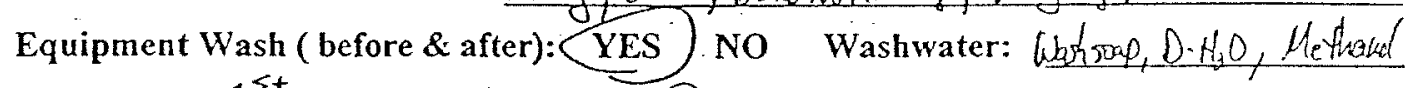

Comments: 1 sample of thiday. Rermoved top $4=$ off $-a$

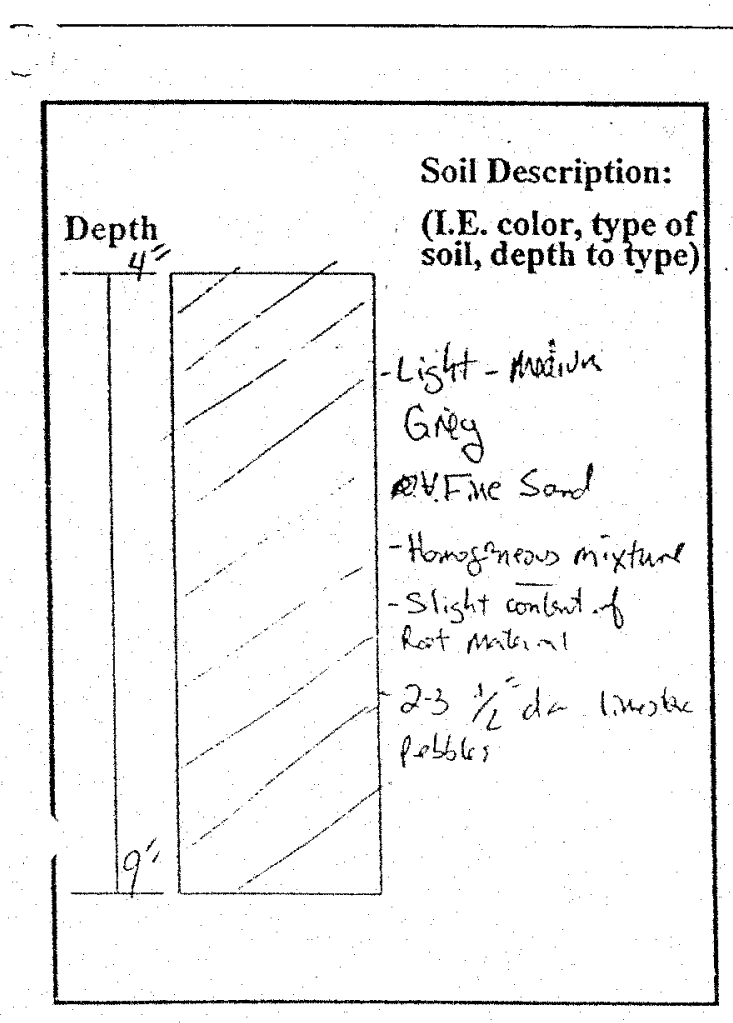

Sample taken by: Tem: DavB

Witness(es) Present: Lesh Smith Fotp SeD,

Terry Dhu FDEP-Brt St Luie, Georag Dlal:

D. Hector Fuentes, Bomard Kinuel.

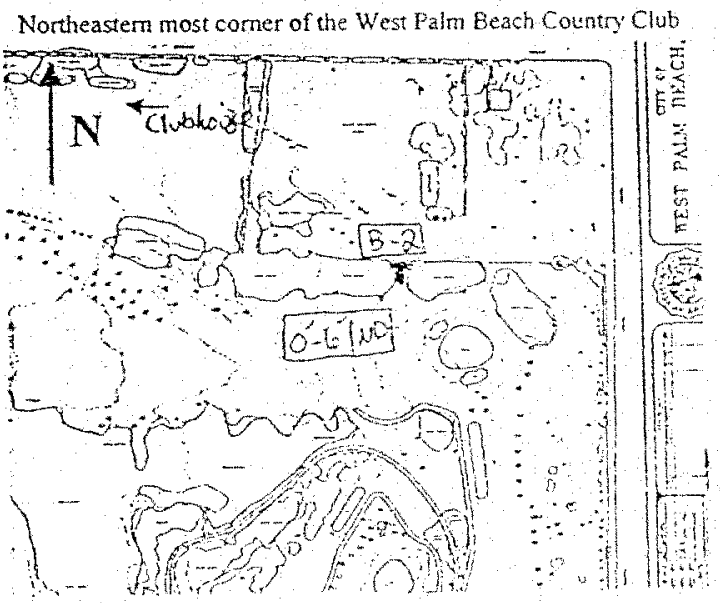




\section{Florida International University Field Sample Data Sheet}

Project: FUWEPA MSMA Dartitiming Study

Approximate Location: SSS

Sampling Date: $1 / 4 / 97$

Sample

Sampling Type and Equipment: Semes Sunficia Smeple (SSS)

Visual Fixes: Same as Suflexá Sorple (SSS)

Depth of Sample: From $\perp^{2} 2$ to ${ }^{\prime \prime} 11 "$

Photos-Roll: $x \quad$ Picture: $x$

Sample Description: Sondy Sorl

Observed Weather Conditions: Plowly, tempeck thridity $\left(70-85^{\circ}\right), 83^{\circ}$

Equipment Wash (before \& after): NES NO Washwater: SSS

Comments: Remoret a prece of concrete.

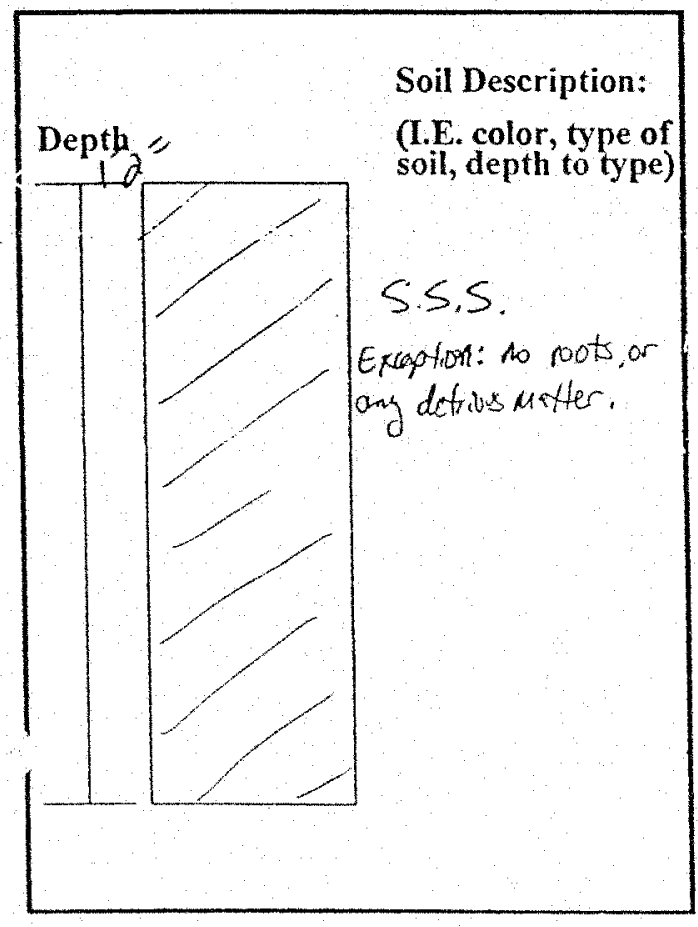

Sample taken by: Terr: Ars

Witness(es) Present: _SSS

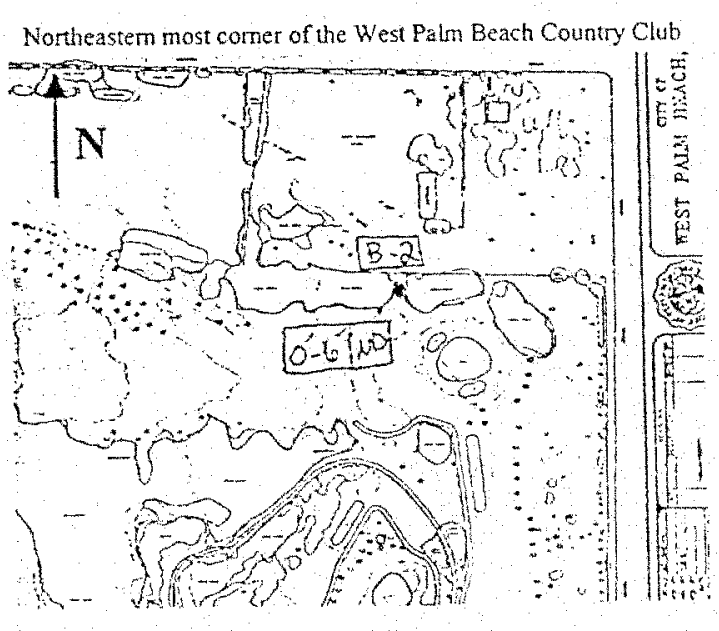




\section{Florida International University \\ Field Sample Data Sheet}

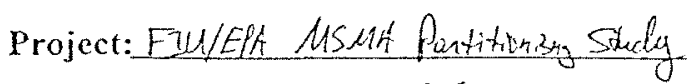

Approximate Location: S.S.S.

Sampling Date: $11 / 4 / 97$

Sample $\#: G D-3$

Sampling Type and Equipment: S.S.S.

Visual Fixes: S.S.S.

Depth of Sample: From 3 $6^{\prime}=$ to $4^{\prime} 6^{\prime \prime}$

Photos - Roll:

Picture: $7>A X 7-13$

Sample Description: S.S.S.

Observed Weather Conditions: S.S.S.

Equipment Wash (before \& after): (TES) No Washwater: S.S.S.

Comments:@2'0" very light cream coln sased.

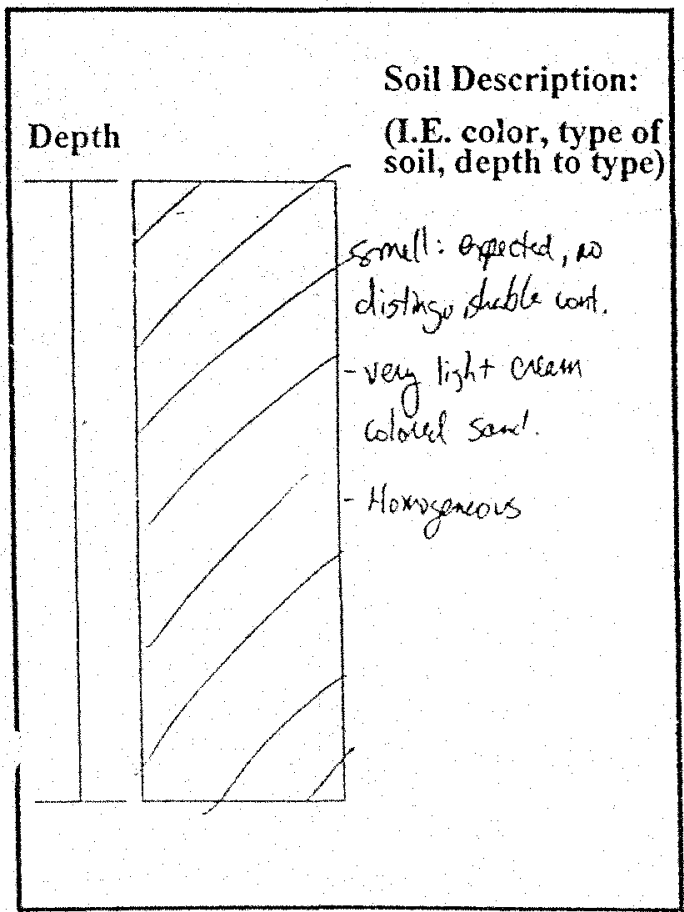

Sample taken by: Terig Davis

Witness(es) Present: S.5. exceptit

Bamad Liminel

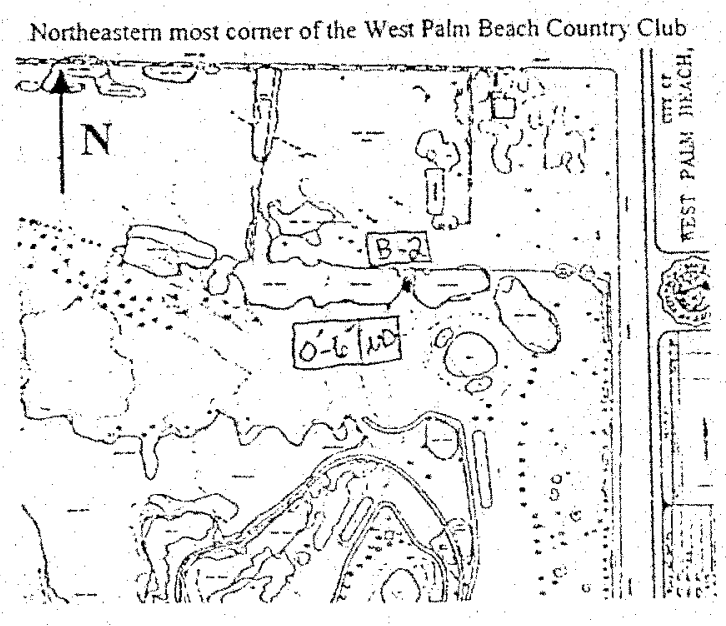




\section{Florida International University \\ Field Sample Data Sheet}

Project: FUJEFA MSAAA Partitionity Study

Approximate Location:S.S.S.

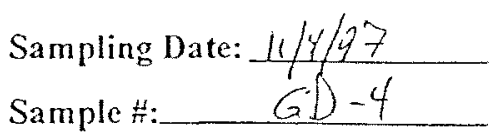

Sampling Type and Equipment: S.5.5.

Visual Fixes: $\quad 5,5,5$.

Depth of Sample: From 56 to 1707

Photos - Roll: Picture: $14-17$

Sample Description: Saady So, 1

Observed Weather Conditions: S.S.5.

Equipment Wash ( before \& after): TES NO Washwater: S.S.S.

Comments: U. musty smell-(organiz smell) $S^{\prime}$. Color is Soluble in Washartes

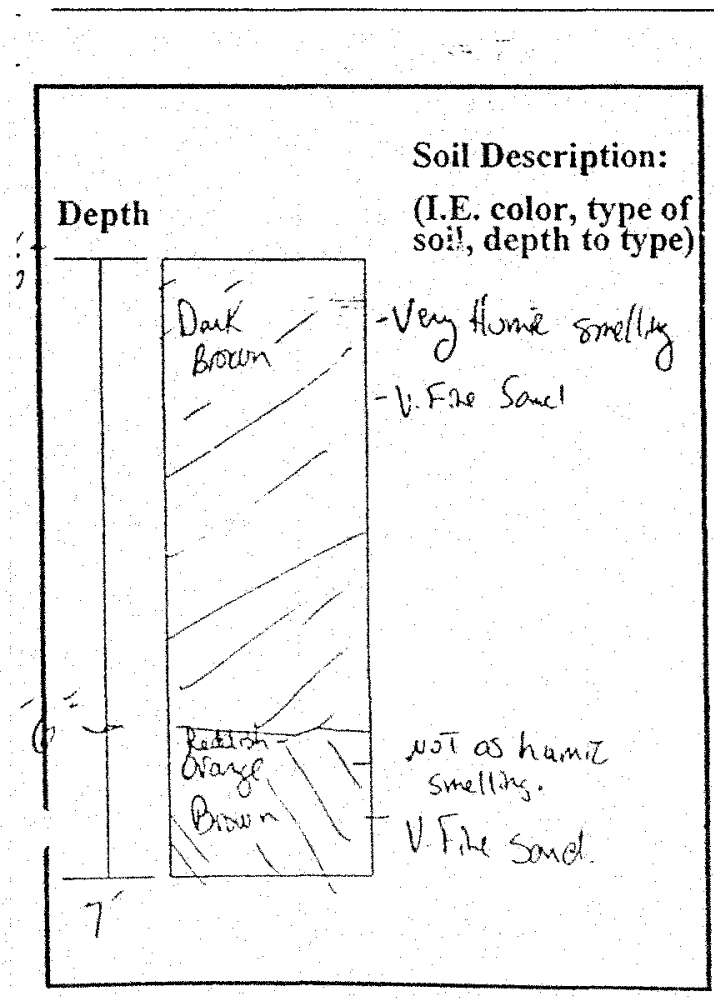

Sample taken by: Terry $D_{\text {nu. }}$

Witness(es) Present: S.S.5.

except Bernard Limkel

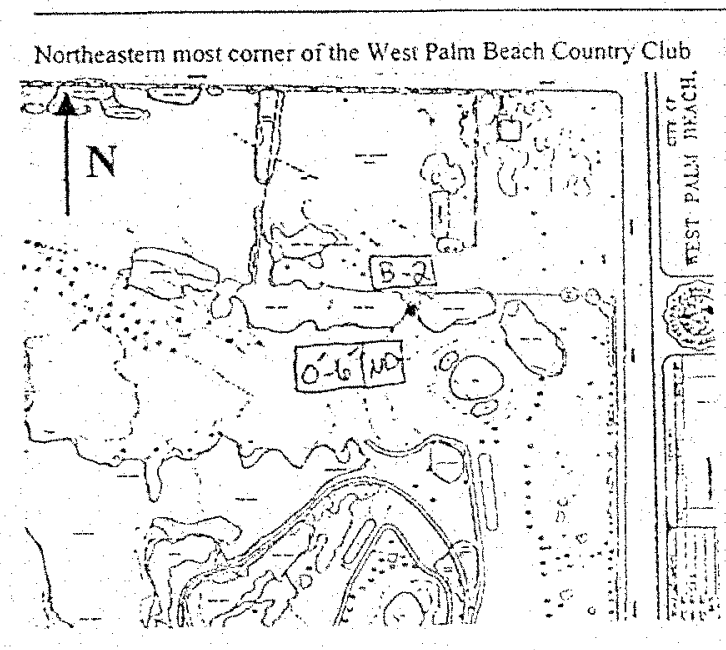


Florida International University

Field Sample Data Sheet

Project: L FIUftefA MSMA Partitioning

Approximate Location: S.S.S.
Sampling Date: $11 / 4 / 92$

Sample \#: GD-S

Sampling Type and Equipment: S.S.S.

Visual Fixes: S.S. S.

Depth of Sample: From $76=$ to $810^{\prime \prime}$

Photos - Roll: 2 - Picture: $10-2 \alpha$

Sample Description: $\quad$ S.S.5.

Observed Weather Conditions: S.S.S.

Equipment Wash (before \& after): YES NO Washwater:

Comments: Can See top of Water kble-masurol (c) $100=18^{\prime} 6^{\prime}$

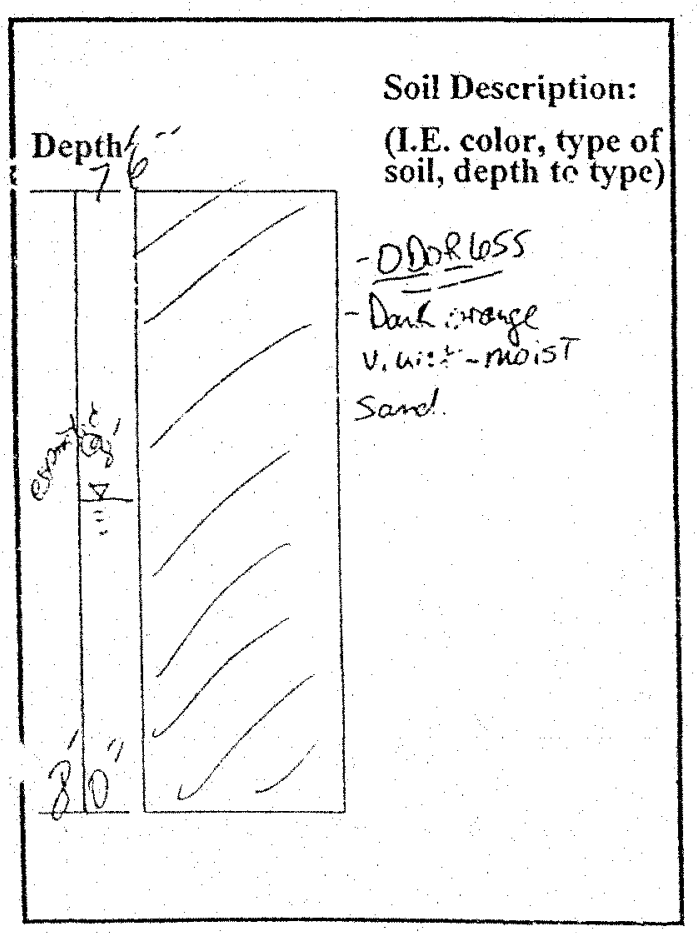

Sample taken by: George Dial

Witnesses) Present: Teary Pavis, Les /e bott.

D. ilector Fuentes

Northeaster most comer of the West Palm Beach Country Club

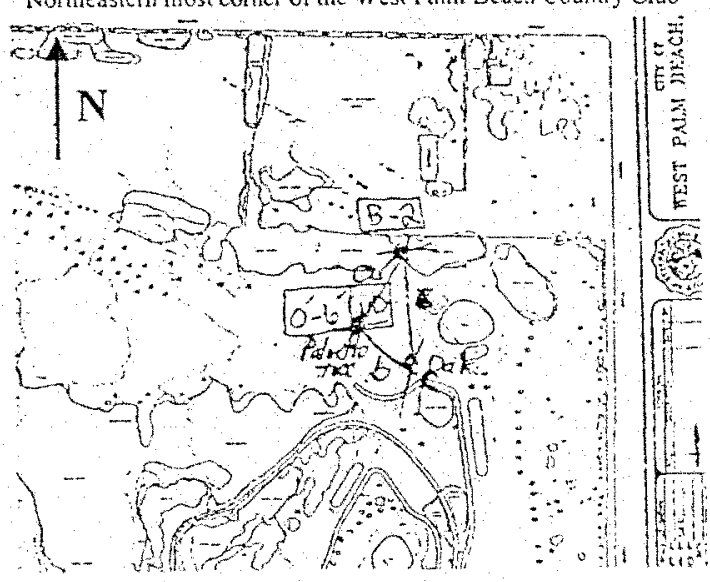

$a-b=63^{\prime} 9^{\prime \prime}$

$5-6$
$\mathrm{c}^{\prime}$

178 
FLORIDA DEPARTMENT OF ENVIRONMENTAL PROTECTION CENTRAL LABORATORY SAMPLE SUBMITTAL FORM

PMAS NO.: 1110

Lab ID:

Requestor: SE-WPB-WSM

Project ID: Golf coucse arsenic study

$R Q-93-J R N-O S-1$

Sample Location:

Field ID/Name:

storet station lumber:
NPDES Number:

Collection Date:

collection Time

Grab:

Composite Begin:

Enc:

\begin{tabular}{|c|c|c|c|c|c|}
\hline \multicolumn{2}{|c|}{ WIE? } & BLANKS & SOLL/SEOIMENT & IISSUE & CKEMICIL WASTE \\
\hline SURFACE (FRESH) & INFLUENT & IRIP GLANK & SOIL & PLANT & \\
\hline - SURFACE(SALT) & EFFLUENT & FIELO BLANK & FRESHUATER SEDIMENT & FISH & _CHEY UASTE \\
\hline GROUND & & EOUIPMENT BLANK & MARINE SEDIMENT & SHELLFISH & \\
\hline
\end{tabular}

Field Parameters Measured By:

Signature:

Sampled BY:

Signature:

Field Report Prepared By:

signature:

Field Parameters:

Depth (Feet)

Chlorine, Total Residuat - $50060(\mathrm{mg} / \mathrm{L}):$

Dissalved Oxygen(Probe) - 00299 (mg/L):

pH - 00400

Salinity - 00680

(Send. Units):

(PPTh)

Secchi Depth - 00078

Specific conductance -00094

Temperature - 00010

(umo/cri)

(C)

(m):

\begin{abstract}
:
:
\end{abstract}

$\begin{array}{lc}\text { Analyses } & \text { Bottle Type } \\ \text { W-ICPMS-F } & \text { P-50OML }\end{array}$

\# Bottles

1

Preservatives

HNO 3 


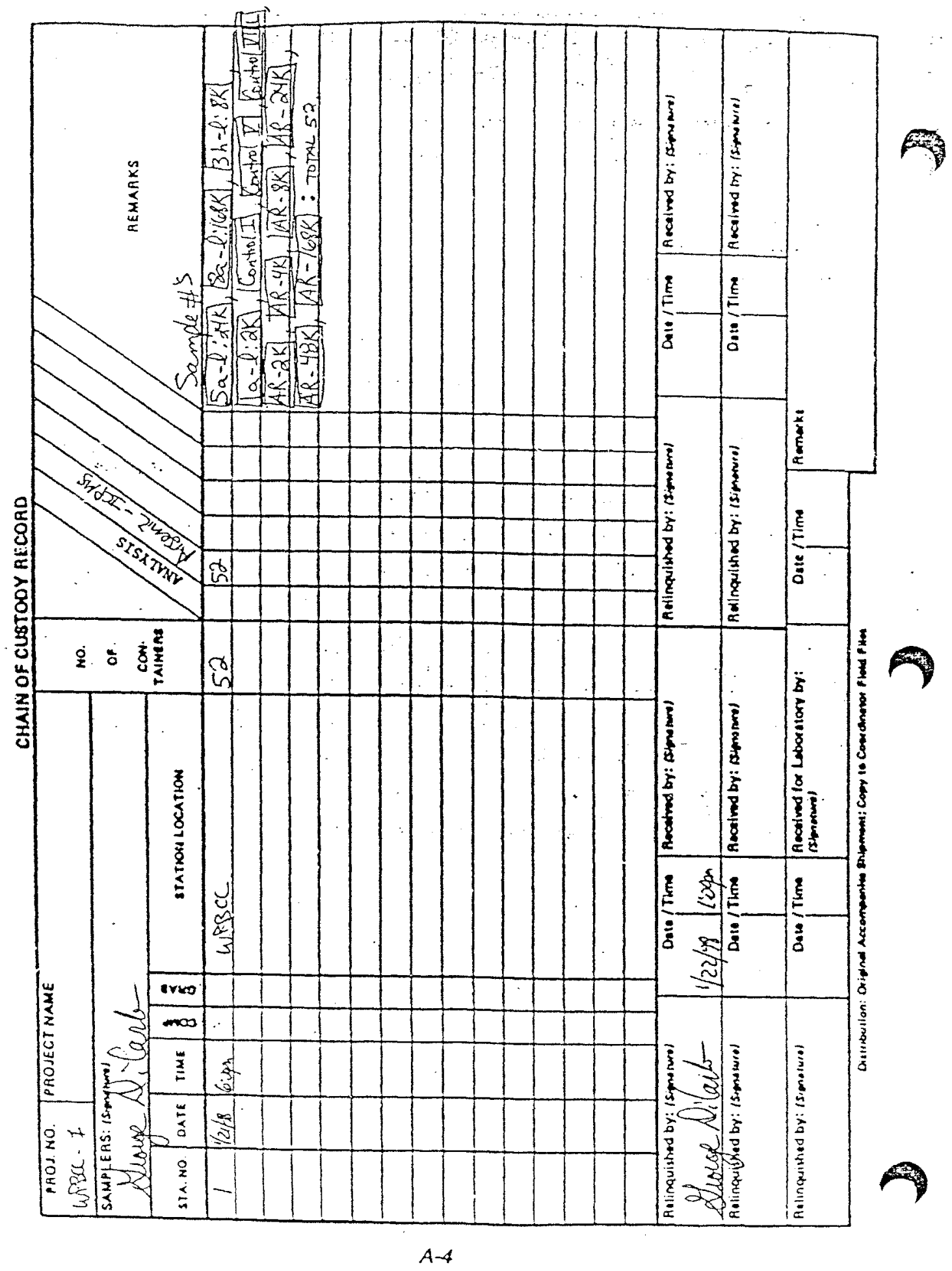


1997 LOCAL CLIMATOLOGICAL DATA

WEST PALM BEACH,

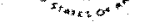

FLORIDA (PBI)

$15820192+635$
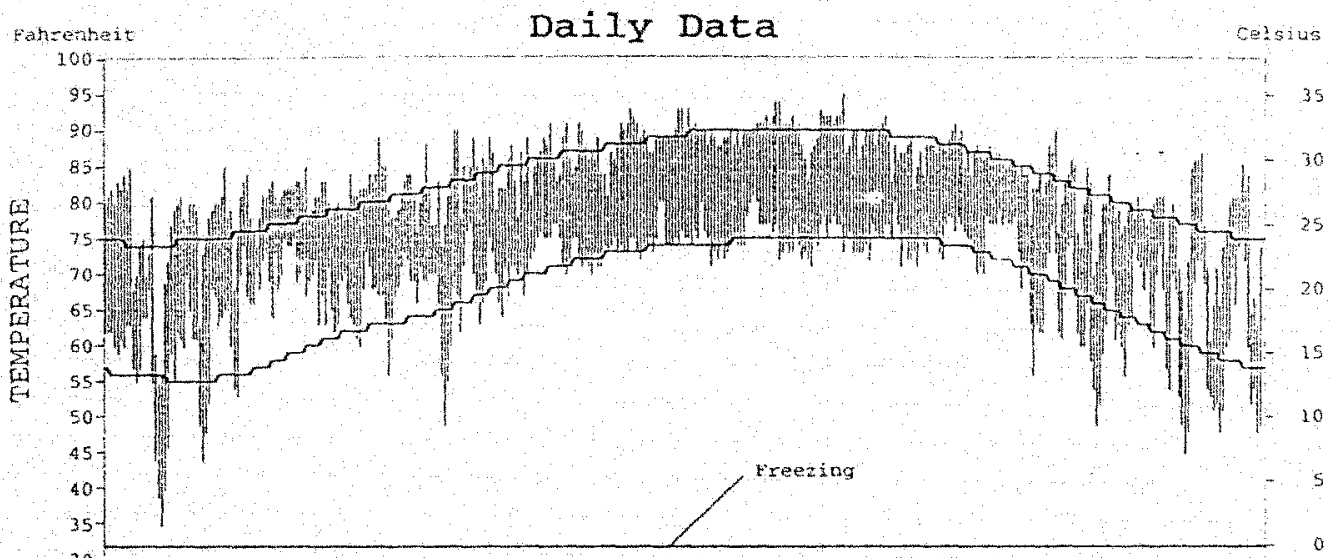

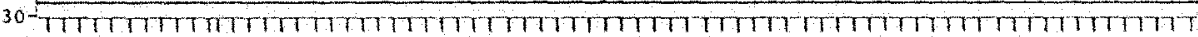

102031102028202031202030102031302030102032102031102030102032102030102031

JAN FEB MAR APR MAY JUN JUL AUG SEP OCT NOV DEC

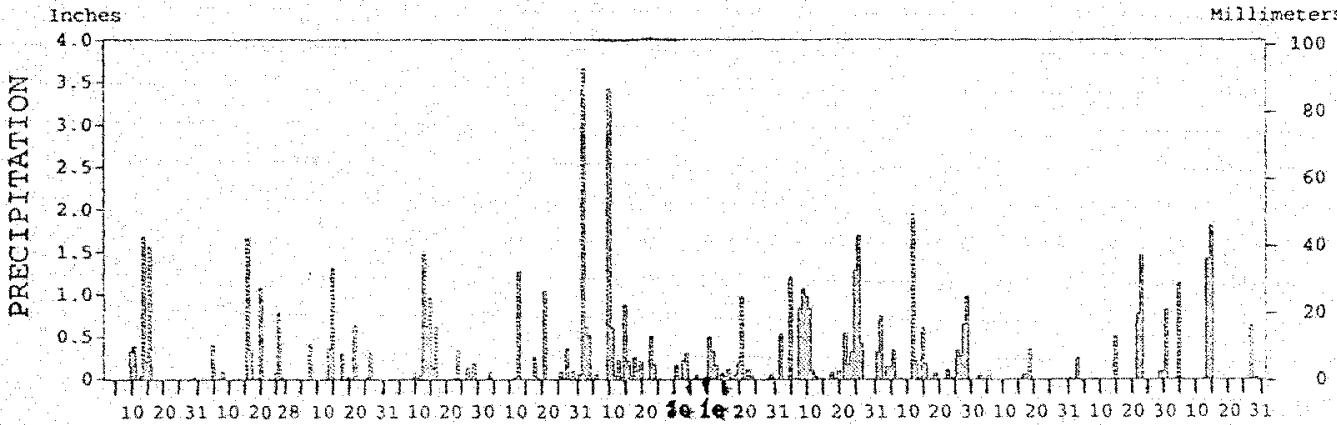

Inches of Narcury

Hectopascals

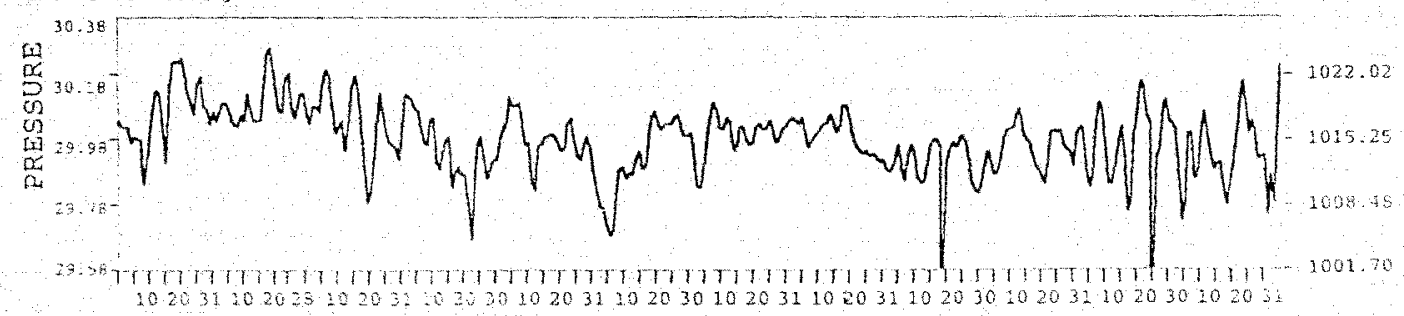

LCBI

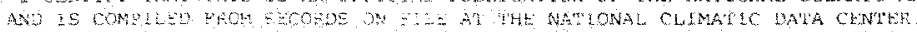

and

$\operatorname{mathin}$

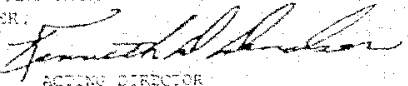

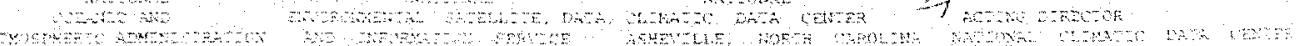


METEOROLOGICAL DATA FOR 1997

WEST PALM BEACH, FL (PBI)

\begin{tabular}{|c|c|c|c|c|c|c|c|c|c|c|c|c|c|c|}
\hline \multicolumn{3}{|c|}{$\begin{array}{l}\text { LATITUDE : } \\
26^{*} 41^{\circ} 05^{*} \mathrm{~N}\end{array}$} & GPA & \multicolumn{3}{|c|}{ ELEVALION (FT): } & 24 & \multicolumn{4}{|c|}{$\begin{array}{l}\text { TIME ZONE: } \\
\text { EASIERN (UTE+ S) }\end{array}$} & \multicolumn{3}{|c|}{ MBAN: 12844} \\
\hline & ELEMLIr!' & Jas & $5 \mathrm{~EB}$ & $M=R$ & $A P F$ & $\operatorname{MAY}$ & Jus: & JUL & AUG & SEP & ocr & LOV & Dete & YEAR \\
\hline 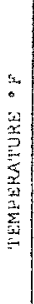 & 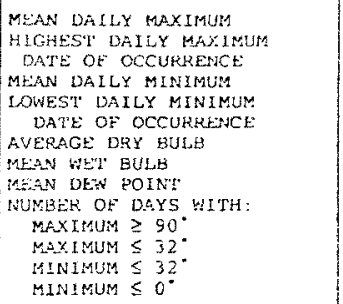 & $\begin{array}{c}75.3 \\
25 \\
9 \\
57.4 \\
35 \\
19 \\
66.4 \\
61.1 \\
55.7\end{array}$ & $\begin{array}{c}79.3 \\
35 \\
8 \\
65.1 \\
4.4 \\
1 \\
72.2 \\
66.9 \\
63.9\end{array}$ & $\begin{array}{l}81.8 \\
89 \\
29 \\
67.4 \\
60 \\
23 \\
74.6 \\
68.5 \\
65.2\end{array}$ & $\begin{array}{c}81.8 \\
90 \\
23 \\
66.6 \\
49 \\
19 \\
74.2 \\
67.1 \\
62.5\end{array}$ & $\begin{array}{c}85.5 \\
91 \\
314 \\
71.8 \\
64 \\
7 \\
78.7\end{array}$ & $\begin{array}{c}88.3 \\
93 \\
16 \\
73.7 \\
70 \\
04 \\
81.0 \\
75.2 \\
72.9\end{array}$ & $\begin{array}{c}90.3 \\
9 . \\
31 \\
75.6 \\
71 \\
11 \\
83.0 \\
77.1 \\
75.0\end{array}$ & $\begin{array}{c}89.9 \\
95 \\
21 \\
74.4 \\
71 \\
11 \\
82.2 \\
76.1 \\
74.1 \\
20 \\
0 \\
0 \\
0\end{array}$ & $\begin{array}{c}87.6 \\
92 \\
03 \\
75.3 \\
71 \\
13 . \\
81.4\end{array}$ & $\begin{array}{c}84.7 \\
90 \\
27 \\
71.1 \\
56 \\
20 \\
77.9 \\
71.0 \\
67.5 \\
1 \\
0 \\
0 \\
0\end{array}$ & $\begin{array}{c}79.2 \\
86 \\
01 \\
64.3 \\
49 \\
9 \\
71.8 \\
\cdots \\
0 \\
0 \\
0 \\
0\end{array}$ & $\begin{array}{c}75.2 \\
87 \\
12 \\
59.3 \\
45 \\
07 \\
67.3 \\
62.8 \\
59.5 \\
0 \\
0 \\
0 \\
0\end{array}$ & $\begin{array}{r}83.2 \\
95 \\
\text { AUG } 21 \\
68.5 \\
35 \\
\text { JAH } 19 \\
75.0\end{array}$ \\
\hline$\sum_{i}^{4}$ & $\begin{array}{l}\text { HEATING DEGREE DAYS } \\
\text { COOLING DEGREE DAYS }\end{array}$ & $\begin{array}{r}79 \\
128\end{array}$ & $\begin{array}{r}13 \\
223\end{array}$ & $\begin{array}{r}0 \\
305\end{array}$ & $\begin{array}{r}2 \\
285\end{array}$ & $\begin{array}{r}0 \\
431\end{array}$ & $\begin{array}{r}0 \\
490\end{array}$ & $\begin{array}{r}0 \\
564\end{array}$ & $\begin{array}{r}0 \\
541\end{array}$ & $\begin{array}{r}0 \\
500\end{array}$ & $\begin{array}{r}0 \\
408\end{array}$ & $\begin{array}{r}8 \\
218\end{array}$ & $\begin{array}{r}75 \\
254\end{array}$ & $\begin{array}{r}177 \\
4247\end{array}$ \\
\hline$\doteq$ & $\begin{array}{l}\text { MAN IPLRCEN" } \\
\text { HOUR OI LST } \\
\text { HOUR O7 LST } \\
\text { HOUR } 13 \text { LST } \\
\text { HOUR } 19 \text { LST }\end{array}$ & $\begin{array}{l}73 \\
81 \\
84 \\
57 \\
71\end{array}$ & $\begin{array}{l}77 \\
85 \\
85 \\
64 \\
76\end{array}$ & $\begin{array}{l}74 \\
81 \\
86 \\
61 \\
72\end{array}$ & $\begin{array}{l}70 \\
78 \\
79 \\
59 \\
68\end{array}$ & $\begin{array}{l}75 \\
82 \\
83 \\
63 \\
76\end{array}$ & $\begin{array}{l}79 \\
89 \\
86 \\
67 \\
77\end{array}$ & $\begin{array}{l}80 \\
88 \\
88 \\
67 \\
79\end{array}$ & $\begin{array}{l}80 \\
88 \\
91 \\
67 \\
78\end{array}$ & $\begin{array}{l}80 \\
88 \\
89 \\
69 \\
79\end{array}$ & $\begin{array}{l}72 \\
80 \\
83 \\
59 \\
72\end{array}$ & $\begin{array}{l}77 \\
84 \\
86 \\
64 \\
76\end{array}$ & $\begin{array}{l}79 \\
88 \\
88 \\
64 \\
79\end{array}$ & $\begin{array}{l}76 \\
84 \\
86 \\
63 \\
75\end{array}$ \\
\hline on & PERCENI POSSIBLE SUNSHINE: & & & & & & & & & & & & & \\
\hline$\frac{9}{3}$ & $\begin{array}{l}\text { NUHBER OF DAYS WITH: } \\
\text { HEAVY FOG (VISEY } \leq 1 / 4 \mathrm{KI}) \\
\text { THUNDERSTORMS }\end{array}$ & $\begin{array}{l}1 \\
1\end{array}$ & $\begin{array}{l}0 \\
1\end{array}$ & $\frac{1}{2}$ & $\begin{array}{l}0 \\
4\end{array}$ & 9 & $\begin{array}{r}0 \\
18\end{array}$ & $\begin{array}{r}0 \\
2.3\end{array}$ & $\begin{array}{r}2 \\
21\end{array}$ & $\begin{array}{r}3 \\
13\end{array}$ & $\begin{array}{l}0 \\
0\end{array}$ & $\begin{array}{l}1 \\
4\end{array}$ & $\begin{array}{l}1 \\
1\end{array}$ & $\begin{array}{r}9 \\
97\end{array}$ \\
\hline 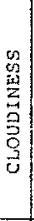 & 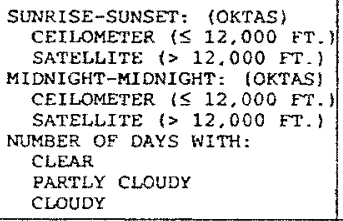 & & & & & & & & & & & & & \\
\hline$\frac{x}{2}$ & $\begin{array}{l}\text { MEAN STATTON PRESS. (IN.) } \\
\text { MEAN SEA-LEVEL PRESS. (IN-) }\end{array}$ & $\begin{array}{l}30.10 \\
30.12 \\
\end{array}$ & $\begin{array}{l}30.13 \\
30.15\end{array}$ & $\begin{array}{l}30.06 \\
30.08\end{array}$ & $\begin{array}{l}29.97 \\
29.99\end{array}$ & $\begin{array}{l}30.01 \\
30.03\end{array}$ & $\begin{array}{l}29.94 \\
29.96\end{array}$ & $\begin{array}{l}30.02 \\
30.04\end{array}$ & $\begin{array}{l}30.01 \\
30.03\end{array}$ & & $\begin{array}{l}29.99 \\
30.01\end{array}$ & & $\begin{array}{l}29.97 \\
29.99\end{array}$ & \\
\hline $\begin{array}{l}0 \\
\frac{3}{Z} \\
3\end{array}$ & $\begin{array}{l}\text { RESULTANT SPEED (MPH) } \\
\text { RES. DIR. (TENS OF DEGS. } \\
\text { MEAN SPEED (MPH) } \\
\text { EREVATL, DIR. (TENS OF DEGS. } \\
\text { MAXIMUM 2-MINUTE WIND: } \\
\text { SPEED (MPH) } \\
\text { DIR. (TENS OE DEGS.) } \\
\text { DATE OF OCCURRENCE } \\
\text { MAXIMUM S-SECOND WIND: } \\
\text { SPEED (MPH) } \\
\text { DIR. (TENS OF DEGS.) } \\
\text { DATE OF OCCURRENCE }\end{array}$ & $\begin{array}{l}32 \\
32 \\
25+ \\
39 \\
31 \\
09\end{array}$ & $\begin{array}{l}25 \\
05 \\
17+ \\
31 \\
20 \\
15\end{array}$ & $\begin{array}{l}26 \\
11 \\
25+ \\
31 \\
29 \\
21+\end{array}$ & $\begin{array}{c}1.5 \\
10 \\
10.9\end{array}$ & $\begin{array}{l}28 \\
33 \\
27 \\
32 \\
24 \\
13\end{array}$ & $\begin{array}{l}30 \\
21 \\
12 \\
34 \\
19 \\
12+\end{array}$ & $\begin{array}{l}38 \\
33 \\
11 \\
\\
45 \\
33 \\
11\end{array}$ & $\begin{array}{l}33 \\
10 \\
24 \\
39 \\
09 \\
24\end{array}$ & $\begin{array}{l}25 \\
20 \\
27+ \\
31 \\
20 \\
27\end{array}$ & $\begin{array}{l}24 \\
07 \\
12+ \\
29 \\
07 \\
104\end{array}$ & $\begin{array}{l}32 \\
30 \\
02 \\
39 \\
30 \\
02\end{array}$ & $\begin{array}{l}2.7 \\
2.5 \\
8.5 \\
33 \\
30 \\
26 \\
29 \\
36 \\
27 \\
29\end{array}$ & $\begin{array}{r}38 \\
33 \\
\text { JUL } 11 \\
\\
45 \\
33 \\
\text { JUL } 11\end{array}$ \\
\hline 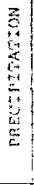 & 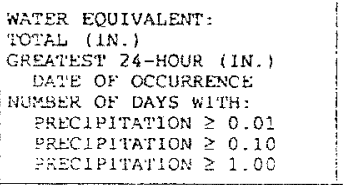 & $\begin{array}{r}4.24 \\
1.85 \\
-3-24\end{array}$ & $\begin{array}{c}4.45 \\
1.82 \\
-5-6\end{array}$ & $\begin{array}{r}3.39 \\
1.31 \\
-4\end{array}$ & $\begin{array}{r}4.66 ! \\
1.48 \\
-2-3 \\
-2-3\end{array}$ & $\begin{array}{l}3.34 \\
1.27 \\
=-2\end{array}$ & $\begin{array}{c}11.75 \\
3.67 \\
9\end{array}$ & $\begin{array}{r}3.29 \\
0.98 \\
20\end{array}$ & $\mid \begin{array}{c}10.60 \\
1.70 \\
25\end{array}$ & $\begin{array}{r}6.85 \\
1.95 \\
\therefore\end{array}$ & $\begin{array}{c}0.56 \\
0.36 \\
-9\end{array}$ & $\begin{array}{r}3.98 \\
1.46 \\
22 \\
\\
7 \\
5 \\
1\end{array}$ & $\left|\begin{array}{c}5.02 \\
3.15 \\
-3-24 \\
6 \\
4 \\
3\end{array}\right|$ & $\begin{array}{r}62.13 \\
3.67 \\
\text { roN } 0: \\
143 \\
89 \\
19\end{array}$ \\
\hline$\frac{4}{3}$ & 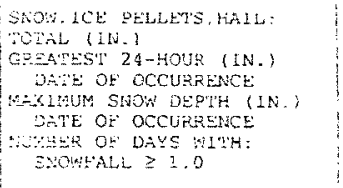 & & & & $\begin{array}{l}0.01 \\
0.01 \\
0\end{array}$ & $\begin{array}{l}0.0 \\
0.0\end{array}$ & $\begin{array}{c}0.0 \\
0.0 \\
0\end{array}$ & $\begin{array}{l}0.0 \\
0.0\end{array}$ & $\begin{array}{l}0.0 \\
0.0\end{array}$ & $\begin{array}{ll}0.0 \\
0.0 \\
0\end{array}$ & $\begin{array}{l}0.0 \\
0.0\end{array}$ & $\begin{array}{l}0.0 \\
0.0\end{array}$ & $\begin{array}{c}0.0 \\
0.0 \\
0 \\
0\end{array}$ & \\
\hline
\end{tabular}

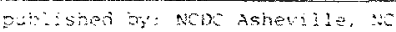




\section{NORMALS, MEANS, AND EXTREMES \\ WEST PALM BEACH, FL (PBI)}

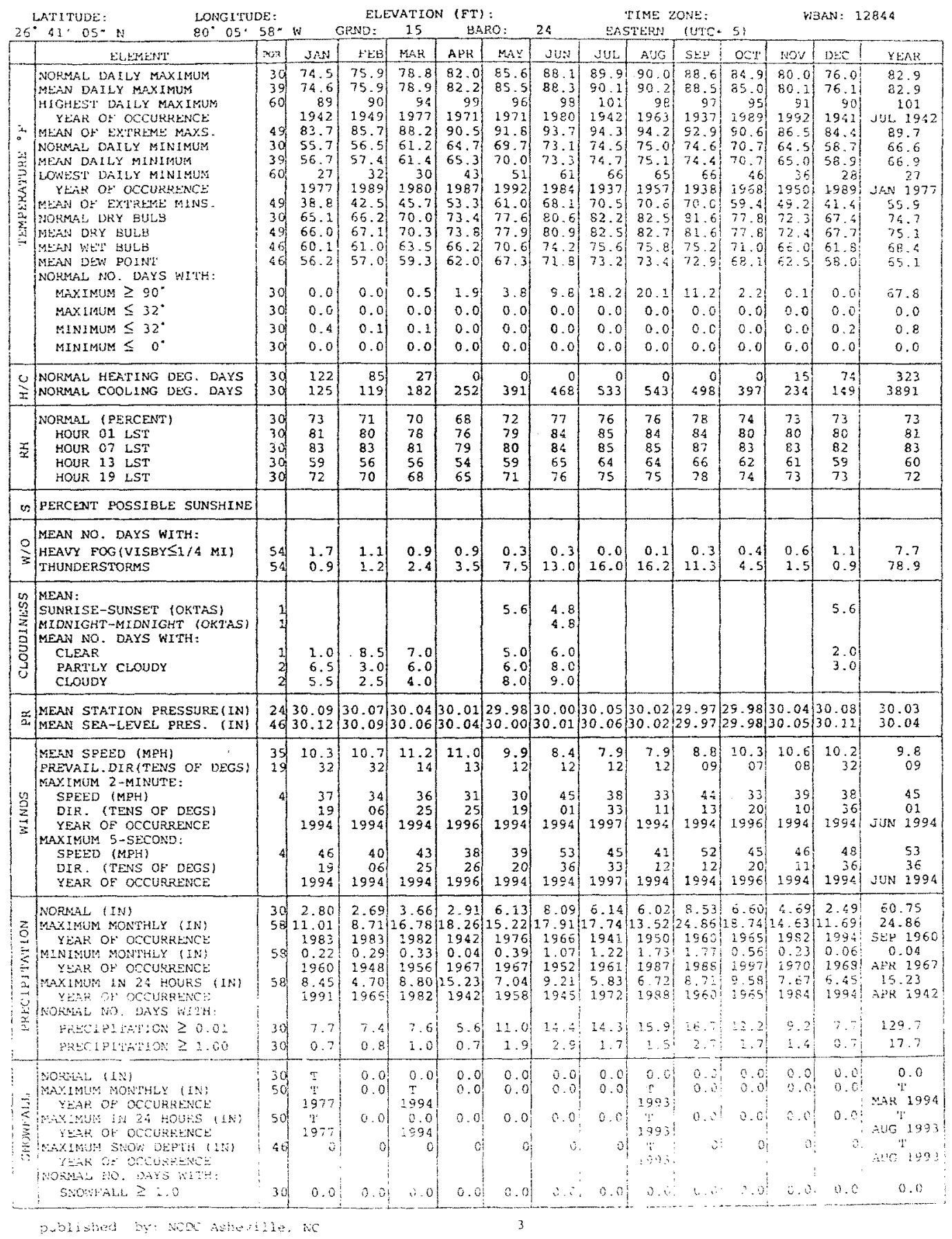




\begin{tabular}{|c|c|c|c|c|c|c|c|c|c|c|c|c|c|}
\hline \multicolumn{4}{|c|}{ PRECIPITATION (inches) } & \multirow{2}{*}{$\begin{array}{l}1997 \\
\text { APR }\end{array}$} & WEST & \multicolumn{2}{|c|}{ PALM BEACH, } & \multicolumn{2}{|c|}{$\mathrm{L}(\mathrm{PBI})$} & \multirow[b]{2}{*}{ OCT } & \multirow[b]{2}{*}{ Nov } & \multirow[b]{2}{*}{ DEC } & \multirow[b]{2}{*}{ ANNUAL, } \\
\hline YEAR & JAN & FEB & MAR & & MAY & JUN & JUL & RUG & SEP & & & & \\
\hline 1968 & 0.56 & 4.44 & 1.48 & 0.72 & 13.82 & 16.78 & 4.65 & 8.14 & 14.01 & 10.24 & $2 . \$ 1$ & 0.06 & 77.42 \\
\hline 1969 & 3.59 & 1.67 & 5.53 & 0.73 & B. 32 & 22.25 & 7.43 & 3.75 & 14.56 & 23.47 & 3.29 & 1.16 & 79.75 \\
\hline 2970 & $4.5 \%$ & 2.98 & 11.95 & 1.00 & 5.83 & 8.23 & 3.17 & 5.47 & 7.61 & 4.12 & 0.23 & 0.11 & 55.28 \\
\hline 2971 & 0.82 & 1.08 & 0.55 & 1.27 & 5.04 & 9.03 & 5.13 & 4.38 & 6.24 & 5.13 & 00.77 & 1.87 & 51.31 \\
\hline 1972 & 2.47 & 2.55 & 3.99 & 12.62 & 11.19 & 12.34 & 13.25 & 2.75 & 3.72 & 1.20 & 6.92 & 2.08 & 75.15 \\
\hline 1973 & 2.62 & 2.71 & 2.28 & 1.45 & 4.13 & 7.53 & 7.74 & 7.51 & 7.59 & 6.57 & 2.05 & 2.15 & 54.74 \\
\hline 1974 & 8.30 & 0.42 & 2.44 & 1.18 & 2.93 & 4.87 & ii. 00 & 5.85 & & & & & 58.46 \\
\hline 1975 & 0.47 & 0.68 & 0.85 & 0.57 & 6.23 & 3.18 & 5.67 & 2.49 & 11.58 & 5.60 & 1.81 & 2.27 & 44.40 \\
\hline 1976 & 1.09 & 4.59 & 1.84 & 1.26 & 15.22 & 4.52 & 2.57 & 7.29 & 3.34 & 3.75 & 3.29 & 3.06 & 55.32 \\
\hline 1972 & 3.49 & 1,11 & 0.53 & 1.65 & 14.80 & 4.03 & 2.19 & 8.03 & 13.21 & $2.0 !$ & 5.84 & 7.37 & 64.26 \\
\hline 1978 & 3.40 & 2.49 & 2.73 & 0.88 & 4. 55 & 30.36 & 5.91 & 2.27 & 6.36 & 6.92 & 10.98 & 5.30 & 62.21 \\
\hline 1979 & 3.06 & 0.80 & 1.06 & B. 71 & 5.09 & 6.34 & 1.39 & 3.08 & 19.63 & 4.78 & $4.0 B$ & & 61.18 \\
\hline 1980 & $\therefore .11$ & 3.85 & 2.53 & 3.90 & 8.06 & 4.26 & 7.61 & 5.02 & 6.76 & $\therefore .02$ & 5.28 & $1 \div 27$ & 56.67 \\
\hline 1981 & 0.43 & 4.22 & 2.49 & 0.43 & 5.12 & 4.58 & 3.72 & 10.33 & 9.30 & 2.10 & 4.52 & 2.50 & 49.74 \\
\hline 1983 & 1.29 & 2.31 & 16.72 & 7.67 & 6.90 & 10.37 & 2.57 & 5.72 & 5.03 & 4.83 & 14.63 & 1.57 & 80.62 \\
\hline 1983 & 11.01 & 8.71 & 3.42 & 3.27 & 5.30 & 5.39 & 4.71 & 8.22 & 9.62 & 7.20 & $4.2 i$ & 7.03 & 62.71 \\
\hline 1984 & 1.36 & 4.49 & 5.06 & 5,99 & 8.44 & 5.84 & 7.34 & 6.39 & & & 14.39 & 0.13 & 69.79 \\
\hline 1985 & 0.84 & 0.53 & 3.49 & 3.35 & 8.63 & 4.84 & 10.77 & 5.38 & 9.38 & 2.89 & 0.54 & 1.35 & 47.99 \\
\hline 1986 & 6.36 & 1.58 & 5.48 & 0.33 & 1.59 & 9.82 & 10.20 & 4.8 & 4.08 & 8.2 & 580 & 10.10 & 59.31 \\
\hline 1987 & 1.17 & 1.20 & 7.75 & 2.61 & 5.63 & 6.60 & 4.42 & 1.73 & 11.90 & 6.72 & 9.43 & 1.47 & 58.69 \\
\hline 1988 & 3.38 & 3.04 & 5.51 & 3.65 & 6.94 & 10.95 & 9.61 & 11.38 & 1.77 & 3.54 & $3 . \overline{5}$ & $1.8 \mathrm{~B}$ & 64.91 \\
\hline $\begin{array}{r}1980^{\circ} \\
\end{array}$ & 0.97 & 1.00 & 2.58 & 6.04 & 0.73 & 4.96 & 3.52 & 5.83 & 4.05 & 5.84 & 1.15 & $\begin{array}{r}1.08 \\
1.94\end{array}$ & 38.66 \\
\hline 2990 & 1.19 & 1.39 & 1.91 & 2.82 & 6.74 & 6.67 & 10.27 & 6.60 & 11.70 & 3.45 & 2.23 & 1. & 55.81 \\
\hline 1991 & 10.43 & 4.36 & 3.36 & 9.54 & 8.94 & 7.45 & 7.16 & 7.34 & 6.44 & 7.58 & 2.32 & 4.44 & 79.36 \\
\hline 1992 & 1.69 & 3.26 & 2.61 & 2.64 & 1.59 & 16.08 & 2.90 & 6.12 & 6.99 & 2.82 & 12.56 & 1.85 & 61.11 \\
\hline 1993 & 8.05 & 2.06 & 11.06 & 2.53 & 2.22 & 2.89 & 5.41 & 4.78 & 5.35 & 11.99 & 5.78 & 0.82 & 62.94 \\
\hline 1994 & 5.85 & 3.22 & 2.62 & 7. & 4.50 & 10.89 & 5.2 & 10.33 & 11.41 & 4.42 & 8.17 & 11.69 & 85.89 \\
\hline 1995 & 3.85 & 1.12 & 2.37 & 3.91 & 0.85 & 2.79 & 5.85 & 20.12 & 5.69 & 11.31 & 1.49 & 1.60 & 66.76 \\
\hline 1996 & 1.54 & 0.67 & 5.06 & 0.78 & 6.52 & 7.56 & 2.77 & 4.24 & 7.53 & 6.54 & 2.06 & 1.55 & 46.82 \\
\hline 1997 & 4.24 & 4.45 & 3.39 & 4.66 & 3.34 & 11.75 & 3.29 & 10.60 & 6.85 & 0.56 & 3.98 & 5.02 & 62.13 \\
\hline $\begin{array}{l}\text { POR }= \\
59 \text { YRS }\end{array}$ & 2.96 & 2.52 & 3.53 & 3.62 & 5.45 & 7.83 & 6.23 & 6.84 & 8.92 & 7.03 & 3.88 & 2.73 & 61.54 \\
\hline
\end{tabular}

\begin{tabular}{|c|c|c|c|c|c|c|c|c|c|c|c|c|c|}
\hline \multicolumn{14}{|c|}{ AVERAGE TEMPERATURE $\left({ }^{\circ} \mathrm{F}\right) 1997$ WEST PALM BEACH, FL (PBI) WBAN $=12844$} \\
\hline YEAR & JAN & FEB & MAR & APR & MAX & SUN & JUL & AdS & SEP & OCI & NOV & $\mathrm{CEC}$ & ANNUAL, \\
\hline 1968 & 64.8 & 60.1 & 64.9 & 74.7 & 76.9 & 78.4 & 80.4 & 81.9 & 80.4 & 75.3 & 67.7 & 63.7 & 72.4 \\
\hline $\begin{array}{l}1969 \\
1970\end{array}$ & 65.1 & 61.7 & 64.7 & 74.8 & 77.0 & 80.4 & 82.8 & 81.4 & 80.5 & 78.8 & 67.7 & 62.7 & 73.1 \\
\hline 1970 & 60.4 & 62.2 & 69.1 & 75.7 & 77.8 & 80.0 & 82.5 & 83.5 & 81.2 & 78.4 & 66.5 & 68.3 & 73.8 \\
\hline 1971 & 65.0 & $67-4$ & 65.9 & 71.8 & 78.8 & 80.9 & 82.3 & 83.1 & 81.1 & 79.0 & 73.1 & 73.1 & 75.1 \\
\hline 1972 & 71.8 & 57.0 & 70.9 & 74.1 & 78.8 & 82.8 & 82.5 & 83.2 & 82.6 & 80.4 & 74.3 & 72.0 & 76.6 \\
\hline 1973 & 68.7 & 64.0 & 73.6 & 74.5 & 79.2 & 81.7 & 82.1 & 81.7 & 82.0 & 77.5 & 75.0 & 66.4 & 75.5 \\
\hline 1974 & 73.2 & 66.7 & 73.6 & 74.3 & 78.6 & 80.0 & 81.8 & 82.7 & 82.3 & 73.0 & 32.0 & 66.8 & 75.8 \\
\hline 1975 & 71.2 & 72.1 & 71.8 & 73.9 & 77.8 & 79.5 & 79.8 & 81.4 & 80.5 & 77.6 & 71.3 & 66.9 & 75.3 \\
\hline 1976 & 62.2 & 66.3 & 72.6 & 72.7 & 77.4 & 78.1 & 81.1 & 81.2 & 80.0 & 75.6 & 70.6 & 66.0 & 73.7 \\
\hline 1977 & 58.5 & 63.6 & 73.7 & 75.0 & 76.9 & 81.2 & 81.9 & 82.5 & 81.0 & 75.3 & 72.6 & 67.3 & 74.1 \\
\hline 1978 & 62.1 & 60.4 & 68.4 & 73.2 & 78.9 & 81.6 & 82.1. & 82.2 & 80.7 & 77.0 & 73.7 & 71.3 & 74.3 \\
\hline 1979 & 62.7 & 63.7 & 68.0 & 74.4 & 76.0 & 80.2 & 82.7 & 82.5 & 81.3 & 77.5 & 73.2 & 67.1 & \\
\hline 1980 & 64.1 & 60.9 & 70.2 & 71.8 & 77.5 & 82.5 & 83.5 & 82.5 & 81.3 & 78.6 & 72.4 & 65.5 & 74.2 \\
\hline 1981 & 58.7 & 67.6 & 67.9 & 75.7 & 78.5 & 83.4 & 84.1 & 82.8 & 81.1 & 78.1 & 67.9 & 65.2 & 74.3 \\
\hline 1982 & 65.7 & 73.6 & 73.0 & 75.9 & 76.8 & 80.6 & 83.2 & 83.0 & $81 . \tilde{8}$ & 78.5 & 75.6 & 70.8 & 76.5 \\
\hline 1983 & 64.8 & 66.1 & 56.5 & 72.2 & 77.6 & 80.6 & 24.0 & 84.3 & 81.6 & 76.9 & 70.0 & 68.3 & 74.4 \\
\hline 1984 & 64.6 & 66.5 & 68.7 & 71.2 & 77.4 & 78.7 & 80.9 & 8.3 & 79.6 & 77.4 & 71.4 & 71.1 & 94.1 \\
\hline 1985 & 60.7 & 67.5 & 71.3 & 73.1 & 77.3 & 82.3 & 81.0 & 82.9 & 80.3 & 80.4 & 75.7 & 65.0 & 74.8 \\
\hline 1986 & $6 \div 2$ & 69.2 & 68.1 & 71.6 & 77.6 & 80.8 & 82.1 & 82.0 & 82.5 & 79.4 & 78.4 & 72.0 & 75.7 \\
\hline 1987 & 64.5 & 68.7 & 70.3 & 69.0 & 77.8 & 82.3 & 83.2 & $8 \div 9$ & 32.7 & 76.5 & 33.9 & 68.4 & 75.2 \\
\hline 1988 & 66.4 & 65.7 & 69.1 & 74.6 & 26.7 & 81.0 & 82.2 & 82.5 & 83.1 & 77.0 & 75.0 & 68.4 & 75.2 \\
\hline 1999 & 71.3 & 68.5 & 72.2 & 74.8 & 79.5 & $8: .9$ & 83.0 & 83.6 & 83.1 & 72.6 & 243 & 62.5 & 76.0 \\
\hline 1990 & 72.3 & 73.8 & 73.2 & 73.9 & 79.7 & 82.2 & 83.3 & 83.7 & 82.7 & $80 . i$ & $\because 3.5$ & 71.3 & 27.5 \\
\hline 1991 & 72.0 & 68.2 & 72.6 & 77.0 & 80.2 & 81.9 & $83 . z$ & 83.6 & 82.0 & 78.8 & $\because 3$ & 70.2 & 76.7 \\
\hline 1992 & 85.3 & 68.8 & 69.7 & 72.5 & 75.9 & 60.6 & $53: 2$ & $52 . ?$ & 81.7 & $37 . \hat{3}$ & 3.5 & 69.5 & 75.2 \\
\hline 1993 & 71.5 & 65.3 & 69.0 & 71.1 & 77.7 & 82.6 & 82.9 & 33.0 & 82.3 & 79.0 & 72.4 & 65.6 & 75.4 \\
\hline 1994 & 68.0 & 71.7 & 21.0 & 77.0 & 78.7 & 42.7 & 81.9 & 81.4 & 80.6 & 77.5 & 74 & 59.4 & 76.2 \\
\hline 1995 & 64.2 & 65.0 & 72.0 & 75.7 & 80.7 & 80.8 & 82.2 & 82.7 & 82.4 & 80.5 & 70.7 & 65.7 & 75.2 \\
\hline 1996 & 65.7 & 64.3 & 67.8 & 73.3 & 79.3 & 80.7 & 83.5 & 820 & $\varepsilon 2.1$ & 72.8 & 22.9 & 68.5 & 74.8 \\
\hline 1997 & 66.4 & 72.2 & 74.5 & 74.2 & 13.7 & $5: 0$ & 53.0 & $6 \geq 2$ & 81.4 & 77.9 & $\because 1.8$ & $6: 3$ & 75.9 \\
\hline $504=$ yos & 66.0 & $6: 0$ & 70.3 & 73.9 & 77.9 & 80.5 & $\therefore$ & $8:-$ & $81 \div$ & $m s$ & $\because z$ & 52.9 & 90.0 \\
\hline
\end{tabular}


HEATENG DEGREE DAYS (baSE 65\%) 1997 WEST PALM BEACH. FL (PBI)

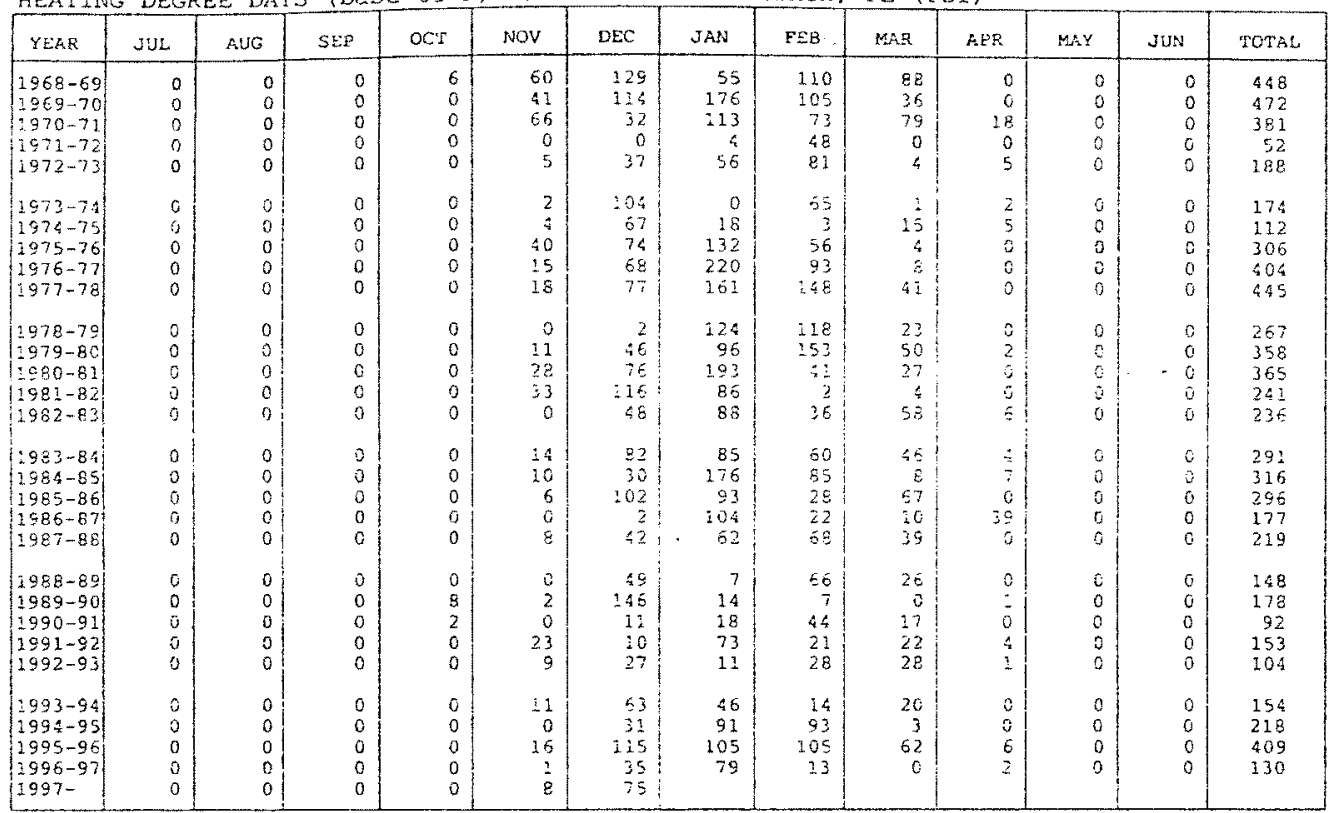

COOLING DEGREE DAYS (base 65"F) 1997 WEST PALM BEACH. FL (PBI)

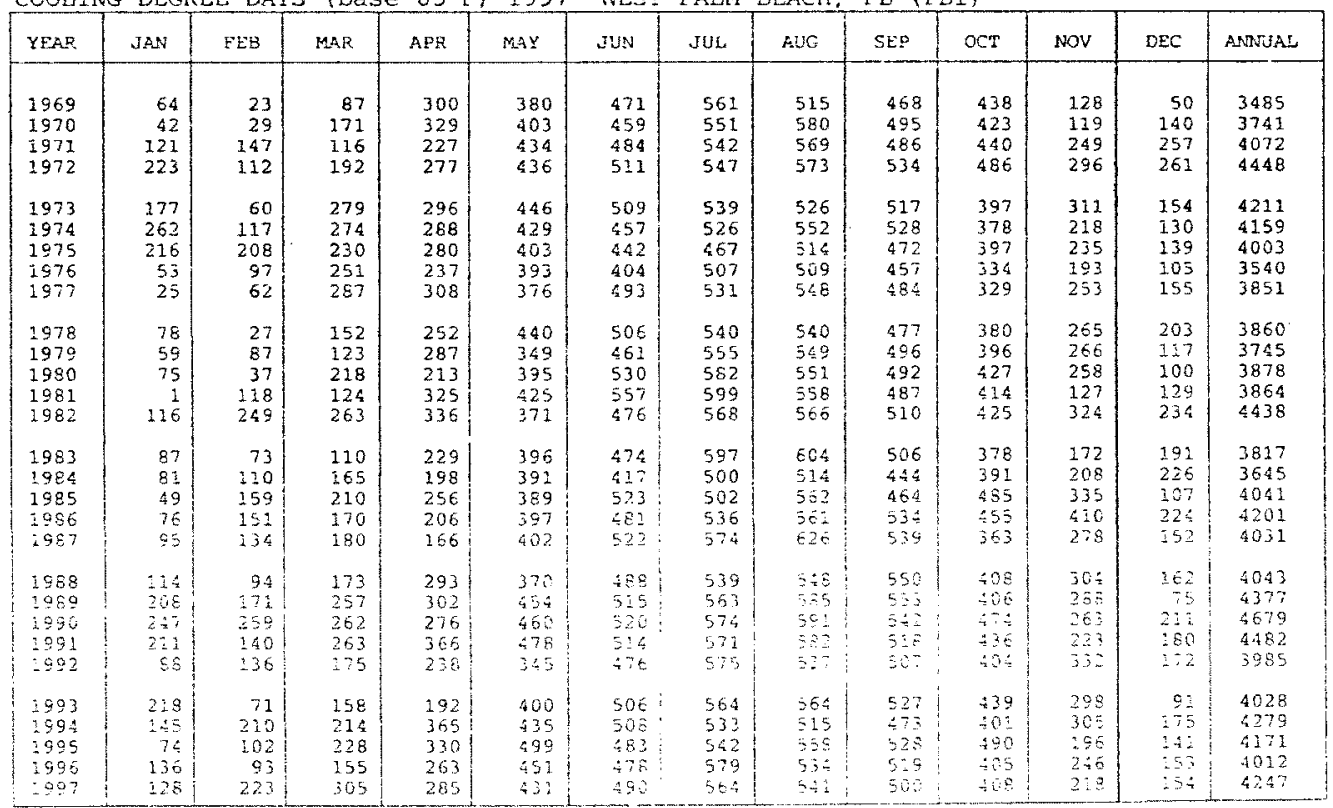


SNOWFALL (inches) 1997 WEST PALM BEACH, EL (PBT)

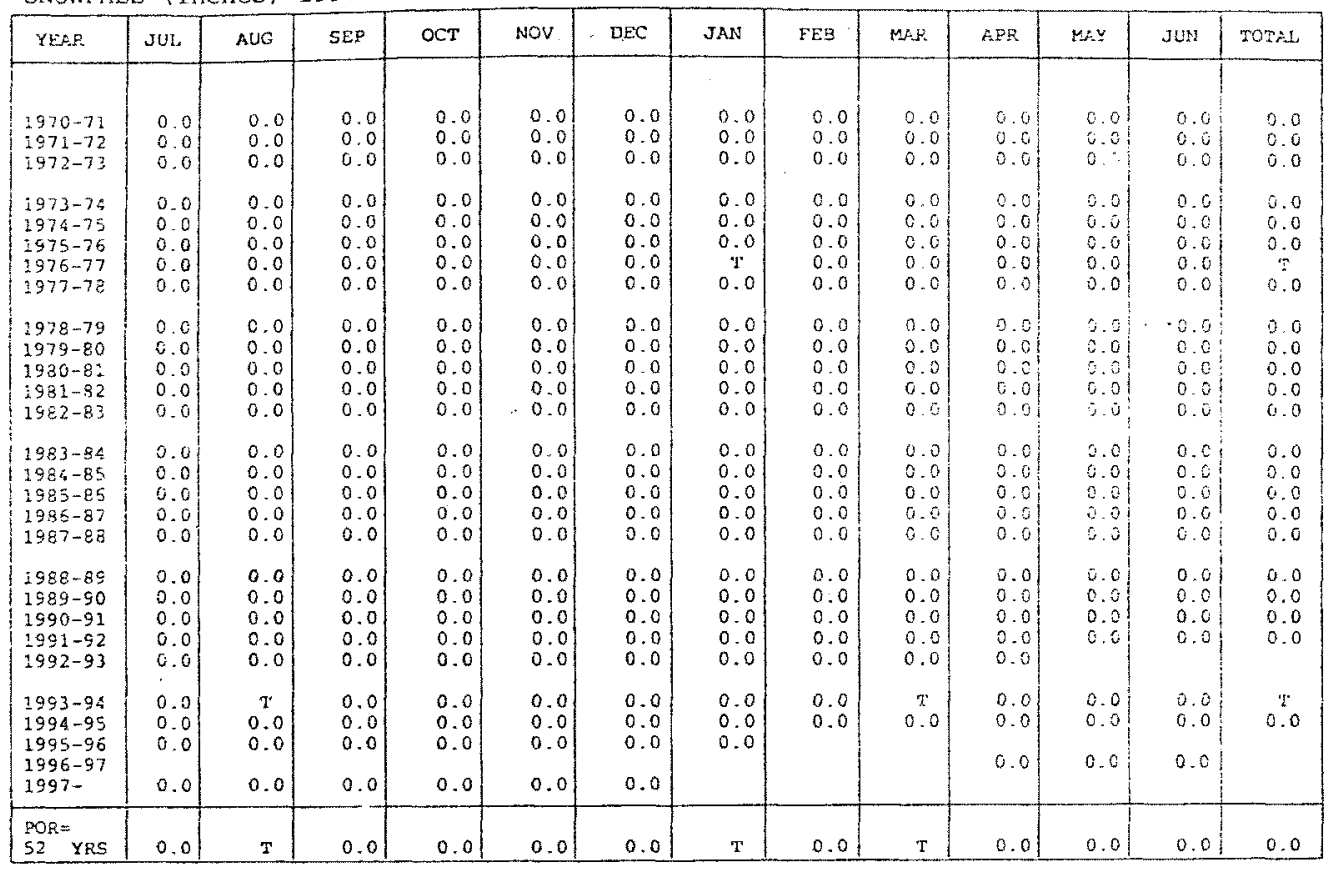

REFERENCE NOTES:

\begin{tabular}{|c|c|}
\hline 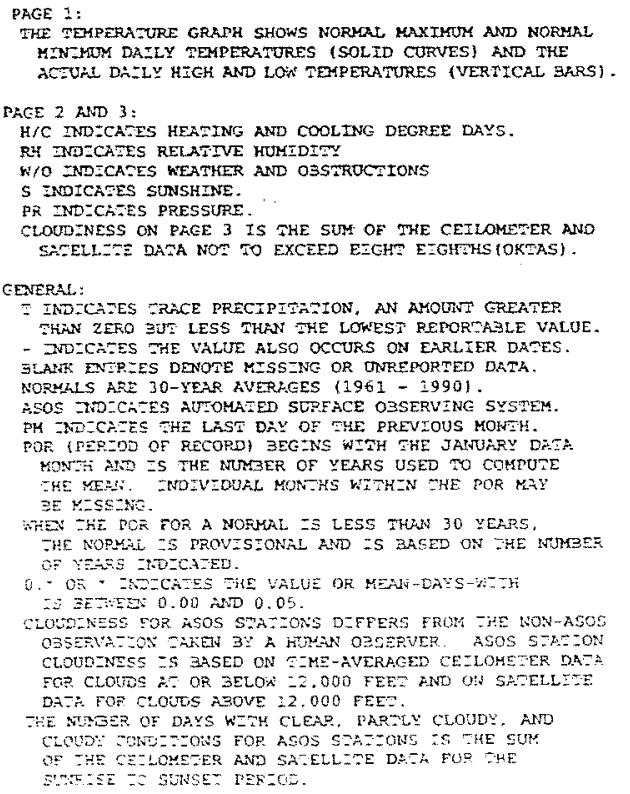 & 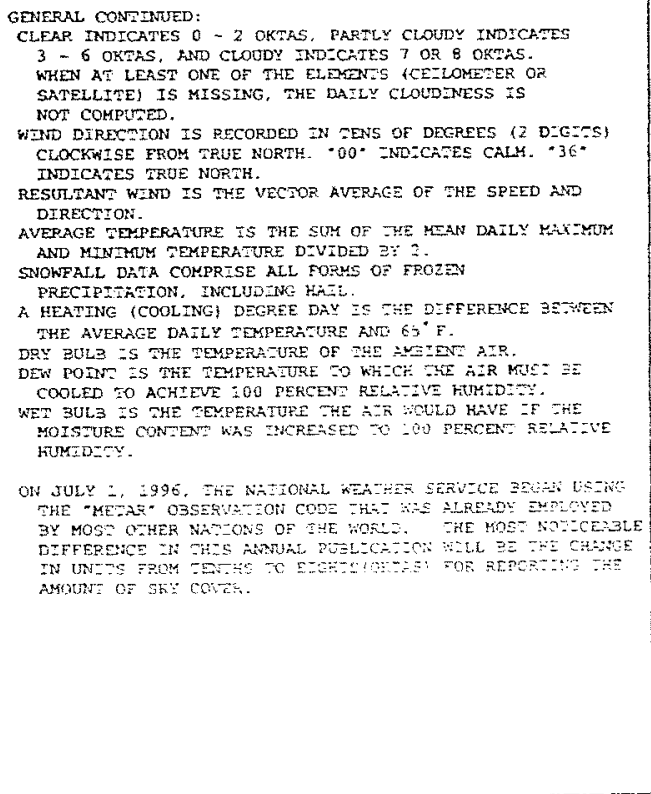 \\
\hline
\end{tabular}

phishes by: NCDC Ashewile. W 
West pani Beach and paim Beach, both located on the loastorida. are separares by lake worth, a portion of the inland tacerway. The entire coastal ridge is only about 5 riles wide and in early times the Everclades reached to its western edge. Now most of tine swareland has been drained and is devoted to agriculcule, the peat-like muck soil being very fertile when fortified with certain lacking minezais. The felantic ocean forms the eastern edge of $=a l m$ etach, and the culf stream flows northwate about 2 miles offshore, its neazesc moroach to the florida coast.

Hecouse of its southeriy location and marise influences, che paia beach area has a notably equable climate. Colc continental air must either travel over wacer or How down the plorida yeninsula to reach the area, and in either case its cold is appreciably modified. Actually, the coldest weacher. with infrequent frosts. is experienced the second or third night after the arrival of the cold air. due to the loss of heat through radiacion cooling. The frequency of temperatures as 10 w as the freezing mark is about one per three years at the National weather service office, but in the famlands farther from the coast the frequency of light freezes is much nigher.
Sumer temperatures are rempered by the ocean breeze. and by the Erequent formation of cumulus clouds, which shade the land somewne without completely obscuring the sun. Temperatures of 89 degrees or higher have occurred in al: months of the year. but the 100 degree mary has tarel. occurred. August is the warmest mantin and has an average maximum cemperature of about 50 degrees: The occurrence of 50 degree cemperacures in iugust is so common thet such can be expected on more than two-thirds of the days. Hovever. terpezatures as high as ino degreas sarely occur.

The moist. unstable air in this area results in Erequent showers. usually of sho: duration. Thunderstorms are irequent curing the sunmer. occuraing every ocher day. fainfali is heaviest during the surmer and fall, the fali raintali occurring from occasional heavy rains accompanying tropical disturbances. High winds asscciaced with hurricanes, have been estimaced at asout 140 mph in the city.

Flying weacher is usually very good in this area. with instrument weacher occurring only rarely. Heavy fog occurs on an average of only one morning a month in the winter and spring, anc almost never in the sumbler and fall. 


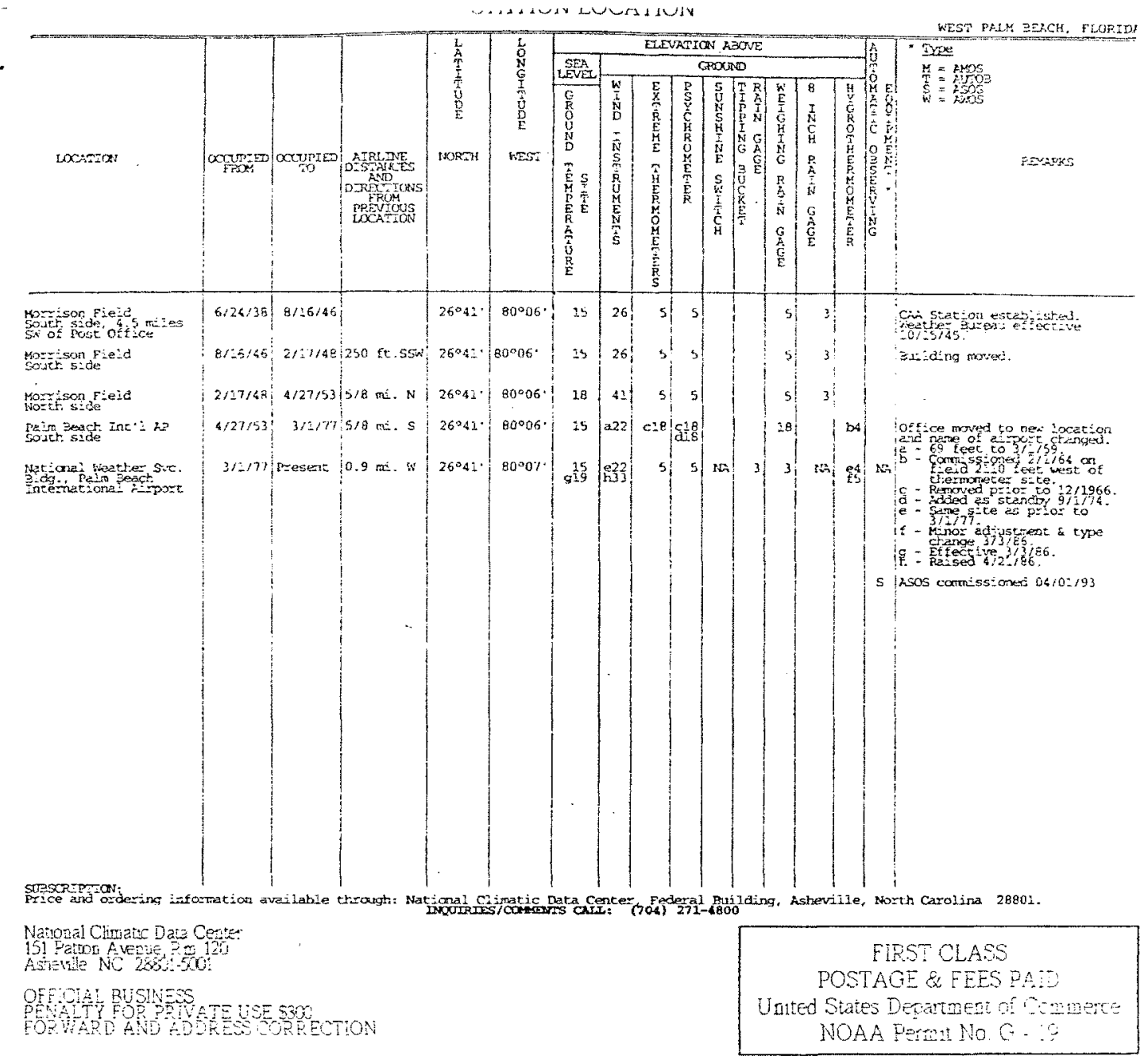


Appendix C - Sample Calculations 


\section{Sample Calculations}

The following is an example of how equilibration values were compared against controls with statistical analysis

\section{Given:}

The following data points were found in Table 18, for Soil 1 with initial $10 \mathrm{ppb}$ As $(+5)$ solution. Controls used for these data points are also in Table 18. (Sample 13:10, Control 2, second page)

\begin{tabular}{|c|c|}
\hline $\begin{array}{c}\text { Sample } \\
\text { ID }\end{array}$ & $\begin{array}{c}\text { Equilibration } \\
\text { (ppb) }\end{array}$ \\
\hline $11: 10$ & 12.25 \\
\hline $12: 10$ & 10.14 \\
\hline $13: 10$ & 3.742 \\
\hline Control 1 & 11.37 \\
\hline Control 2 & 7.449 \\
\hline
\end{tabular}

Find:

Mass of As (+5) adsorbed per gram of soil using Q-Test.

Solution:

1) Find differences between the corresponding control and the data values (i.e. control 1 with 11:10, 12:10; and control 2 with 13:10)

$\begin{array}{llllll}\text { Replicate 1 } & 11.37 & - & 12.25 & = & -0.88 \mathrm{ppb} \\ \text { Replicate 2 } & 11.37 & - & 10.14 & = & 1.23 \mathrm{ppb} \\ \text { Replicate 3 } & 7.449 & - & 3.742 & = & 3.71 \mathrm{ppb}\end{array}$

2) Apply Q-Test to data:

Use procedures outlined in Section 3.6, there are no outliers in data set if $Q$ values are $<0.94$ :
a) -0.88
b) check highest point
$\frac{2.278}{4.5}=0.54$, less than 0.94
$\frac{3.71}{4.59}$ range
$\frac{-3.71}{2.48}$ difference
Therefore, not an outlier. 


\section{Sample Calculations (continued)}

c) check lowest data point

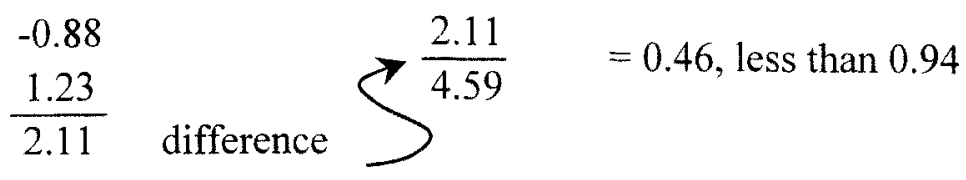

\section{Therefore, not an outlier}

3) Find average value (since all data are considered acceptable) and convert ppb to micrograms of arsenic adsorbed:

a) convert:

$-0.88 \mathrm{ppb}$ $=-0.11$ ug As $(+5)$ adsorbed

$1.23 \mathrm{ppb}$

$\mathrm{X} 0.125 \mathrm{~L}$

$=0.154$ ug As (+5) adsorbed

$3.71 \mathrm{ppb}$

TOTAL $\frac{=0.464 \text { ug As }(+5) \text { adsorbed }}{\mathbf{0 . 5 0 8} \text { ug As }(+5) \text { adsorbed }}$

b) find average:

0.508 As $(+5)$ adsorbed divided by 3 samples $=0.169 \mathrm{ug} \mathrm{As}(+5)$ adsorbed $/$ sample *

* For Soil 1, initial concentration of $10 \mathrm{ppb}$

4) Find $\mathrm{As}(+5)$ adsorbed per gram of soil:

$0.169 \mathrm{ug} \mathrm{As}(+5)$ adsorbed/sample divided by $0.5000^{1} \mathrm{~g}$ of Soil 1

$=0.338$ ug As $(+5)$ adsorbed $/ g$ Soil 1

${ }^{1}$ Compare against value reported in Table 20, 0.338 versus 0.332

equates to $1.8 \%$ accuracy of reporting

5) Thus, values $1(\operatorname{As}(+5)$ in solution $)$ and $2(\operatorname{As}(+5)$ in Soil 1) were used with other points, to evaluate alternative isotherms (See Tables 9-20, and Figures 12-23 and 42-61). 
Appendix D - FIU Data Sheets 
Arsenic Data 


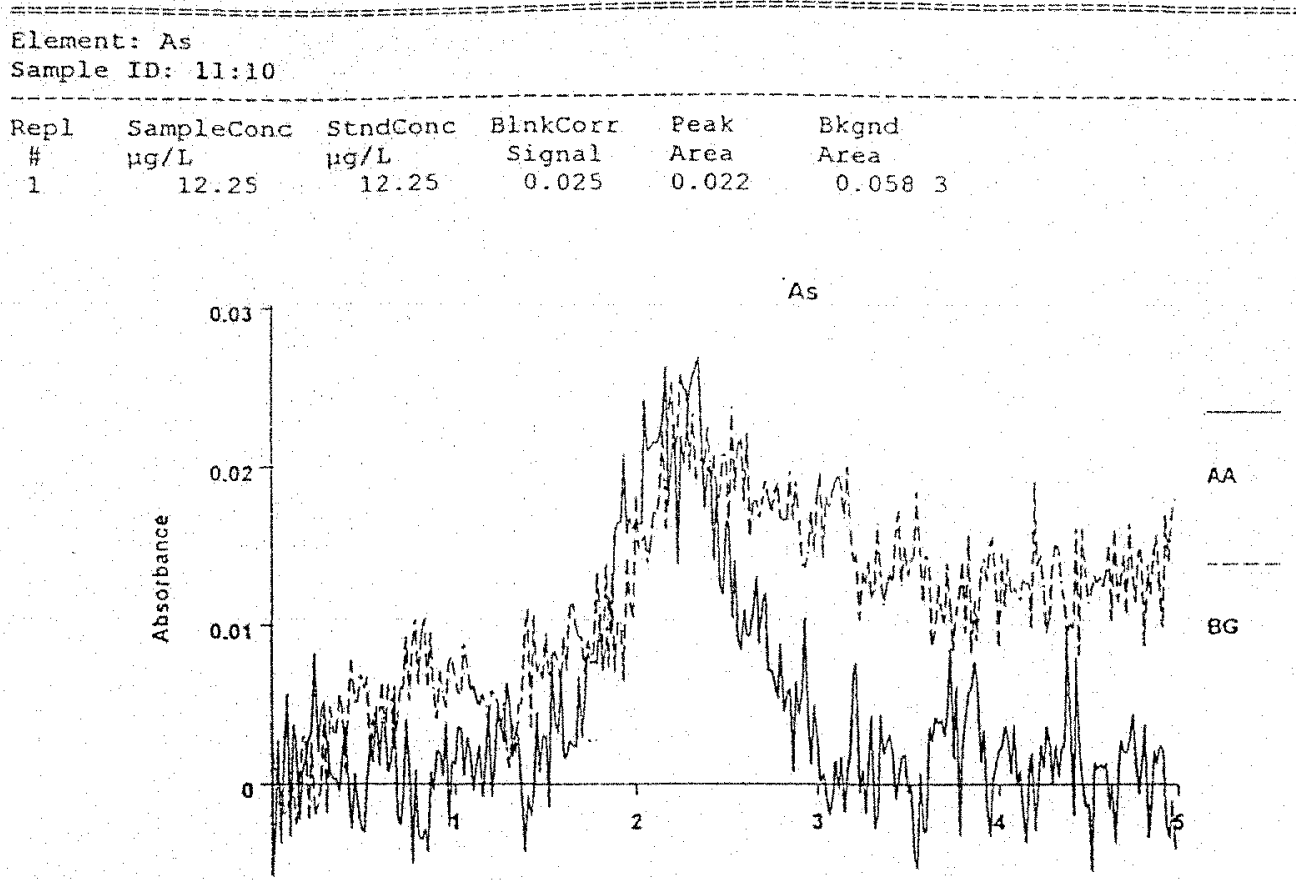

Time (seconds)

Element: As

Sample ID: 12:10

$\begin{array}{cccccc}\text { Rep1 Sampleconc stndConc Blnkcor } & \text { Peak } & \text { Bkgnd } & \\ \# & \mu g / L & \mu g / L & \text { Signal } & \text { Area } & \text { Area } \\ 1 & 10.14 & 10.14 & 0.021 & 0.018 & 0.0553\end{array}$

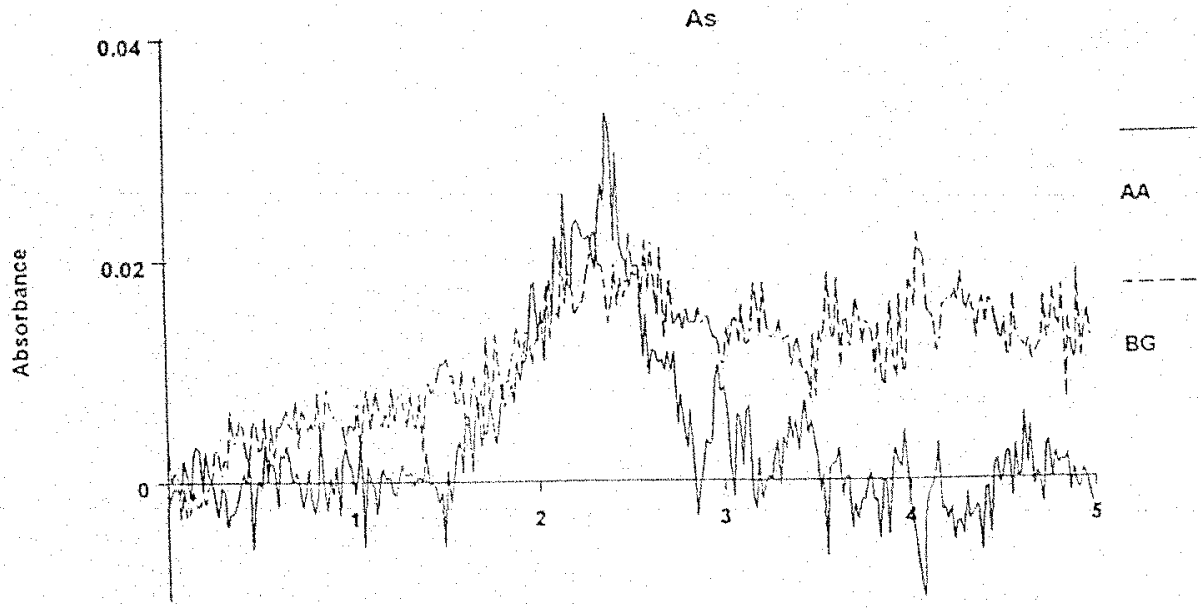

Time (seconds) 

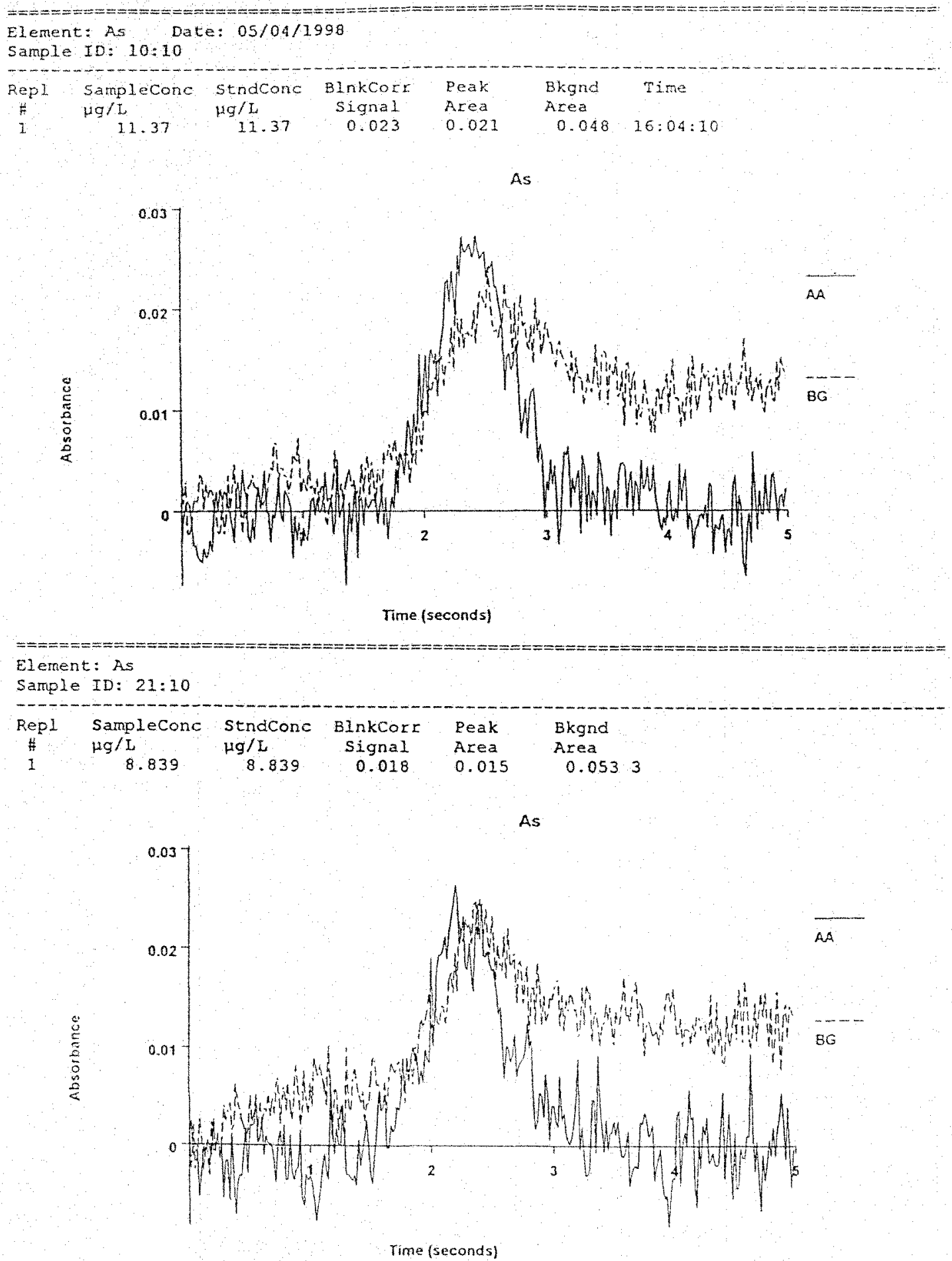

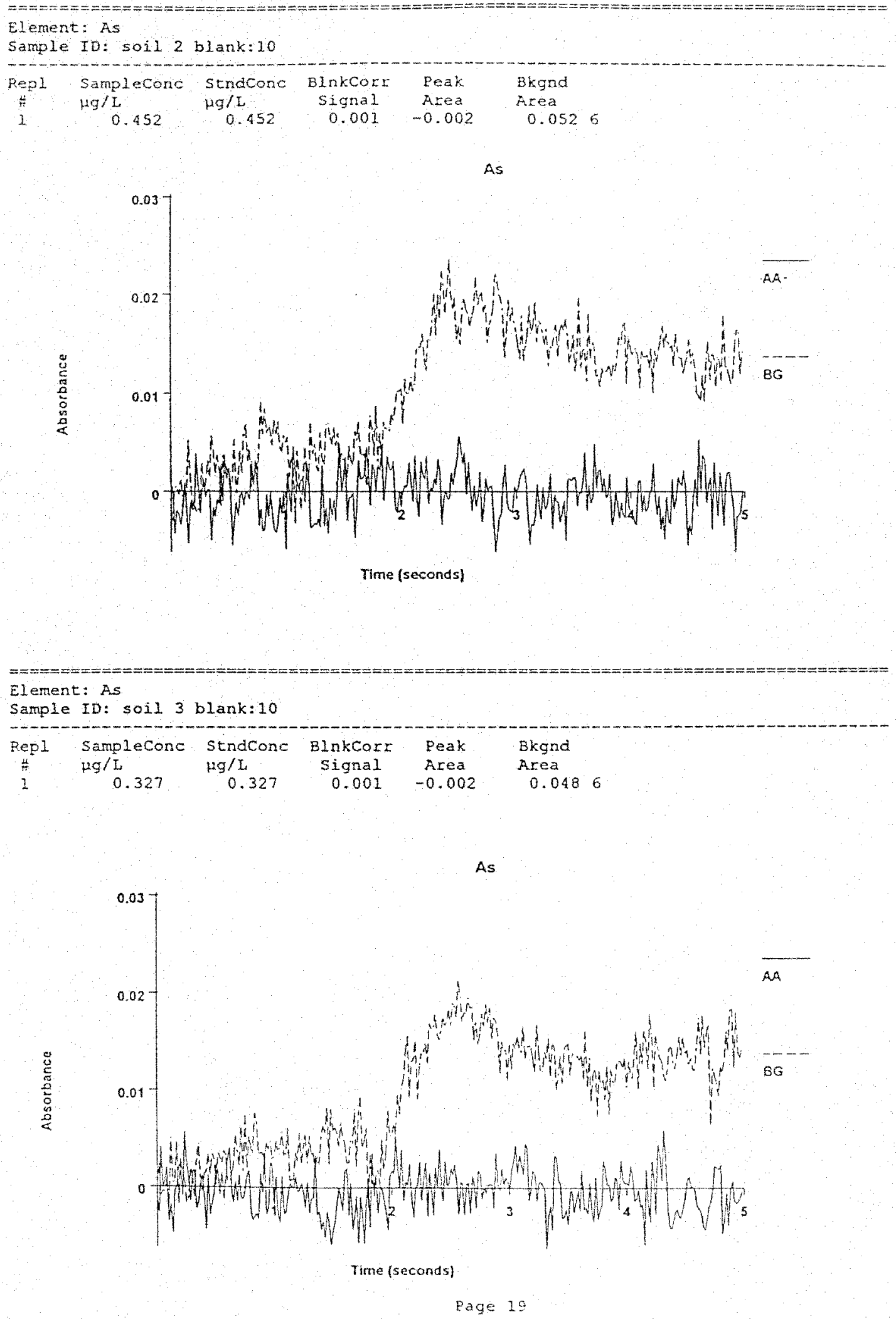


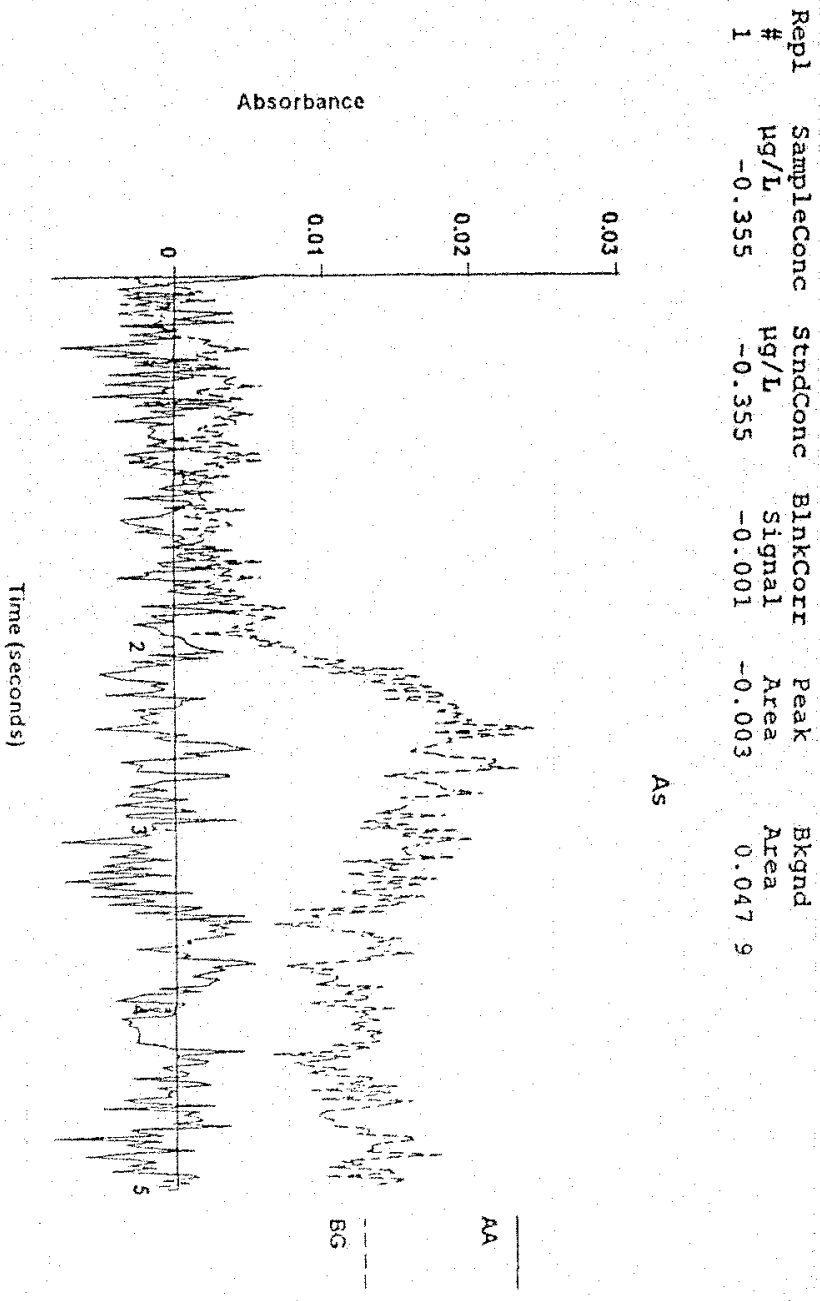



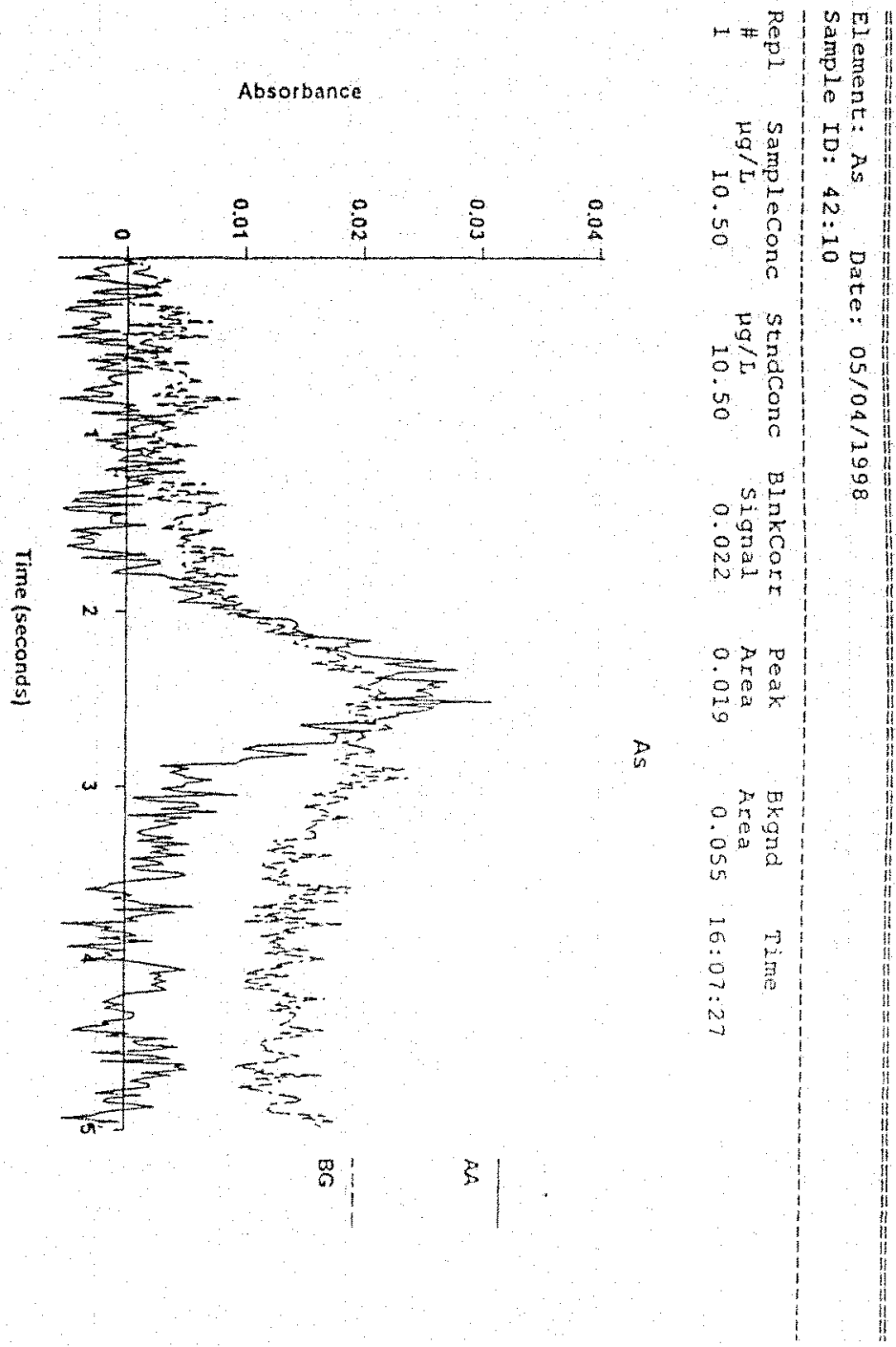
(spuosos) out!

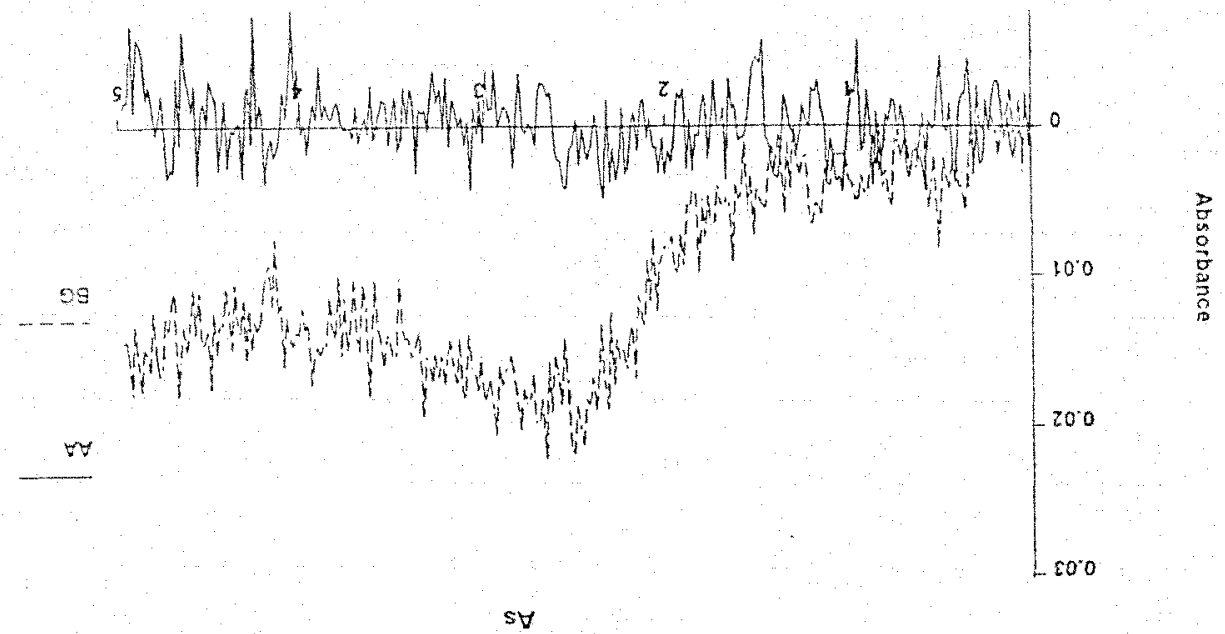

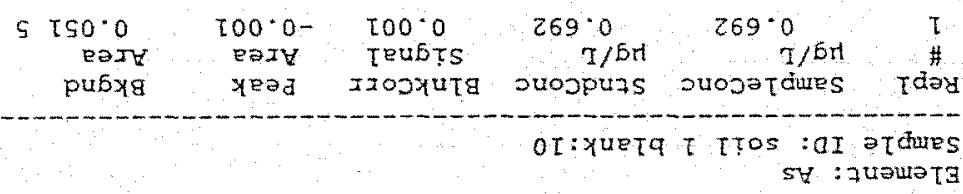

(spuosas) จ4!1

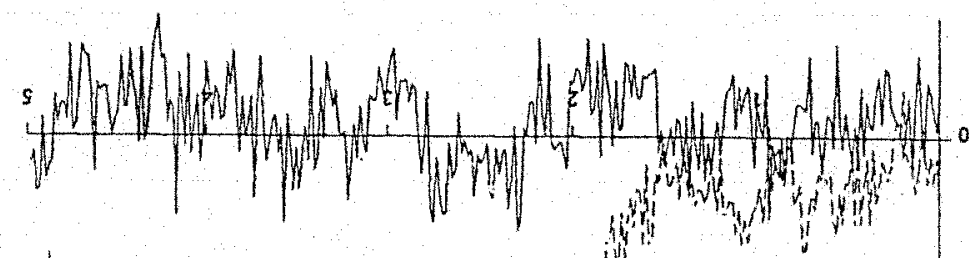

os

St

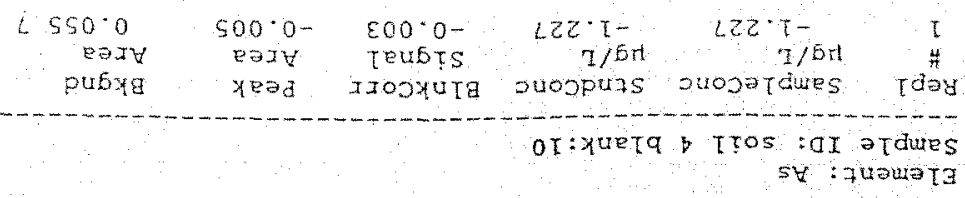

5४ : 7upus $\mathrm{TI}$ 
Element $/ 5$

Sample ID: $22: 10$

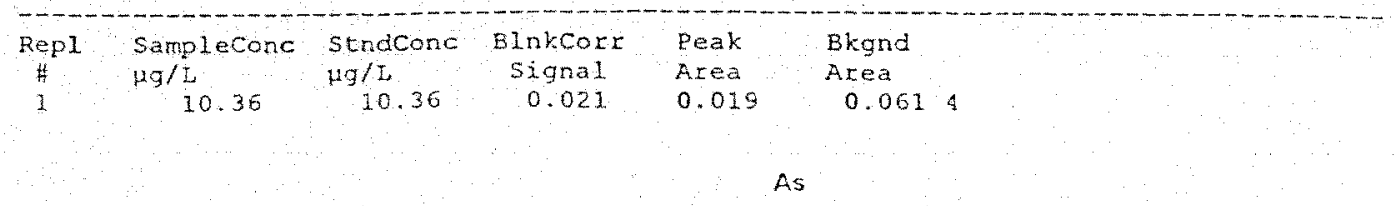
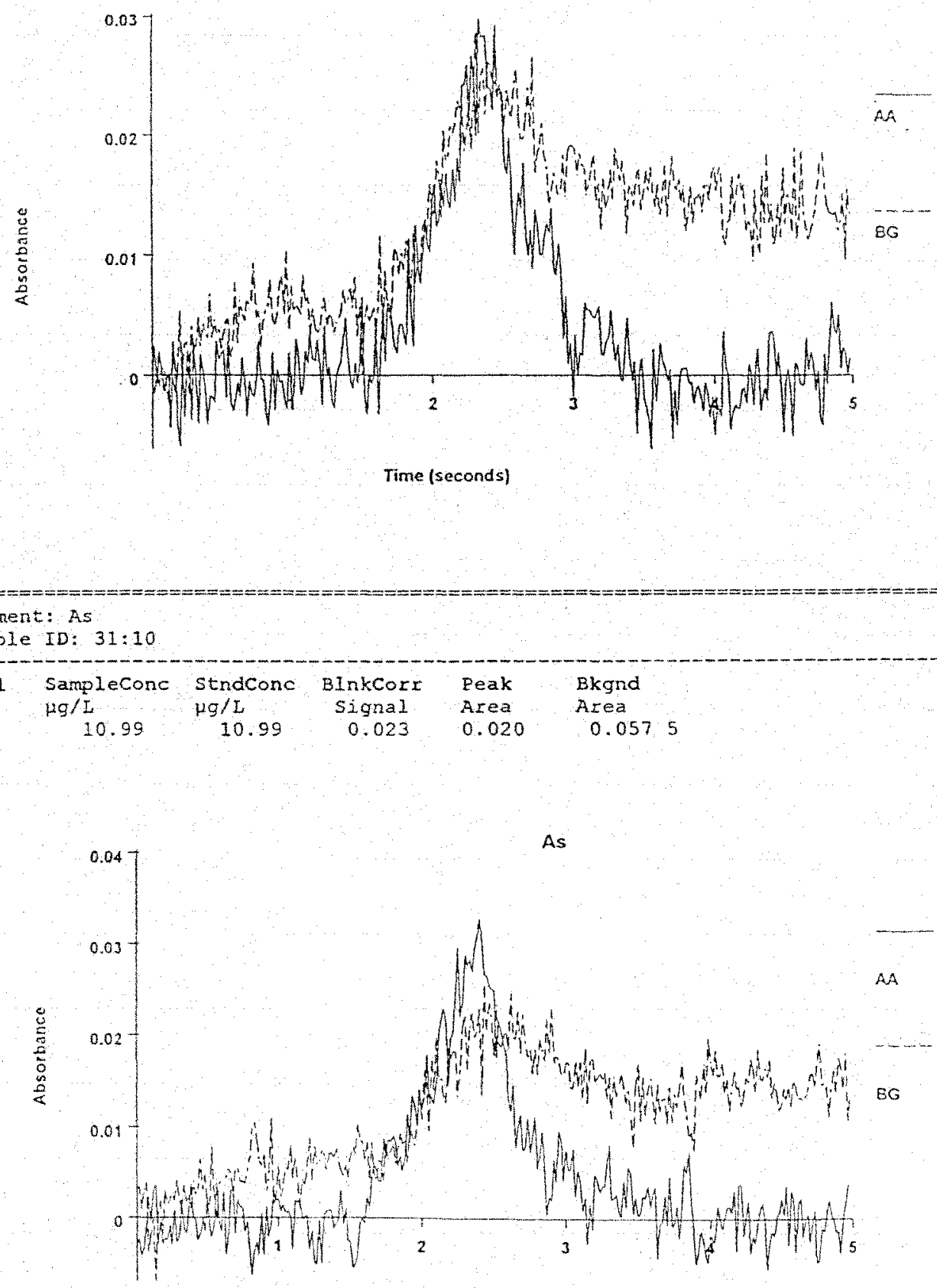

Time (seconds) 


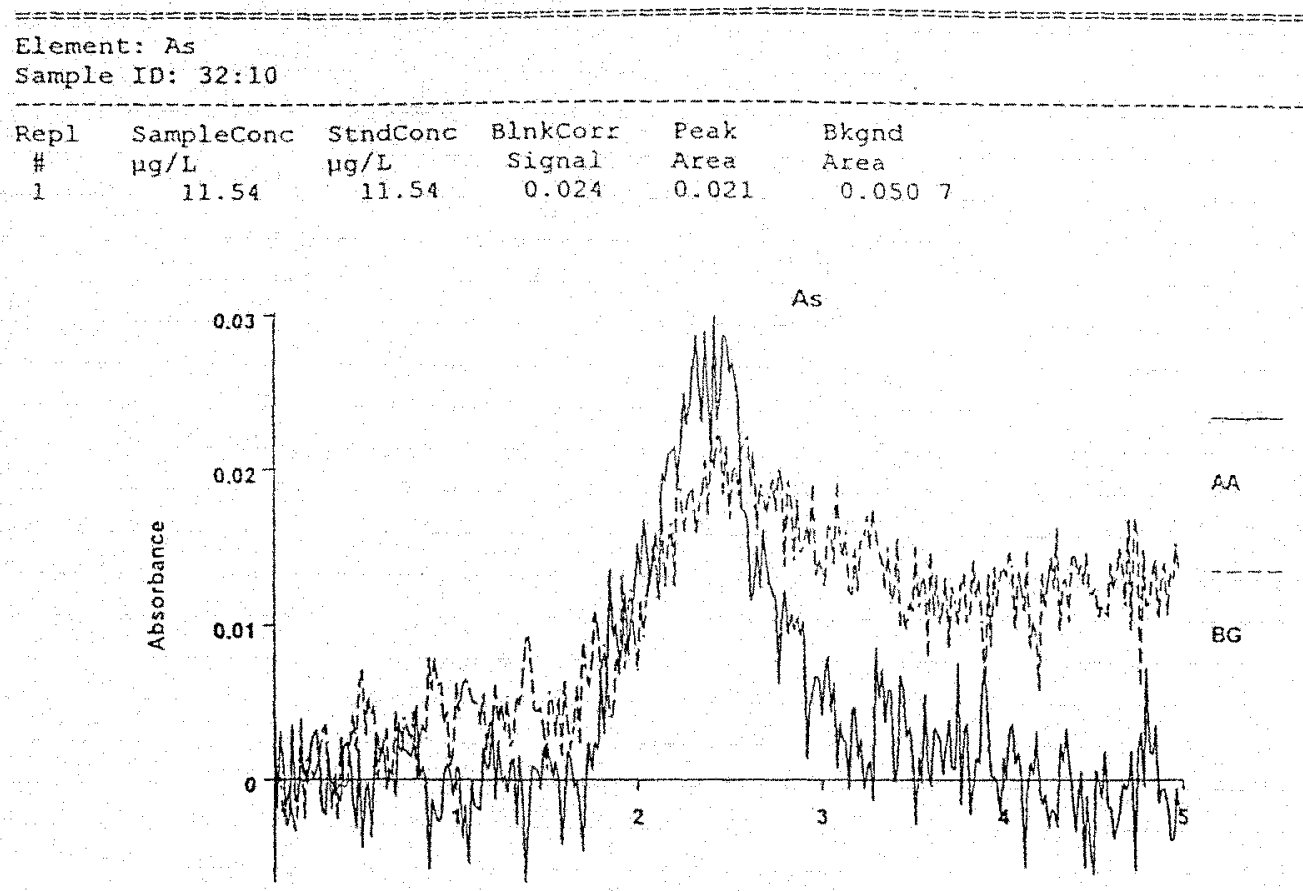

Time (seconds)
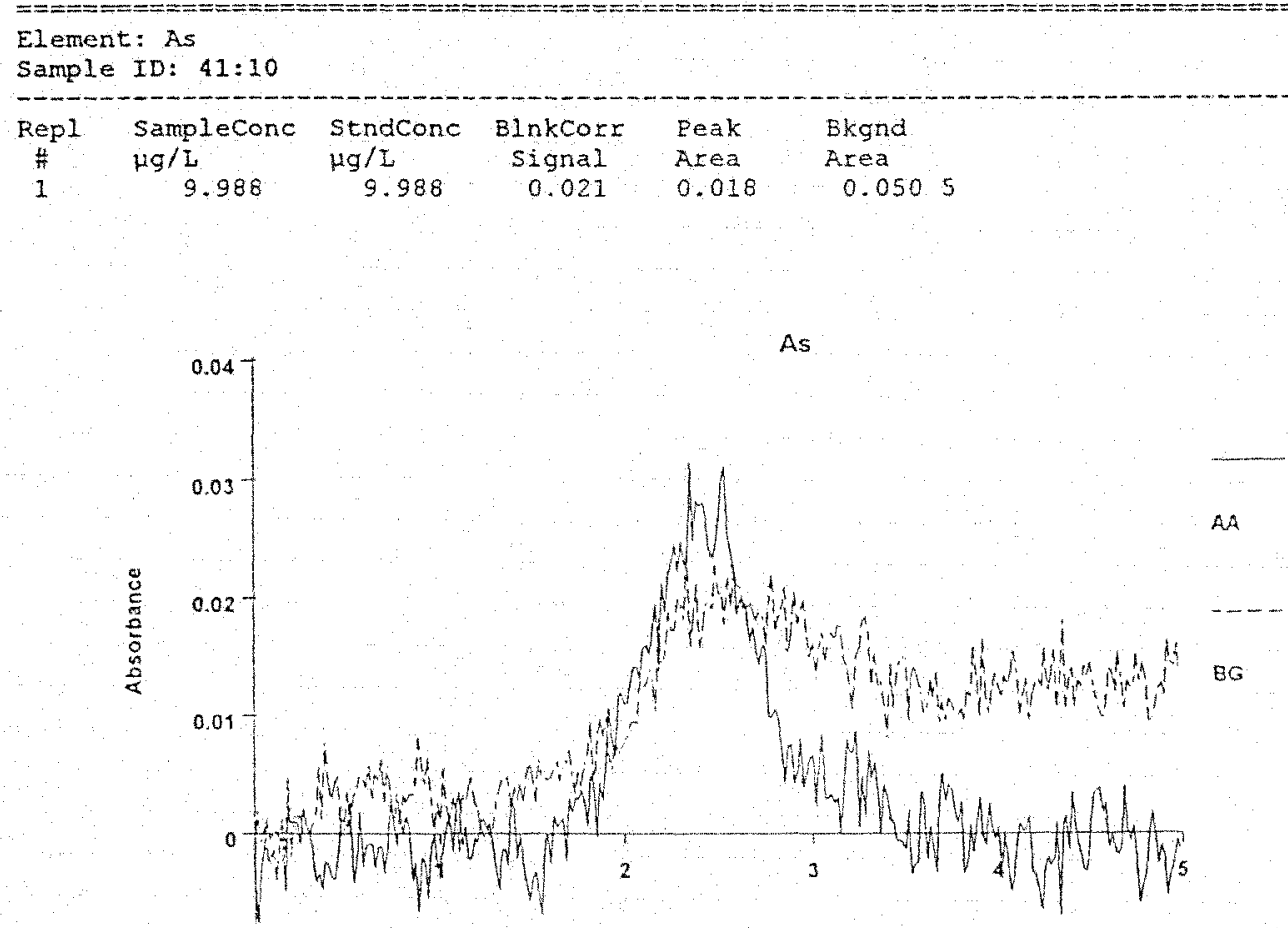

Time (seconds) 
Element: As

Sample ID: S1:10

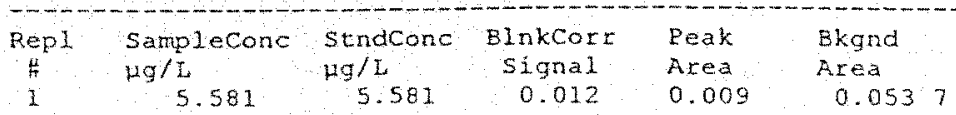

As

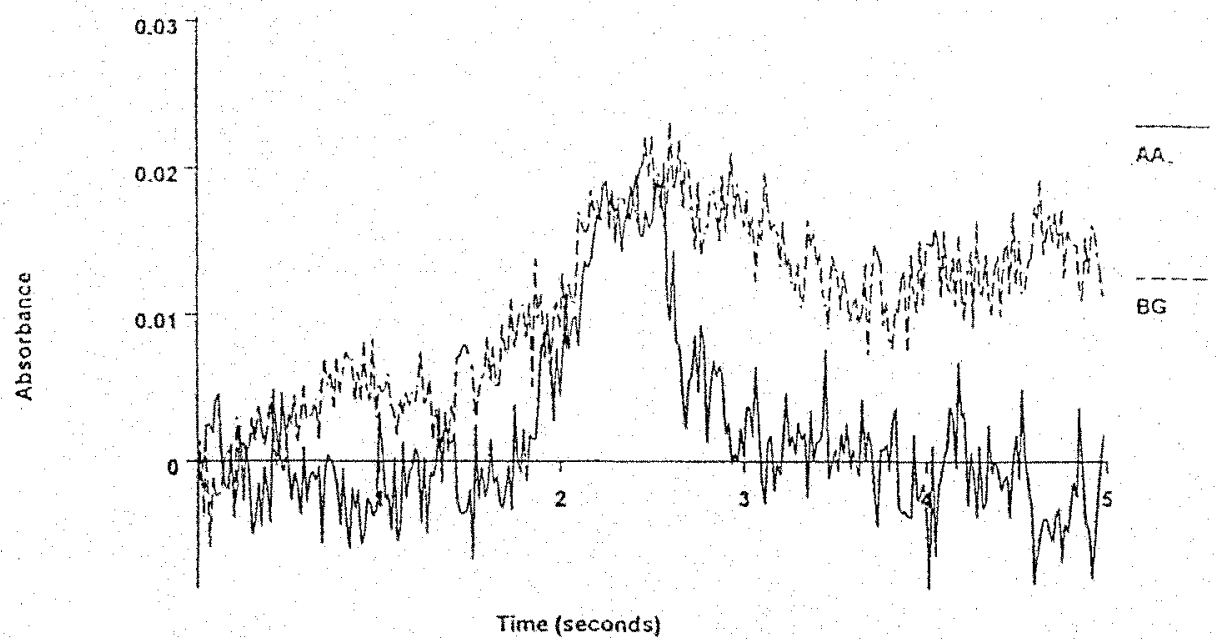

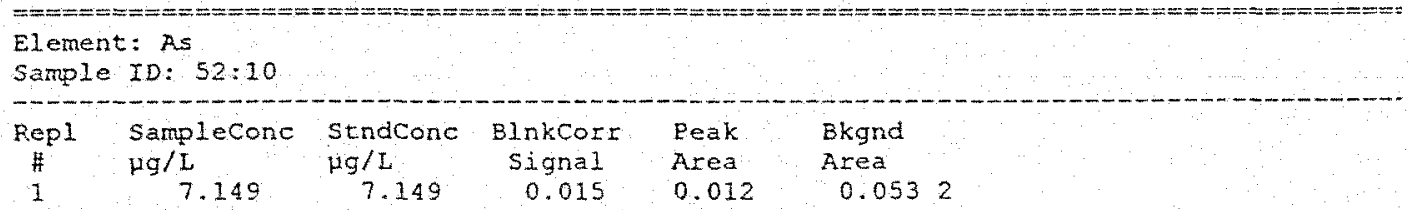

As

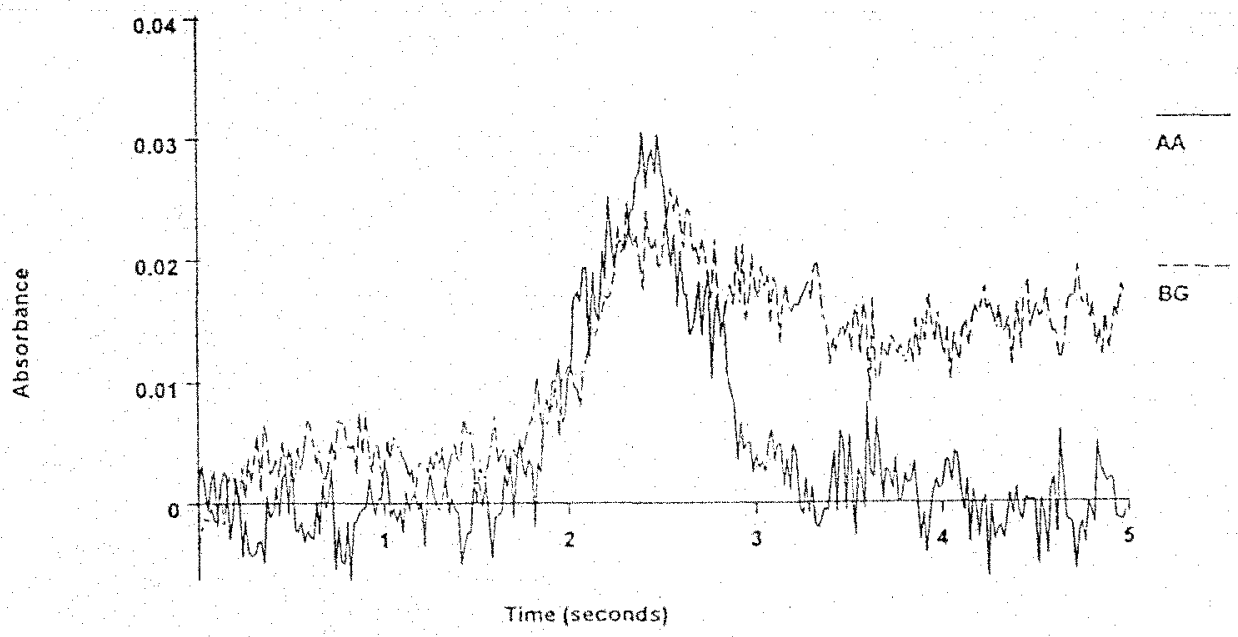


Element: As

Sample to: $0: 10$

\begin{tabular}{|c|c|c|c|c|c|}
\hline $\begin{array}{c}\text { Rep } 1 \\
\frac{4}{1}\end{array}$ & $\begin{array}{l}\text { Samplecone } \\
19 / L \\
-0,704\end{array}$ & $\begin{array}{l}\text { Strdeone } \\
\mu g / L \\
-0.704\end{array}$ & $\begin{array}{l}\text { BlnkCors } \\
\text { signal } \\
-0.001\end{array}$ & $\begin{array}{l}\text { Peak } \\
\text { Area } \\
-0.004\end{array}$ & $\begin{array}{l}\text { Bkgnd } \\
\text { Area } \\
0.0515\end{array}$ \\
\hline
\end{tabular}

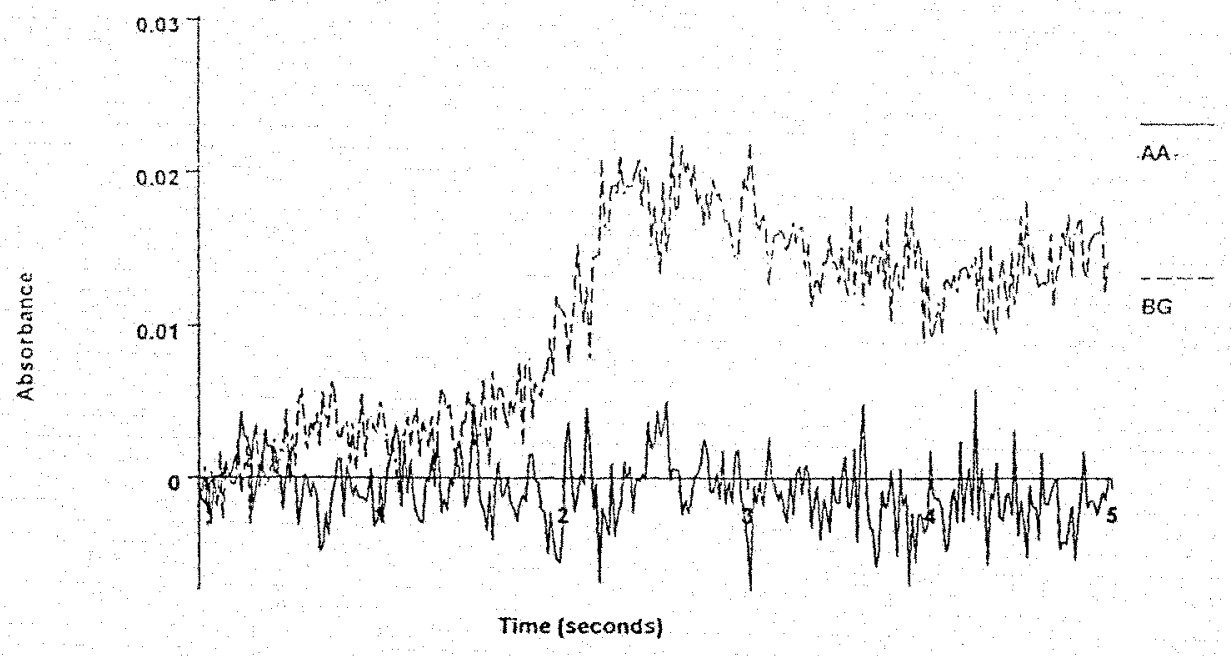




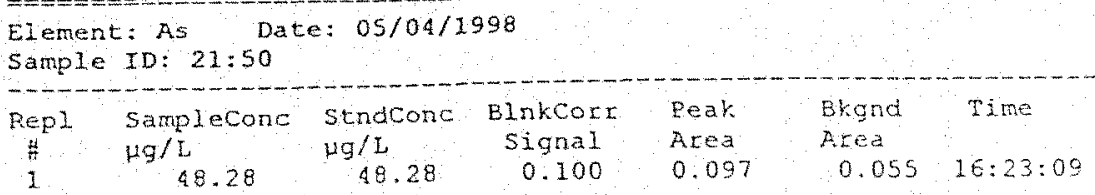

As

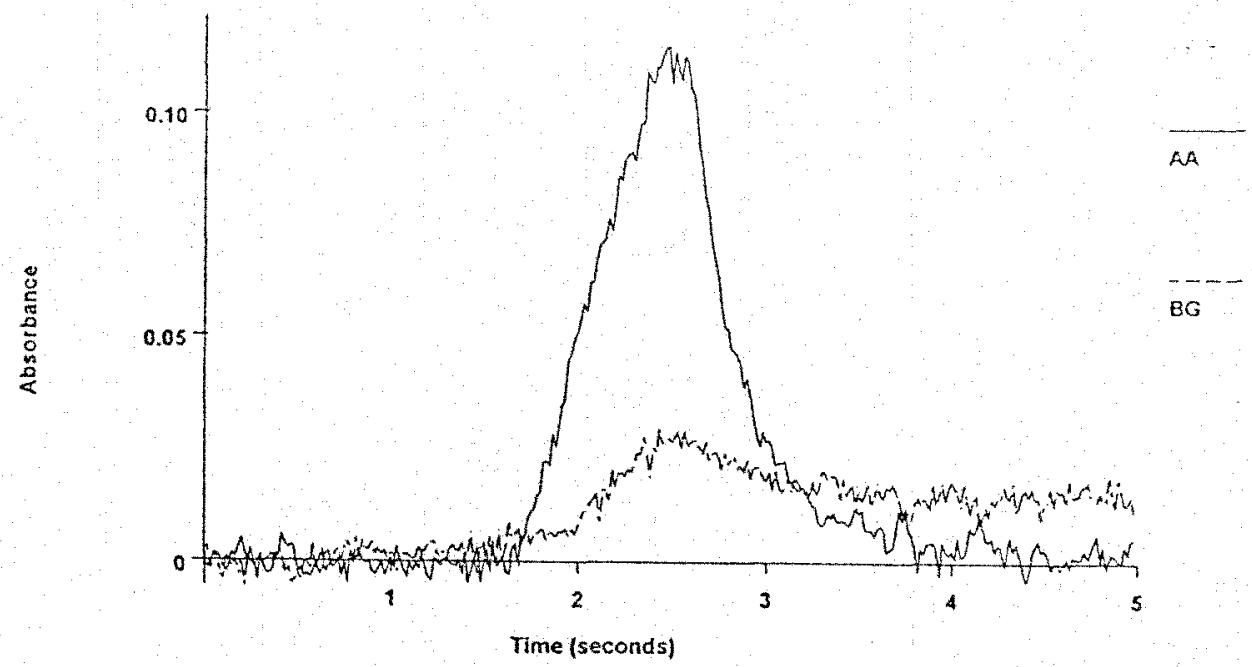

Element: As Date: $05 / 04 / 1998$

Sample ID: $22: 50$

\begin{tabular}{|c|c|c|c|c|c|c|}
\hline $\begin{array}{c}\text { Repl } \\
4 \\
1\end{array}$ & $\begin{array}{l}\text { Sampleconc } \\
\mu g / L \\
49.74\end{array}$ & $\begin{array}{l}\text { Stndconc } \\
H g / L \\
49.74\end{array}$ & $\begin{array}{c}\text { BlnkCorr } \\
\text { Signal } \\
0.103\end{array}$ & $\begin{array}{l}\text { Peak } \\
\text { Area } \\
0.100\end{array}$ & $\begin{array}{l}\text { Bkgnd } \\
\text { Area } \\
0.059\end{array}$ & $16: 25: 51$ \\
\hline
\end{tabular}

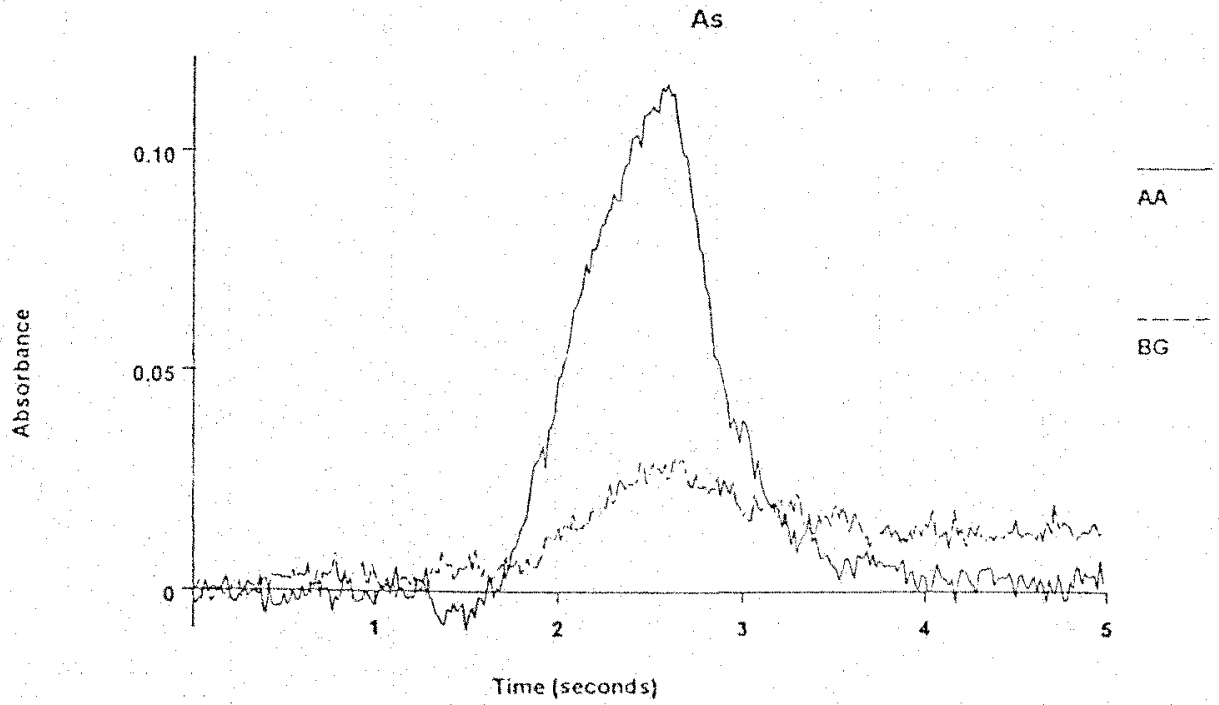




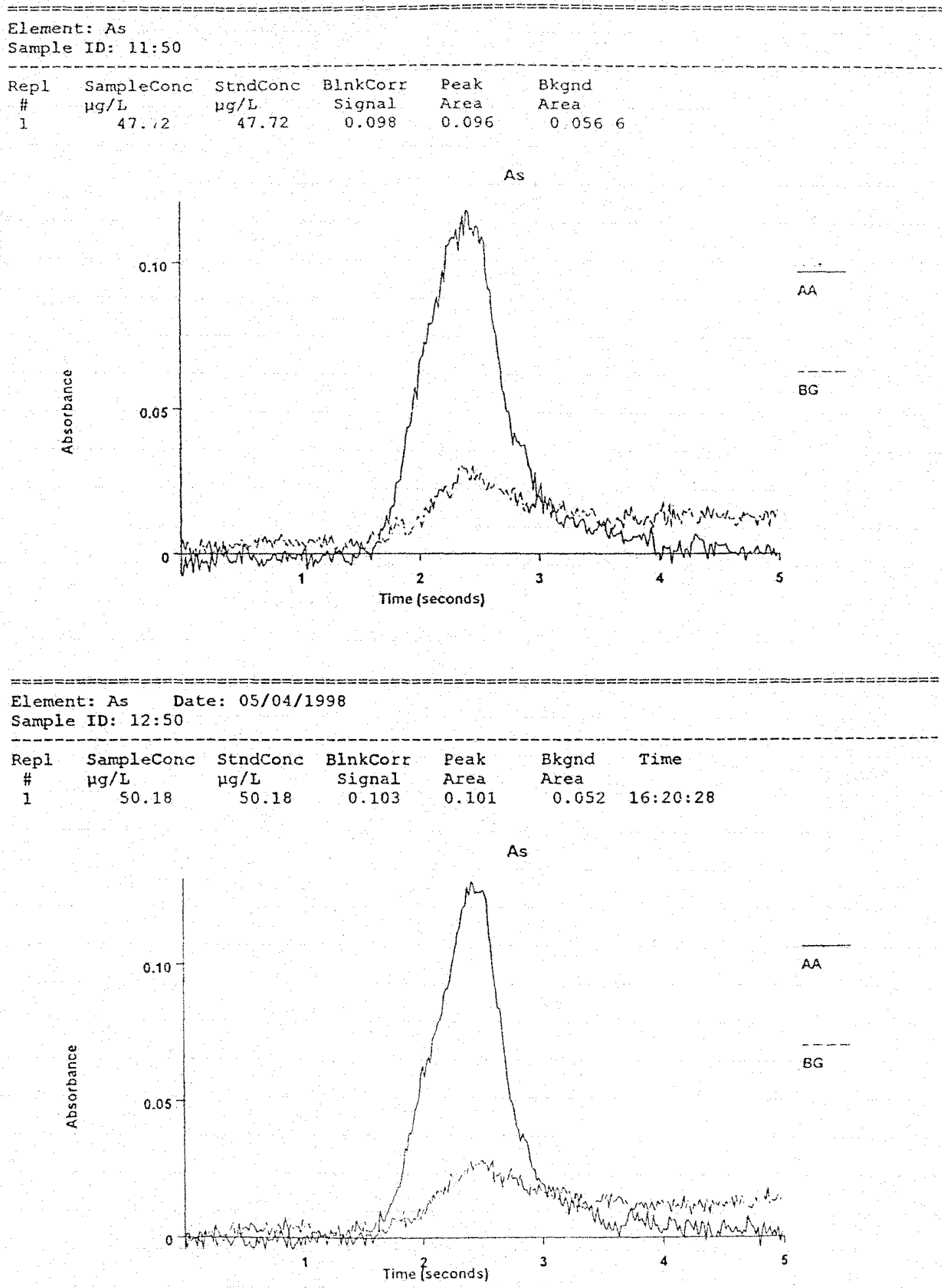




\begin{tabular}{|c|c|c|c|c|c|c|}
\hline $\begin{array}{l}\text { Element: } \\
\text { Sample }\end{array}$ & $\begin{array}{l}\text { As: Dat } \\
\text { ID: } 31: 50\end{array}$ & $e=05 / 04 / 1$ & $\because \because$ & & & \\
\hline $\begin{array}{c}\operatorname{Rep} 1 \\
\frac{1}{\pi} \\
\lambda\end{array}$ & $\begin{array}{l}\text { SampleConc } \\
H g / L \\
48.30\end{array}$ & $\begin{array}{l}\text { stndCone } \\
19 / \mathrm{L} \\
48.30\end{array}$ & $\begin{array}{c}\text { BInkCor } \\
\text { signa1 } \\
0.100\end{array}$ & $\begin{array}{l}\text { Peak } \\
\text { Area } \\
0.097\end{array}$ & $\begin{array}{l}\text { Bkgnd } \\
\text { Axed } \\
\quad 0.060\end{array}$ & $\begin{array}{l}\text { Time } \\
16: 28: 33\end{array}$ \\
\hline
\end{tabular}

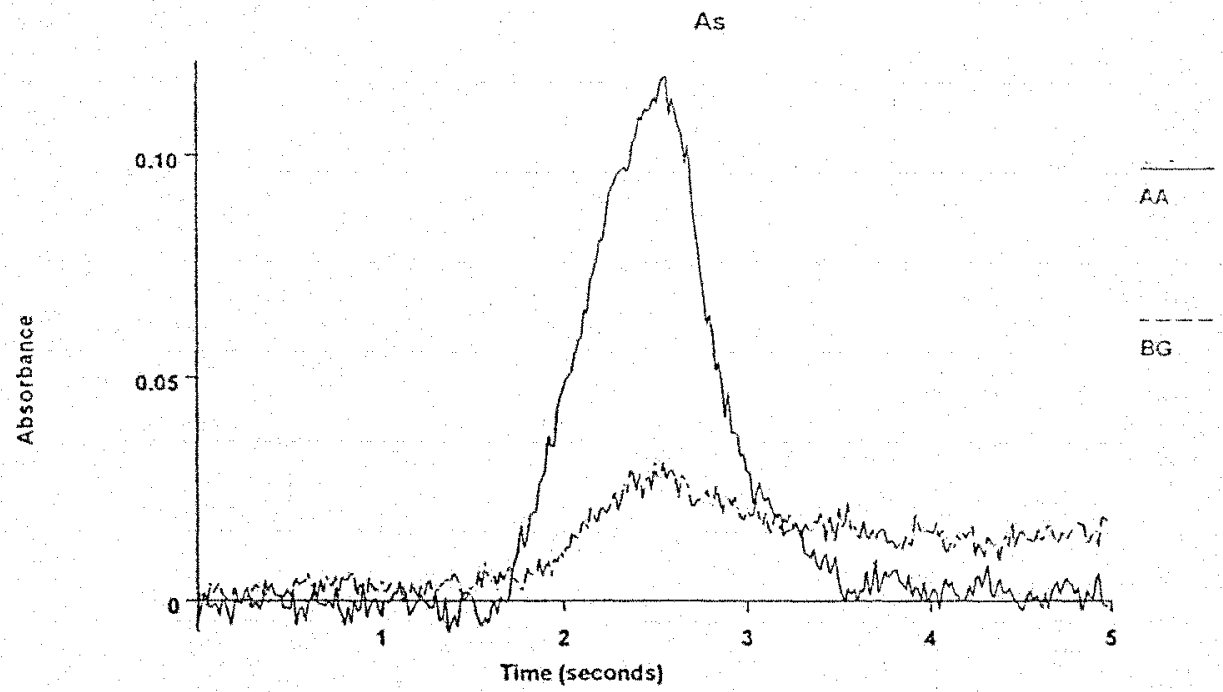

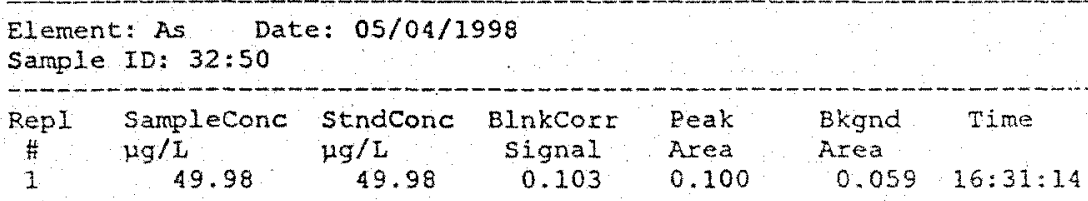

As

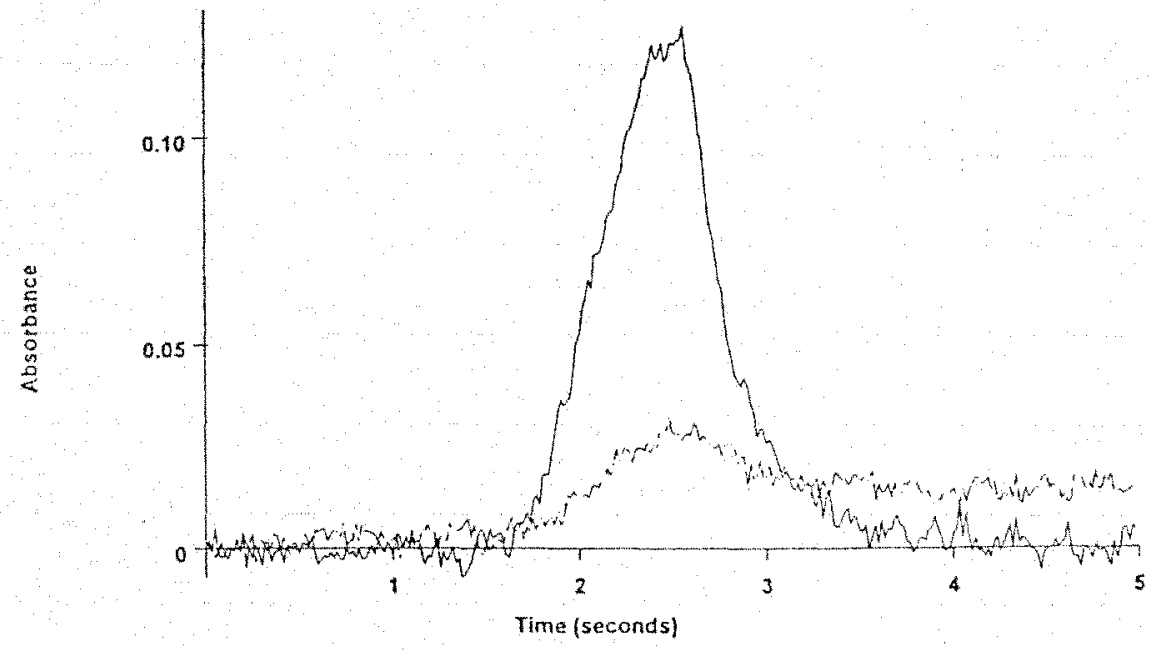




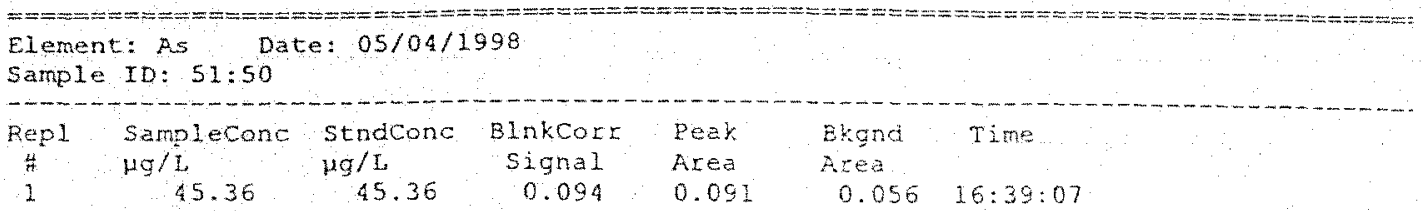

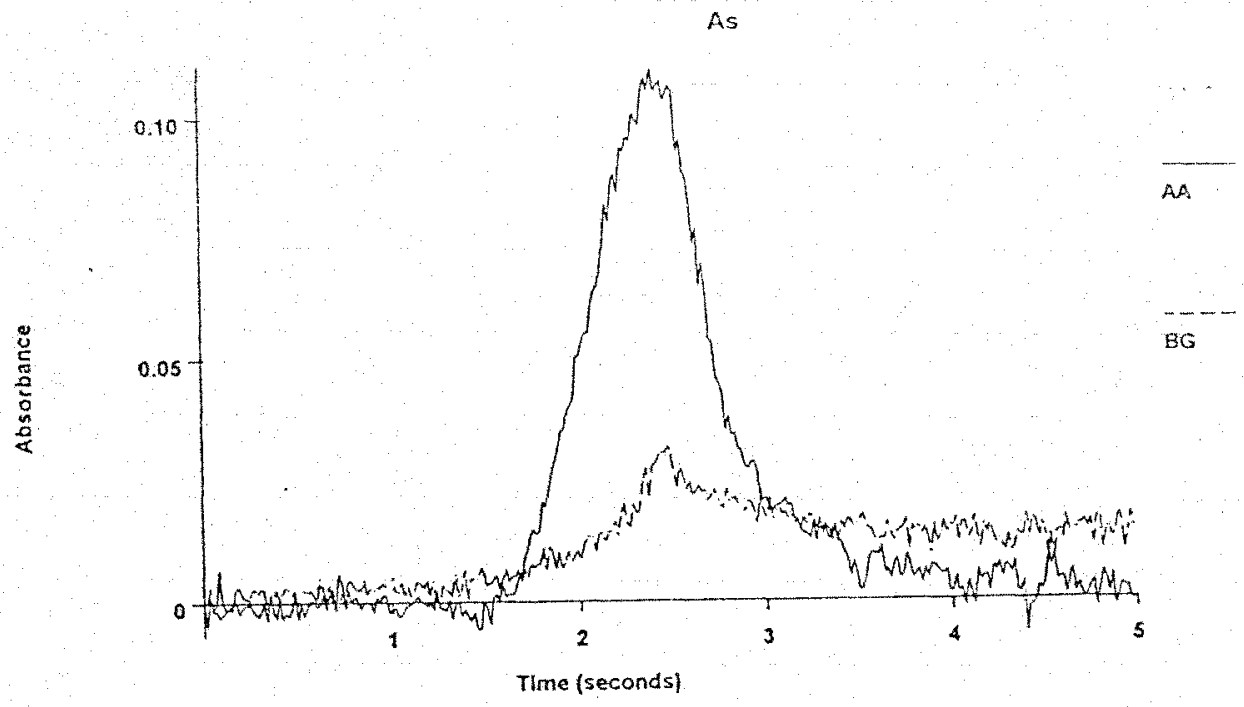




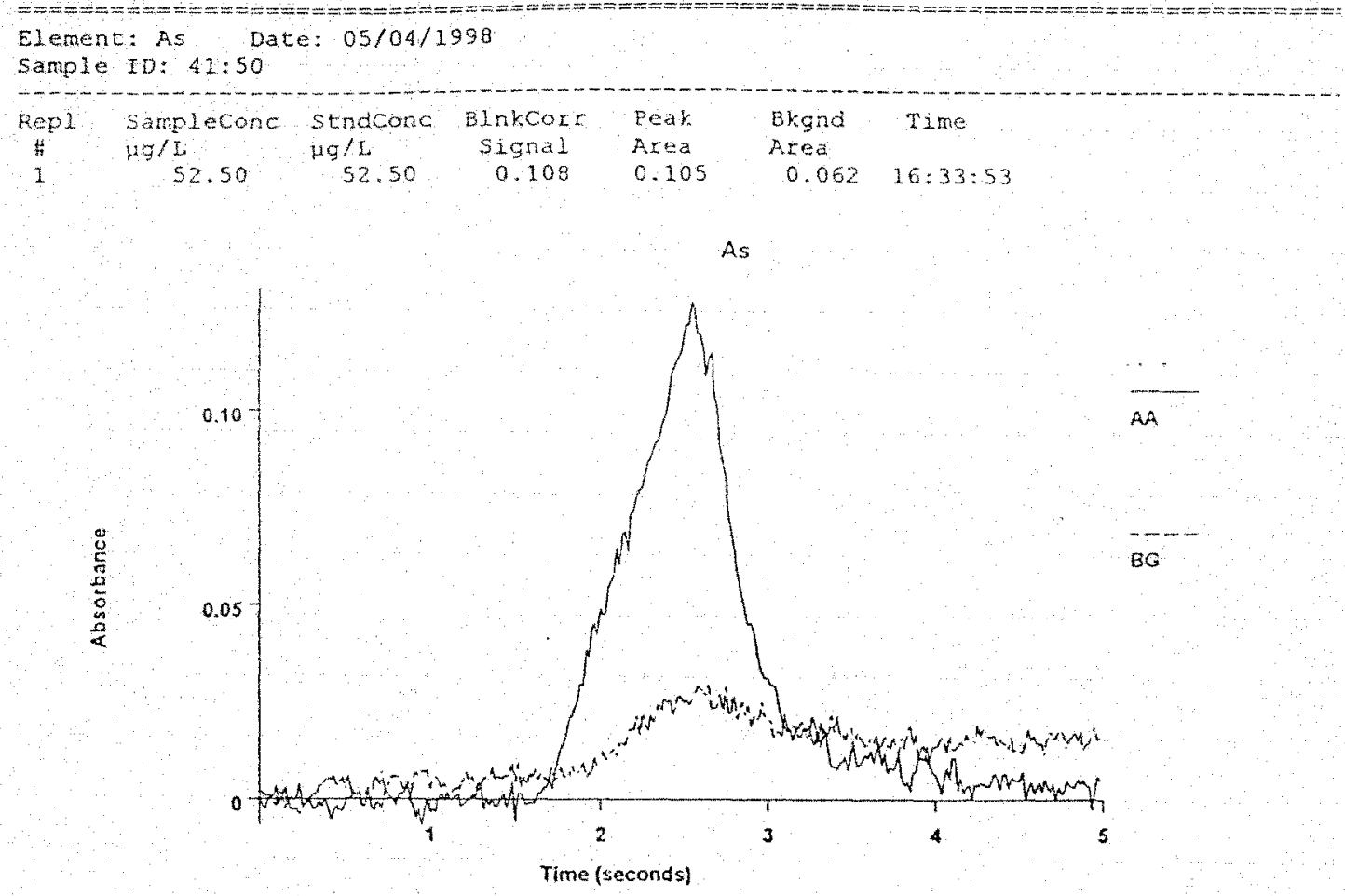

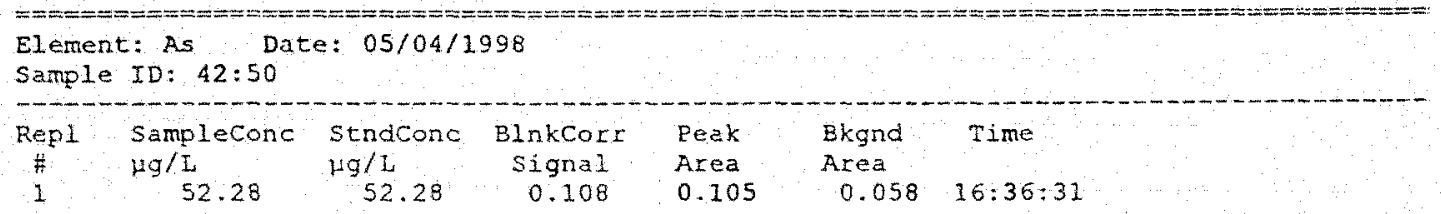

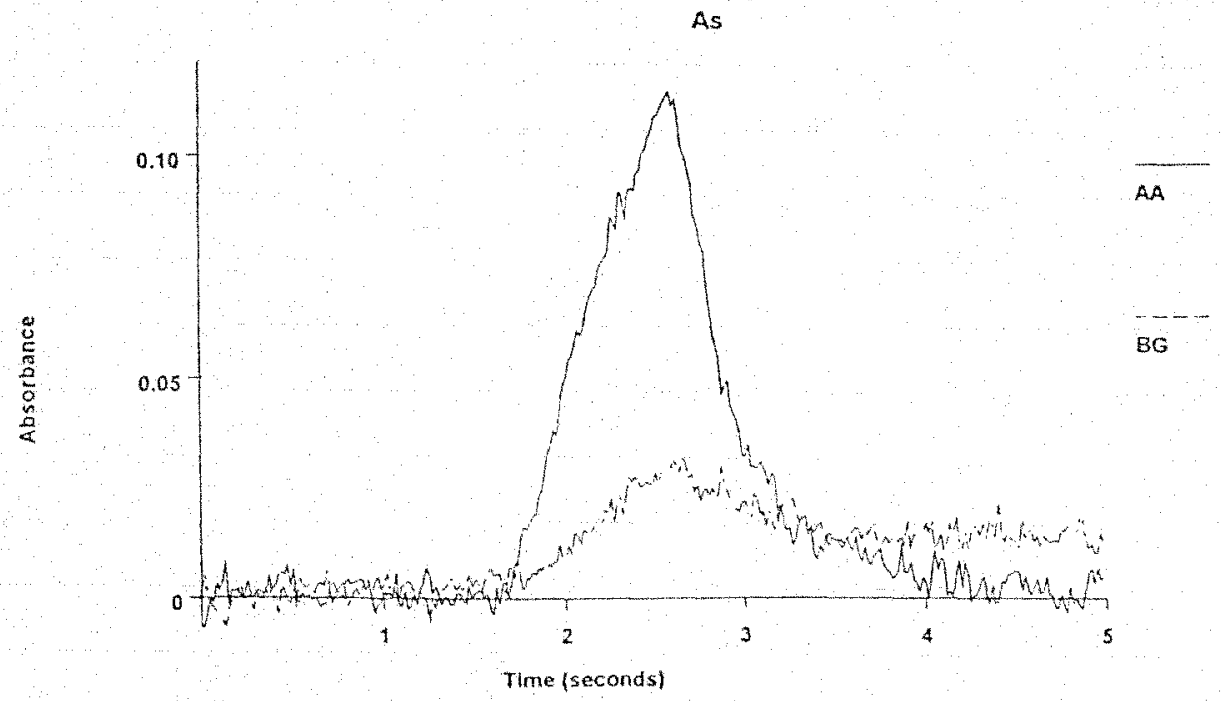


Elenent: As Date: 05/04/1998

Sample ID: solisblank: 50

\begin{tabular}{|c|c|c|c|c|c|}
\hline $\begin{array}{l}\operatorname{lep}_{4} 1 \\
1 \\
1\end{array}$ & $\begin{array}{l}\text { Sampleconc } \\
H g / L \\
1.073\end{array}$ & $\begin{array}{l}\text { StndConc } \\
\mu g / L \\
1.073\end{array}$ & $\begin{array}{c}\text { Blnkcote } \\
\text { Signal } \\
0.002\end{array}$ & $\begin{array}{c}\text { Peak } \\
\text { Area } \\
-0.001\end{array}$ & $\begin{array}{l}\text { Skgnd } \\
\text { Area } \\
0.046\end{array}$ \\
\hline
\end{tabular}

As

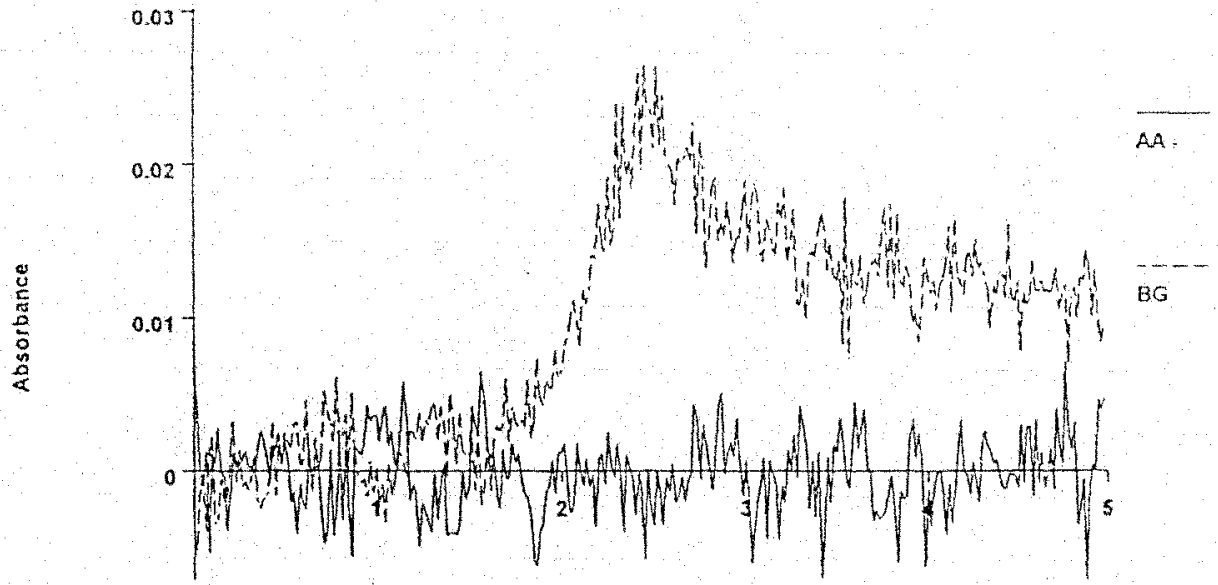

Time (seconds)

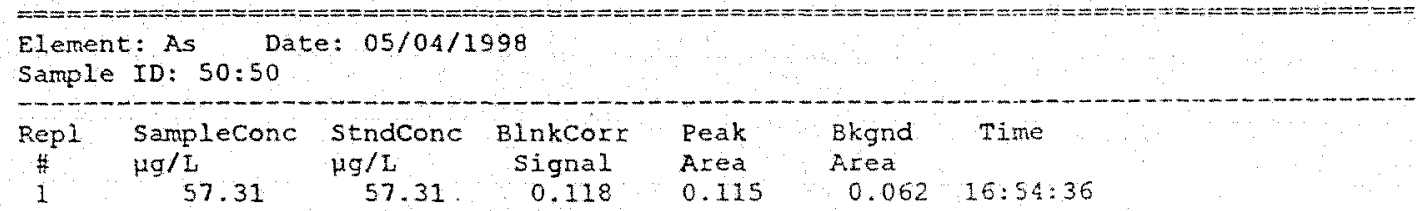

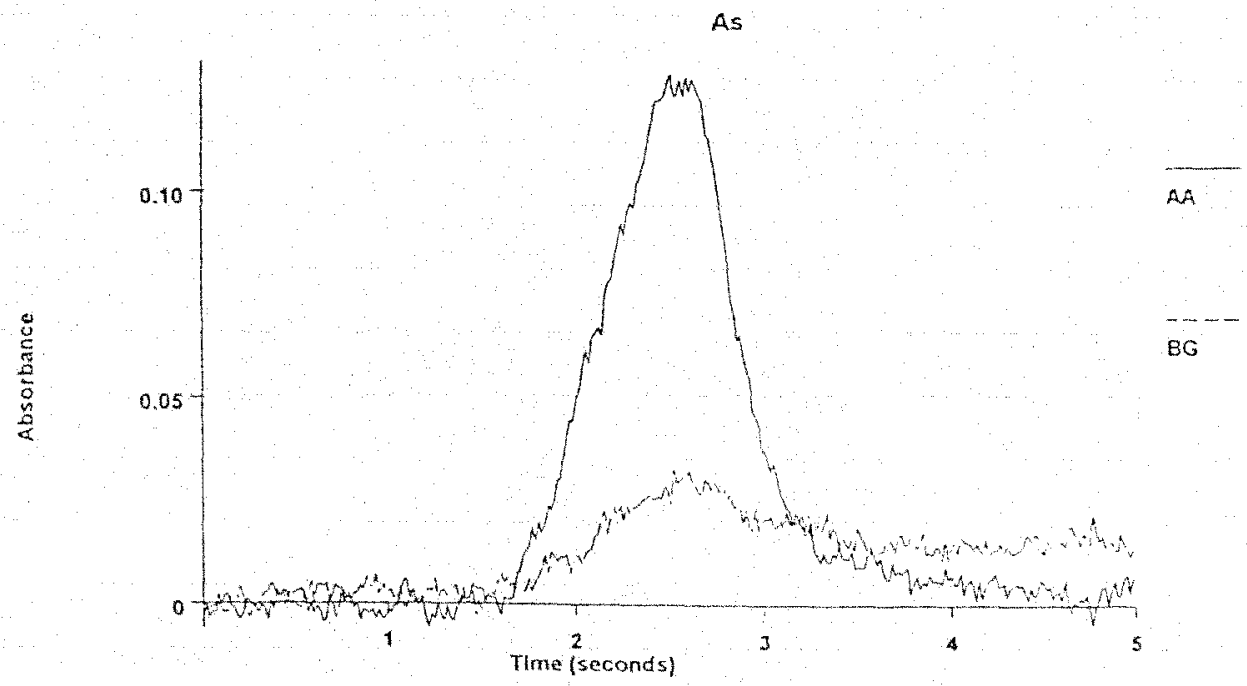


Sample ID: 0:50

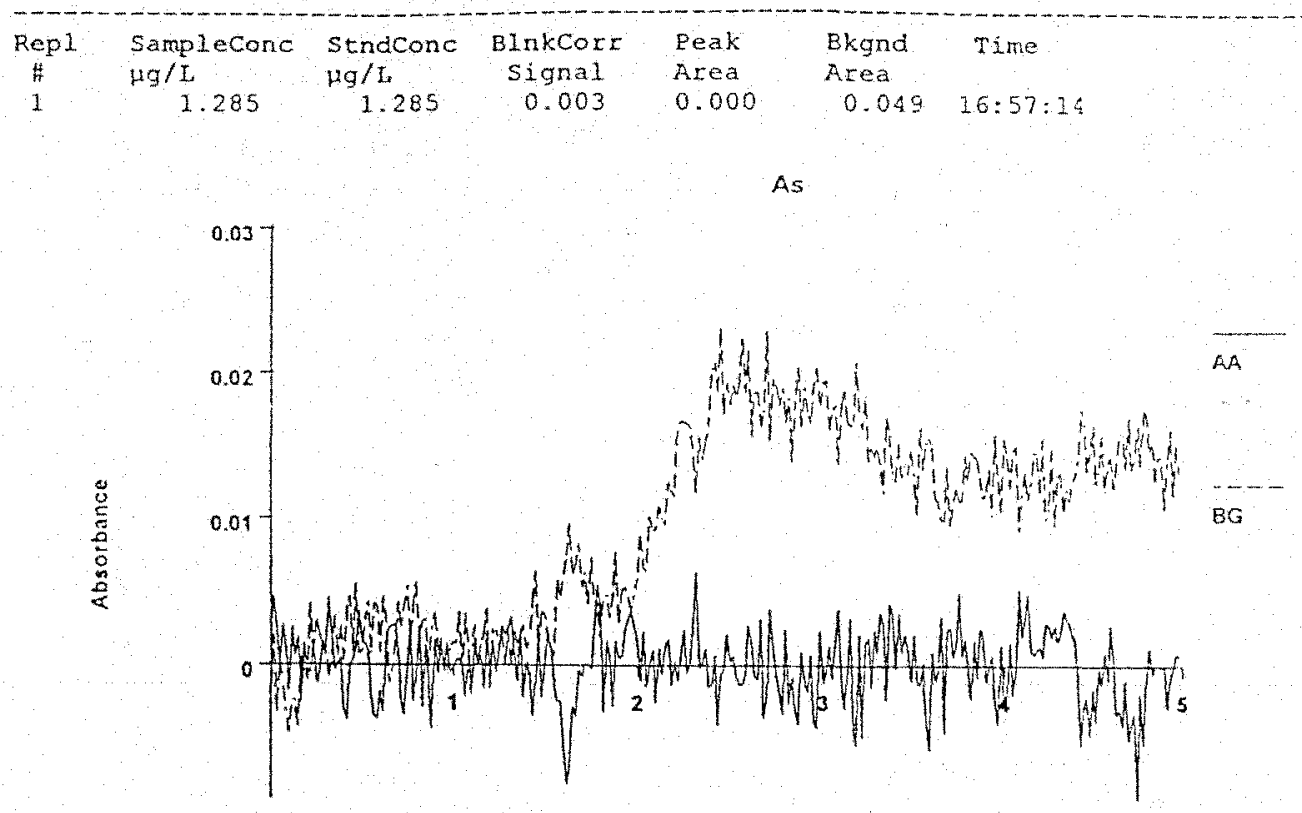

Time (seconds)

\begin{tabular}{|c|c|c|c|c|c|c|}
\hline \multicolumn{4}{|c|}{$\begin{array}{l}\text { Element: As Date: 05/04/1998 } \\
\text { Sample ID: soilfblank:50 }\end{array}$} & & & \\
\hline $\begin{array}{l}\text { Repl } \\
\# \\
1 \\
1\end{array}$ & $\begin{array}{c}\text { SampleConc } \\
\mathrm{Hg} / \mathrm{L} \\
0.068\end{array}$ & $\begin{array}{c}\text { StndConc } \\
\mathrm{Hg} / \mathrm{L} \\
0.068\end{array}$ & $\begin{array}{c}\text { BlnkCorr } \\
\text { Signal } \\
0.000\end{array}$ & $\begin{array}{c}\text { Peak } \\
\text { Area } \\
-0.003\end{array}$ & $\begin{array}{l}\text { Bkgnd } \\
\text { Area } \\
0.055\end{array}$ & $16: 49: 18$ \\
\hline
\end{tabular}

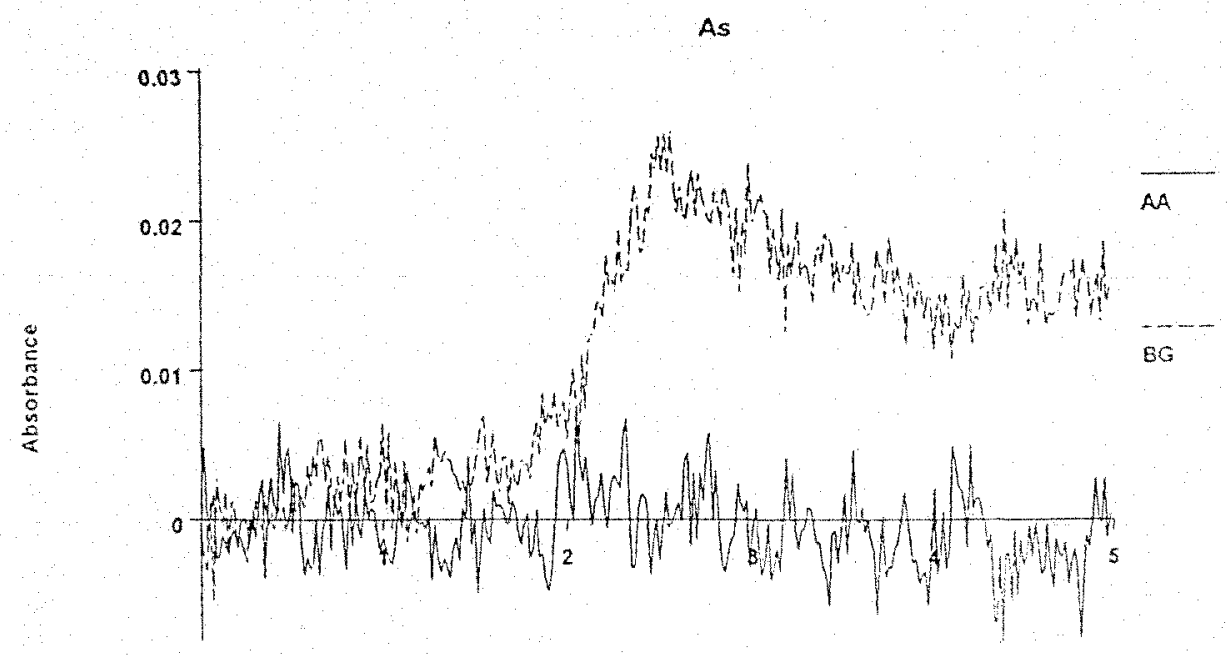

Time (seconds) 


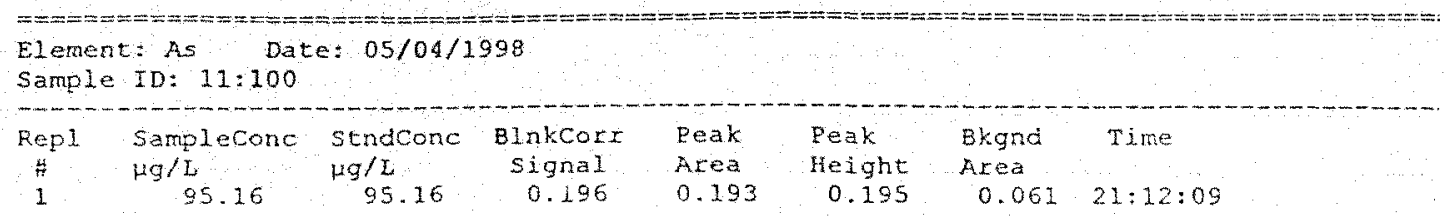

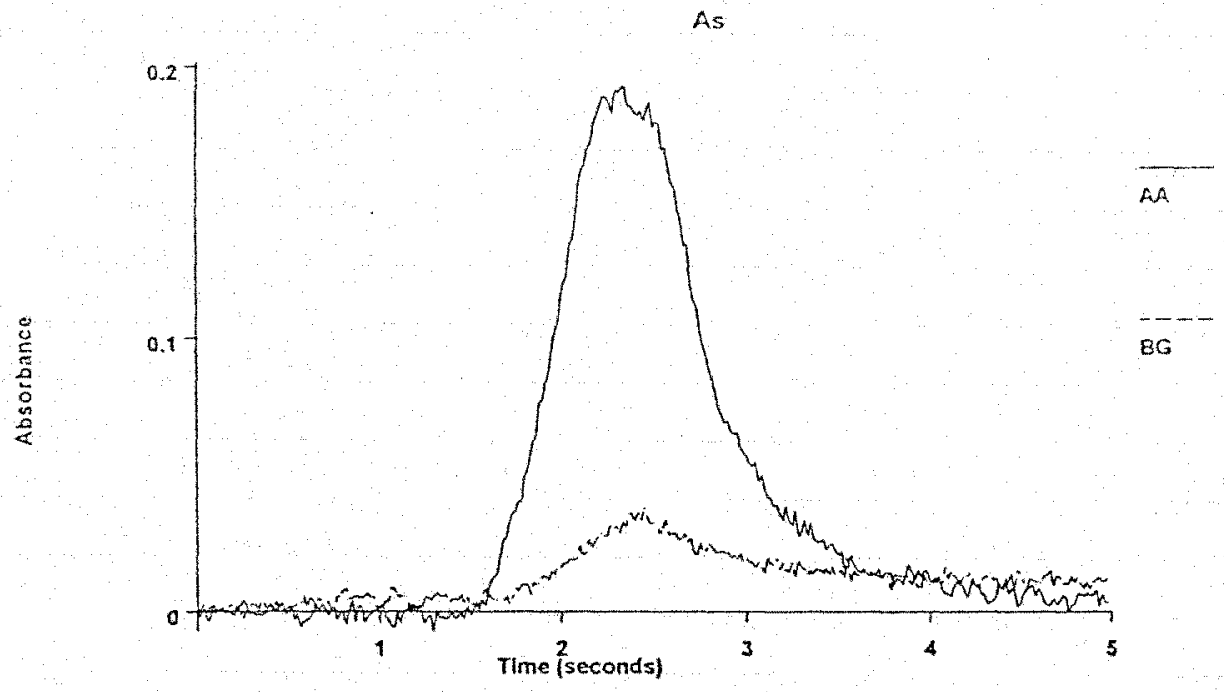

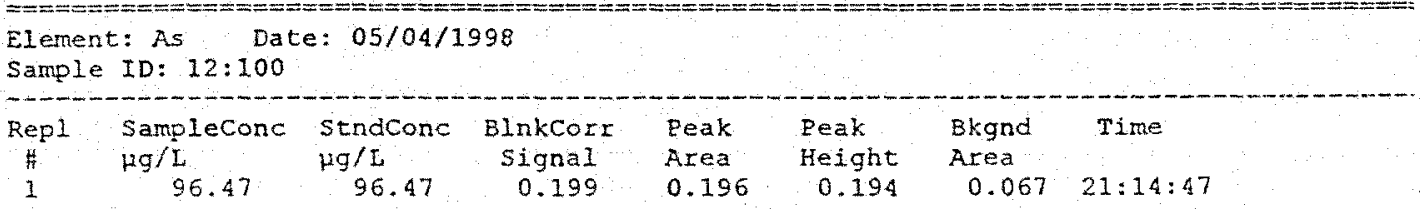

As

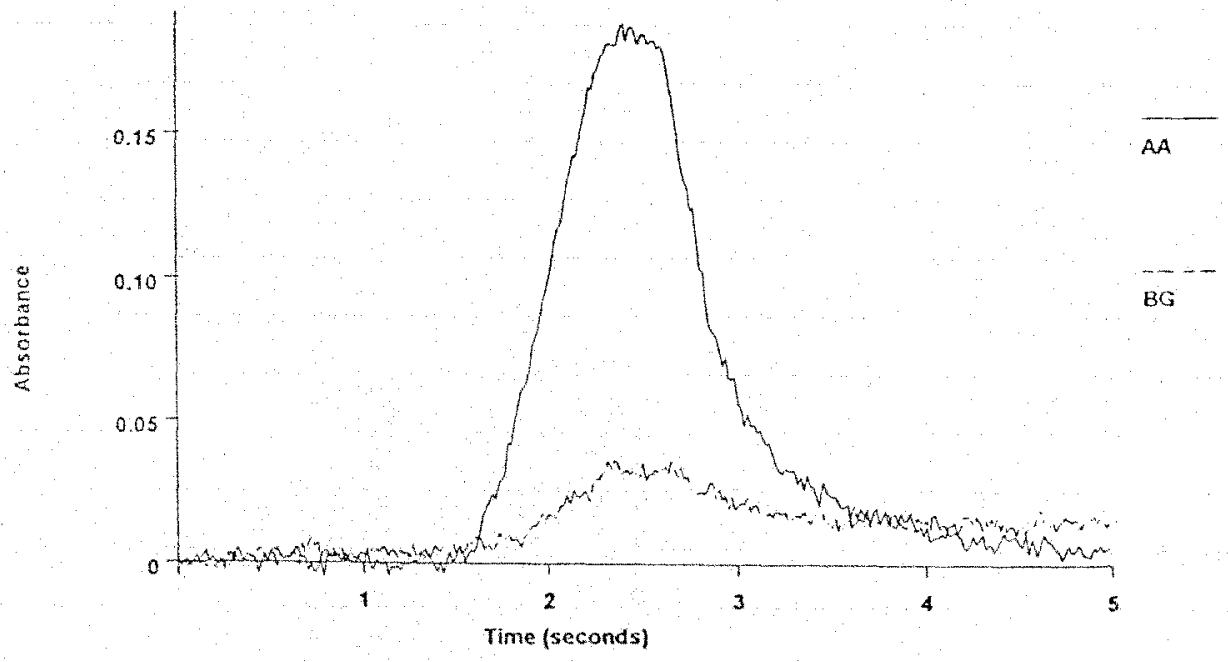


Element: As Date: 05/04/1998

Sample ID: 22:100

\begin{tabular}{|c|c|c|c|c|c|c|c|}
\hline $\begin{array}{l}\text { Repl } \\
\# \\
2\end{array}$ & $\begin{array}{l}\text { Sampleconc } \\
\mu g / L \\
96.10\end{array}$ & $\begin{array}{c}\text { StndConc } \\
\mu g / L \\
96.10\end{array}$ & $\begin{array}{c}\text { Blnkcor } \\
\text { signal } \\
0.198\end{array}$ & $\begin{array}{l}\text { Peak } \\
\text { Area } \\
0.195\end{array}$ & $\begin{array}{l}\text { Peak } \\
\text { Height } \\
0.220\end{array}$ & $\begin{array}{l}\text { Bkgnd } \\
\text { Area } \\
0.060\end{array}$ & $\begin{array}{l}\text { Time } \\
21: 20: 07\end{array}$ \\
\hline
\end{tabular}

As

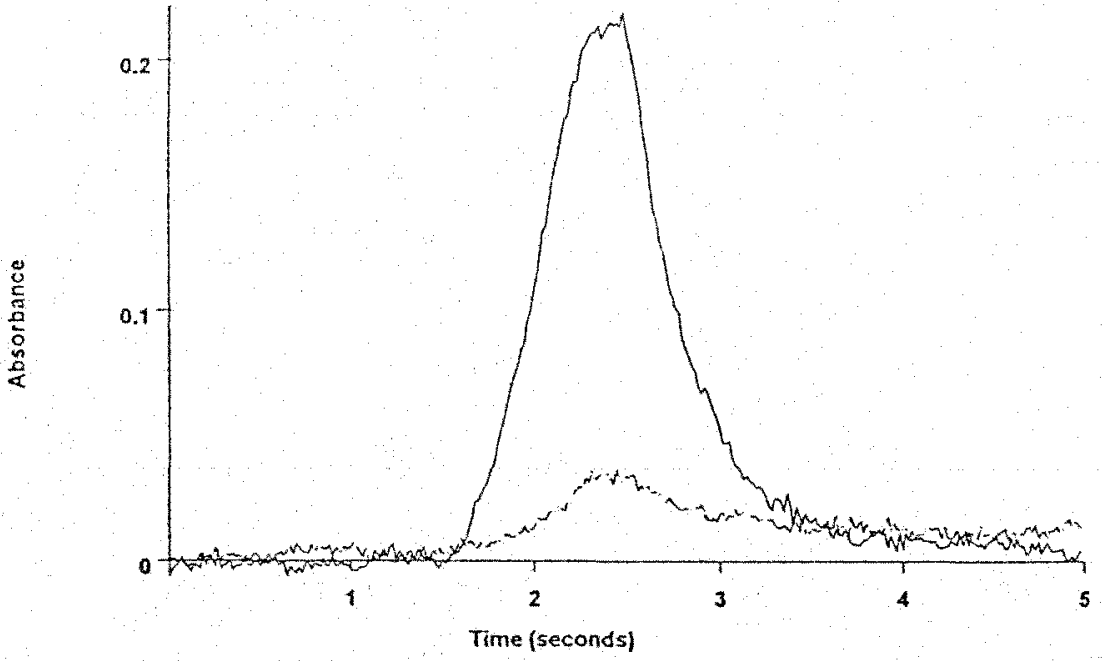

AA.

$\mathrm{BG}$

\begin{tabular}{|c|c|c|c|c|c|c|c|}
\hline $\begin{array}{l}\text { Elemen } \\
\text { Sample }\end{array}$ & $\begin{array}{l}\text { E: Dat } \\
\text { ID: } 31: 100\end{array}$ & e: $05 / 04 / 1$ & 998 & & & & \\
\hline $\begin{array}{c}\text { Repl } \\
\text { \# } \\
1\end{array}$ & $\begin{array}{l}\text { Sampleconc } \\
\mu g / L \\
99.17\end{array}$ & $\begin{array}{l}\text { StndCone } \\
\mu g / L \\
99.48\end{array}$ & $\begin{array}{c}\text { BinkCorr } \\
\text { Signal } \\
0.204\end{array}$ & $\begin{array}{l}\text { Peak } \\
\text { Area } \\
0.202\end{array}$ & $\begin{array}{l}\text { Peak } \\
\text { Height } \\
0.226\end{array}$ & $\begin{array}{l}\text { Bkgnd } \\
\text { Area } \\
0.062\end{array}$ & $\begin{array}{l}\text { Time } \\
21: 22: 48\end{array}$ \\
\hline
\end{tabular}

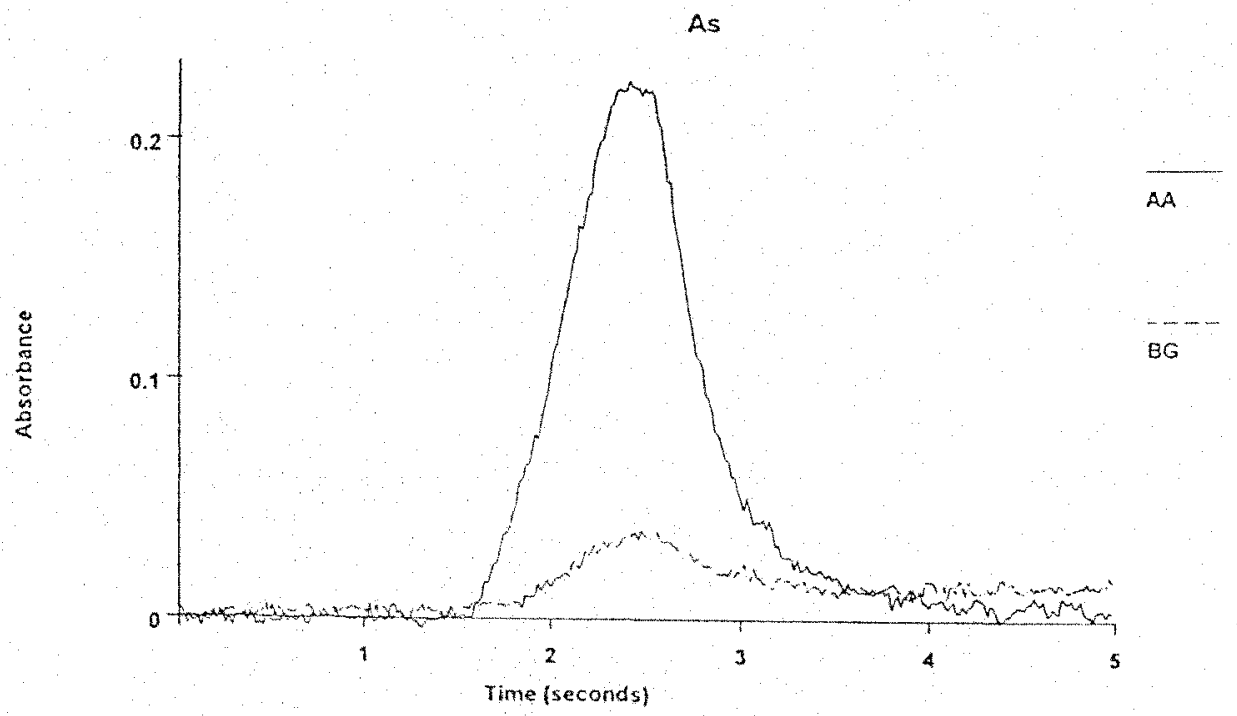




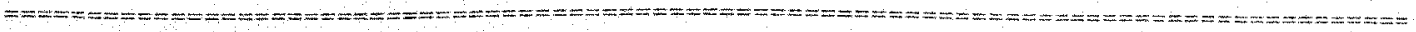

Element: As Date: $05 / 04 / 1998$

Sample ID: $21: 100$

\begin{tabular}{|c|c|c|c|c|c|c|c|}
\hline $\begin{array}{l}\operatorname{Rep} 1 \\
4 \\
1\end{array}$ & $\begin{array}{l}\text { Sampleconc } \\
19 / \mathrm{I} \\
97.97\end{array}$ & $\begin{array}{l}\text { StridConc } \\
\mathrm{Hg} / \mathrm{L} \\
\quad 97.97\end{array}$ & $\begin{array}{c}\text { BlnkCor } \\
\text { signal } \\
0.202\end{array}$ & $\begin{array}{l}\text { Peak } \\
\text { Area } \\
0.199\end{array}$ & $\begin{array}{l}\text { Peak } \\
\text { Height } \\
0.215\end{array}$ & $\begin{array}{l}\text { Bkgred } \\
\text { A.tea } \\
0.059\end{array}$ & $21: 37: 27$ \\
\hline
\end{tabular}

As

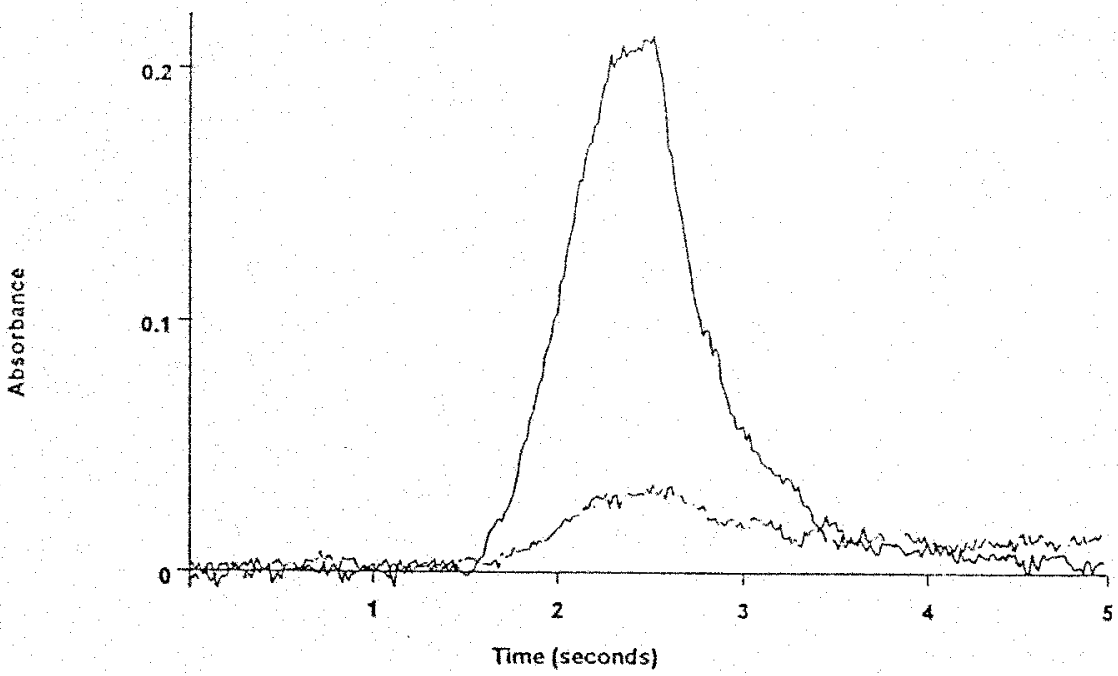

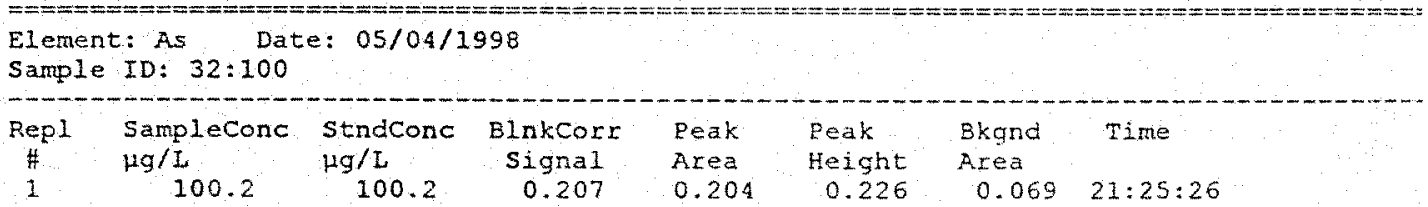

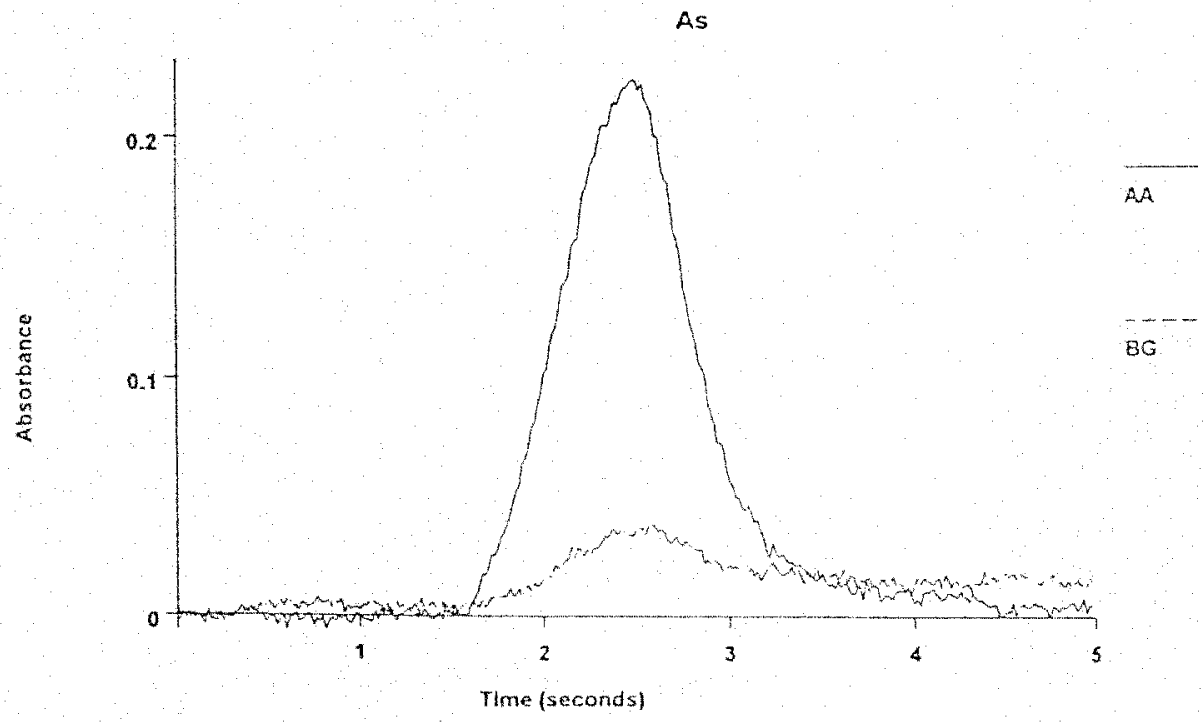




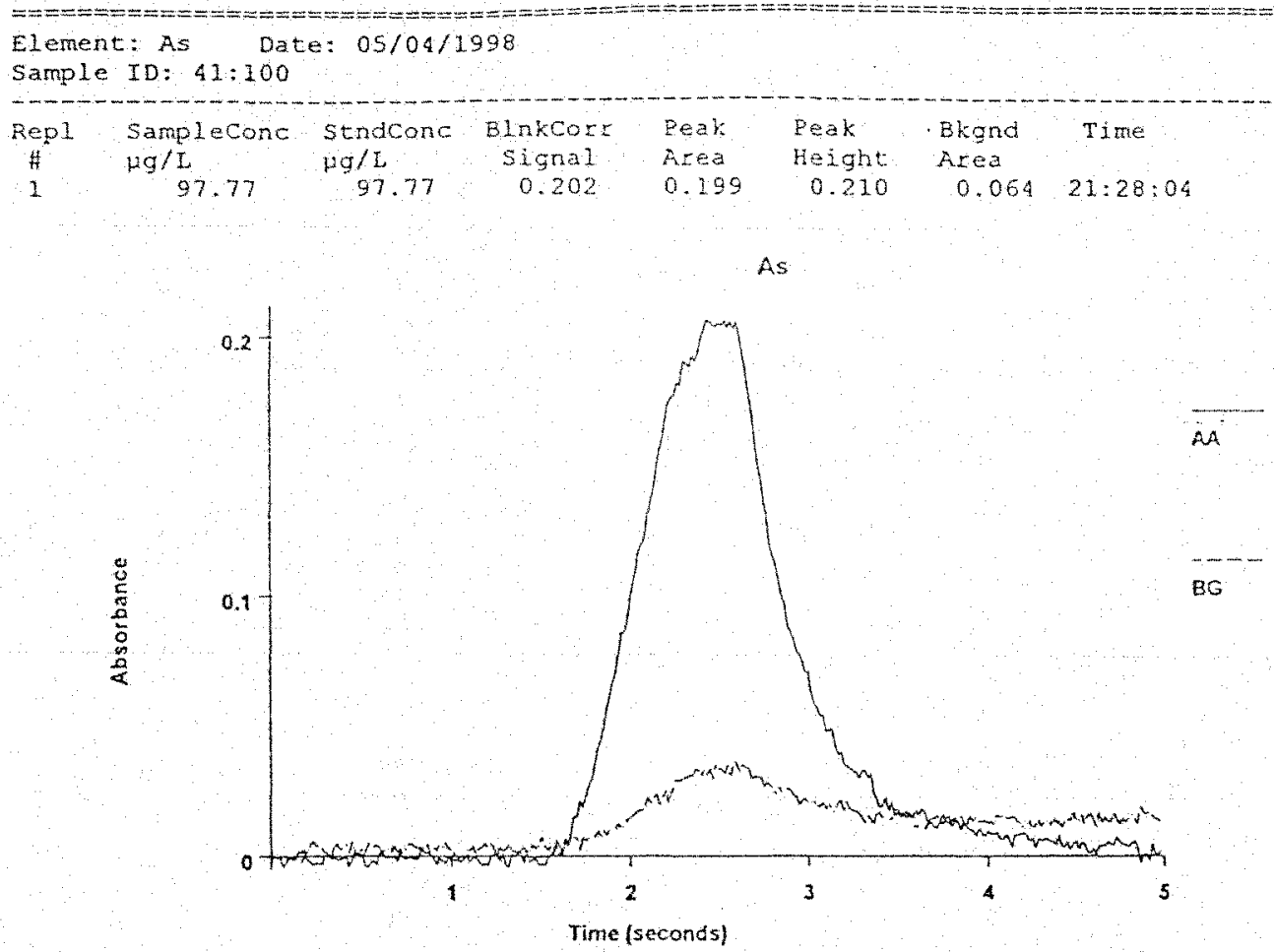

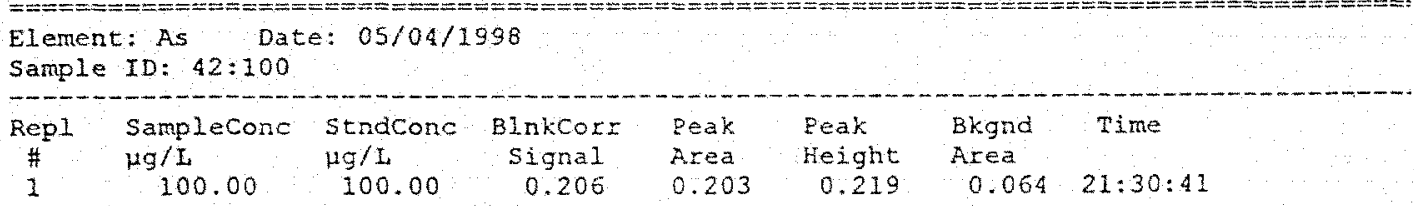

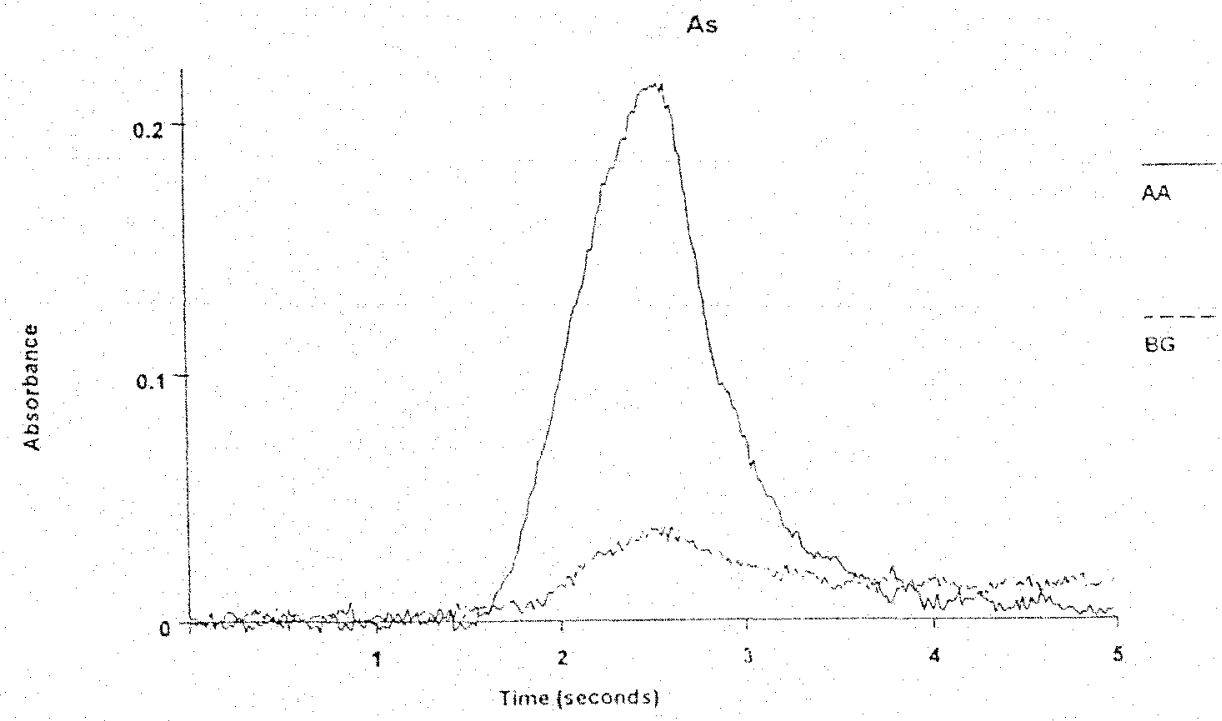




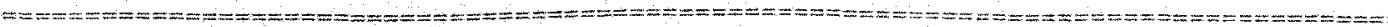
Element: As Date: 05/04/1998

Sample ID: $51: 200$

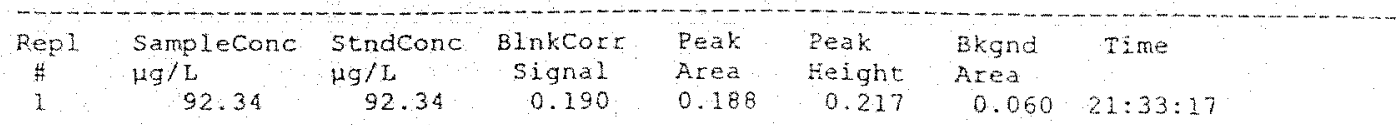

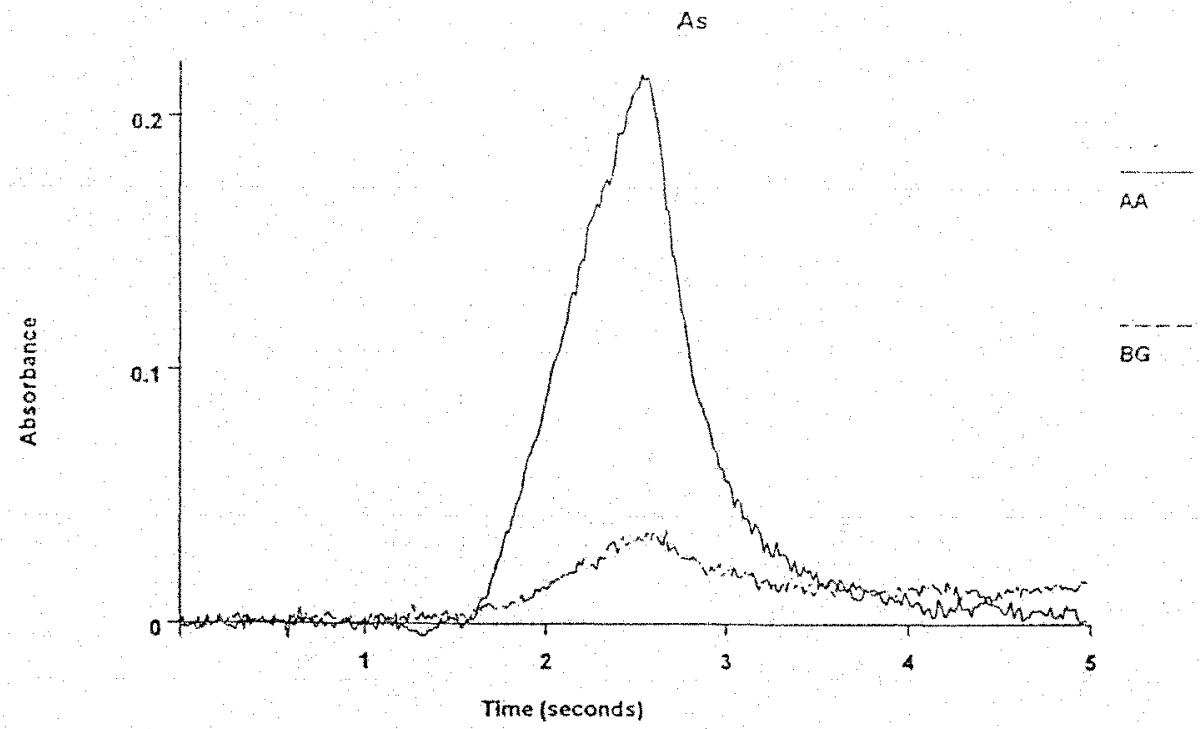




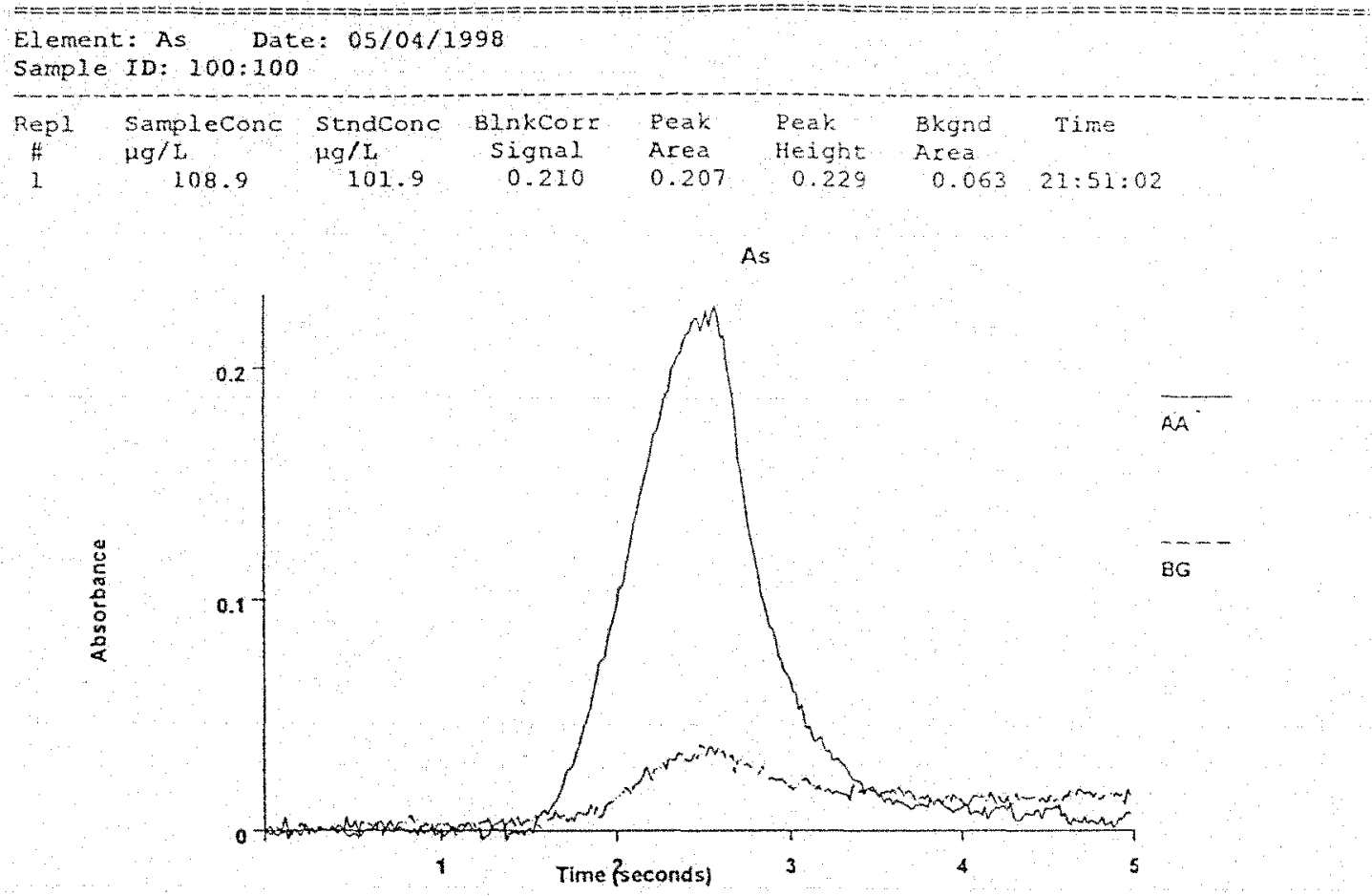

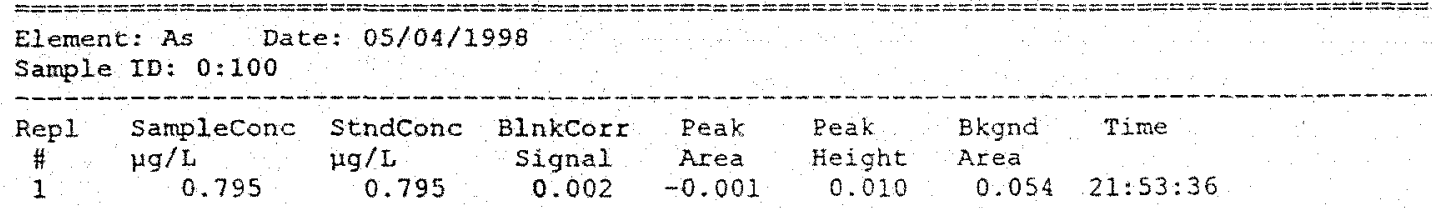

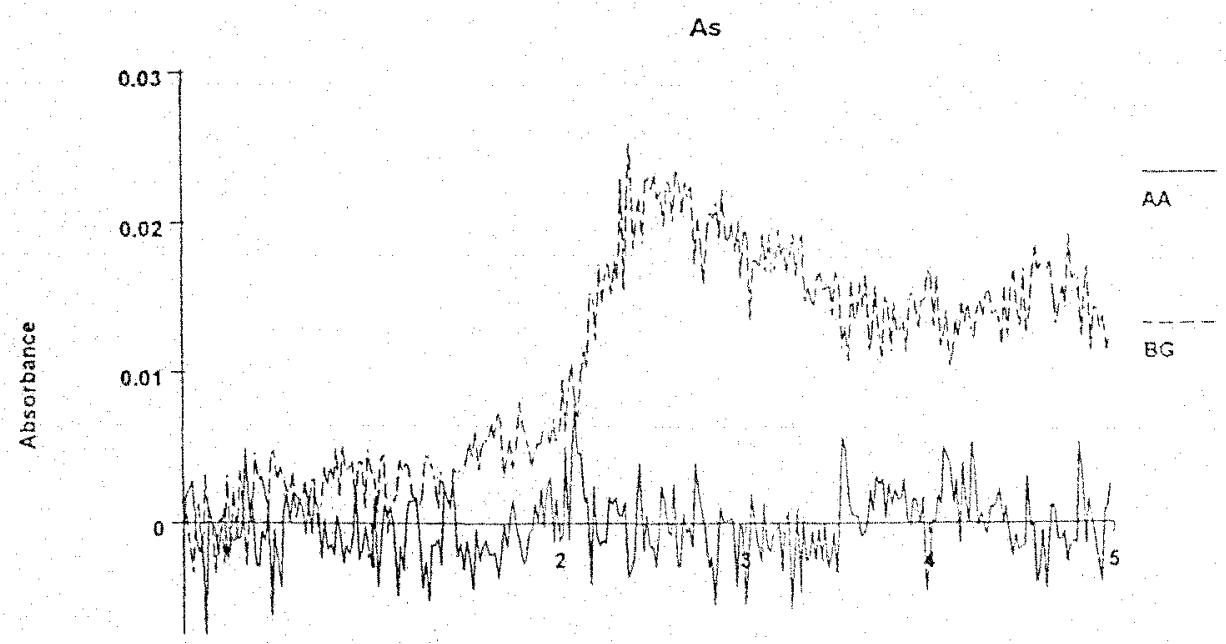

Time (seconds) 


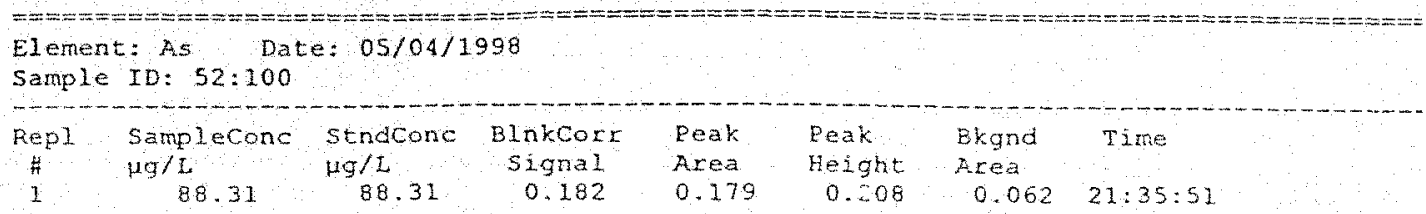

As

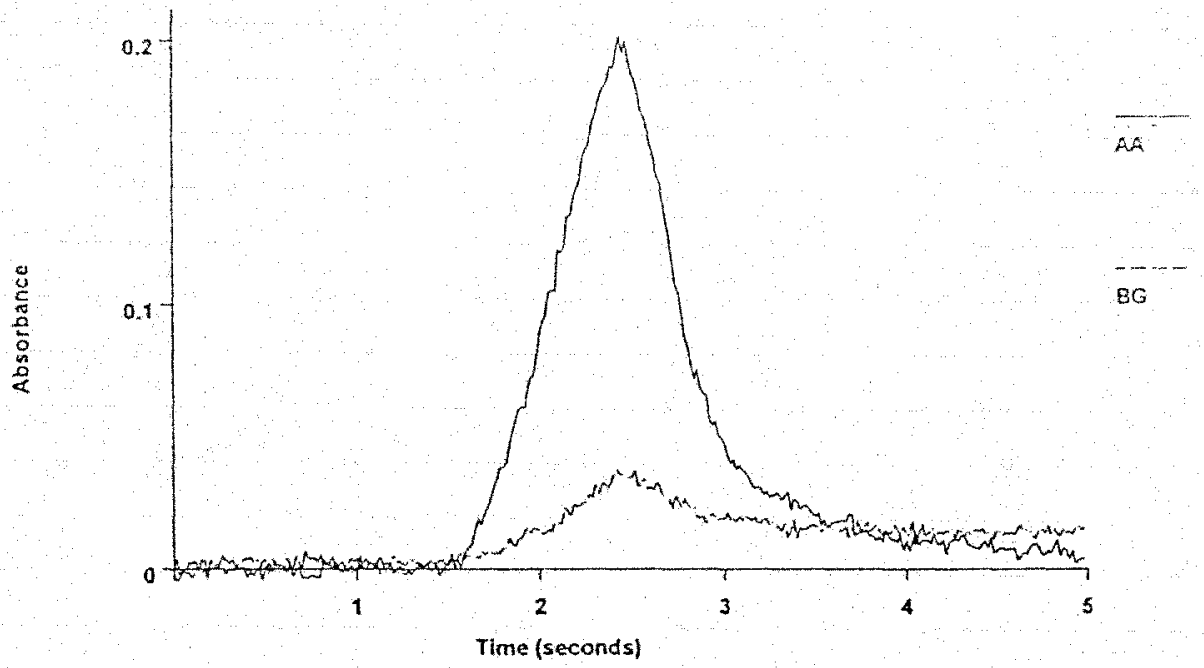

\begin{tabular}{|c|c|c|c|c|c|c|}
\hline $\begin{array}{l}\text { Element: As Dat } \\
\text { sample ID: soillbi }\end{array}$ & $\begin{array}{l}05 / 04 / 1 \\
\text { ank: } 100\end{array}$ & 98 & & & & \\
\hline $\begin{array}{c}\text { Repl Samplecone } \\
\frac{\mu g / L}{2} \\
1\end{array}$ & $\begin{array}{l}\text { stndconc } \\
\mathrm{Hg} / \mathrm{L} \\
2.358\end{array}$ & $\begin{array}{c}\text { BInkCorr } \\
\text { Signal } \\
0.005\end{array}$ & $\begin{array}{l}\text { Peak } \\
\text { Area } \\
0.002\end{array}$ & $\begin{array}{l}\text { Peak } \\
\text { Height } \\
0.011\end{array}$ & $\begin{array}{l}\text { Bkgnd } \\
\text { Area } \\
0.050\end{array}$ & $\begin{array}{l}\text { Time } \\
21: 38: 24\end{array}$ \\
\hline
\end{tabular}

As

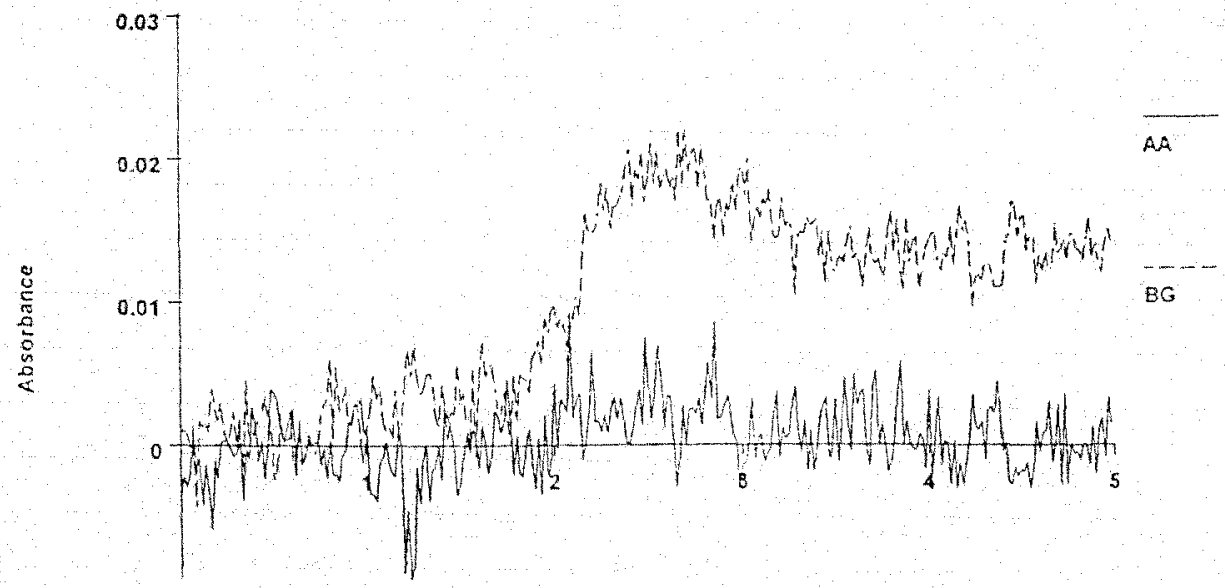

Tirne (seconds) 


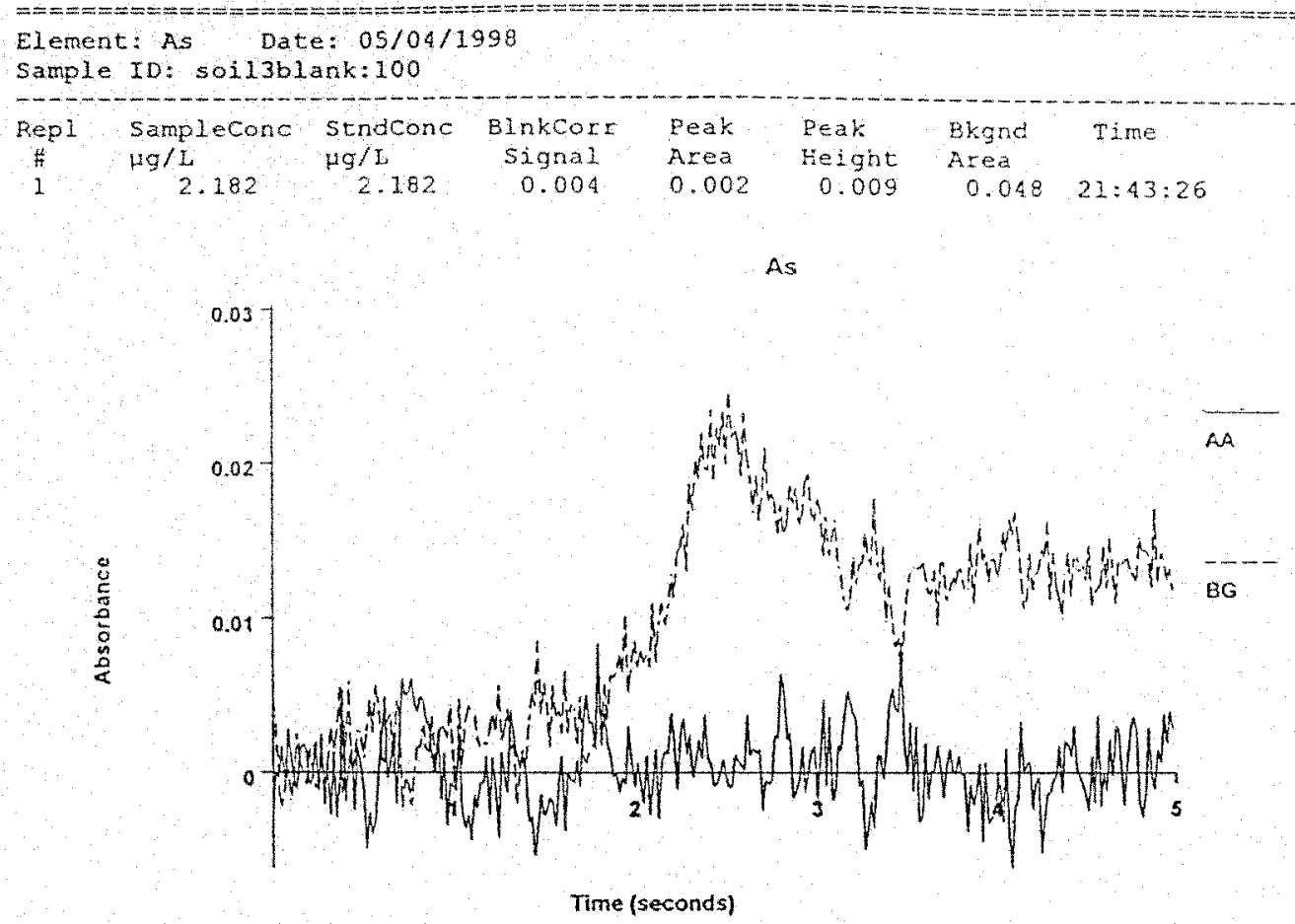

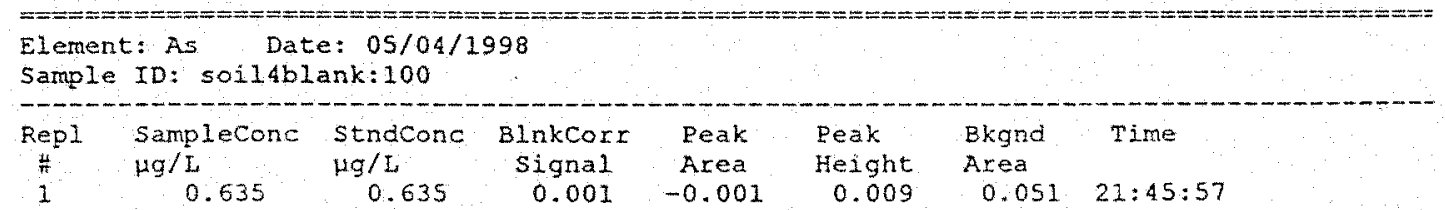

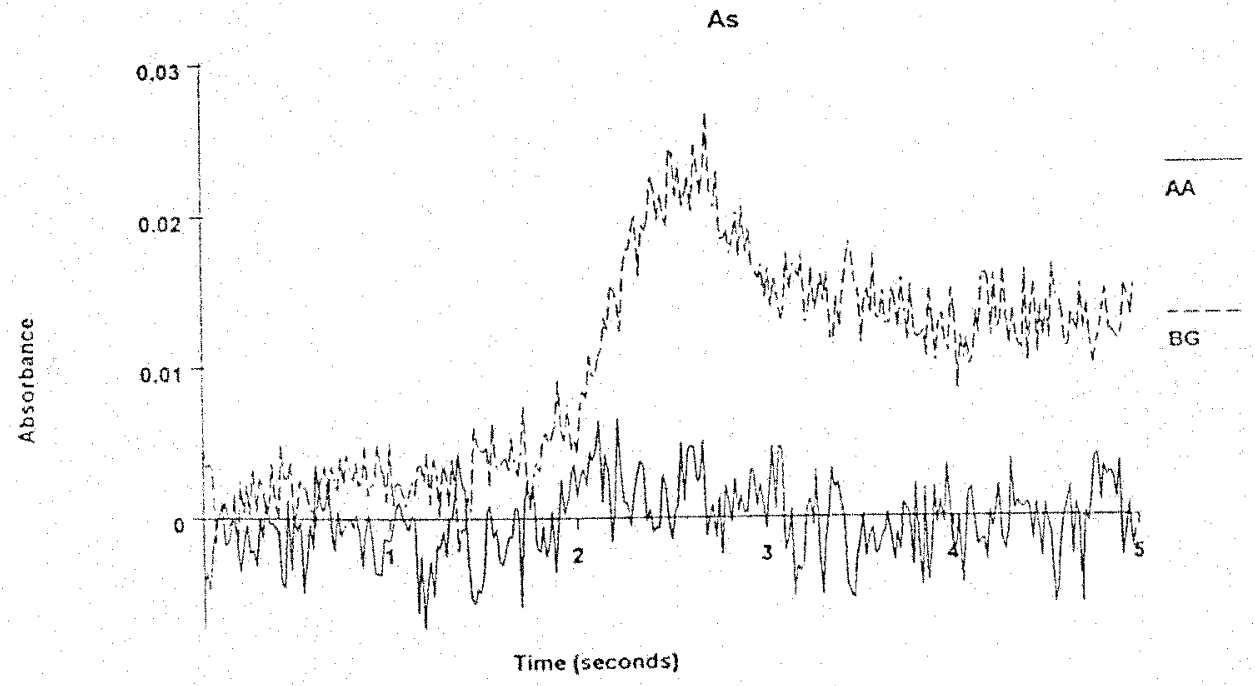




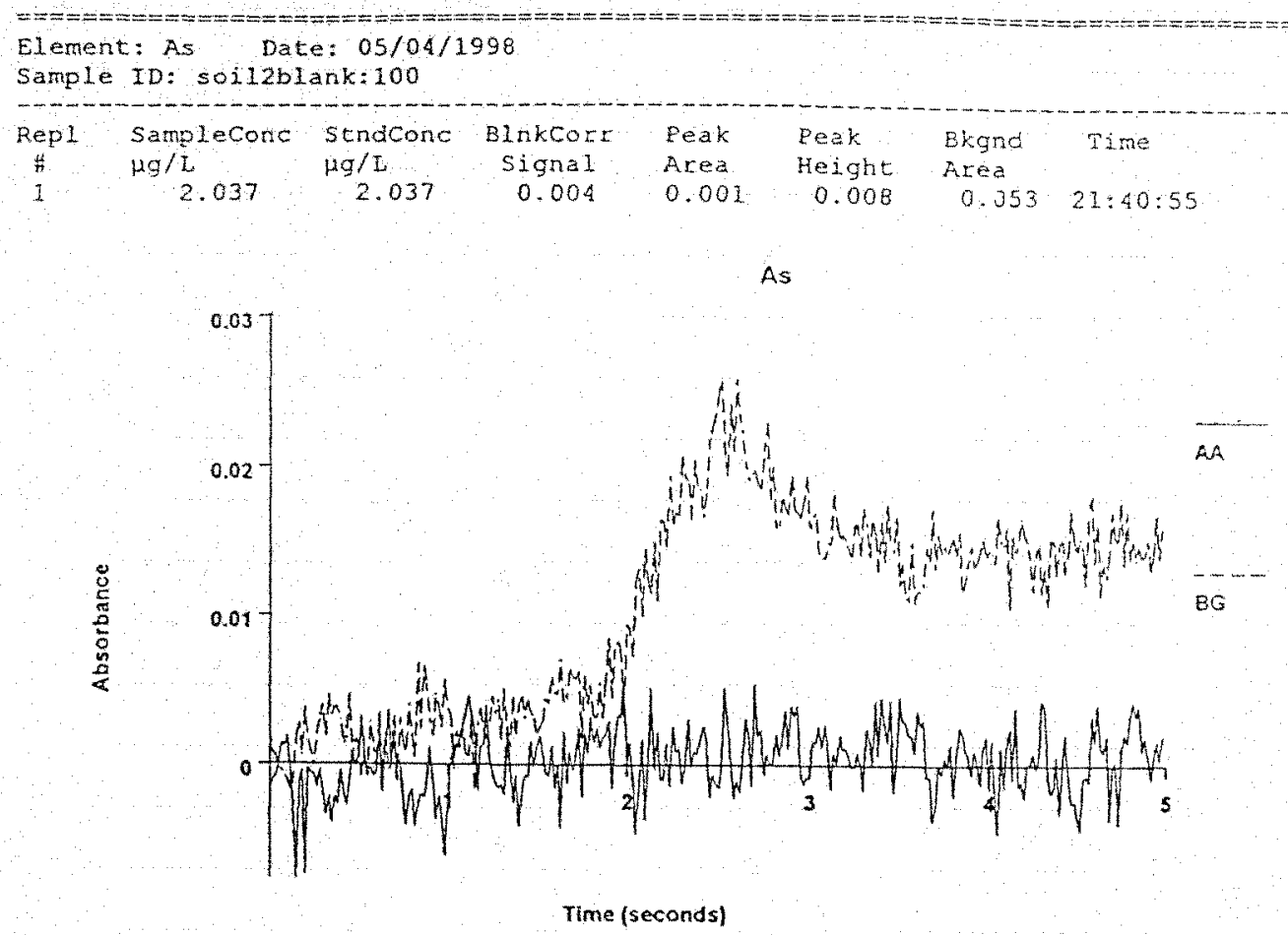

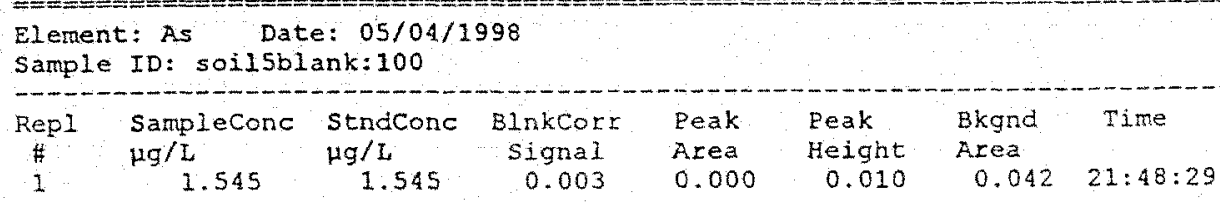

As

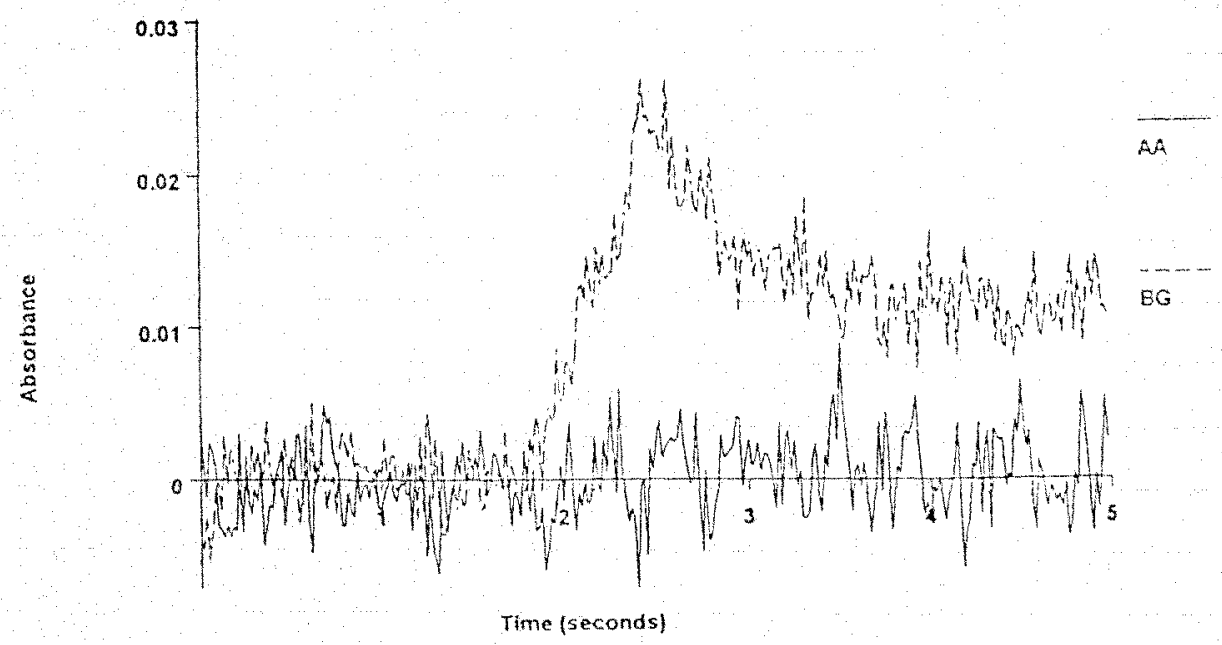




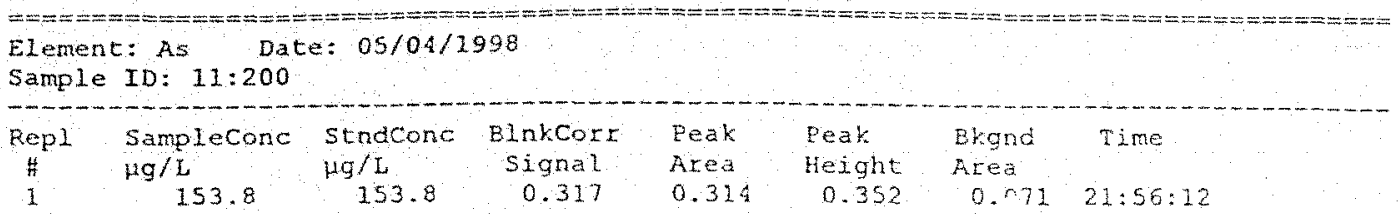

As

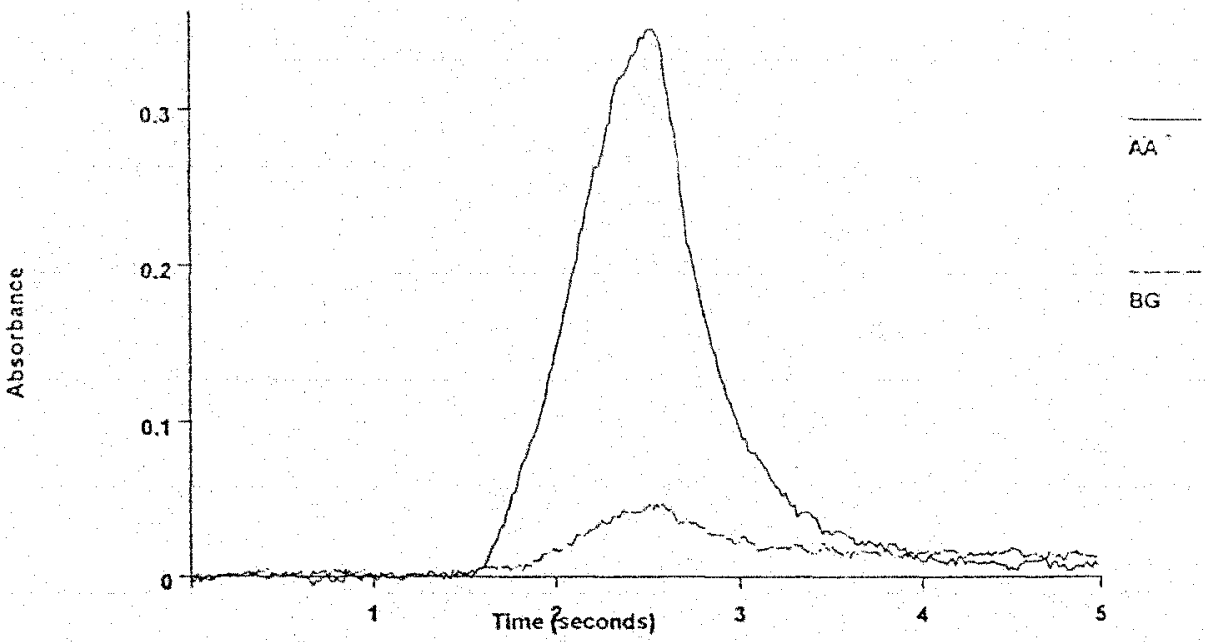

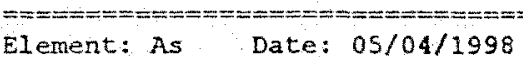

Sample ID: 12:200

\begin{tabular}{|c|c|c|c|c|c|c|c|}
\hline $\begin{array}{l}\text { Rep } 1 \\
4 \\
I\end{array}$ & $\begin{array}{l}\text { SampleConc } \\
\mu g / L \\
149.9\end{array}$ & $\begin{array}{c}\text { StndConc } \\
\mu \mathrm{g} / \mathrm{L} \\
149.9\end{array}$ & $\begin{array}{c}\text { Blnkcorr } \\
\text { Signal } \\
0.309\end{array}$ & $\begin{array}{l}\text { Peak } \\
\text { Area } \\
0.306\end{array}$ & $\begin{array}{l}\text { Peak } \\
\text { Height } \\
0.347\end{array}$ & $\begin{array}{l}\text { Bkgnd } \\
\text { Area } \\
0.066\end{array}$ & $\begin{array}{l}\text { Time } \\
21: 58: 49\end{array}$ \\
\hline
\end{tabular}

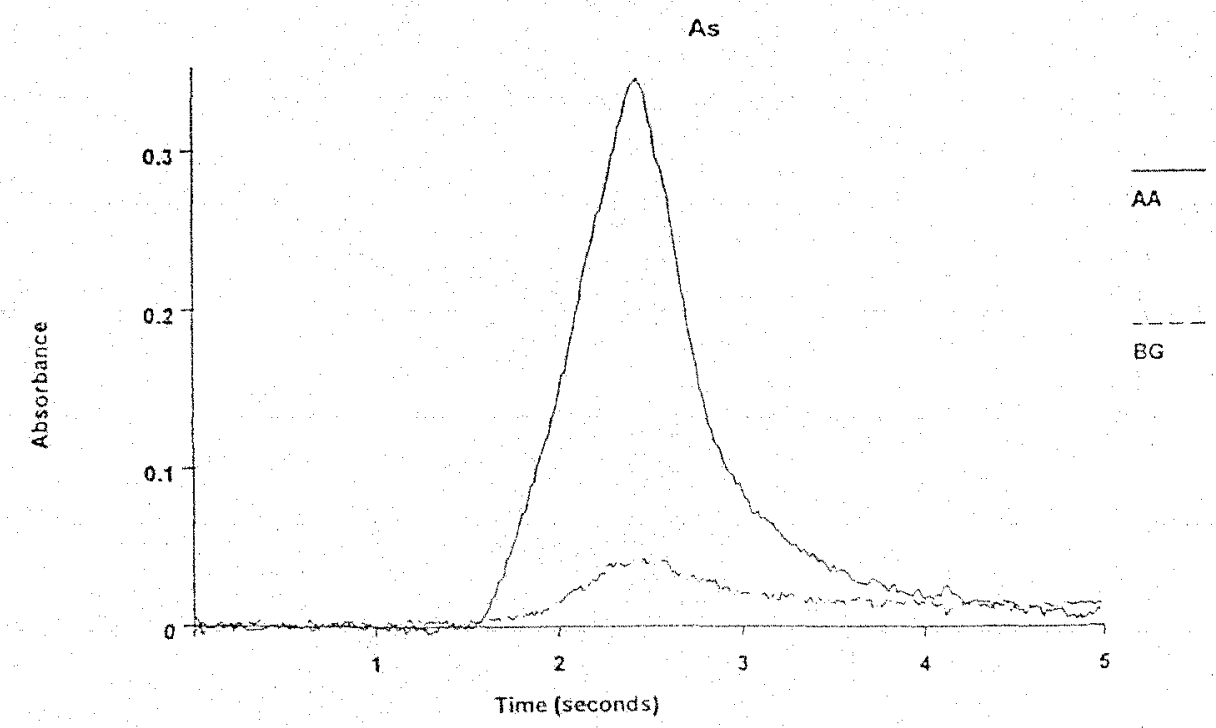




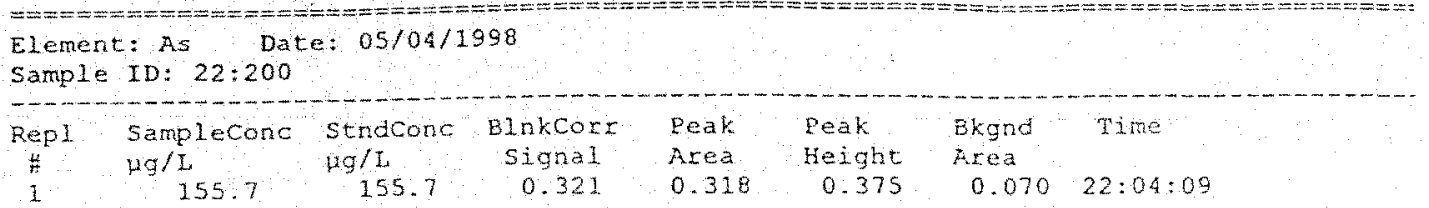

As

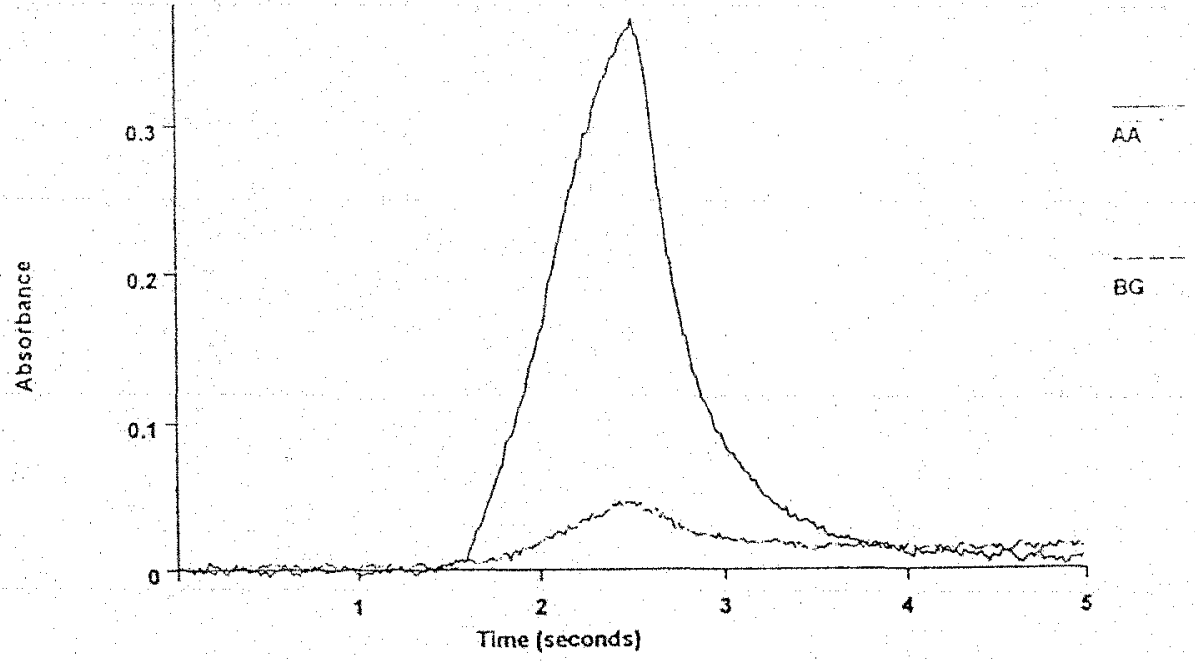

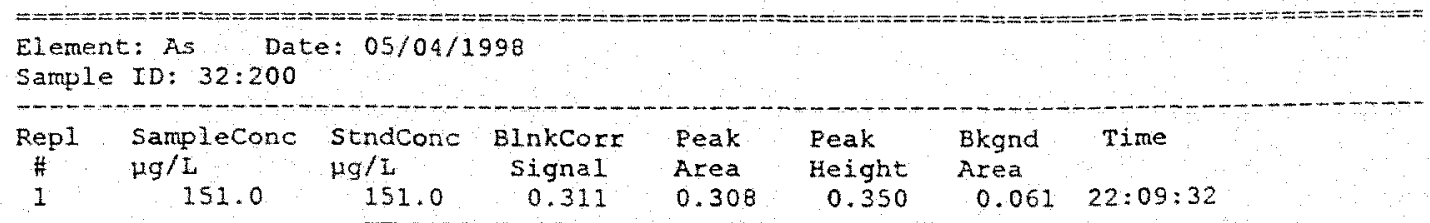

As

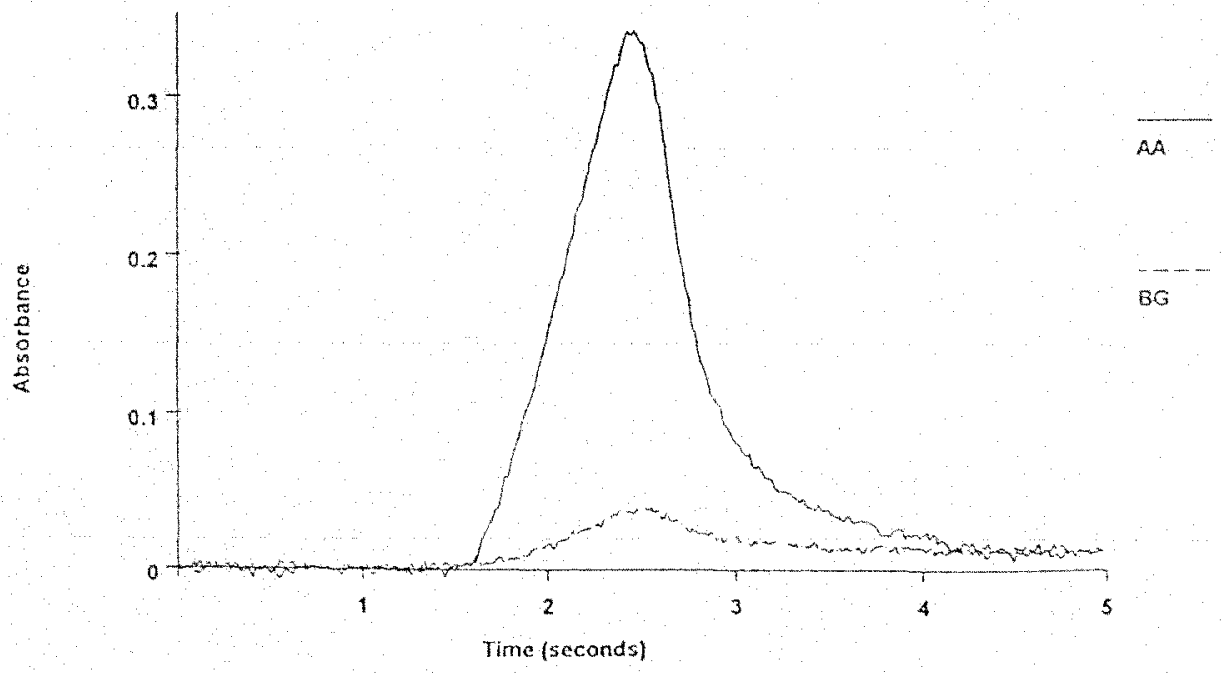



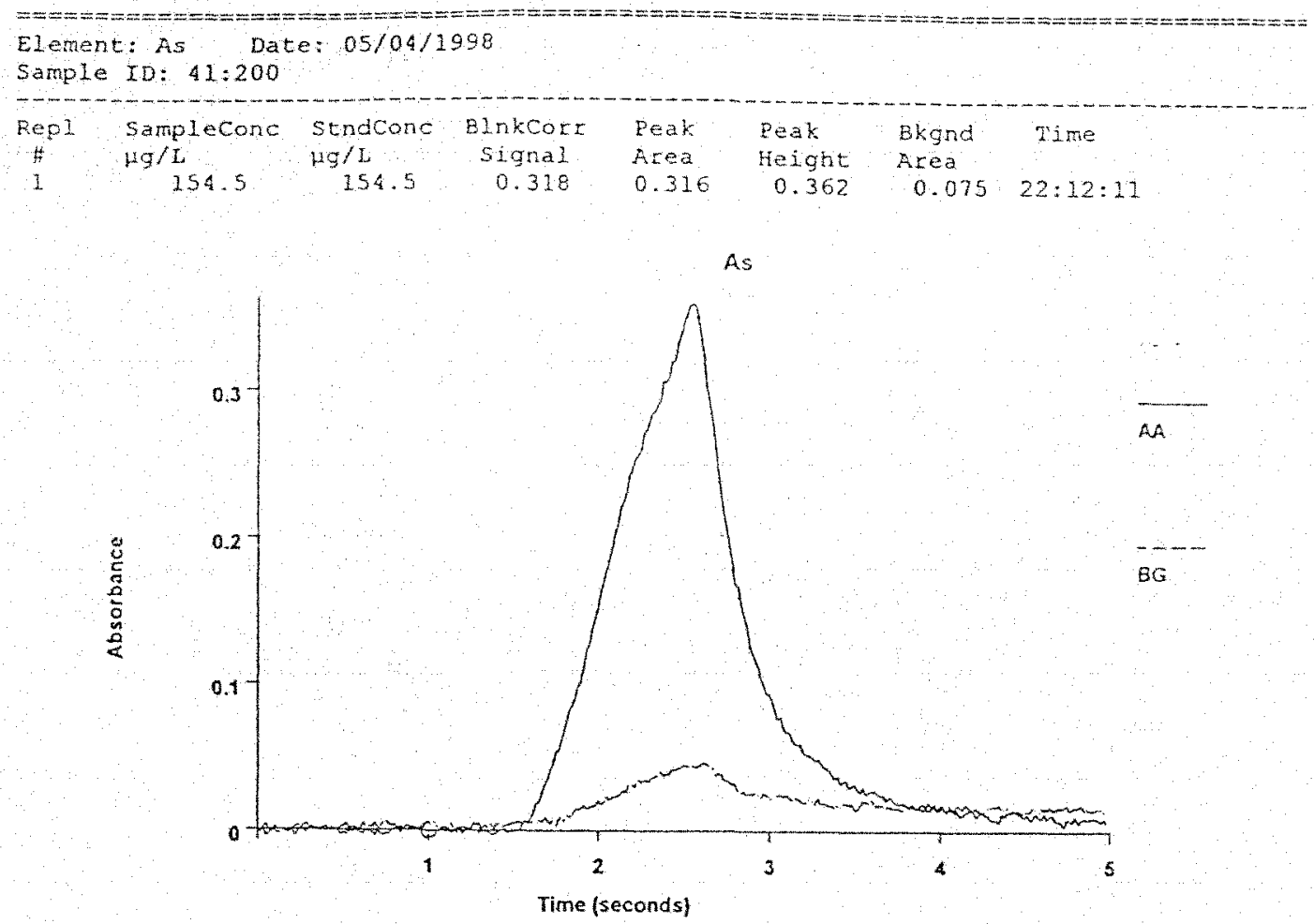

\begin{tabular}{|c|c|c|c|c|c|c|}
\hline $\begin{array}{l}\text { Element } \\
\text { Sample }\end{array}$ & $\begin{array}{l}\text { As } \\
\text { ID: } 51: 200\end{array}$ & $=05 / 04 / 1998$ & & & & \\
\hline $\begin{array}{l}\text { Rep } 1 \\
1 \\
1\end{array}$ & $\begin{array}{l}\text { Sampleconc } \\
\qquad g / \mathrm{L} \\
149.3\end{array}$ & $\begin{array}{lc}\text { StndConc: BlnkCort } \\
\mu g / L \\
149.3 & 0.308\end{array}$ & $\begin{array}{l}\text { Reak } \\
\text { Afea } \\
0.305\end{array}$ & $\begin{array}{l}\text { Peak } \\
\text { Hejght } \\
0.372\end{array}$ & $\begin{array}{l}\text { Bkgnd } \\
\text { Area } \\
0.069\end{array}$ & $\begin{array}{l}\text { Time } \\
22: 17: 24\end{array}$ \\
\hline
\end{tabular}

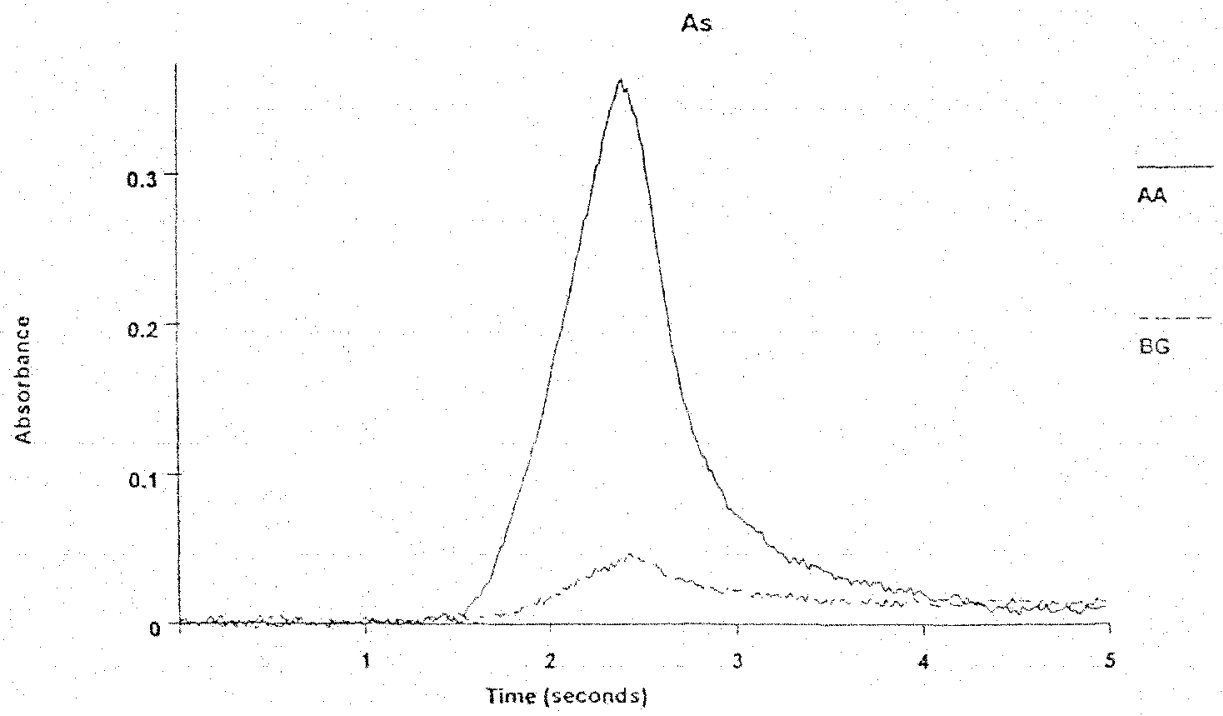




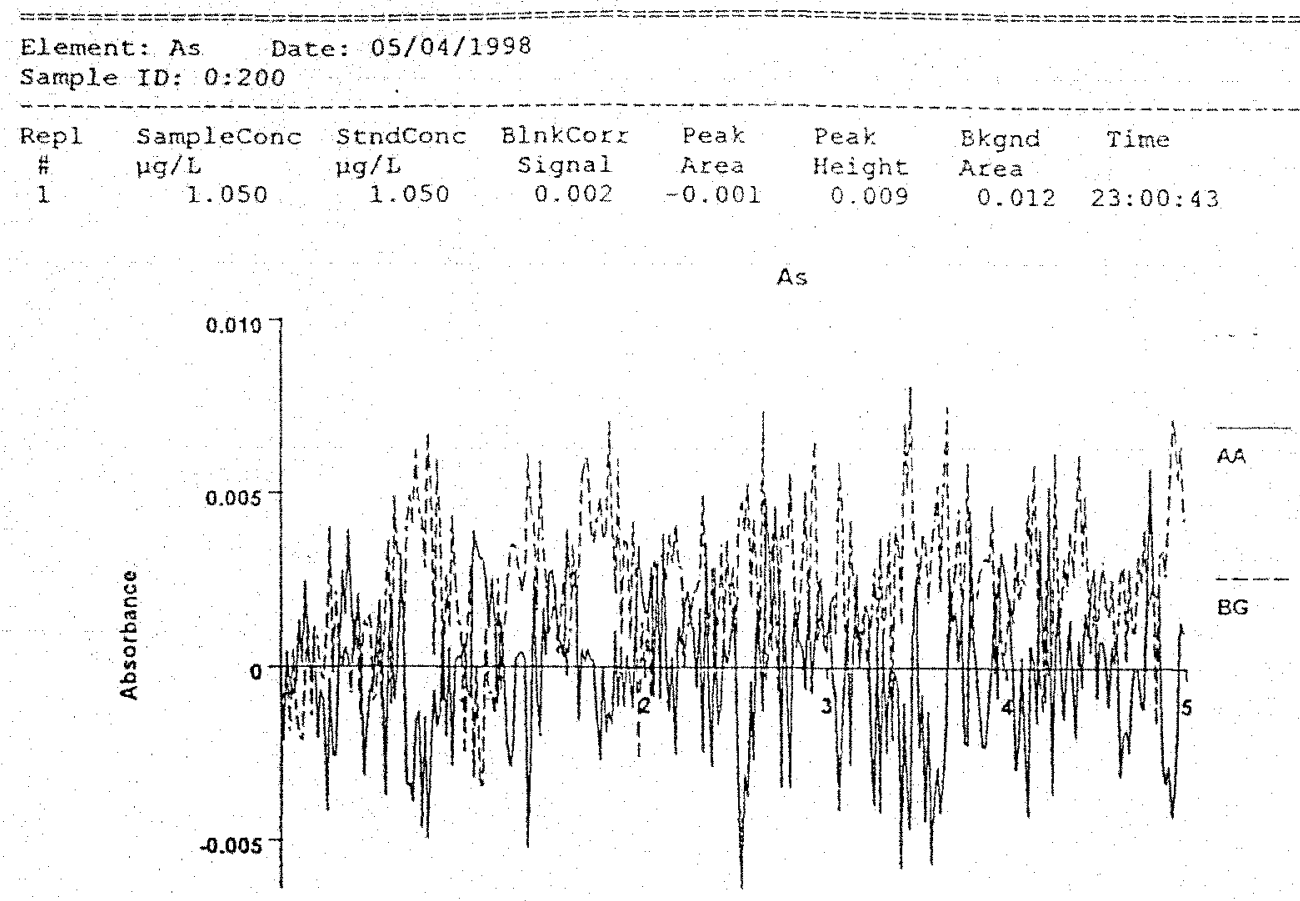

Time (seconds)

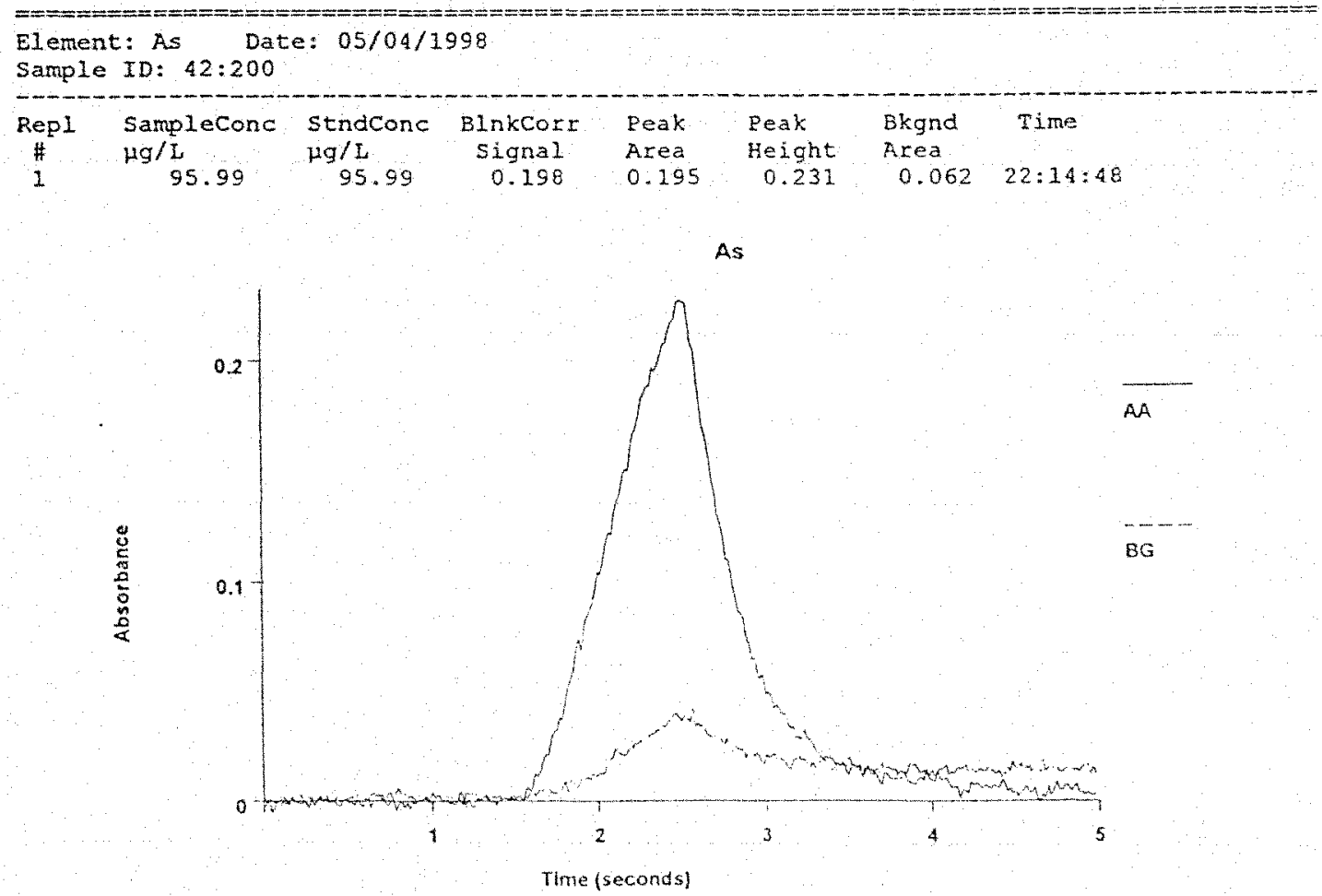




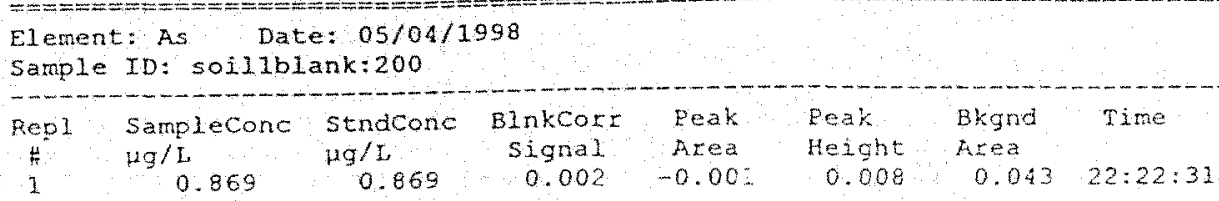

As

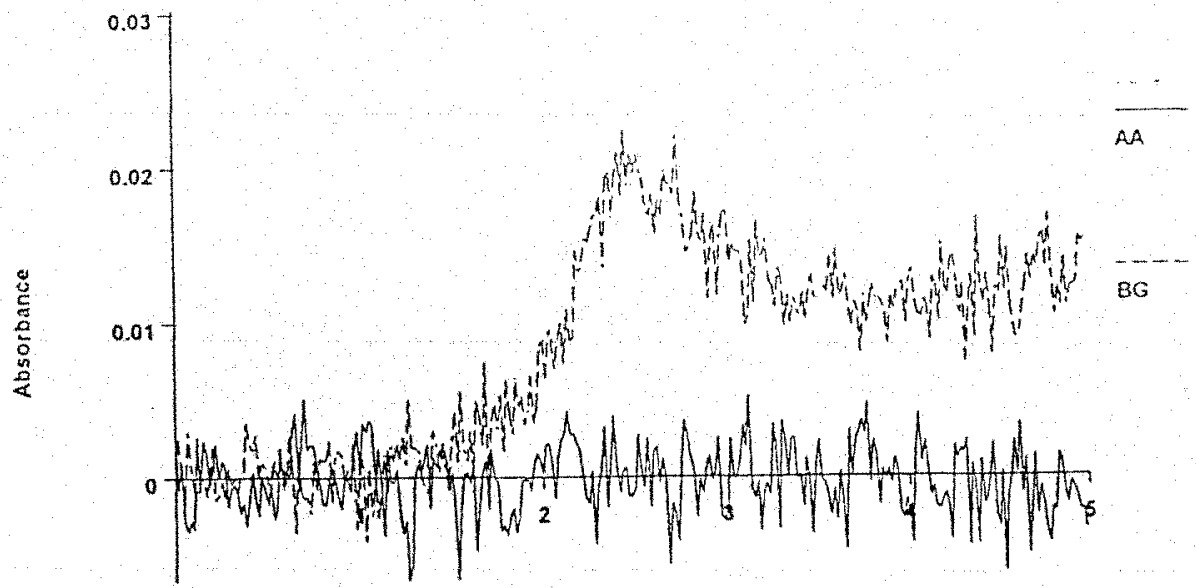

Time (seconds)

\begin{tabular}{|c|c|c|c|c|c|c|c|}
\hline $\begin{array}{l}\text { Elem } \\
\text { Samp }\end{array}$ & $\begin{array}{l}\text { As Dat } \\
\text { ID: } 52: 200\end{array}$ & e: $05 / 04 /$ & 998 & & & & \\
\hline $\begin{array}{c}\text { Rep1 } \\
\# \\
1\end{array}$ & $\begin{array}{l}\text { Sampleconc } \\
\mu \mathrm{g} / \mathrm{I} \\
88.19\end{array}$ & $\begin{array}{c}\text { stndCone } \\
\mu g / L \\
88.19\end{array}$ & $\begin{array}{c}\text { BlnkCorr } \\
\text { Signal } \\
0.182\end{array}$ & $\begin{array}{l}\text { Peak } \\
\text { Area } \\
0.179\end{array}$ & $\begin{array}{l}\text { Beak } \\
\text { Height } \\
0.207\end{array}$ & $\begin{array}{l}\text { Bkgnd } \\
\text { Area } \\
0.058\end{array}$ & Time \\
\hline
\end{tabular}

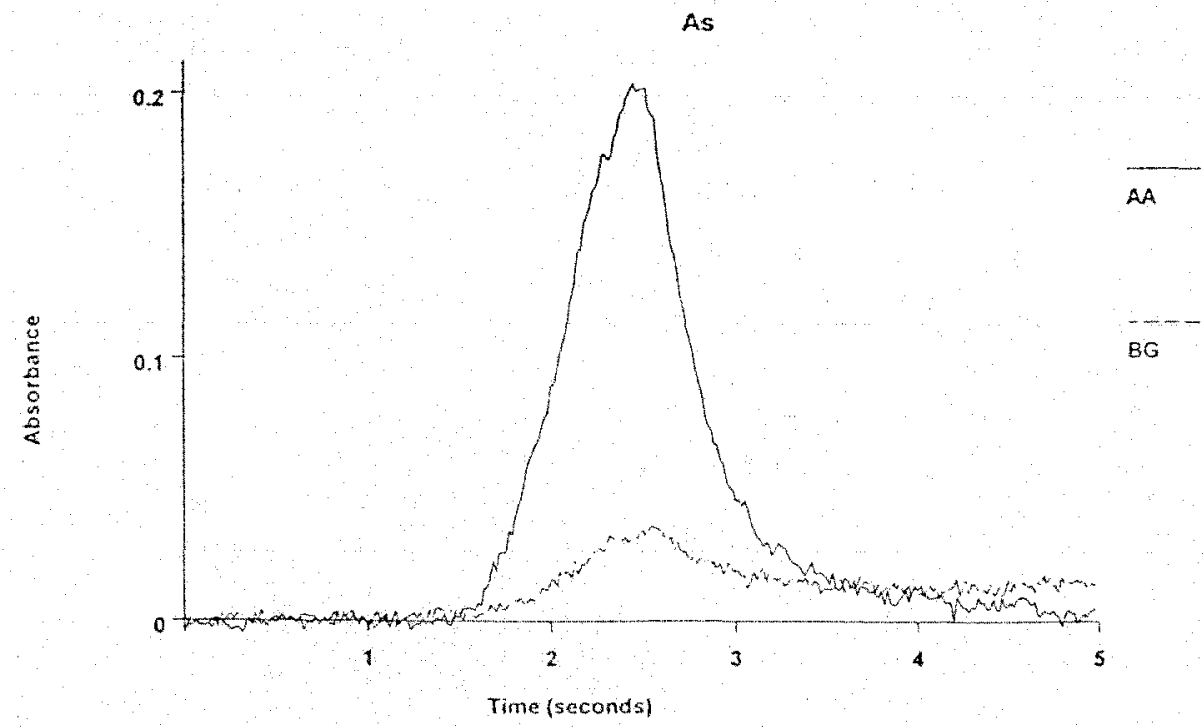


Element As Date $05 / 04 / 1998$

Sample ID: soli2blank:200

\begin{tabular}{|c|c|c|c|c|c|c|c|}
\hline Fepl & $\begin{array}{l}\text { Samp } 1 \text { econo } \\
\mu 9 / 1 \\
0.776\end{array}$ & $\begin{array}{c}\text { Stadcone } \\
1 \mathrm{~g} / \mathrm{L} \\
0.776\end{array}$ & $\begin{array}{c}\text { BlnkCort } \\
\text { Signal } \\
0.002\end{array}$ & $\begin{array}{l}\text { Peak } \\
\text { Area } \\
-0.001\end{array}$ & $\begin{array}{l}\text { Peak } \\
\text { Height } \\
0.008\end{array}$ & $\begin{array}{l}\text { Ekgnd } \\
\text { Area } \\
0.011\end{array}$ & $\begin{array}{c}\text { Time } \\
22: 25: 02\end{array}$ \\
\hline
\end{tabular}

As

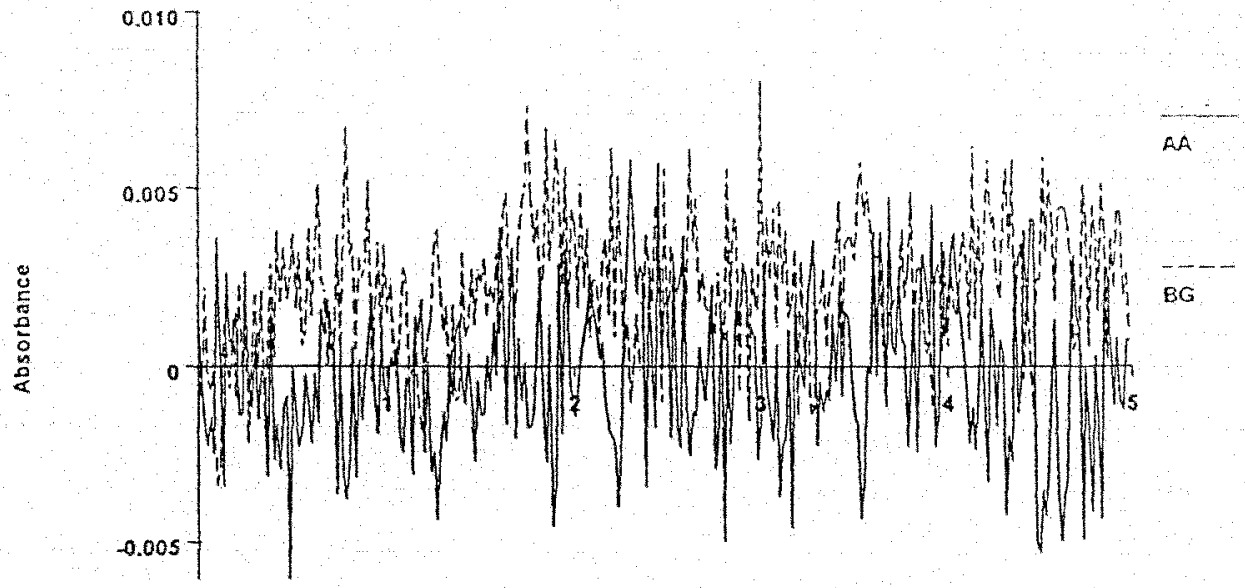

Time (seconds)

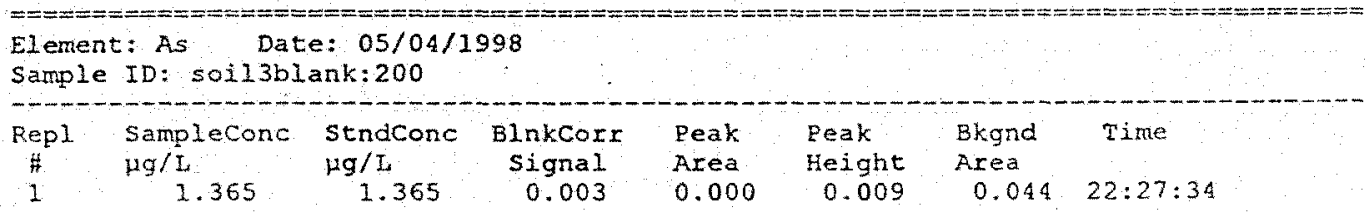

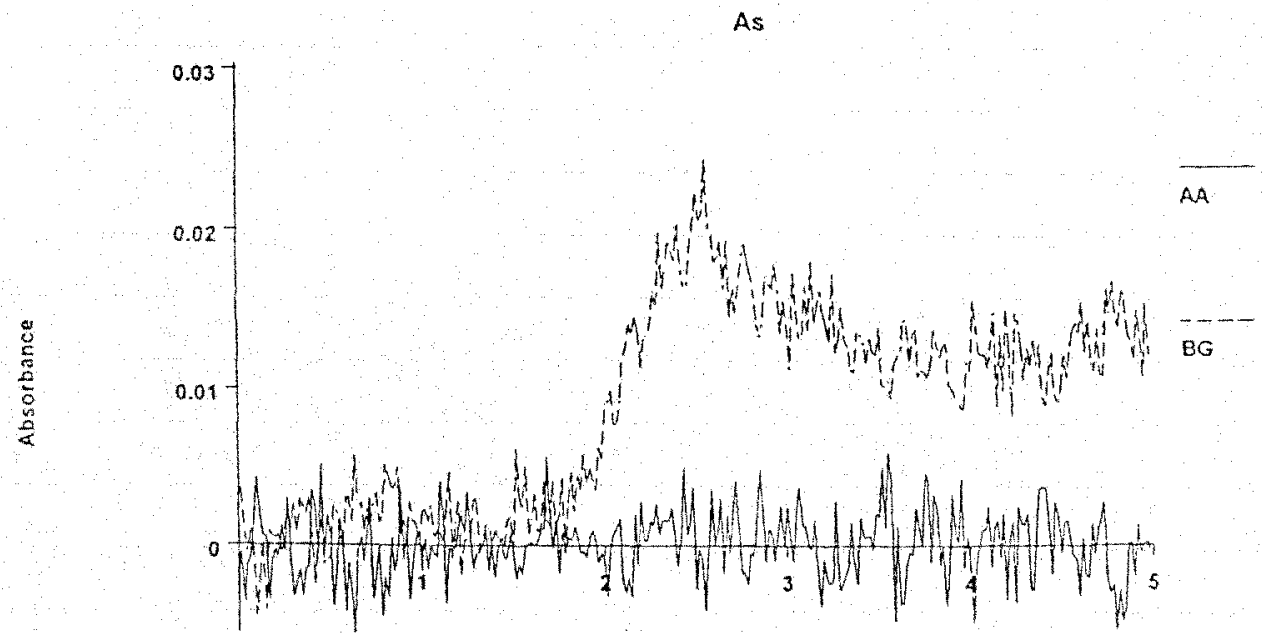

Time (seconds) 


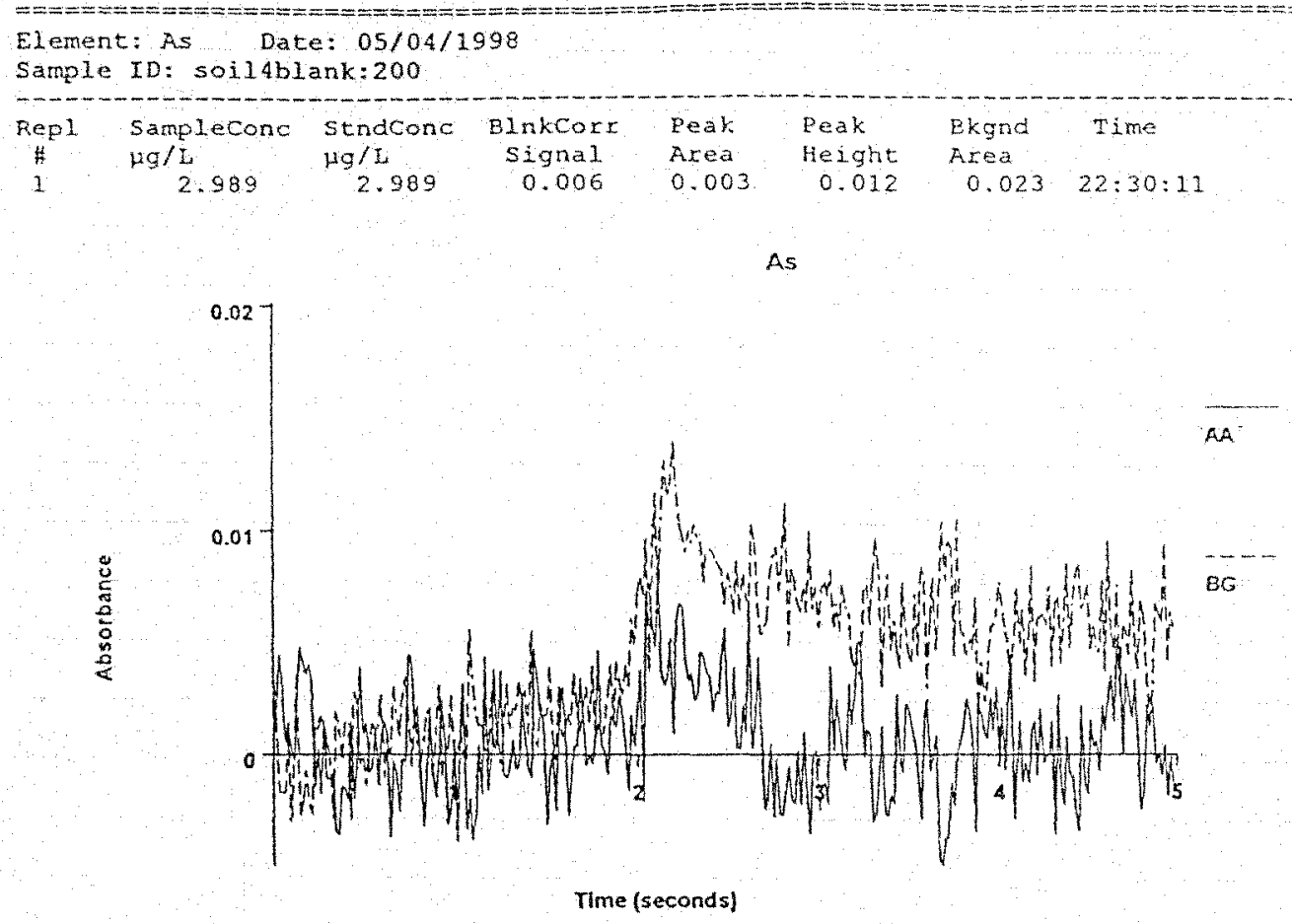

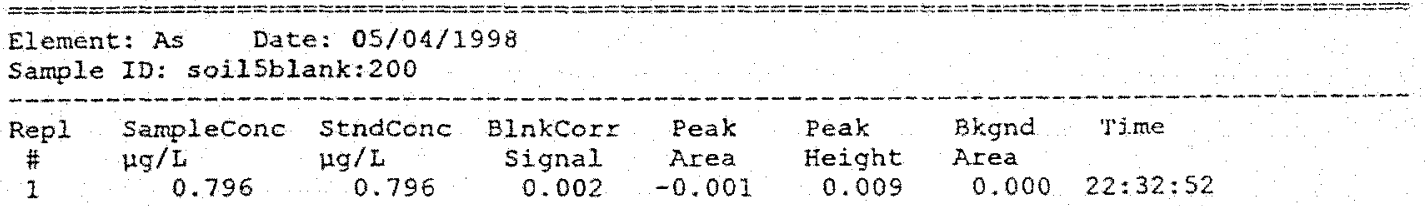

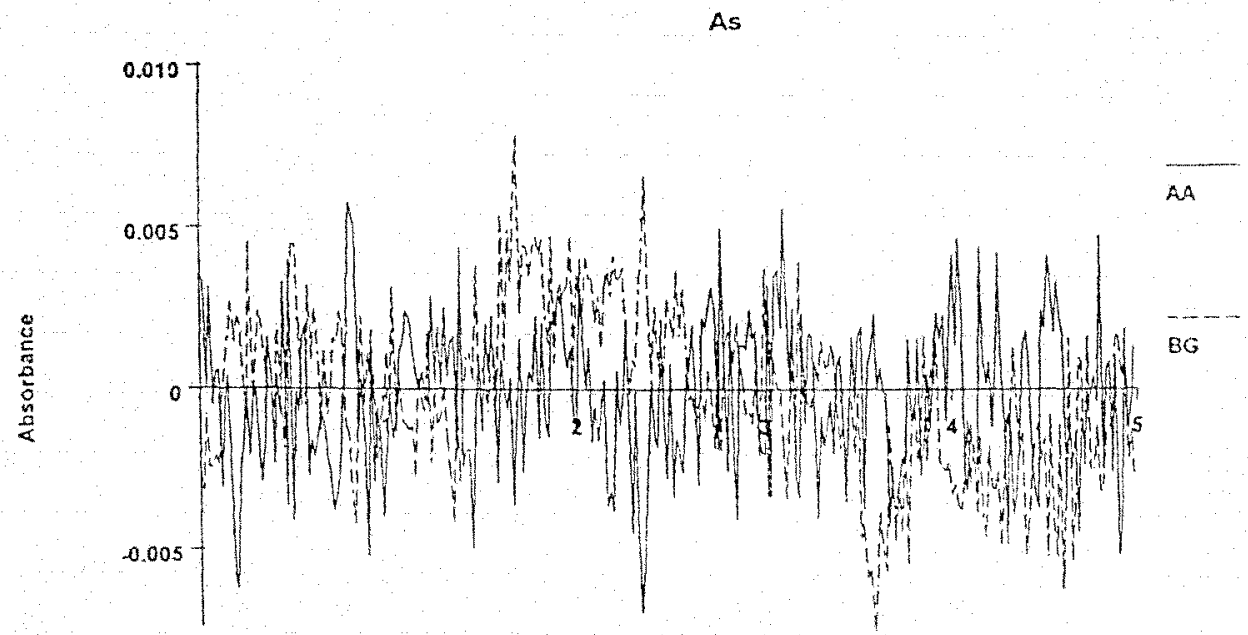

Time (seconds) 


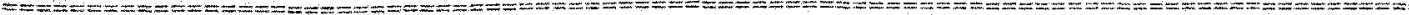

Element: As Date: $05 / 04 / 1998$

Sample ID: $200: 200$

\begin{tabular}{|c|c|c|c|c|c|c|}
\hline $\begin{array}{c}\text { Repl. } \\
\underset{4}{4} \\
1\end{array}$ & $\begin{array}{l}\text { Sampleconc } \\
\text { ug/L } \\
\qquad 51.59\end{array}$ & $\begin{array}{l}\text { stndeonc } \\
\mu g / 1 \\
51: 59\end{array}$ & $\begin{array}{c}\text { BlnkCore } \\
\text { Signal } \\
0.106\end{array}$ & $\begin{array}{l}\text { Peak } \\
\text { Area } \\
0.104\end{array}$ & $\begin{array}{l}\text { Peak } \\
\text { Height } \\
0.201\end{array}$ & $\begin{array}{l}\text { Exgnd } \\
\text { Frea } \\
0.020\end{array}$ \\
\hline
\end{tabular}

As

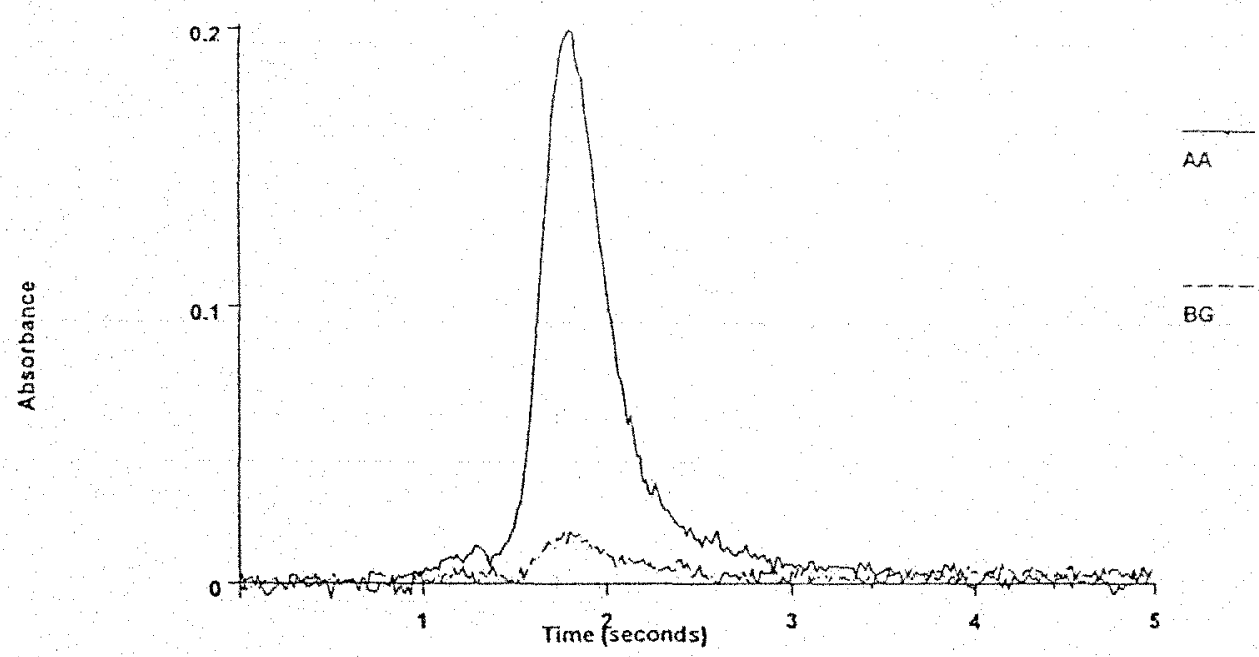




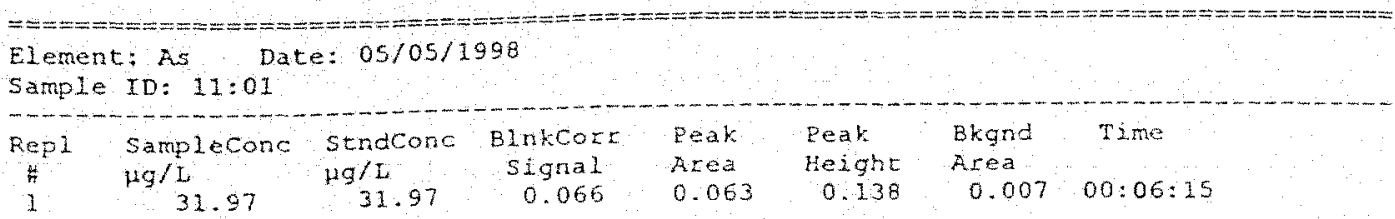

As

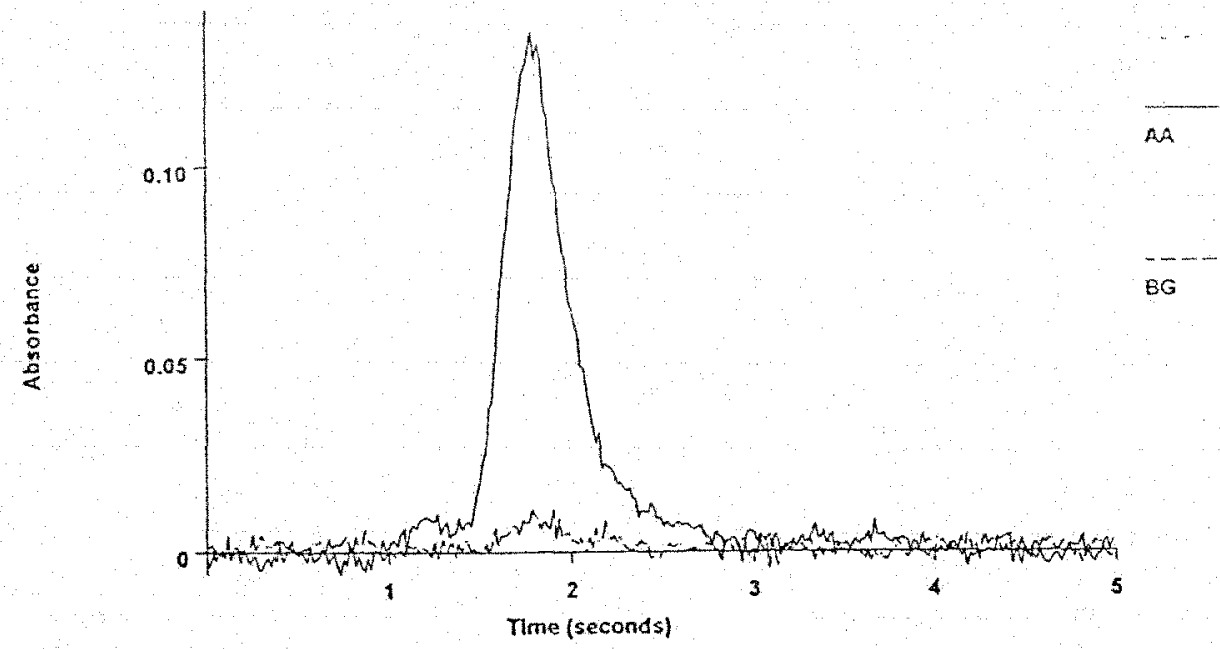

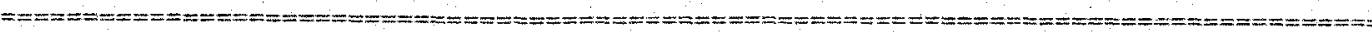

Eiement: As Date: 0S/04/1998

Sample ID: $12: 01$

\begin{tabular}{|c|c|c|c|c|c|c|c|}
\hline $\begin{array}{l}\text { Rep I } \\
4 \\
1\end{array}$ & $\begin{array}{l}\text { Sampleconc } \\
19 / \mathrm{L} \\
\quad 33.28\end{array}$ & $\begin{array}{l}\text { StndCone } \\
\mu g / \mathrm{L} \\
\frac{33.28}{}\end{array}$ & $\begin{array}{c}\text { BInkCorr } \\
\text { sjgnal } \\
0.069\end{array}$ & $\begin{array}{l}\text { Peak } \\
\text { Afea } \\
0.066\end{array}$ & $\begin{array}{l}\text { Peak } \\
\text { Heigint } \\
0.133\end{array}$ & $\begin{array}{l}\text { Bkgno } \\
\text { Area } \\
0.022\end{array}$ & $23: 07: 29$ \\
\hline
\end{tabular}

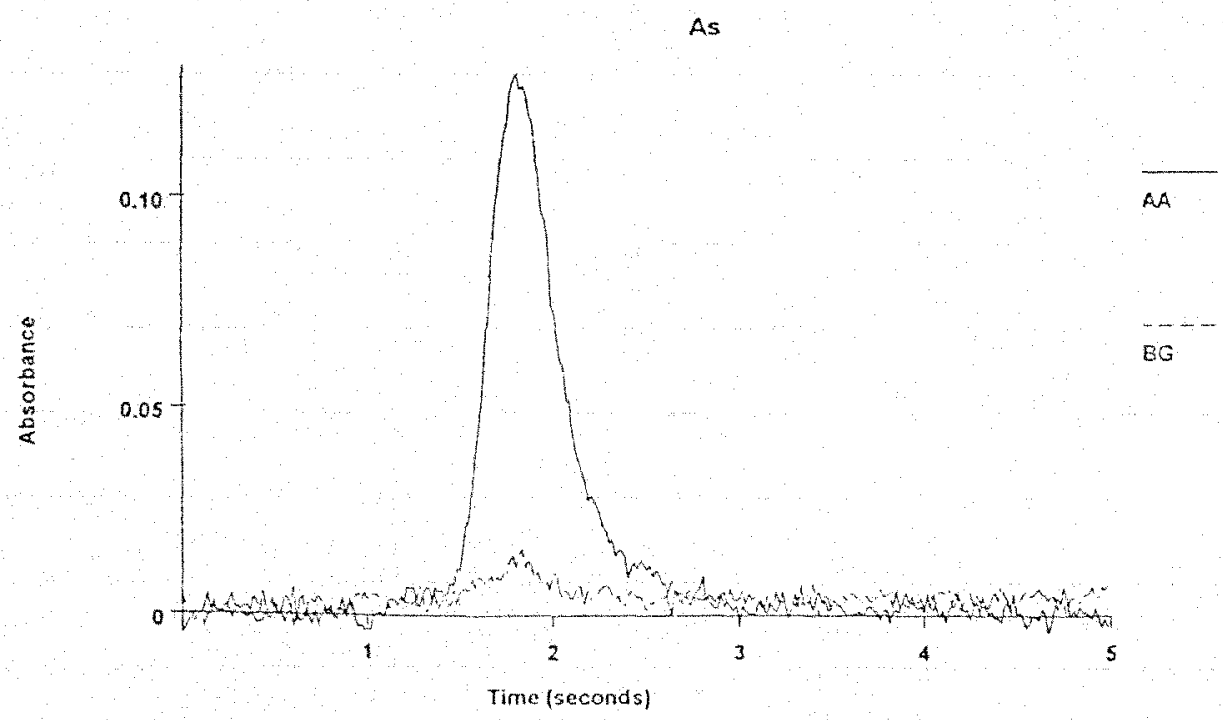




\begin{tabular}{|c|c|c|c|c|c|c|}
\hline $\begin{array}{l}\text { Element: As Dat } \\
\text { Sample ID: } 21: 01\end{array}$ & $=05 / 04 / 1$ & 398 & & & & \\
\hline $\begin{array}{c}\text { Samplecone } \\
\mathrm{Hg} / \mathrm{L} \\
45.55\end{array}$ & $\begin{array}{c}\text { Strdcone } \\
\mu g / L: \\
45.55\end{array}$ & $\begin{array}{c}\text { BlnkCorr } \\
\text { signal } \\
0.094\end{array}$ & $\begin{array}{l}\text { Peak } \\
\text { Axea } \\
0.091\end{array}$ & $\begin{array}{l}\text { teak } \\
\text { Hedght } \\
0.175\end{array}$ & $\begin{array}{l}\text { Ekgnd } \\
\text { Ared } \\
0.011\end{array}$ & $\begin{array}{l}\text { Tine } \\
23: 10: 16\end{array}$ \\
\hline
\end{tabular}

As
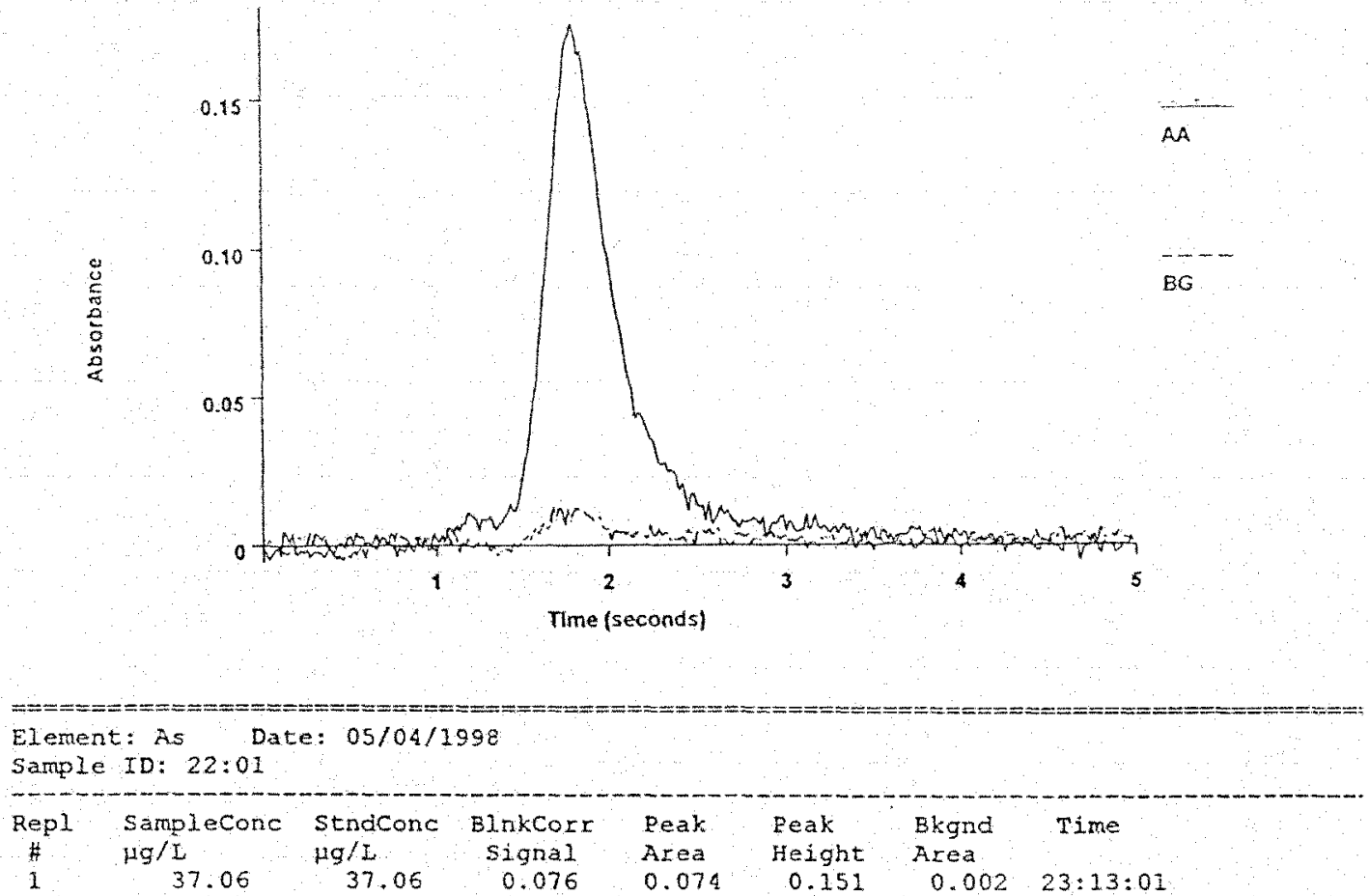

As

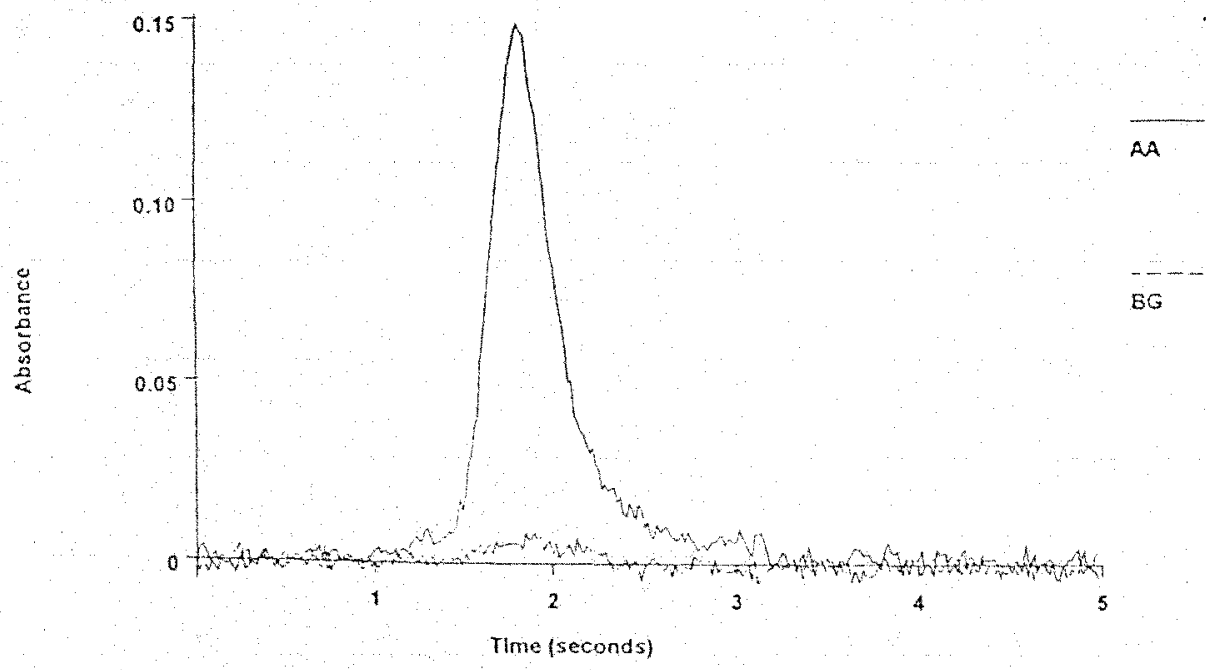




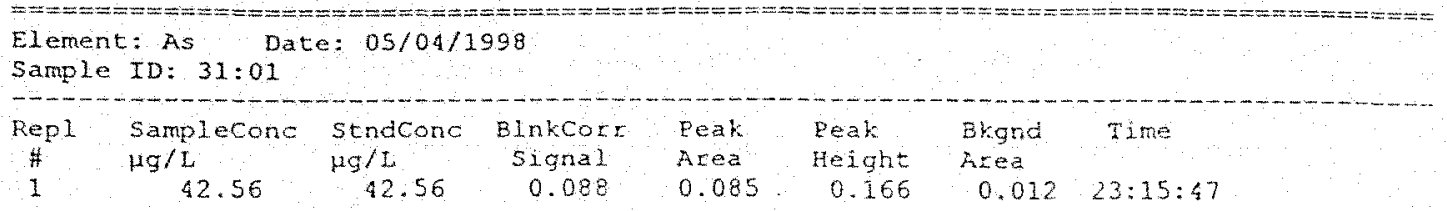

As

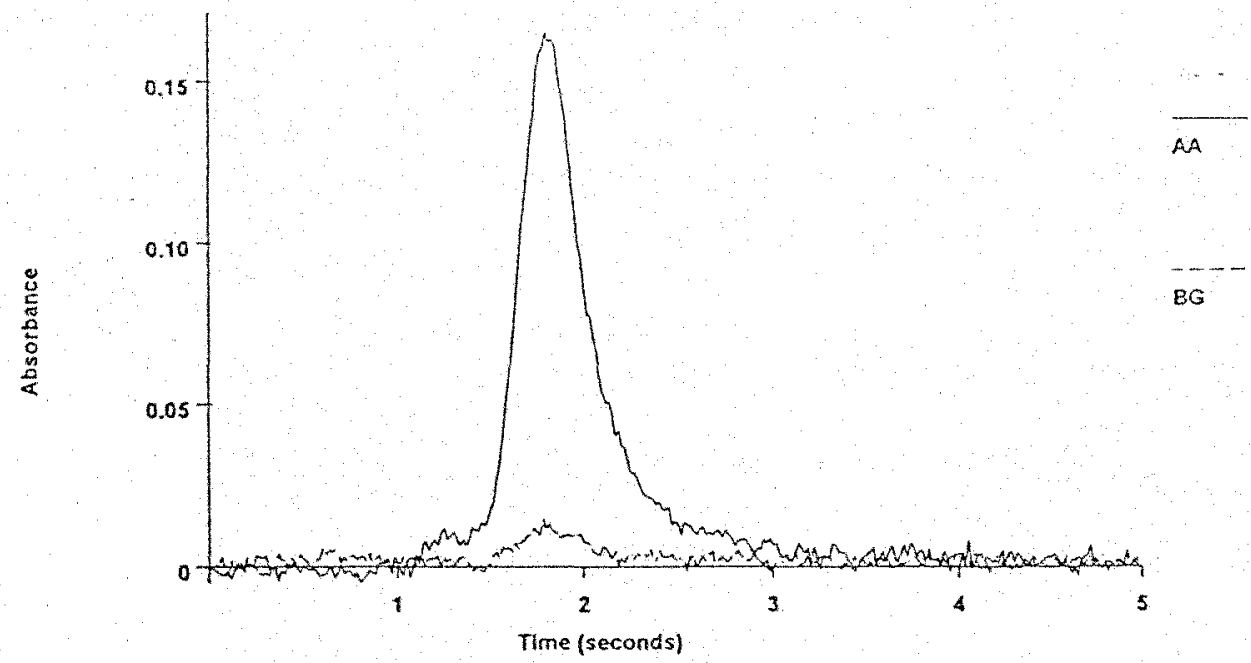

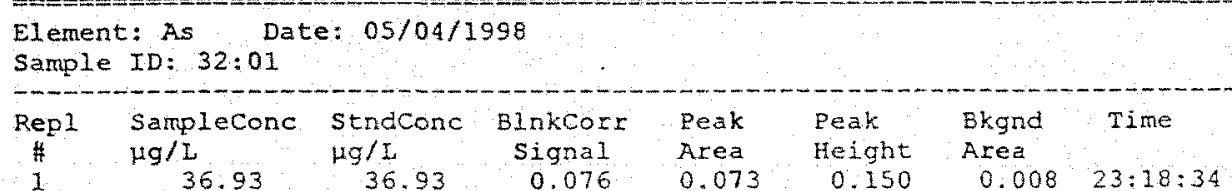

As

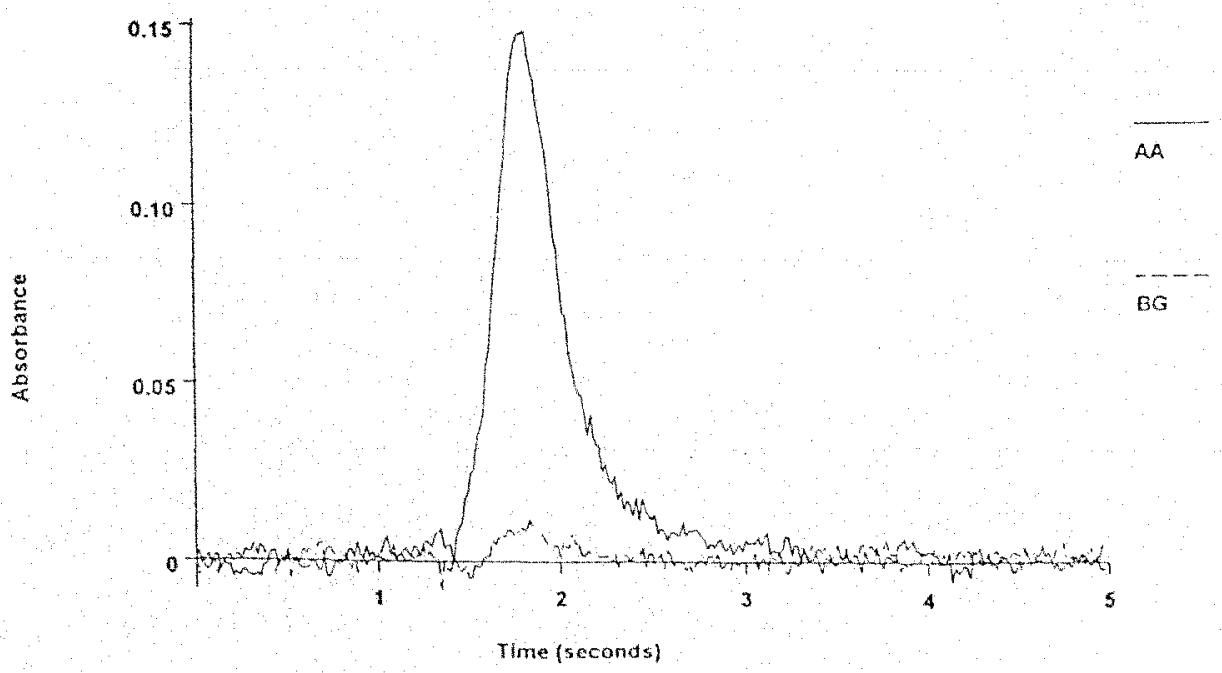


Element: As Date: 05/04/1998

Sample ID: $41: 01$

\begin{tabular}{|c|c|c|c|c|c|c|c|}
\hline $\begin{array}{l}\text { iep } 1 \\
1 \\
1\end{array}$ & $\begin{array}{c}\text { Sampleconc } \\
\mu g / 1 \\
34.94\end{array}$ & $\begin{array}{c}\text { StndConc } \\
\mu g / L \\
34,94\end{array}$ & $\begin{array}{c}\text { Blakcore } \\
\text { signal } \\
0.072\end{array}$ & $\begin{array}{l}\text { Peak } \\
\text { Area } \\
0.069\end{array}$ & $\begin{array}{l}\text { Reak } \\
\text { Hejght } \\
0.145\end{array}$ & $\begin{array}{l}\text { Bkgnd } \\
\text { Area } \\
0.011\end{array}$ & $23: 21: 21$ \\
\hline
\end{tabular}

As

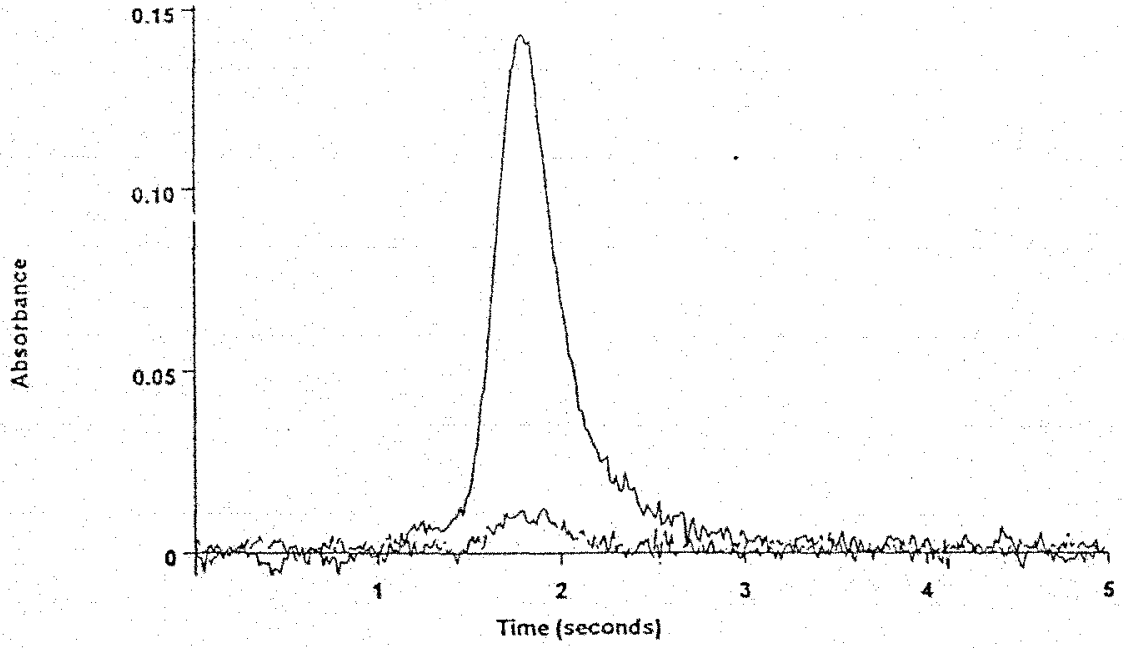

\begin{tabular}{|c|c|c|c|c|c|c|c|}
\hline $\begin{array}{l}\text { Elemen } \\
\text { Sample }\end{array}$ & $\begin{array}{l}\text { t: A.s Dat } \\
\text { ID: } 42: 01\end{array}$ & $=05 / 04 / 1$ & 998 & & & & \\
\hline $\begin{array}{c}\text { Rep } 1 \\
\# \\
1\end{array}$ & $\begin{array}{l}\text { Sampleconc } \\
\mathrm{Hg} / \mathrm{L} \\
41.16\end{array}$ & $\begin{array}{l}\text { Stndconc } \\
\mu g / I \\
41.16\end{array}$ & $\begin{array}{c}\text { Blnkcort } \\
\text { Signal } \\
0.085\end{array}$ & $\begin{array}{l}\text { Peak } \\
\text { Area } \\
0.082\end{array}$ & $\begin{array}{l}\text { Peak } \\
\text { Height } \\
0.171\end{array}$ & $\begin{array}{l}\text { Bkgnd } \\
\text { Area } \\
0.007\end{array}$ & $\begin{array}{l}\text { Time } \\
23: 24: 08\end{array}$ \\
\hline
\end{tabular}

As

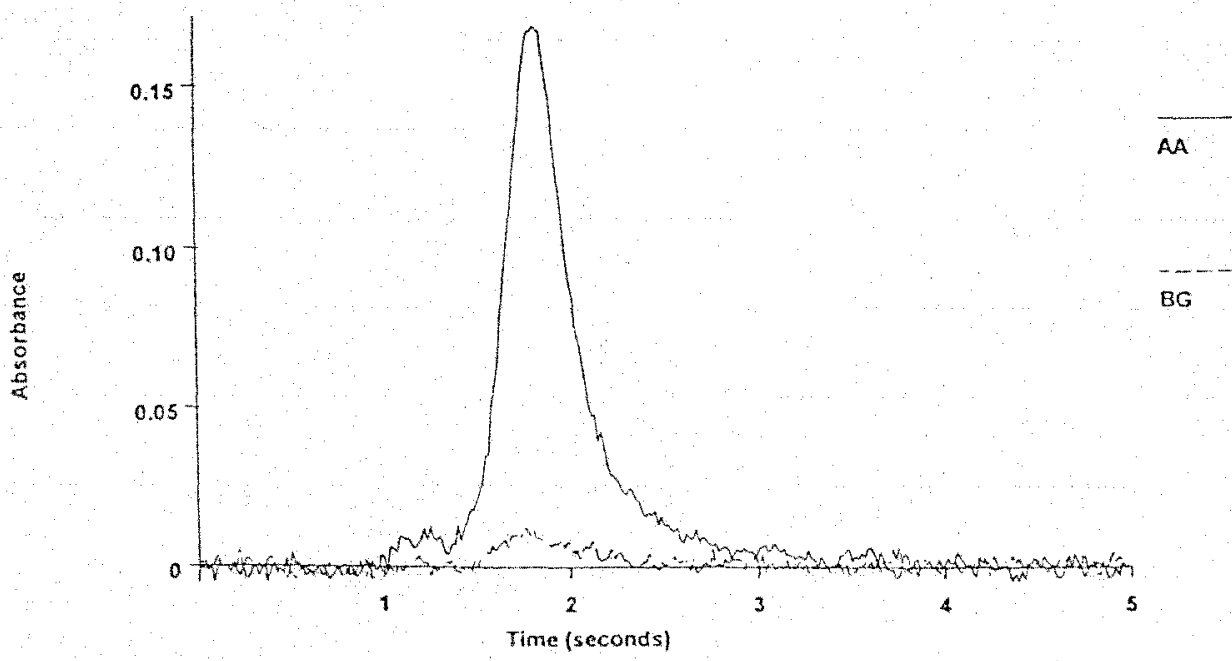




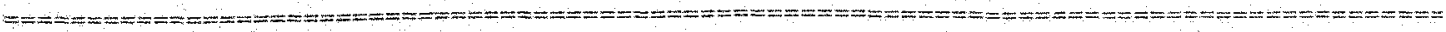

Element: As Date: $05 / 04 / 1998$

Sample ID: $11: 01$

\begin{tabular}{|c|c|c|c|c|c|c|c|}
\hline $\begin{array}{c}\text { Rep } 1 \\
\frac{\pi}{*} \\
1\end{array}$ & $\begin{array}{l}\text { Sampleconc } \\
\lg 11 \\
\quad 37.91\end{array}$ & $\begin{array}{l}\text { StndCone } \\
\mu 9 / L \\
37.91\end{array}$ & $\begin{array}{c}\text { BlnkCort } \\
\text { signal } \\
0.078\end{array}$ & $\begin{array}{l}\text { Peak } \\
\text { Area } \\
0.075\end{array}$ & $\begin{array}{l}\text { Eeak } \\
\text { Height } \\
0.155\end{array}$ & $\begin{array}{l}\text { Bkgnd } \\
\text { Axea } \\
0.015\end{array}$ & $\begin{array}{l}\text { Time } \\
23: 26: 54\end{array}$ \\
\hline
\end{tabular}

As

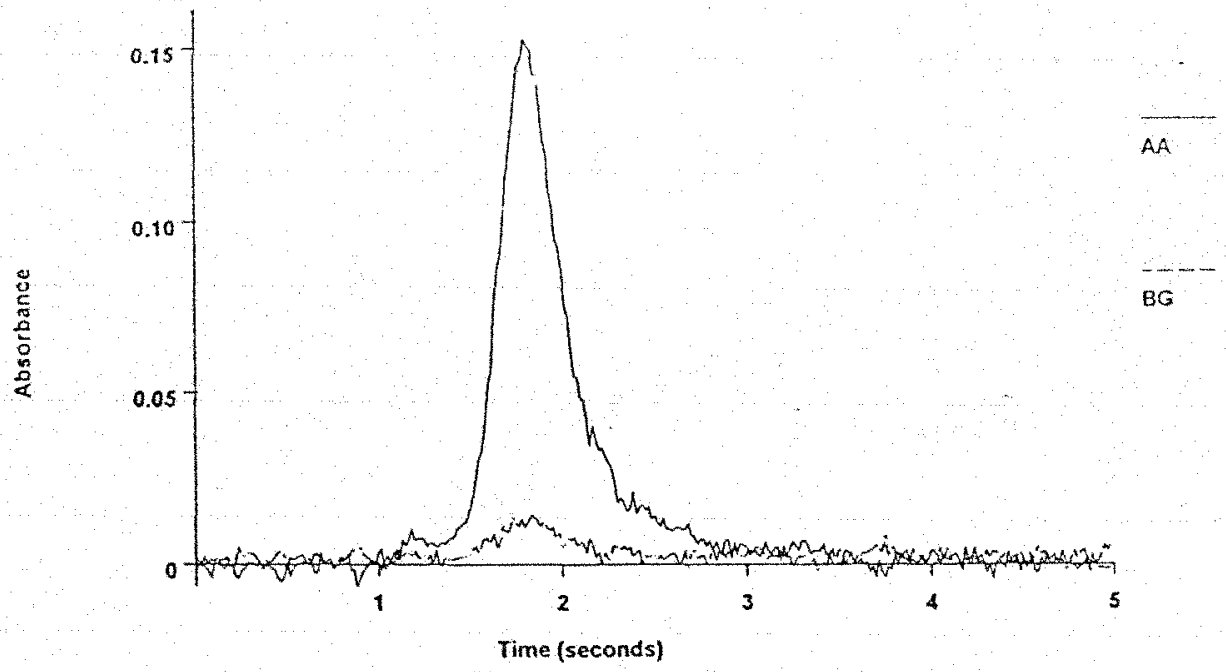

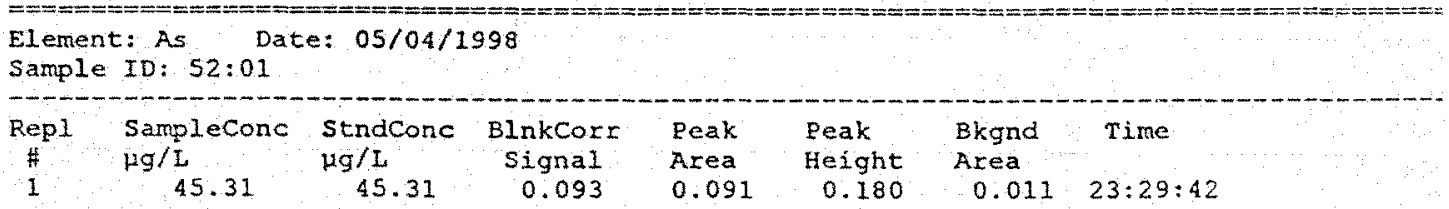

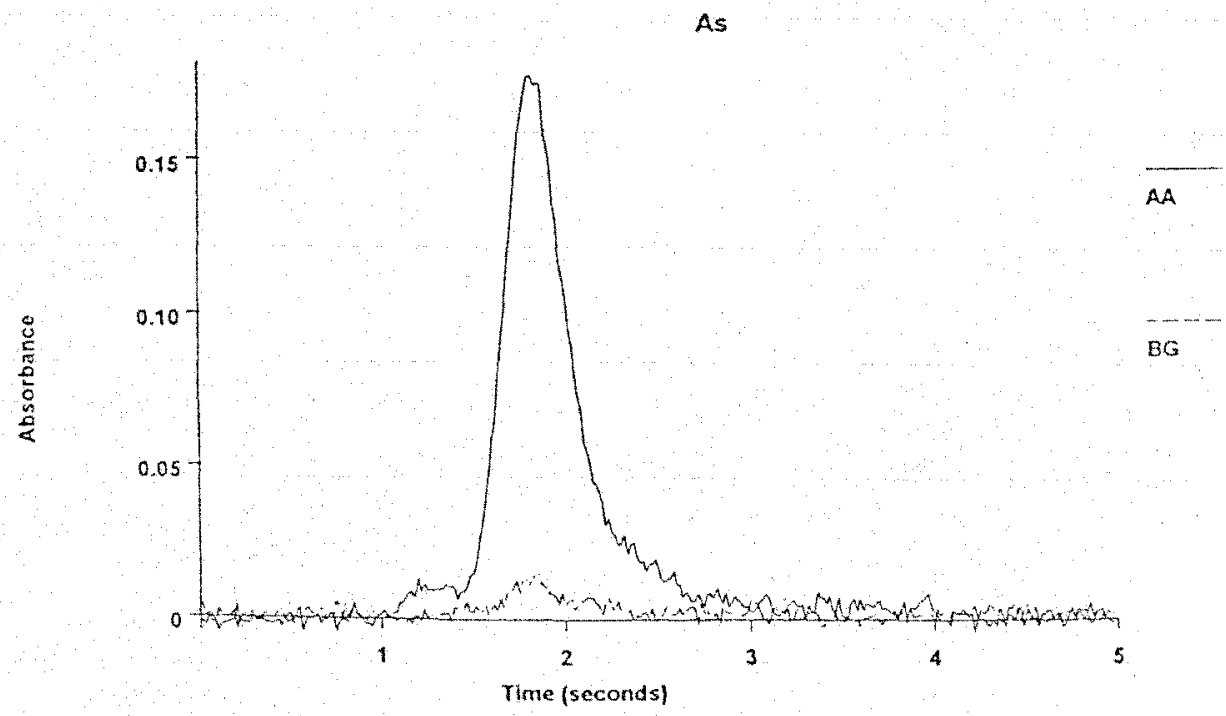




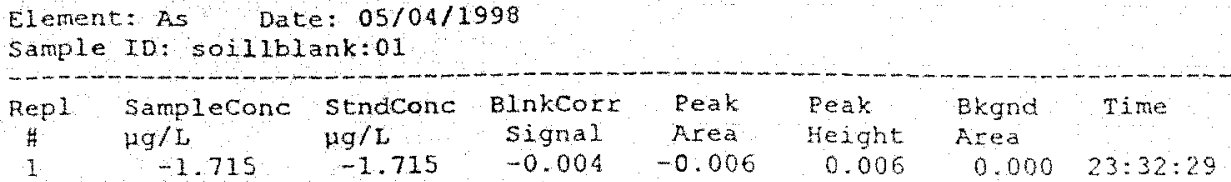

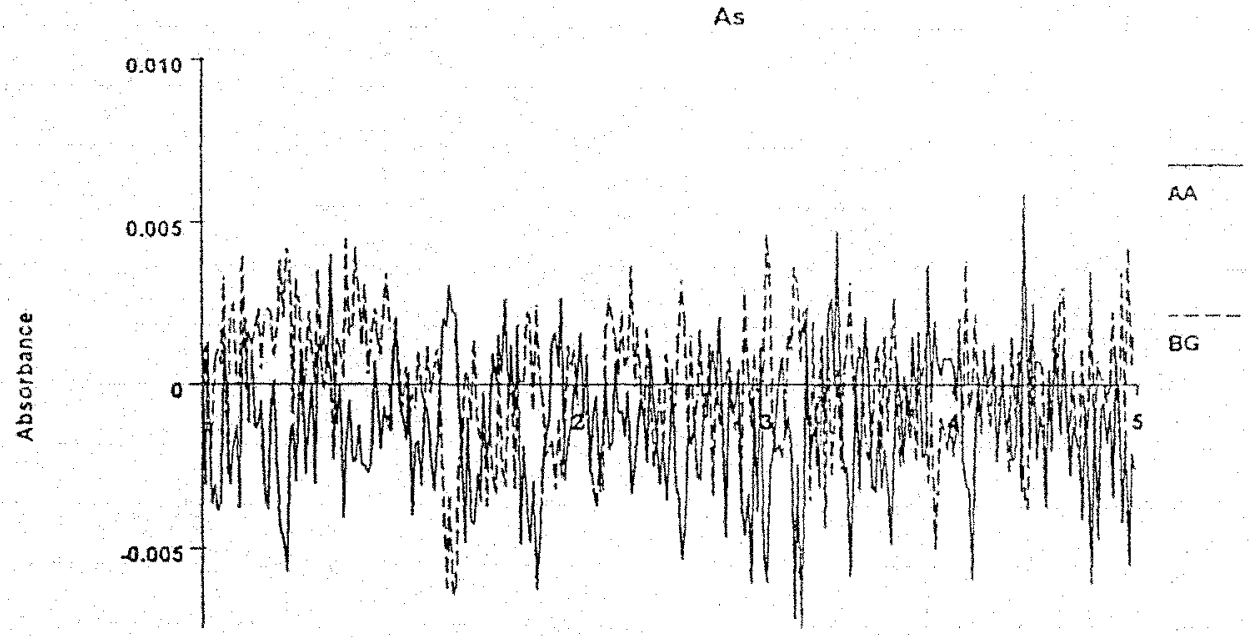

Time (seconds)

Element As Date 05/04/1998

Sample ID: soilzblank:01

\begin{tabular}{|c|c|c|c|c|c|c|c|}
\hline $\begin{array}{l}\text { Repl } \\
\text { H } \\
1\end{array}$ & $\begin{array}{l}\text { Sampleconc } \\
\text { Hg/I } \\
\frac{2.277}{2}\end{array}$ & $\begin{array}{l}\text { StndConc } \\
\mu g / x \\
2.277\end{array}$ & $\begin{array}{c}\text { BlnkCorr } \\
\text { Signal } \\
0.005\end{array}$ & $\begin{array}{l}\text { Peak } \\
\text { AIea } \\
0.002\end{array}$ & $\begin{array}{l}\text { Peak } \\
\text { Height } \\
0.009\end{array}$ & $\begin{array}{l}\text { Bkgnd } \\
\text { Area } \\
0.005\end{array}$ & Time \\
\hline
\end{tabular}

As

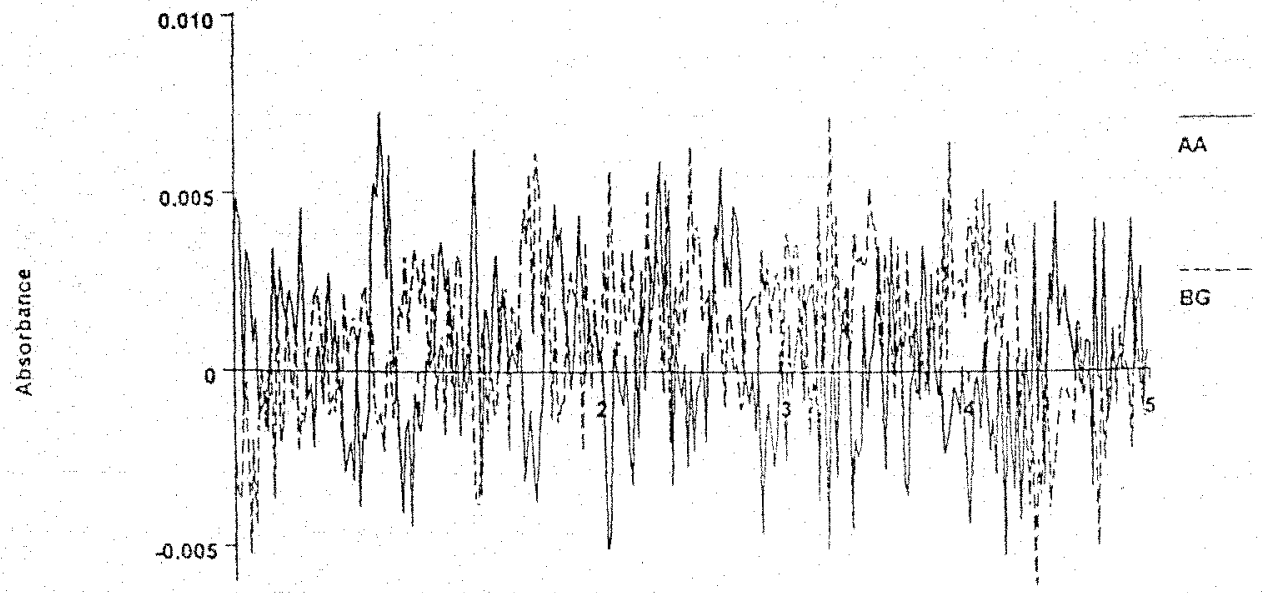

rine (seconds) 


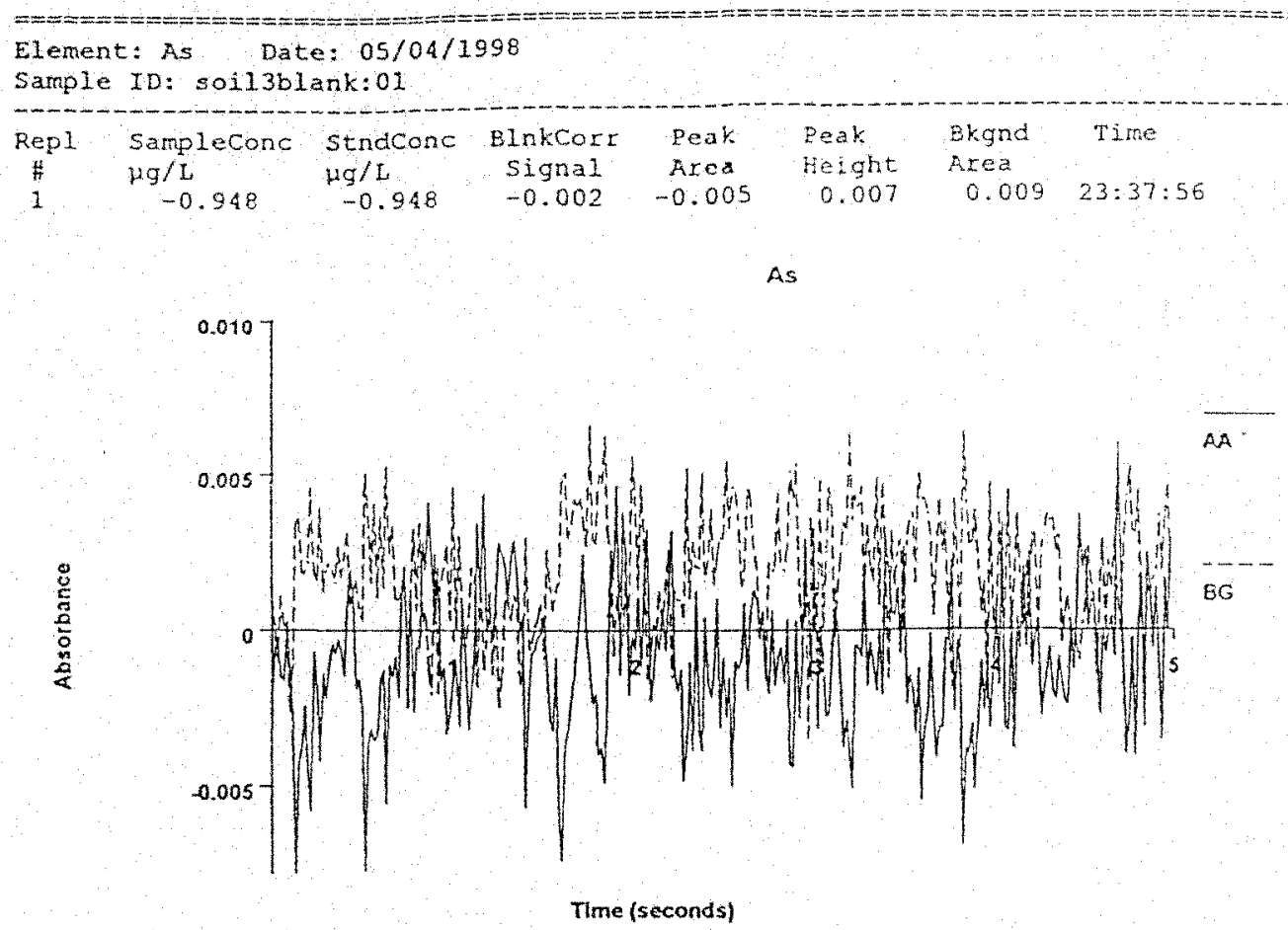

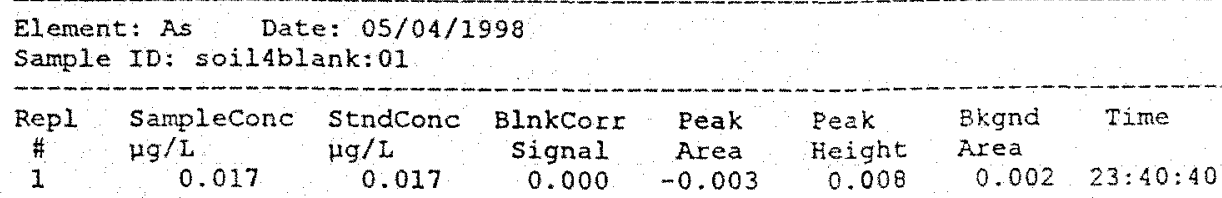

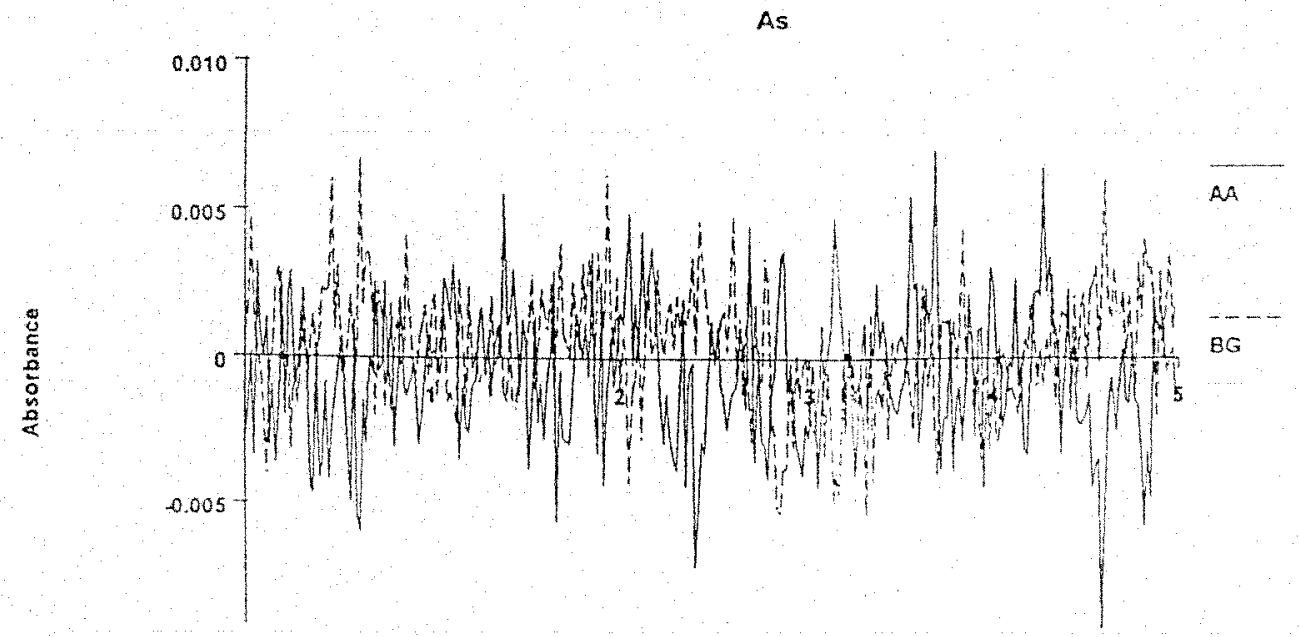

Time (seconds) 
Element: as Dates $05 / 04 / 1998$

Sample ID: sol15blank:01

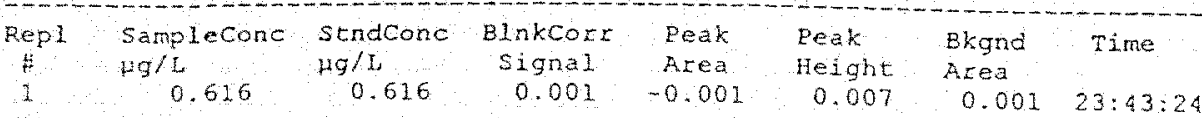
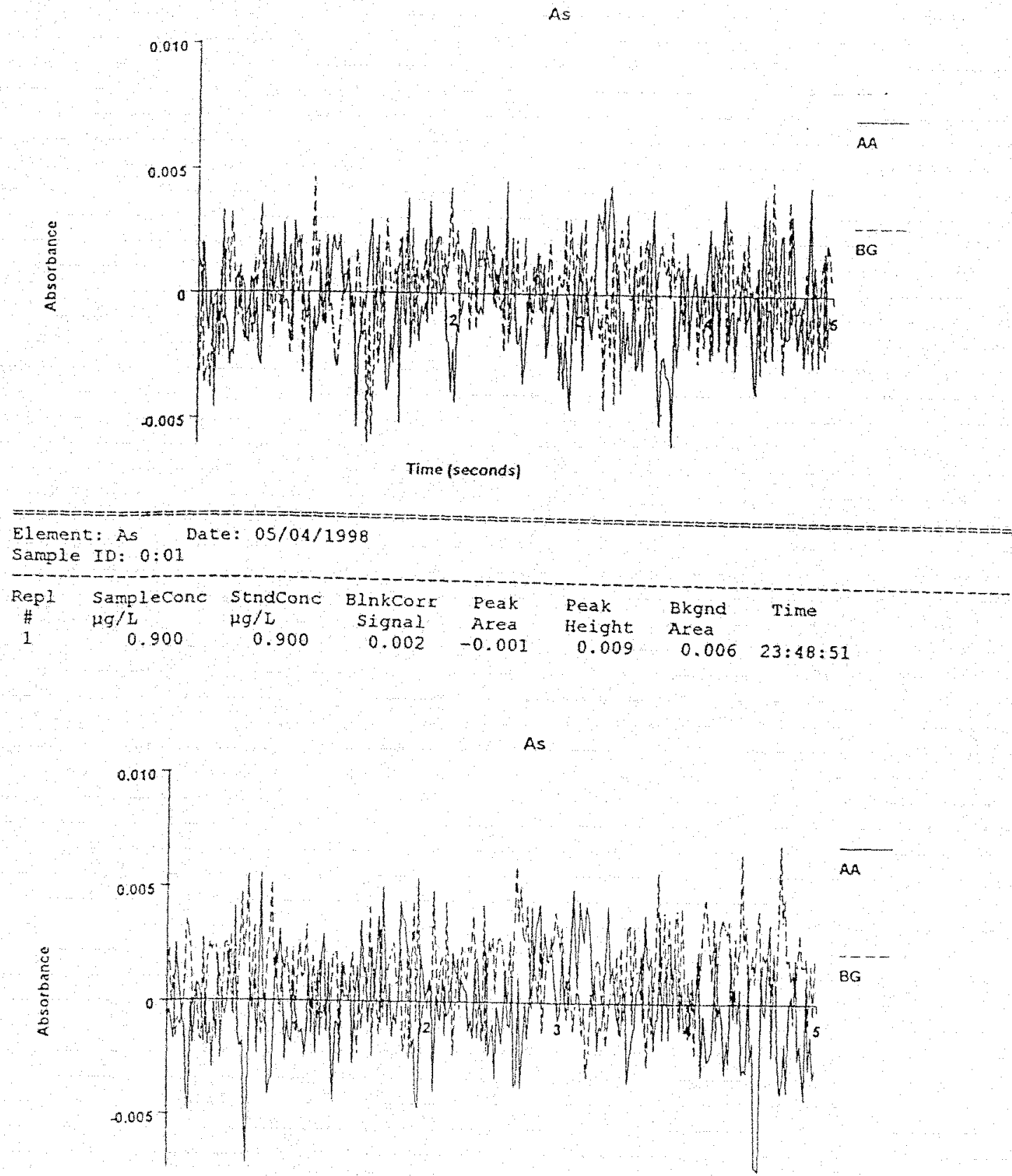

Time (seconds) 

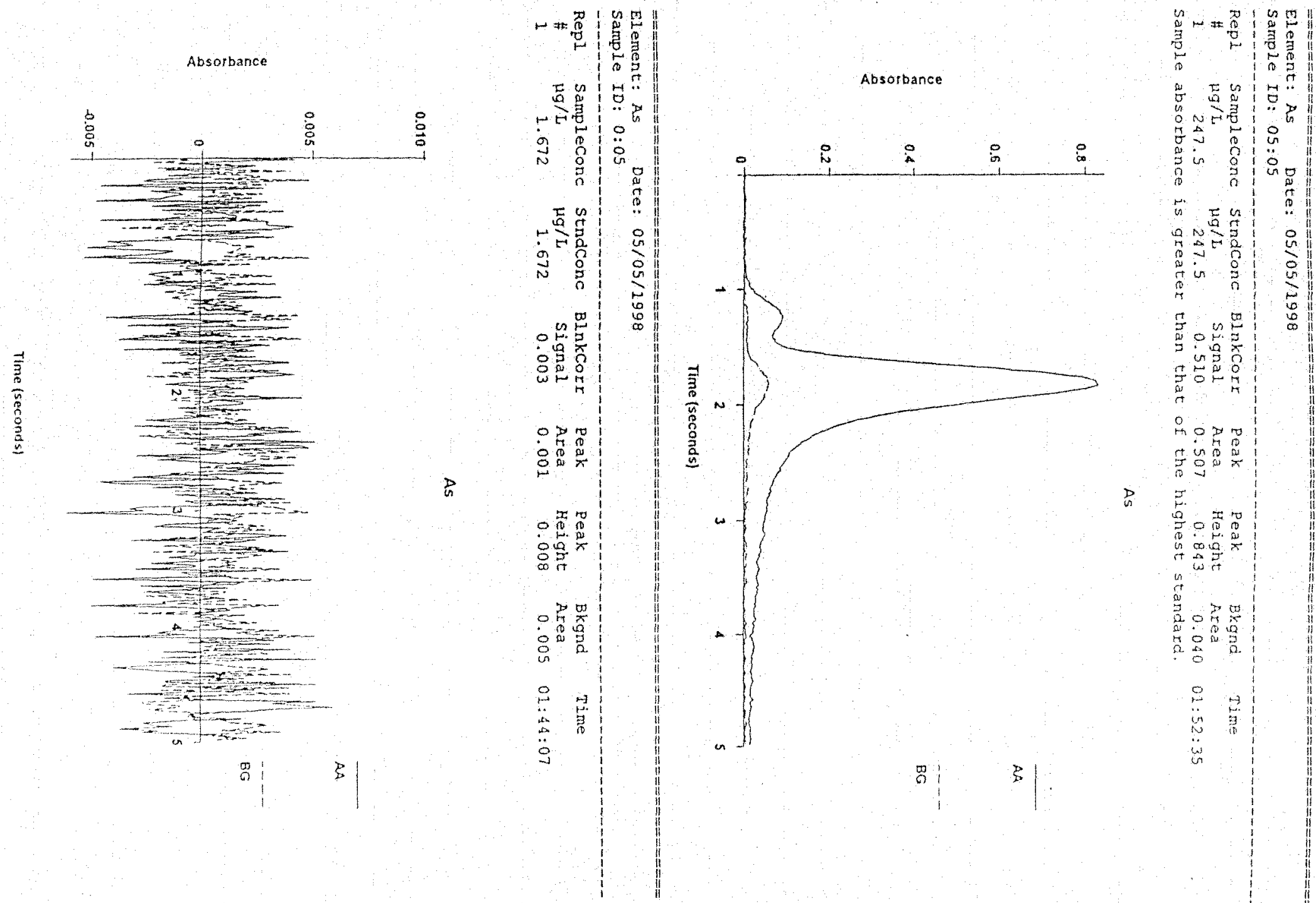


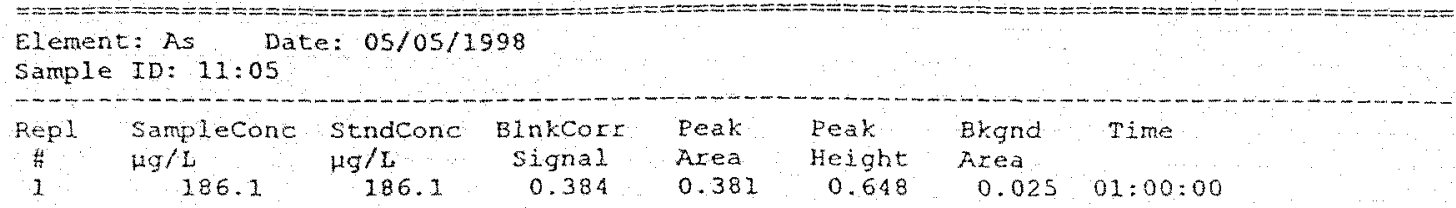

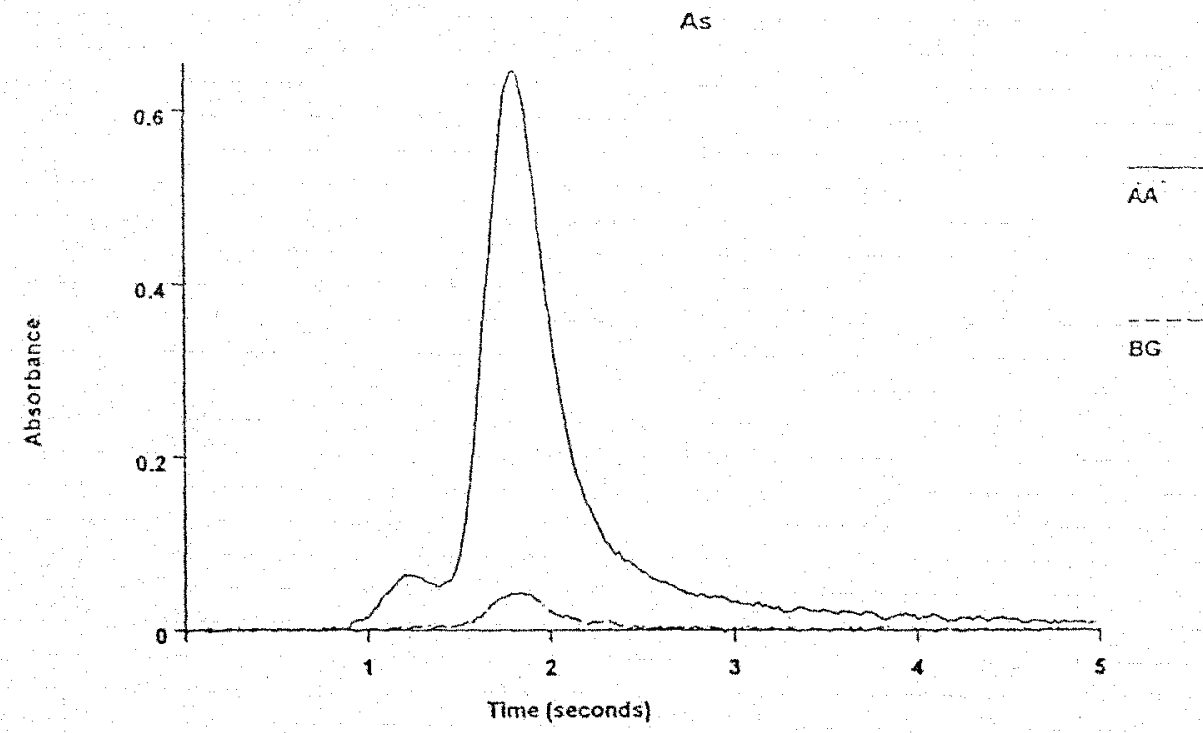

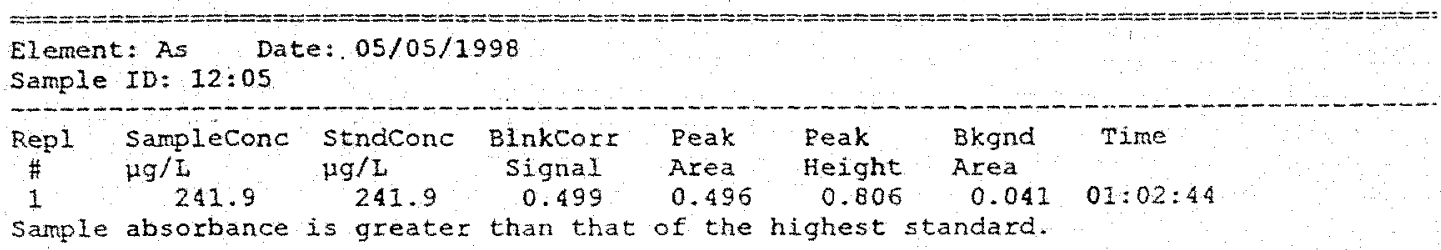

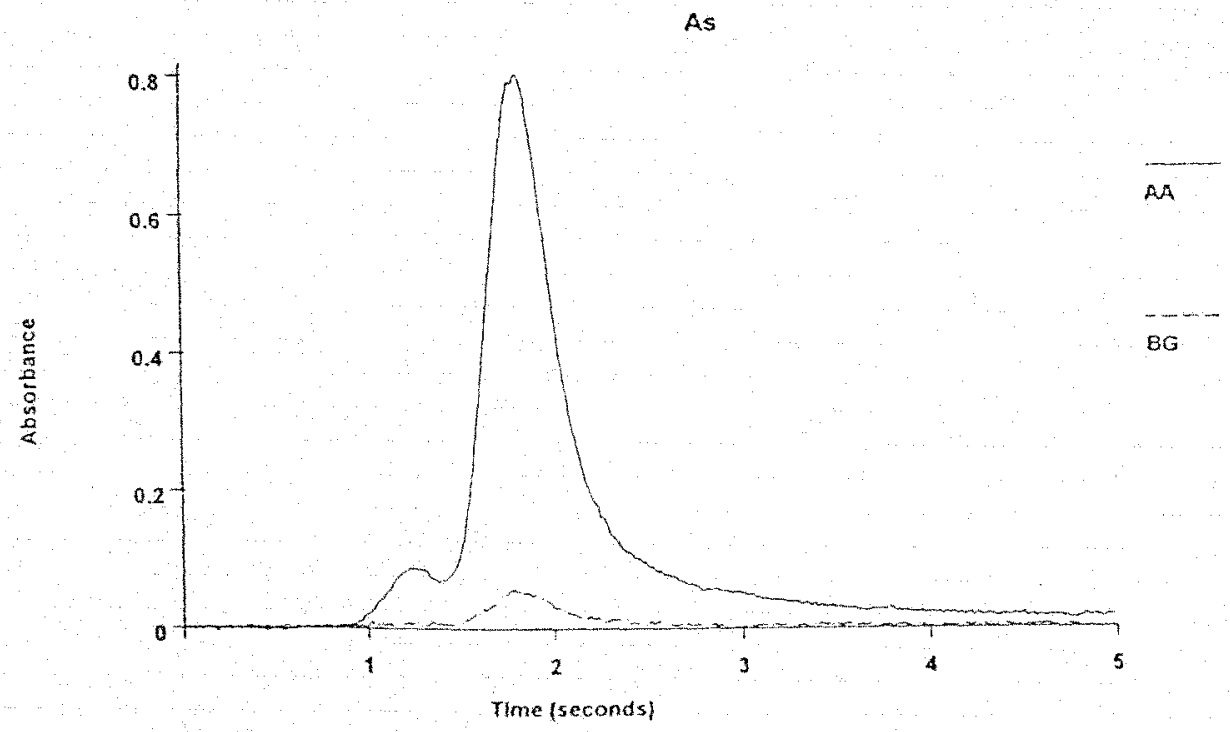




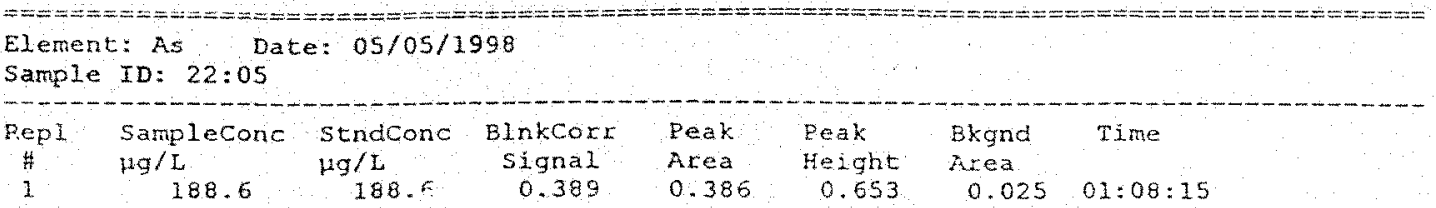

As

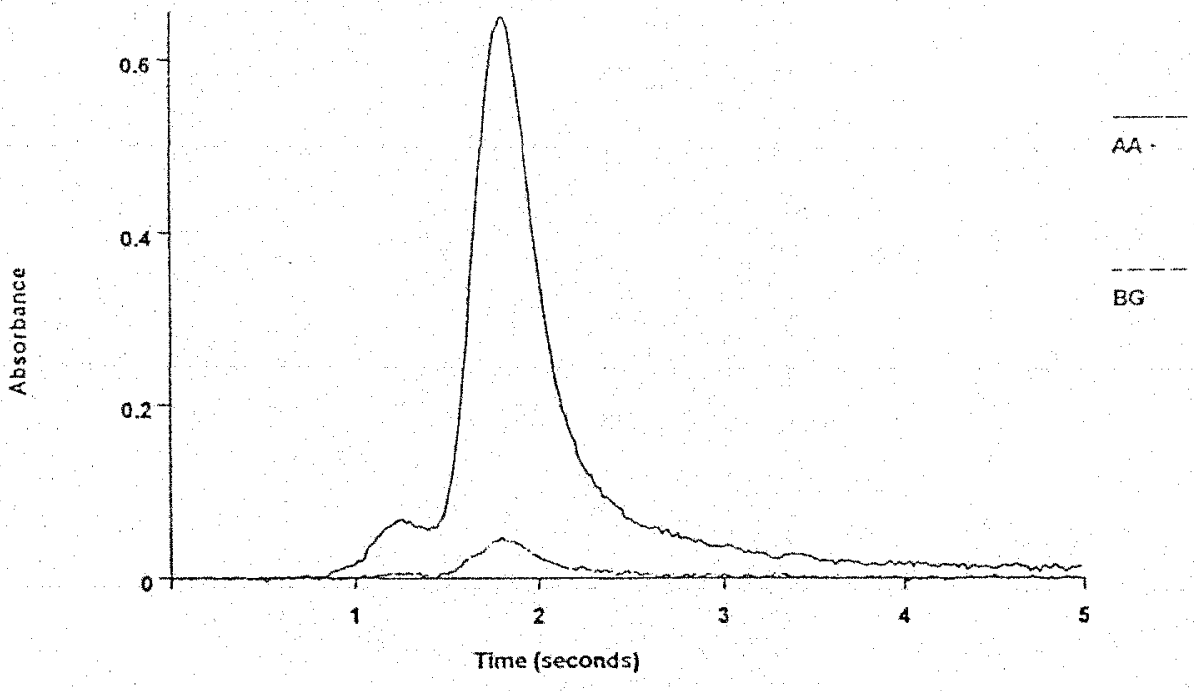

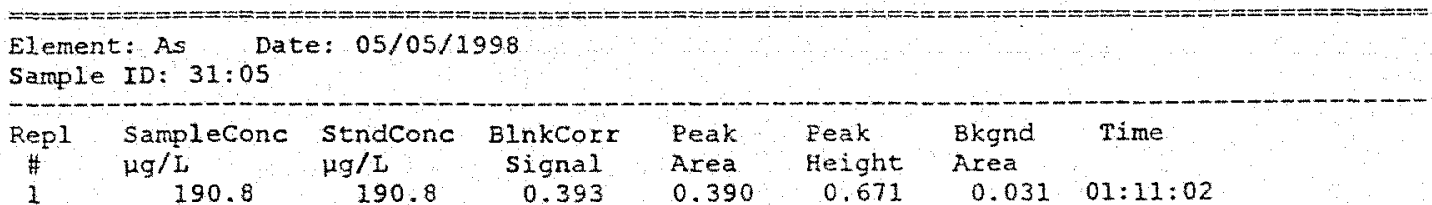

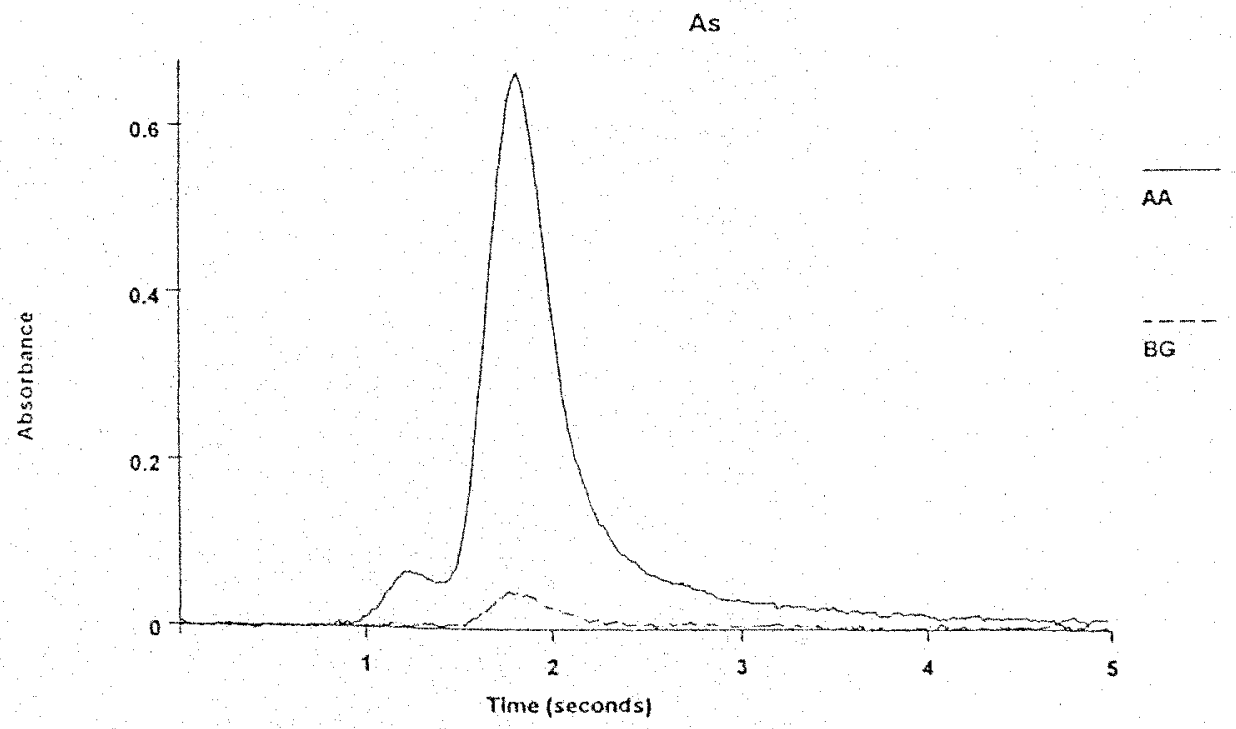




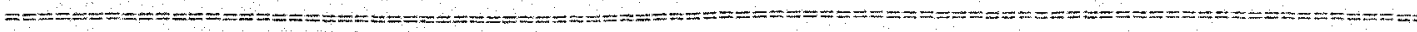

Element: As

Date: $05 / 05 / 1998$

Sample ID: $41: 05$

\begin{tabular}{|c|c|c|c|c|c|c|c|}
\hline $\begin{array}{l}\text { Rep } 1 \\
H \\
1\end{array}$ & $\begin{array}{l}\text { Sampleconc } \\
\mathrm{hg} / \mathrm{L} \\
234.9\end{array}$ & $\begin{array}{l}\text { Stndcone } \\
\mu g / L \\
234.9\end{array}$ & $\begin{array}{c}\text { Buncort } \\
\text { signal } \\
0.484\end{array}$ & $\begin{array}{l}\text { Peak } \\
\text { Area } \\
0.48 I\end{array}$ & $\begin{array}{l}\text { Peak } \\
\text { Height } \\
0.799\end{array}$ & $\begin{array}{l}\text { Bkgnd } \\
\text { Area }\end{array}$ & Time \\
\hline
\end{tabular}

As

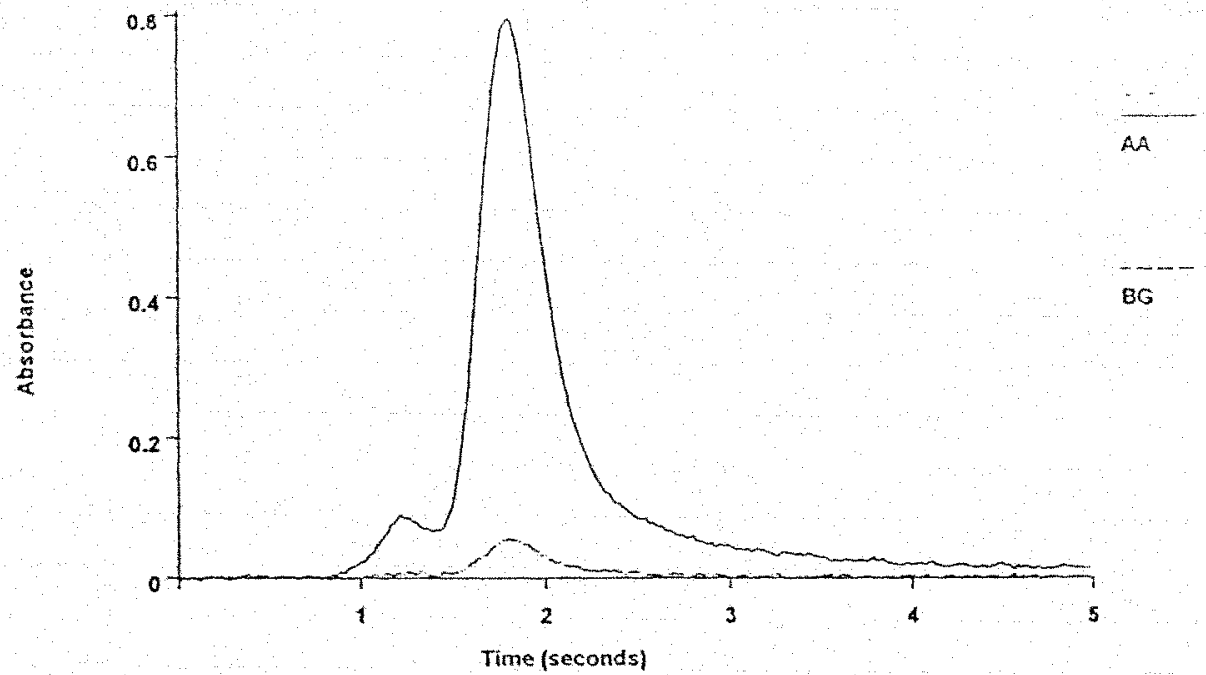

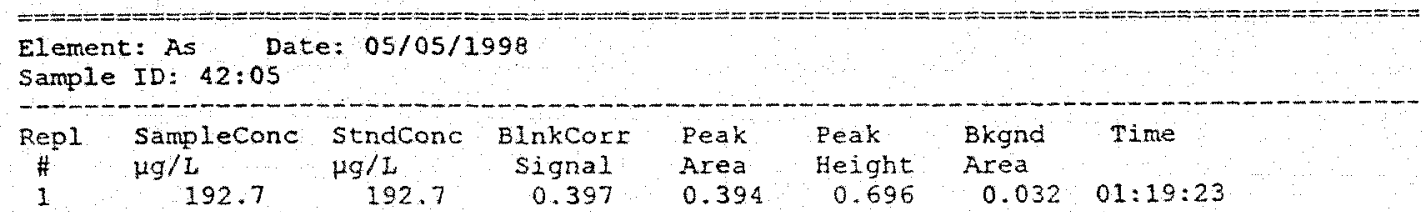

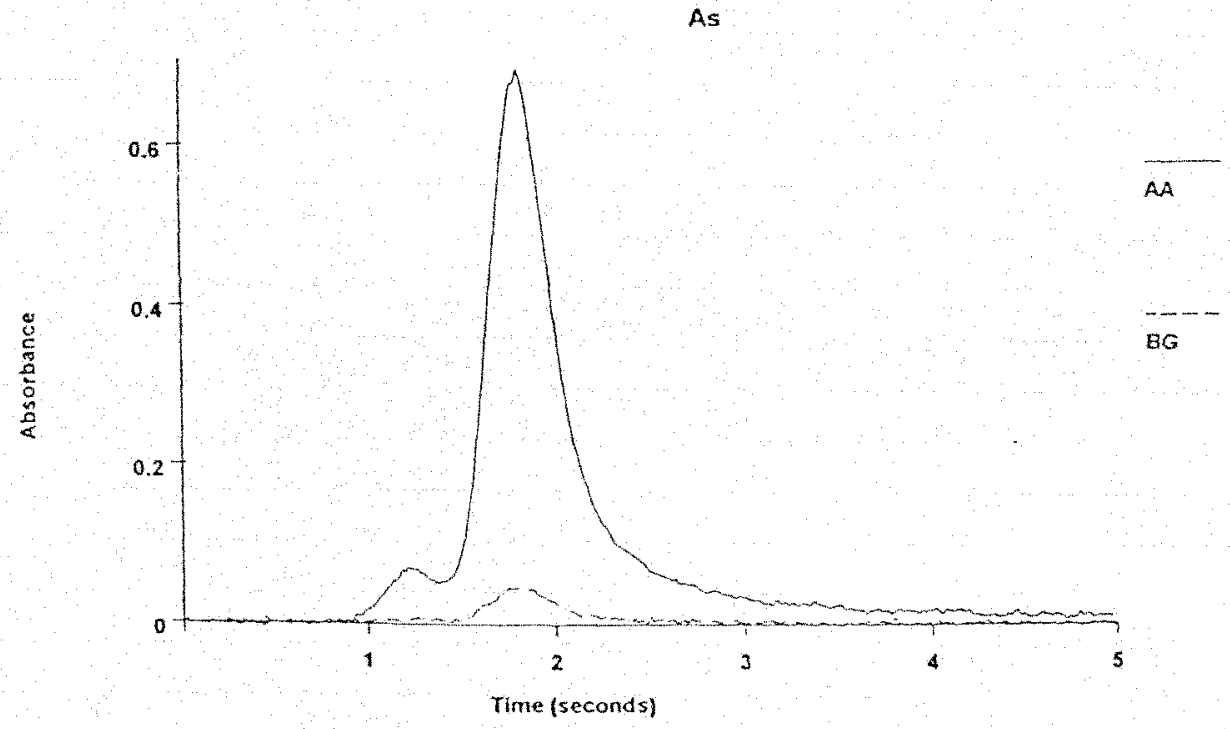




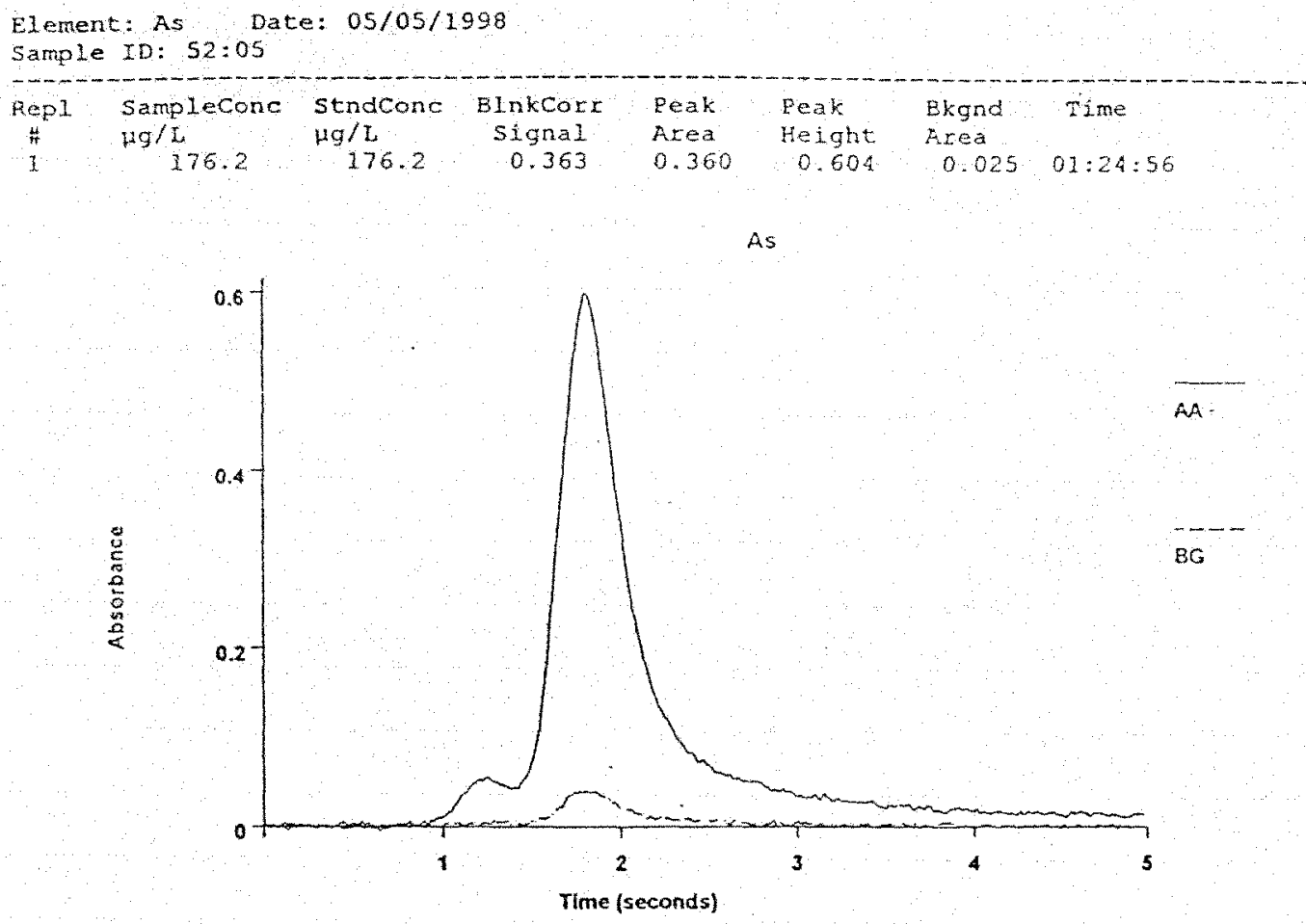

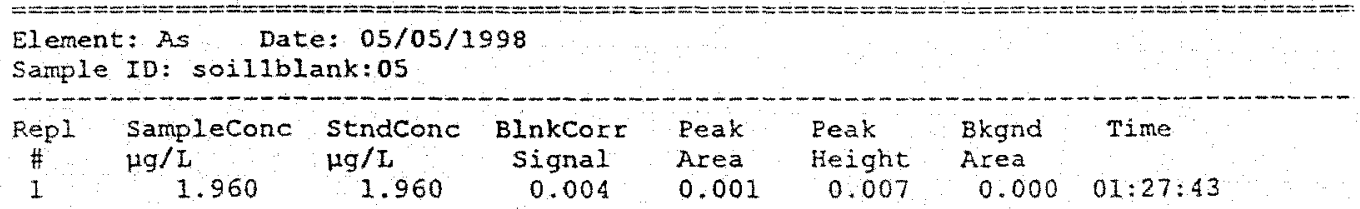

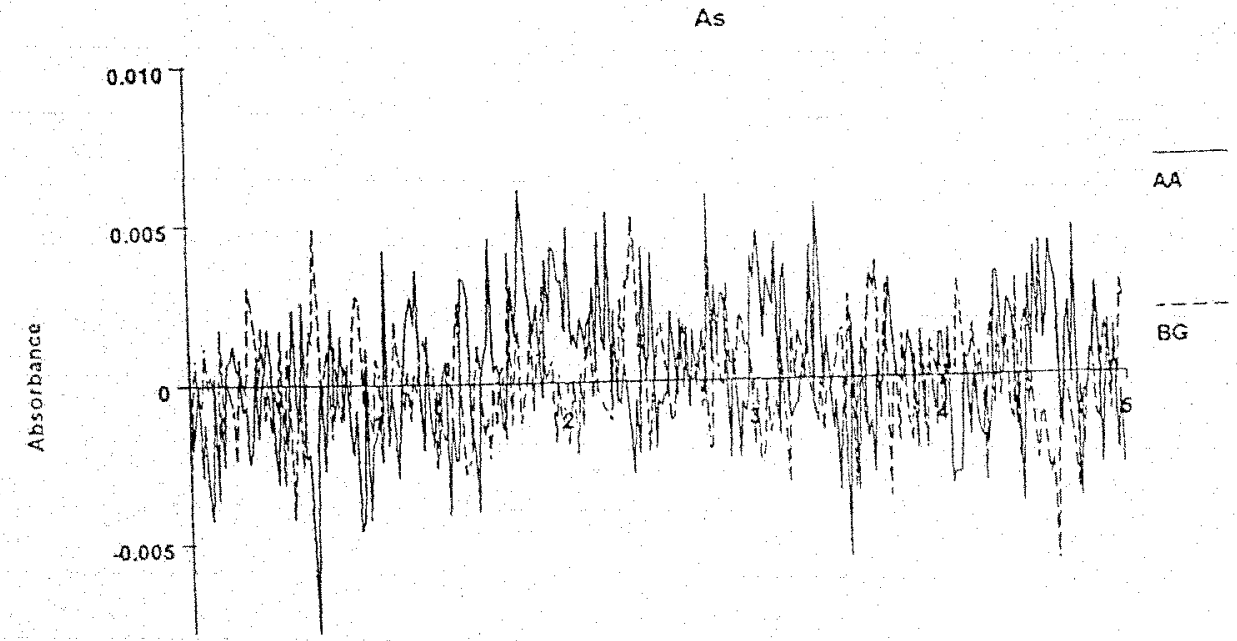

Time (seconds) 


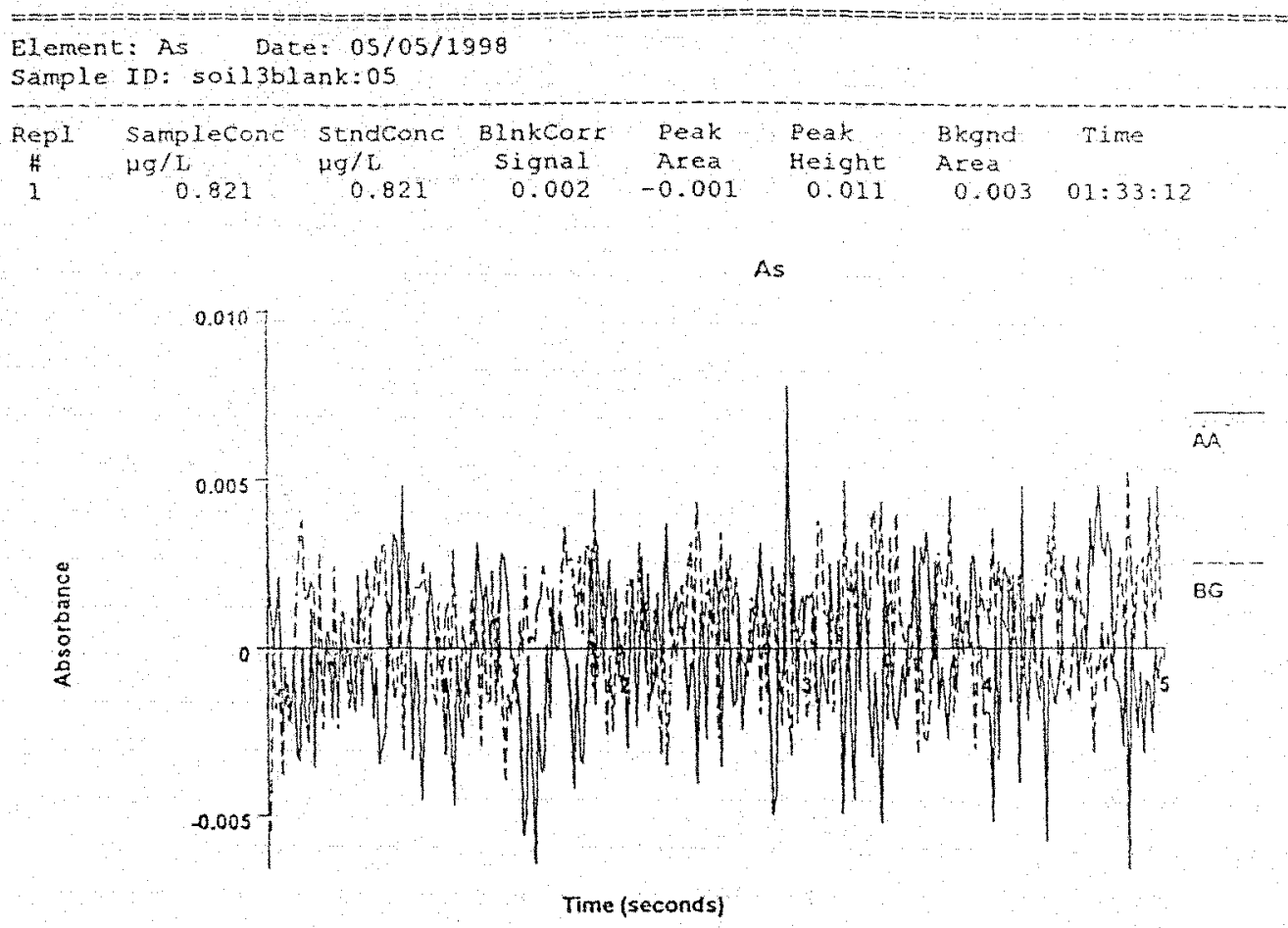

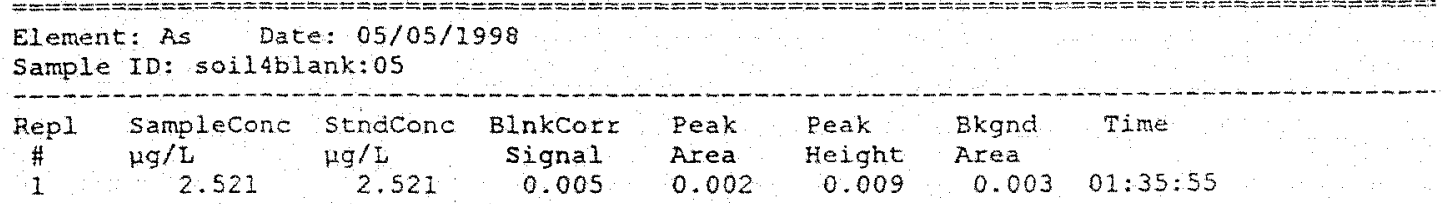

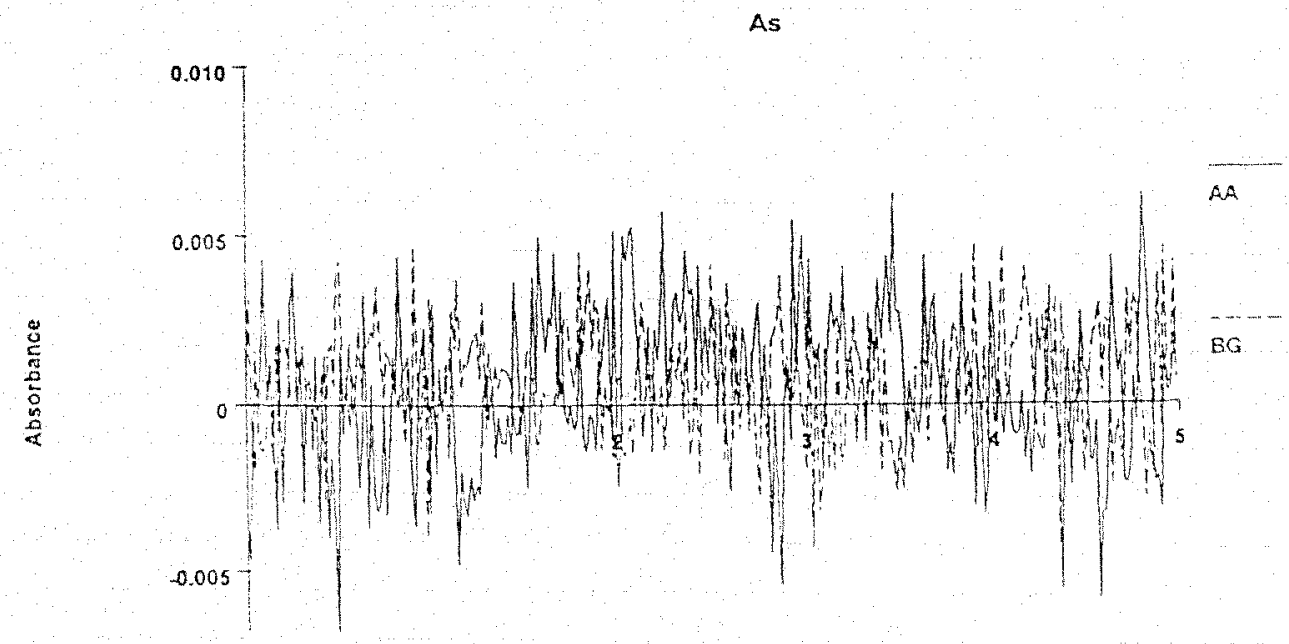

Time (seconds) 


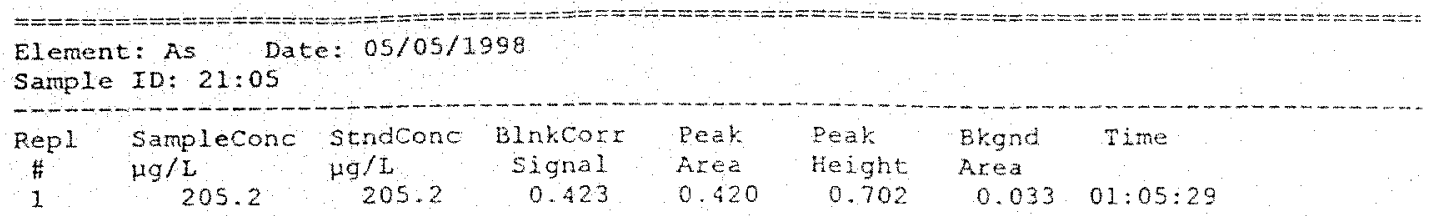

As

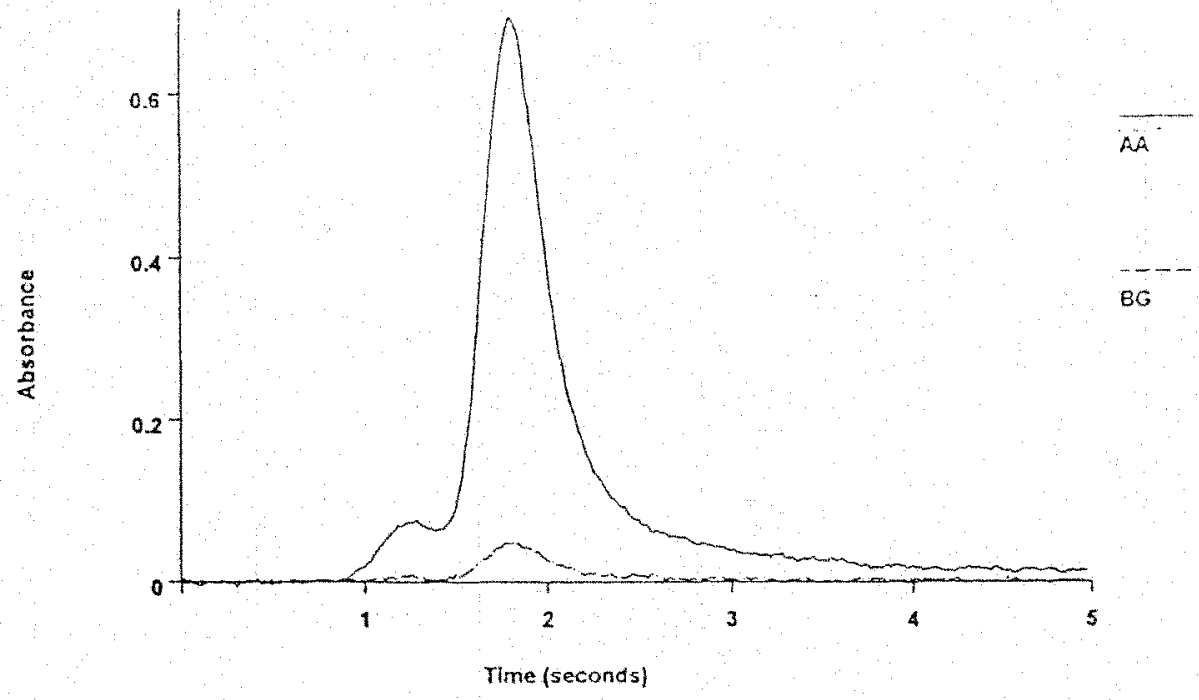

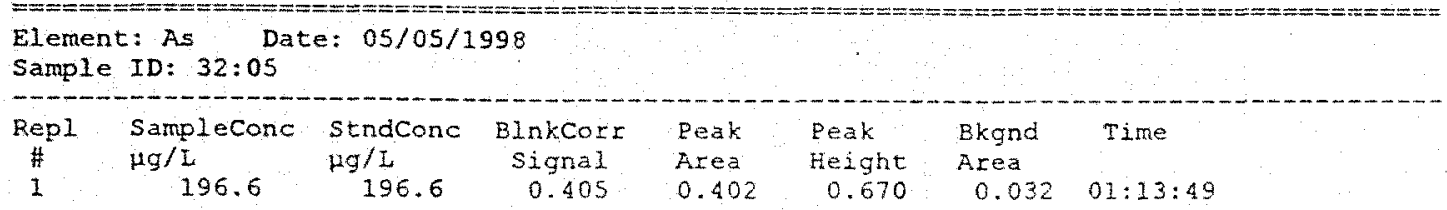

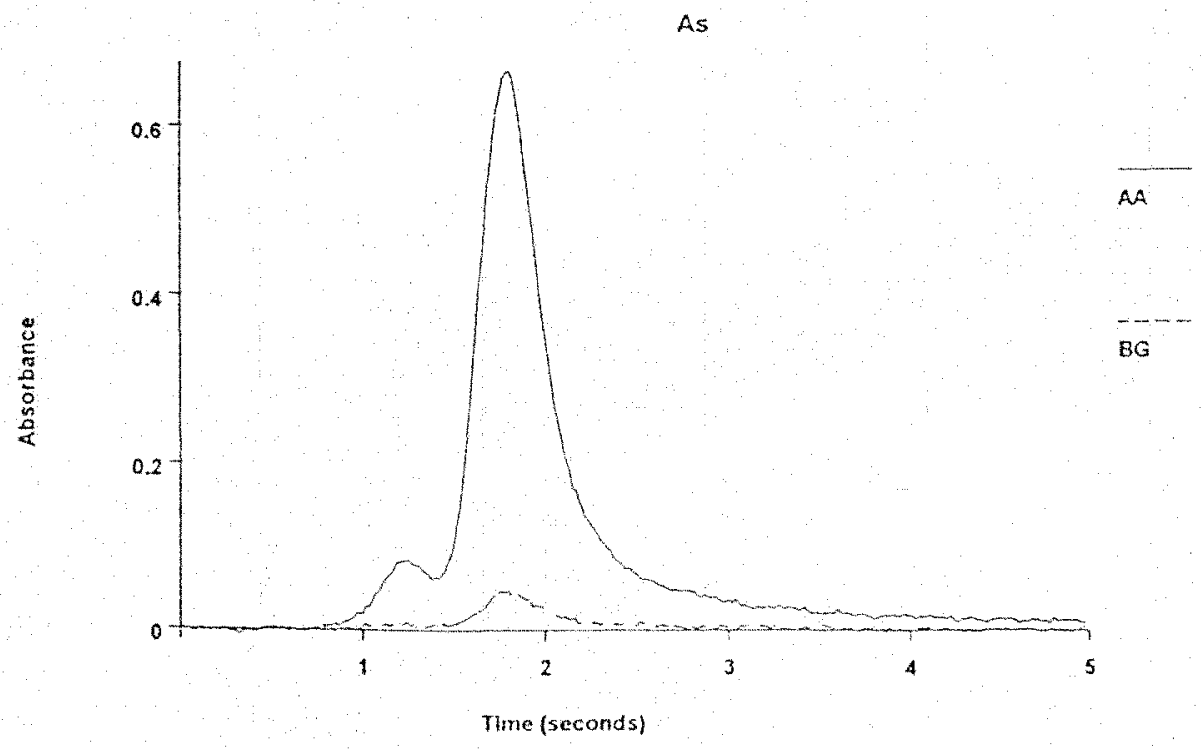



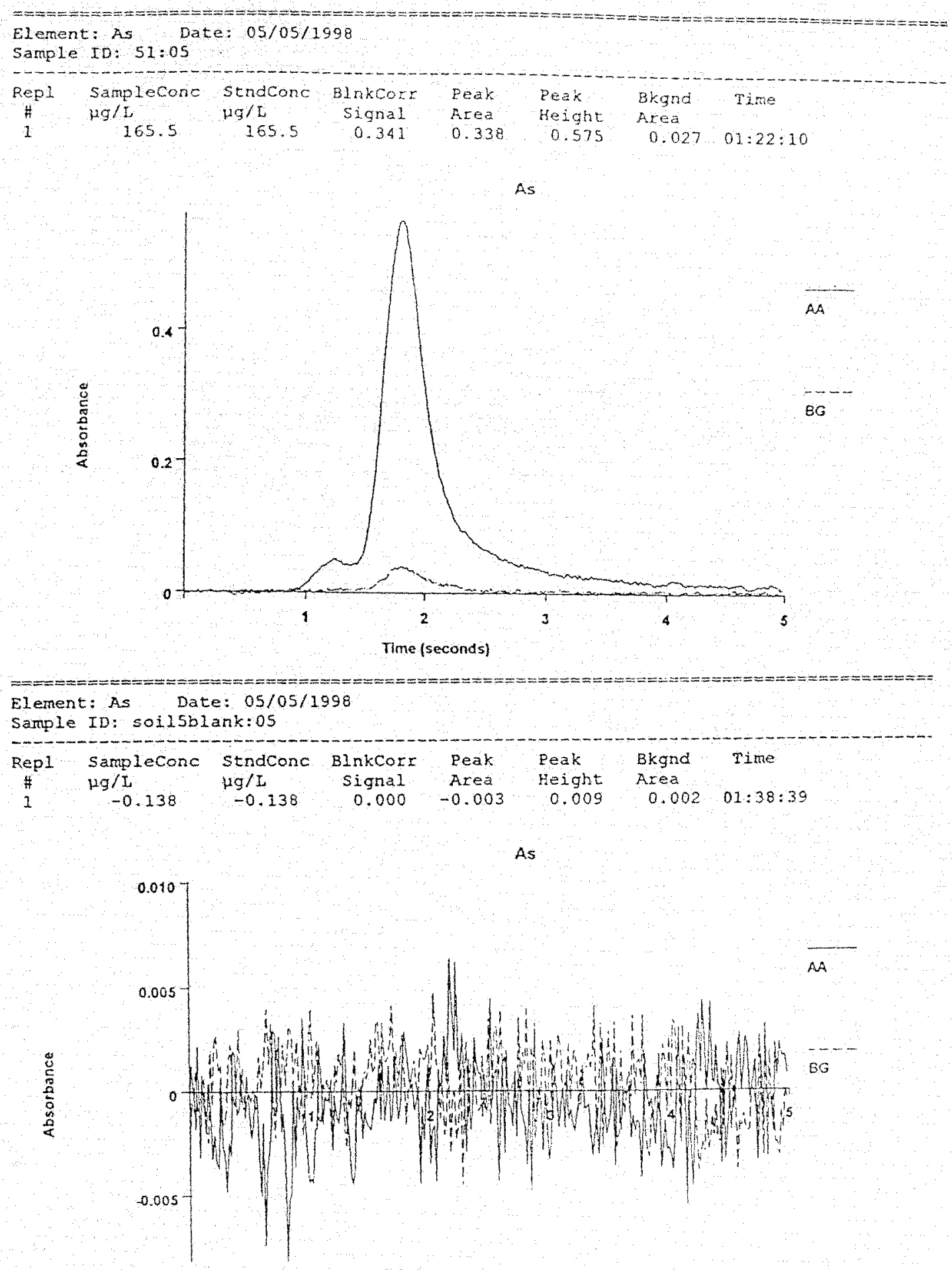

Tine (seconds) 


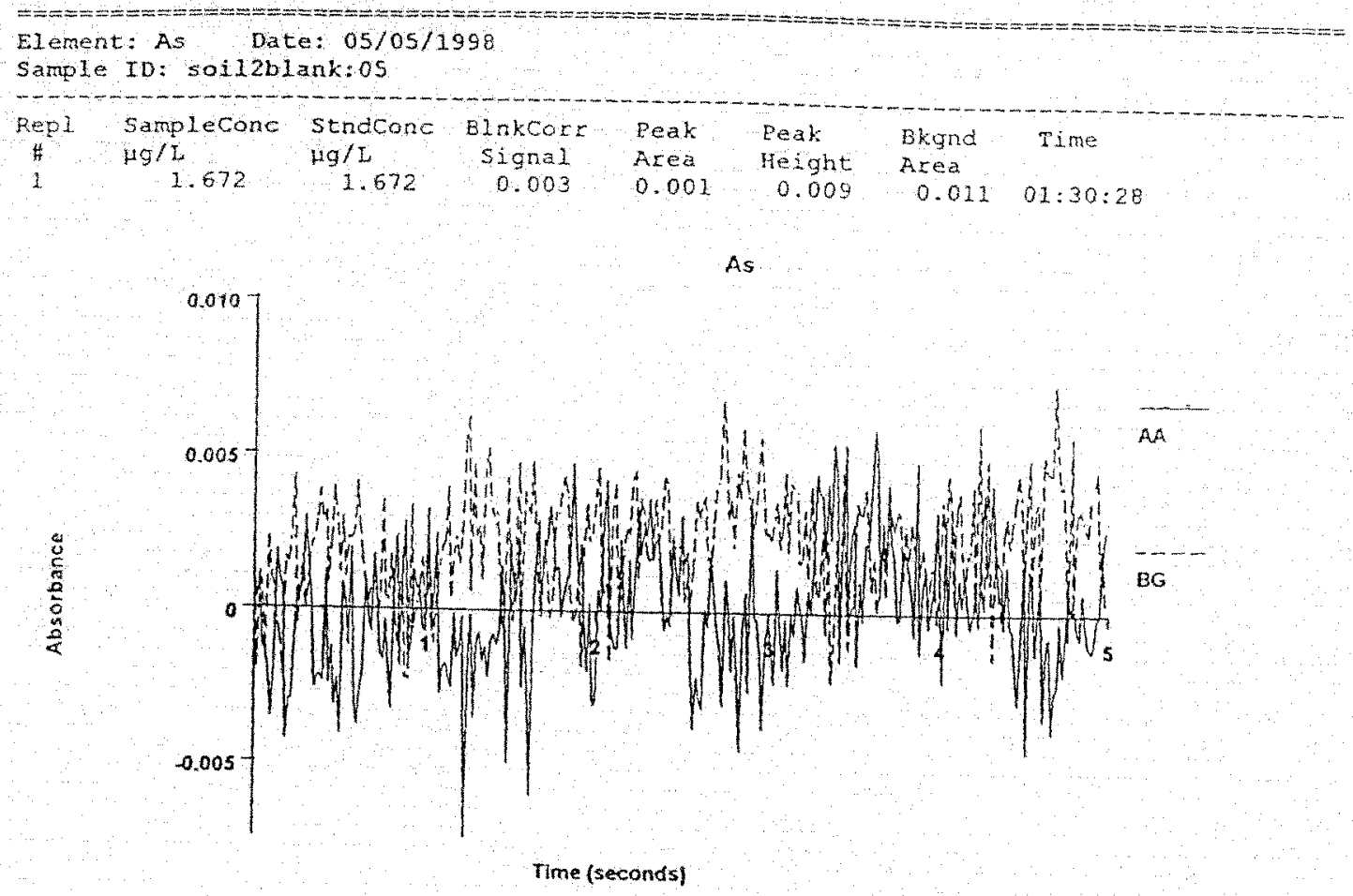



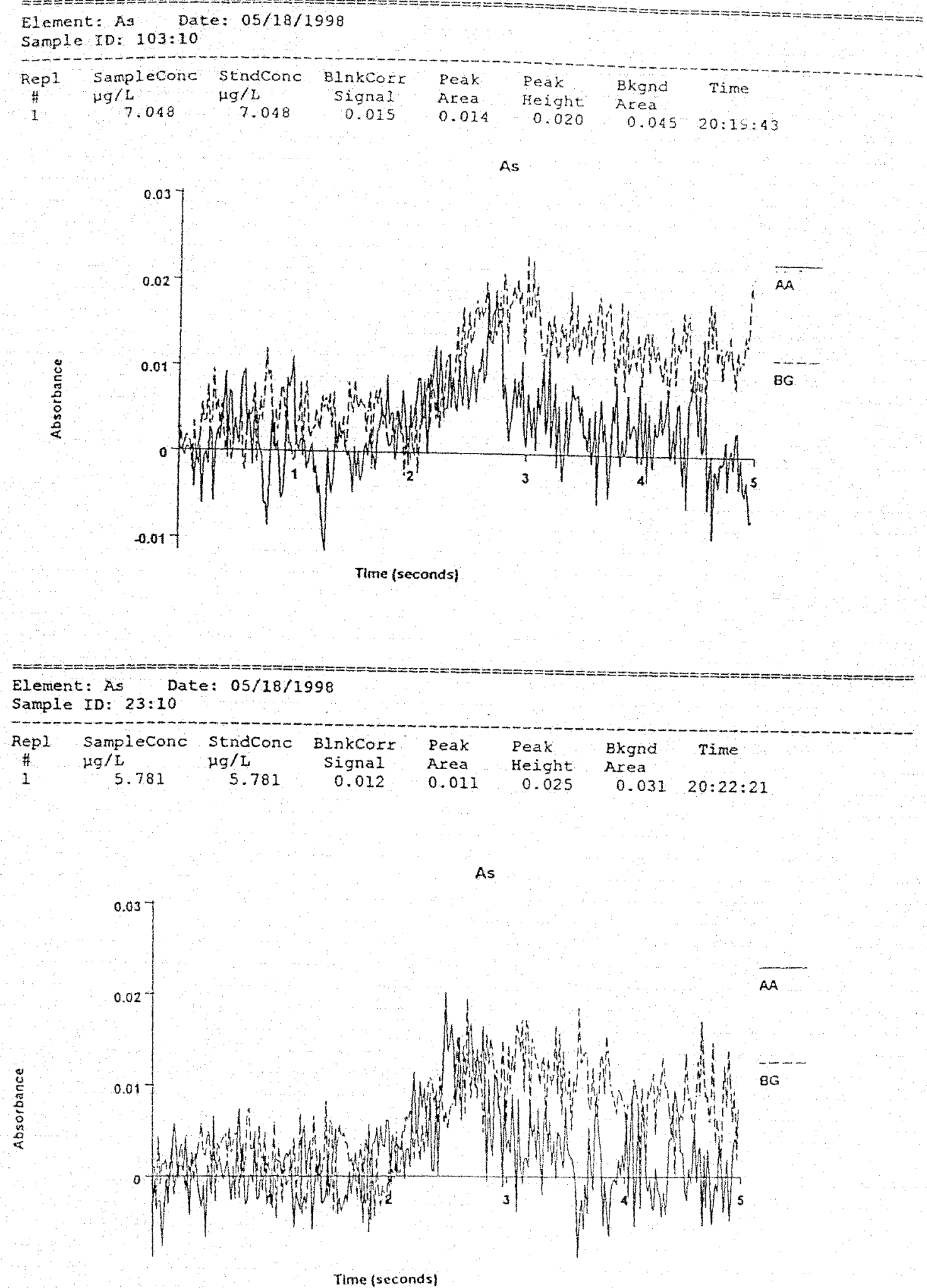


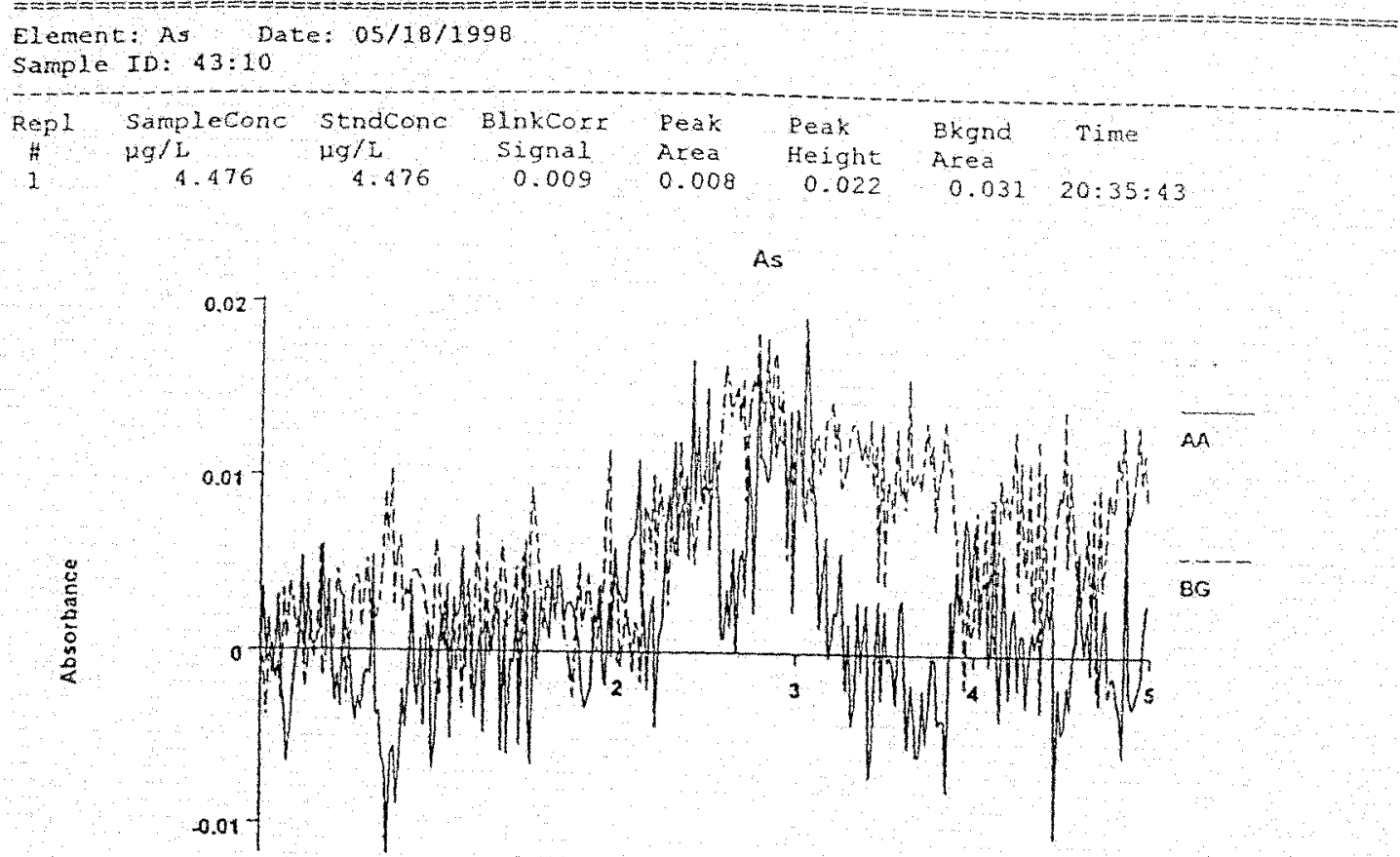

Time (seconds)

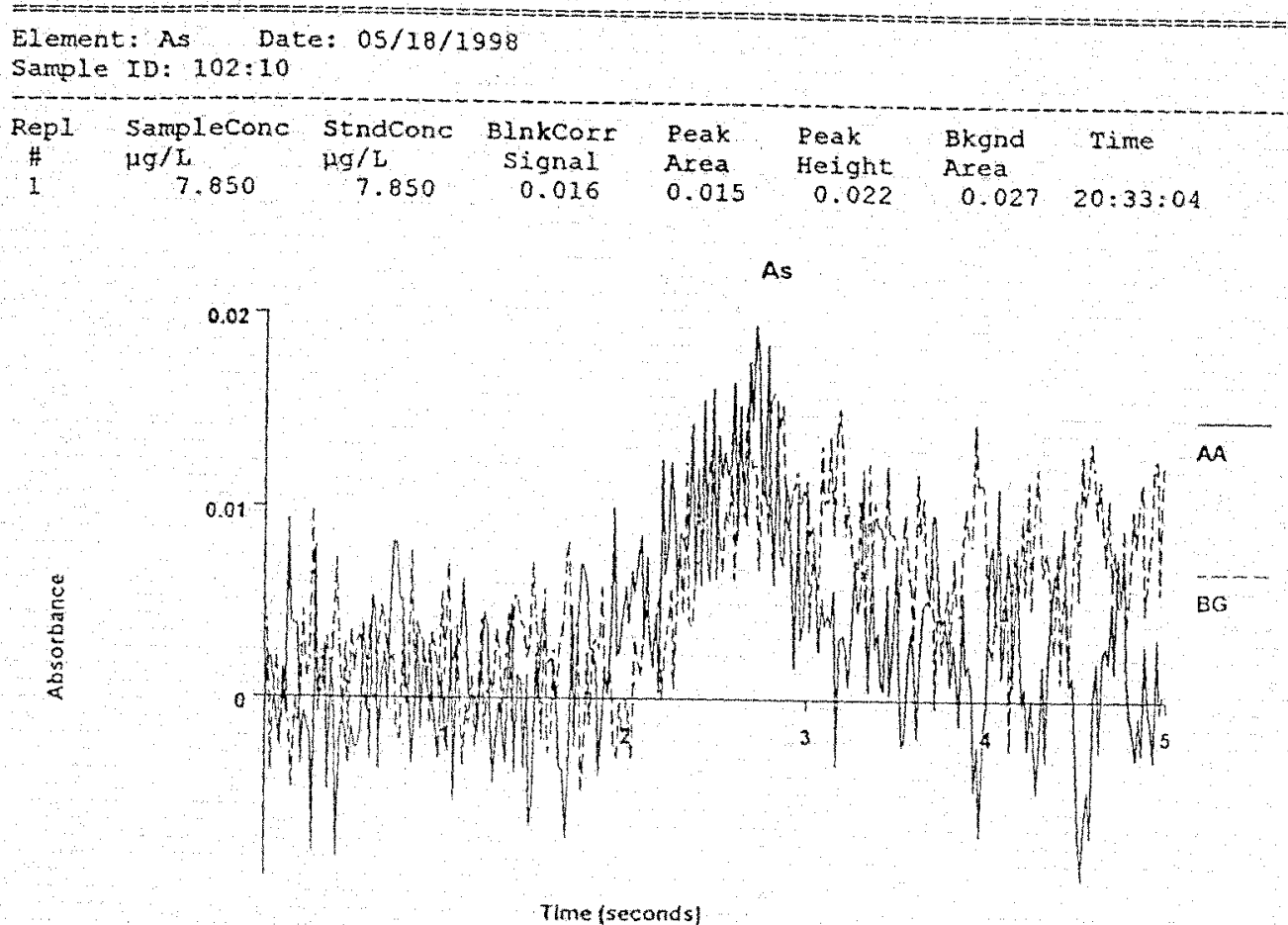



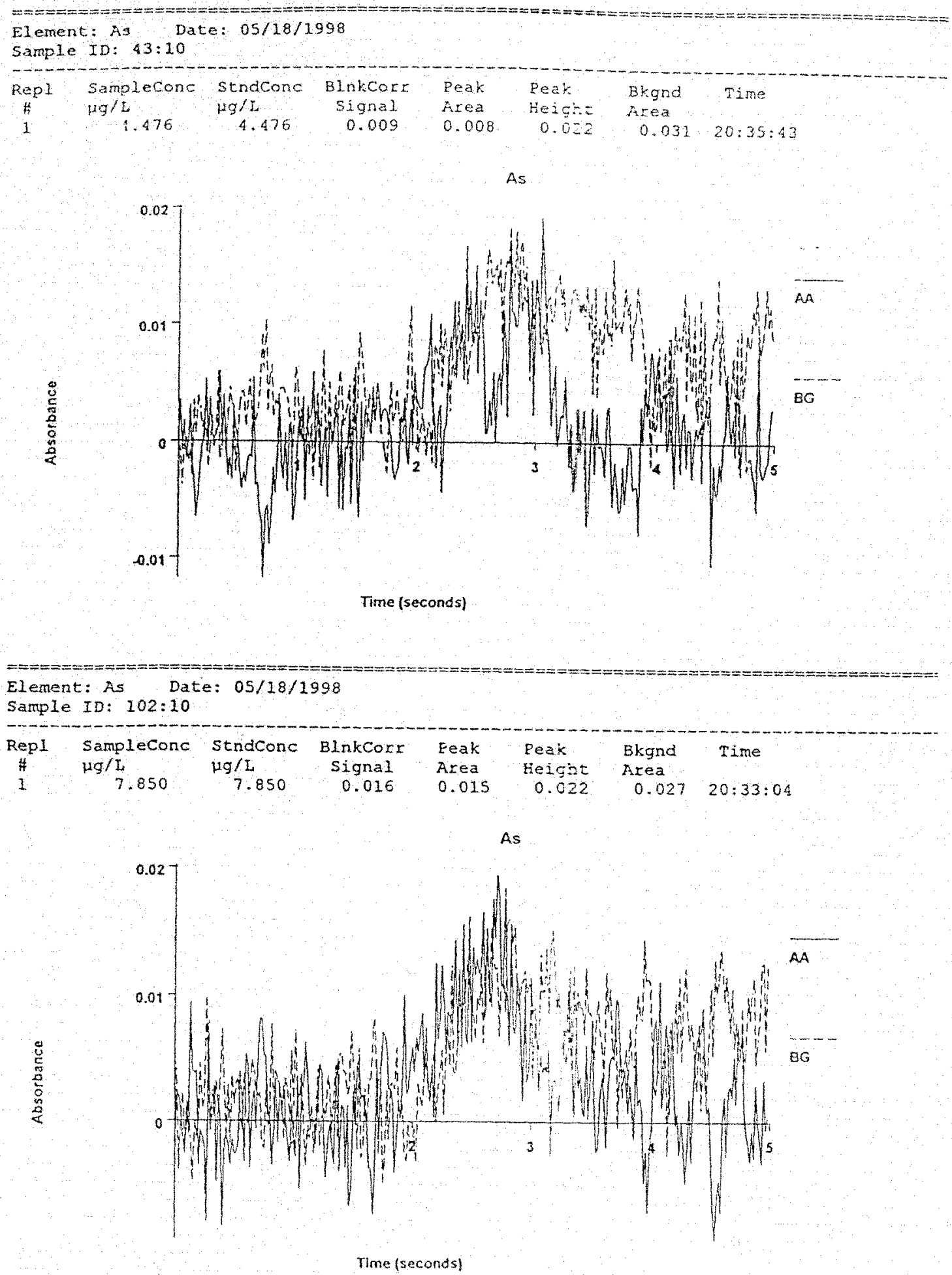


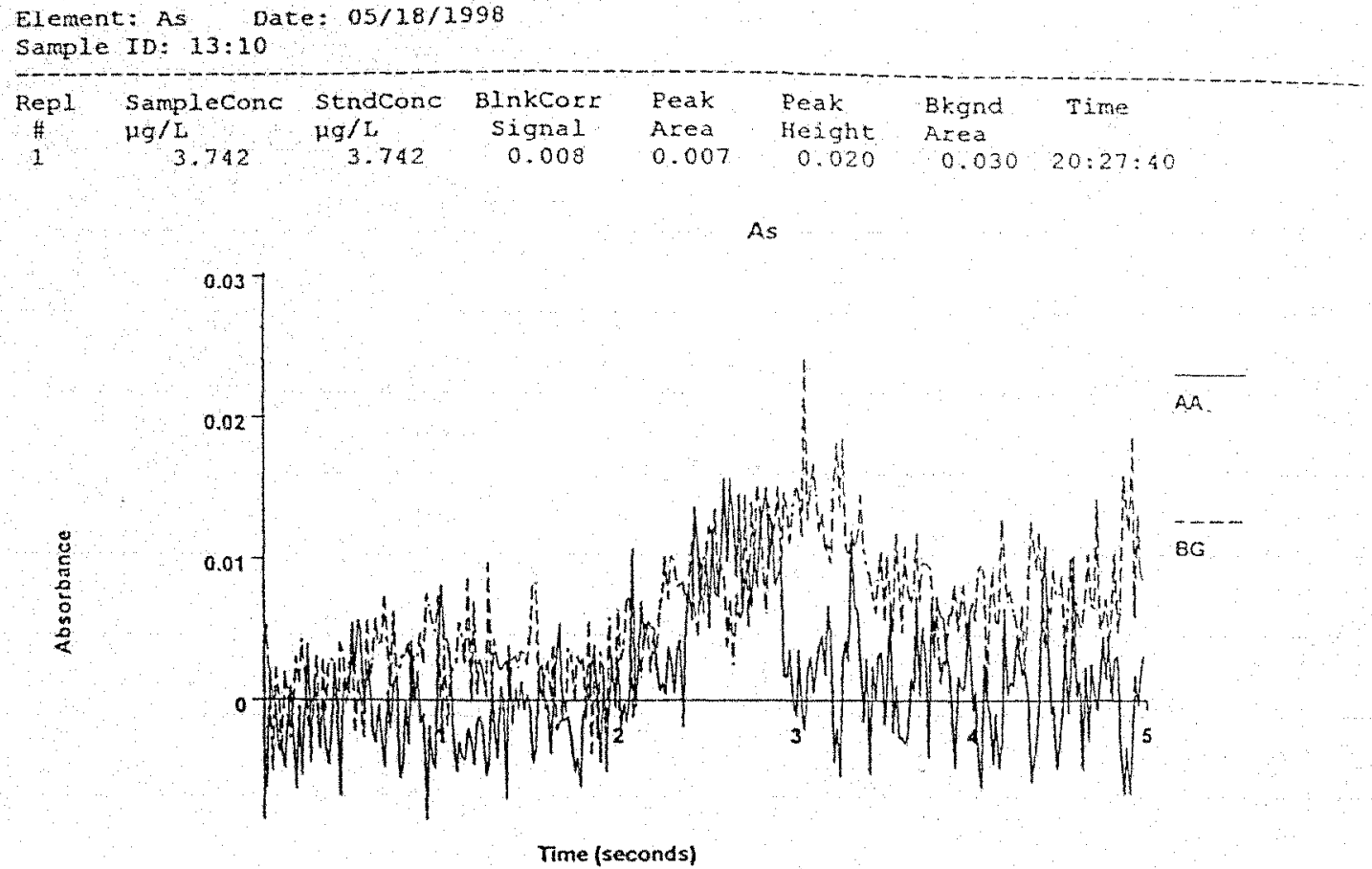

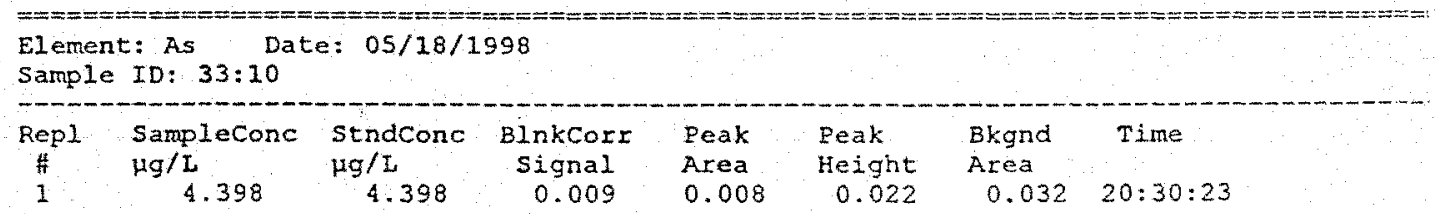

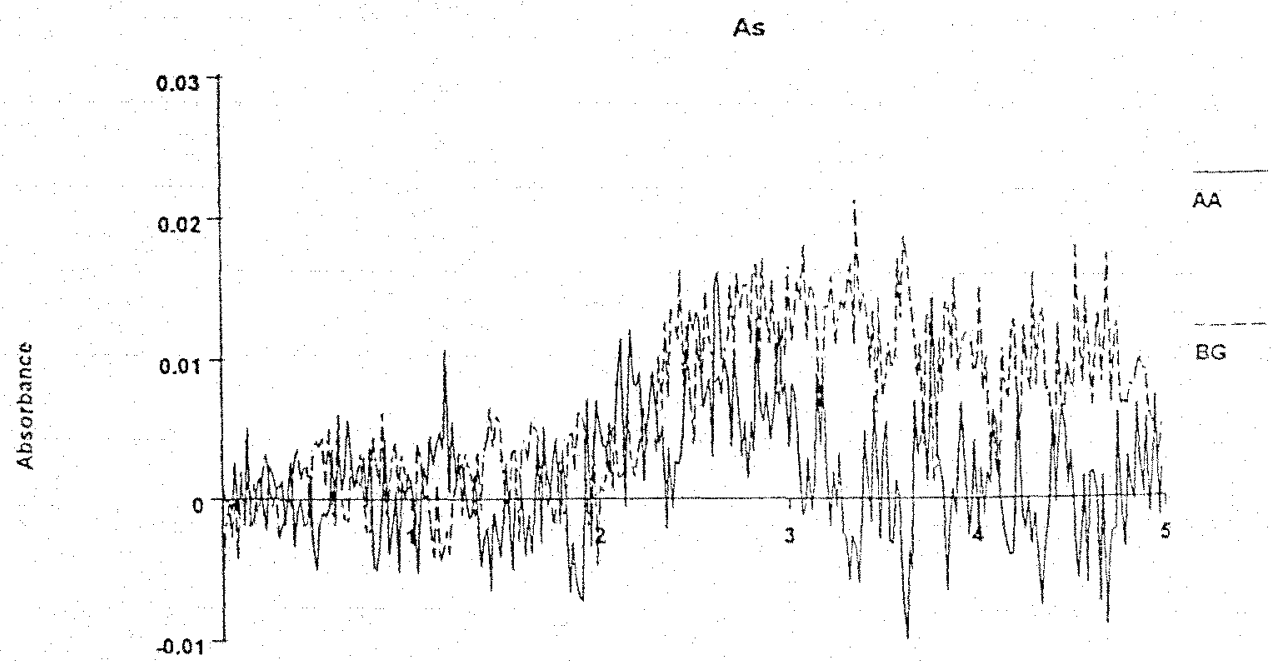

Time (seconds) 

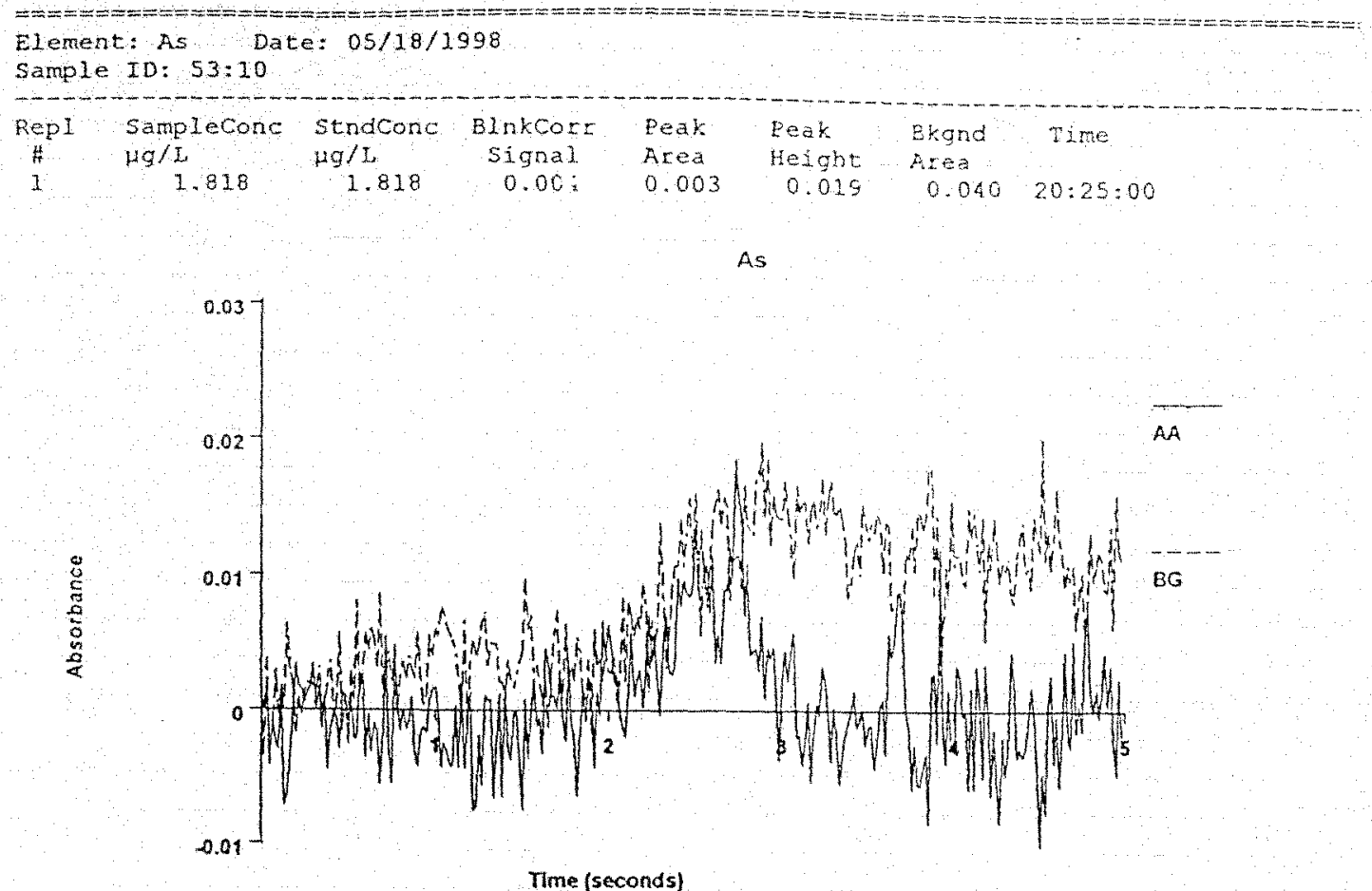
Element: As Date: 05/18/1998

Sample ID: $33: 50$

\begin{tabular}{|c|c|c|c|c|c|c|c|}
\hline $\begin{array}{c}\text { Repl } \\
\text { H. } \\
1\end{array}$ & $\begin{array}{l}\text { Sampleconc } \\
\mu \mathrm{g} / \mathrm{L} \\
49.37\end{array}$ & $\begin{array}{c}\text { StndConc } \\
\mathrm{hg} / \mathrm{L} \\
49.37\end{array}$ & $\begin{array}{c}\text { Blnkcort } \\
\text { Signal } \\
0.102\end{array}$ & $\begin{array}{l}\text { Peak } \\
\text { Area } \\
0.101\end{array}$ & $\begin{array}{l}\text { Reak } \\
\text { Height } \\
0.115\end{array}$ & $\begin{array}{l}\text { Ekgnd } \\
\text { Area } \\
0.038\end{array}$ & $19: 59: 21$ \\
\hline
\end{tabular}

As

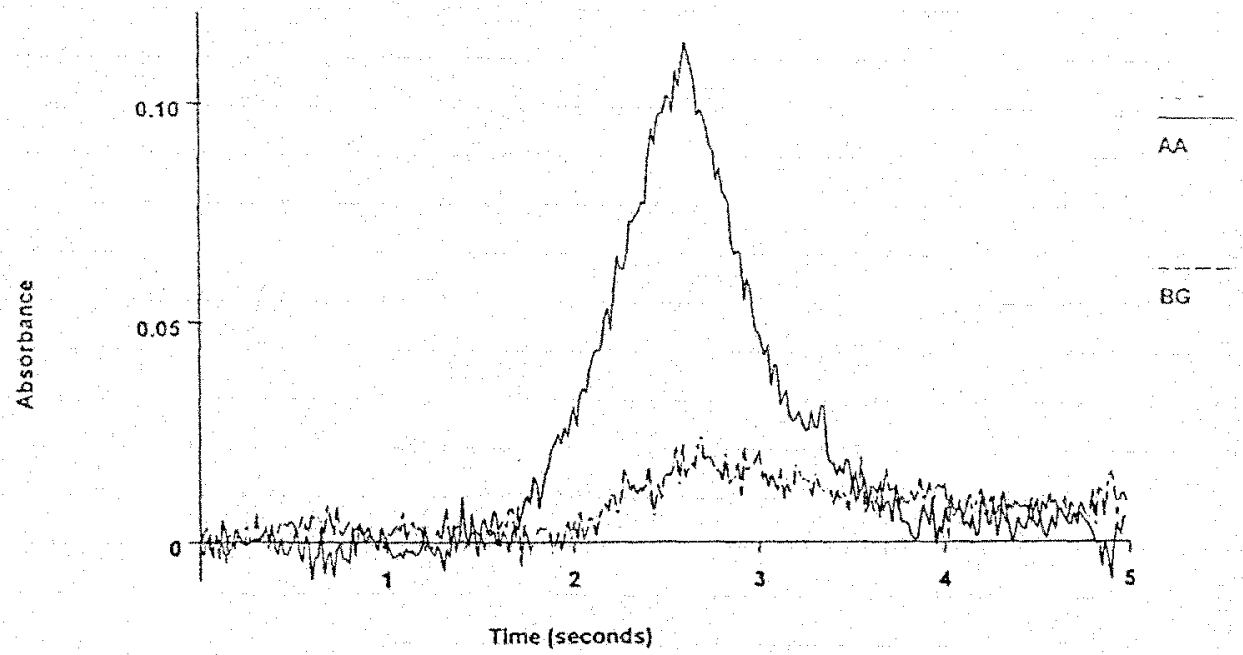

\begin{tabular}{|c|c|c|c|c|c|c|c|}
\hline $\begin{array}{l}\text { Eleme } \\
\text { Sampl }\end{array}$ & $\begin{array}{l}: \text { Ds } \text { Dat } \\
\text { ID: } 54: 50\end{array}$ & $=05 / 18 /$ & 98 & & & & \\
\hline $\begin{array}{c}\text { Repl } \\
\# \\
1\end{array}$ & $\begin{array}{l}\text { Sampleconc } \\
\mathrm{Hg} / \mathrm{L} \\
42.48\end{array}$ & $\begin{array}{l}\text { Stndcone } \\
\mu g / L \\
42.48\end{array}$ & $\begin{array}{c}\text { BlnkCort } \\
\text { Signa1 } \\
0.088\end{array}$ & $\begin{array}{l}\text { Peak } \\
\text { Area } \\
0.087\end{array}$ & $\begin{array}{l}\text { Peak } \\
\text { Height } \\
0.108\end{array}$ & $\begin{array}{l}\text { Bkgnd } \\
\text { Area } \\
0.037\end{array}$ & $\begin{array}{l}\text { Thme } \\
20: 01: 54\end{array}$ \\
\hline
\end{tabular}

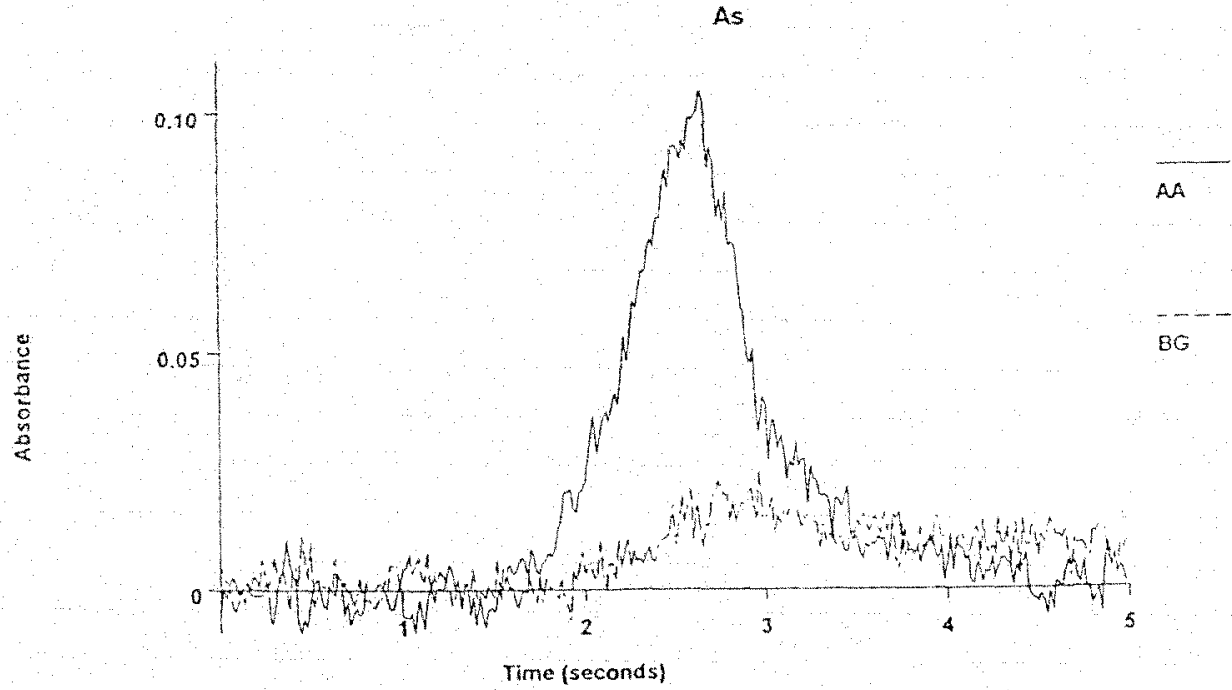




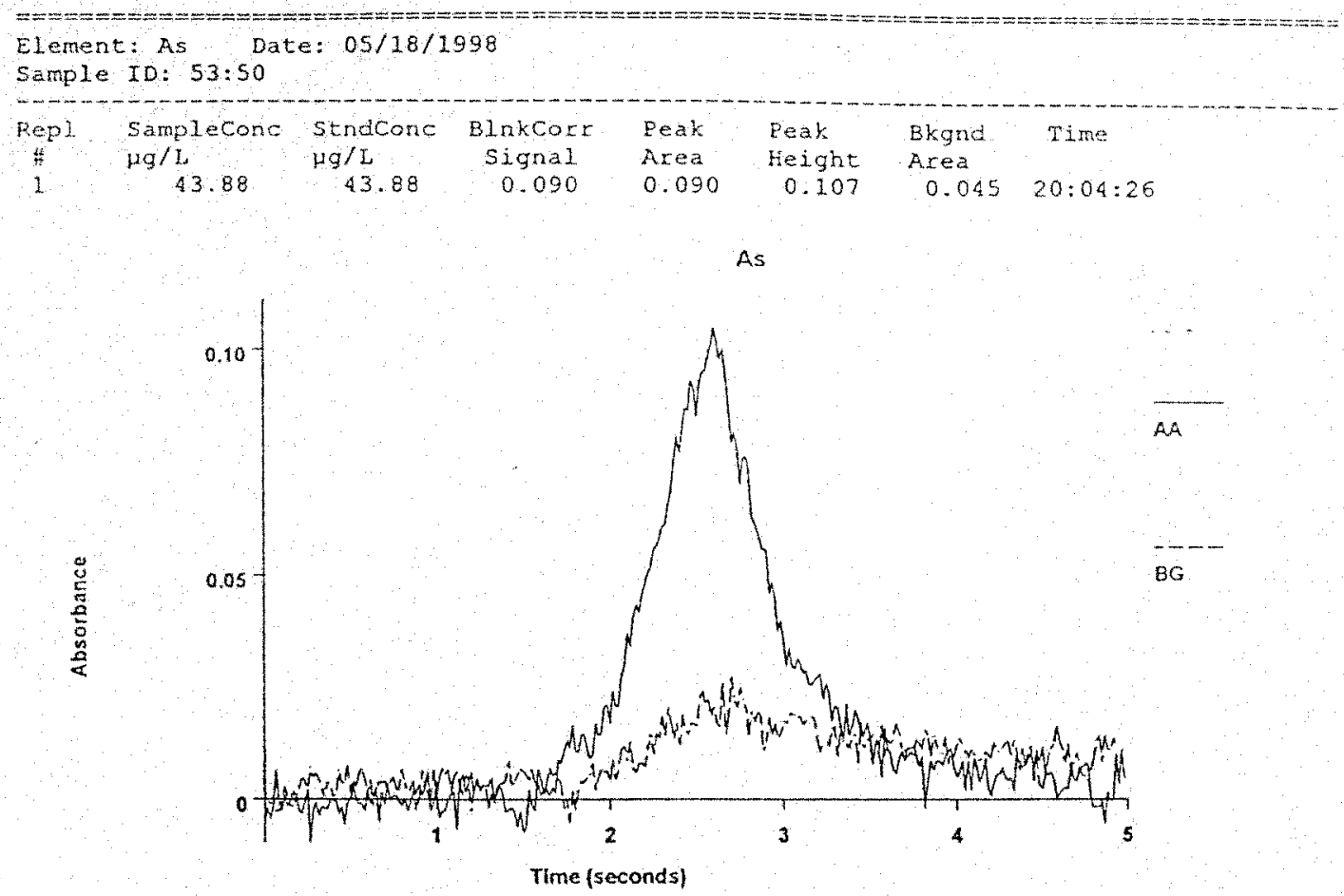

\begin{tabular}{|c|c|c|c|c|c|c|}
\hline $\begin{array}{l}\text { Element: As Dat } \\
\text { Sample ID: } 13: 50\end{array}$ & $05 / 18 / 1$ & 998 & & & & \\
\hline $\begin{array}{c}\text { Repl SampleCone } \\
1 \\
1\end{array} \quad \frac{\mu g / L}{44.20}$ & $\begin{array}{l}\text { Stndcone } \\
\text { Hg/J } \\
44.20\end{array}$ & $\begin{array}{c}\text { Blikcort } \\
\text { signal } \\
0.091\end{array}$ & $\begin{array}{l}\text { Eeak } \\
\text { Area } \\
0.090\end{array}$ & $\begin{array}{l}\text { Peak } \\
\text { Height } \\
0.117\end{array}$ & $\begin{array}{l}\text { Bkgnd } \\
\text { Area } \\
0.054\end{array}$ & $\begin{array}{l}\text { Time } \\
20: 06: 57\end{array}$ \\
\hline
\end{tabular}

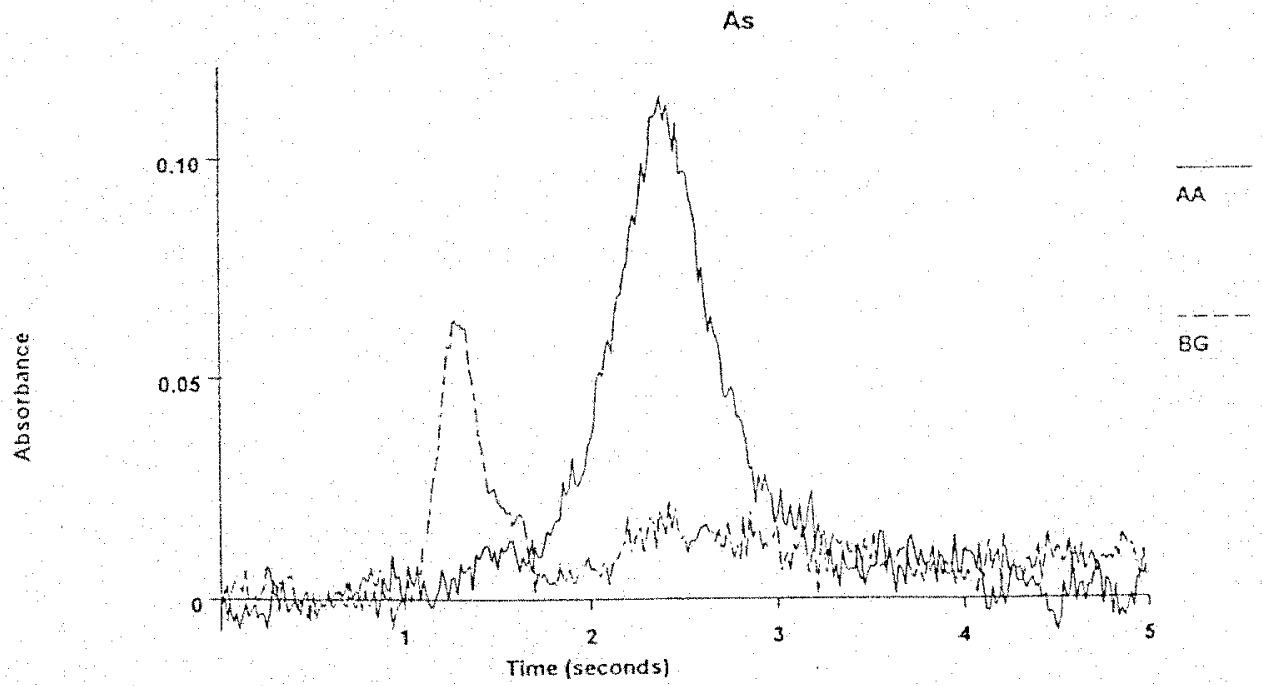



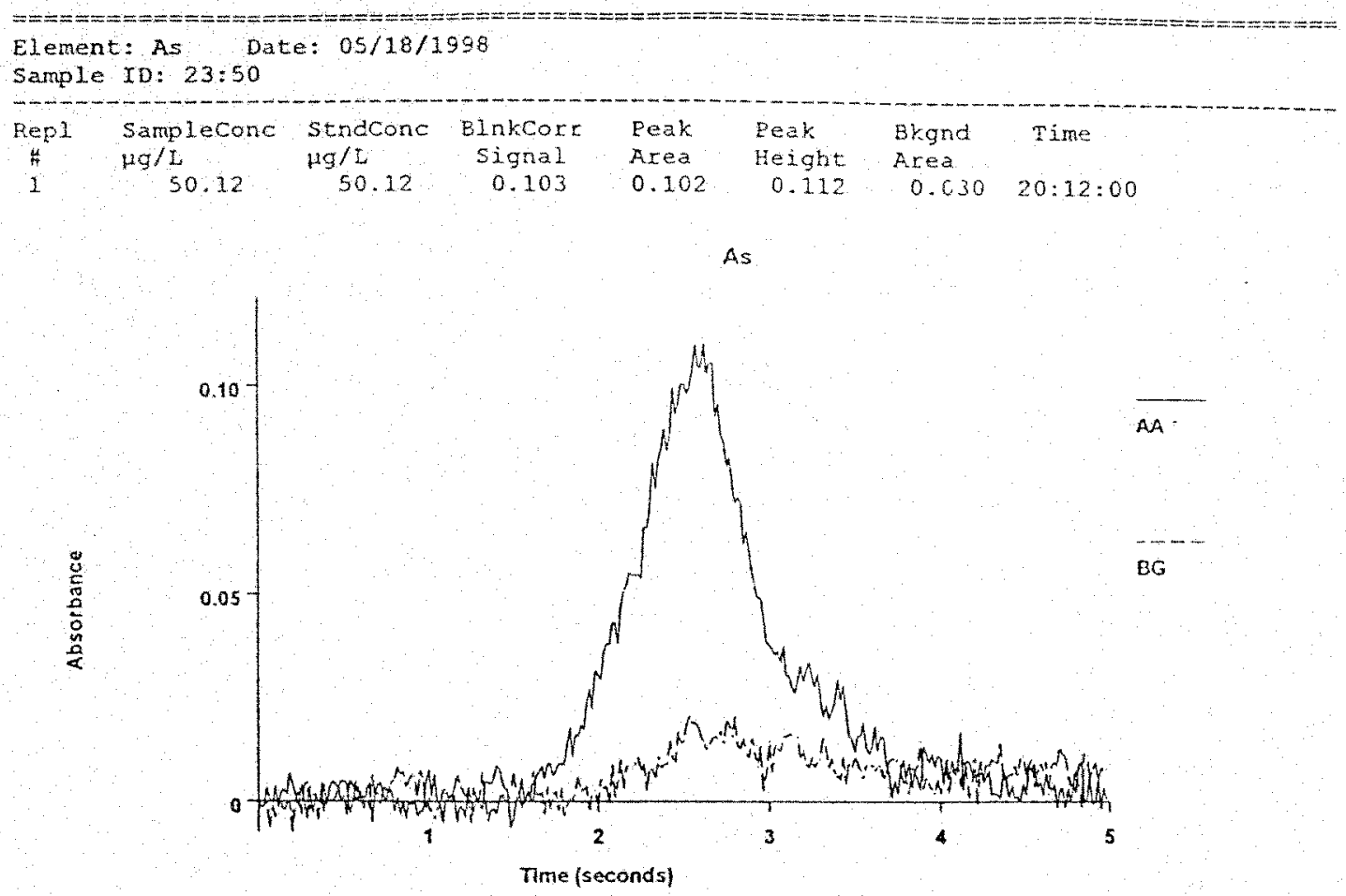

$== \pm= \pm== \pm=$

Element: As Date: 05/18/1998

Sample ID: $503: 50$

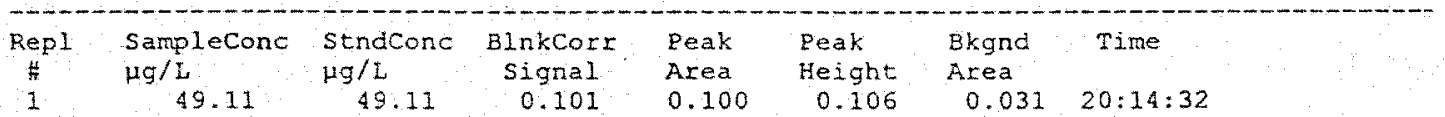

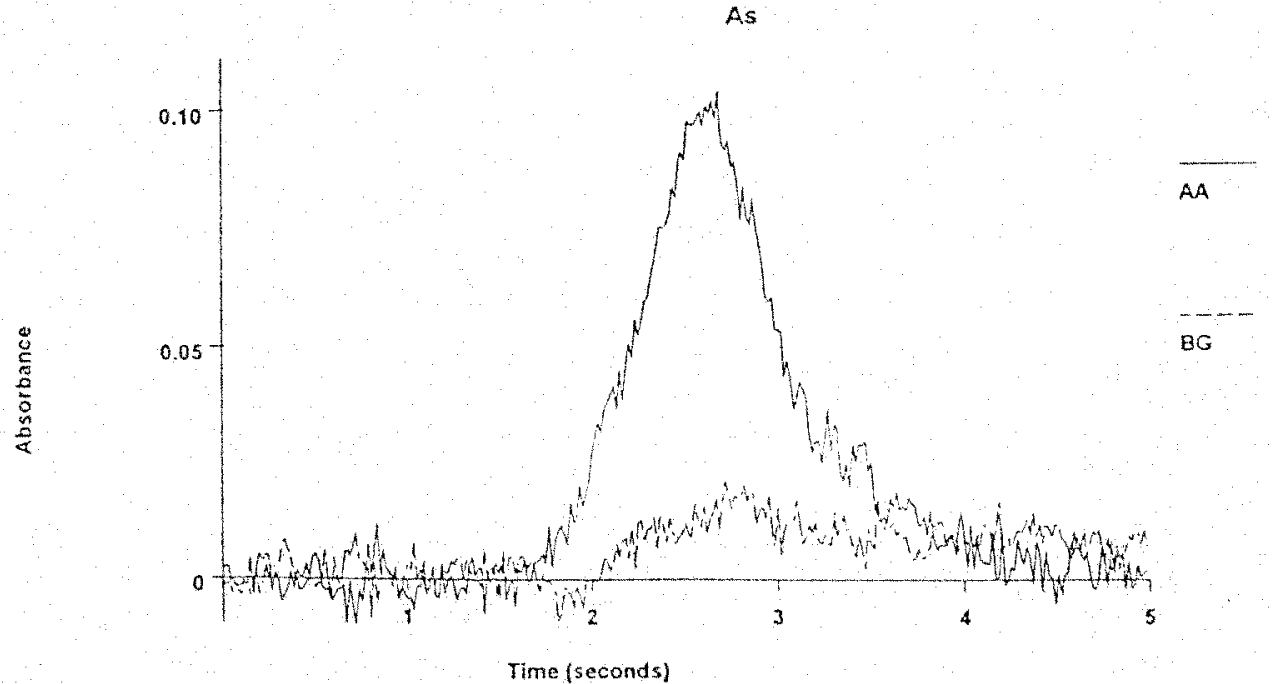




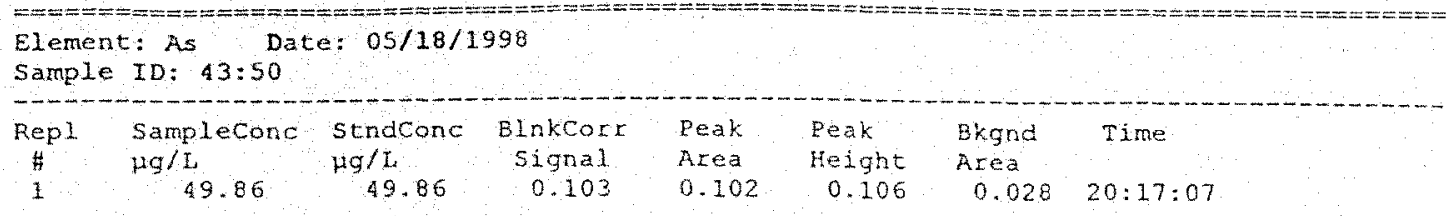

As
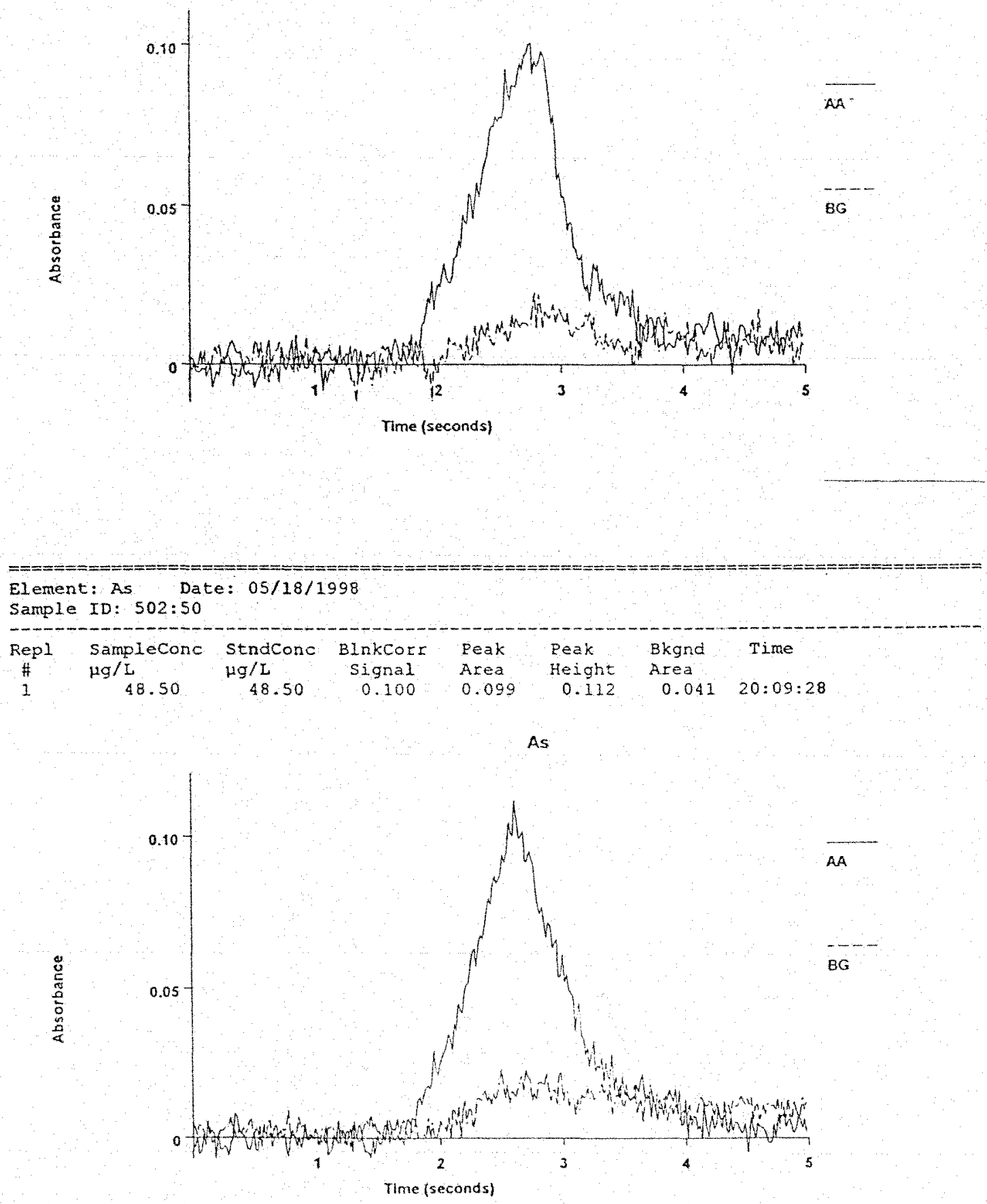

252 


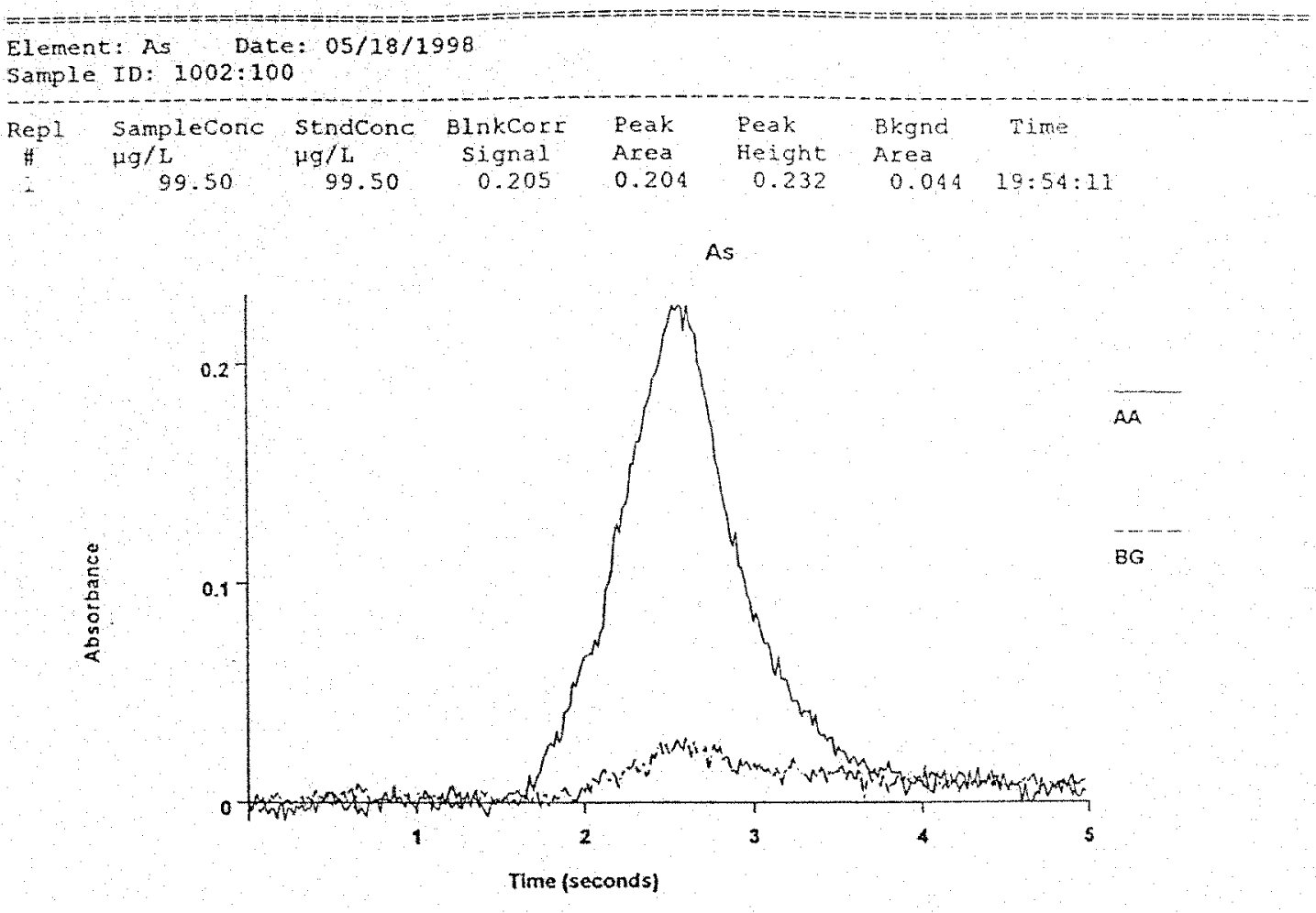

\begin{tabular}{|c|c|c|c|c|c|c|c|}
\hline $\begin{array}{l}\text { Elemer } \\
\text { Sample }\end{array}$ & $\begin{array}{l}\text { As Dat } \\
\text { ID: } 1003: 10\end{array}$ & $=05 / 18 / 1$ & 98 & & & & \\
\hline $\begin{array}{c}\text { Repl } \\
\# \\
1\end{array}$ & $\begin{array}{c}\text { Sampleconc } \\
\mu \mathrm{g} / \mathrm{L} \\
99.17\end{array}$ & $\begin{array}{c}\text { StndConc } \\
\mu \mathrm{g} / \mathrm{L} \\
99.48\end{array}$ & $\begin{array}{l}\text { Blnkcort } \\
\text { Signal } \\
0.205\end{array}$ & $\begin{array}{l}\text { Peak } \\
\text { Area } \\
0.204\end{array}$ & $\begin{array}{l}\text { Peak } \\
\text { Height } \\
0.225\end{array}$ & $\begin{array}{l}\text { Bkgnd } \\
\text { Area } \\
0.045\end{array}$ & $\begin{array}{l}\text { Time } \\
19: 56: 47\end{array}$ \\
\hline
\end{tabular}

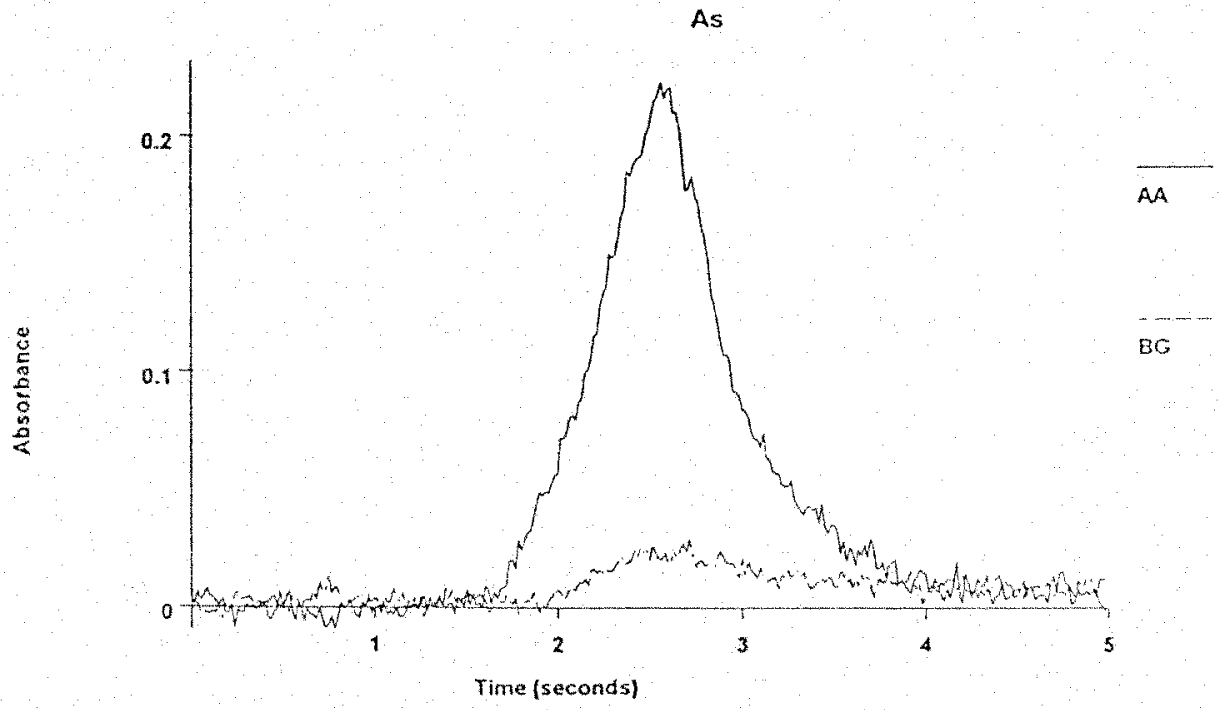




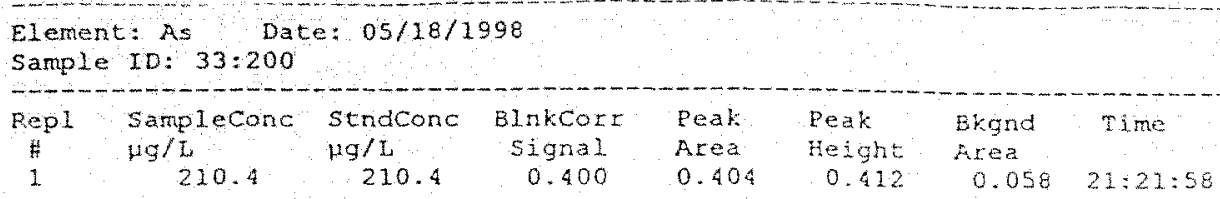

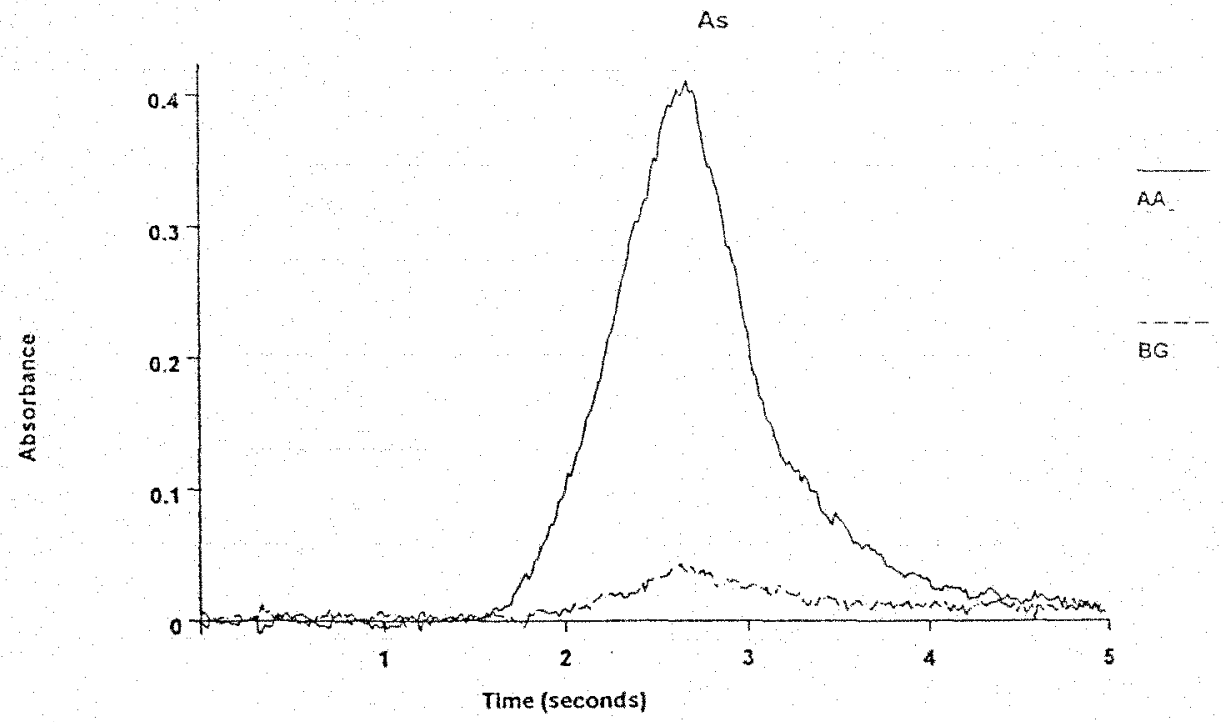

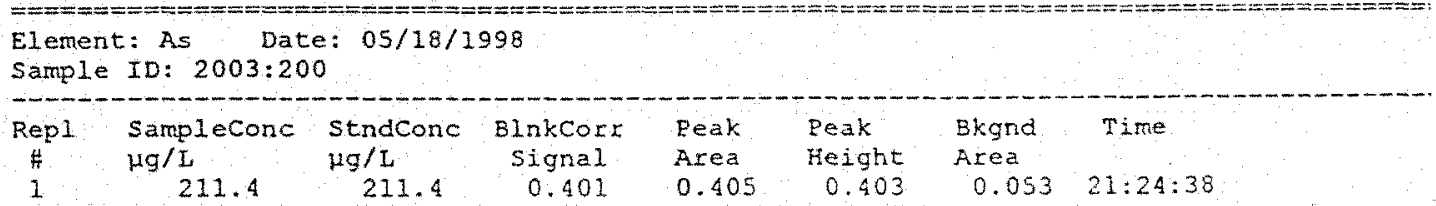

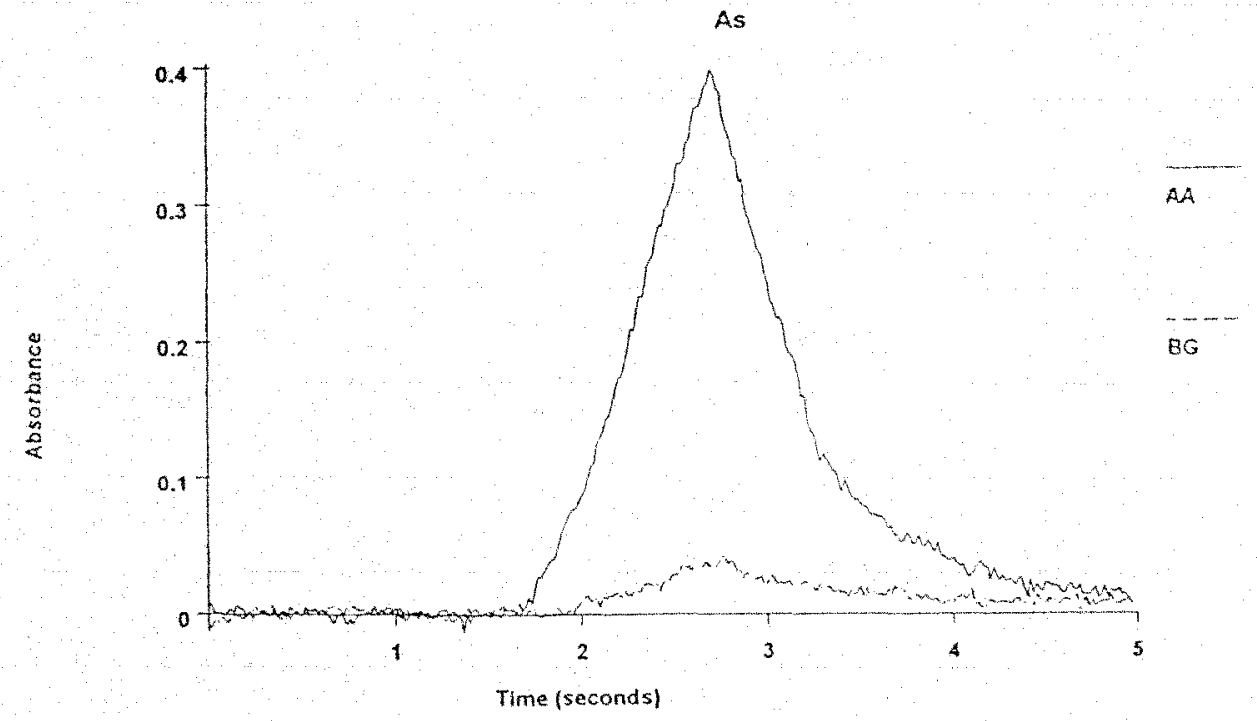




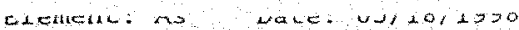

Sample ID: $43: 200$

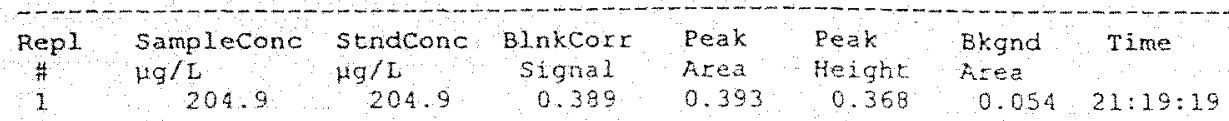

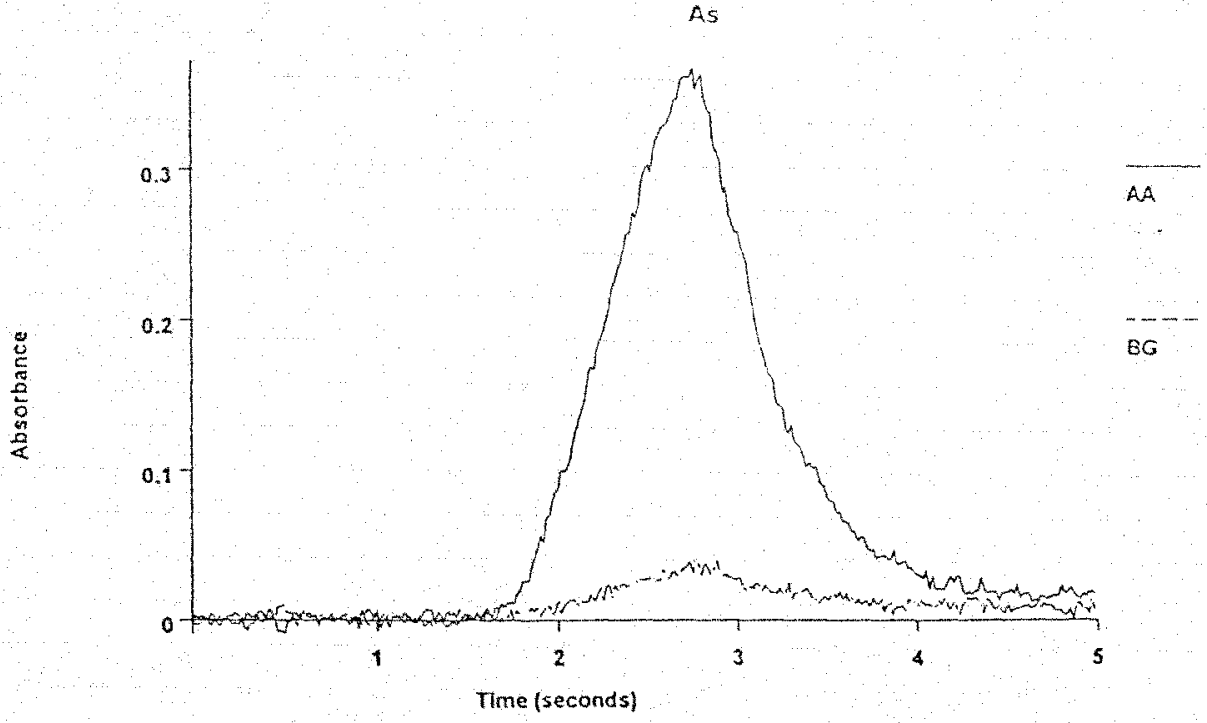

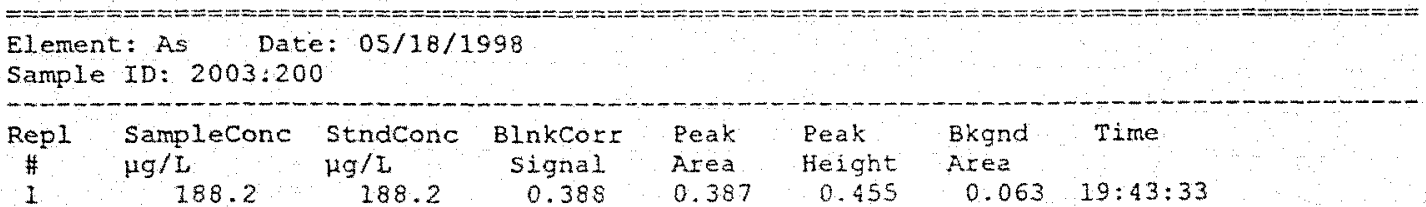

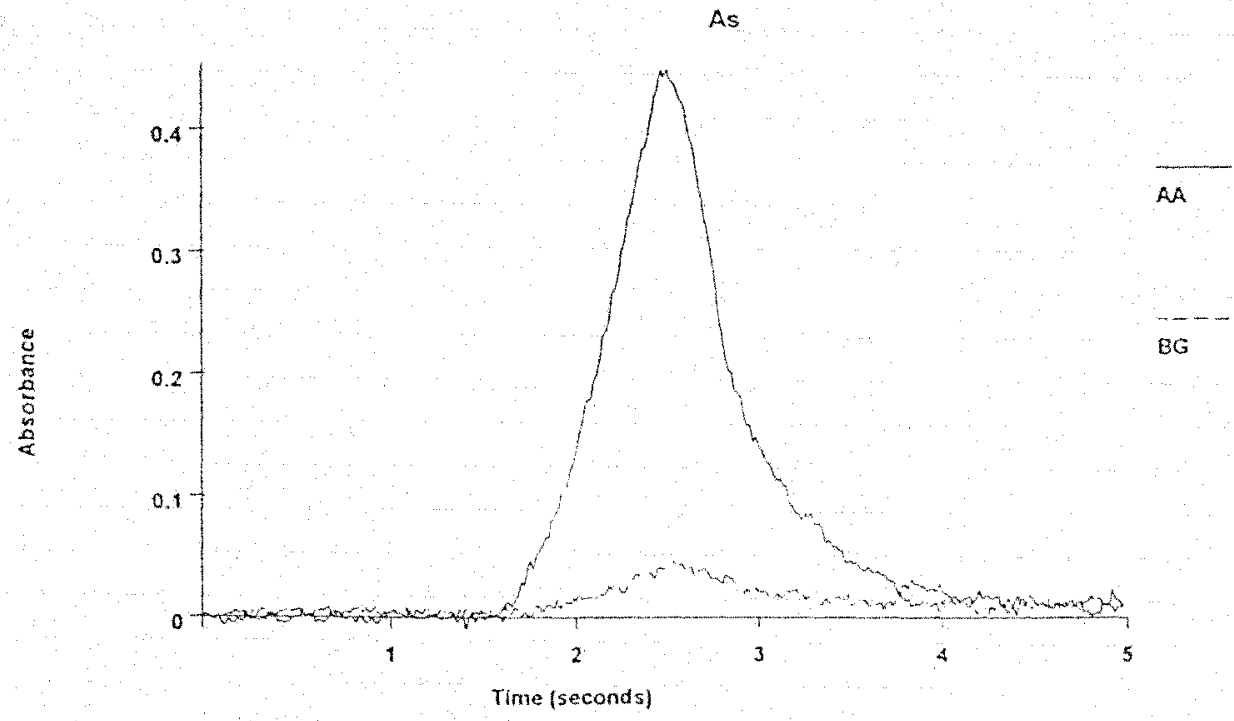




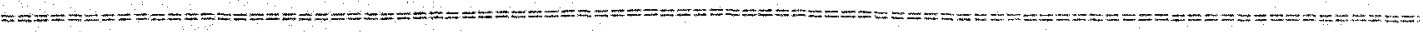

Elemerit hs Date: $05 / 18 / 1998$

Sample $1 \mathrm{D}: 2002: 200$

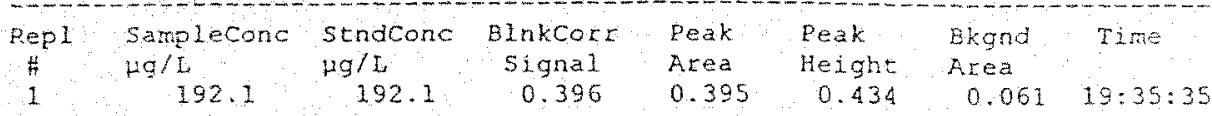

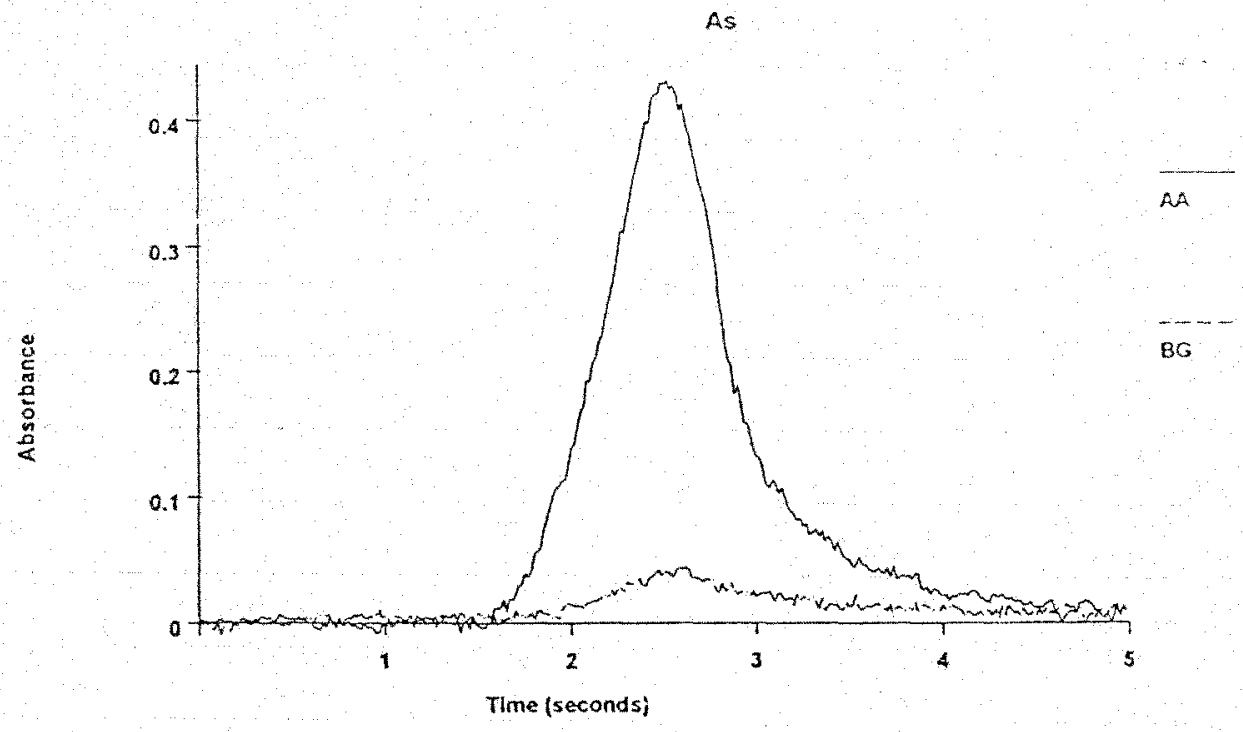




\begin{tabular}{|c|c|c|c|c|c|c|c|}
\hline $\begin{array}{l}\text { Rep } 1 \\
\text { 4 } \\
1\end{array}$ & $\begin{array}{l}\text { Samplecone } \\
\text { Hg/4 } \\
\qquad 196.9\end{array}$ & $\begin{array}{c}\text { StndConc } \\
\mu g / I \\
196.9\end{array}$ & $\begin{array}{c}\text { BlnkCotr } \\
\text { signal } \\
0.374\end{array}$ & $\begin{array}{l}\text { Reak } \\
\text { Area } \\
0.378\end{array}$ & $\begin{array}{l}\text { Peak } \\
\text { Hejght } \\
0.277\end{array}$ & $\begin{array}{l}\text { Ekgnd } \\
\text { Area } \\
0.067\end{array}$ & $\begin{array}{l}\text { Time } \\
22: 01: 06\end{array}$ \\
\hline
\end{tabular}

As

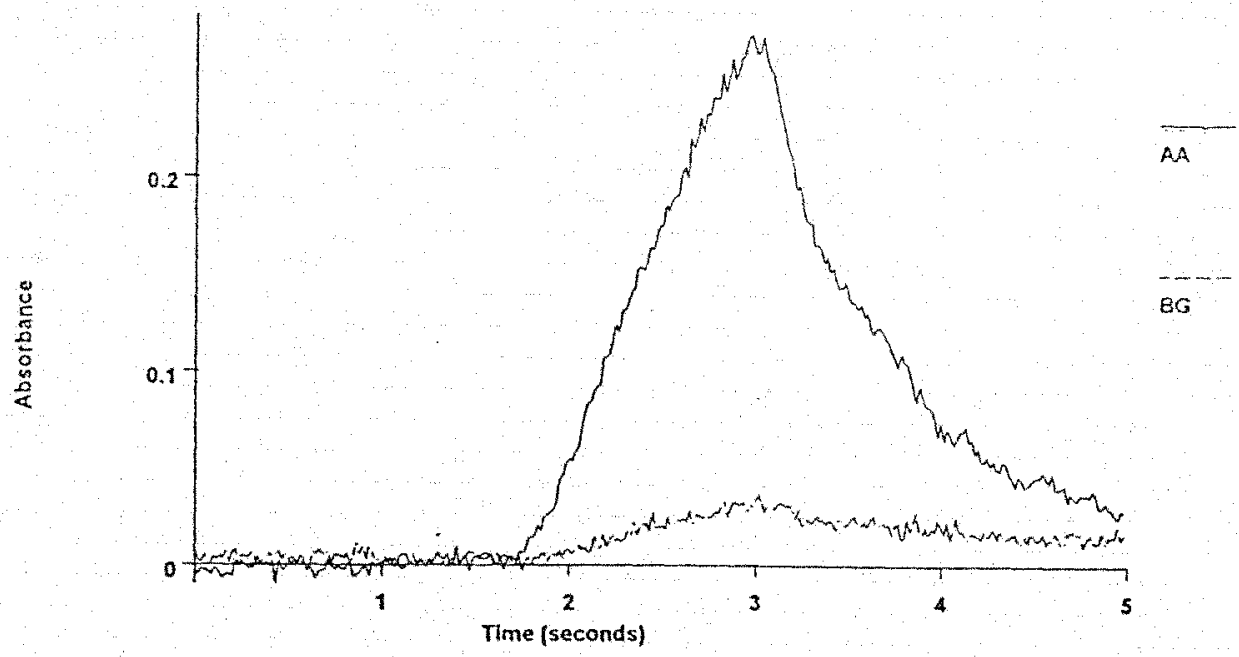

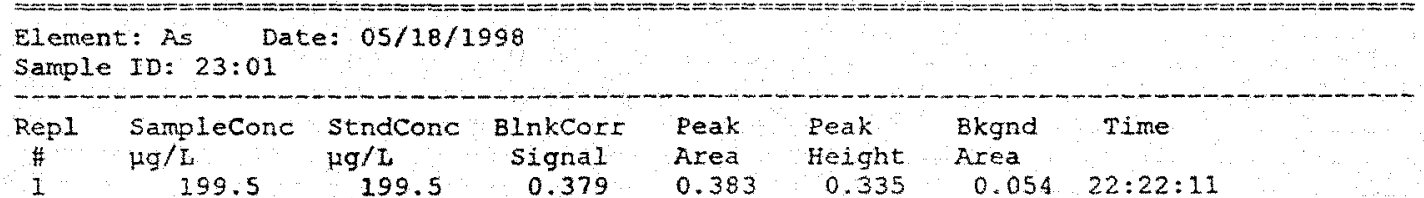

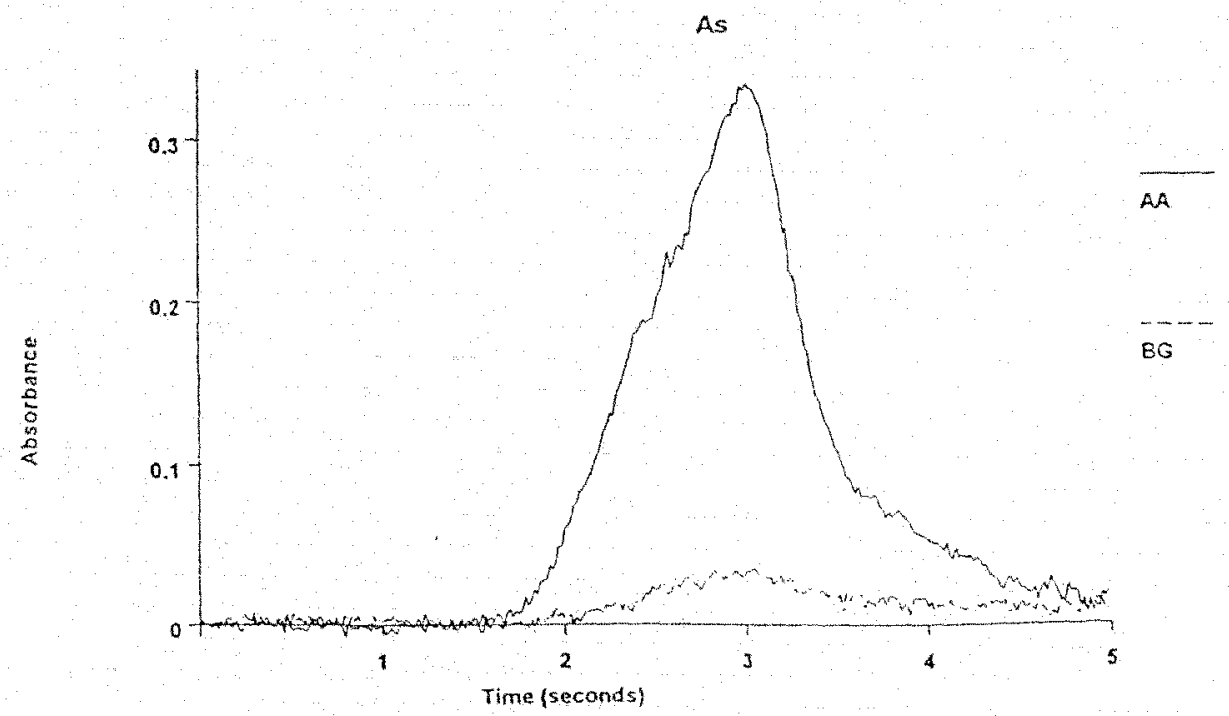




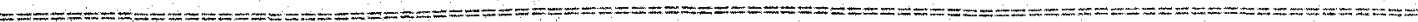

Element: As Date: 05/18/1998

Sample ID: $43: 01$

\begin{tabular}{|c|c|c|c|c|c|c|c|}
\hline $\begin{array}{c}\text { Repl } \\
\text { H } \\
1\end{array}$ & $\begin{array}{l}\text { Sampleconc } \\
\mu g / L \\
193.3\end{array}$ & $\begin{array}{l}\text { Strdcone } \\
19 / 1 \\
193.3\end{array}$ & $\begin{array}{c}\text { BLnkCorr } \\
\text { Signal } \\
0.367\end{array}$ & $\begin{array}{l}\text { Peak } \\
\text { Area } \\
0.3 .1\end{array}$ & $\begin{array}{l}\text { Peak } \\
\text { Height } \\
0.294\end{array}$ & $\begin{array}{l}\text { Bkgnd } \\
\text { Area } \\
0.056\end{array}$ & $22: 14: 33$ \\
\hline
\end{tabular}
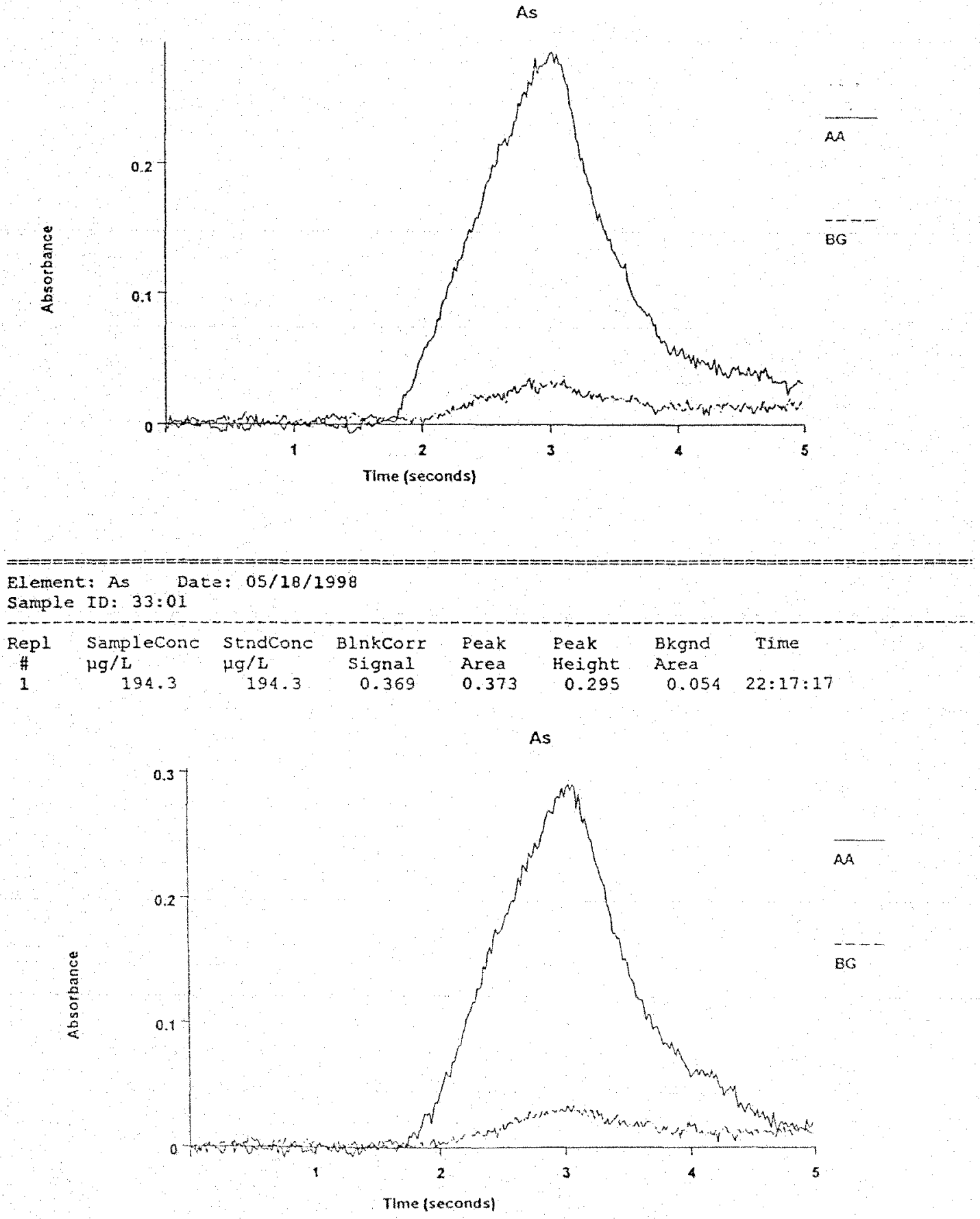


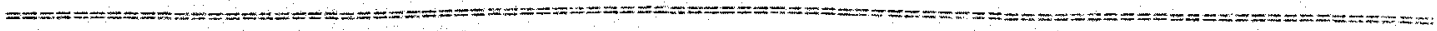

Element: As Date: $05 / 18 / 1998$

Sample ID: $012: 01$

\begin{tabular}{|c|c|c|c|c|c|c|c|}
\hline Repl & Sampleconc & StndConc & BLnkCor & Peak & Peak & Bkgnd & Time \\
\hline 特。 & $\mu g / L$ & $\mathrm{Hg} / \mathrm{I}$ & $\operatorname{signal}$ & AIEa & Height & Area & \\
\hline 1 & 165.6 & $\therefore 165.6$ & 0.324 & 0.32 .8 & 0.253 & 0.048 & $22: 07: 43$ \\
\hline
\end{tabular}

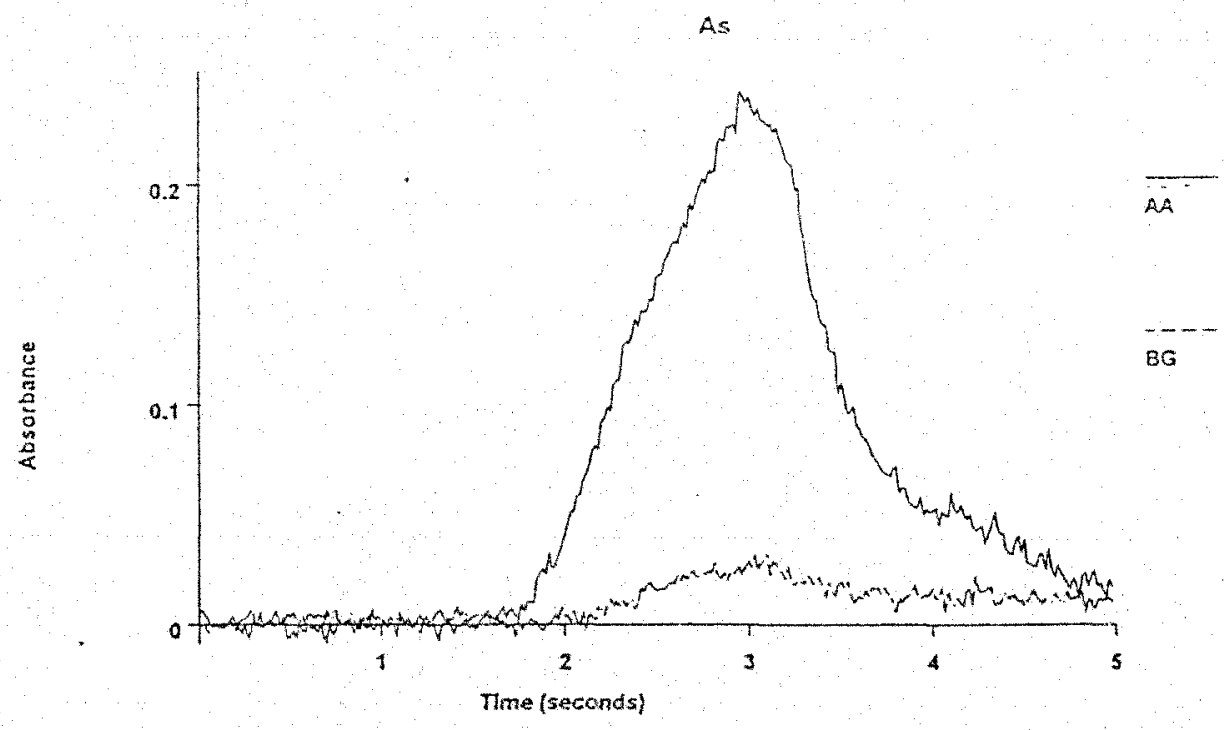


Arsenic (+3) Digested

Arsenic (+3) Undigested

MSMA Digested 
Element: As Date: 05/18/1998

Sample ID: As 3:501

\begin{tabular}{|c|c|c|c|c|c|c|c|}
\hline $\begin{array}{c}\text { Repl } \\
0 \\
1 \\
1\end{array}$ & $\begin{array}{c}\text { Sampleconc } \\
\mu g / L \\
43.47\end{array}$ & $\begin{array}{l}\text { StndConc } \\
\mu \mathrm{g} / \mathrm{I} \\
43.47\end{array}$ & $\begin{array}{c}\text { BlnkCort } \\
\text { Signal } \\
0.083\end{array}$ & $\begin{array}{l}\text { Peak } \\
\text { Area } \\
0.087\end{array}$ & $\begin{array}{l}\text { Peak } \\
\text { Height } \\
0.069\end{array}$ & $\begin{array}{l}\text { Bkgad } \\
\text { Area } \\
0.032\end{array}$ & $23: 11: 32$ \\
\hline
\end{tabular}

As

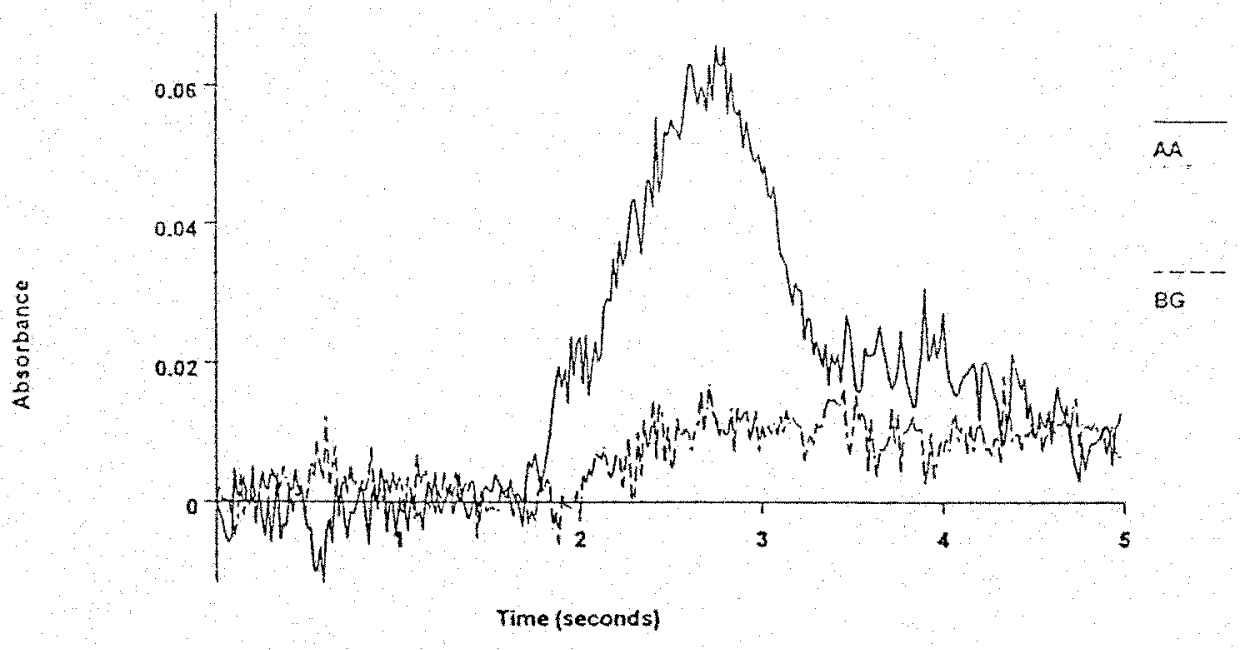

\begin{tabular}{|c|c|c|c|c|c|c|c|}
\hline $\begin{array}{l}\text { Eleme } \\
\text { Samp1 }\end{array}$ & $\begin{array}{l}\text { : As Dat } \\
\text { ID: As } 3: 502\end{array}$ & e: $05 / 18 / 1$ & 998 & & & & \\
\hline $\begin{array}{c}\text { Rep } 1 \\
\# \\
1\end{array}$ & $\begin{array}{l}\text { Sampleconc } \\
\mu g / L \\
52.35\end{array}$ & $\begin{array}{l}\text { stridcone } \\
\mu g / L \\
52.35\end{array}$ & $\begin{array}{c}\text { BlnkCorr } \\
\text { Signal } \\
0.099\end{array}$ & $\begin{array}{l}\text { Peak } \\
\text { Area } \\
0.103\end{array}$ & $\begin{array}{l}\text { Peak } \\
\text { Height } \\
0.104\end{array}$ & $\begin{array}{l}\text { Bkgnd } \\
\text { Area } \\
0.036\end{array}$ & $\begin{array}{l}\text { Time } \\
23: 14: 10\end{array}$ \\
\hline
\end{tabular}

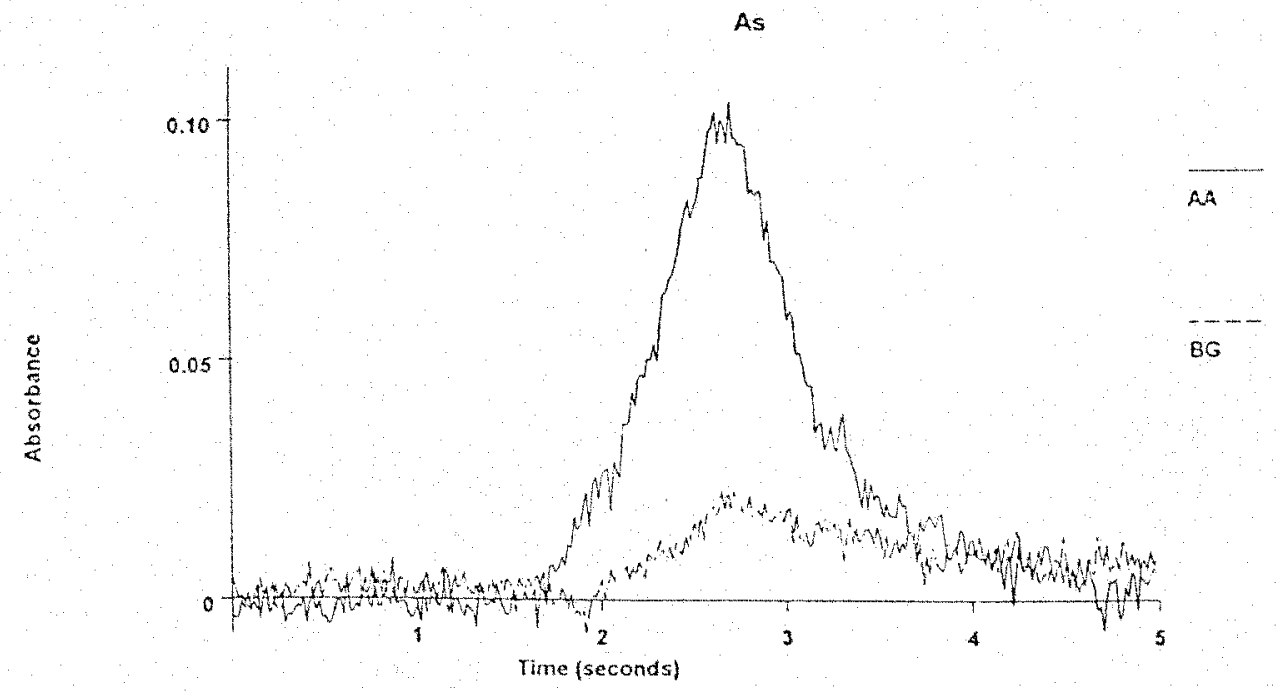



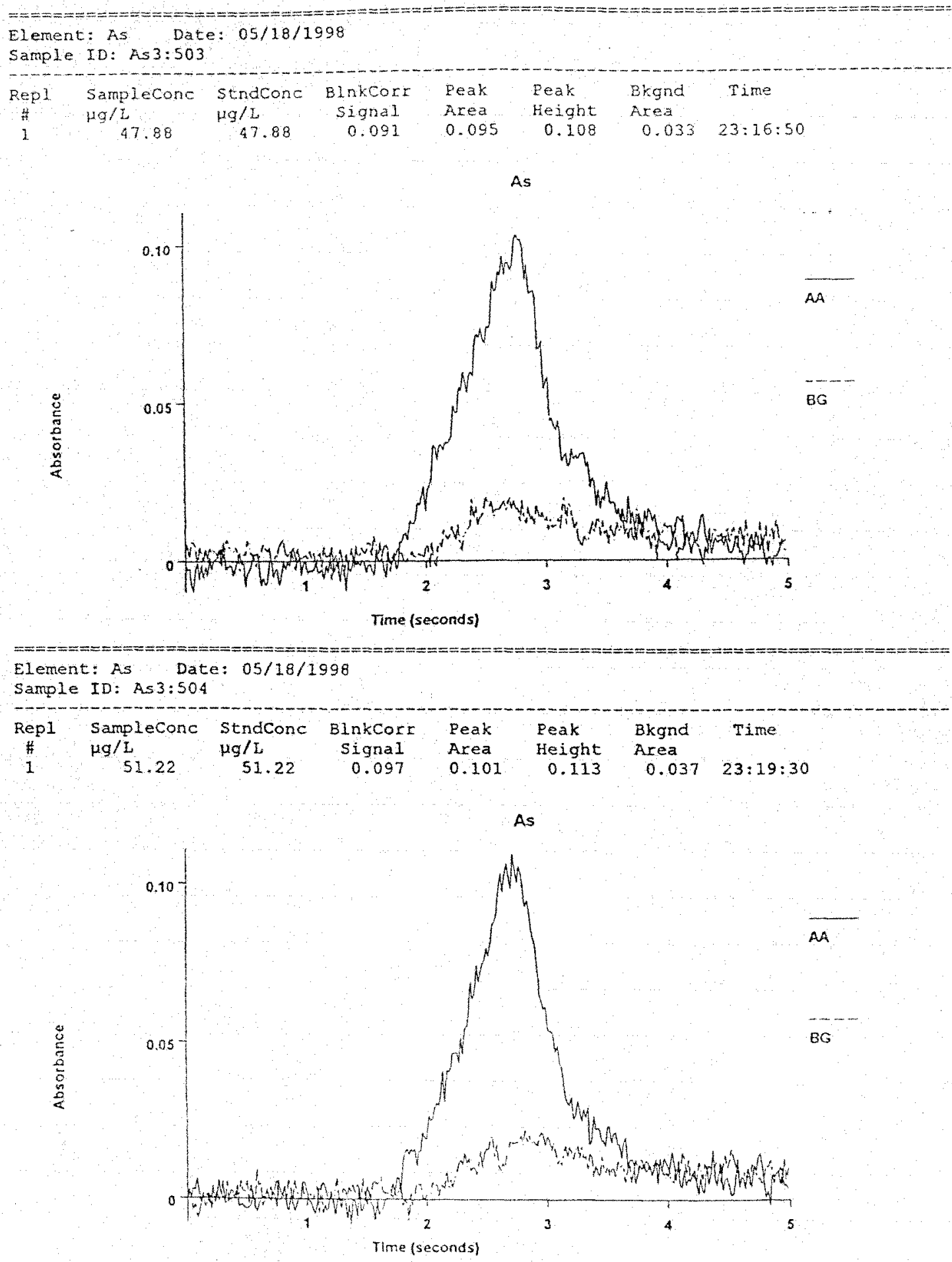
Element: As Date: 05/18/1998

Sample ID: As3:S0S

\begin{tabular}{|c|c|c|c|c|c|c|c|}
\hline $\begin{array}{c}\text { Repl } \\
H \\
1\end{array}$ & $\begin{array}{l}\text { Sampleconc } \\
\mathrm{Hg} / \mathrm{L} \\
50.94\end{array}$ & $\begin{array}{l}\text { stndcone } \\
\mathrm{Hg} / \mathrm{L} \\
50.94\end{array}$ & $\begin{array}{c}\text { BInkCorr } \\
\text { signal } \\
0.097\end{array}$ & $\begin{array}{l}\text { Peak } \\
\text { Area } \\
0.101\end{array}$ & $\begin{array}{l}\text { Peak } \\
\text { Height } \\
0.109\end{array}$ & $\begin{array}{l}\text { Bkgnd } \\
\text { Area } \\
0.038\end{array}$ & $\begin{array}{l}\text { Time } \\
23: 22: 11\end{array}$ \\
\hline
\end{tabular}

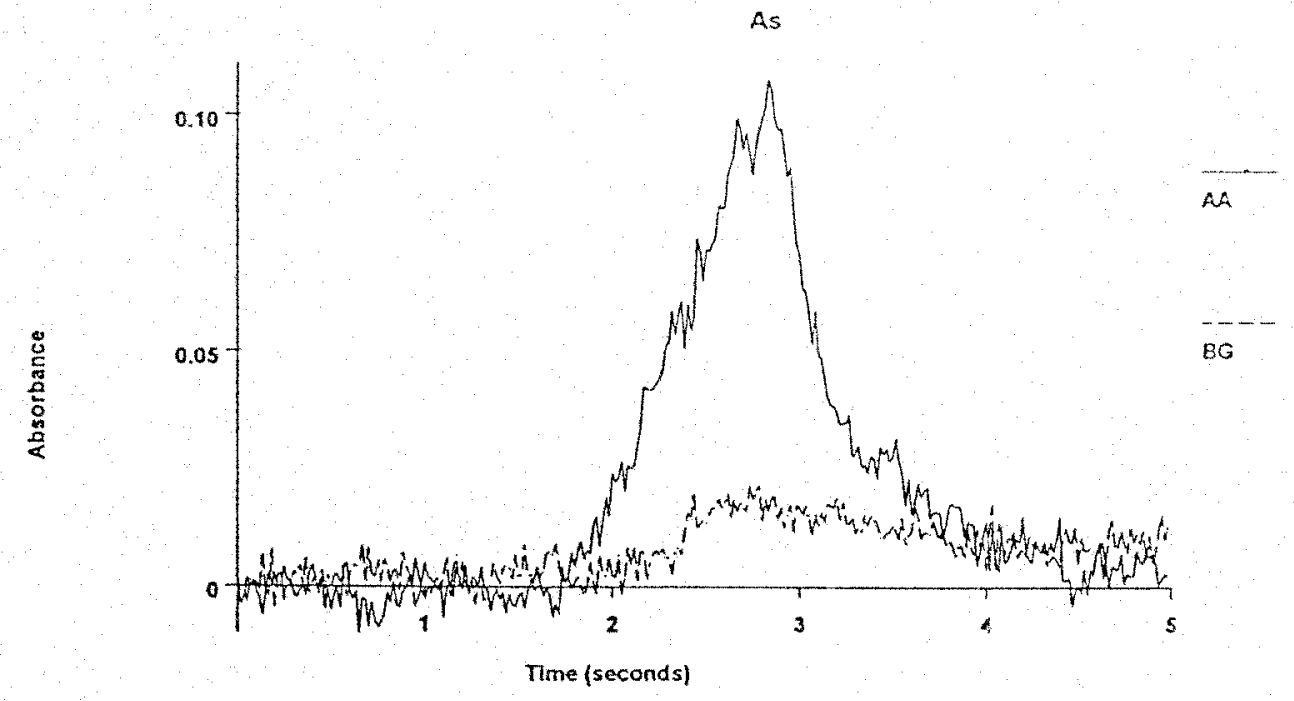

\begin{tabular}{|c|c|c|c|c|c|c|c|}
\hline $\begin{array}{l}\text { Eleme } \\
\text { Sampl }\end{array}$ & ID: As $3: 50$ & $2=05 / 18 / 1$ & 998 & & & & \\
\hline $\begin{array}{c}\text { Rep1 } \\
\# \\
1\end{array}$ & $\begin{array}{c}\text { Sampleconc } \\
\mathrm{\mu g} / \mathrm{L} \\
45.06\end{array}$ & $\begin{array}{l}\text { StridConc } \\
\mathrm{\mu g} / \mathrm{L} \\
45.06\end{array}$ & $\begin{array}{c}\text { BlnkCorx } \\
\text { Signal } \\
0.086\end{array}$ & $\begin{array}{l}\text { Peak } \\
\text { Area } \\
0.090\end{array}$ & $\begin{array}{l}\text { Peak } \\
\text { Feight } \\
0.077\end{array}$ & $\begin{array}{l}\text { Bkgnd } \\
\text { Area } \\
0.029\end{array}$ & Time \\
\hline
\end{tabular}

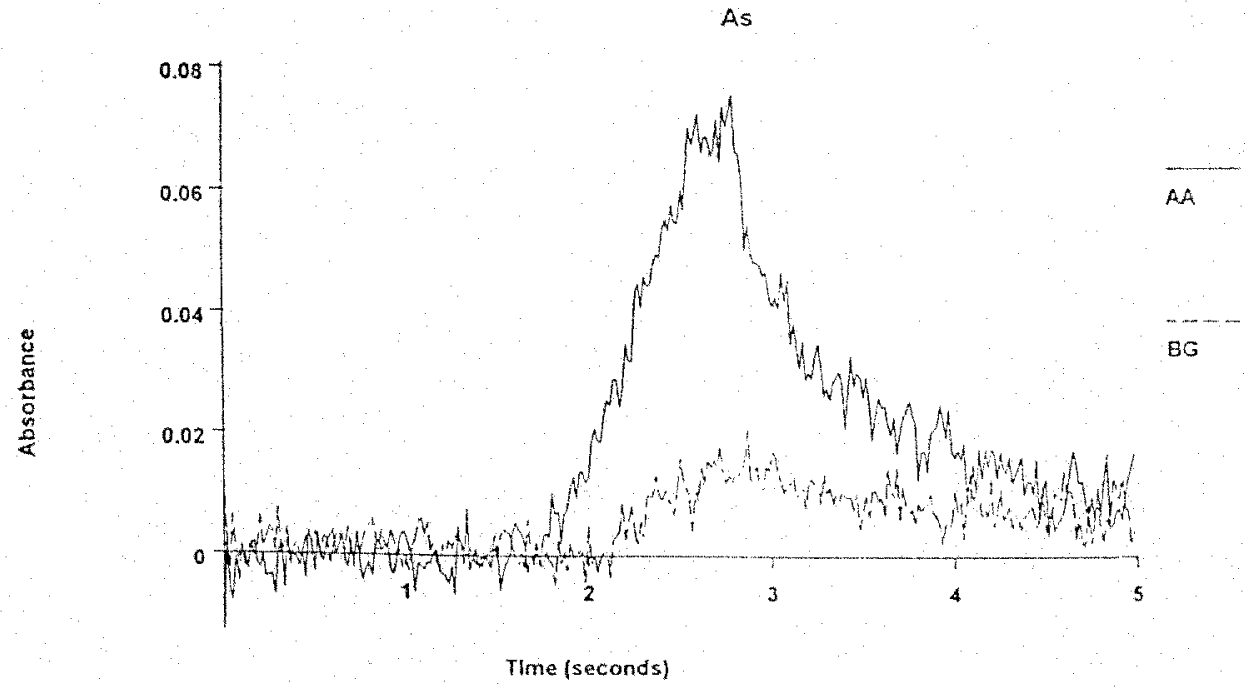




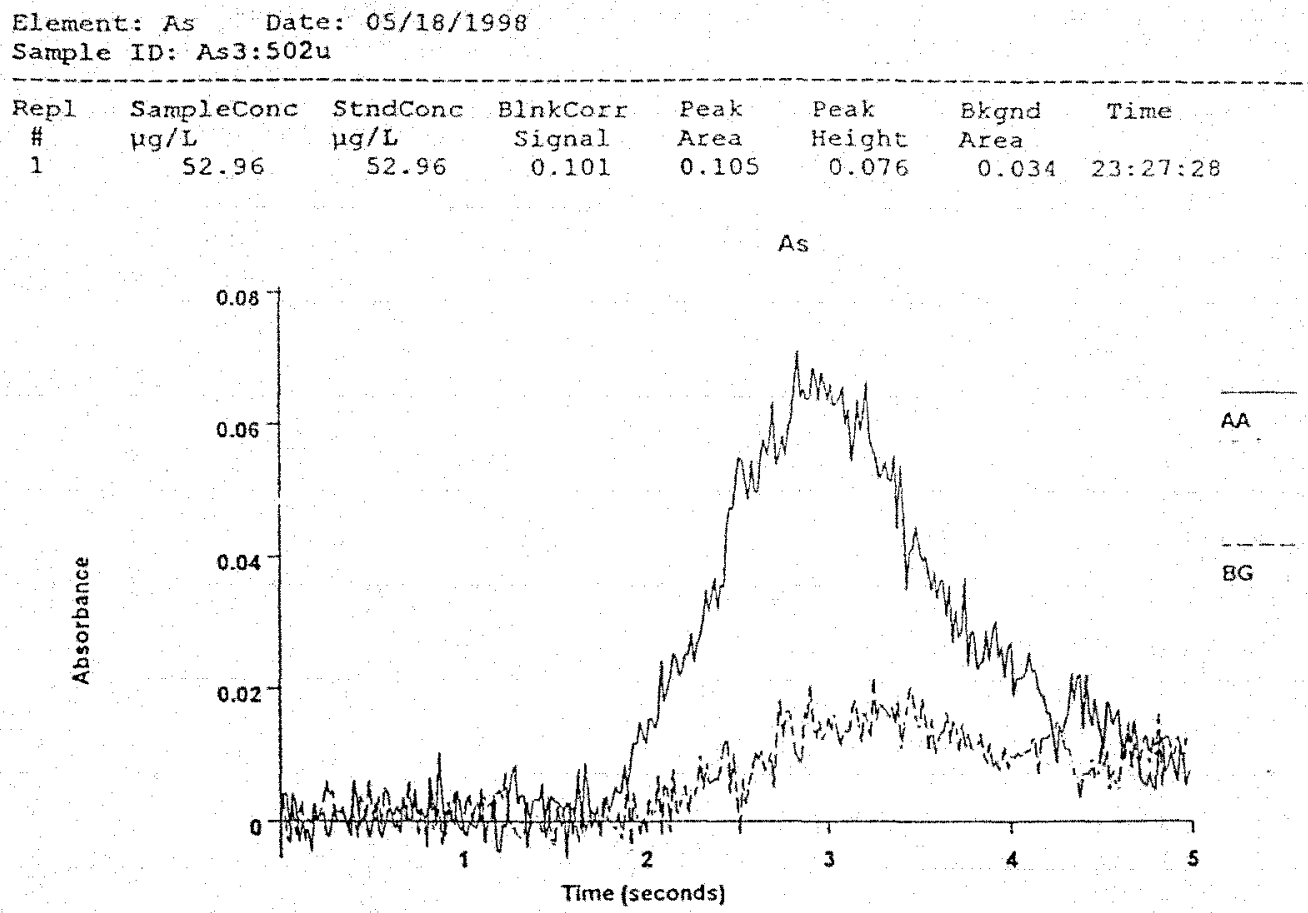

\begin{tabular}{|c|c|c|c|c|c|c|c|}
\hline $\begin{array}{l}\text { Element } \\
\text { Sample }\end{array}$ & $\begin{array}{l}\text { As Dat } \\
\text { ID: As } 3: 503\end{array}$ & $05 / 28 / 1$ & 998 & & & & \\
\hline $\begin{array}{l}\text { Repl } \\
1\end{array}$ & $\begin{array}{l}\text { Samplecone } \\
\mu \mathrm{g} / \mathrm{L} \\
\frac{53.99}{}\end{array}$ & $\begin{array}{l}\text { stndconc } \\
\mu g / 1 \\
53.99\end{array}$ & $\begin{array}{c}\text { EInkCor } \\
\text { Signa } 1 \\
0.103\end{array}$ & $\begin{array}{l}\text { Peak } \\
\text { Area } \\
0.107\end{array}$ & $\begin{array}{l}\text { Peak } \\
\text { Height } \\
0.075\end{array}$ & $\begin{array}{l}\text { Bkgnd } \\
\text { Area } \\
0.029\end{array}$ & $\begin{array}{l}\text { Time } \\
23: 30: 05\end{array}$ \\
\hline
\end{tabular}

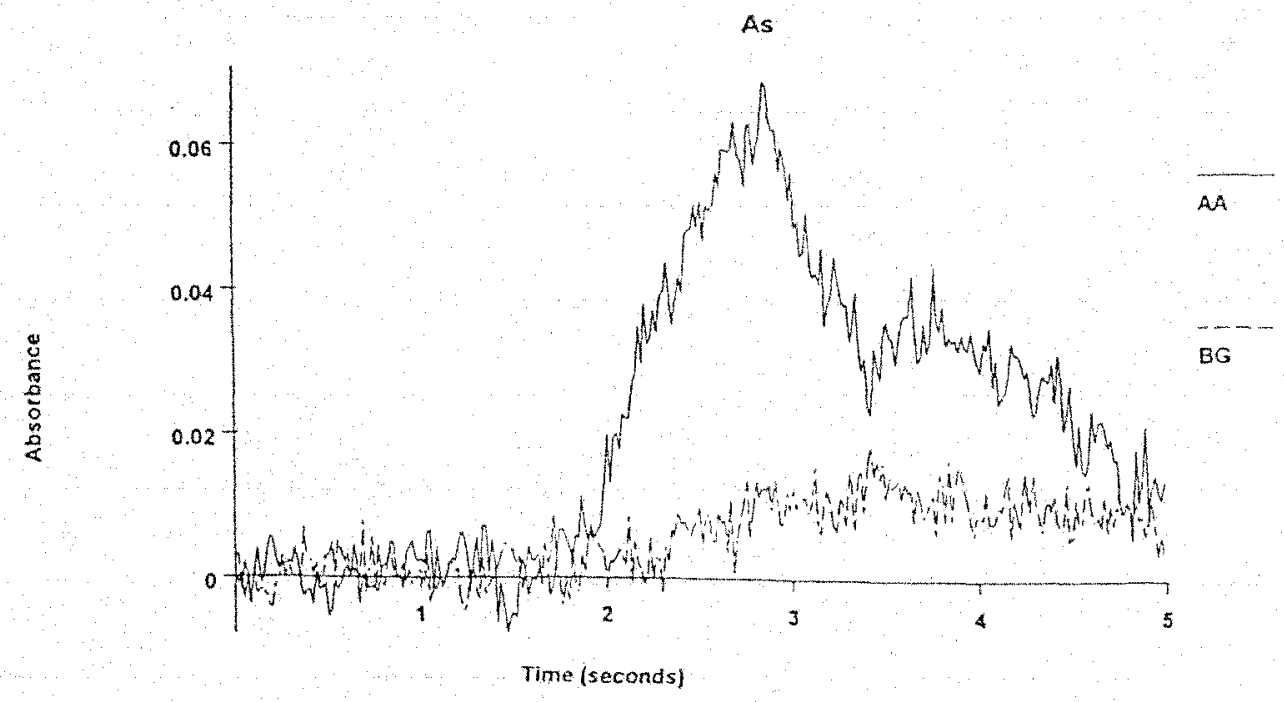




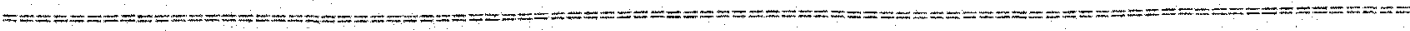

Element: As Date: $05 / 18 / 1998$

Sample ID: As $3: 504 \mathrm{U}$

\begin{tabular}{|c|c|c|c|c|c|c|c|}
\hline Repl & Sampleconc & stndeono & 81nkCorr & Peak & Peak & Bkgnd & Time \\
\hline$\#$ & $\lg / \mathrm{L}$ & $\mu g / L$ & Sigral & A Iea & Eeight & Area & \\
\hline 1 & 54.23 & 54.23 & 0.103 & 0.107 & 0.075 & 0.038 & $23: 32: 4$ \\
\hline
\end{tabular}

As

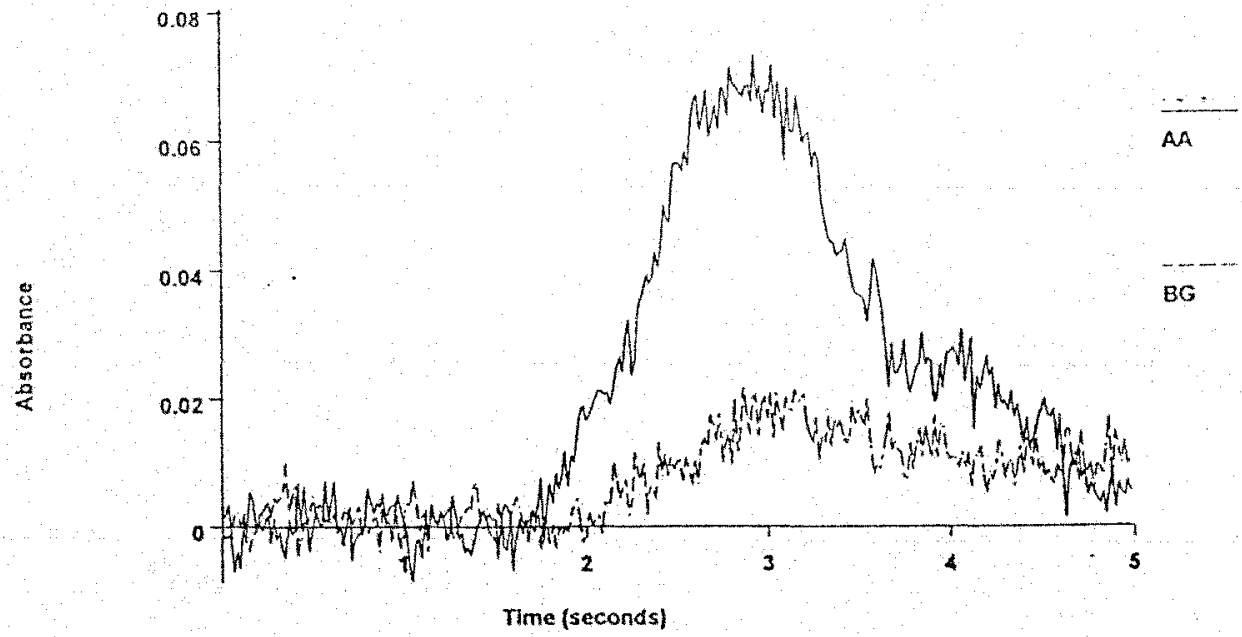

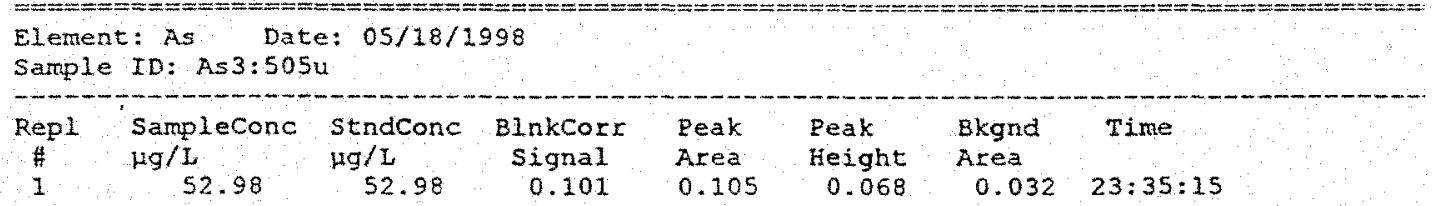

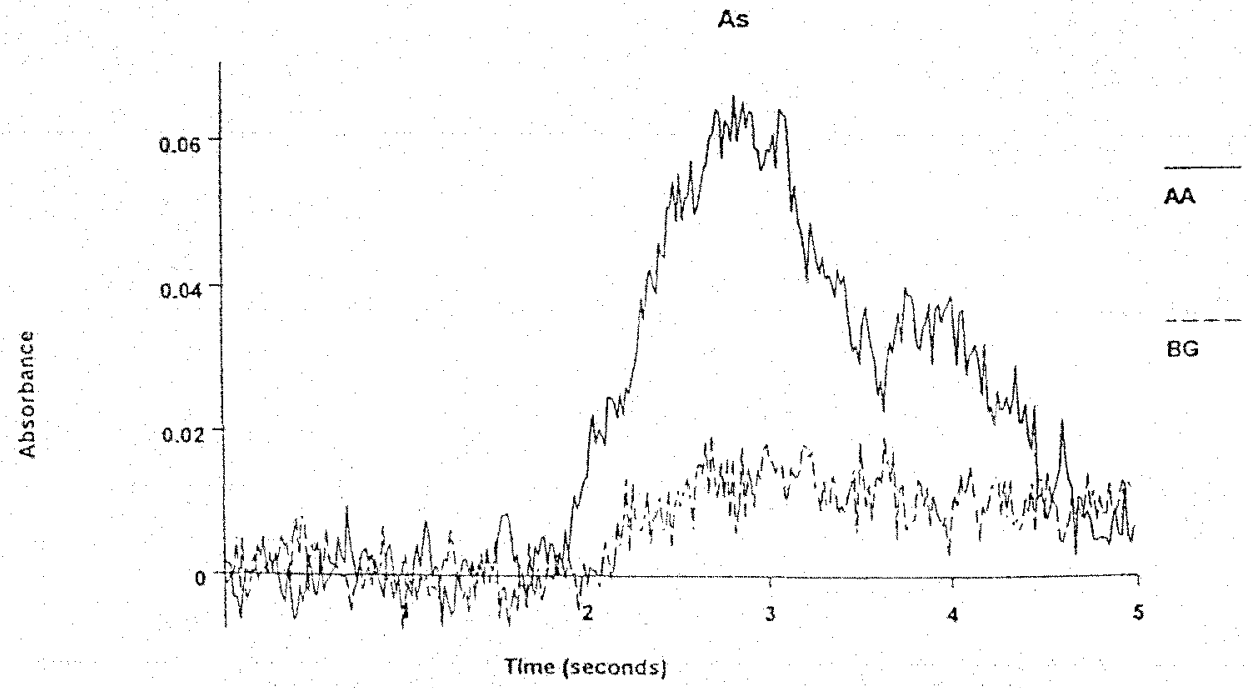



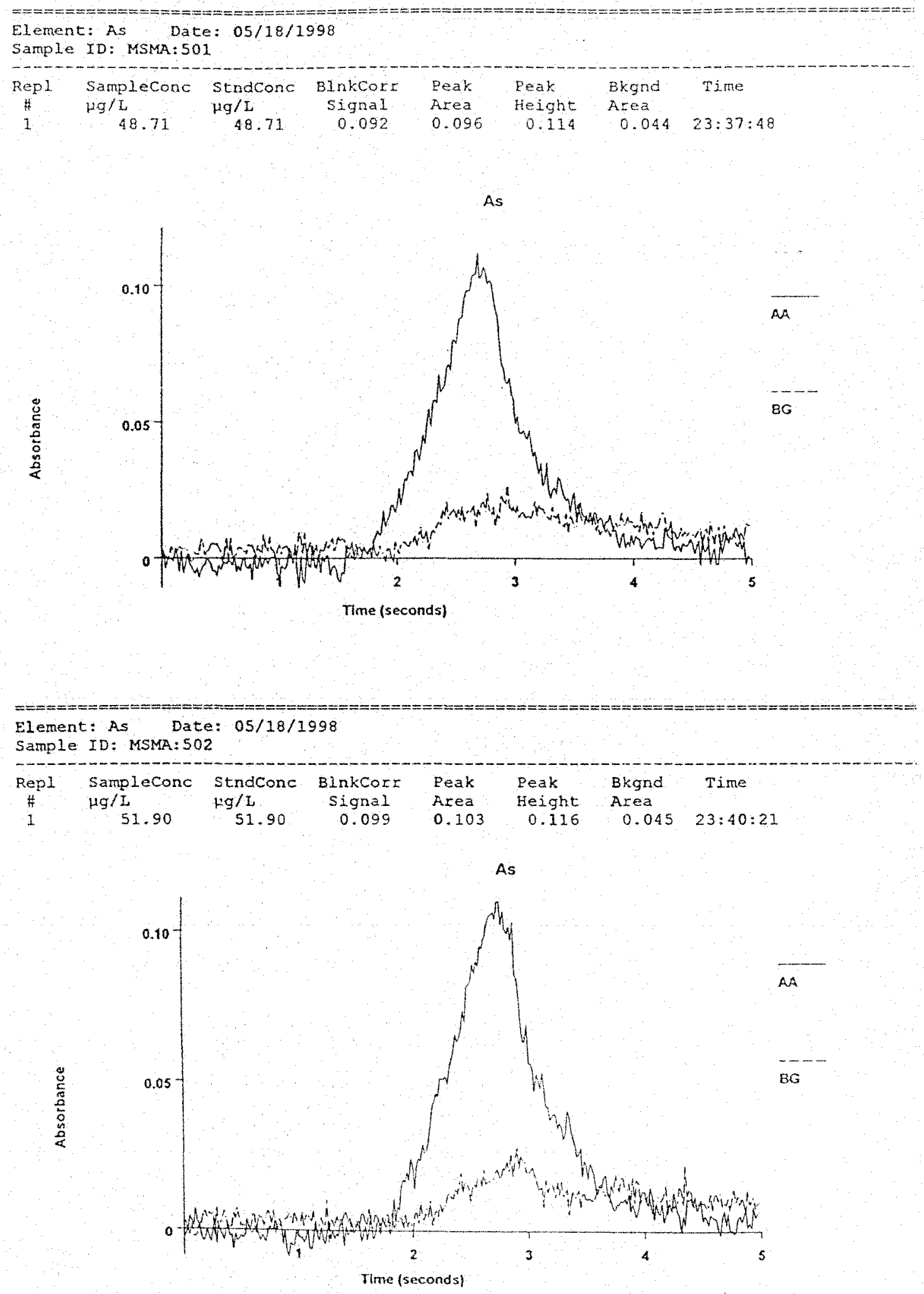


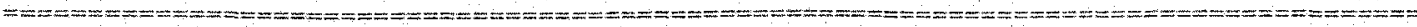

Element: As Date: $05 / 18 / 1998$

Sample ID: MSMA: 503

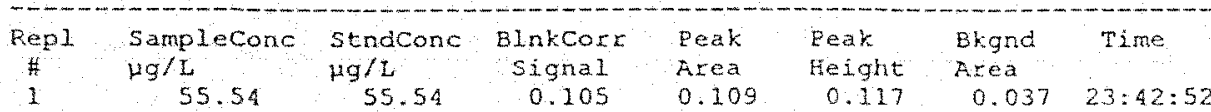

As

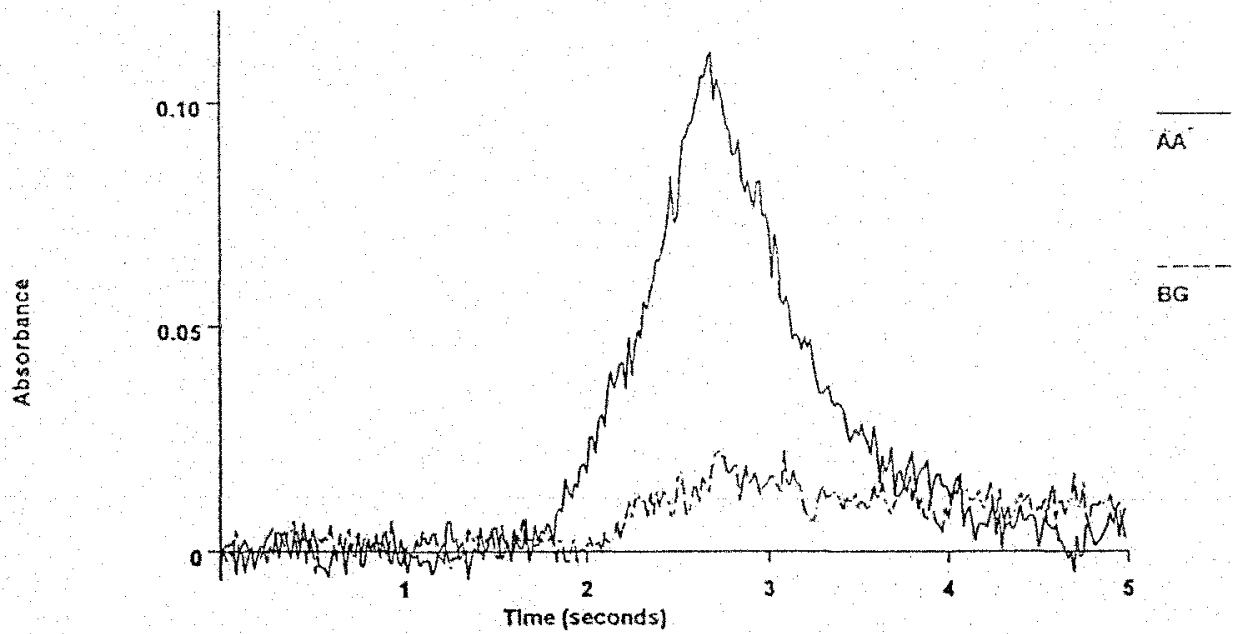

\begin{tabular}{|c|c|c|c|c|c|c|}
\hline $\begin{array}{l}\text { Element: As Dat } \\
\text { Samp1e ID: MSMA: } 50\end{array}$ & $=05 / 18 /$ & 98 & & & & \\
\hline $\begin{array}{l}\text { Sampleconc } \\
\qquad \mathrm{g} / \mathrm{L} \\
52 \cdot 14\end{array}$ & $\begin{array}{l}\text { Stndcone } \\
19 / 2 \\
52 \cdot 14\end{array}$ & $\begin{array}{c}\text { BInkCor } \\
\text { Signal } \\
0.099\end{array}$ & $\begin{array}{l}\text { Peak } \\
\text { Area } \\
0.103\end{array}$ & $\begin{array}{l}\text { Peak } \\
\text { Height } \\
0.105\end{array}$ & $\begin{array}{l}\text { Bkgnd } \\
\text { Area } \\
0.028\end{array}$ & $\begin{array}{l}\text { Time } \\
23: 45: 23\end{array}$ \\
\hline
\end{tabular}

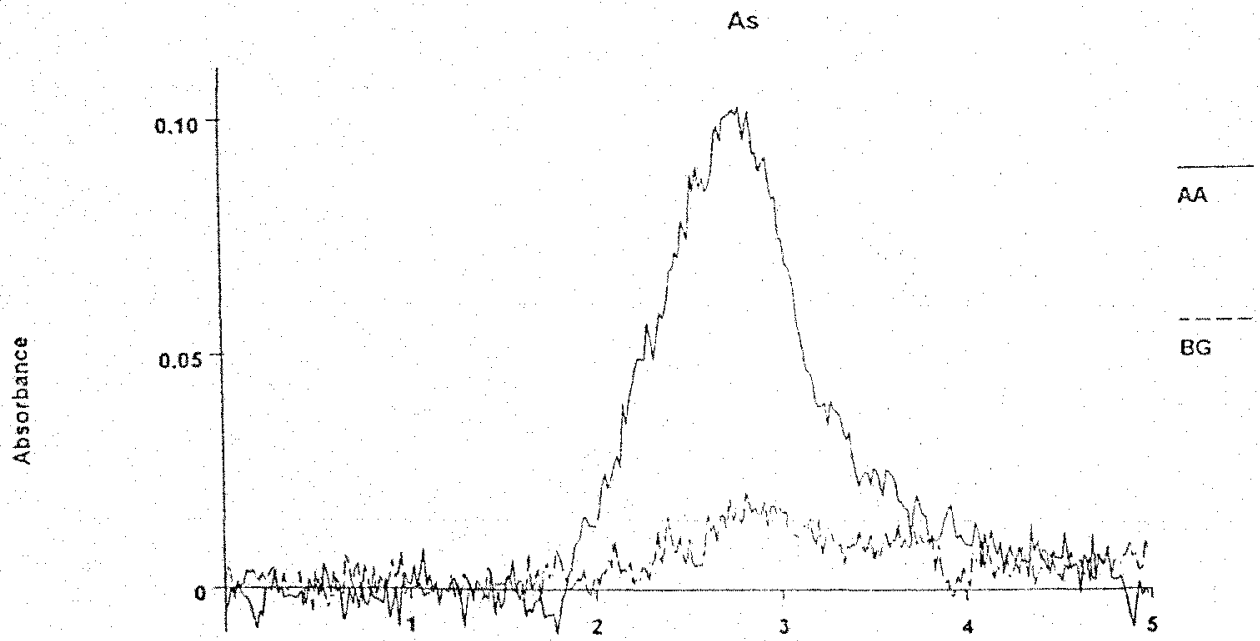

Time (seconds) 

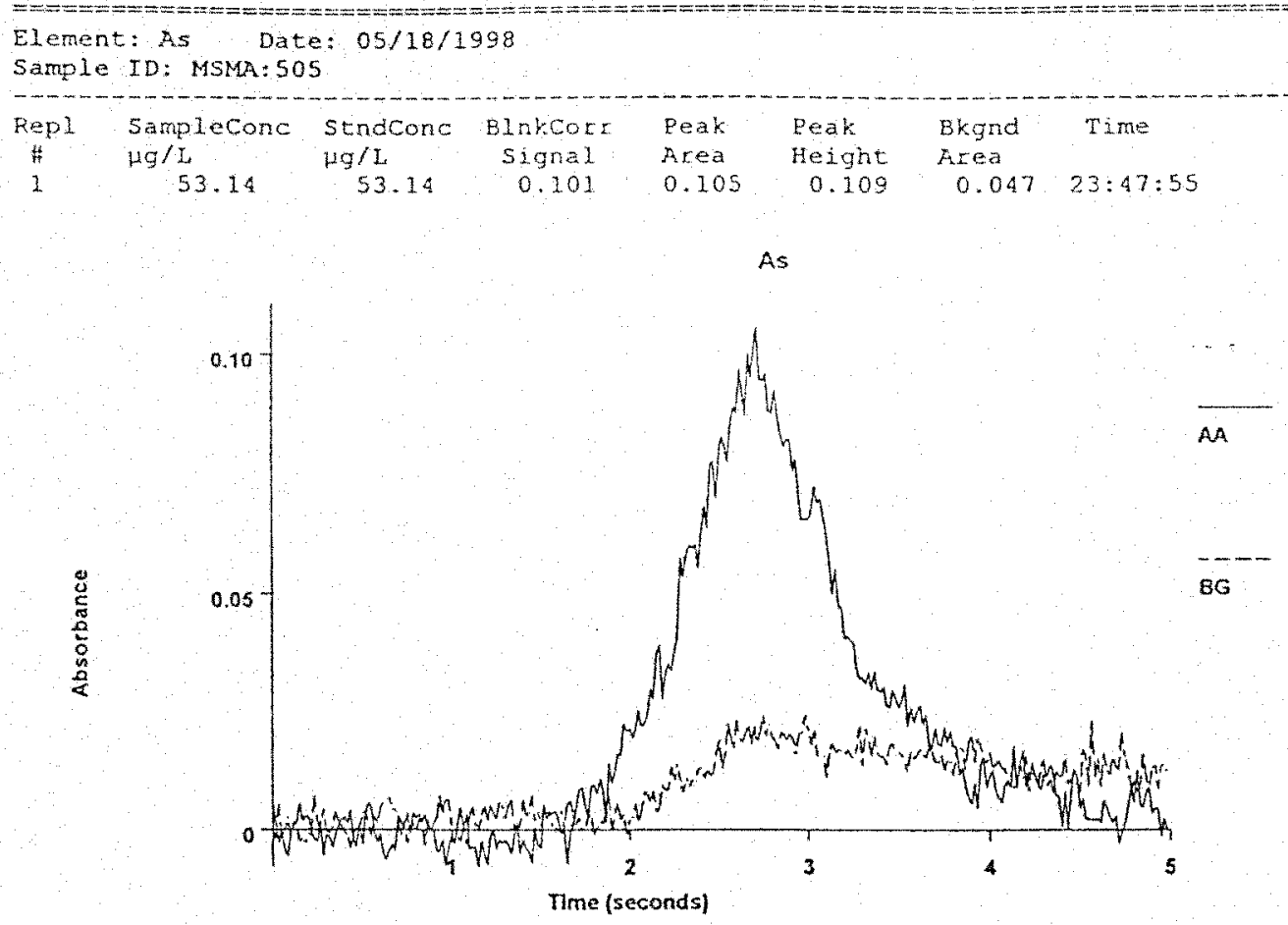
MSMA Data 

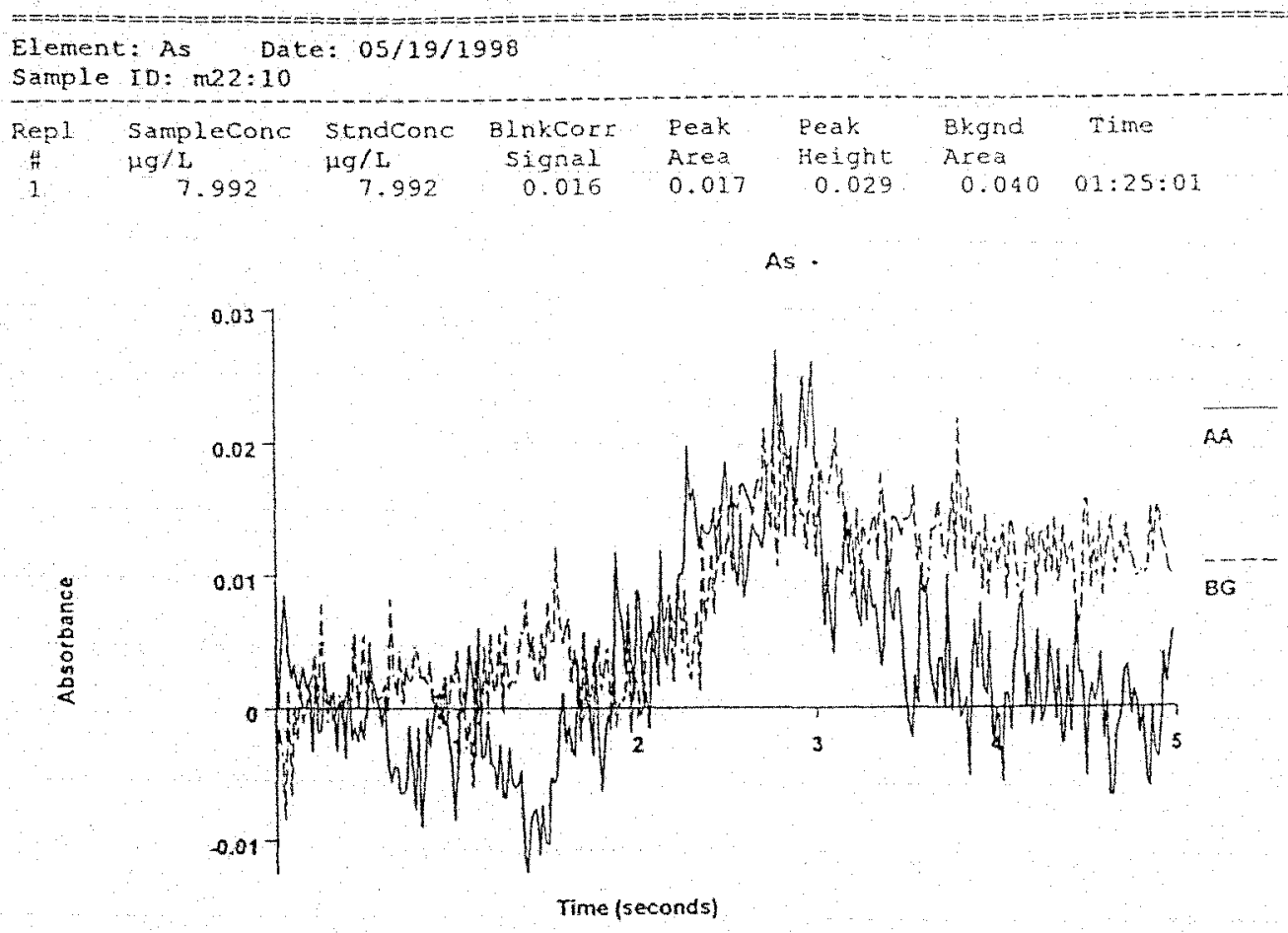
Element: As Date $05 / 19 / 1998$

Sample ID: $\mathrm{mS2}, 10$

\begin{tabular}{|c|c|c|c|c|c|c|c|}
\hline$\underset{\frac{H}{H}}{\operatorname{Rep} 1}$ & $\begin{array}{l}\text { Samplecone } \\
\text { ug/L. }\end{array}$ & $\begin{array}{l}\text { Stndconc } \\
\mathrm{H} / \mathrm{L}\end{array}$ & $\begin{array}{c}\text { ElnkCor } \\
\text { signal }\end{array}$ & $\begin{array}{l}\text { Peak } \\
\text { Area }\end{array}$ & $\begin{array}{l}\text { Eeat } \\
\text { Dejght }\end{array}$ & $\begin{array}{l}\text { Bkgnd } \\
\text { Area }\end{array}$ & Time \\
\hline 1 & 6.937 & 6.937 & 0.014 & 0.014 & 0.028 & 0.023 & $01: 32: 35$ \\
\hline
\end{tabular}

As

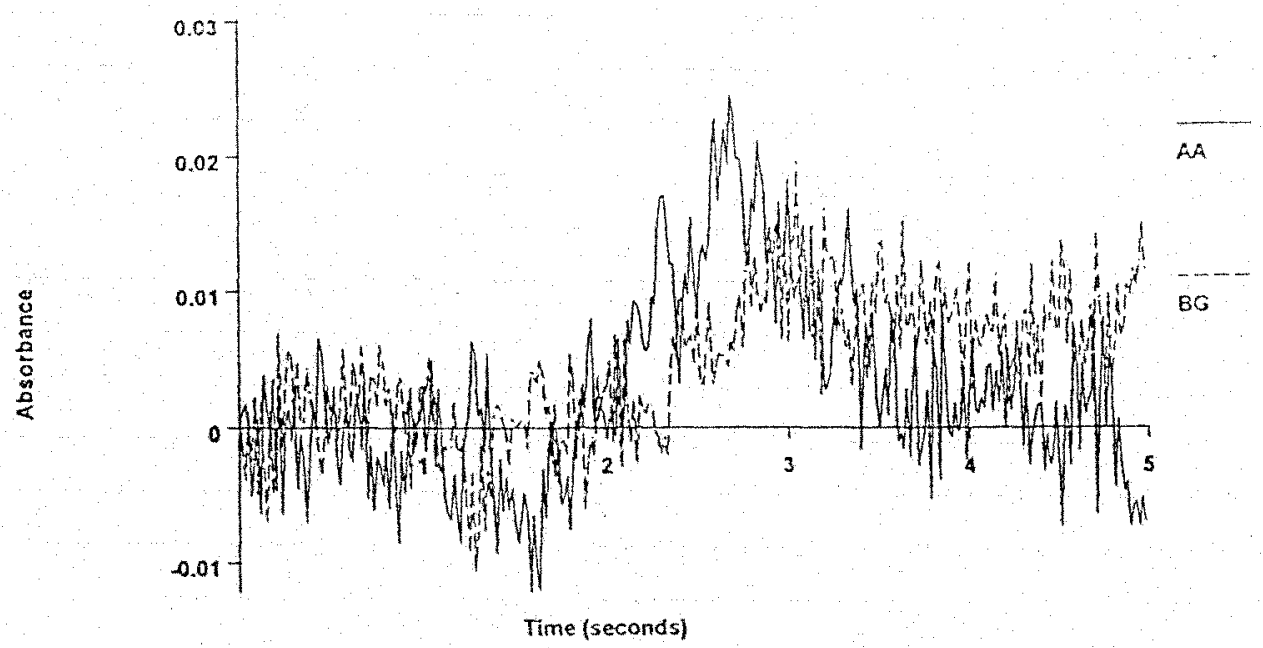

Element: As Date: $05 / 19 / 1990$

Sample ID: $m 53: 10$

\begin{tabular}{|c|c|c|c|c|c|c|c|}
\hline $\begin{array}{c}\text { Rep } 1 \\
\# \\
1\end{array}$ & $\begin{array}{l}\text { SampleConc } \\
\qquad 9 / \mathrm{I} \\
7.995\end{array}$ & $\begin{array}{l}\text { StndConc } \\
119 / I \\
7.995\end{array}$ & $\begin{array}{c}\text { BInkCort } \\
\text { signal } \\
0.016\end{array}$ & $\begin{array}{l}\text { Peak } \\
\text { Area } \\
0.017\end{array}$ & $\begin{array}{l}\text { Peak } \\
\text { Height } \\
0.025\end{array}$ & $\begin{array}{l}\text { Bkgnd } \\
\text { Area } \\
0.033\end{array}$ & $01: 35: 06$ \\
\hline
\end{tabular}

As

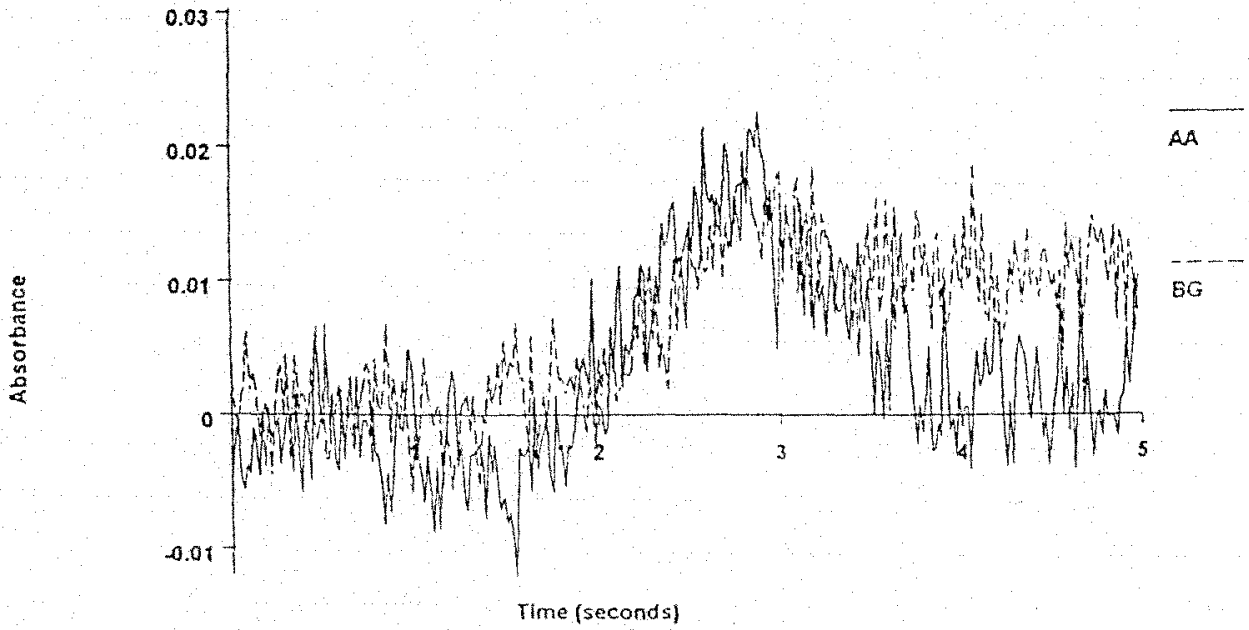




\begin{tabular}{|c|c|c|c|c|c|c|c|}
\hline \multicolumn{8}{|c|}{ Element: As Date: 05/19/1998 } \\
\hline $\begin{array}{c}\text { Repl } \\
4 \\
1 \\
1\end{array}$ & $\begin{array}{l}\text { Sampleconc } \\
\mathrm{Hg} / \mathrm{L} \\
10.36\end{array}$ & $\begin{array}{c}\text { Stndeonc } \\
\mu g / D \\
10.36\end{array}$ & $\begin{array}{c}\text { BlnkCore } \\
\text { Signal } \\
0.021\end{array}$ & $\begin{array}{l}\text { Peak } \\
\text { Area } \\
0.022\end{array}$ & $\begin{array}{l}\text { Feak } \\
\text { Height } \\
0.030\end{array}$ & $\begin{array}{l}\text { Bkgnd } \\
\text { Area. } \\
0.038\end{array}$ & $01: 42: 51$ \\
\hline
\end{tabular}

As

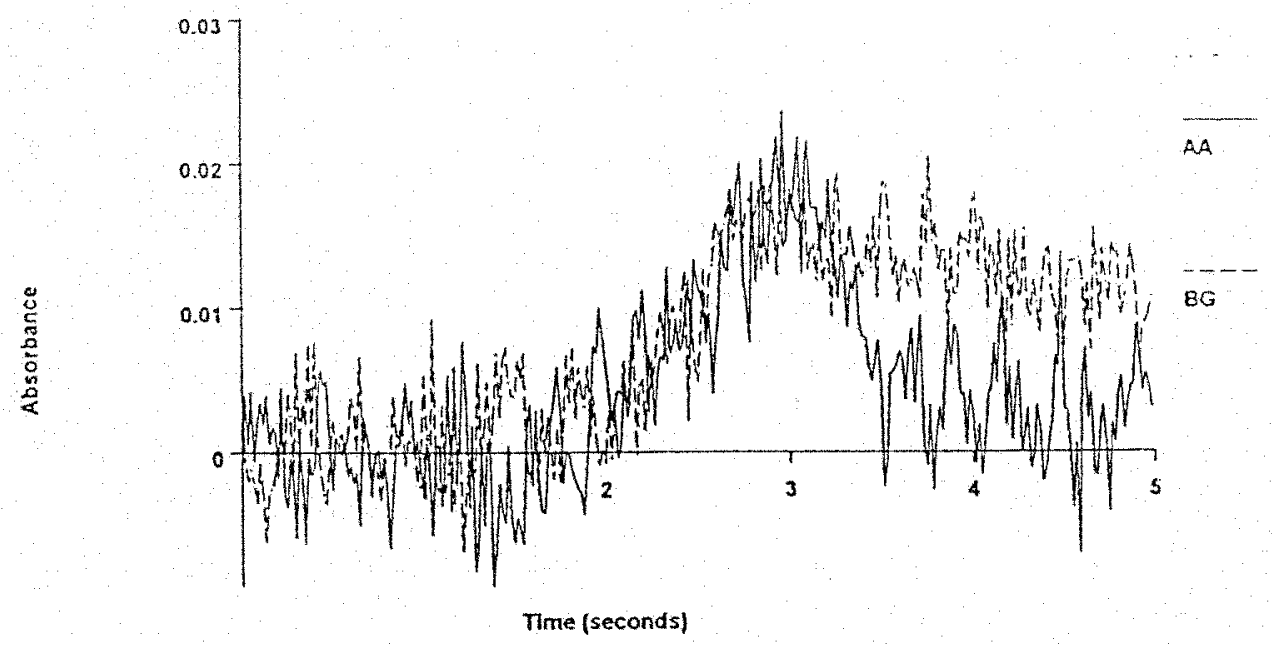

\begin{tabular}{|c|c|c|c|c|c|c|c|}
\hline \multicolumn{8}{|c|}{$\begin{array}{l}\text { Element: As Date: 05/19/1998 } \\
\text { Sample ID: m102:10 }\end{array}$} \\
\hline $\begin{array}{c}\text { Repl } \\
\# \\
1\end{array}$ & $\begin{array}{l}\text { Sampleconc } \\
\mathrm{Hg} / \mathrm{L} \\
7.185\end{array}$ & $\begin{array}{l}\text { StndConc } \\
\mu g / L \\
7.185\end{array}$ & $\begin{array}{c}\text { BinkCorr } \\
\text { Signal } \\
0.015\end{array}$ & $\begin{array}{l}\text { Peak } \\
\text { Area } \\
0.015\end{array}$ & $\begin{array}{l}\text { Peak } \\
\text { Height } \\
0.027\end{array}$ & $\begin{array}{l}\text { Bkgnd } \\
\text { Area } \\
0.033\end{array}$ & $\begin{array}{l}\text { Time } \\
01: 48: 33\end{array}$ \\
\hline
\end{tabular}

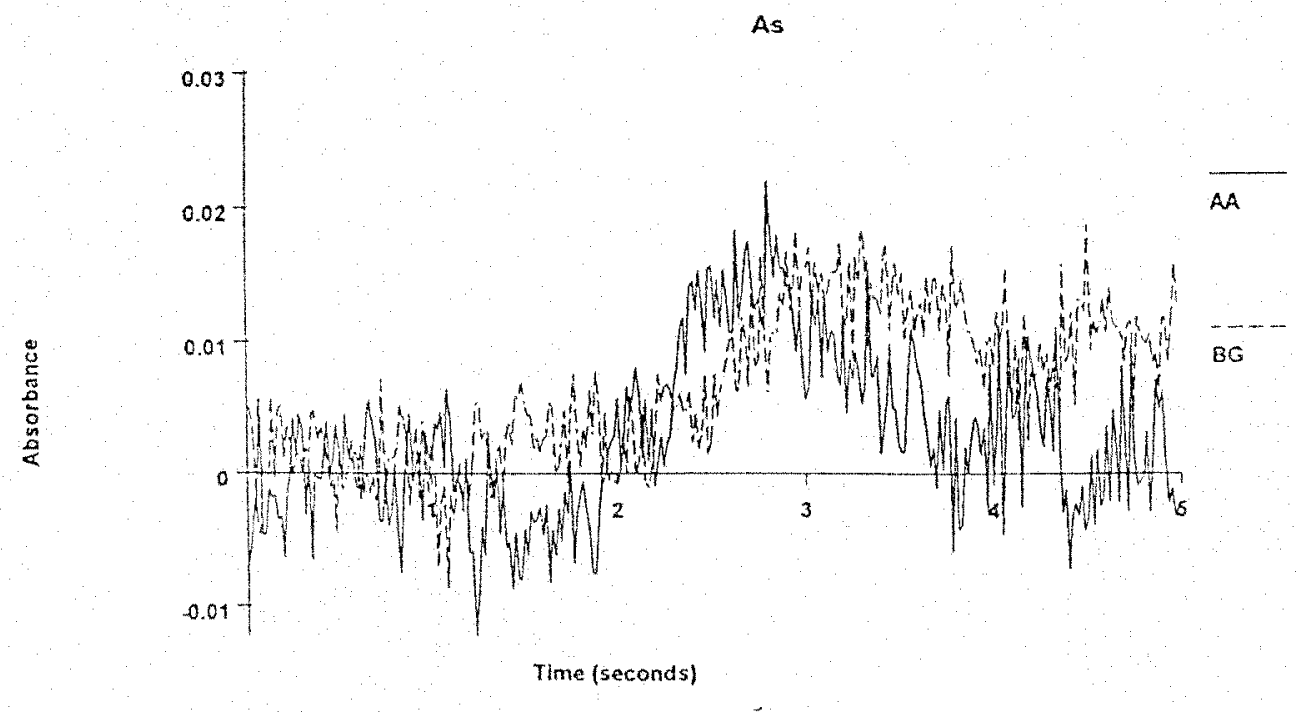



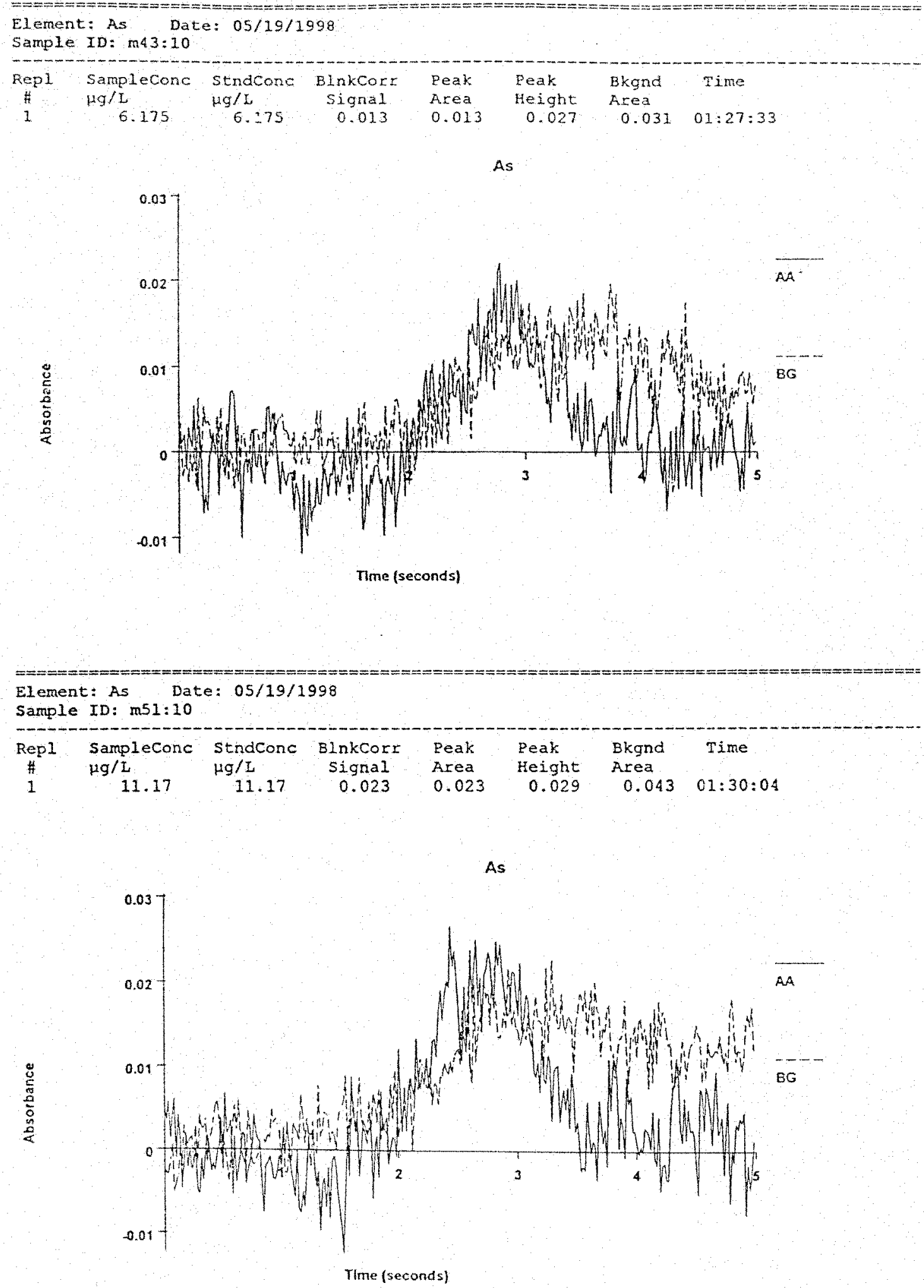


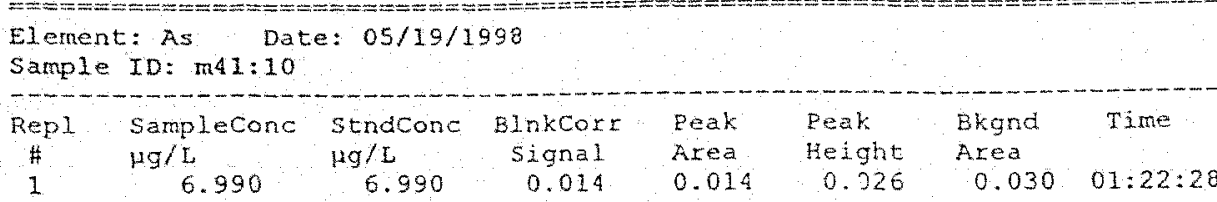

As
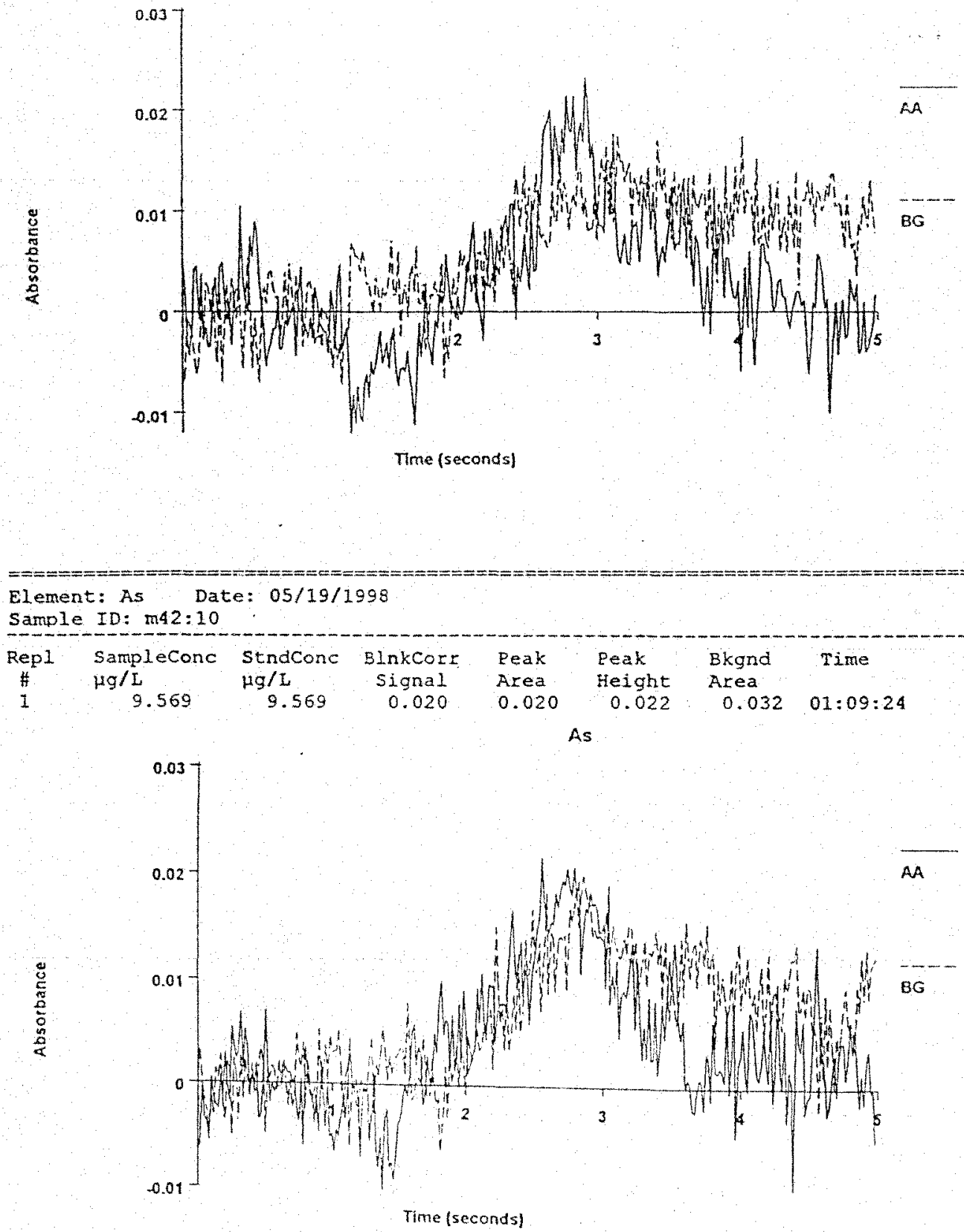

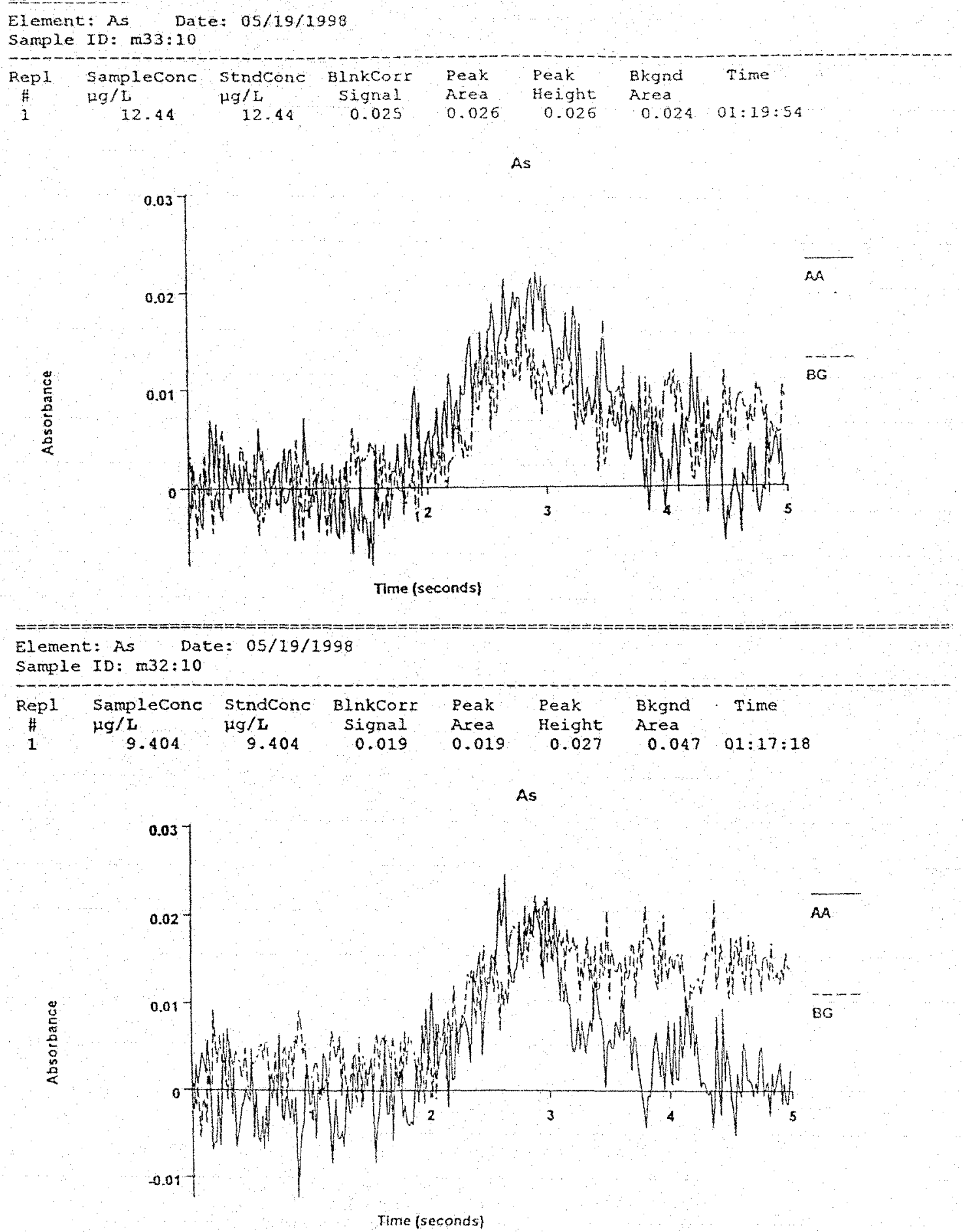
Element: As Date: $05 / 19 / 1998$

Sample ID: m23:10

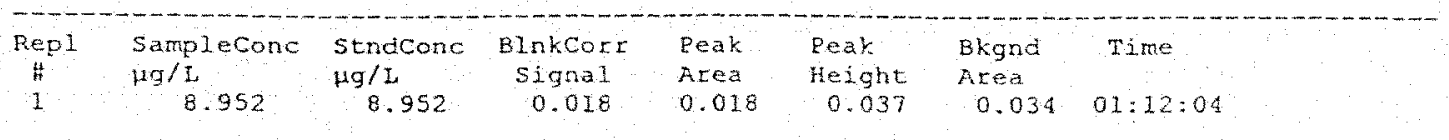

As

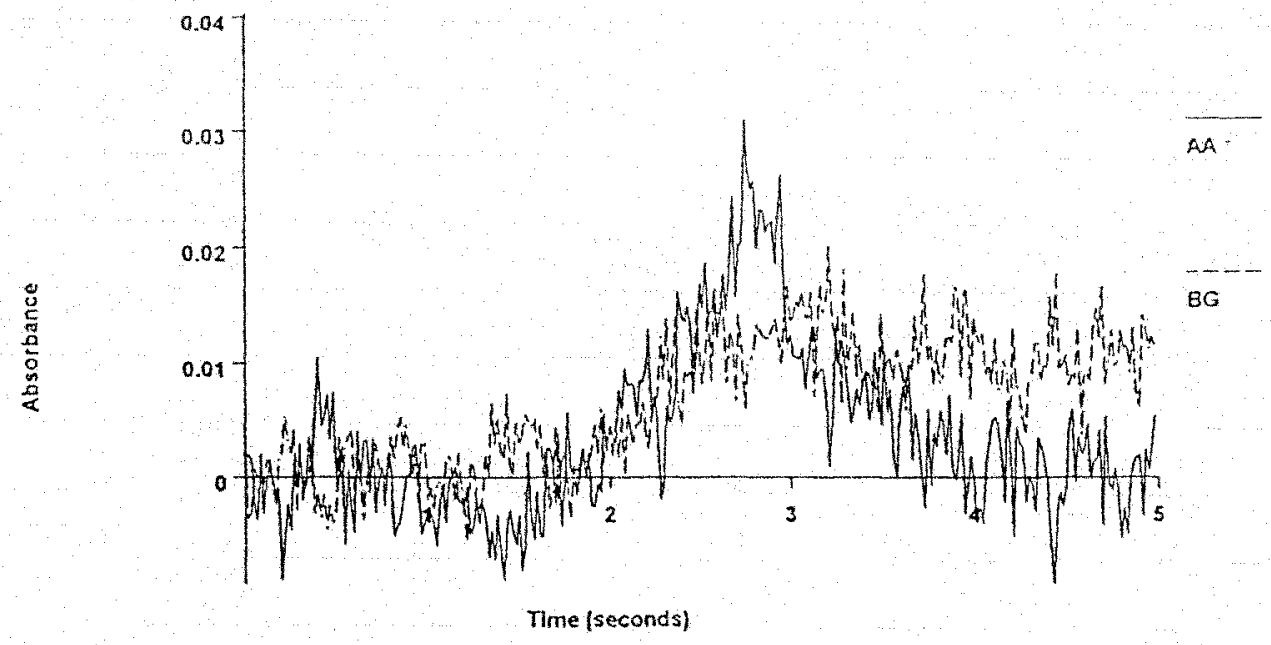

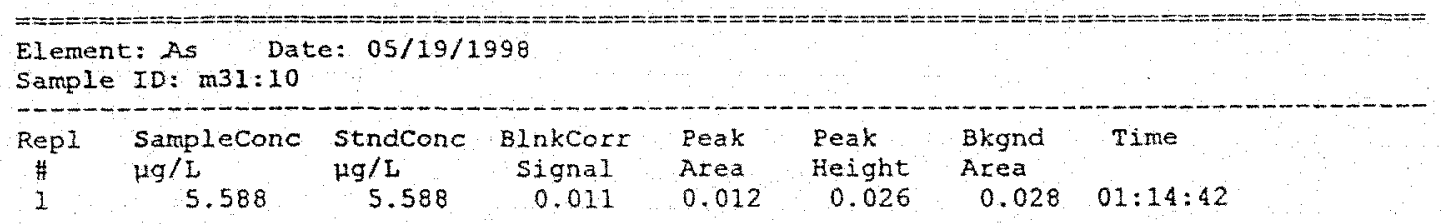

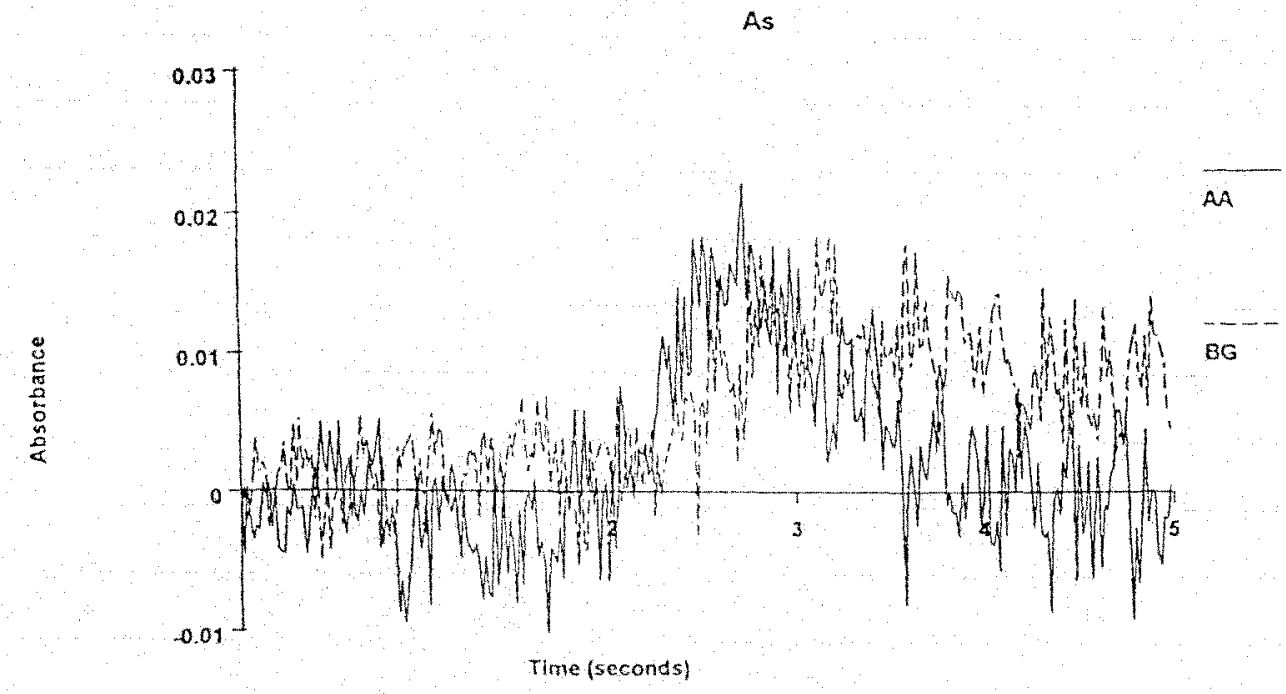


19

Element: As Date: $05 / 19 / 1998$

Sample ID: $\mathrm{m13:10}$

\begin{tabular}{|c|c|c|c|c|c|c|c|}
\hline $\begin{array}{l}\text { Repl } \\
\text { in } \\
1\end{array}$ & $\begin{array}{l}\text { SampleConc } \\
\text { Hg/L } \\
7.941\end{array}$ & $\begin{array}{l}\text { Stndcone } \\
129 / 2 \\
7.941\end{array}$ & $\begin{array}{c}\text { BlnkCore } \\
\text { Sigral } \\
0.016\end{array}$ & $\begin{array}{l}\mathrm{E} e \mathrm{ak} \\
A=\mathrm{a}^{2} \\
0.026\end{array}$ & $\begin{array}{l}\text { Bezk } \\
\text { Height } \\
0.023\end{array}$ & $\begin{array}{l}\text { bkgnd } \\
\text { ficea } \\
0.034\end{array}$ & $01: 04: 04$ \\
\hline
\end{tabular}

As

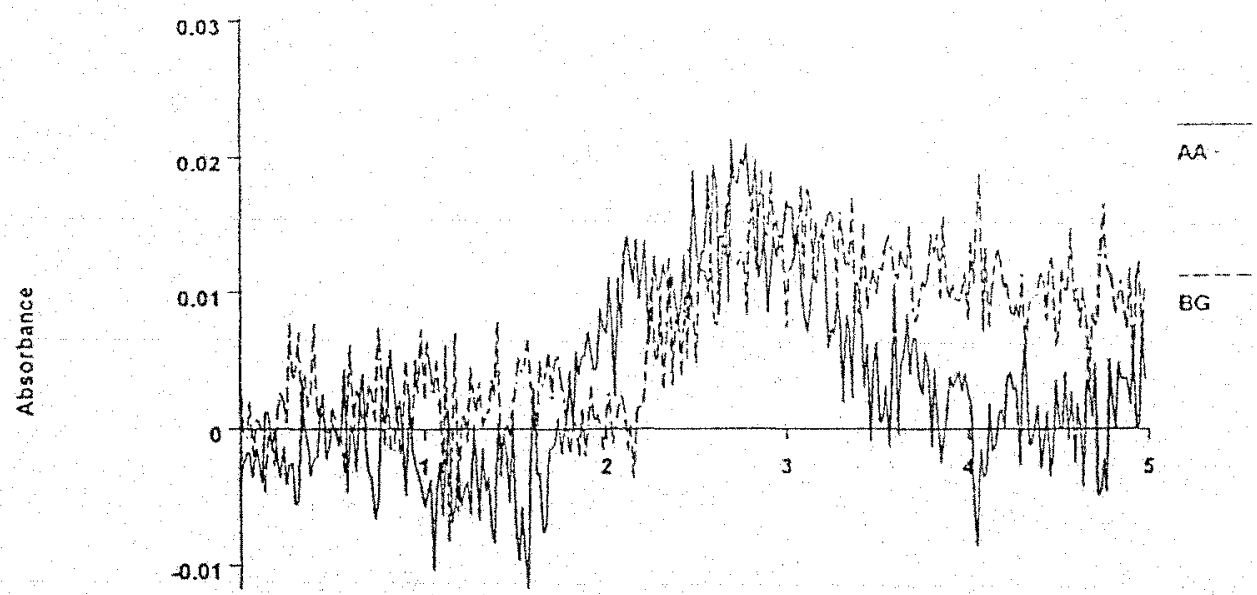

Time (seconds)

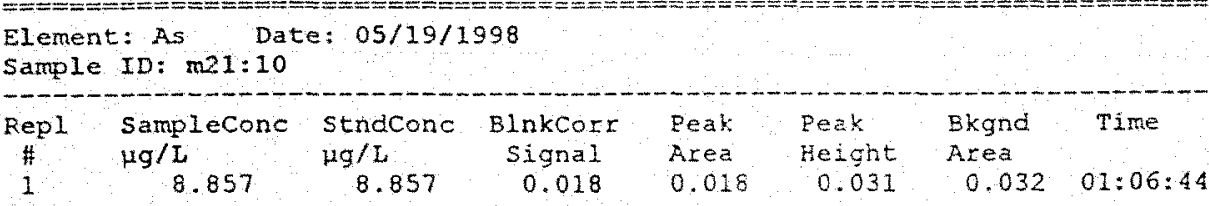

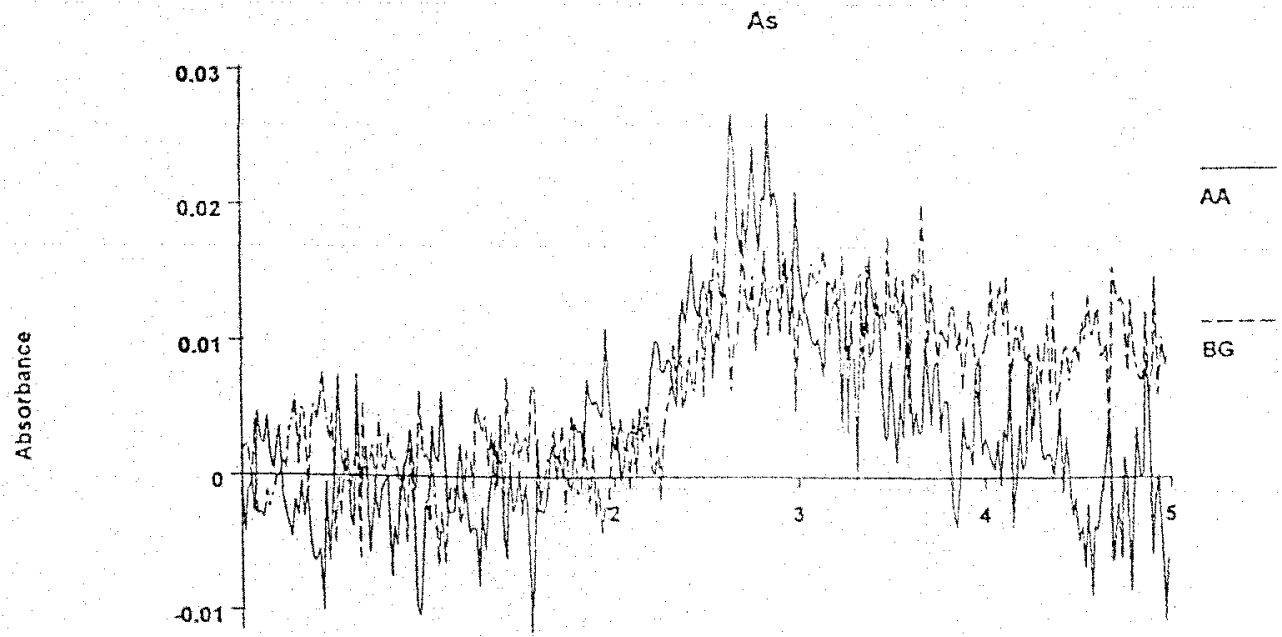

Time (seconds) 

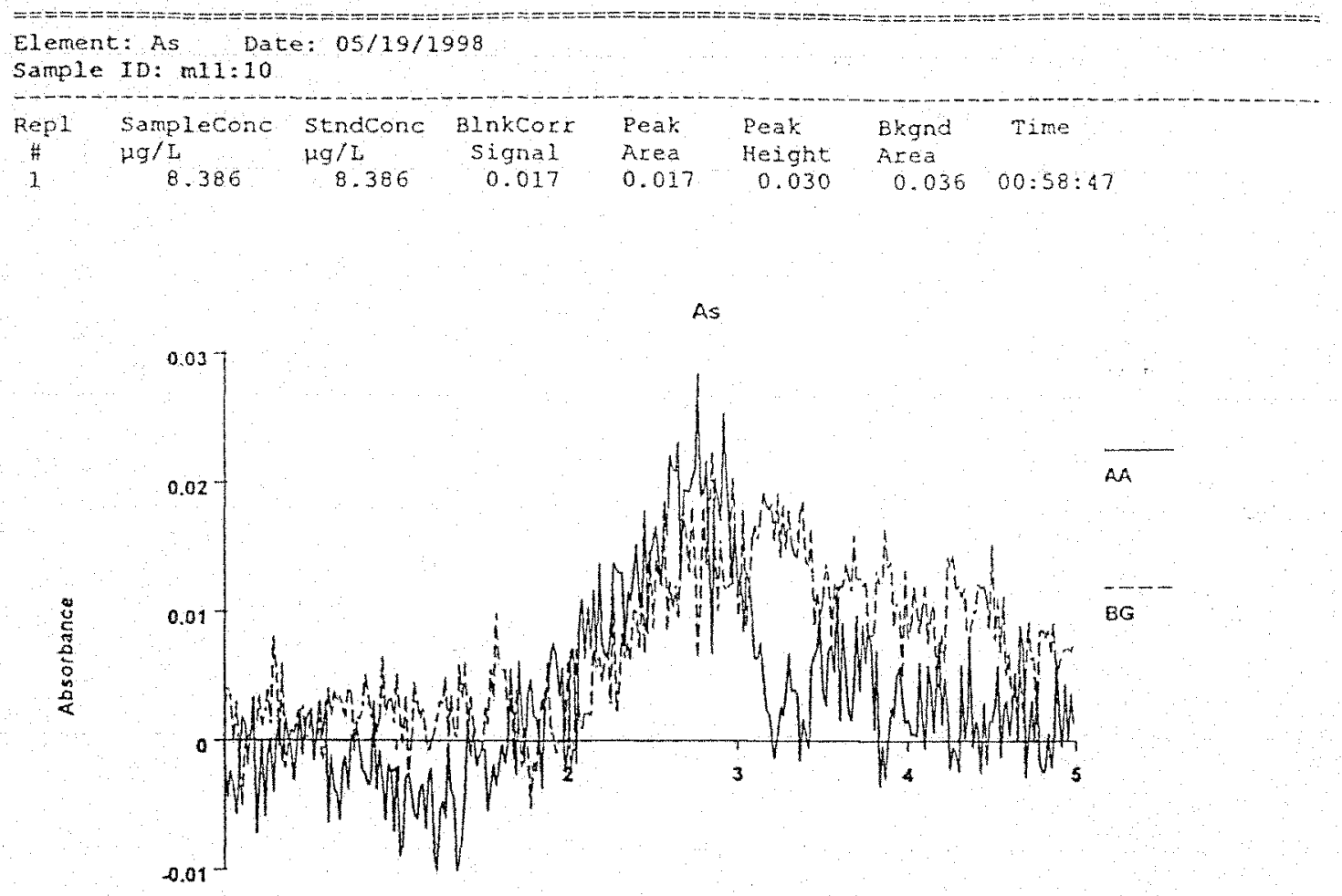

Time (seconds)

\begin{tabular}{|c|c|c|c|c|c|c|c|}
\hline Siem & $\begin{array}{l}\text { As } \mathrm{Da} \\
\text { ID: } \mathrm{m12}: 10\end{array}$ & $05 / 19$ & & & & & \\
\hline$\frac{\operatorname{epl}}{4}$ & $\begin{array}{l}\text { Sampleconc } \\
\mu g / L \\
8.667\end{array}$ & $\begin{array}{c}\text { StndCone } \\
\mu g / 1 \\
8.667\end{array}$ & $\begin{array}{c}\text { BInkcorr } \\
\text { Signal } \\
0.018\end{array}$ & $\begin{array}{l}\text { Peak } \\
\text { Rrea } \\
0.018\end{array}$ & $\begin{array}{l}\text { Peak } \\
\text { Height } \\
0.028\end{array}$ & $\begin{array}{l}\text { Bkgnd } \\
\text { Area } \\
0.034\end{array}$ & Time \\
\hline
\end{tabular}

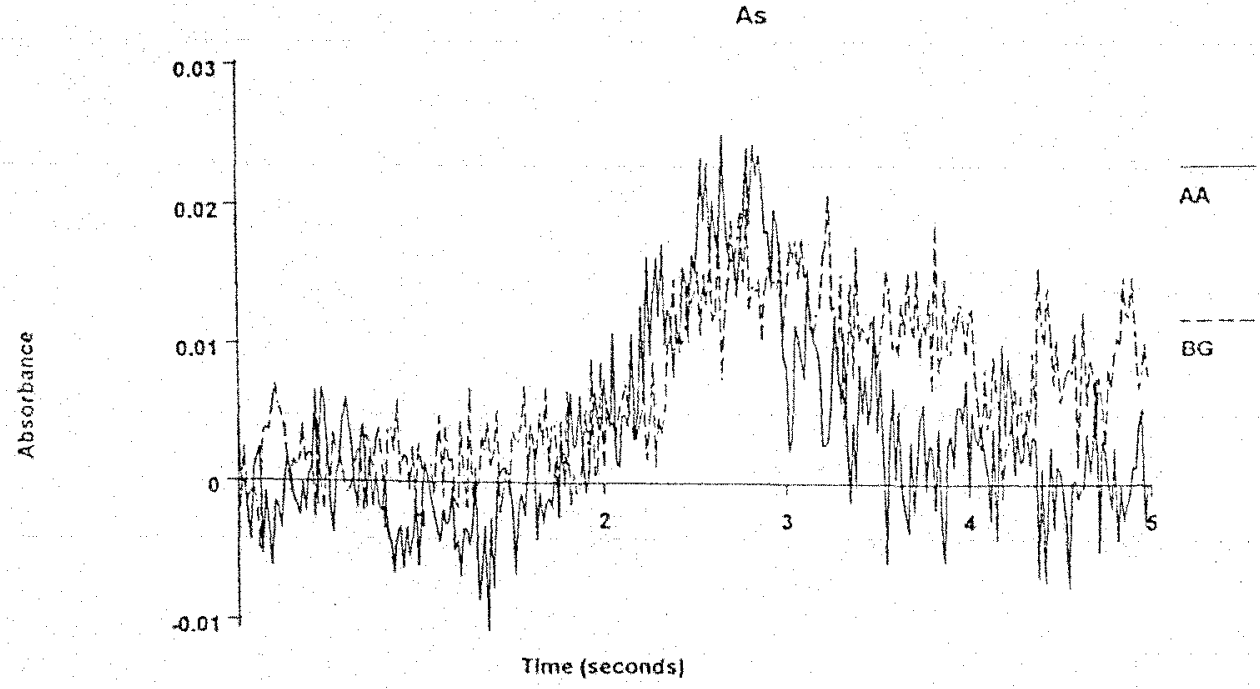




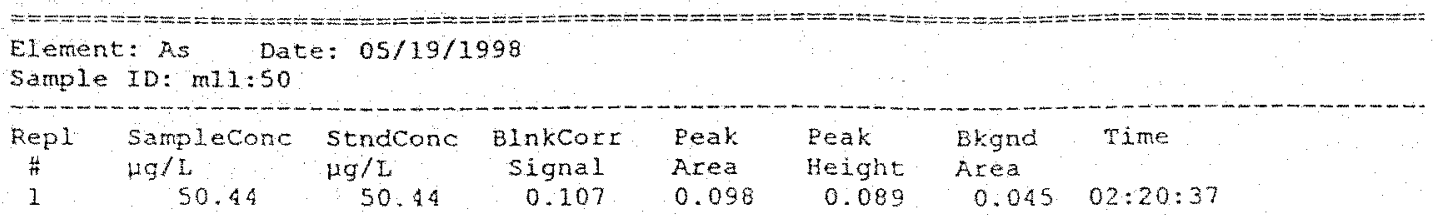

As

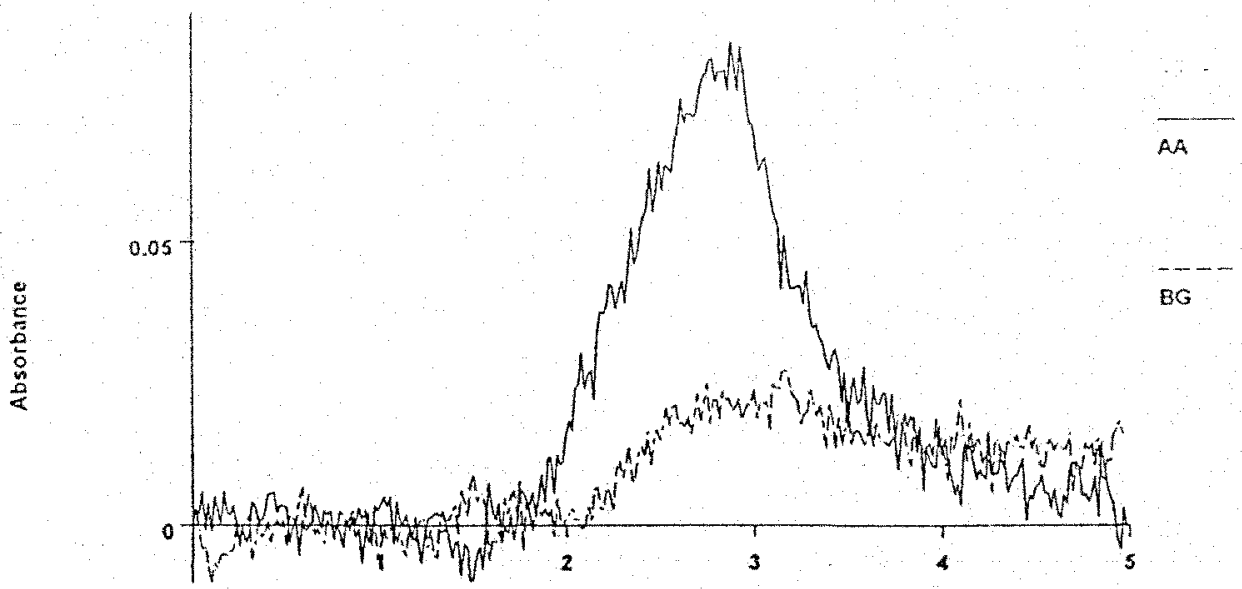

Time (seconds)

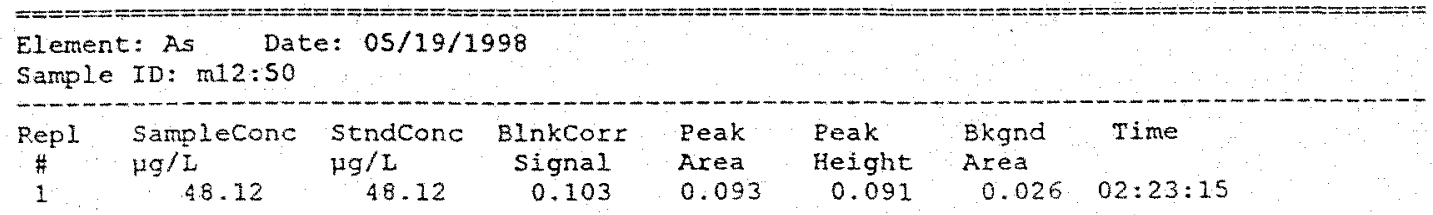

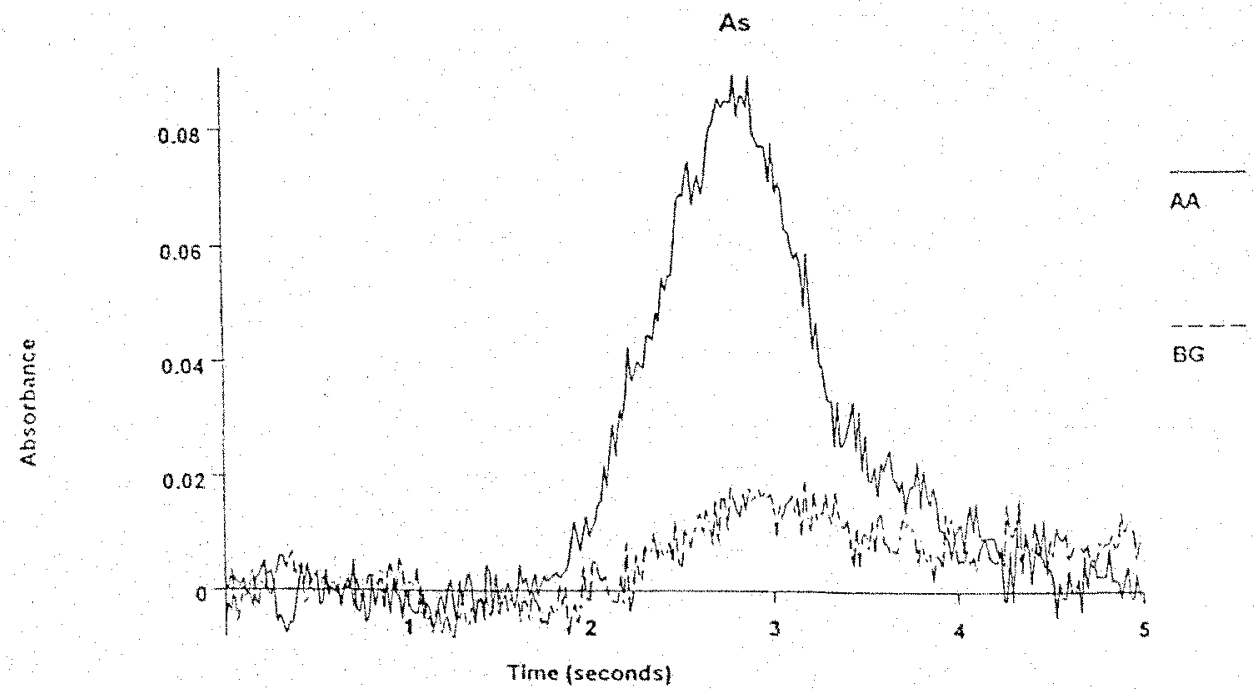




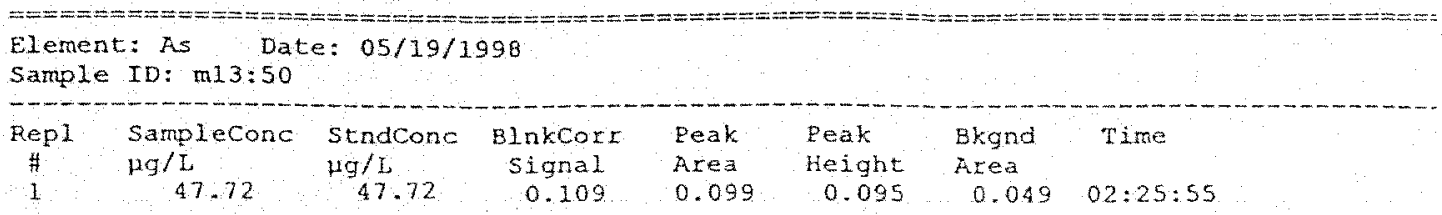

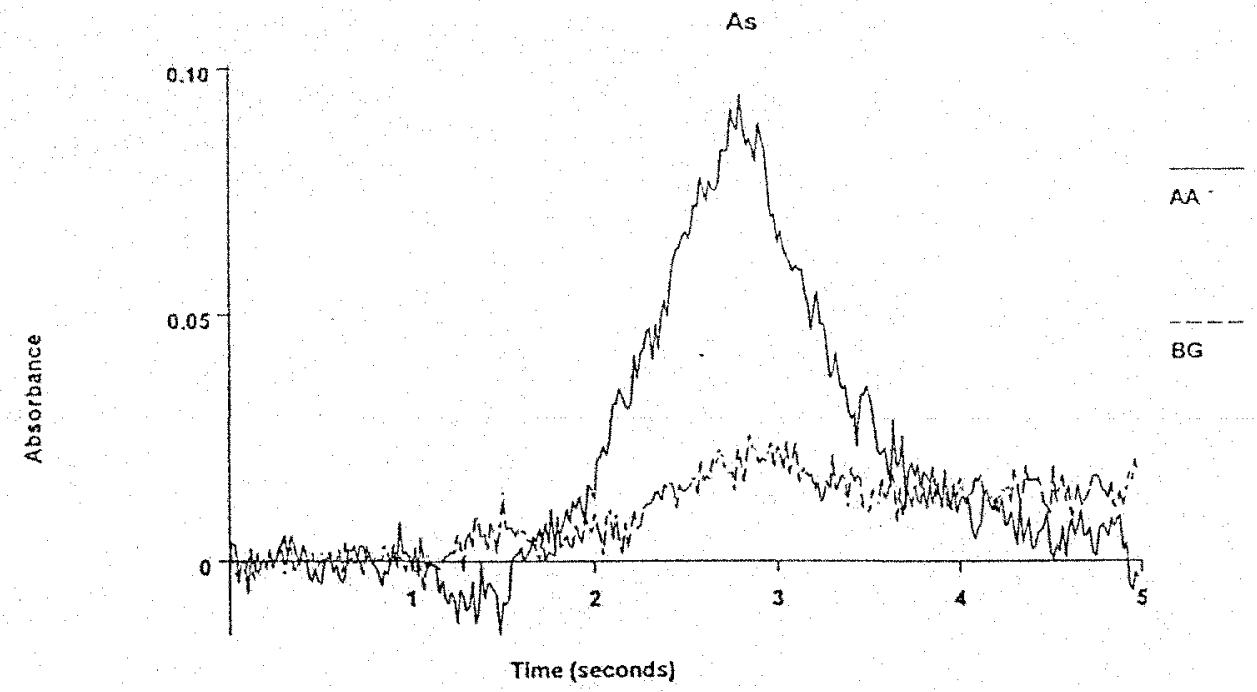

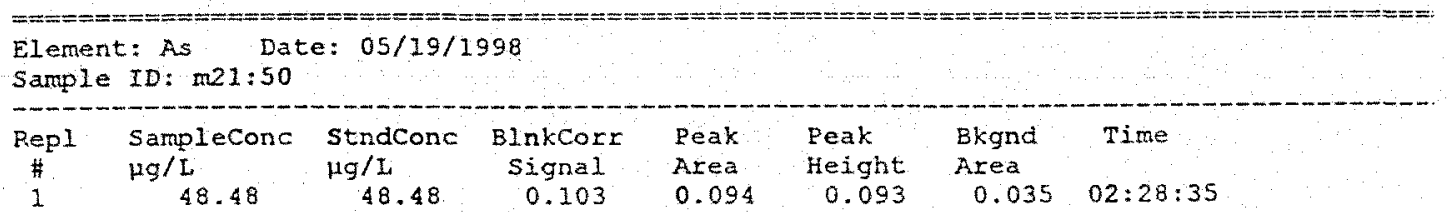

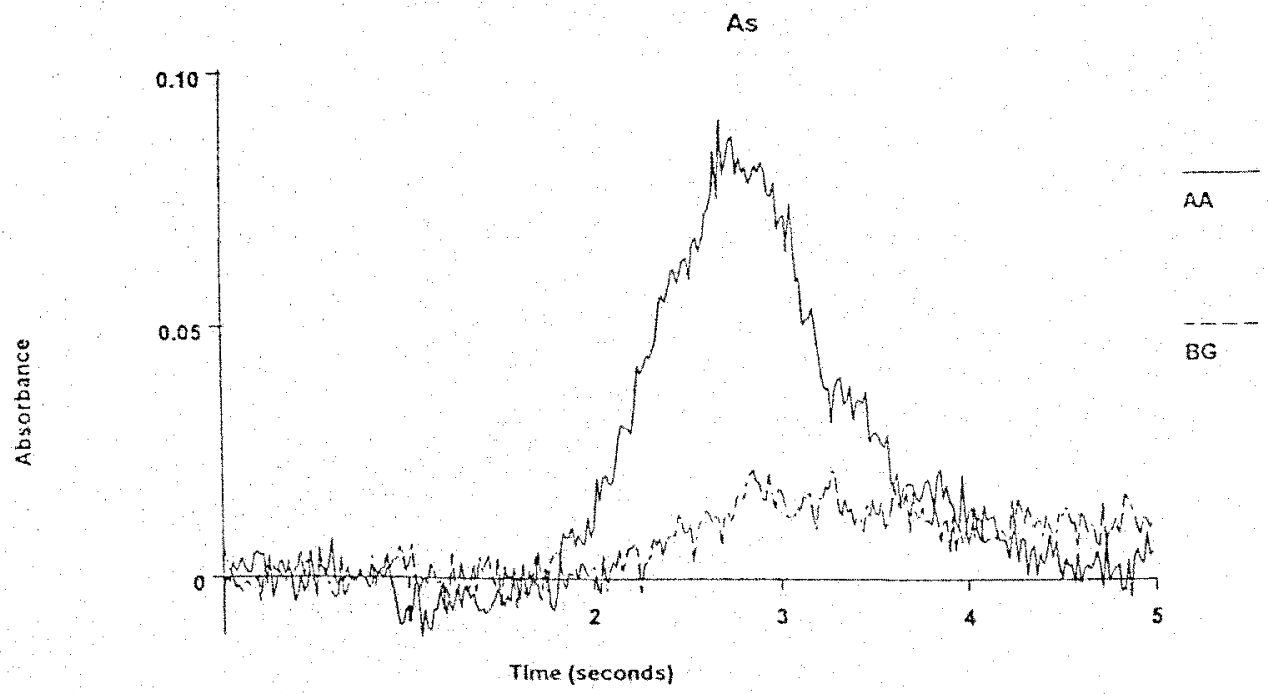




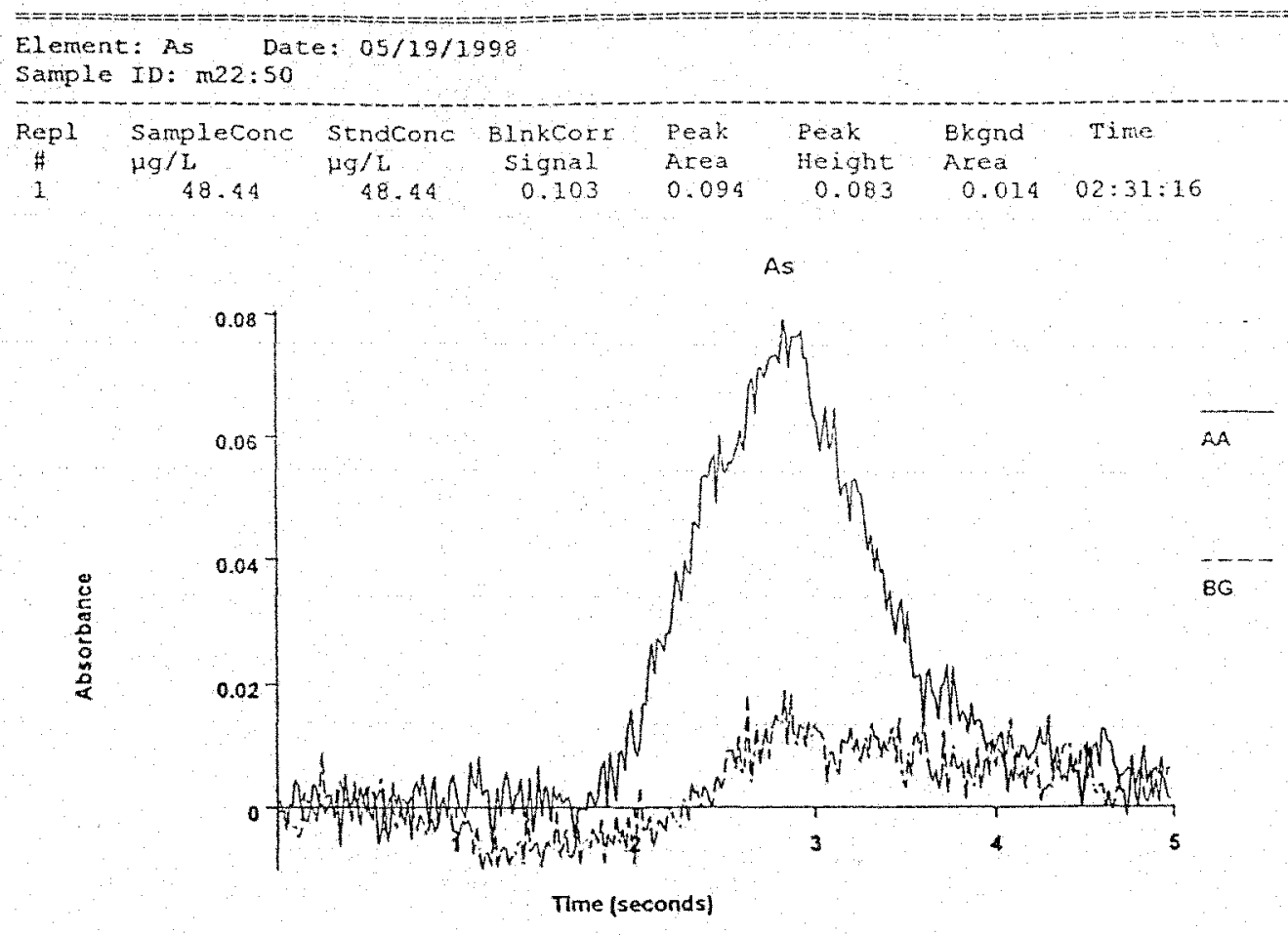

\begin{tabular}{|c|c|c|c|c|c|c|}
\hline $\begin{array}{l}\text { Element: As : Dat } \\
\text { Sample ID: } \mathrm{m} 23: 50\end{array}$ & $: 05 / 19 / 3$ & 998 & & & . & \\
\hline $\begin{array}{l}\text { Sampleconc } \\
\mu \mathrm{g} / \mathrm{L} \\
49.98\end{array}$ & $\begin{array}{l}\text { Stndcone } \\
\mu g / L \\
49.98\end{array}$ & $\begin{array}{c}\text { BlnkCort } \\
\text { signal } \\
0.106\end{array}$ & $\begin{array}{l}\text { Eeak } \\
\text { Area } \\
0.097\end{array}$ & $\begin{array}{l}\text { Peak } \\
\text { Height } \\
0.087\end{array}$ & $\begin{array}{l}\text { Bkgnd } \\
\text { Area } \\
\quad 0.032\end{array}$ & $\begin{array}{c}\text { Time } \\
02: 33: 55\end{array}$ \\
\hline
\end{tabular}

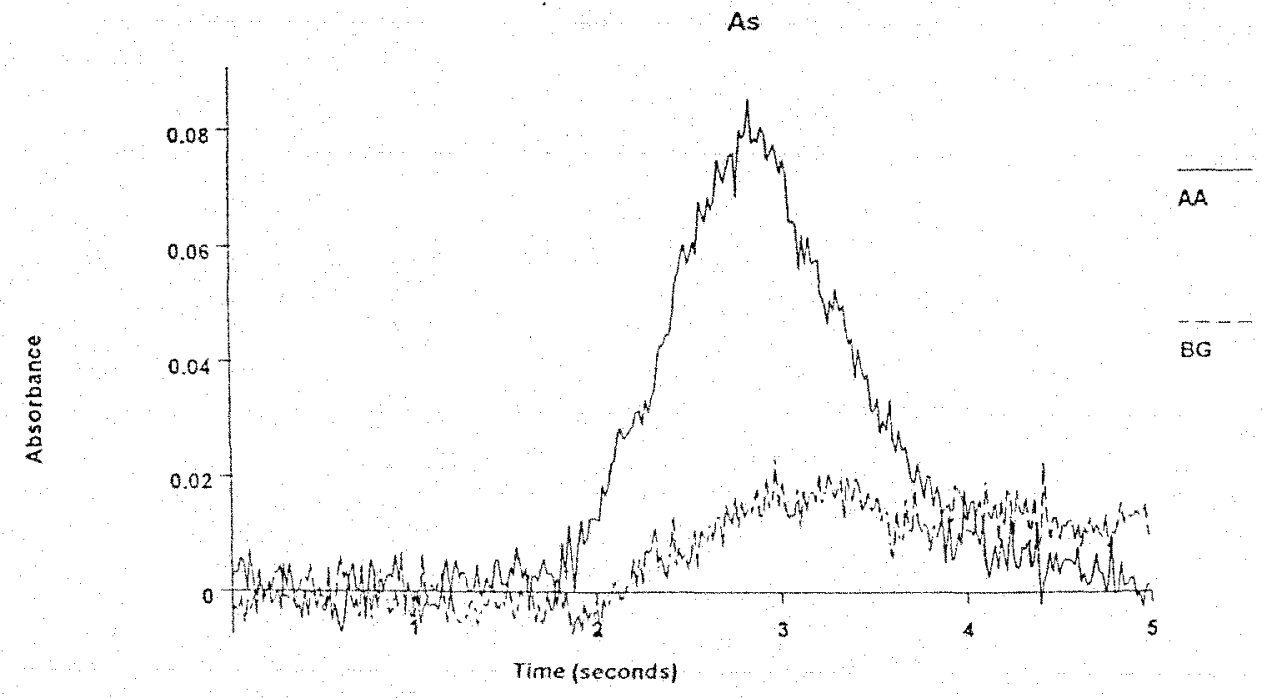




\begin{tabular}{|c|c|c|c|c|c|}
\hline $\begin{array}{l}\text { Element: Dat } \\
\text { Sample ID: } \mathrm{m} 3: 50\end{array}$ & $=05 / 19 /$ & 98 & & & \\
\hline $\begin{array}{l}\text { Sampleconc } \\
\mu g / L \\
46.48\end{array}$ & $\begin{array}{l}\text { StndCons } \\
\qquad 9 / 2 \\
46.48\end{array}$ & $\begin{array}{c}\text { Elnkcotr } \\
\text { signal } \\
0.099\end{array}$ & $\begin{array}{l}\text { peak } \\
\text { AEea } \\
0.089\end{array}$ & $\begin{array}{l}\text { Peak } \\
\text { Height } \\
0.091\end{array}$ & $\begin{array}{l}\text { Bkgnd } \\
\text { Area } \\
\quad 0.050 \quad 02: 36: 33\end{array}$ \\
\hline
\end{tabular}

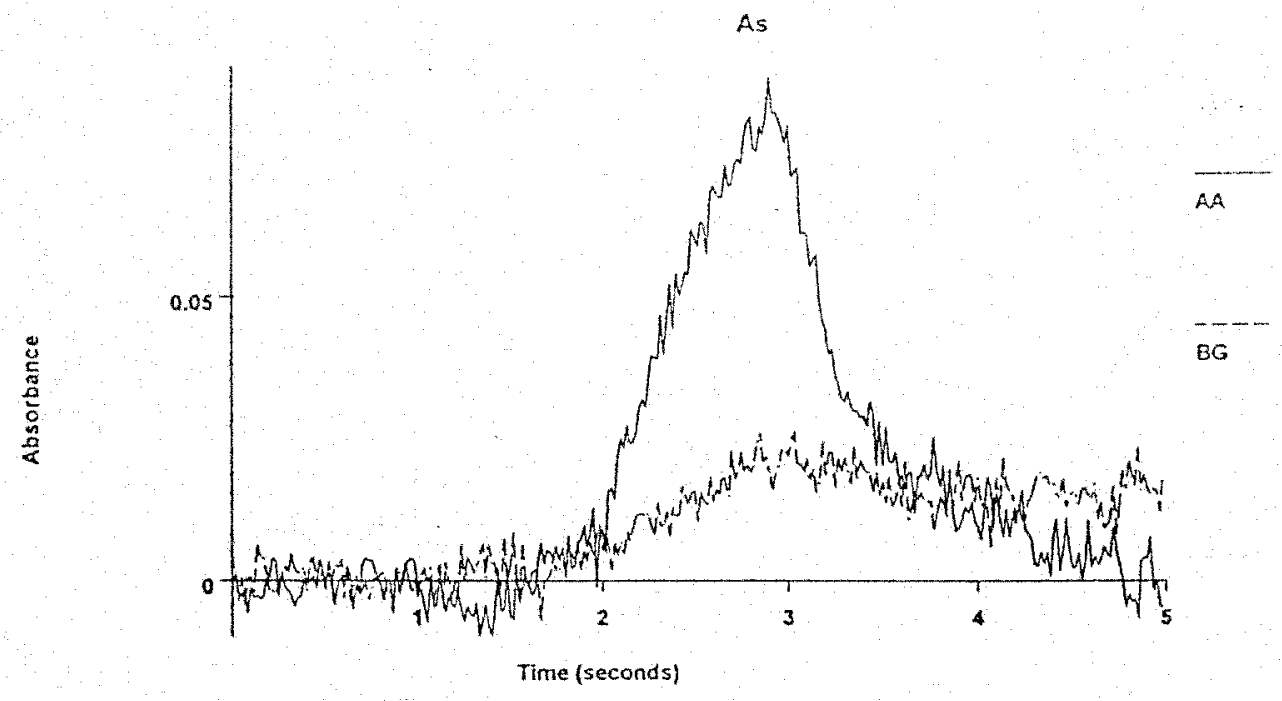

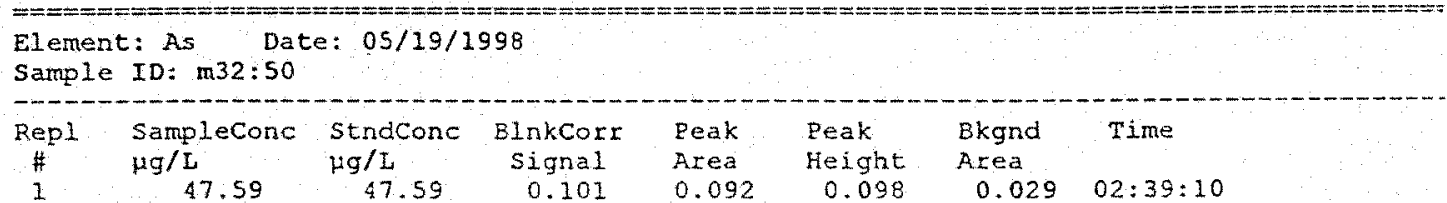

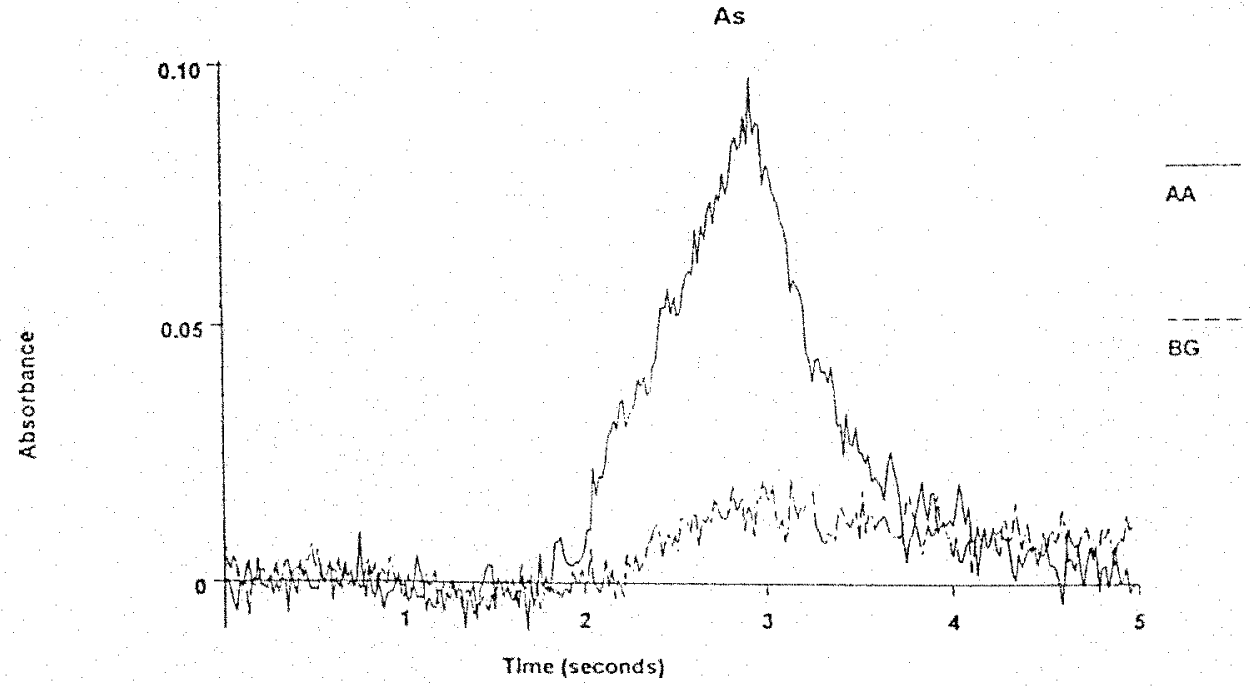


Element: As Date 05/19/1998

Sample ID: m42:50

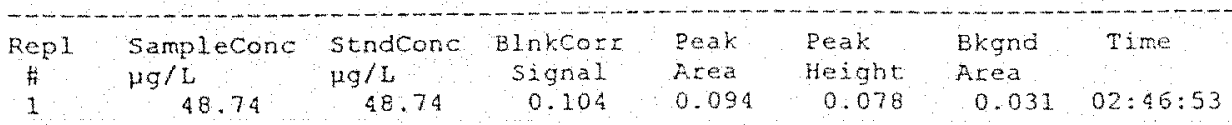

As

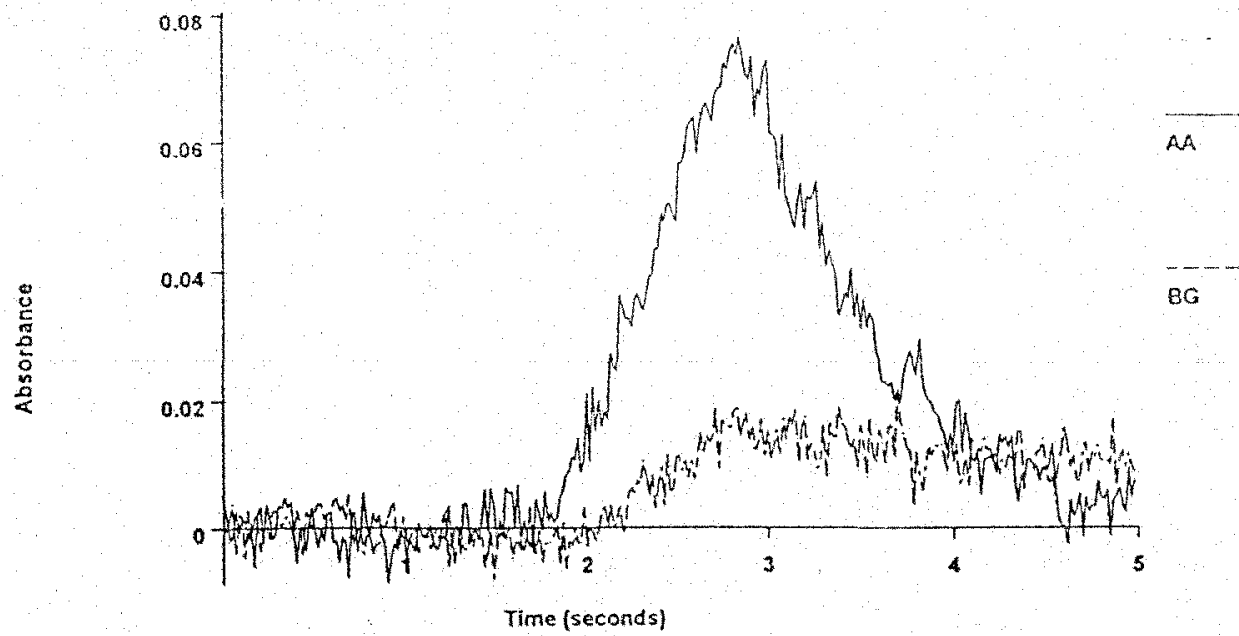

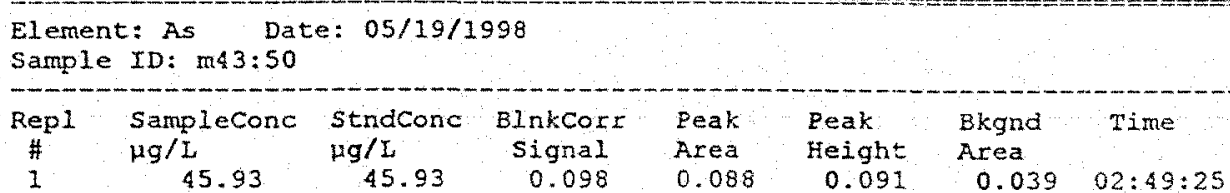

As

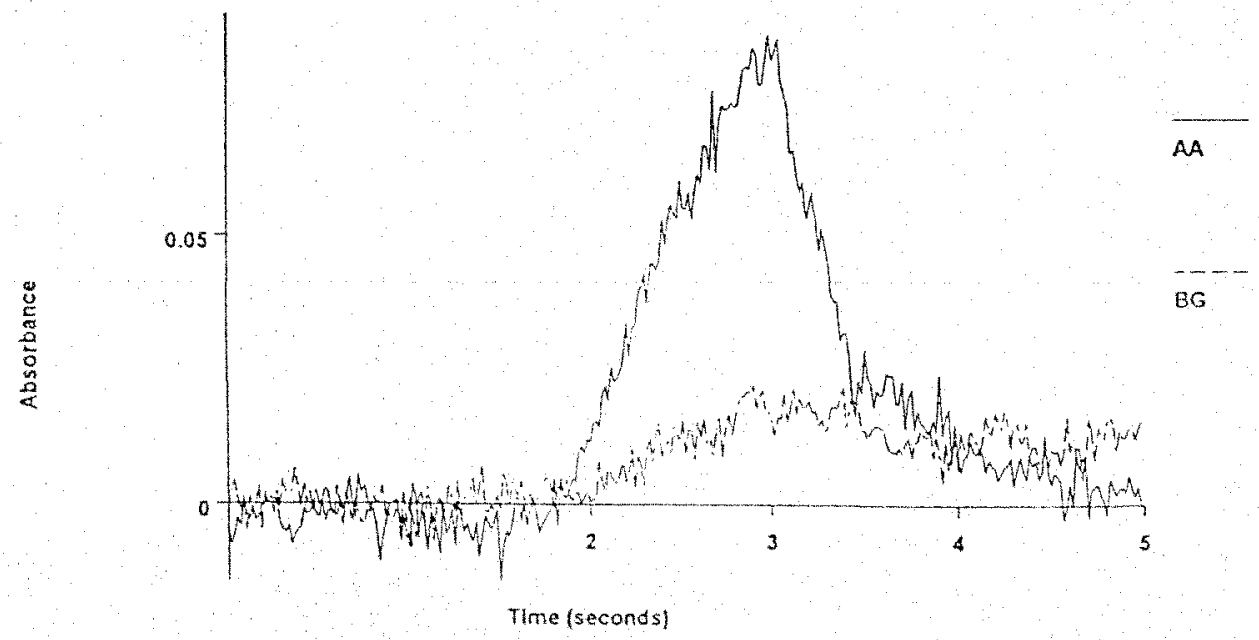


Element: As Date: 05/19/1998

Sample ID: m51:50

\begin{tabular}{|c|c|c|c|c|c|c|c|}
\hline $\begin{array}{l}\text { Repl } \\
\# \\
1\end{array}$ & $\begin{array}{c}\text { Samplecone } \\
\mu g / L \\
49.30\end{array}$ & $\begin{array}{c}\text { stndcone } \\
\mu g / t \\
49.30\end{array}$ & $\begin{array}{c}\text { BInkCorr } \\
\text { Signal } \\
0.105\end{array}$ & $\begin{array}{l}\text { Peak } \\
\text { Area } \\
0.095\end{array}$ & $\begin{array}{l}\text { Eeak } \\
\text { Height } \\
0.097\end{array}$ & $\begin{array}{l}\text { Bkgnd } \\
\text { Axea } \\
0.022\end{array}$ & $\begin{array}{l}\text { Time } \\
02: 51: 56\end{array}$ \\
\hline
\end{tabular}
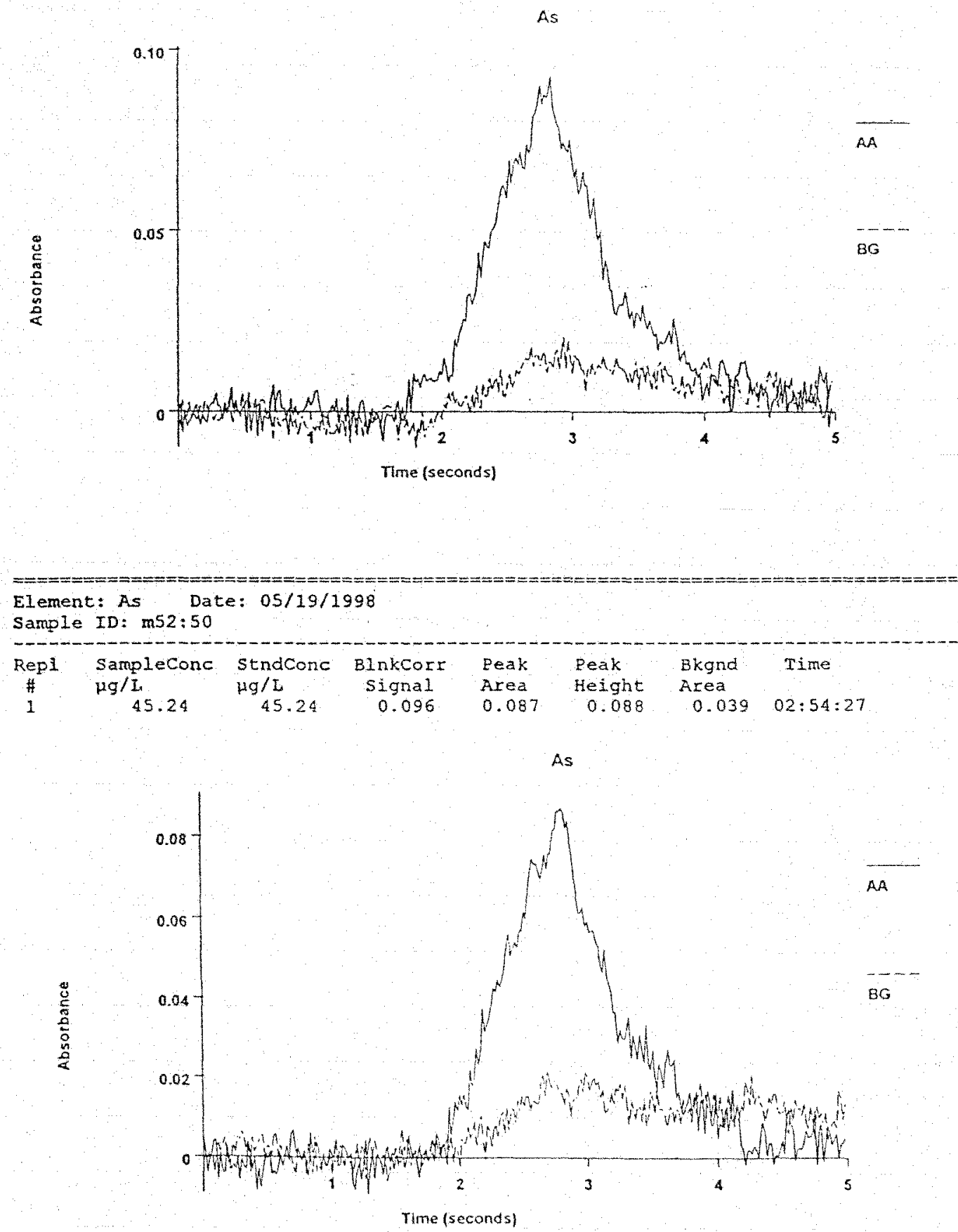


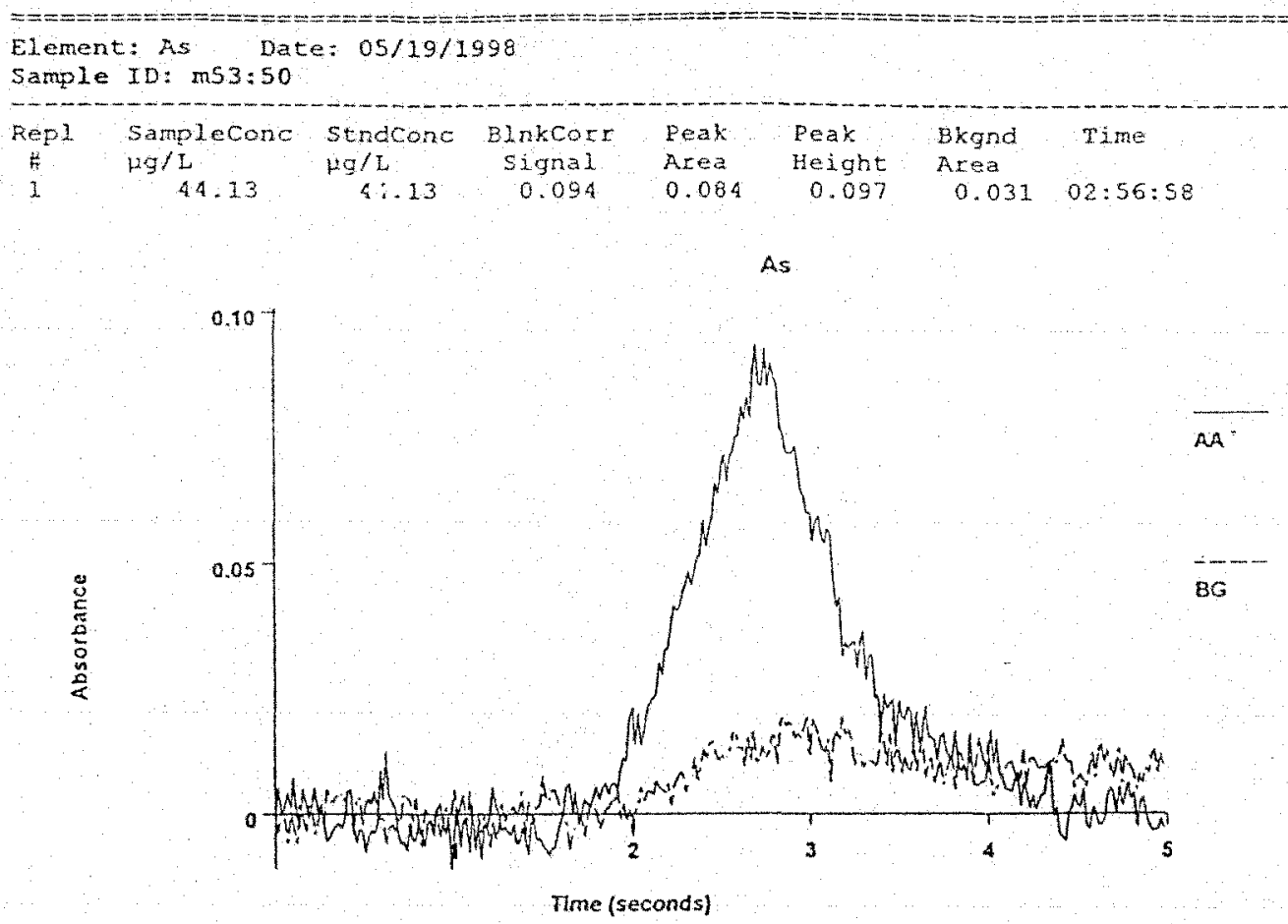

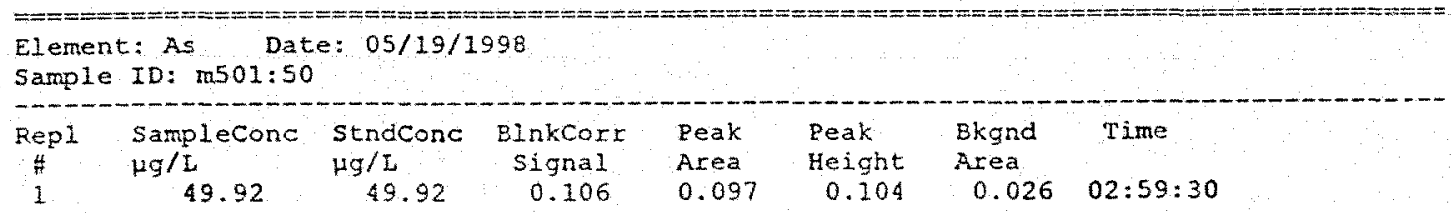

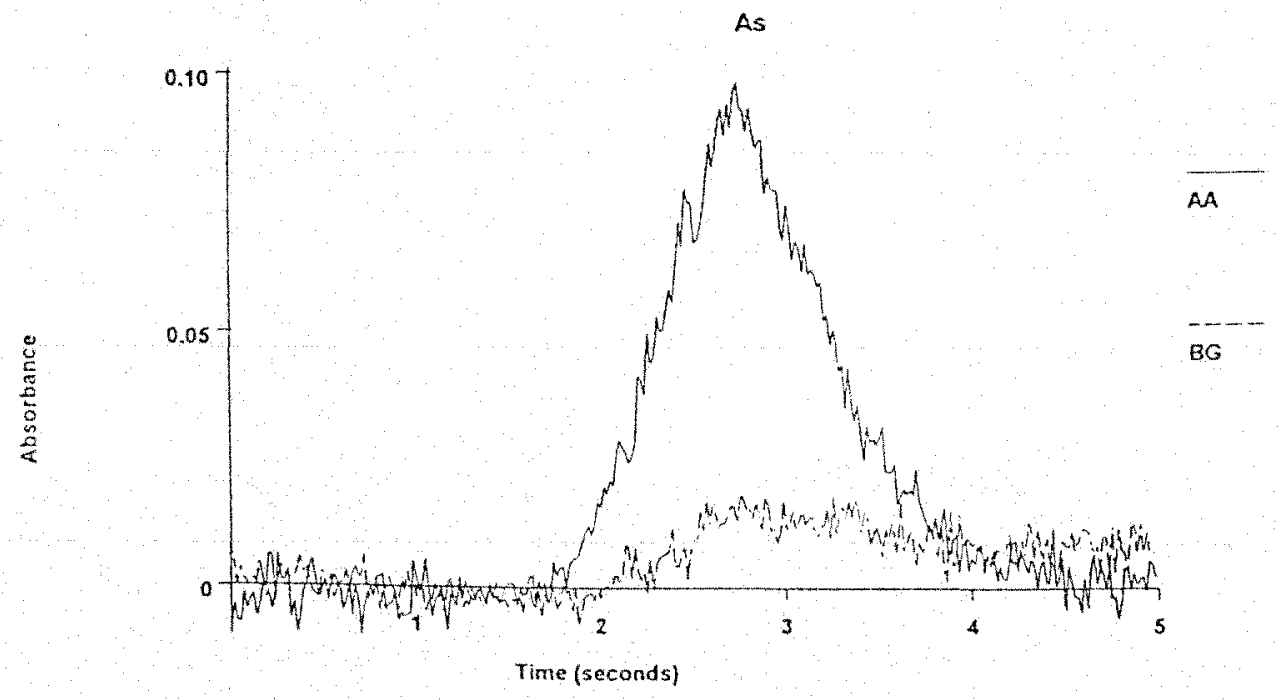




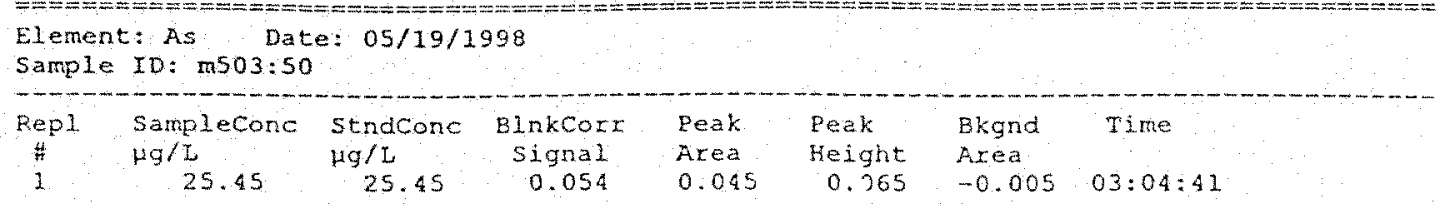

As

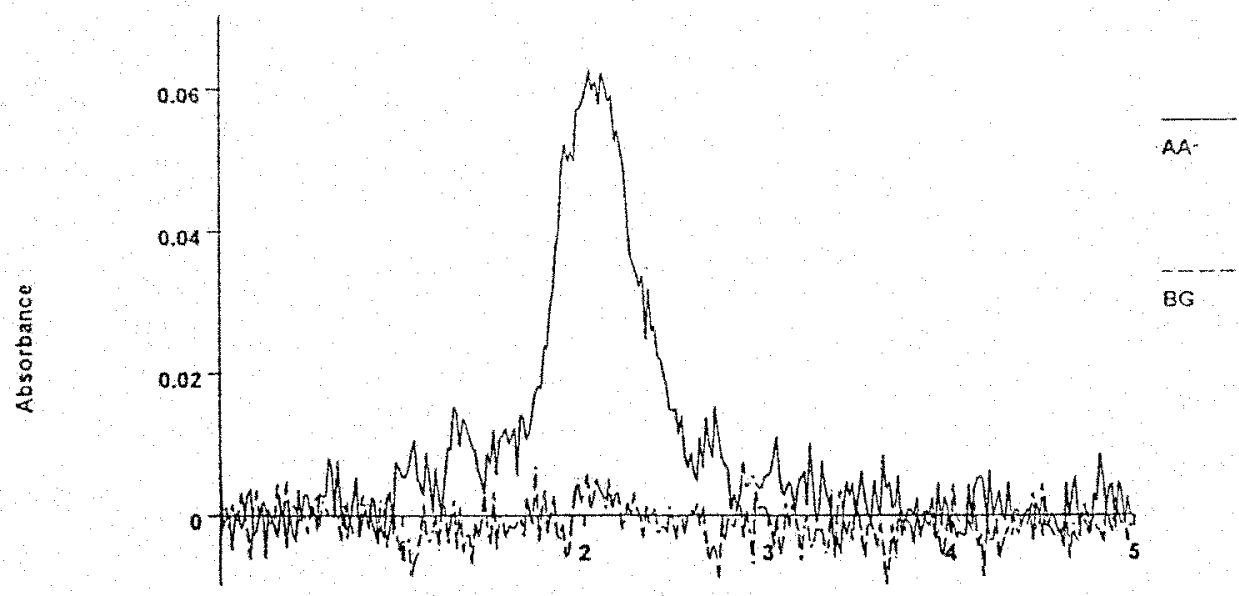

Time (seconds)

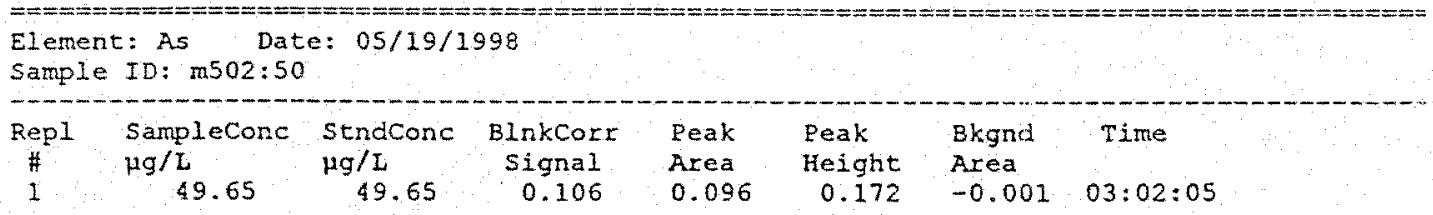

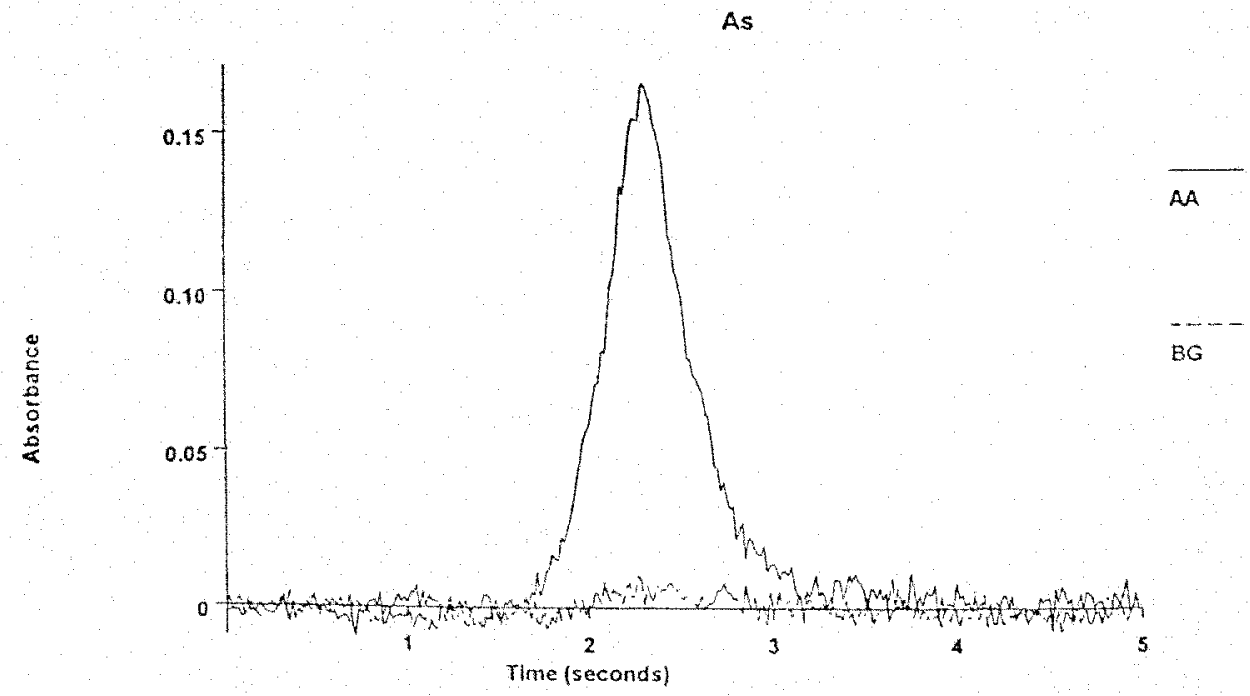



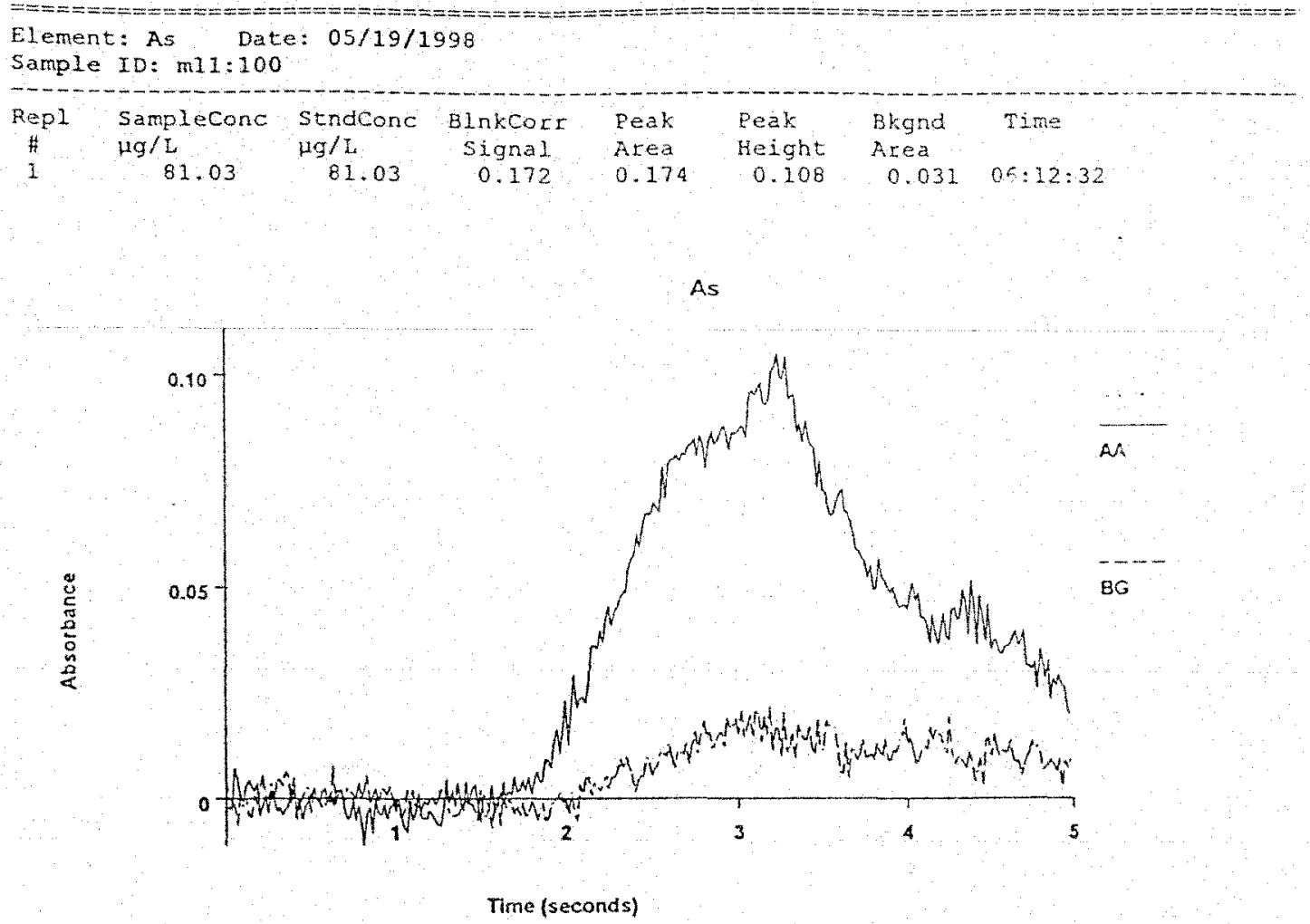

\begin{tabular}{|c|c|c|c|c|c|c|}
\hline $\begin{array}{l}\text { Element: As Dat } \\
\text { Sample ID: m12:100 }\end{array}$ & $=0.05 / 19 /$ & 998 & & & & . \\
\hline $\begin{array}{l}\text { Sampleconc } \\
\mu g / \mathrm{L} \\
\qquad 92.28\end{array}$ & $\begin{array}{l}\text { StndConc } \\
\mu g / \mathrm{I} \\
\quad 92.28\end{array}$ & $\begin{array}{c}\text { BInkCorr } \\
\text { Signal } \\
0.196\end{array}$ & $\begin{array}{l}\text { Peak } \\
\text { Area } \\
0.198\end{array}$ & $\begin{array}{l}\text { Peak } \\
\text { Height } \\
0.183\end{array}$ & $\begin{array}{l}\text { Bkgnd } \\
\text { Area } \\
0.028\end{array}$ & $\begin{array}{l}\text { Time } \\
06: 15: 09\end{array}$ \\
\hline
\end{tabular}

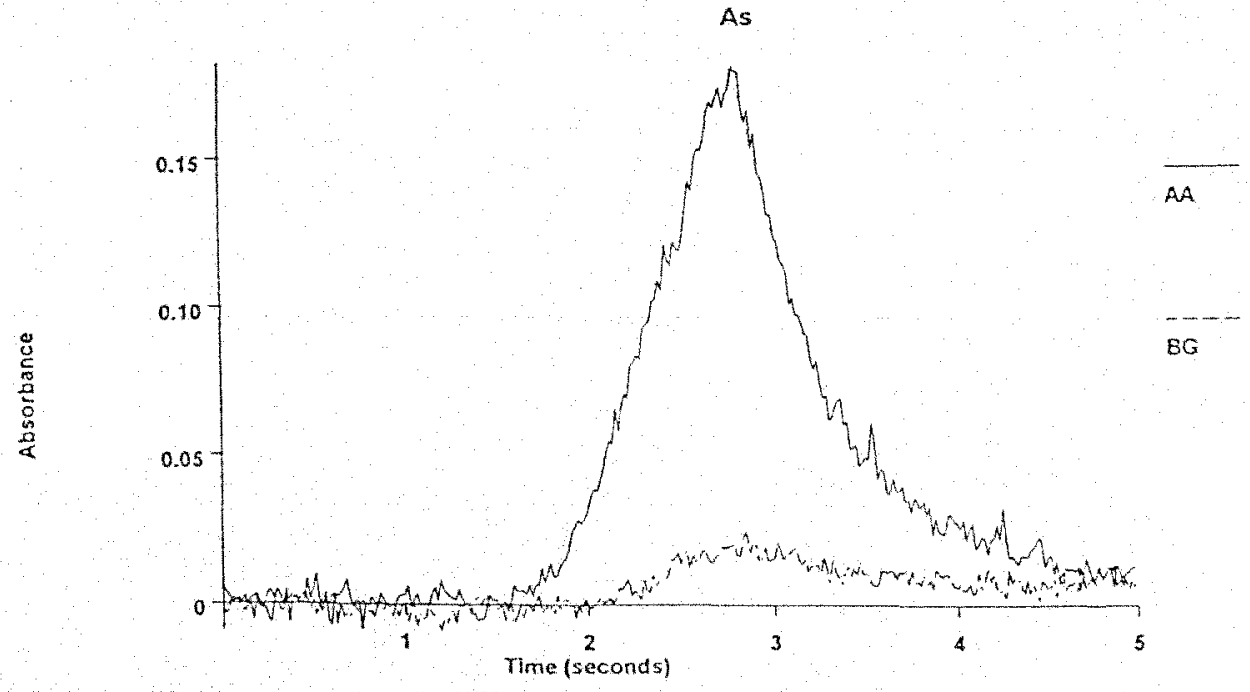




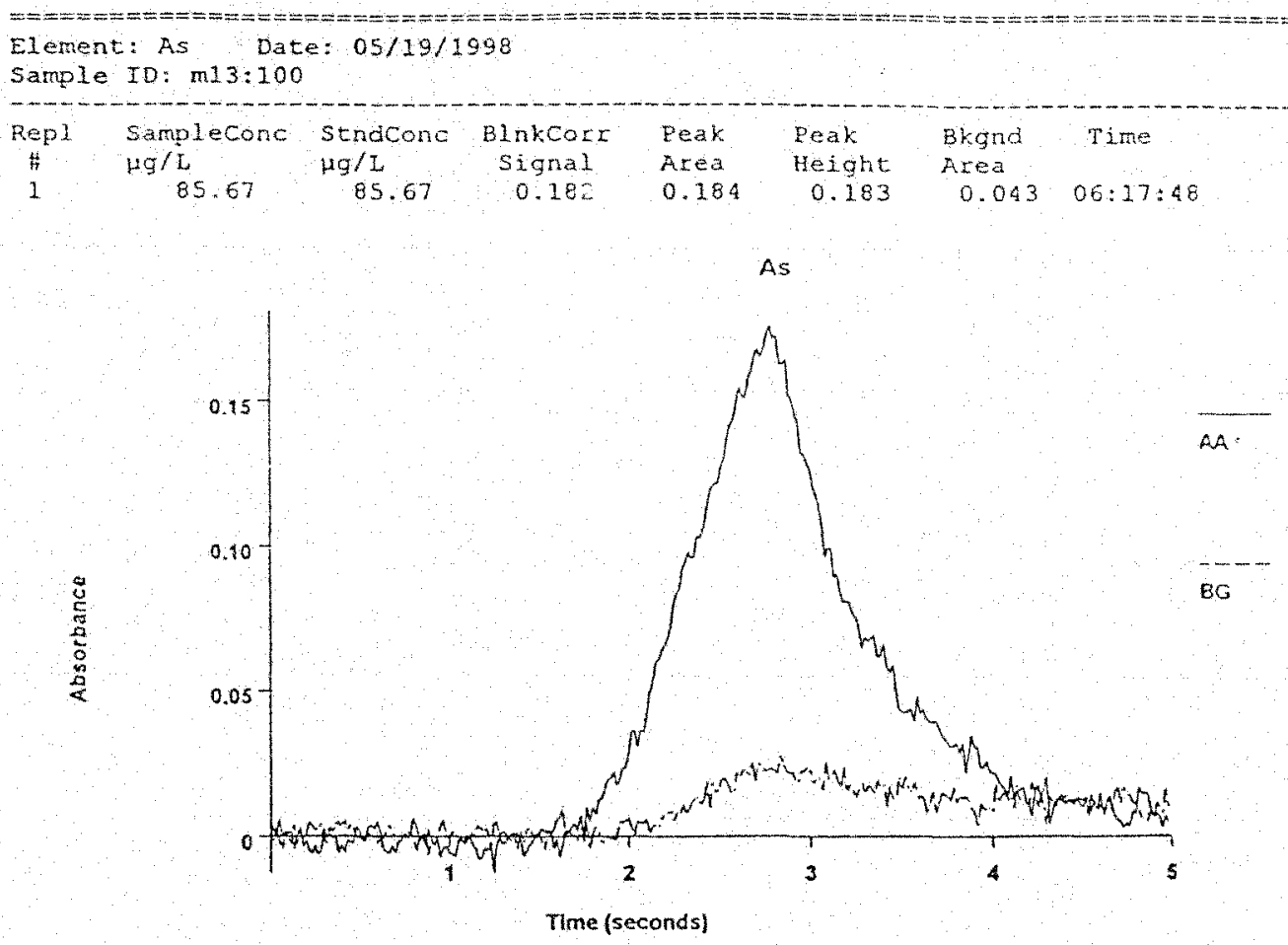

\begin{tabular}{|c|c|c|c|c|c|c|}
\hline $\begin{array}{l}\text { Element: As Dat } \\
\text { Sample ID: } \mathrm{m} 21: 100\end{array}$ & $=: 05 / 19 /$ & 98 & : & & & - \\
\hline $\begin{array}{l}\text { Repl Sampleconc } \\
1 \\
1\end{array}$ & $\begin{array}{l}\text { Stndcone } \\
\operatorname{Hg} / 1 \\
91.71\end{array}$ & $\begin{array}{l}\text { BlnkCorr } \\
\text { signal } \\
0.195\end{array}$ & $\begin{array}{l}\text { Eeak } \\
\text { Area } \\
0.197\end{array}$ & $\begin{array}{l}\text { Eeak } \\
\text { Height } \\
0.172\end{array}$ & $\begin{array}{l}\text { Bkgnd } \\
\text { Area } \\
\quad 0.038\end{array}$ & $\begin{array}{l}\text { Time } \\
06: 20: 29\end{array}$ \\
\hline
\end{tabular}

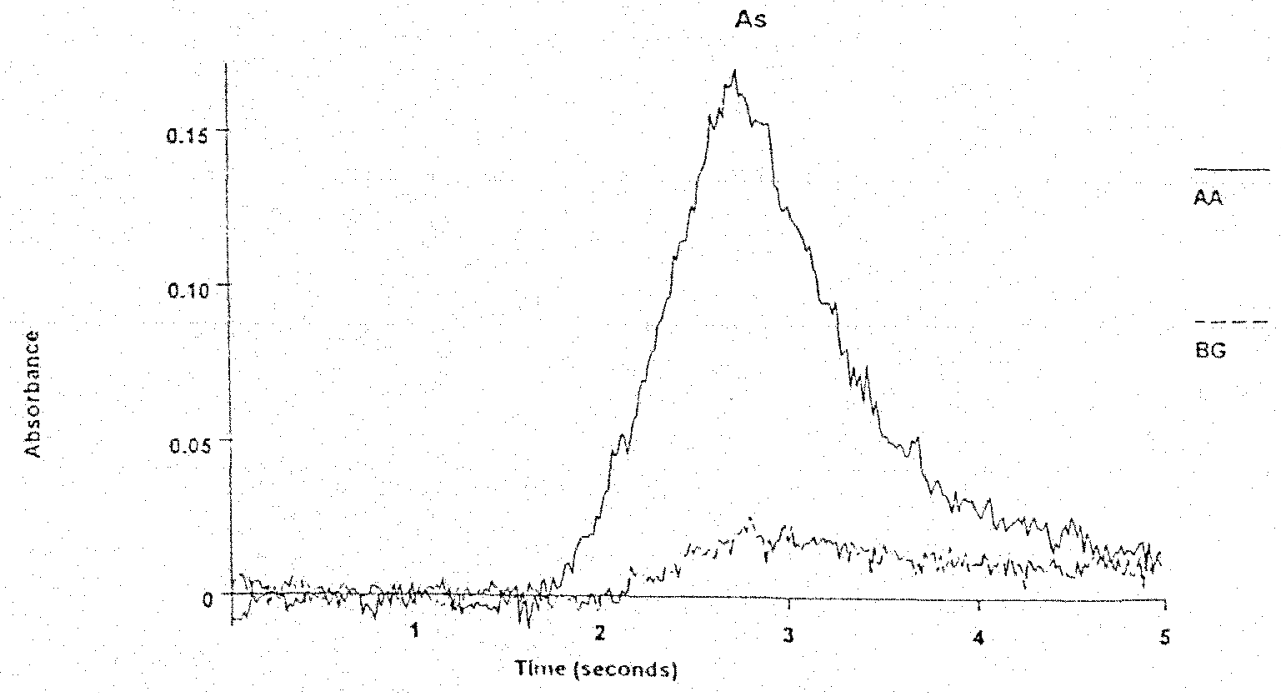



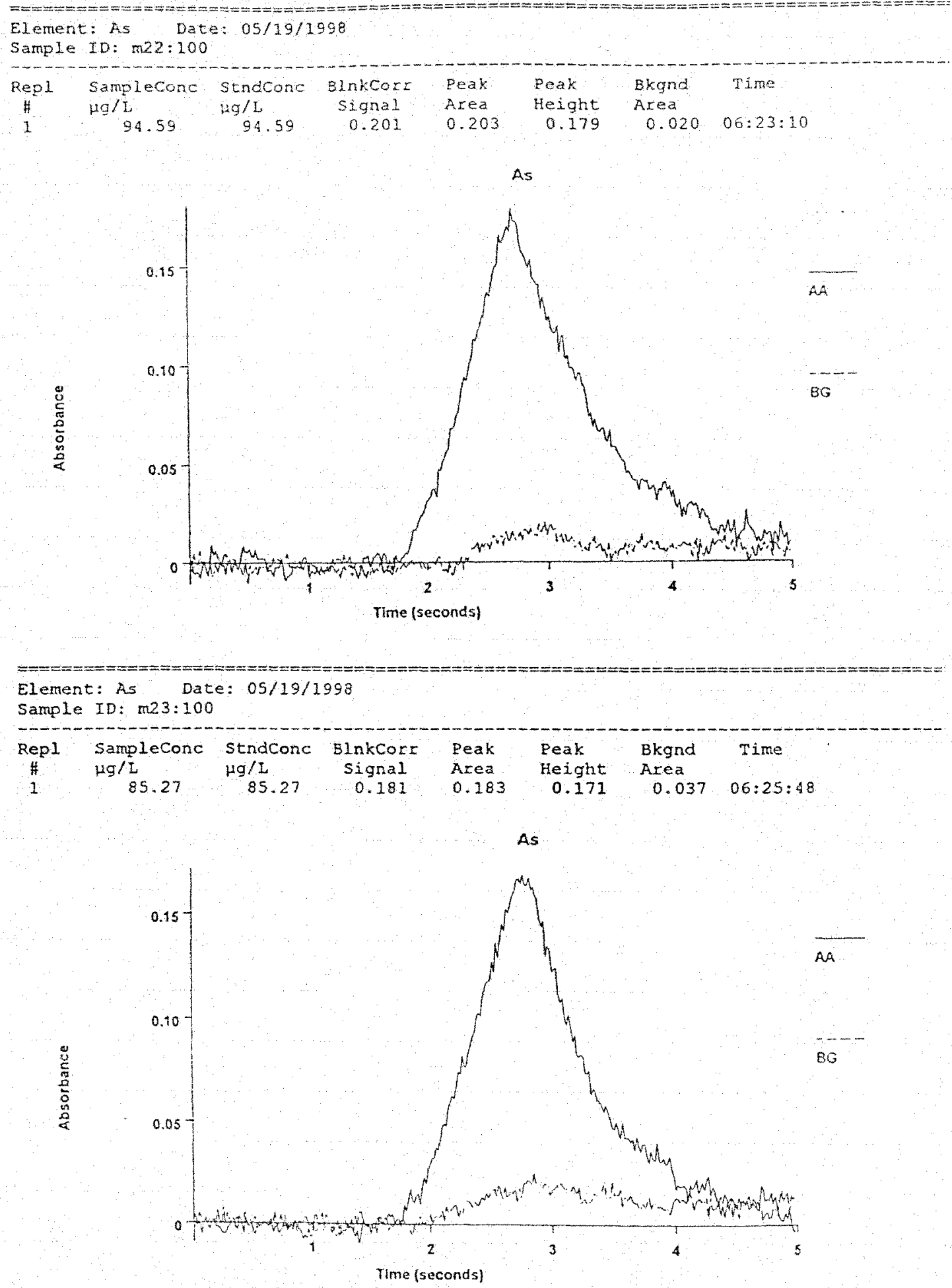
Element: As Date: $05 / 19 / 1998$

Sample ID: $\mathrm{m31:100}$

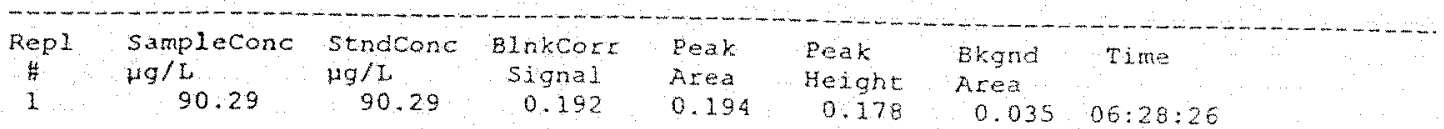

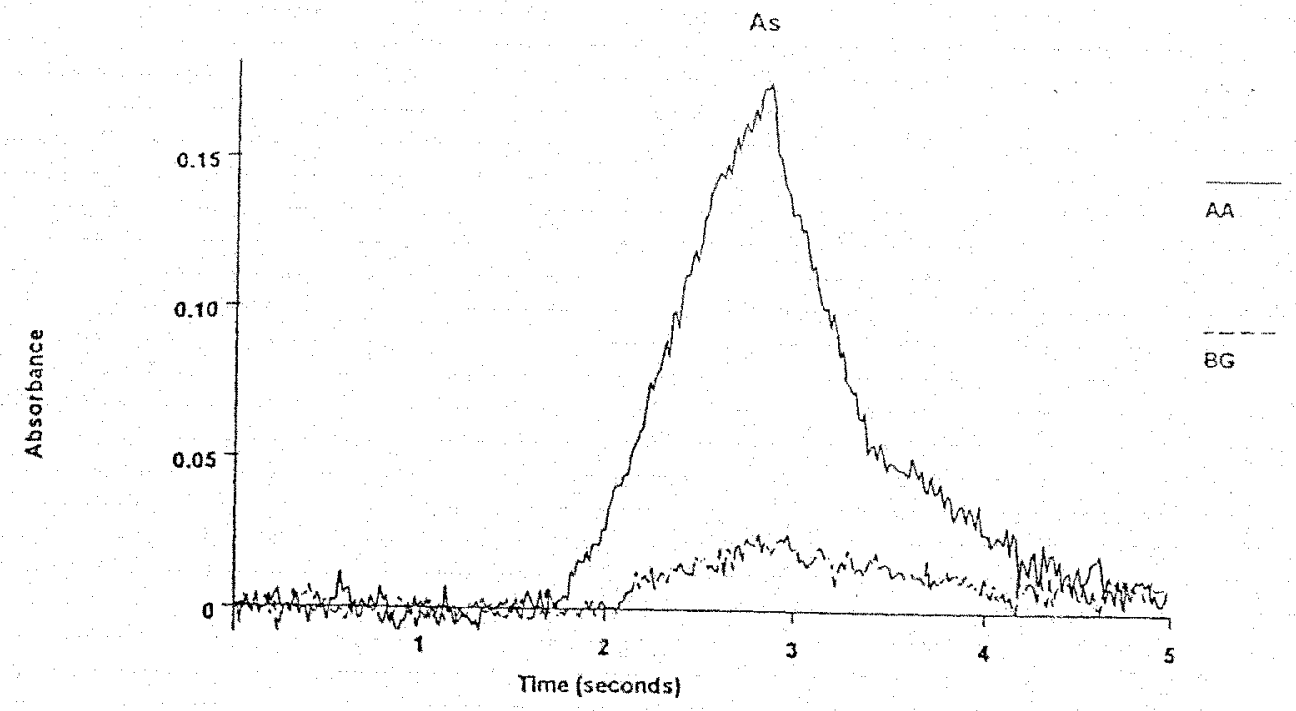

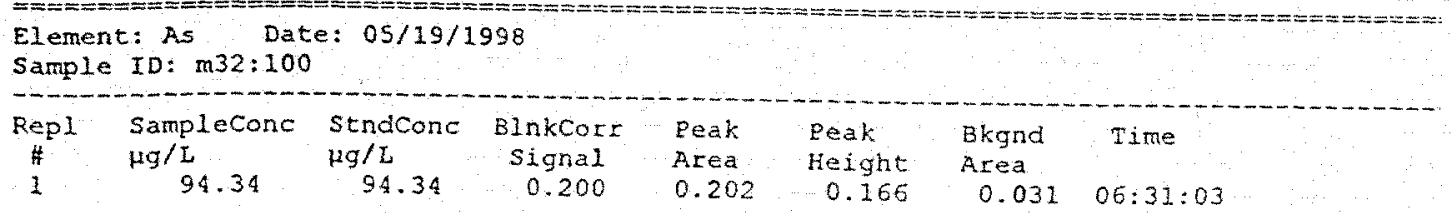

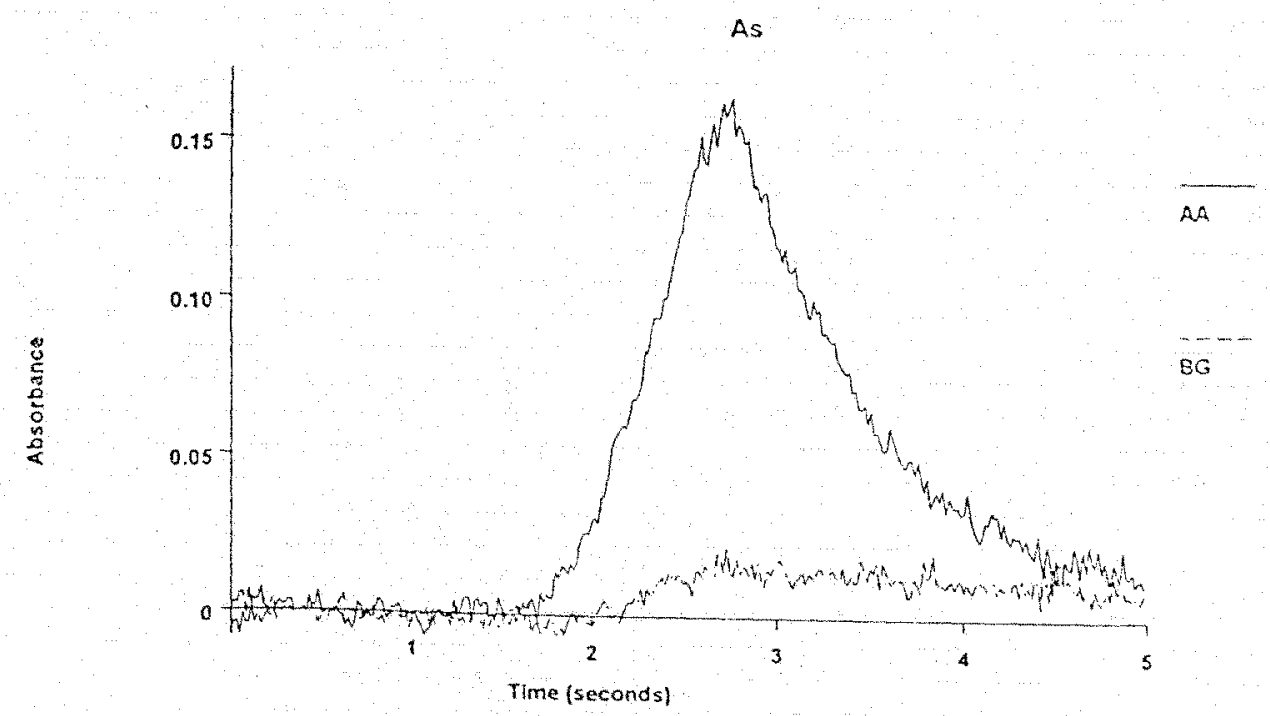




\begin{tabular}{|c|c|c|c|c|c|c|c|}
\hline $\begin{array}{l}\text { Eleme } \\
\text { Sampl }\end{array}$ & $\begin{array}{l}\text { As Da } \\
\text { ID: } \mathrm{m} 33: 10\end{array}$ & $=: \quad 05 / 19 / 1$ & 98 & & & & \\
\hline $\begin{array}{c}\operatorname{Rep} 1 \\
\# \\
1\end{array}$ & $\begin{array}{c}\text { Samplecono } \\
\mathrm{Hg} / \mathrm{L} \\
96.04\end{array}$ & $\begin{array}{l}\text { StndCone } \\
\mathrm{Hg} / \mathrm{L} \\
96.04\end{array}$ & $\begin{array}{c}\text { BinkCorr } \\
\text { Signal } \\
0.204\end{array}$ & $\begin{array}{l}\text { Peak } \\
\text { Area } \\
0.206\end{array}$ & $\begin{array}{l}\text { Peak } \\
\text { Height } \\
0.169\end{array}$ & $\begin{array}{l}\text { Bkgnd } \\
\text { Area } \\
0.024\end{array}$ & Time \\
\hline
\end{tabular}

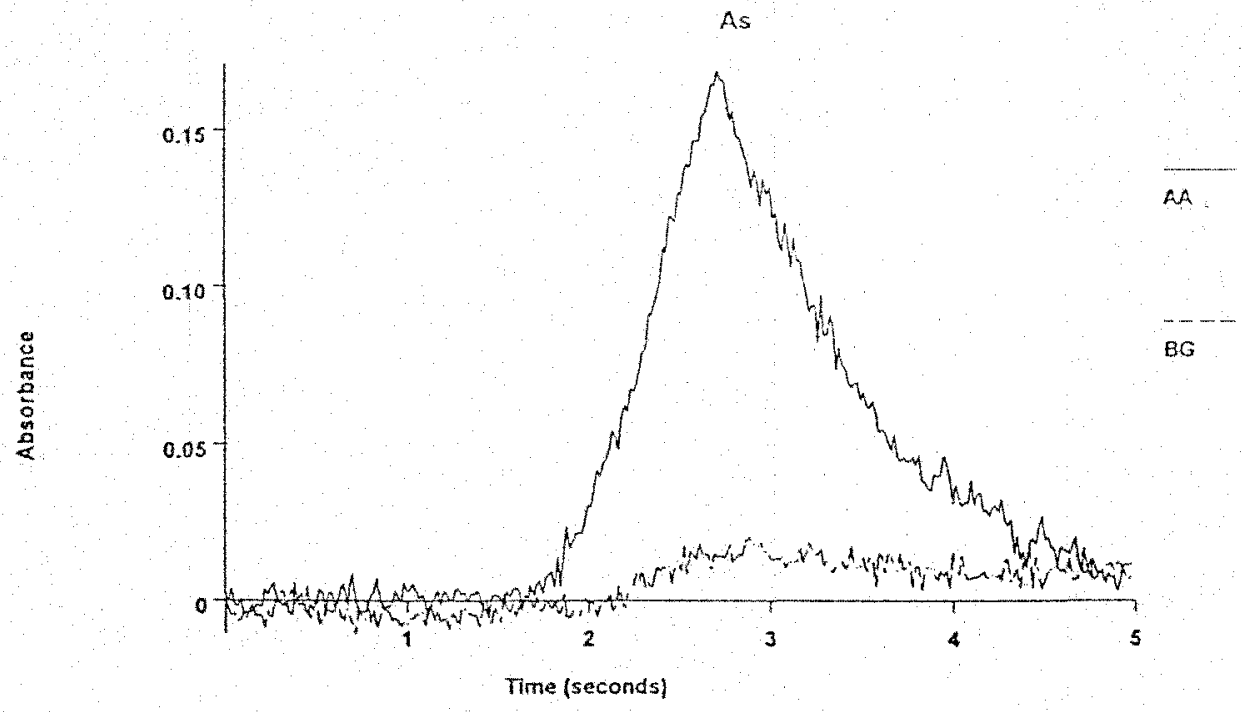

\begin{tabular}{|c|c|c|c|c|c|c|c|}
\hline $\begin{array}{l}\text { Eleme } \\
\text { Sampl }\end{array}$ & $\begin{array}{l}\text { As Dat } \\
\text { ID: In } 1: 10\end{array}$ & $=05 / 19 / 1$ & 998 & & & & \\
\hline $\begin{array}{c}\text { Repl } \\
1 \\
1\end{array}$ & $\begin{array}{c}\text { Samplecono } \\
\mu \mathrm{g} / \mathrm{I} \\
99.17\end{array}$ & $\begin{array}{c}\text { strndConc } \\
\mu g / I \\
99.17\end{array}$ & $\begin{array}{c}\text { BlnkCort } \\
\text { Signal } \\
0.210\end{array}$ & $\begin{array}{l}\text { Peak } \\
\text { Area } \\
0.213\end{array}$ & $\begin{array}{l}\text { Peak } \\
\text { Height } \\
0.161\end{array}$ & $\begin{array}{l}\text { Bkgnd } \\
\text { Area } \\
0.032\end{array}$ & $\begin{array}{l}\text { Time } \\
06: 36: 13\end{array}$ \\
\hline
\end{tabular}

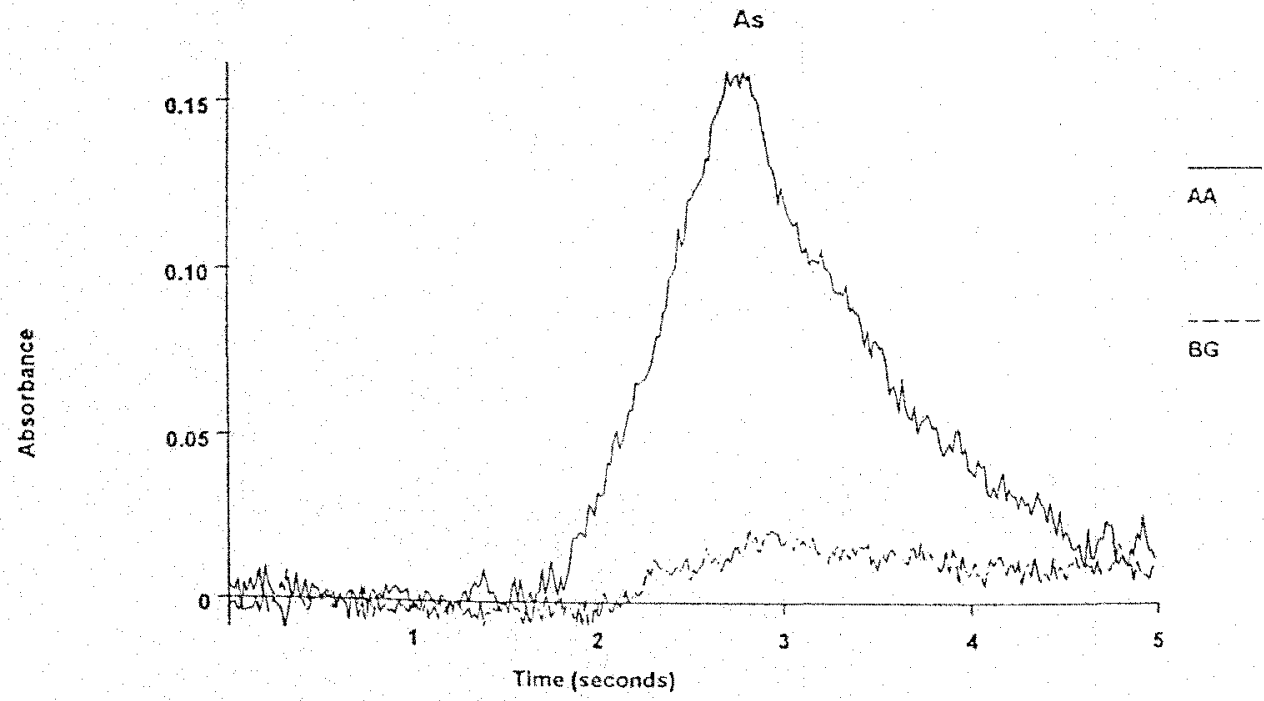



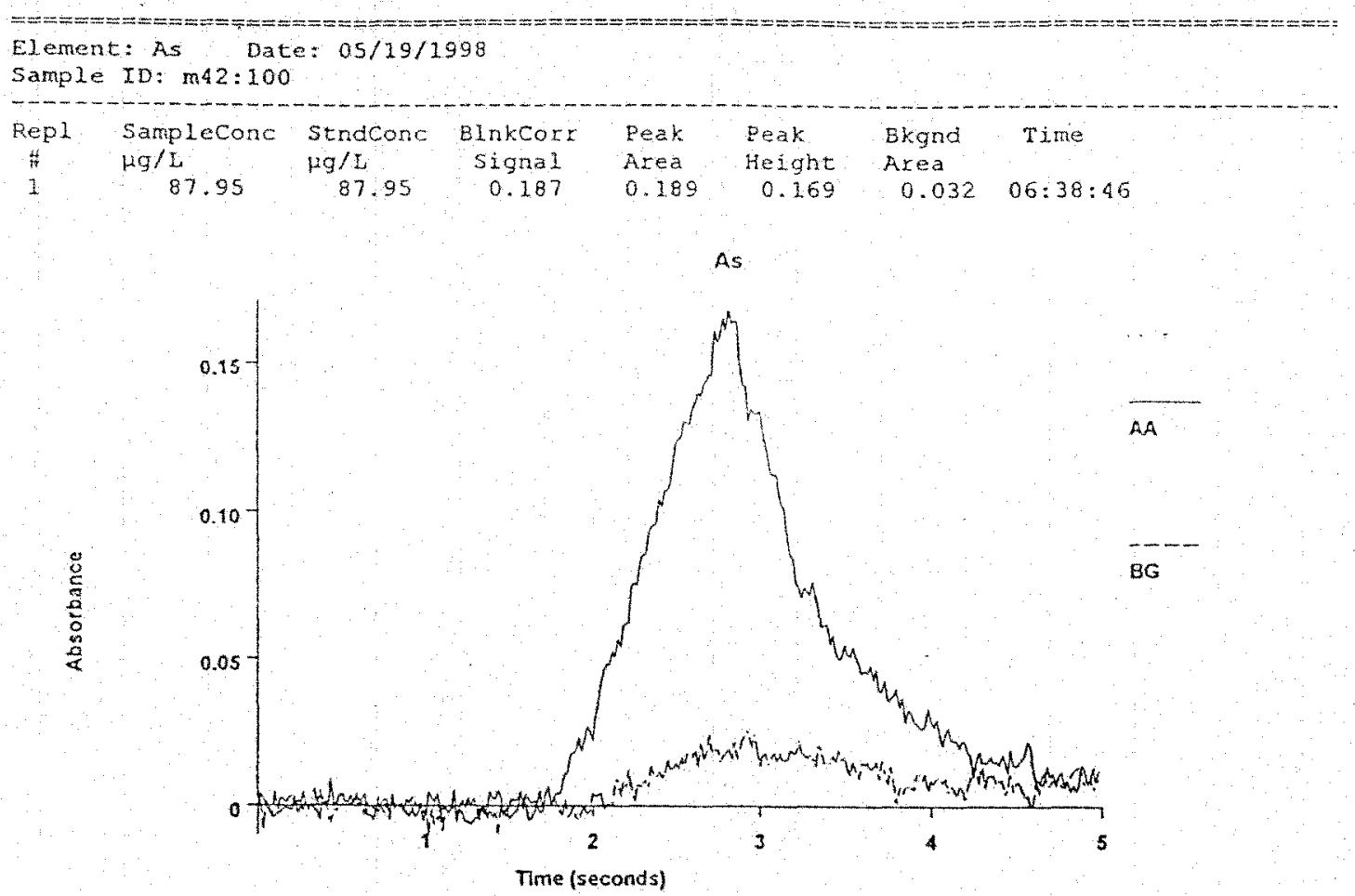

\begin{tabular}{|c|c|c|c|c|c|c|}
\hline $\begin{array}{l}\text { Element: As Dat } \\
\text { Sample ID: m43:100 }\end{array}$ & $=0.05 / 19 /$ & 998 & & & & \\
\hline $\begin{array}{l}\text { Sampleconc } \\
\mathrm{Hg} / \mathrm{L} \\
\qquad 89.87\end{array}$ & $\begin{array}{l}\text { Stndedne } \\
19 / \mathrm{L} \\
89.87\end{array}$ & $\begin{array}{c}\text { BukCorr } \\
\text { Signal } \\
0.191\end{array}$ & $\begin{array}{l}\text { Peak } \\
\text { Area } \\
0.193\end{array}$ & $\begin{array}{l}\text { Peak } \\
\text { Keight } \\
0.186\end{array}$ & $\begin{array}{l}\text { Bkgnd } \\
\text { Area } \\
0.037\end{array}$ & $06: 41: 1$ \\
\hline
\end{tabular}

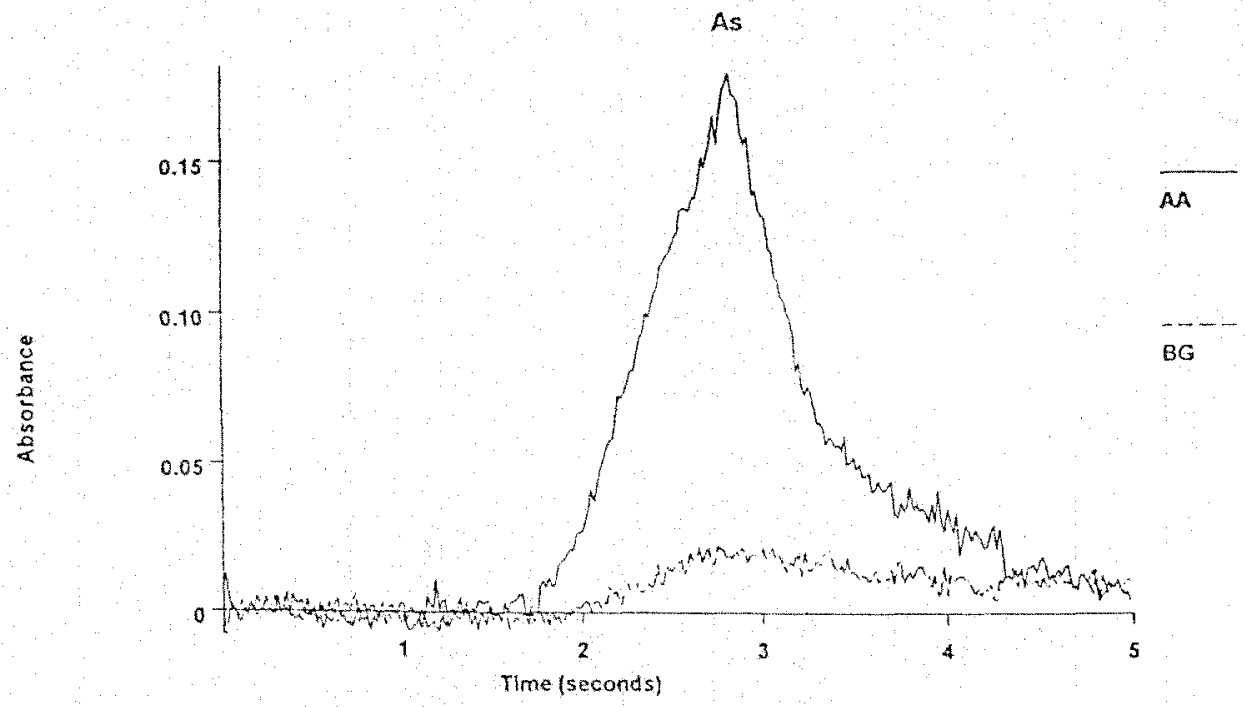




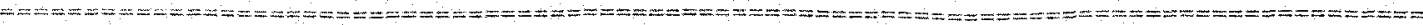

Element: As: Date: $05 / 19 / 1998$

Sample ID: $\mathrm{mS} 1: 100$

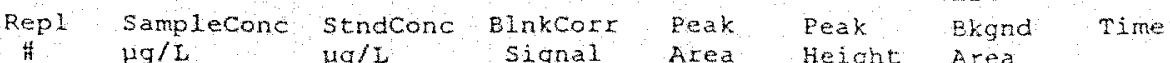

$1 \quad 86.56 \quad 06.56 \quad 0.184 \quad \because 0.186 \quad \therefore \quad 0.165 \quad \therefore 0.0340694349$

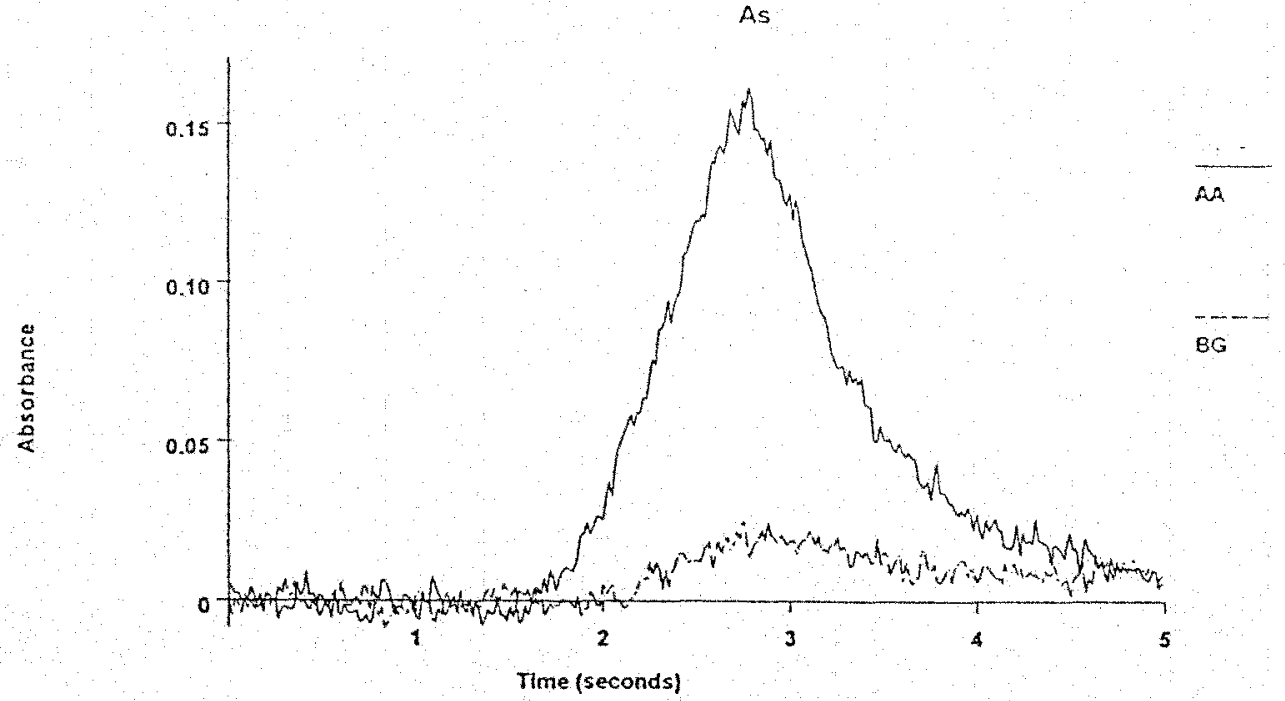

\begin{tabular}{|c|c|c|c|c|c|c|c|}
\hline $\begin{array}{l}\text { Elem } \\
\text { Samp }\end{array}$ & $\begin{array}{l}\text { As } \\
\mathrm{ID}: \mathrm{ms} 2: 10\end{array}$ & $=05 / 19 /$ & 96 & & & & \\
\hline$\underset{1}{\operatorname{Repl}}$ & $\begin{array}{l}\text { Sampleconc } \\
\mu 9 / 4 \\
83.62\end{array}$ & $\begin{array}{l}\text { StndConc } \\
\mu g / L \\
83.62\end{array}$ & $\begin{array}{c}\text { BlnkCorr } \\
\text { Signal } \\
0.177\end{array}$ & $\begin{array}{l}\text { Peak } \\
\text { Area } \\
0.180\end{array}$ & $\begin{array}{l}\text { Peak } \\
\text { Height } \\
0.170\end{array}$ & $\begin{array}{l}\text { Bkgrad } \\
\text { Area } \\
0.037\end{array}$ & $\begin{array}{l}\text { Time } \\
06: 46: 2\end{array}$ \\
\hline
\end{tabular}

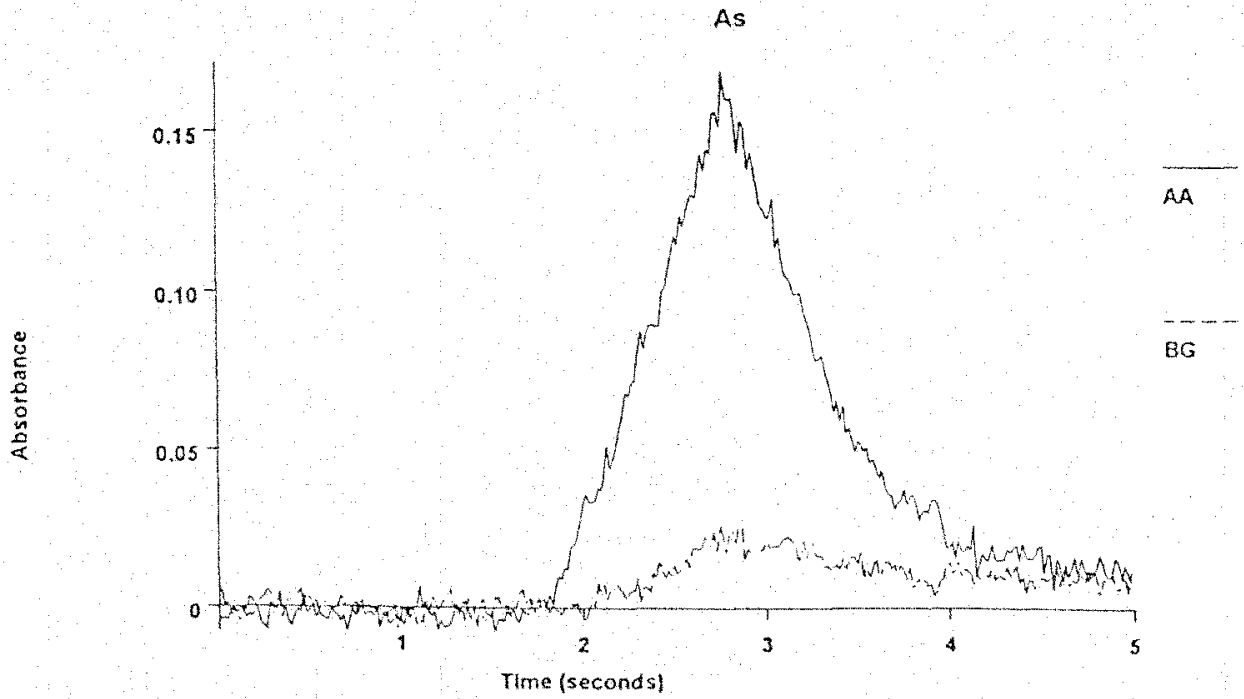



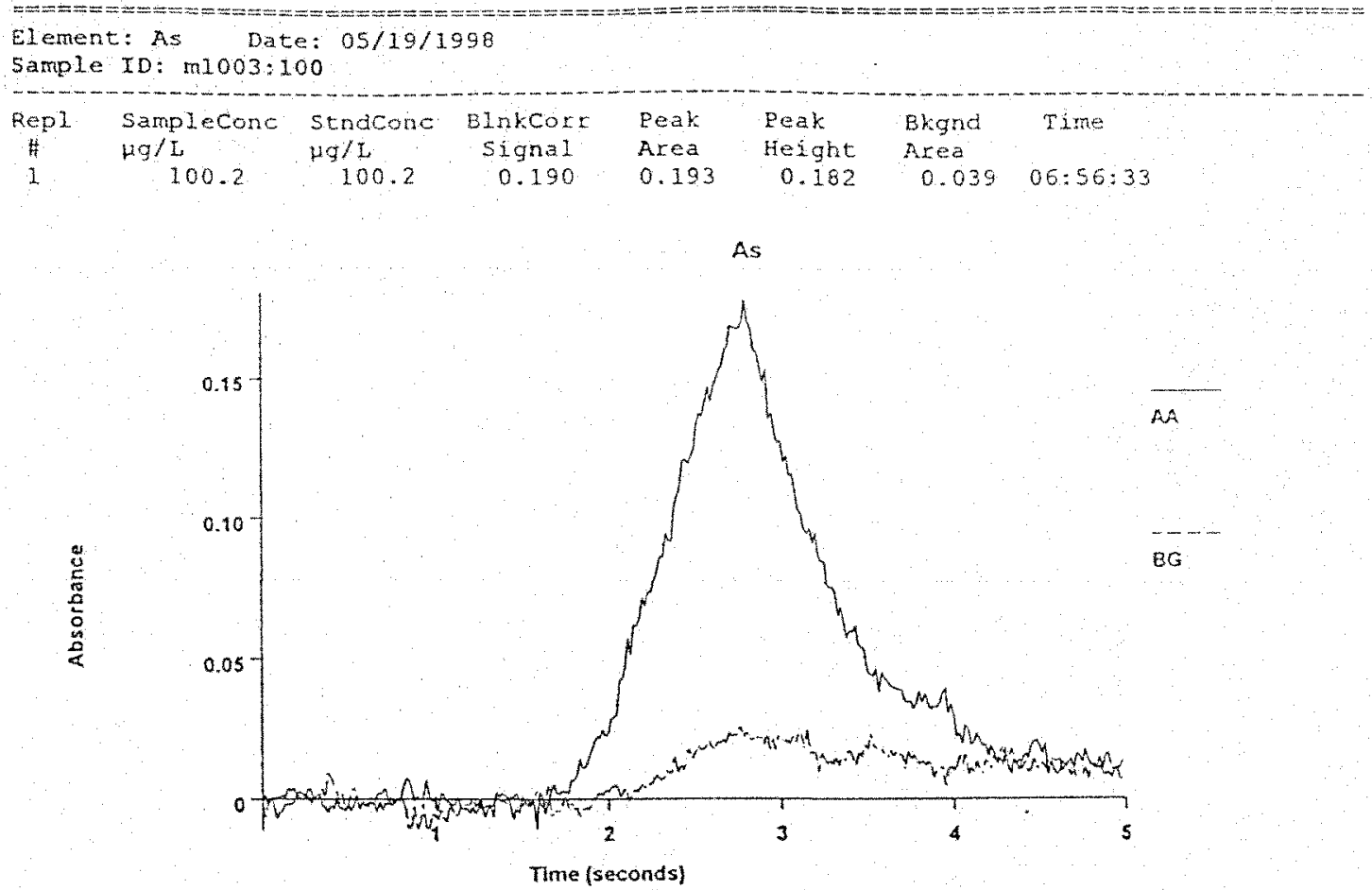

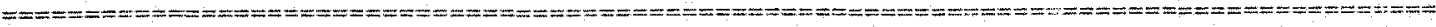

Element: As Date: $05 / 19 / 1998$

Sample ID: ml002:100

\begin{tabular}{|c|c|c|c|c|c|c|c|}
\hline $\begin{array}{l}\text { Rep } 1 \\
1\end{array}$ & $\begin{array}{l}\operatorname{Samp} 1 \text { eConc } \\
\mu g / \mathrm{L} \\
95.16\end{array}$ & $\begin{array}{l}\text { Stndconc } \\
\mu g / \mathrm{L} \\
95.16\end{array}$ & $\begin{array}{c}\text { BlnkCort } \\
\text { Signal } \\
0.191\end{array}$ & $\begin{array}{l}\text { Peak } \\
\text { Area } \\
0.193\end{array}$ & $\begin{array}{l}\text { Peak } \\
\text { Feight } \\
0.172\end{array}$ & $\begin{array}{l}\text { Bkgnd } \\
\text { Afea } \\
0.024\end{array}$ & $06: 53: 57$ \\
\hline
\end{tabular}

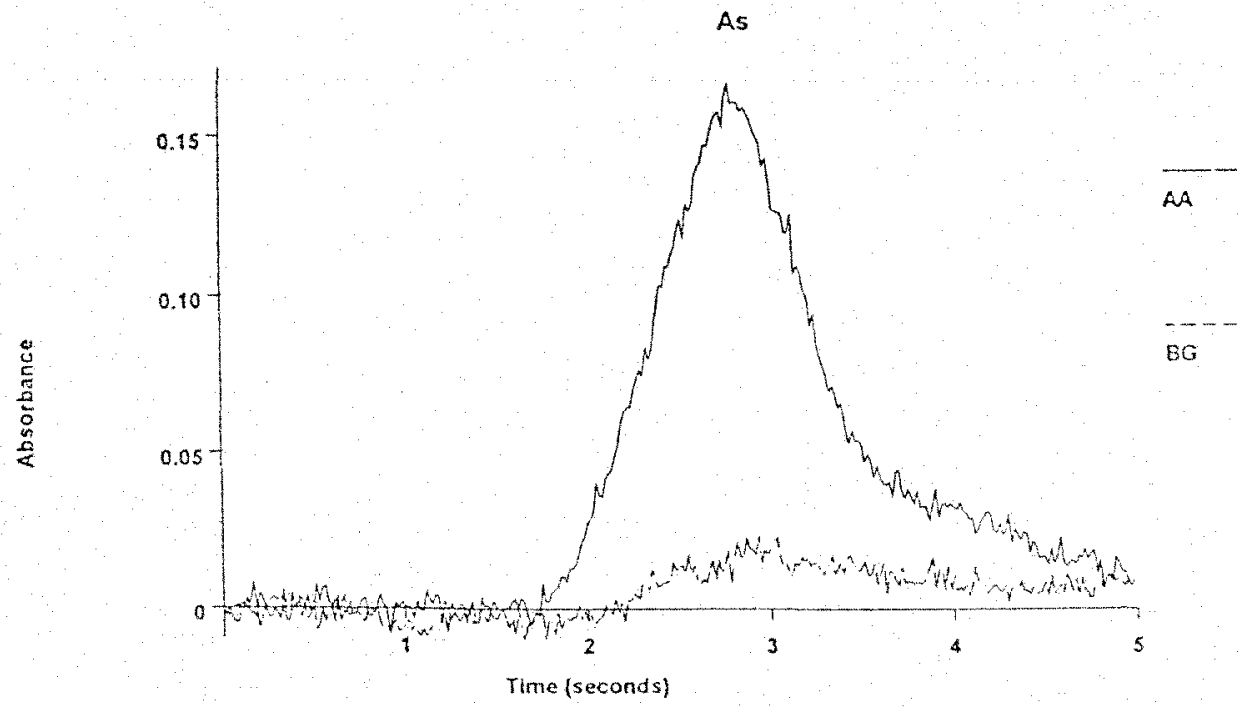




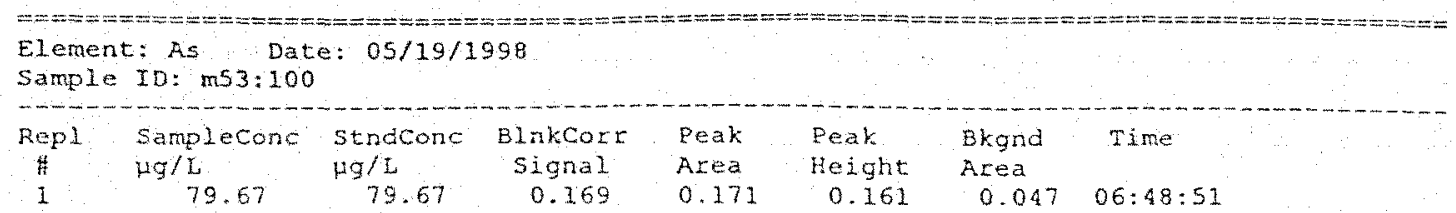

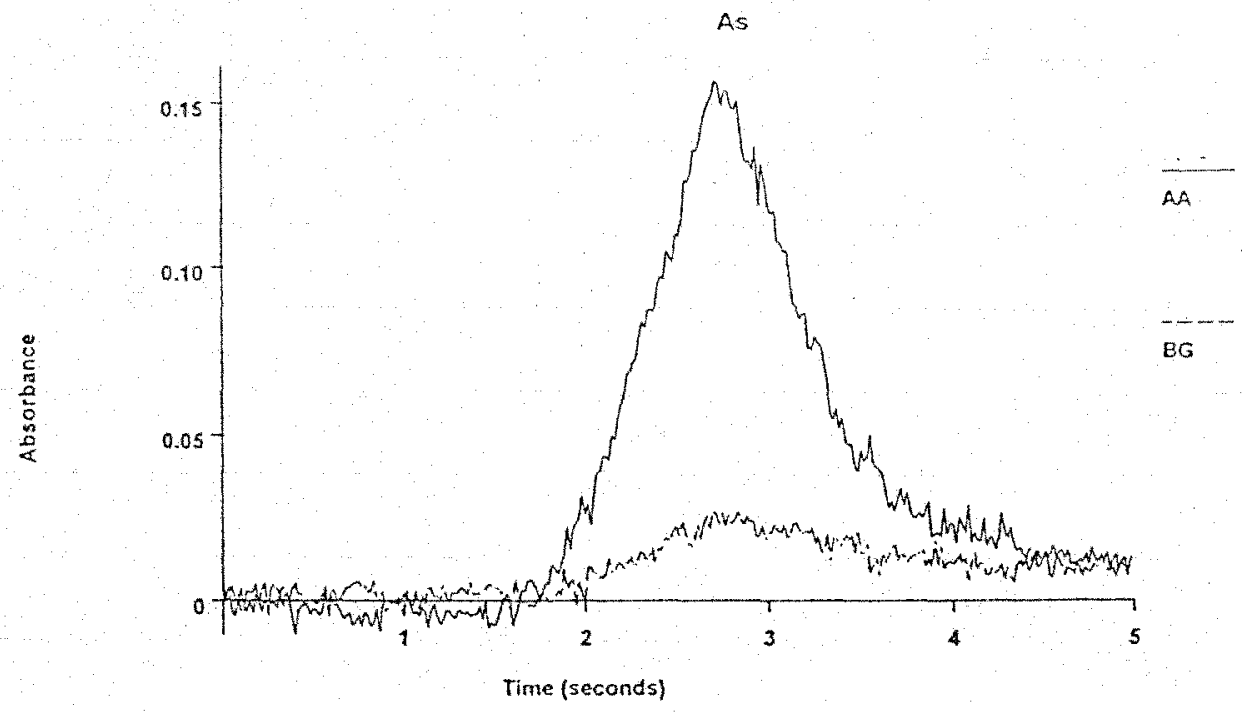

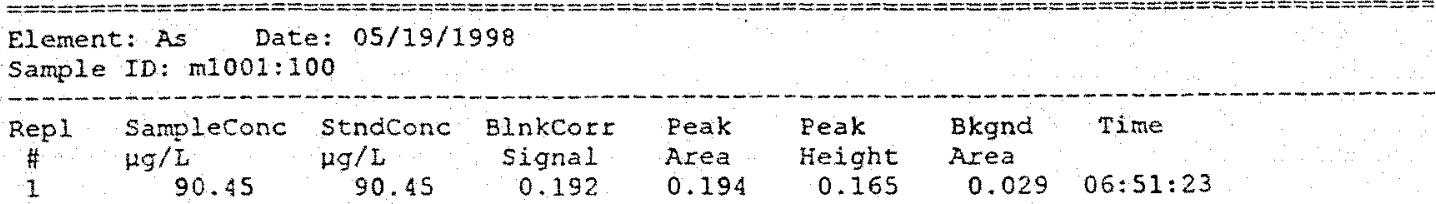

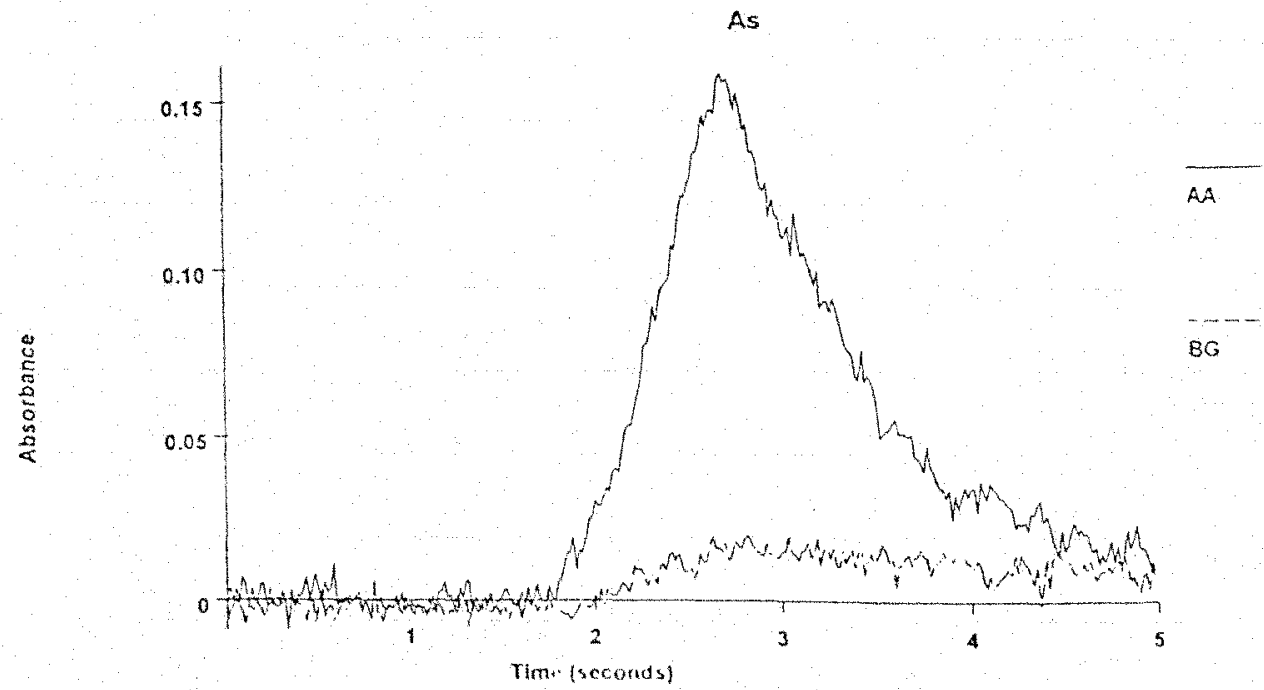



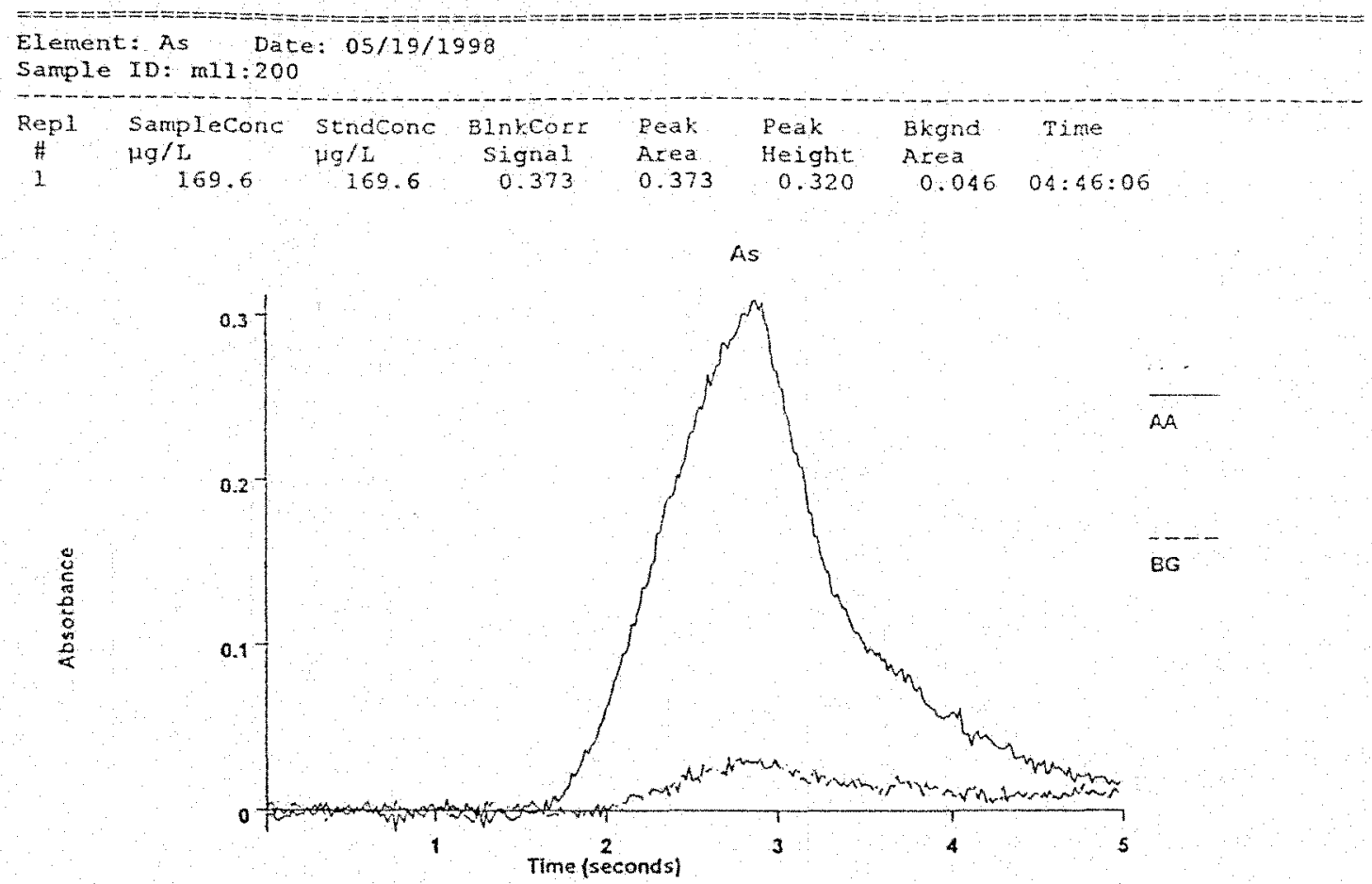

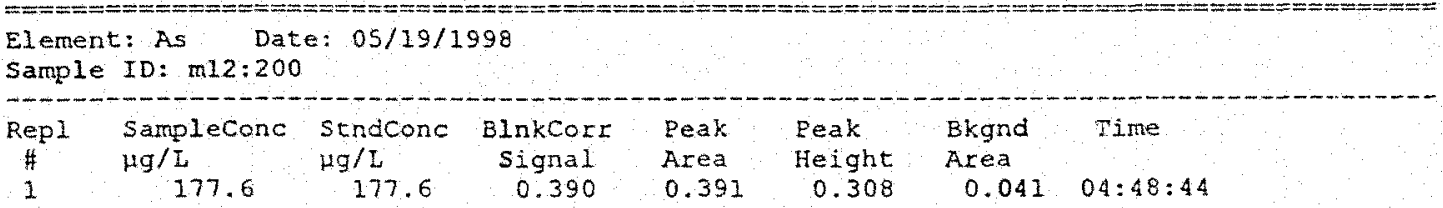

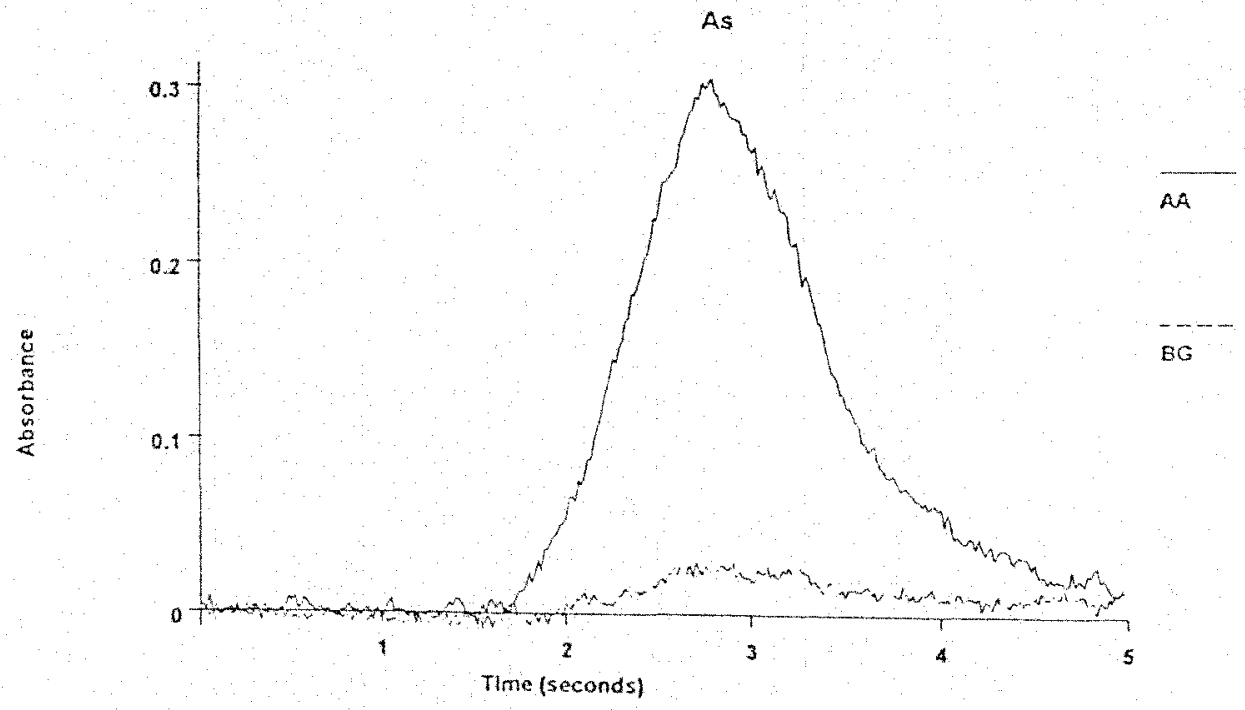




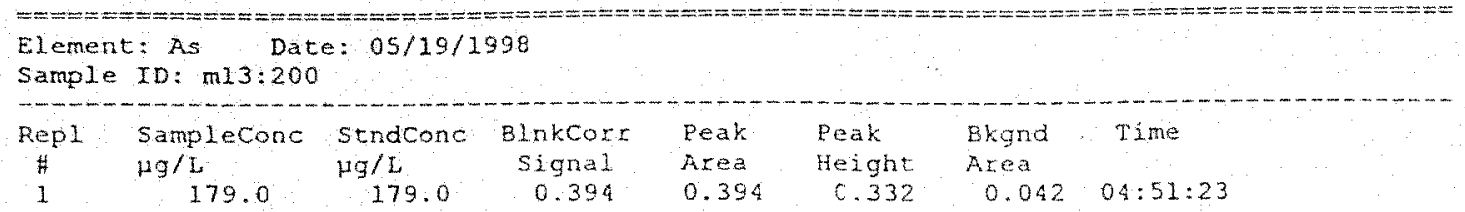

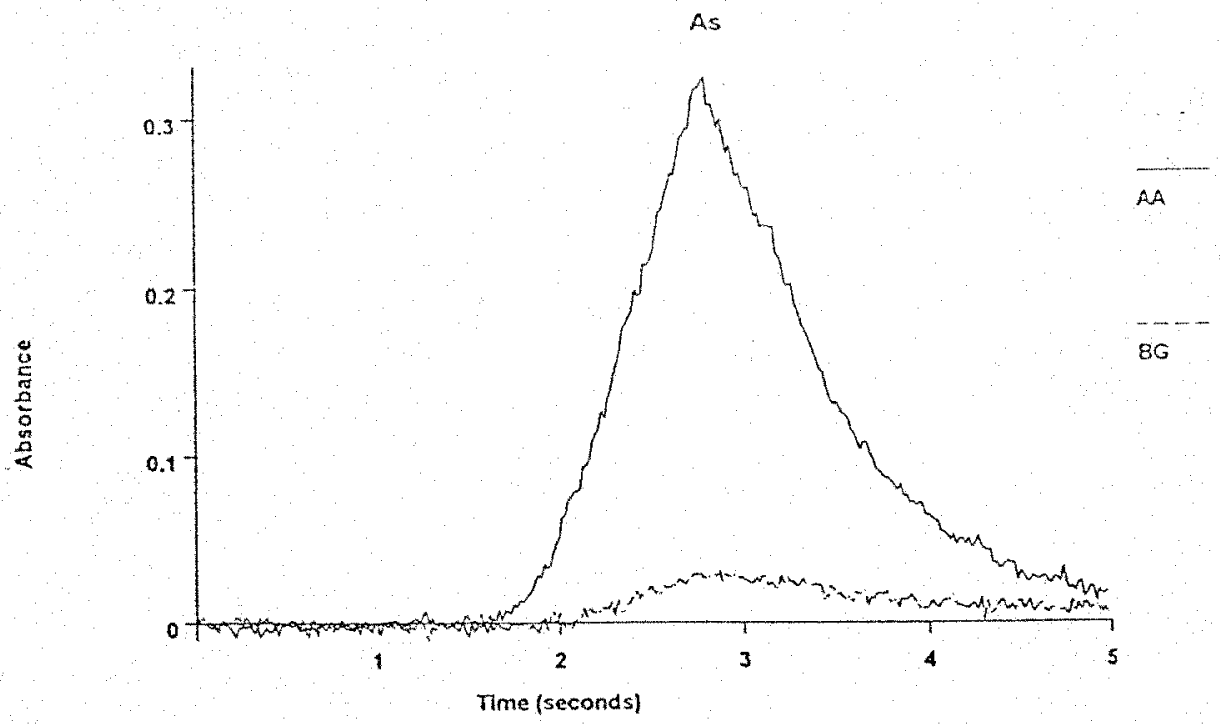

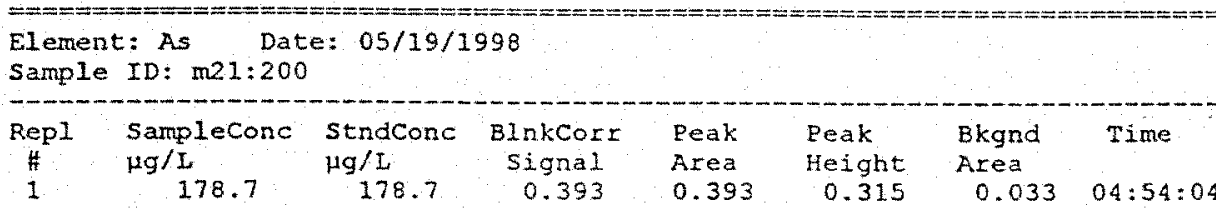

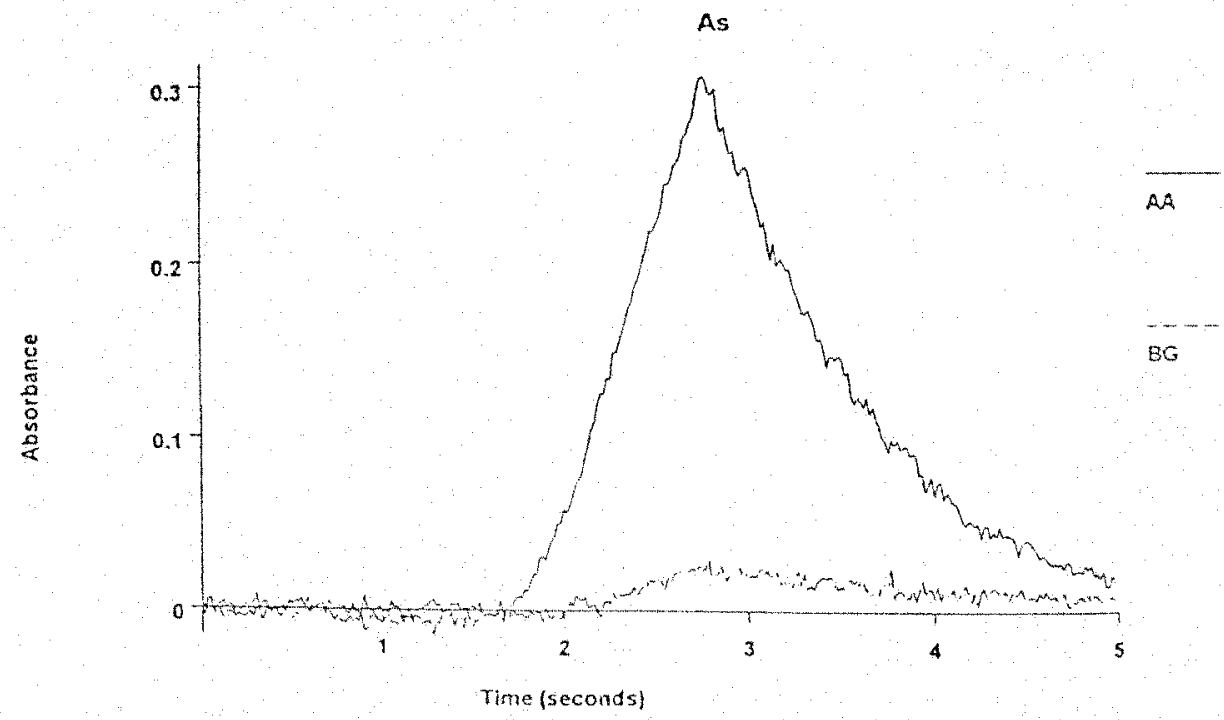




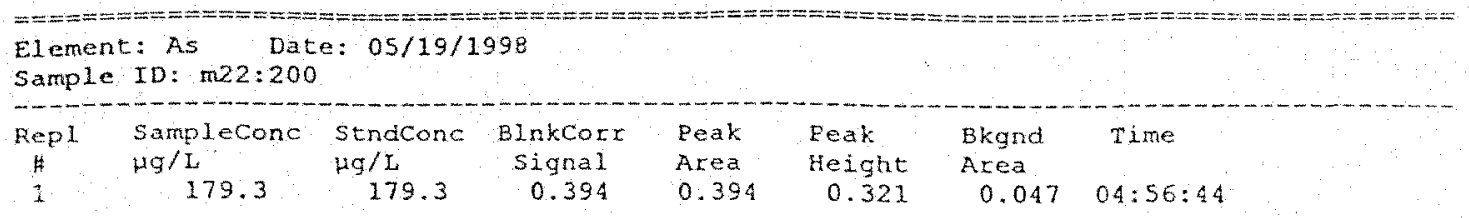

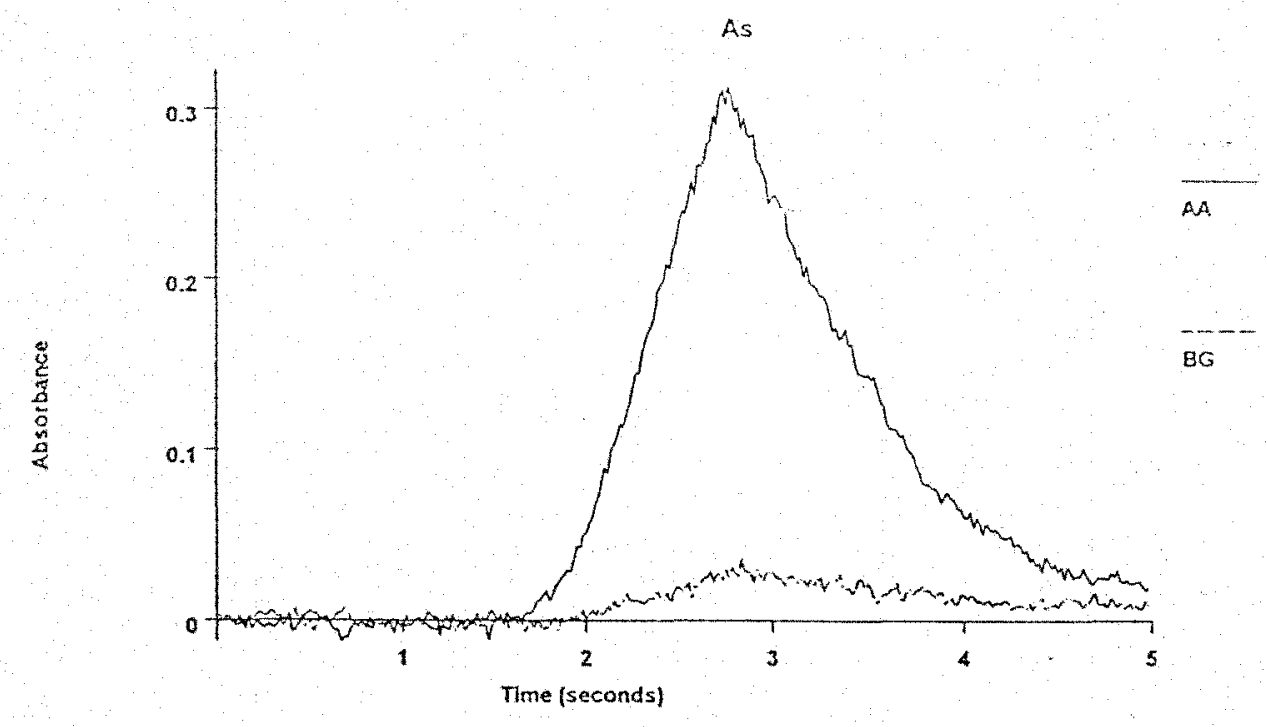

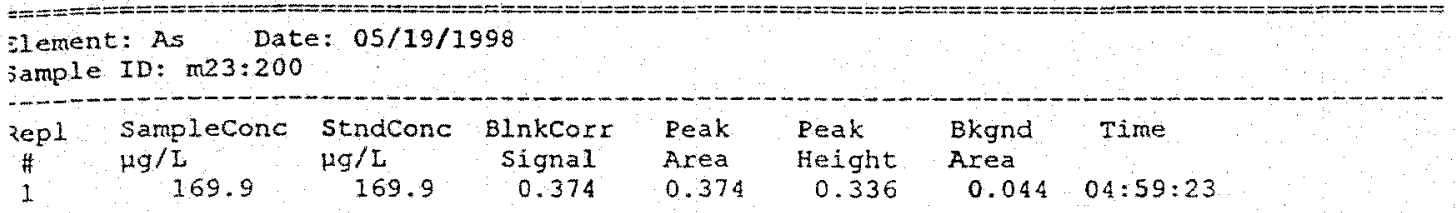

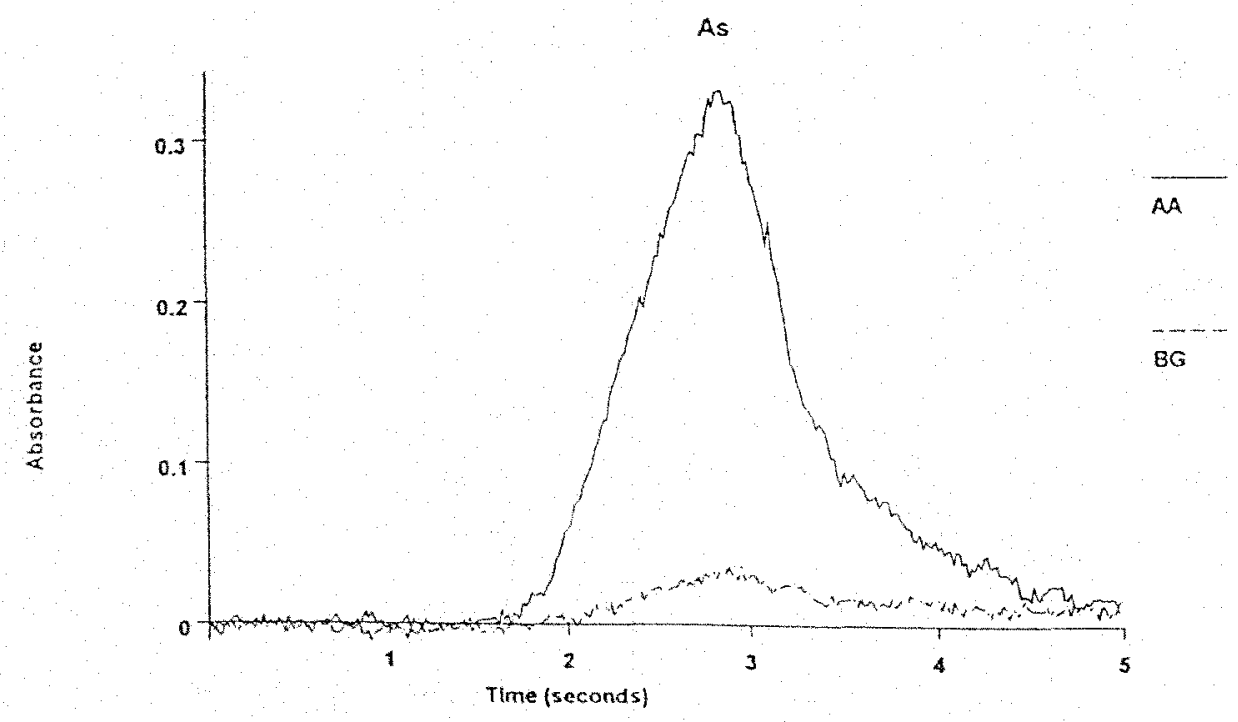




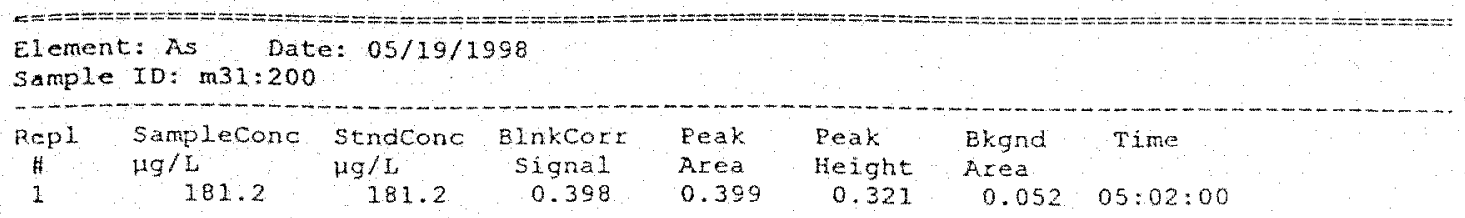
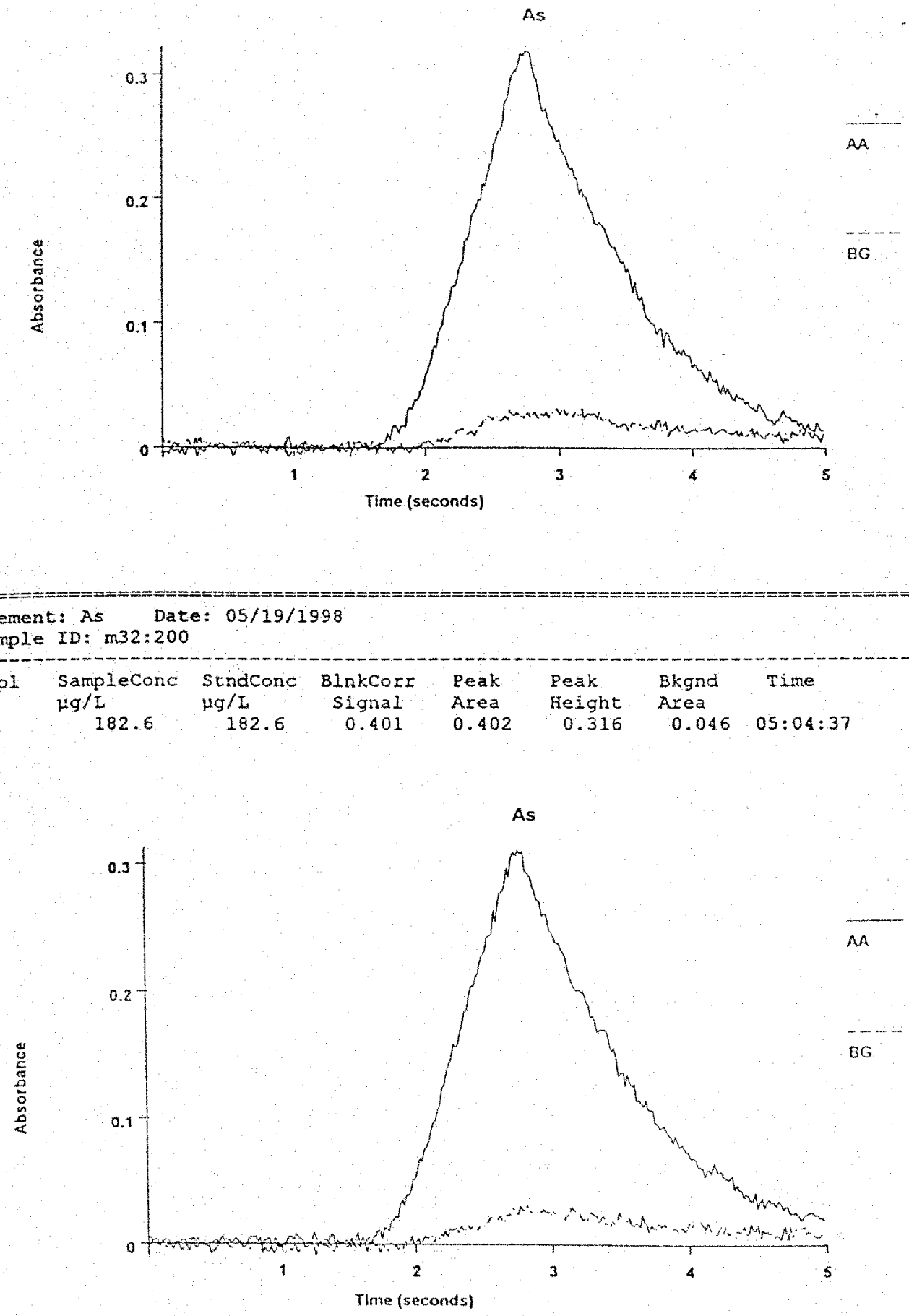

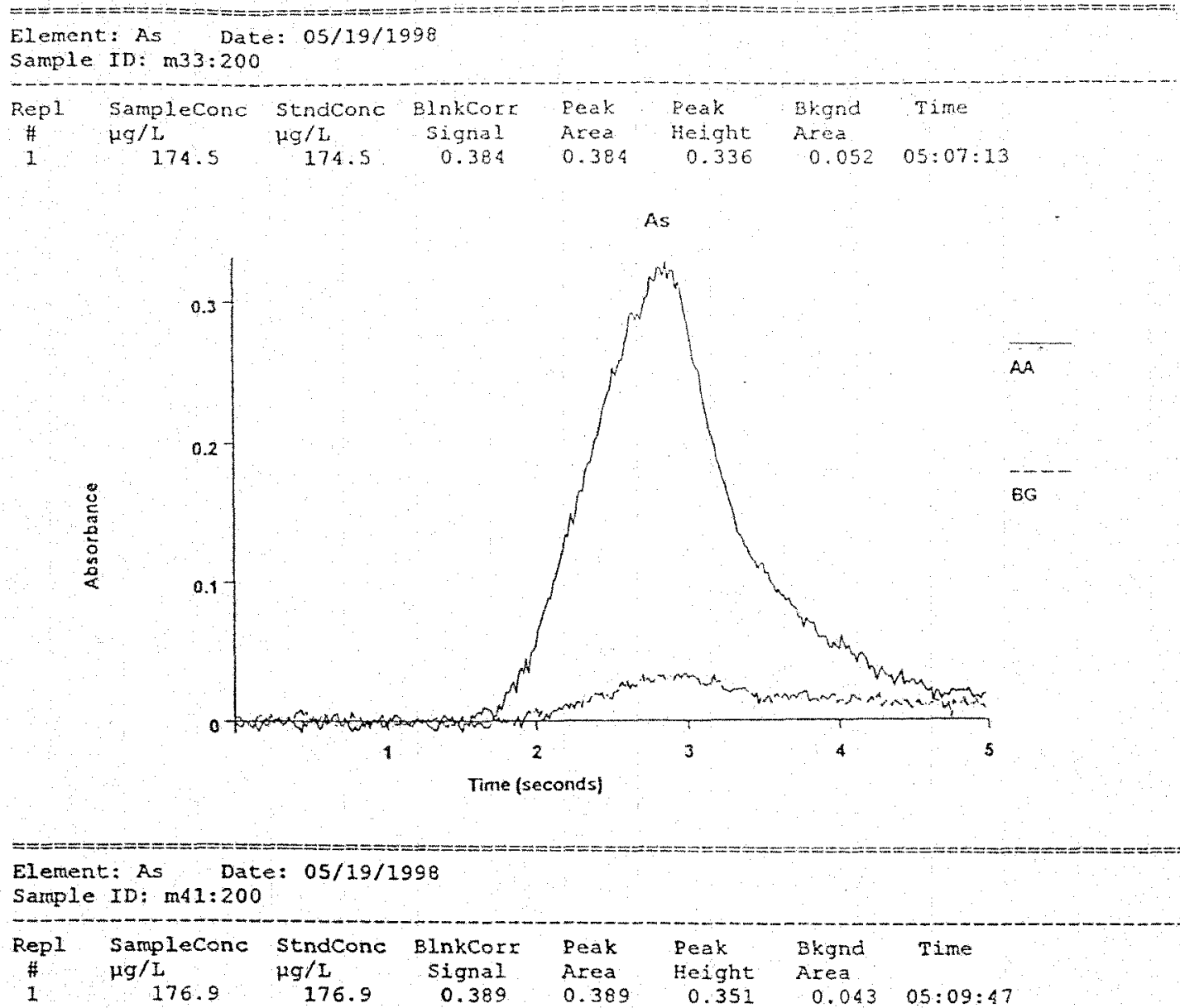

As

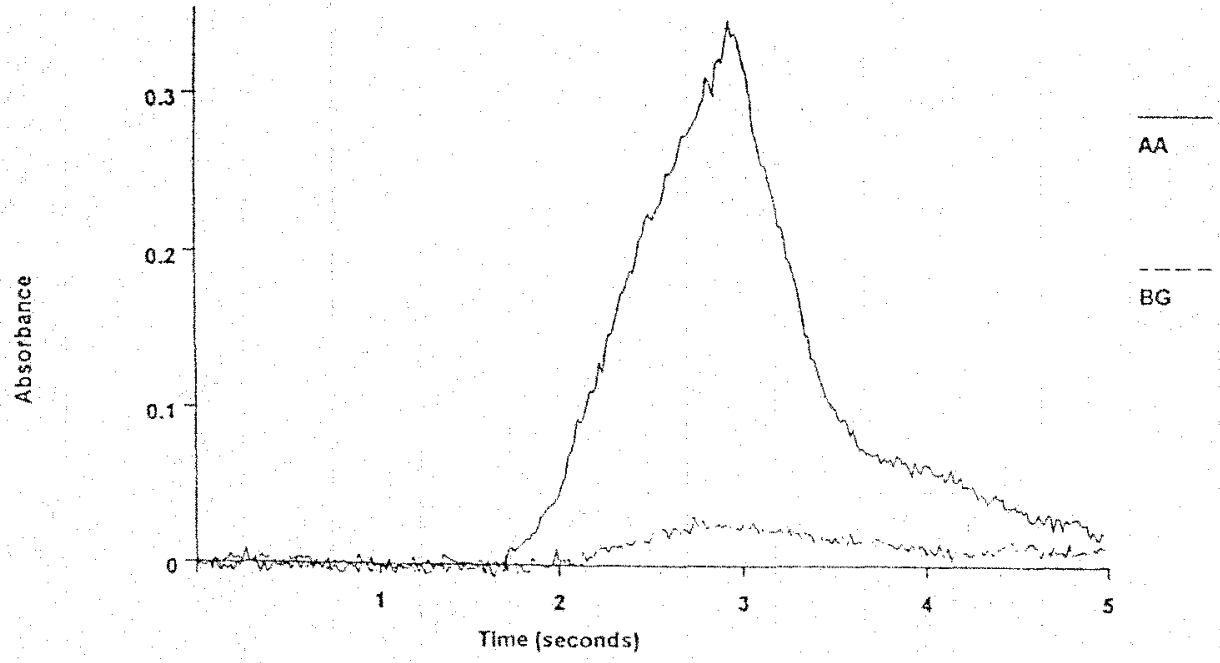




\begin{tabular}{|c|c|c|c|c|c|c|c|}
\hline $\begin{array}{l}\text { Rep } 1 \\
\# \\
1\end{array}$ & $\begin{array}{l}\text { Sampleconc } \\
\text { Hg/L } \\
176.5\end{array}$ & $\begin{array}{l}\text { Strdeone } \\
\mu g / 1 \\
176.5\end{array}$ & $\begin{array}{c}\text { Blnkcort } \\
\text { Signal } \\
0.388\end{array}$ & $\begin{array}{l}\text { Peak } \\
\text { Area } \\
0.389\end{array}$ & $\begin{array}{l}\text { Reak } \\
\text { Height } \\
0.357\end{array}$ & $\begin{array}{l}\text { Ekgnd } \\
\text { Area } \\
0.046\end{array}$ & Time \\
\hline
\end{tabular}
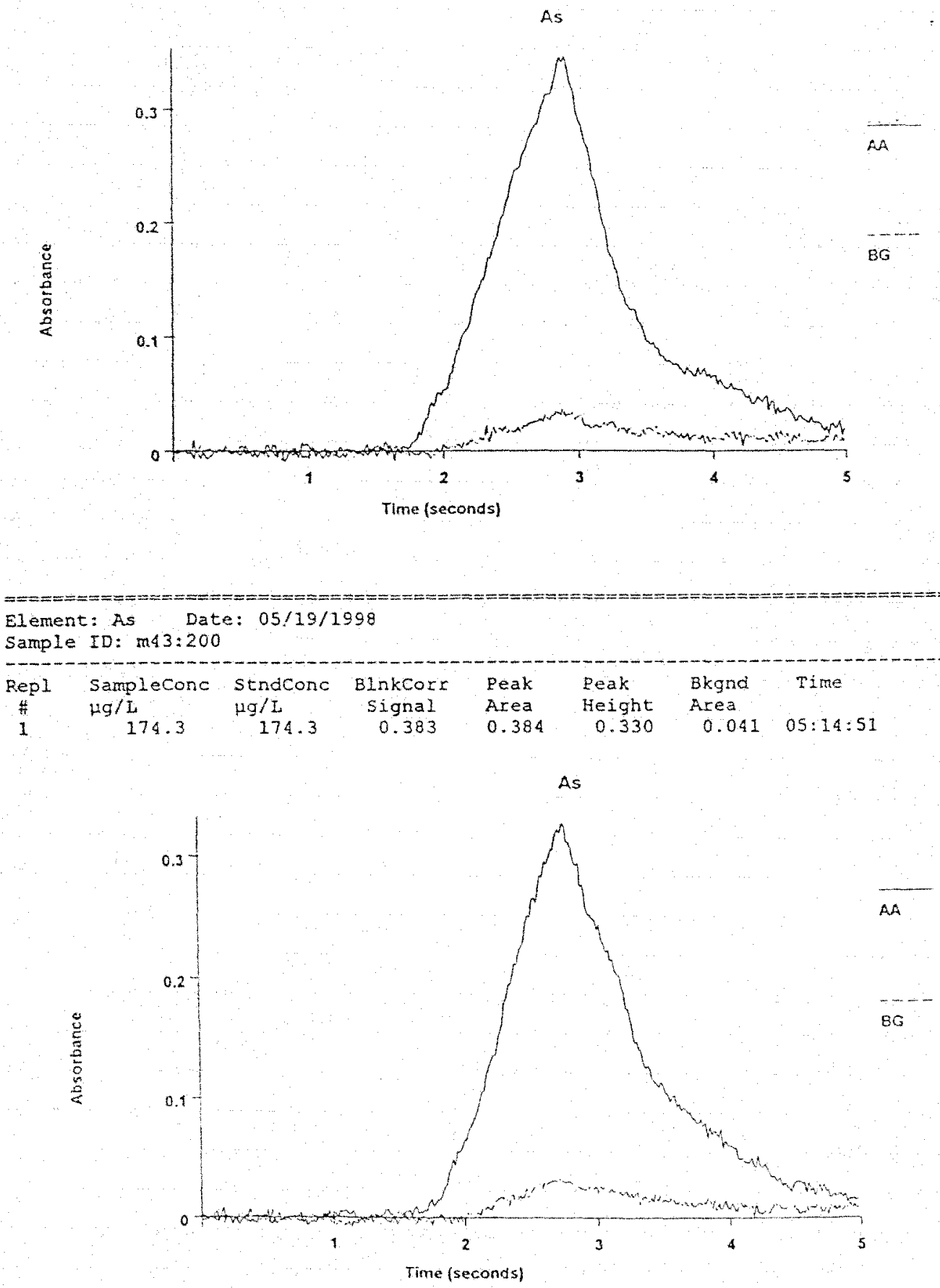


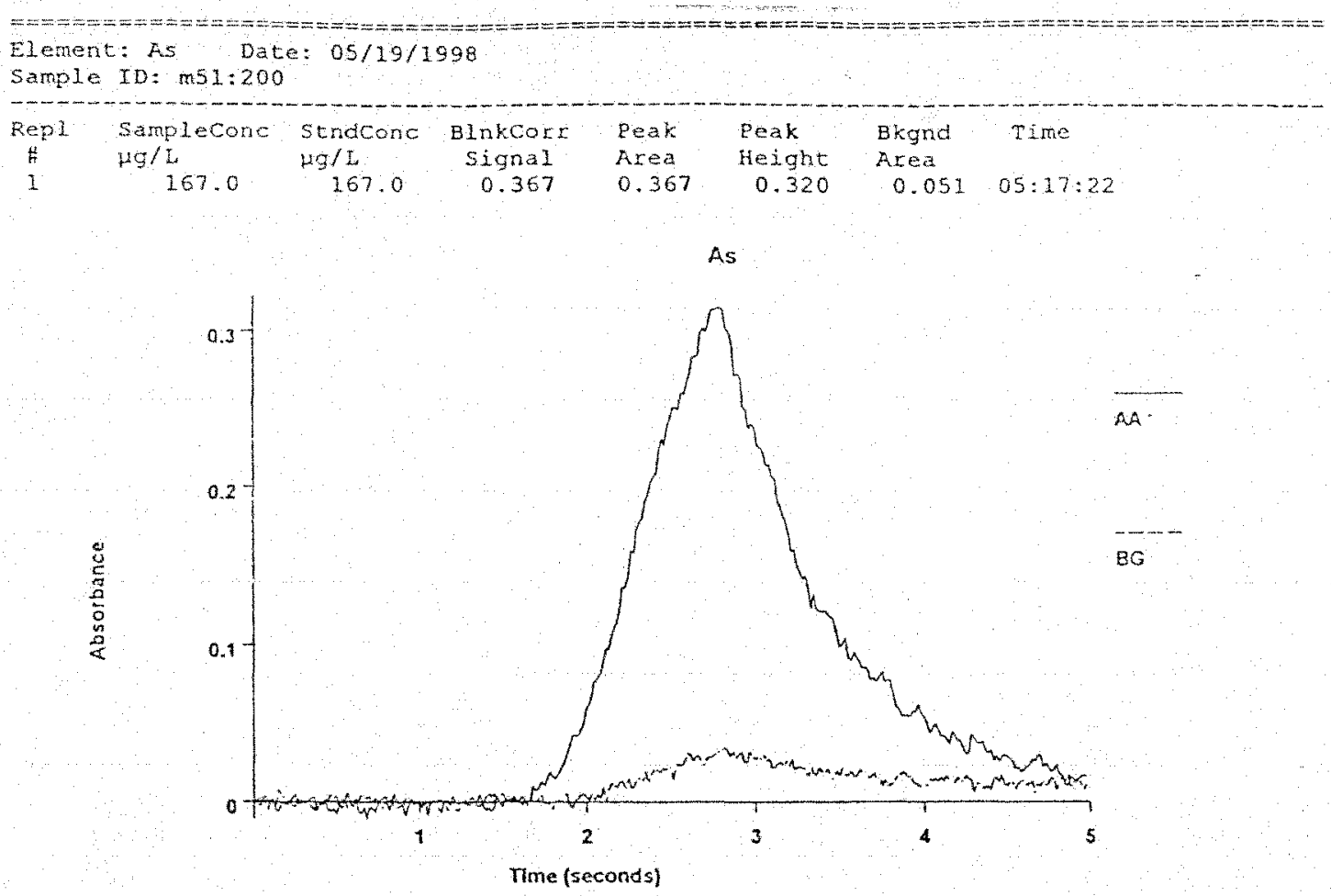

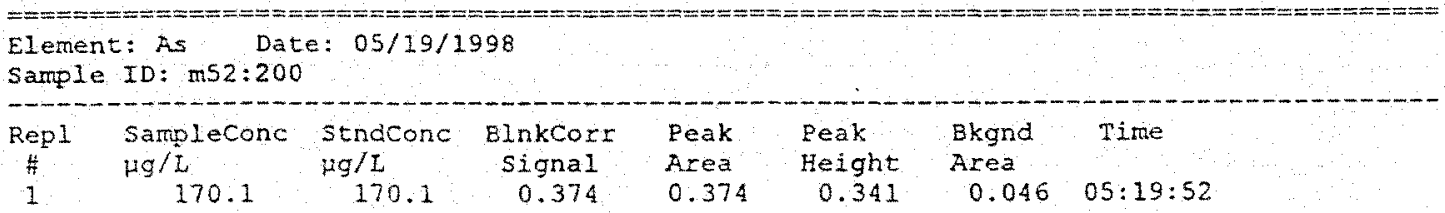

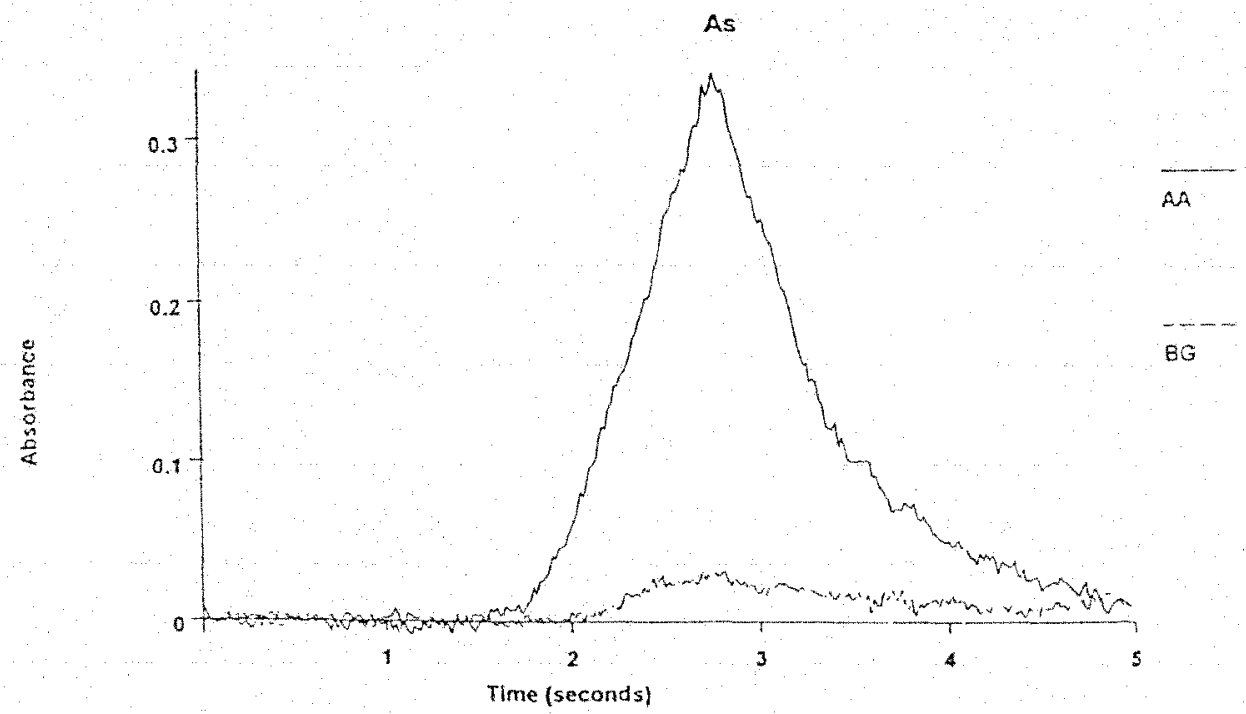




\begin{tabular}{|c|c|c|c|c|c|c|c|}
\hline $\begin{array}{l}\text { Repl } \\
\# \\
1\end{array}$ & $\begin{array}{l}\text { Samplecoric } \\
\mu g / L \\
192,1\end{array}$ & $\begin{array}{l}\text { StndConc } \\
\mathrm{Hg} / \mathrm{L} \\
192.1\end{array}$ & $\begin{array}{c}\text { BinkCort } \\
\text { signal } \\
0.393\end{array}$ & $\begin{array}{l}\text { Peak } \\
\text { Area } \\
0.393\end{array}$ & $\begin{array}{l}\text { Peak } \\
\text { Height } \\
0.332\end{array}$ & $\begin{array}{l}\text { Bkgnd } \\
\text { Area } \\
0.040\end{array}$ & $05: 27: 31$ \\
\hline
\end{tabular}
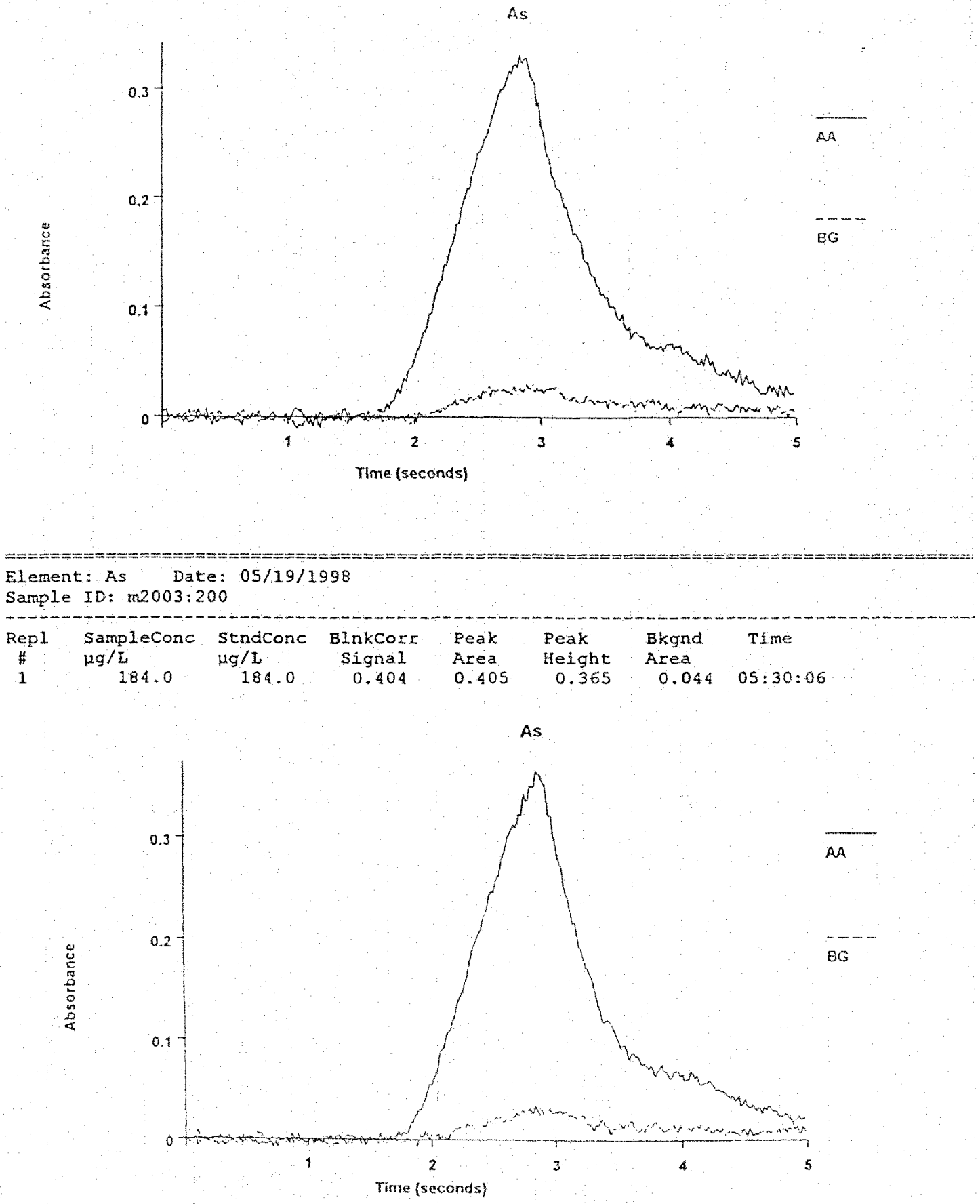


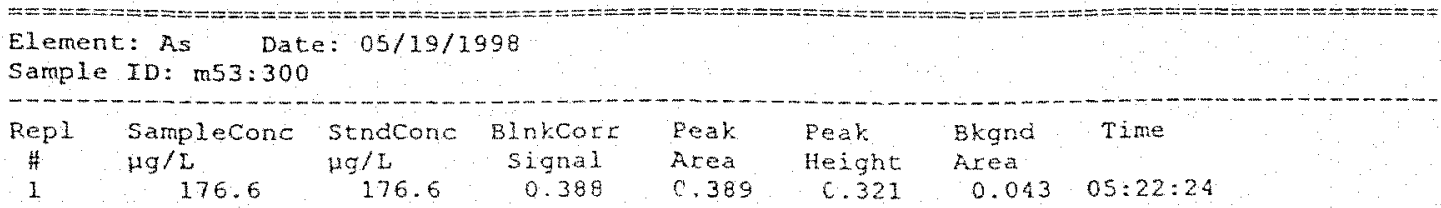

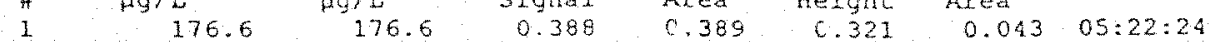

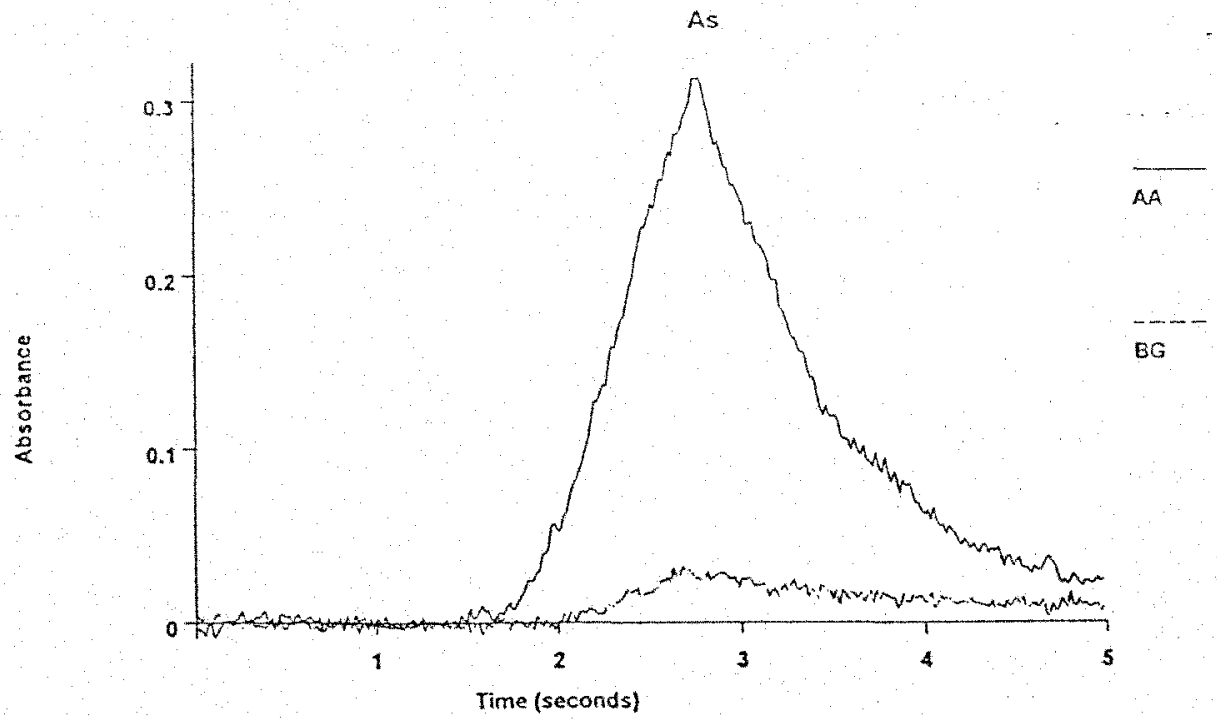

\begin{tabular}{|c|c|c|c|c|c|c|c|}
\hline \multicolumn{8}{|c|}{$\begin{array}{l}\text { Element: As Date: } 05 / 19 / 1998 \\
\text { Sample ID: } \mathrm{m} 2001: 200\end{array}$} \\
\hline $\begin{array}{c}\text { Repl } \\
\# \\
1\end{array}$ & $\begin{array}{l}\text { Sampleconc } \\
\mu \mathrm{g} / \mathrm{L} \\
182.1\end{array}$ & $\begin{array}{c}\text { stndcone } \\
\mu g / L \\
182.1\end{array}$ & $\begin{array}{c}\text { BInkCorr } \\
\text { Signal } \\
0.400\end{array}$ & $\begin{array}{l}\text { Peak } \\
\text { Area } \\
0.401\end{array}$ & $\begin{array}{l}\text { Reak } \\
\text { Height } \\
0.340\end{array}$ & $\begin{array}{l}\text { Bkgnd } \\
\text { Area } \\
0.044\end{array}$ & $05: 24: 57$ \\
\hline
\end{tabular}

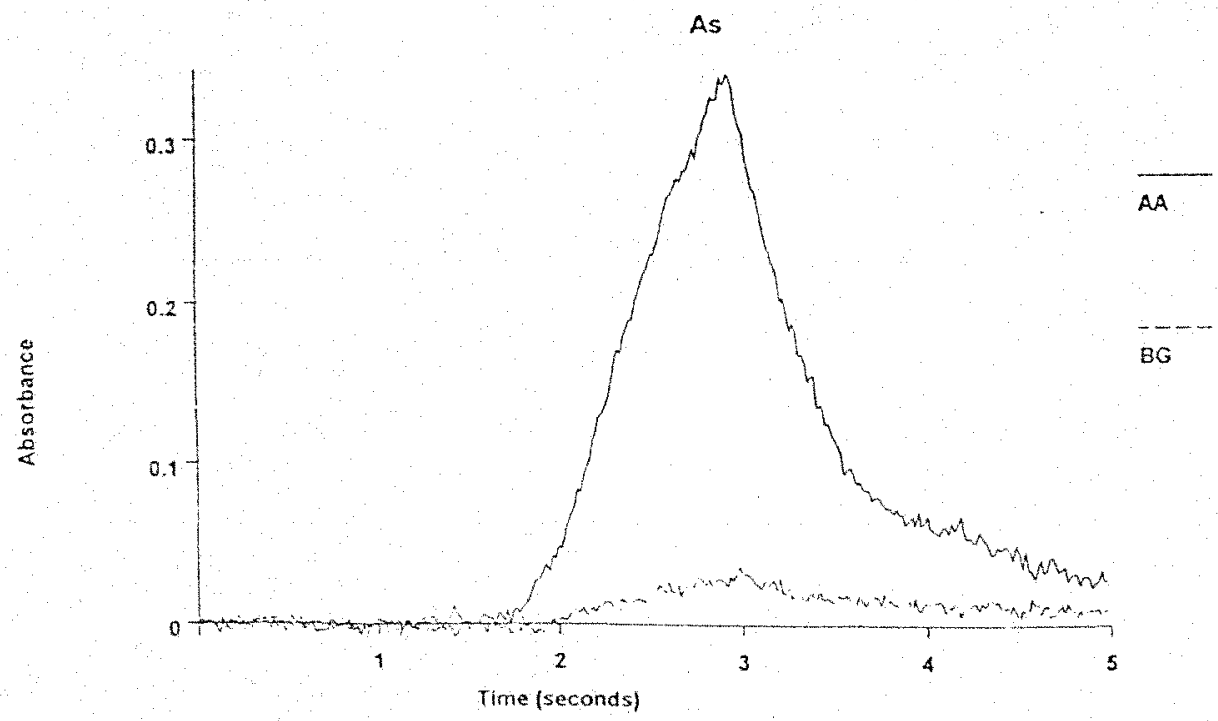


Appendix E - FDEP Data Sheets 


\title{
Chemical Analysis Report
}

\author{
Central Laboratory \\ 2600 Blair Stone Road \\ Tallahassee, FL 32399-2400 \\ CompQAP\# $870688 \mathrm{C}$
}

Florida Department of Enviromental Protection

Event Description: Golf Course Arsenic Study

Request 1D: RQ-1998-01-05-17

Customer: SE-DIST

Project ID: OTHER-WSM

Job: TLH-1998-01-24-03

Group: Metals

Send Reports to

FL Dept. of Environmental Protection

P.O. Box 15425

$400 \mathrm{~N}$. Congress Ave.

West Paim Beach, FL 33401

Attr: Leslie Smith

For additional information please contact Timothy W. Fitzpatrick

$\begin{array}{ll} & \text { Timothy W. Fitzpatick } \\ \therefore & \text { Yuh-Hsu Pan, Ph.D }\end{array}$

$\therefore \quad$ Julio Arecis, Ph.D.

$\therefore \quad-\quad$ Liang-Tsair Lin, Ph.D.

Certified By: TWF

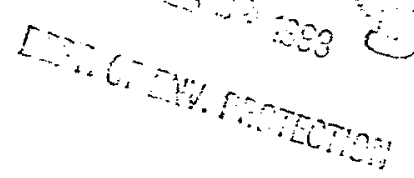

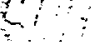

Report Printed Date: Feb 13, 1998

Abbreviations and data remark codes

A - Value reported is the mean of two or more determinations

$B$ - Results based on colony counts outs ide the acceptable range.

I-Value reported is less than the minimumquantitation firtit, and greater than or equal to the minimum detection firtit.

J. Estimated value

$K$ - Actual vatue is know $n$ to be less than value given

$L$ - Actual value is know $n$ to be greater than value given

$N$ - Presumptive evidence of presence of material.

O- Sampled, but analysis lost or not performed.

Q- Sample held beyond normal habing tire.

T-Vaive reported is less than the criterion of detection

U. Naterial $w$ as analyzed for but not detected: The value reported is the nirimum detection timt.

$V$ - Analyte $w$ as detected in both sample and method blank.

$Z$ - Colonies were too numerous to count (TNTC). 
Sample Location: WPBCC

Field ID: 1A:2K

Collection Date/Time: $1 / 13 / 1998$ 3:36 PM

Matix: W-SURFFRH

$\begin{array}{llll}\text { Lab iD } & \text { Storet Code Component } & \text { Result } & \text { Code Units } \\ 303372 & & \end{array}$

Test: Metals, dissolved, in filtered, aqueous samples using ICP mass spectros copy. (EPA $200.8 \mathrm{mod}$ )
01000
Arsenin
96.4
ugh

Sample Location: WPBCC

Field 10: 1B:2K

Collection Date/Time: 1/13/1998 3:36 PM

MatiX: W-SURF-FRH

Lab iD Storet Code Component Fesult Code Units
303373

Test: Metals, dissolved, in filtered, aqueous samples using ICP mass spectros copy. (EPA 200.B mod.)
01000
Arsenic
94.0
ugh

\section{Sample Location: WPBCC}

Field ID: 1C:2K

Collection Date/Time: 1/13/1998 3:36 PM

Matrix: W-SURF-FRH

Lab ID StoretCode Component Result Code Units

Test: Metals, dissolved, in filtered, aque ous samples using ICP mass spectros copy. (EPA 200.8 mod.)

\begin{tabular}{|c|c|c|c|c|c|}
\hline & 01000 & Arsenic & 2 & U & $\operatorname{ug} / \mathrm{L}$ \\
\hline \multicolumn{6}{|c|}{ Sample Location: WPBCC } \\
\hline \multicolumn{6}{|c|}{ Field ID: 10:2K } \\
\hline \multicolumn{6}{|c|}{ Collection Date/Time: 1/13/1998 3:36 PM } \\
\hline \multicolumn{6}{|c|}{ Matrix: W-SURF-FRH } \\
\hline Lab 10 & Storet Code & Component & Result & Code & Units \\
\hline \multicolumn{6}{|l|}{303375} \\
\hline \multicolumn{6}{|c|}{ Test: Metals, dissolved, in filtered, aqueous samples using (CP mass spectroscopy. (EPA 200.8 mod.) } \\
\hline & 01000 & Arsenic & 97.2 & & $\operatorname{ug} / \mathrm{L}$ \\
\hline
\end{tabular}

Sample Location: WPBCC

Field 10: 1E:2K

Collection Date/Time: 1/13/1998 3:36 PM

Matrix: W-SURF-FRH

Lab ID Storet Code Component Result Code Units
303376

Test: Metals, dissolved, in filtered, aqueous samples using ICP mas s sectros copy. (EPA 200.8 mod.)
01000
Arsenic
99.0
ugh 
Sample Location: WPBCC

Field 10: 1F:2K

Collection Date/Time: 1/13/1998 4:00 PM

Matrix: W-SURFFRH
Lab 10
Storet code component
Result
Code Units

303377

Test: Metals, dissolved, in filtered, aqueous samples using ICP mass spectroscopy. (FPA 200.8 mod.)

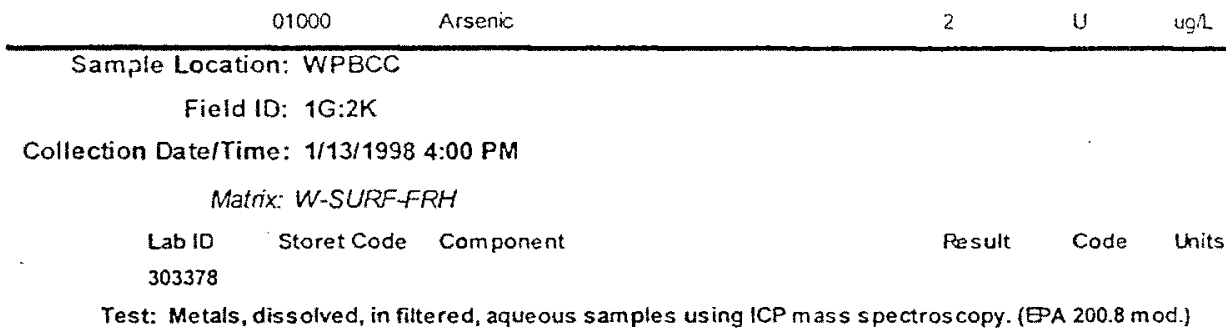

\begin{tabular}{|c|c|c|c|c|c|}
\hline & 01000 & Arsenic & 95.6 & & $\operatorname{tog} h$ \\
\hline \multicolumn{6}{|c|}{ Sample Location: WPBCC } \\
\hline \multirow{2}{*}{\multicolumn{6}{|c|}{ Field ID: $1 \mathrm{H}: 2 \mathrm{~K}$}} \\
\hline \multicolumn{2}{|c|}{ Collection Date/Time: 1/13/1998 4:00 PM } & & & & \\
\hline \multicolumn{6}{|c|}{ Matrix: W-SURFFRH } \\
\hline Lab 10 & Storet Code & Component & Fesult & Code & Units \\
\hline \multicolumn{6}{|c|}{303379} \\
\hline \multicolumn{6}{|c|}{ Test: Metals, dissolved, in fittered, aqueous samples using ICP mass spectros Copy. (EPA 200.8 mod.) } \\
\hline & 01000 & Arsenic & 2 & $\mathrm{U}$ & $u g h$ \\
\hline
\end{tabular}

Sample Location: WPBCC

Field ID: 11:2K

Collection Date/Time: 1/13/1998 4:00 PM

Matrix: W-SURFFRH

Lab ID Storet Code Component Result Code Units
303380

Test: Metals, dissolved, in filtered, aqueous samples using ICP mass spectroscopy. (EPA 200.8 mod.)
01000
Arsenic
98.0
$\operatorname{vg} h$

Sample Location: WPBCC

Field ID: $1 \mathrm{~J}: 2 \mathrm{~K}$

Collection Date/Time: 1/13/1998 4:40 PM

Matrix: W-SURF-FRH

LabID Storet Code Component Result Code Units
303381

Test: Metals, dissolved, in filtered, aqueous samples using ICP mass spectros Copy. (EPA 200.8 mod.)
01000
Arsenic
2
$\mathrm{U}$ ugh 
Sample Location: WPBCC

Field 1D: $1 \mathrm{~K}: 2 \mathrm{~K}$

Collection Date/Time: 1/13/1998 4:40 PM

Matrix: W-SURF-FRH

\begin{tabular}{|c|c|c|}
\hline Lab iD & Storet Code & Component \\
\hline
\end{tabular}

Test: Metals, dissolved, in filtered, aqueous samples using ICP mass spectros Copy. (EPA 200.8 mod.)
01000
Arsenic
90.9
ugh

Sample Location: WPBCC

Field ID: 1L:2K

Collection Date/Time: 1/13/1998 4:40 PM

Matrix: W-SURFFRH

LabID Storet Code Component Pesult Code Units
303383

Test: Metals, dissolved, in filtered, aqueous samples using ICP mass spectroscopy. (EA 200.8 mod.)
01000
Arsenic
103
A
ugh

\section{Sample Location: WPBCC}

Field ID: $3 \mathrm{H}: 8 \mathrm{~K}$

Collection Date/Time: 1/20/1998 5:15 PM

Matrix: W-SURFFRH

Lab ID Storet Code Component Result Code Units

Test: Metals, dis solved, in filtered, aqueous samples using ICP mass spectroscopy. (EPA 200.8 mod.)

$01000 \quad$ Arsenic $\quad 2 \quad U$ ug $h$

Sample Location: WPBCC

Field ID: $31: 8 \mathrm{~K}$

Collection Date/Time: 1/20/1998 5:15 PM

Matrix: W-SURF-FRH

Lablo Storet Code Component Result Code Units
303385

Test: Metals, dissolved, in filtered, aque ous samples using ICP mass spectros copy. (EPA 200.8 mod.)
01000
Arsenic
90.8
ugh

Sample Location: WPBCC

Field 10: $3 J: 8 K$

Collection Date/Time: 1/20/1998 5:15 PM

Matrix: W-SURFFFH

$\begin{array}{lll}\text { Lablo Storet Code Component } & \text { Result } \text { Code Units } \\ 303386 & \end{array}$

Test: Metals, dissolved, in fittered, aqueous samples using ICP mass spectroscopy. (EPA 200.8 mod.)
01000
Arsenic
2
U ugh 
Sample Location: WPBCC

Field 1D: $3 \mathrm{~K}: 8 \mathrm{~K}$

Collection Date/Time: 1/20/1998 5:15 PM

Matrix: W-SURF-FRH

$\begin{array}{lllll}\text { Lablo Storet Code Component } & \text { Result } & \text { Code } & \\ 303337 & & \end{array}$

Test: Metals, dissolved, in filtered, aqueous samples using ICP mass spectroscopy. (EPA 200.8 mod.)
01000
Arsenic
85.0
ugh

Sample Location: WPBCC

Field ID: 3L:8K

Collection Date/Time: 1/20/1998 5:15 PM

Matrix: W-SURF-FRH

Lab10 StoretCode Component Result Code Units
303388

Test: Metals, dissolved, in filtered, aqueous samples using ICP mass spectros copy. (EPA 200.8 mod.)

$01000 \quad$ Arsenic

89.7

ugh

Sample Location: WPBCC

Field ID: SA:24K

Collection Date/Time: 1/17/1998 5:15 PM

Matrix: W-SURF-FRH

Lab iD Storet Code Component Result Code thits 303389

Test: Metals, dissolved, in fittered, aqueous samples using ICP mass spectros Copy. (EPA 200.8 mod.)
01000
Arsenic
102
ugh

Sample Location: WPBCC

Field ID: 58:24K

Collection DaterTime: 1/17/1998 5:15 PM

Matrix: W-SURFFRH

Lablo Storet Code Component Result Code Units 303390

Test: Metals, dissolved, in filtered, aqueous samples using ICP mass spectroscopy. (EPA 200.8 mod.)
01000
Arsenic
101
ugh

Sample Location: WPBCC

Field 10: $5 \mathrm{C}: 24 \mathrm{~K}$

Collection Date/Time: 1/17/1998 5:15 PM

Matrix: W-SURF-FRH

Lab ID Storet Code Component Result Code Units

Test: Metals, dissoived, in filtered, aqueous samples using ICP mass spectros copy. (EPA 200.8 mod.)
01000
Arsenic
2
U ugh 


\section{Sample Location: WPBCC}

Field ID: 5D:24K

Collection DaterTime: 1/17/1998 3:15 PM

Matrix: W-SURF-FRH

Lab to StoretCode Component Result Code Units
303392

Test: Metals, dissolved, in filtered, aqueous samples using ICP mass spectros copy. (EPA $200.8 \mathrm{mod}$.)

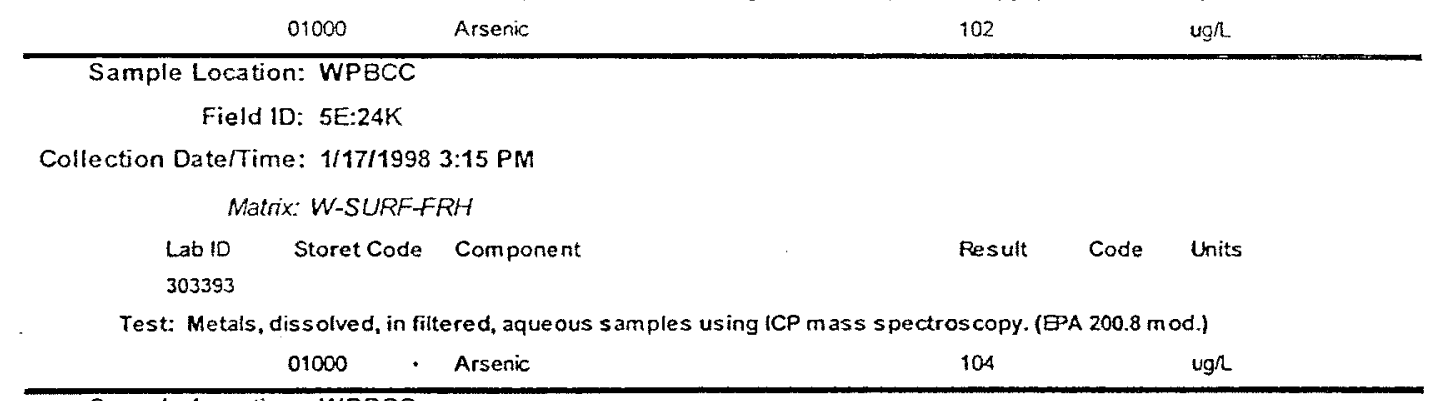

Sample Location: WPBCC

Field IO: $5 F: 24 K$

Collection Date/Time: 1/17/4998 5:15 PM

Matrix: W-SURF-FRH

Lab10 Storet Code Component Result Code Lnits
303394

Test: Metals, dissolved, in filtered, aqueous samples using ICP mass spectroscopy. (EPA 200.8 mod.)

\begin{tabular}{|c|c|c|c|c|}
\hline & Arsenic & 2 & $\mathbf{U}$ & $u g h$ \\
\hline \multicolumn{5}{|c|}{ Sample Location: WPBCC } \\
\hline \multicolumn{5}{|c|}{ Field ID: $5 G: 24 \mathrm{~K}$} \\
\hline \multicolumn{5}{|c|}{ Collection Date/Time: 1/17/1998 5:15 PM } \\
\hline \multicolumn{5}{|c|}{ Matrix: W-SURF-FRH } \\
\hline Lab 10 & Storet Code & Result & Code & Units \\
\hline 303395 & & & & \\
\hline
\end{tabular}

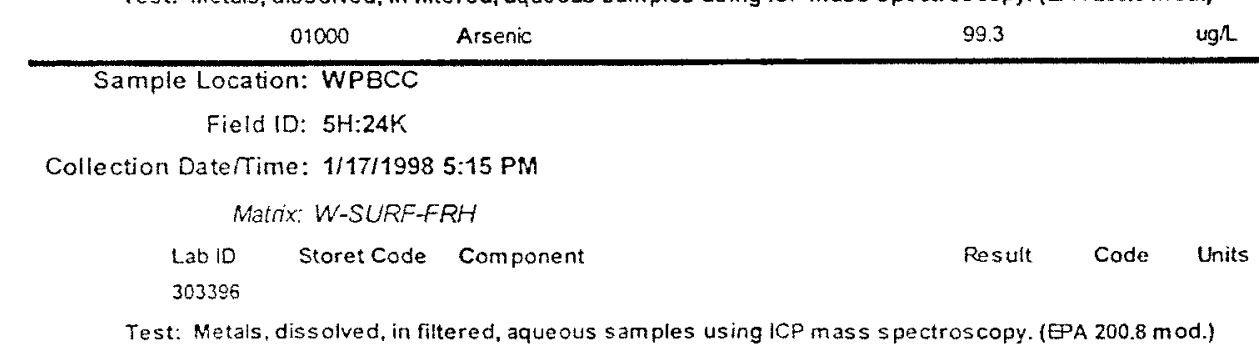

$01000 \quad$ Arsenic $\quad 2 \quad u g h$ 
Sample Location: WPBCC

Field ID: $51: 24 \mathrm{~K}$

Collection Date/Time: 1/17/1998 5:15 PM

Matrix: W-SURF-FRH

$\begin{array}{lll}\text { Lab } 10 & \text { Storetcode Component } & \text { Result Code Units } \\ 303397 & & \cdots .\end{array}$

Test: Metals, dissolved, in filtered, aqueous samples using ICP mass spectros COpy. ( $D P A 200.8 \mathrm{mod}$ )

01000 Arsenic $100 \quad$ ugh

Sample Location: WPBCC

Field ID: $5 \mathrm{~J}: 24 \mathrm{~K}$

Collection Date/Time: 1/17/1998 3:15 PM

Matrix: W-SURF-FRH
Lab 10
Storet Code Component
Result
Code units

303398

Test: Metals, dissolved, in fittered, aqueous samples using ICP mass spectroscopy. (EPA $200.8 \mathrm{mod}$ )

01000 Arsenic 20 U ugh

Sample Location: WPBCC

Field ID: 5K:24K

Collection Date/Time: 1/17/1998 5:15 PM

Matrix: W-SURF-FRH

$\begin{array}{lll}\text { Lab ID Storet Code Component } & \text { Result Code Units } \\ 303399 & \end{array}$

Test: Metals, dissolved, in filtered, aqueous samples using ICP mass spectroscopy. (EPA 200.8 mod.)
01000
Arsenic
90.8
$\operatorname{ug} h$

Sample Location: WPBCC

Field 1D: $5 \mathrm{~L}: 24 \mathrm{~K}$

Collection Date/Time: 1/17/1998 5:15 PM

Matrix: W-SURF-FRH

Lablo Storet Code Component Result Code Units

303400

Test: Metals, dissolved, in fitered, aque ous samples using ICP mass spectros copy. (EPA 200.8 mod.)
01000
Arsenic
93.4
ug $h$

Sample Location: WPBCC

Field ID: 8A:168K

Collection Date/Time: 1/14/1998 3:00 PM

Matrix: W-SURF-FRH

Lab ID Storet Code Component Result Code Units 303401

Test: Metals, dissolved, in filtered, aqueous samples using ICP mass spectroscopy. (BPA 200.8 mod.)
01000
Arsenic
77.2
ugh 
Sample Location: WPBCC

Field ID: $8 \mathrm{~B}: 168 \mathrm{~K}$

Collection Date/Time: 1/14/1998 3:00 PM

Matrix: W-SURF-FRH

Lab10 Storet Code Component Result Code Units.
303402

Test: Metals, dissolved, in filtered, aqueous samples using ICP mass spectros copy. (EPA 200.8 mod.)
01000
Arsenic
82.4
ugh

Sample Location: WPBCC

Field ID: 8C:168K

Collection Date/Time: 1/14/1998 3:00 PM

Matrix: W-SURFFRH

Lab $10 \quad$ Storet Code Component . Pesult Code Units
303403

Test: Metals, dissolved, in filtered, aqueous samples using ICP mass spectros copy. (EPA 200.8 mod.)
01000
Arsenic
2
$\mathrm{U}$
$\operatorname{ugh}$

Sample Location: WPBCC

Field 1D: $80: 168 K$

Collection Date/Time: 1/14/1998 3:00 PM

Matrix: W-SURF-FRH

Lab ID Storet Code Component Result Code Units
303404

Test: Metals, dissolved, in filtered, aqueous samples using ICP mass spectros copy. (EPA 200.8 mod.)
01000
Arsenic
90.1
A
$u g /$

Sample Location: WPBCC

Field ID: $8 \mathrm{E}: 168 \mathrm{~K}$

Collection Date/Time: 1/14/1998 3:30 PM

Matrix: W-SURF-FFH

Lab ID StoretCode Component Result Code Units 303405

Test: Metals, dissolved, in filtered, aqueous samples using ICP mass spectros Copy. (BPA 200.8 mod.)
01000
Arsenic
96.8
ugn

Sample Location: WPBCC

Field $10: 8 F: 168 \mathrm{~K}$

Collection DatelTime: 1/14/1998 3:30 PM

Matrix: W-SURF-FRH

Lab ID Storet Code Component Result Code Units 303406

Test: Metals, dissolved, in filtered, aqueous samples using $1 \mathrm{CP}$ mas $\$$ spectroscopy. (GP. $200.8 \mathrm{mod}$ )
01000
Arsenic
2
u ugh 
Sample Location: WPBCC

Field ID: 8G:168K

Collection Date/Time: 1/1411998 3:30 PM

Matrix: W-SURF-FRH

LablD Storet Code Component Result Code Units.

Test: Metals, dissolved, in filtered, aqueous samples using ICP mass spectros copy. ( $\square$ A 200.8 mod.)

\begin{tabular}{|c|c|c|c|c|c|}
\hline & 01000 & Arsenic & 93.8 & & $\mathrm{ug} h$ \\
\hline \multicolumn{6}{|c|}{ Sample Location: WPBCC } \\
\hline \multicolumn{6}{|c|}{ Field ID: $8 H: 168 \mathrm{~K}$} \\
\hline \multicolumn{6}{|c|}{ Collection Date/Time: 1/14/1998 3:30 PM } \\
\hline \multicolumn{6}{|c|}{ Matrix: W-SURF-FRH } \\
\hline Lab 10 & Storet Code & Component & Result & Code & Units \\
\hline \multicolumn{6}{|l|}{303408} \\
\hline \multicolumn{6}{|c|}{ Test: Metals, dissolved, in filtered, aqueous samples using ICP mass spectros copy. ( $¥$ A 200.8 mod.) } \\
\hline & 01000 & Arsenic & 2 & u & ugh \\
\hline
\end{tabular}

Sample Location: WPBCC

Field ID: $81: 168 \mathrm{~K}$

Collection Date/Time: 1/14/1998 4:00 PM

Matrix: W-SURFFRH

Lab10 Storet Code Component Pesult Code Units
303409

Test: Metals, dissolved, in filtered, aqueous samples using ICP mass spectros COpy. (EPA 200.8 mod.)
01000
Arsenic
91.8
$u g / 2$

Sample Location: WPBCC

Field 10: 8J:168K

Collection Date/Time: 1/14/1998 4:00 PM

Matrix: W-SURFFFRH

$\begin{array}{llll}\text { Lablo } & \text { Storet Code Component } & \text { Result Code Units }\end{array}$

Test: Metals, dissolved, in filtered, aqueous samples using ICP mass spectros copy. (EPA 200.8 mod.)
01000
Arsenic
2
U
$49 /$

Sample Location: WPBCC

Field ID: $8 \mathrm{~K}: 168 \mathrm{~K}$

Collection Date/Time: 1/14/1998 4:00 PM

Matix: W-SURF-FRH

Lab to Storet Code Component Result Code Units 303411

Test: Metals, dissolved, in fittered, aqueous samples using ICP mass spectros copy. (EA 200.8 mod.)
01000
Arsenic
305
$\mathrm{ug} / \mathrm{L}$ 
Sample Location: WPBCC

Field ID: AR-AK

Collection Date/Time: 1/21/1998 3:56 PM

Matrix: W-SURF-FRH

Lab10 StoretCode Component Result Code units
303416

Test: Metals, dissolved, in filtered, aqueous samples using ICP mass spectros copy. (EPA 200.8 mod.)
01000
Arsenic
91.0
ugh

Sample Location: WPBCC

Field ID: $A R-B K$

Collection Date/Time: 1/17/1998 6:00 PM

Matrix: W-SURF-FRH

Lab io Storet Code Component Pesult Code Units

303417

Test: Metals, dissolved, in filtered, aqueous samples using ICP mass spectros copy. (EPA 200.8 mod.)
01000
Arsenic
97.5
$u g h$

Sample Location: WPBCC

Field ID: $A S-O A$

Collection DatefTime: 1/20/1998 3:00 PM

Matrix: W-SURF-FRH

LabiD Storet Code Component Fas Code Units

est: Metals, dissolved, in filtered, aqueous samples using ICP mass spectros copy. (EPA 200.8 mod.)

Test: Metals, dissolved, in filtered, aqueous samples using ICP mass spectros copy. (EPA 200.8 mod.)
\[ 01000 ; \quad \text { Arsenic } \]

\begin{tabular}{|c|c|c|c|c|c|}
\hline & 01000 & Arseric & 2 & $U$ & $\operatorname{tgg} h$ \\
\hline \multicolumn{6}{|c|}{ Sample Location: WPBCC } \\
\hline \multicolumn{6}{|c|}{ Field ID: AS-150A } \\
\hline \multicolumn{6}{|c|}{ Collection Date/Time: 1/12/1998 3:00 PM } \\
\hline \multicolumn{6}{|c|}{ Matrix: W-SURFFRH } \\
\hline Lab 10 & Storet Code & Component & Result & Code & Units \\
\hline \multicolumn{6}{|l|}{303414} \\
\hline \multicolumn{6}{|c|}{ Test: Metals, dis solved, in filtered, aqueous samples using ICP mass spectroscopy. (EPA 200.8 mod.) } \\
\hline & 01000 & Arsenic & 26.9 & & $\operatorname{ug} \Omega$ \\
\hline
\end{tabular}

Sample Location: WPBCC

Field ID: CONTROLI

Collection Date/Time: 1/13/1998 4:40 PM

Matix: W-SURF-FRH
Lab 10
Storetcode Component
Result
Code Units

303421

Test: Metals, dissolved, in filtered, aqueous samples using ICP mass spectroscopy. (EPA 200.8 mod.)
01000
Arsenic
2
U ugh 


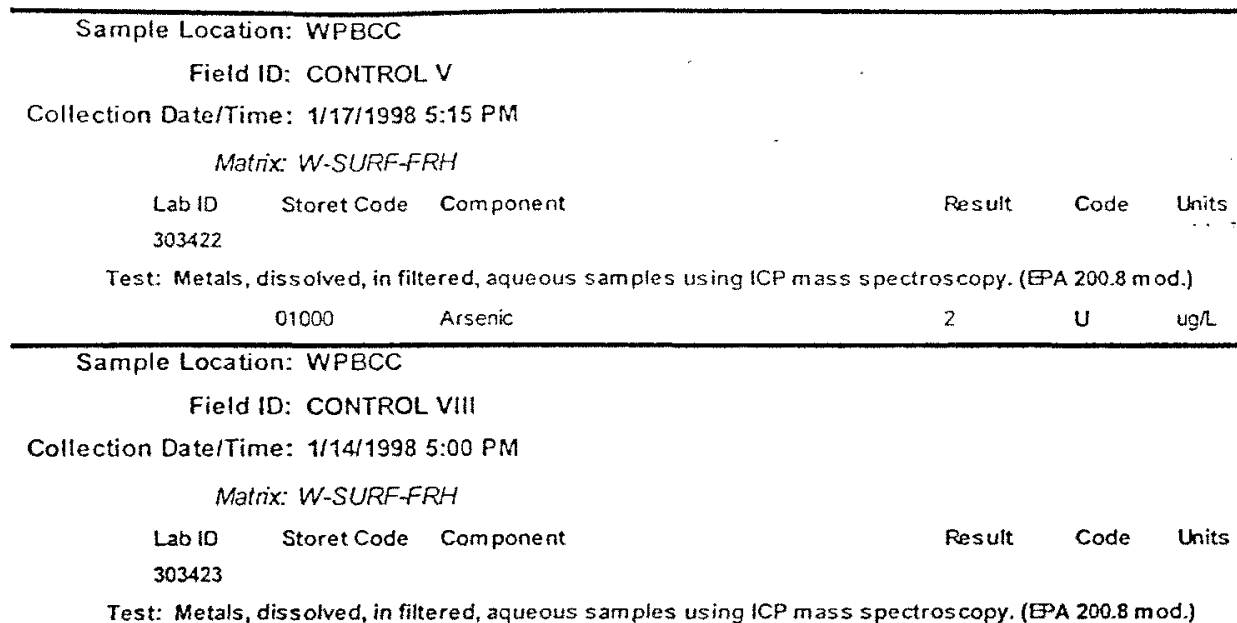

01000 Arsenic

2

$U$

$\operatorname{ug} \Omega$ 
SE-OIST-1958-01-24-01

Seriat Number. 0000037 Section 2 of 2 Quality Control Report Page 1 of 1

Quality Control Report

Test Analyte
W-CPMS-F Arsenic
Batch 10: 30671
Eatch 10: 30672
Batch 10: 30771
Batch 10: 30772

Job ID: TLH-1998-01-24-03

LFB \%Recovery

MS \%Recovery
$\begin{array}{ll}82.4 & 83.8 \\ 93.7 & 94.4 \\ 103 & 109 \\ 86.1 & 93.3\end{array}$

Precision \%p80

Precision \%RSO

0.0834

0.735

1.70

1.87 
Chemical Analysis Report

Florida Department of Envromental Protection Central Laboratory 2600 Blair Stone Road Tallahassee, FL 32399-2400 CompQAPH 8706886

Event Description: Golf Course Arsenic Study

Request ID: R2-1998-01-12-13

Customer. SE-DIST

Project 10: OTHER-WSM

Job: IL:-19g2-01-20-29

JoD: $T L \div-1558-01-20-30$

Job: TLI-1098-01-20-31

Send Reports to

FL Dept. of Environmental Protection

P.O. Box 15425

$400 \mathrm{~N}$. Congress Ave.

West Palm Beach. FL 33401

Attn: John Molton
Group: Metals

Group: Nutrients

Group: Metals

For additional information please contact

Timothy W. Fitzpatrick

Yuh-Hsu Pan. Ph.D.

Julio Artecis, Ph.D.

Liang-Tsair Lin, Ph.D.

Suncom 277-2571 Phone (850) 487-2571

certified By: $\quad \mathrm{Han}_{2}$

Date: $2-27-48$

Report Printed Date: Feb 25, 1998

Abbreviations and data remark codes

A - Value reported is the rean of two or nore determinations

$B$ - Resuts based on colony counts outside the acceptable range.

1. Value reporied is less than the minmum quantitation frit, and greater than or equal to the rinimum detection limt.

J. Estrireted value

$K$ - Actual value is known to be less than value given

$L$ - Actual value is known to be greater than value given

$\mathrm{N}$ - Presurptive evidence of presence of material.

0 - Sampled, but analysis lost or not performed.

Q - Sample heid beyond norrmat holding tirne.

$T$ - Value reported is less than the criterion of detection.

U. Naterial $w$ as ariatyzed for but not detected; The value reported is the minimum detection irrit.

$V$ - Anatyte w as detected in both sample and method blank.

$Z$ - Colonies were too numerous to count (TNTC). 
Sample Location: WPBCC

Field ID: $2 A: 4 K$

Collection Date/Time: 1/12/1998 4:10 PM

Matrix: W-GROUND
Lab 10
Storet Code Component
Result
Code
Units.

Test: Metals, dissolved, in filtered, aqueous samples using ICP mass spectros Copy. (EPA 200.8 mod.)

\begin{tabular}{|c|c|c|c|c|c|}
\hline & 01000 & Arsenic & 98.0 & & ugh \\
\hline \multicolumn{6}{|c|}{ Sample Location: WPBCC } \\
\hline \multicolumn{6}{|c|}{ Field ID: $28: 4 \mathrm{~K}$} \\
\hline \multicolumn{6}{|c|}{ Collection Date/Time: 1/12/1998 6:10 PM } \\
\hline \multicolumn{6}{|c|}{ Matrix: W-GROUND } \\
\hline Lab ID & Storet Code & Component & Result & Code & Units \\
\hline 302302 & $\cdot$ & & & & \\
\hline \multicolumn{6}{|c|}{ Test: Metals, dissolved, in filtered, aqueous samples using ICP mass spectros copy. (EPA $200.8 \mathrm{mod}$.) } \\
\hline & 01000 & Arsenic & 97.4 & & $\operatorname{ug} \pi$ \\
\hline \multicolumn{6}{|c|}{ Sample Location: WPBCC } \\
\hline \multicolumn{6}{|c|}{ Field ID: $2 \mathrm{C:}: 4 \mathrm{~K}$} \\
\hline \multicolumn{6}{|c|}{ Collection DaterTime: 1/12/1998 6:10 PM } \\
\hline \multicolumn{6}{|c|}{ Matrix: W-GROUND } \\
\hline Lab ID & Storet Code & Component & Fesult & Code & Units \\
\hline \multicolumn{6}{|l|}{302303} \\
\hline \multicolumn{6}{|c|}{ Test: Metals, diss olved, in filtered, aqueous samples using ICP mass spectroscopy. (EPA 200.8 mod.) } \\
\hline & 01000 & Arsenic & 2 & U & $\operatorname{vg} h$ \\
\hline
\end{tabular}

Sample Location: WPBCC

Field ID: $2 \mathrm{D}: 4 \mathrm{~K}$

Collection Date/Time: 1/12/1998 6:10 PM

Matrix: W-GROUND

$\begin{array}{lll}\text { Lab ID Storet Code Component } & \text { Result Code Units } \\ 302304 & & \end{array}$

Test: Metals, dissolved, in filtered, aqueous samples using ICP mass spectroscopy. (EPA 200.8 mod.)
01000
Arsenic
2
$\mathrm{U}$
ugn

Sample Location: WPBCC

Field 10: 2E:4K

Collection Date/Time: 1/12/1998 4:10 PM

Matrix: W-GROUND
LabiD Storet Code Component Result Code Units
302305

Test: Metais, dissolved, in filtered, aqueous samples using ICP mass spectros Copy. (EPA 200.8 mod.)
01000
Arsenic
976
ugh 
Sample Location: WPBCC

Field 10: $2 F: 4 K$

Collection Date/Time: 1/12/1998 4:10 PM

Matrix: W-GROUND

Lab 10 Storet Code Component Result Code Units
302306

Test: Metals, dissolved, in filtered, aqueous 5 amples using ICP mass spectros copy. (EPA 200.8 mod)

$$
01000 \quad \text { Arsenic }
$$

ugh

Sample Location: WPBCC

Field 1D: $2 \mathrm{G}: 4 \mathrm{~K}$

Collection Date/Time: 1/12/1998 4:10 PM

Matrix: W-GROUND
Lab lo . Storet Code Component
Pesult Code Units
302307 ,

Test: Metals, dissolved, in filtered, aqueous samples using ICP mass spectros copy. (EPA 200.8 mod.)

$$
01000 \quad \text { Arsenic }
$$

93.9

ugh

Sample Location: WPBCC

Field ID: $2 \mathrm{H}: 4 \mathrm{~K}$

Collection Date/Time: 1/12/1998 4:10 PM

Matrix: W-GROUND

$\begin{array}{lll}\text { Lab } 10 & \text { Storet Code Component } & \text { Result } \text { Code Units } \\ 302308 & \end{array}$

Test: Metals; dissolved, in filtered, aqueous samples using ICP mass spectroscopy. (EPA 200.8 mod.)
01000
Arsenic
2
$\mathrm{u} \quad \mathrm{ugh}$

Sample Location: WPBCC

Field ID: 21:4K

Collection Date Time: 1/12/1998 4:10 PM

Matrix W-GROUND

Lab tD Storet Code Component inosult Code Units

Test: Metals, dis solved, in filtered, aqueous samples using ICP mass spectroscopy. (EPA $200.8 \mathrm{mod}$.)
01000
Arsenic
96.8
ug $\Omega$

Sample Location: WPBCC

Field ID: 2J:4K

Collection Date/Time: 1/12/1998 4:10 PM

Matrix: W-GROUND

Lablo Storet Code Component Rosuit Code Units

Test: Metals, dissolved, in filtered, aqueous samples using ICP mass spectros Copy. (EPA 200.8 mod.)
01000
Arsenic
90.4
ugit 


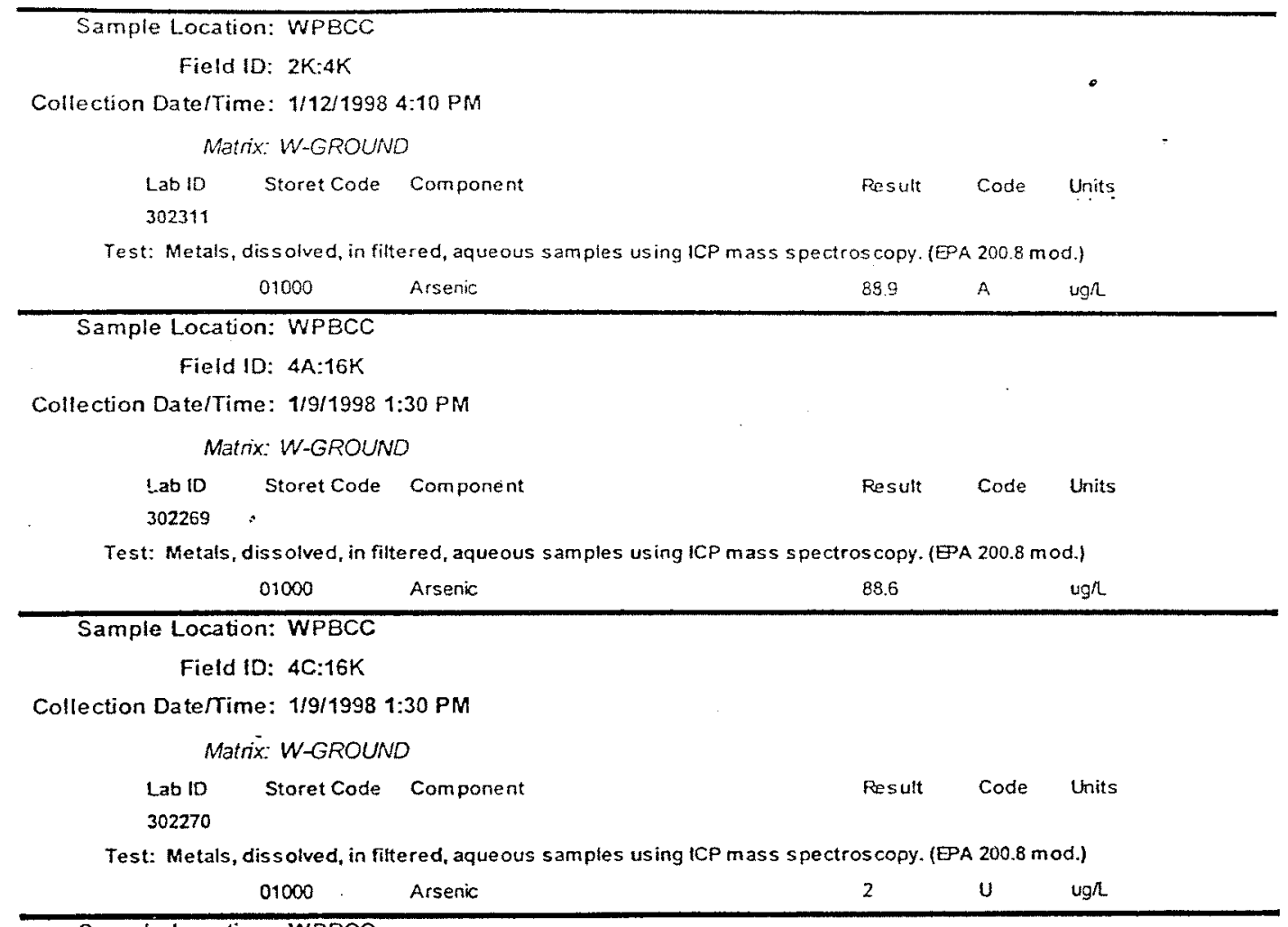

Sample Location: WPBCC

Field ID: 4G:16K

Collection Date/Time: 1/9/1998 1:30 PM

Matrix: W-GROUND

$\begin{array}{lll}\text { Lab ID Storet Code Component } & \text { Result Code Units } \\ 302271 & \end{array}$

Test: Metals, dissolved, in filtered, aqueous samples using ICP mass spectroscapy. (EPA 200.8 mod.)
01000
Arsenic
2
U
ug $\Omega$

Sample Location: WPBCC

Field 10: $4 \mathrm{H}: 16 \mathrm{~K}$

Collection Date/Time: 1/9/1998 1:30 PM

Matrix: W-GROUND

Lab 10 Storet Code Component Result Code Units
302272

Test: Metals, dissolved, in fiftered, aqueous samples using ICP mass s pectros Copy. (EPA 200,8 mod.)
01000
Arsenic
918
ugh 
Sample Location: WPBCC

Field 10: 4l:16K

Collection DatelTime: 1/9/1998 1:30 PM

Matrix: W-GROUNO

Lablo Storet Code Component Result Code Units.

Test: Metals, dissolved, in filtered, aqueous samples using ICP mass spectros COPy. (EPA 200.8 mod.)
01000
Arsenic
90.4
ug $\Omega$

Sample Location: WPBCC

Field 1D: 4J:16K

Collection Date/Time: 1/9/1998 2:00 PM

Matrix: W-GROUND

LabID Storet Code Component Result Code Units

202274 .

Test: Metals, dissolved, in filtered, aqueous samples using ICP mass spectros copy. (EPA 200.8 mod.)
01000
Arsenic
2
$U$
ugh

Sample Location: WPBCC

Field ID: 4K:16K

Collection Date/Time: 1/9/1998 2:00 PM

Matrix: W-GROUND
Lab ID StoretCode Component Result Code Units
302275

Test: Metals, dissolved, in fittered, aque ous samples using ICP mass s pectros COPy-(EPA 200.8 mod.)

01000 Arsenic $\quad 60.2 \quad \mathrm{ugh}$

Sample Location: WPBCC

Field ID: 4L:16K

Colfection Date/Time: 1/9/1998 2:00 PM

Matrix: W-GROUND

Lablo Storet Code Component Result Code Units 302276

Test: Metals, dissolved, in filtered, aqueous samples using ICP mass spectros copy. (EPA 200.8 mod.)
01000
Arsenic
60.3
ugh

Sample Location: WPBCC

Field ID: $6 \mathrm{~A}: 48 \mathrm{~K}$

Collection Date/Time: 1/9/1998 1:30 PM

$$
\text { Matrix: W-GROUND }
$$

Lab 10 Storet Code Component Result Code Units

Test: Metals, dissolved, in filtered, aqueous samples using tCP mass spectros copy. (EPA $200.8 \mathrm{~m}$ od.)
01000
Arsenic
82.9
ugh 
Sample Location: WPBCC

Field 1D: $6 \mathrm{~B}: 48 \mathrm{~K}$

Collection Date/Time: 1/9/1998 1:30 PM

Matrix: W-GROUND

Lab 10 Storetcode Component Result Code Units

Test: Metais, dissolved, in fittered, aqueous samples using ICP mass spectroscopy. (EPA 200.8 mod.)

\begin{tabular}{cccc}
01000 & Arsenic & 84.5 & ugh \\
\hline
\end{tabular}

Sample Location: WPBCC

Field ID: $6 \mathrm{C}: 48 \mathrm{~K}$

Collection Date/Time: 1/9/1998 1:30 PM

Matrix: W-GROUND

Lab10 Storet Code Component Result Code Units
302279

Test: Metals, diss olved, in filtered, aqueous samples using ICP mass spectros copy. ( $\oplus A 200.8$ mod.)

\begin{tabular}{ccccc}
01000 & Arsenic & 2 & U & ugh \\
\hline
\end{tabular}

Sample Location: WPBCC

Field 10: 60:48K

Collection Date/Time: 1/9/1998 2:00 PM

Matrix: W-GROUND

Lab ID Storet Code Component Result Code Units
302280

Test: Metals, dissolved, in fittered, aqueous samples using ICP mass spectros copy. (EPA 200.8 mod.)

\begin{tabular}{rrcc}
01000 & Arsenic & 87.4 & ugh \\
\hline
\end{tabular}

Sample Location: WPBCC

Field 1D: 6E:48K

Collection Date/Time: 1/9/1998 2:00 PM

Matrix: W-GROUND

Lab ID Storet Code Component Fosult Code Units

302281

Test: Metals, dissolved, in filtered, aqueous samples using ICP mass spectroscopy. (EPA 200.8 mod.)

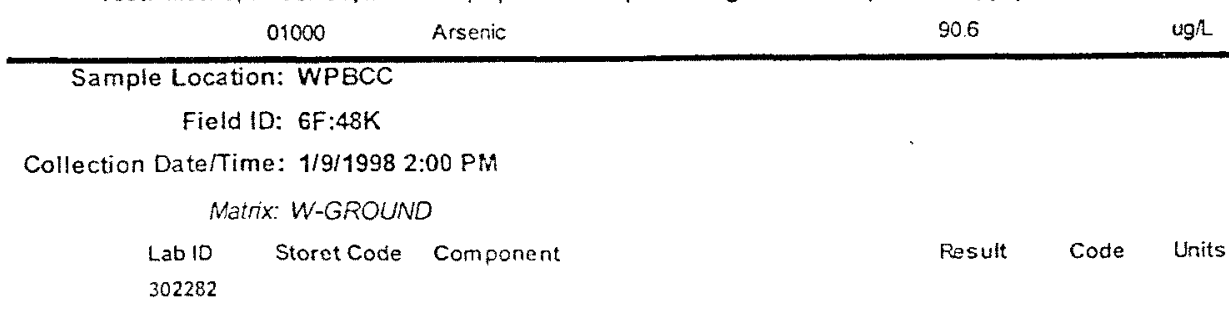

Test: Metals, dissolved, in filtered, aqueous samples using ICP mass spectros Copy. ( $\square$ A 200.8 mod.)

01000 Arsenic $\quad 2 \quad u$ ugh 
Sample Location: WPBCC

Field ID: 6G:48K

:ollection Date/Time: 1/9/1998 2:30 PM

Matrix: W-GROUND

Lablo Storet Code Component Result Code Units
302283

Test: Metals, dissolved, in filtered, aqueous samples using ICP mass spectros copy. ( $\boxminus$ A 200.8 mod.)

\begin{tabular}{cccc}
01000 & Arsenic & 93.5 & ugh \\
\hline Sample Location: WPBCC &
\end{tabular}

Field ID: $6 \mathrm{H}: 48 \mathrm{~K}$

zollection Date/Time: 1/9/1998 2:30 PM

Matrix: W-GROUND

Lablo Storet Code Component Result Code Units
302284 .

Test: Metals, dissolved, in filtered, aqueous samples using ICP mass spectros copy. (BPA 200.8 mod.)

\begin{tabular}{|c|c|c|c|c|c|}
\hline & 01000 & Arsenic & 2 & $u$ & $\operatorname{tg} \Omega$ \\
\hline \multicolumn{6}{|c|}{ Sample Location: WPBCC } \\
\hline \multicolumn{6}{|c|}{ Field ID: $61: 48 \mathrm{~K}$} \\
\hline \multicolumn{6}{|c|}{ Jollection Date/Time: 1/9/1998 2:30 PM } \\
\hline \multicolumn{6}{|c|}{ Matrix: W-GROUND } \\
\hline Labio & Storet Code & Component & Result & Code & Units \\
\hline \multicolumn{6}{|l|}{302285} \\
\hline \multicolumn{6}{|c|}{ Test: Metals, dissolved, in filtered, aque ous samples using ICP mass spectroscopy. (EPA 200.8 mod.) } \\
\hline & $01000 \quad:$ & Arsenic & 92.2 & & $\operatorname{ug} h$ \\
\hline
\end{tabular}

\section{Sample Location: WPBCC.}

Field ID: $6 \mathrm{~J}: 48 \mathrm{~K}$

Vollection Date/Time: 1/9/1998 3:00 PM

Matrix: W-GROUND

Lablo Storet Code Component Result Code Units
302286

Test: Metals, dissolved, in fittered, aqueous samples using ICP mass spectros copy. (EPA 200.8 mod.)

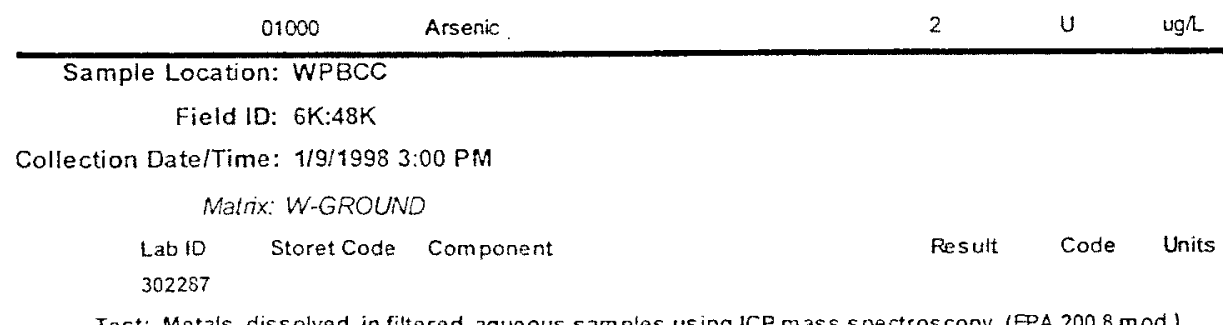

Test: Metals, dissolved, in filtered, aqueous samples using ICP mass spectroscopy. (EPA 200.8 mod.)
01000
Arsenic
53.5
ug/ 
Sample Location: WPBCC

Field ID: $6 \mathrm{~L}: 48 \mathrm{~K}$

Collection Date/Time: 1/9/1998 3:00 PM

Matrix W-GROUNO

Lab 10 Storet Code Component $\quad$ Result Code Units
302288

Test: Metals, dissalved, in fittered, aqueous samples using $1 C P$ mass spectros Copy. (EPA 200.8 mod.)
01000
Arsenic
51.0
$\cup g h$

Sample Location: WPBCC

Field 1D: 7A:96K

Collection Daterime: 1/11/1998 12:00 PM

Matrix: W-GROUND

Lab ID Storet Code Component Pesult Code Gits
302289 .

Test: Metals, dissolved, in filtered, aqueous samples using ICP mass spectros copy. (EPA 200.8 mod.)
01000
Arsenic
88.6
$\operatorname{ug} \Lambda$

Sample Location: WPBCC

Field ID: 7B:96K

Collection Date/Time: 1/11/1998 12:00 PM

Matrix: W-GROUND

LabID Storet Code Component Fesult Code Units

302290

Test: Metals, dissolved, in filtered, aqueous samples using ICP mass spectros copy. (EPA 200.8 mod.)
01000
Arsenic
85.1
ugh

Sample Location: WPBCC

Field ID: 7C:96K

Collection Daterime: 1/11/1998 12:00 PM

Matrix W-GROUND

Labto StoretCode Component Fesult Code Units

Test: Metals, dissolved, in filtered, aqueous samples using ICP mass spectroscopy. (EPA $200.8 \mathrm{mod}$.)

$01000 \quad$ Arsenic $\quad 2 \quad U$ ug

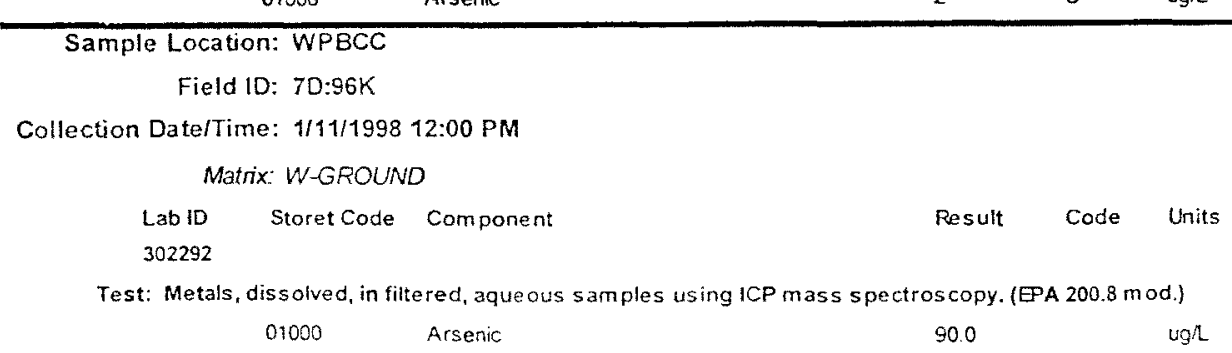


Sample Location: WPBCC

Field ID: $7 E: 96 K$

Collection Date/Time: 1/11/1998 2:00 PM

Matix: W-GROUND

Lab 10 Storet Code Component Result Code Units.

Test: Metals, dissolved, in fittered, aqueous samples using ICP mass s pectroscopy. (EPA 200.8 mod.)
01000
Arsenic
88.7
ugh

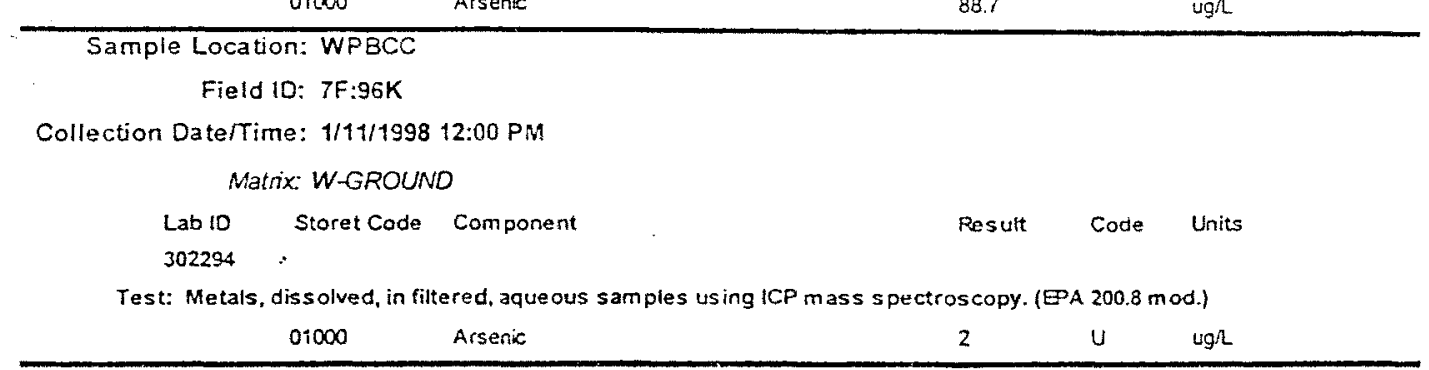

Sample Location: WPBCC

Field ID: $7 G: 96 K$

Collection Date/Time: 1/11/1998 12:00 PM

Matrix: W-GROUND

Lablo Storet Code Component Result Code Units

302295

Test: Metals, dissolved, in fittered, aqueous samples using ICP mass spectros copy. (EPA 200.8 mod.)

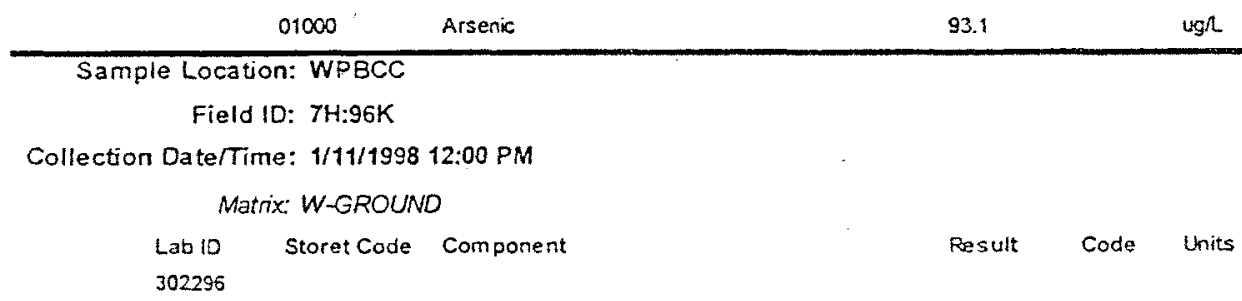

Test: Metals, dissolved, in filtered, aque ous samples using ICP mass s pectros copy. ( $(\triangle A A 200.8$ mod.)

\begin{tabular}{cccc}
01000 & Arsenic & 92.4 & ug $h$ \\
\hline Sample Location: WPBCC &
\end{tabular}

Sample Location: WPBCC

Field ID: $71: 96 \mathrm{~K}$

Collection Date/Time: 1/11/1998 12:00 PM

Matrix: W-GROUND

$\begin{array}{llll}\text { Lablo Storet Code Component } & \text { Resutt Code Units } \\ 302297 & \end{array}$

Test: Metals, dissolved, in filtered, aqueous samples using 1CP mass spectros copy. (EPA 200.8 mod.)

01000 Arsenic 2 ugh 
Sample Location: WPBCC

Field 10: 7J:96K

Collection Date/Time: 1/11/1998 12:00 PM

Matrix: W-GROUND

$\begin{array}{llll}\text { LabID Storet Code Component } & \text { Result Code Units } \\ 302298 & & \end{array}$

Test: Metals, dissolved, in filtered, aqueous samples using ICP mass spectros copy. (EPA 200.8 mod.)

\begin{tabular}{|c|c|c|c|c|c|}
\hline & 01000 & Arsenic & 2 & U & $\operatorname{ug} h$ \\
\hline \multicolumn{6}{|c|}{ Sample Location: WPBCC } \\
\hline \multicolumn{6}{|c|}{ Field ID: $7 \mathrm{~K}: 96 \mathrm{~K}$} \\
\hline \multicolumn{6}{|c|}{ Collection Date/Time: 1/11/1998 12:00 PM } \\
\hline \multicolumn{6}{|c|}{ Matrix: W-GROUND } \\
\hline Lab 10 & Storet Code & Component & Result & Code & Units \\
\hline \multicolumn{6}{|l|}{302299} \\
\hline \multicolumn{6}{|c|}{ Test: Metals, dis solved, in filtered, aqueous samples using ICP mass spectros COPy. (EPA $200.8 \mathrm{mod}$ ) } \\
\hline & 01000 & Arsenic & 45.1 & & ug $/$ \\
\hline
\end{tabular}

Sample Location: WPBCC

Field ID: $7 \mathrm{~L}: 96 \mathrm{~K}$

Collection Date/Time: 1/11/1998 12:00 PM

Matrix: W-GROUNO

LabID Storet Code Component Result Code Units
302300

Test: Metals, dissolved, in filtered, aqueous samples using ICP mass spectros copy. (BPA 200.8 mod.)

01000 Arsenic $\quad 46.8$ ugh

Sample Location: WPBCC

Field ID: AS-100A

Collection Date/Time: 1/7/1998 9:10 AM

Matrix: W-GROUND

$\begin{array}{ll}\text { Lab ID Staret Code Component } & \text { Result Code Units } \\ 302267 & \end{array}$

Test: Metals, dissolved, in filtered, aqueous samples using ICP mass spectros copy. (EPA 200.8 mod.)

$01000 \quad$ Arsenic $\quad 47.2 \quad$ ugh

Sample Location: WPBCC

Field ID: AS-200A

Collection Date/Time: 1/7/1998 9:00 AM

Matrix: W-GROUND

Lab I0 Storet Code Component Result Code Units

302268

Test: Metals, dissolved, in filtered, aqueous samples using $1 \mathrm{CP}$ mass spectros copy. (EPA $200.8 \mathrm{mod}$ )
01000
Arsenic
71.5
ugh 
Sample Location: WPBCC

Field 1D: AS-25A

Collection Date/Time: 1/7/1998 9:10 AM

Matrix: W-GROUND

Labio Storet Code Component Result Code Units
302265

Test: Metals, dissolved, in fittered, aqueous samples using ICP mass spectros copy. (EPA 200.8 mod.)
01000
Arsenic
9.6
ugh

Sample Location: WPBCC

Field ID: AS-50A

Collection Date/Time: 1/7/1998 9:00 AM

Matrix: W-GROUND

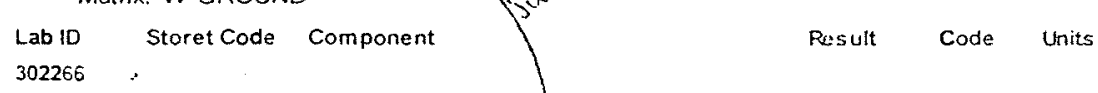

Test: Metals, dissolved, in fittered, aqueous samples using ICP mass spectros copy. (BPA 200.8 mod.)

Sample Location: WPBCC
Field ID: AS-5A

Collection DaterTime: 1/12/1998 4:10 PM

Matrix: W-GROUND

LabID Storet Code Component Pesult Code Units

302312

Test: Metals, dissolved, in fittered, aqueous samples using ICP mass spectros copy. (EPA 200.8 mod.)
01000
Arsenic
22.8
ugh

Sample Location: WPBCC

Field ID: CONTROL II

Collection Date/Time: 1/12/1998 4:10 PM

Matrix: W-GROUND

LabID StoretCode Component Result Code Units

302313

Test: Metals, dissolved, in filtered, aqueous samples using ICP mass spectros copy. (EPA 200.B mod.)

\begin{tabular}{rllll}
01000 & Arsenic & 2 & $u$ & ugh \\
\hline
\end{tabular}

Sample Location: WPBCC

Field ID: CONTROL IV

Collection Date/Time: 1/9/1998 2:00 PM

Matrix: W-GROUND

LabID Storet Code Component Result Code Units

302314

Test: Metals, dissolved, in filtered, aqueous samples using ICP mass spectros copy. (EPA 200.8 mod.)
01000
Arsenic
2
U ugn 


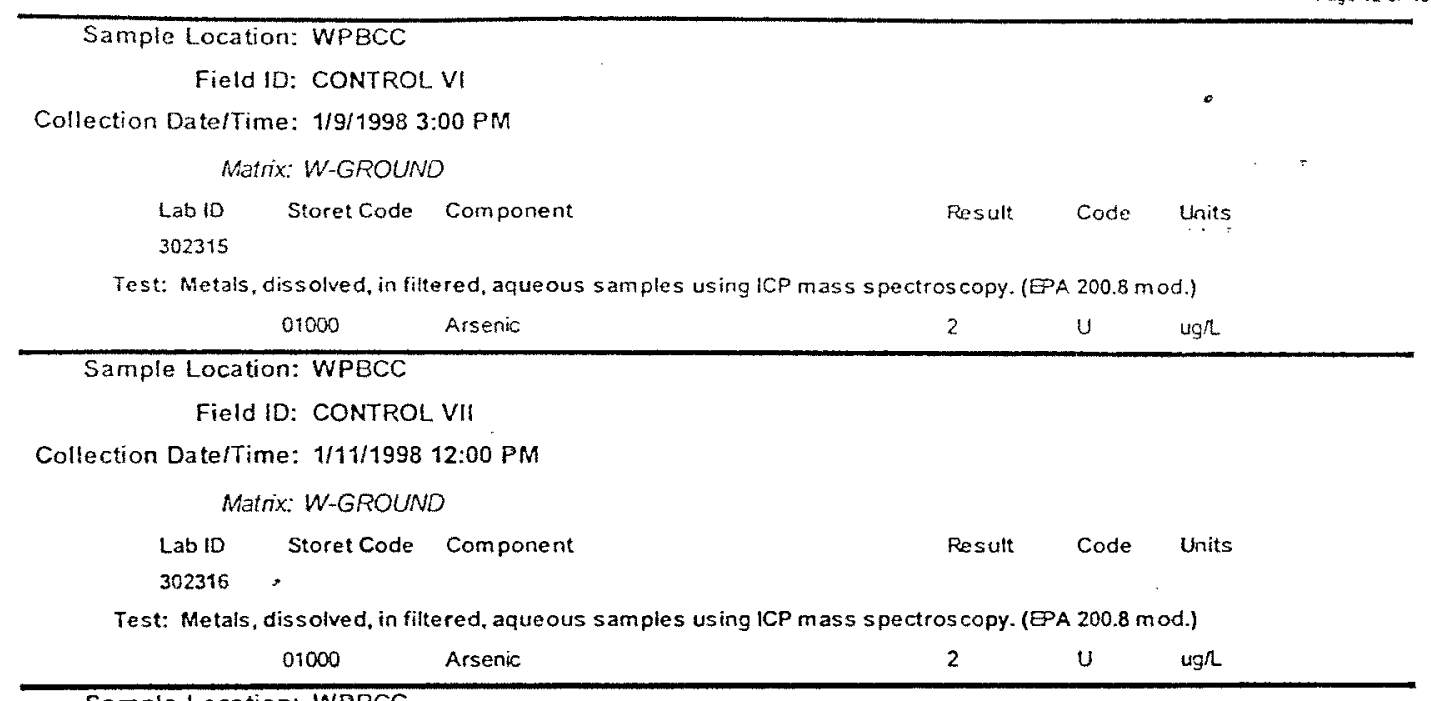

Sample Location: WPBCC

Field ID: GD:2D

Collection DatefTime: 11/4/1997 3:00 PM

Matrix: S-SOIL

LabID Storet Code Component Pesult Code Units
302255

Test: Metals, total recoverable, in solid samples using ICP em is sion spectros copy. ( $\square$ A 6010 mod.)

The Fe precision was outside the control limts.

$\begin{array}{lllll}01003 & \text { Arsenic } & 8 & U & \mathrm{mg} / \mathrm{kg} \\ 01170 & \text { tron } & 237 & \mathrm{~J} & \mathrm{mg} / \mathrm{kg}\end{array}$

302260

Test: Total Phosphorus in solid matrices ( $\odot$ A 365.4 mod.)

Sample expired prior to receipt.

$\begin{array}{llll}\text { TotatP } & 32 & \mathrm{Q} & \mathrm{rg} / \mathrm{kg}\end{array}$

Sample Location: WPBCC

Field ID: GD:3D

Collection Date/Time: 11/4/1997 3:00 PM

Matrix: S-SOIL

Lablo Storet Code Component Result Code Units

302256

Test: Metals, total recoverable, in solid sam ples using ICP emission spectroscopy. (GA 6010 mod.)

The Fe precision w as outside the control limts.

$\begin{array}{lllll}01003 & \text { Arsenk } & 7 & \mathrm{U} & \mathrm{mg} / \mathrm{kg} \\ 01170 & \text { Iron } & 43.5 & \mathrm{~m} & \mathrm{mg} / \mathrm{kg}\end{array}$

302261

Test: Total Phosphorus in solid $m$ atrices (EPA $365.4 \mathrm{mod}$ )

Sample expired prior to receipt. 
Sample Location: WPBCC

Field 1D: GD:4D

Collection Date/Time: 11/4/1997 3:00 PM

Matrix: S-SOIL

\begin{tabular}{|c|c|c|}
\hline Lab 10 & Storet Code & Component \\
\hline
\end{tabular}

Test: Metals, total recoverable, in solid samples using 1 CP em is sion spectroscopy. (EPA 6010 mod)

The Fe precision was outside the control firrts.

$\begin{array}{lllll}01003 & \text { Arsenic } & 8 & \text { U } & 1 \mathrm{rg} / \mathrm{kg} \\ 01170 & \text { hon } & 34.5 & J & \mathrm{mg} / \mathrm{kg}\end{array}$

302262

Test: Total Phosphorus in solid matrices (EPA 365.4 mod.)

Sample expired prior to receipt.

$\begin{array}{lllll}3 & \text { TotatP } & 120 & \mathrm{rg} & \mathrm{kg}\end{array}$

Sample Location: WPBCC

Field ID: GD:5D

Collection Date/Time: 11/4/1997 3:00 PM

Matrix: S-SOIL
Lab ID
Storet Code
Component
Result
Code Units

302258

Test: Metals, total recoverable, in solid samples using ICP emis sion spectroscopy. (EPA $6010 \mathrm{mod}$.)

The As MO was adjusted due to matrix interference. The Fe precision w as outside the control lirits.

$\begin{array}{lllll}01003 & \text { Arsenic } & 20 & \mathrm{U} & \mathrm{mg} / \mathrm{kg} \\ 01170 & \text { tron } & 1530 & \mathrm{~J} & \mathrm{mg} / \mathrm{kg}\end{array}$

302263

Test: Total Phosphorus in solid matrices (EPA 365.4 mod.)

Sample expired prior to receipt.

TotatP

390

Q $\quad m g k g$

Sample Location: WPBCC

Field 1D: SURF 4"-9"D

Collection Date/Time: 11/4/1997 3:00 PM

Matrix: S-SOIL

Lab 10 Storet Code Component Result Code Units

302259

Test: Metals, total recoverable, in solid samples using ICP emis sion s pectroscopy. (EPA $6010 \mathrm{mod}$ )

The Fe precision was outside the control imits

$\begin{array}{lllll}01003 & \text { Arsenic } & 7 & \mathrm{U} & \mathrm{mg} / \mathrm{kg} \\ 01170 & \text { tron } & 233 & J & \mathrm{mg} / \mathrm{kg}\end{array}$

302264

Test: Total Phosphorus in solid matrices ( $P$ A $365.4 \mathrm{mod}$ )

Sample expired prior to receipt

$\begin{array}{lllll}\text { TotalP } & 32 & \mathrm{mg} / \mathrm{kg}\end{array}$


SE-DIST-1998-01-20-01 Serial Number: 0000009 Section 2 of 2 Quality Comrod Repor Page i of 1

Quality Control Report

* - Item failed QC

Test Analyte

5. 10 Arsenic

Eatch ID: 30618

S. $1 \mathrm{CP}$

Batch fD: 30618

- ltem failed OC

Test Analyte

S-TP Total

Batch 1D: 30488

* Hem failed QC

Test Analyte

W-KPMS-F Arseriic

Batch 10: 30649

Batch ID: 30571

Eatch ID: 30672

Batch ID: 30673
Job 10: TLH-1998-01-20-29

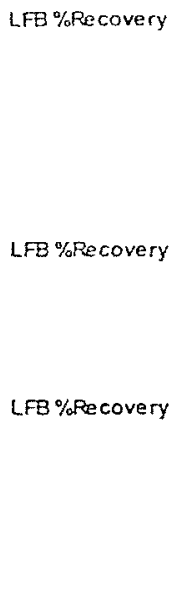

MS \%Recovery

$91.9 \quad 97.8$

99.3

Job ID: TLH-1998-01-20-30

MS \%Recovery

$91.3 \quad 92.3$

Job ID: TLH-1998-01-20-31

MS \%Recovery

$94.7 \quad 96.3$

82.483 .8

$93.7 \quad 94.4$

93.395 .2
Precision \%FOD Precision \%RSD

F, 16

$73.2^{*}$

Precision \%RPD Precision $\%$ RSO

6.40

Precision \%RPD Precision \%RSD

1.65

0.0834

0.735

1.99 


\section{Chemical Analysis Report}

Event Name (ID): SE-DIST-1998-05-12-01
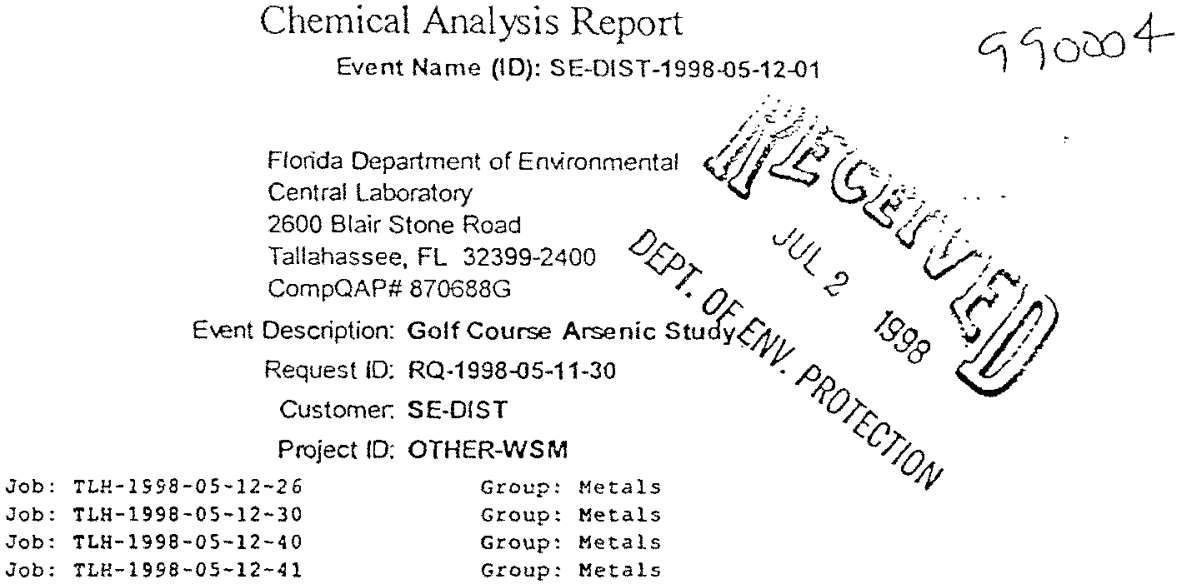

For additional information please contact Timothy W. Fitzpatrick

Yuh-Hsu Pan, Ph.D.

Julio Arrecis, Ph.D.

Liang-Tsair Lin, Ph.D.

Suncom 277-2571 Phone (850) 487-2571

Certifed By: $\quad 20$

Date: $6-30-98$

Report Printed Date: Jun 26, 1998

Abbreviations and data remark codes

A - Value reported is the rean of two or more determinations

B- Resuth based on colony counts outside the acceptable range.

1. Value reported is kss than the mininum quantitation limit, and greater than or equal to the

minimum detection limt

J. Estirated value

$K$ - Actual value is known to be less than value given

$L$. Actual value is know $n$ to be greater than value given

$N$ - Presumptive evidence of presence of material.

O- Sampled, but anatysis lost or not performed

Q- Sample held beyond normal holding tire.

$T$. Value reported is less than the crierion of defection.

$U$ - Material was anatyzed for but not detected, The value reported is the rrinimum detection linit

$V$ - Analyte was detected in both sample and method blank.

$Z$. Colonies were too numerous to count (TNT). 
Sample Location: WPBCC

Field 1D: 00:05

Collection Date/Time: 5/41998 12:00 AM

Matrix: W-OTHER

Lablo Storet Code Component Result Code Urits-

Test: Metals, dis solved, in filtered, aqueous samples using ICP mass spectros copy. (EPA 200.8 mod.)

01000 Arsenic $2 \quad U$ ugh

Sample Location: WPBCC

Field tD: 05:05

Collection Date/Time: 5/4/1998 12:00 AM

Matrix: W-OTHER

Lab 10 Storet Code Component Result Code Units

323803

Test: Metals, dissolved, in fittered, aqueous samples using ICP mass spectroscopy. (EPA 200.8 mod.)
01000
Arsenic
6100
ugn

Sample Location: WPBCC

Field ID: 0:10

Collection Date/Time: 4/2/1998 12:00 AM

Matrix: W-OTHER

Lab I0 Storet Code Component Result Code Units

323666

Test: Metals, diss olved, in filtered, aqueous samples using ICP mass spectroscopy. (EPA 200.8 mod.)
01000
Arsenic
ugh

Sample Location: WPBCC

Field ID: 0:100

Collection Date/Time: 4/30/1998 12:00 AM

Matrix: W-OTHER

$\begin{array}{llll}\text { Lablo Storet Code Component } & \text { Result Code Lnits } \\ 323809 & & \end{array}$

Test: Metals, dissolved, in filtered, aque ous samples using ICP mass spectros copy. (EPA 200.8 mod.)

$01000 \quad$ Arsenic $\quad 2 \quad$ U ugh

Sample Location: WPBCC

Field ID: 0:50

Collection Date/Time: 4/3/1998 12:00 AM

Matrix: W-OTHER
Lablo Storet Code Component Result Code Units
323498

Test: Metals, dis solved, in filtered, aqueous samples using ICP mass spectros copy. (EPA $200.8 \mathrm{~m}$ od.)
01000
Arsenic
U ug/L 
Sample Location: WPBCC

Field ID: 1 BLANK:10

Collection Date/Time: 4/3/1998 12:00 AM

Matrix: W-OTHER

$\begin{array}{lll}\text { Lab 1D Storet Code Component } & \text { Result Code Units = } \\ 323475 & & \end{array}$

Test: Metals, dissolved, in filtered, aqueous samples using ICP mass spectros copy. (EPA 200.8 mod.)
01000
Arsenic
$U \quad u g h$

Sample Location: WPBCC

Field ID: 1 BLANK:50

Collection DaterTime: 4/3/1998 12:00 AM

Matrix: W-OTHER

Lab ID StoretCode Component Result Code Units
323474

Test: Metals, dissolved, in filtered, aqueous samples using ICP mass spectros copy. (EPA 200.8 mod.)

Comments:

The As resutt was confirmed on 05/27/98.
01000
Arsenic
452
$\operatorname{tgh}$

Sample Location: WPBCC

Field ID: 100:100

Collection Date/Time: 5/1/1998 12:00 AM

Matrix: W-OTHER

Lab to Storet Code Component Result Code Uhits

323808

Test: Metals, dissolved, in fittered, aqueous samples using ICP mass spectroscopy. (EPA 200.8 mod.)

01000 Arsenic $\quad 93.1 \quad$ ugh

Sample Location: WPBCC

Field 10: 10:10

Collection Date/Time: 4/2/1998 12:00 AM

Matrix: W-OTHER

Labio Storet Code Component Result Code Units

323663

Test: Metals, dissolved, in filtered, aqueous samples using ICP mass spectros copy. (EPA 200.8 mod.)

$01000 \quad$ Arsenic $0.5 \quad$ ugh

Sample Location: WPBCC

Field 1D: 11:100

Collection Date/Time: 5/1/1998 12:00 AM

Matrix: W-OTHER
1 ab 10
Storet Code Component
Resuit
Code Units 323483

Test: Metals, dissolved, in filtered, aqueous samples using ICP mass spectroscopy. (EPA 200.8 mod.)
01000
Arsent:
87.3
ug/ 
Sample Location: WPBCC

Field 10: 11:16

Collection Date/Time: 3/2/1998 12:00 AM

$$
\text { Matrix: W-OTHER }
$$

Lab 10 StoretCode Component Result Code Units.

Test: Metals, dissolved, in fittered, aqueous samples using ICP mass spectros copy. (EPA 200.8 mod.)
01000
Arsenic
13.4
$\operatorname{ug}$ R

Sample Location: WPBCC

Fie!d ID: 11:200

Collection Date/Time: 5/1/1998 12:00 AM

Matrix: W-OTHER

Lab ID Storet Code Component .. Result Code Urits

Test: Metals, dissolved, in filtered, aqueous samples using ICP mass spectros copy. (EPA 200.8 mod.)

$01000 \quad$ Arsenic $139 \quad$ ugh

Sample Location: WPBCC

Field ID: $11: 50$

Collection DaterTime: 4/3/1998 12:00 AM

Matrix: W-OTHER

Lablo StoretCode Component Result Code Units

Test: Metals, dissolved, in filtered, aqueous samples using ICP mass spectroscopy. (EAA 200.8 mod.)

$01000 \ldots$ Arsenic
Sample Location: WPBCC
Field ID: $11: 96$

Collection Date/Time: 3/4/1998 12:00 AM

Matrix: W-OTHER

$\begin{array}{llll}\text { Lablo Storet Code Component Result Code Units } \\ 323805 & & \end{array}$

Test: Metals, dissolved, in filtered, aqueous samples using ICP mass spectros copy. (EPA 200.8 mod.)

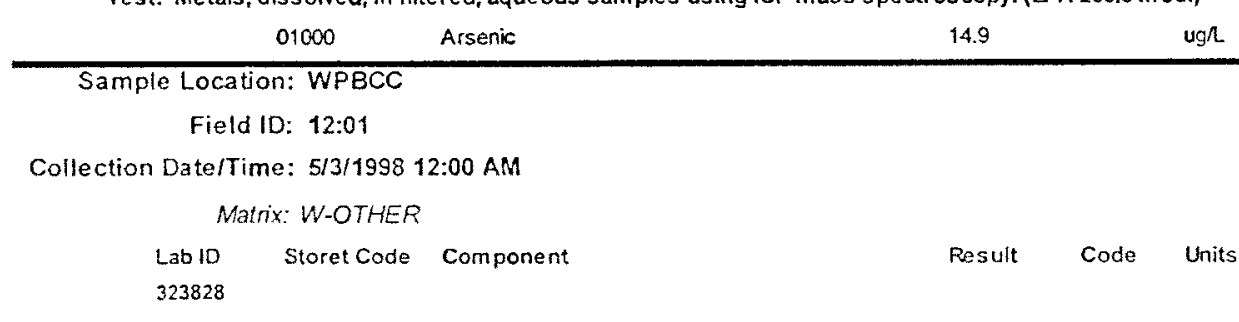

Test: Metals, dissolved, in filtered, aque ous samples using ICP mass spectroscopy. (EPA. 200.8 mod.)
01000
Arsenic
864
$\lg h$ 
Sample Location: WPBCC

Field 1D: 12:05

Collection Date/Time: 5/4/1998 12:00 AM

Matix: W-OTHER

LablD Storet Code Component Result Code Units.
323674

Test: Metals, dissolved, in filtered, aqueous samples using ICP mass spectros copy. (EPA 200.8 mod.)

\begin{tabular}{cccc}
01000 & Arsenic & 5840 & ugh \\
\hline Sample Location: WPBCC &
\end{tabular}

Field ID: $12: 10$

Collection Date/Time: 4/2/1998 12:00 AM

Matrix: W-OTHER

Lab tD Storetccte Component Result Code Units
323506

Test: Metals, dissolved, in filtered, aqueous samples using ICP mass spectroscopy. (EPA 200.8 mod.)

\begin{tabular}{cccc}
01000 & Arsenic & 7.7 & ugh \\
\hline Sample Location: WPBCC &
\end{tabular}

Field 10: 12:100

Collection Date/Time: 5/1/1998 12:00 AM

Matix: W-OTHER

$\begin{array}{llll}\text { Lablo Storet Code Component } & \text { Result Code Units } \\ 323821 & & \end{array}$

Test: Metals, dissolved, in filtered, aqueous samples using ICP mass spectros copy. (EPA 200.8 mod.)

\begin{tabular}{cccc}
01000 & Arsenic & 93.2 & ug $/$ \\
\hline Sample Location: WPBCC &
\end{tabular}

Sample Location: WPBCC

Field 10: 12:200

Collection Date/Time: 5/1/1998 12:00 AM

Matrix: W-OTHER

Lablo Storet Code Component Result Code Units
323813

Test: Metals, dissolved, in filtered, aqueous samples using ICP mass spectros copy. (EPA 200.8 mod.)

\begin{tabular}{|c|c|c|c|c|}
\hline & Arsenic & 141 & & $\operatorname{ug} \Omega$ \\
\hline \multicolumn{5}{|c|}{ Sample Location: WPBCC } \\
\hline \multicolumn{5}{|c|}{ Field ID: $12: 50$} \\
\hline \multicolumn{5}{|c|}{ Collection Date/Time: 4/3/1998 12:00 AM } \\
\hline \multicolumn{5}{|c|}{ Matrix: W-OTHER } \\
\hline Lab 10 & Storet Code & Result & Code & Units \\
\hline 323826 & & & & \\
\hline
\end{tabular}
01000
Arsenic
47.7
ugh. 
Sample Location: WPBCC

Field ID: 12:96

Collection Date/Time: 3/4/1998 12:00 AM

Matrix: W-OTHER

Labid Storet Code Component Result Code Units.
323468

Test: Metals, dissolved, in fittered, aqueous samples using ICF mass spectros Copy. (EPA 200.8 mod.)
01000
Arsenic
10.9
$\operatorname{ug} h$

Sample Location: WPBCC

Field ID: 2 BLANK: 10

Collection Date/Time: $4 / 3 / 1998$ 12:00 AM

Matrix: W-OTHER

LabID StoretCode Component Result Code Units 323667

Test: Metals, dissolved, in filtered, aqueous samples using ICP mass spectros Copy. (EPA 200.8 mod.) $01000 \quad$ Arsenic $\quad 2 \quad$ u ugh

Sample Location: WPBCC

Field ID: 2 BLANK:50

Collection Date/Time: 4/3/1998 12:00 AM

Matrix: W-OTHER

LabID StoretCode Component Result Code Units

323822

Test: Metals, dissolved, in filtered, aqueous samples using ICP mass spectroscopy. (EPA 200.8 mod.)

Comrents:

The As resutt was confirmed on $6 / 16198$

01000 Arsenic

47.7

$\operatorname{ug} \Omega$

Sample Location: WPBCC

Field ID: 21:05

Colfection Date/Time: 5/4/1998 12:00 AM

Matrix: W-OTHER

Lab ID StoretCode Component Result Code Units

323503

Test: Metals, dissolved, in fittered, aqueous samples using ICP mas s pectroscopy. (EPA 200.8 mod.)

01000

Arsenic

4520

ught

Sample Location: WPBCC

Field 1D: 21:10

Collection Date/Time: 4/2/1998 12:00 AM

Matrix: W-OTHER

Lab ID Storetcode Component Result Code Units

323662

Test: Metals, dissoived, in filtered, aqueous samples using 1CP mass spectros copy. (BPA 200.8 mod.)

$01000 \quad$ Arsenic

9.3

$u g h$. 
Sample Location: WPECC

Field ID: 21:100

Collection Date/Time: 5/1/1998 12:00 AM

Matrix: W-OTHER

Lab 10 Storet Code Component Result Code Units.
323510

Test: Metals, dissolved, in filtered, aqueous samples using ICP mass spectros copy. (EPA 200.8 mod.)

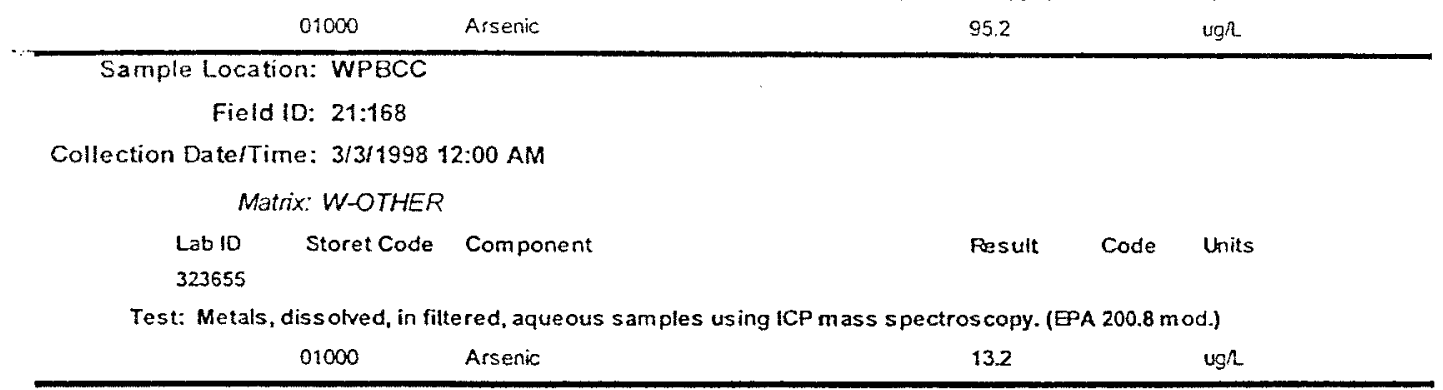

Sample Location: WPBCC

Field ID: $21: 200$

Collection Date/Time: $5 / 1 / 1998$ 12:00 AM

Matrix W-OTHER

$\begin{array}{llll}\text { Lab ID Storet Code Component Result Code Units } \\ 323827 & \end{array}$

Test: Metals, dissolved, in filtered, aque ous samples using ICP mass spectros copy. (EPA 200.8 mod.)

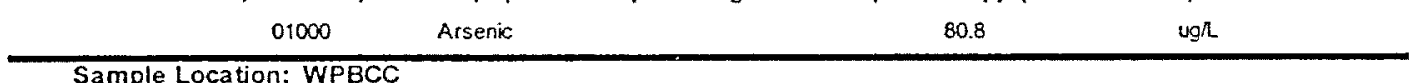

Sample Location: WPBCC

Field ID: $21: 50$

Collection Date/Time: 4/3/1998 12:00 AM

Matrix: W-OTHER

Lab ID Storet Code Component Result Code Units
323504

Test: Metals, dissolved, in filtered, aqueous samples using ICP mass spectros copy. (EPA 200.8 mod.)

$\begin{array}{cccc}01000 & \text { Arsenic } & 46.5 & \text { ug } \Omega \\ \text { Field ID: } & 21: 96 & & \\ \text { Sample Location: WPBCC } & & & \\ \text { Collection Date/Time: } 3 / 411998 & 12: 00 \mathrm{AM} & & \\ \text { Matrix: W-OTHER } & \text { Storet Code Component } & \text { Result } & \text { Code Units } \\ \text { Lablo } 323467 & & & \end{array}$

Test: Metals, dissolved, in filtered, aqueous samples using ICP mass spectros copy. (EPA 200.8 mod.)
01000
Arsenic
10.7
ugh 
Sample Location: WPBCC

Field 10: 22:01

Collection Date/Time: 5/3/1998 12:00 AM

Matix: W-OTHER

Lab to Storet Code Component Result Code Units.

323671

Test: Metals, dissolved, in fiftered, aqueous samples using ICP mass spectroscopy. (EPA 200.8 mod.)

$$
01000 \quad \text { Arsenic }
$$

827

ugh

Sample Location: WPBCC

Field 10: 22:05

Collection Date/Time: 5/4/1998 12:00 AM

Matix: W-OTHER

Lab ID Storet Code Component Posult Code Units

323801

Test: Metals, dissolved, in filtered, aqueous samples using ICP mass spectros copy. (EPA 200.8 mod.)

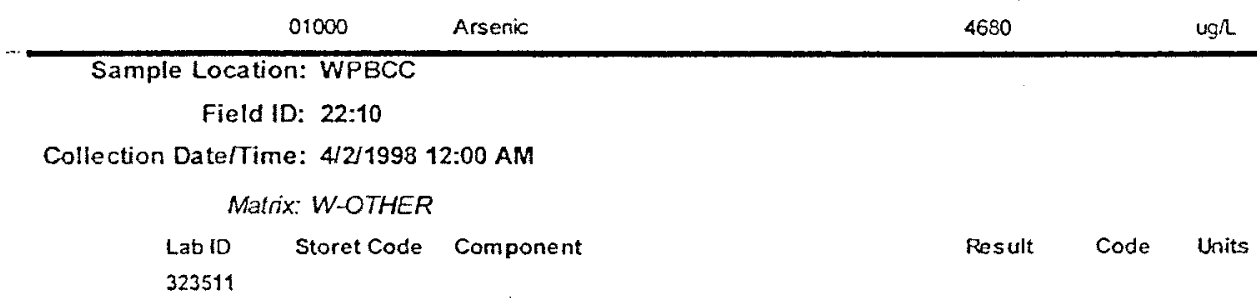

Test: Metals, dissolved, in fittered, aqueous samples using ICP mass spectros Copy. (EPA 200.8 mod.)

$$
01000 \text { : Arsenic }
$$

10.4

ugh

Sample Location: WPBCC

Field 1D: 22:100

Collection Date/Time: 5/1/1998 12:00 AM

Matrix: W-OTHER

Lab ID Storet Code Component Result Code Units

323484

Test: Metals, dissolved, in filtered, aqueous samples using ICP mass spectroscopy. (EPA 200.8 mod.) $01000 \quad$ Arsenic $\quad 86.9 \quad \mathrm{ug} / \mathrm{h}$

Sample Location: WPBCC

Field 1D: $22: 200$

Collection Date/Time: 5/1/1998 12:00 AM

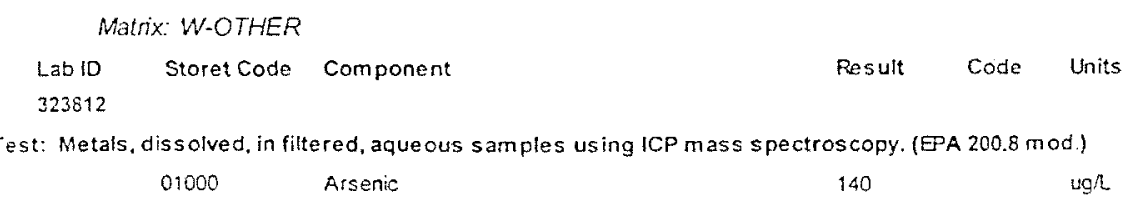


Sample Location: WPBCC

Field ID: $22: 50$

Collection Date/Time: 4/3/1998 12:00 AM

$$
\text { Matrix: W-OTHER }
$$

\begin{tabular}{|c|c|c|}
\hline Lab ID & Storet Code & Component \\
\hline
\end{tabular}

Test: Metals, dissolved, in fitered, aqueous samples using 1 CP mas s sectros copy. (EPA 200.8 mod.)

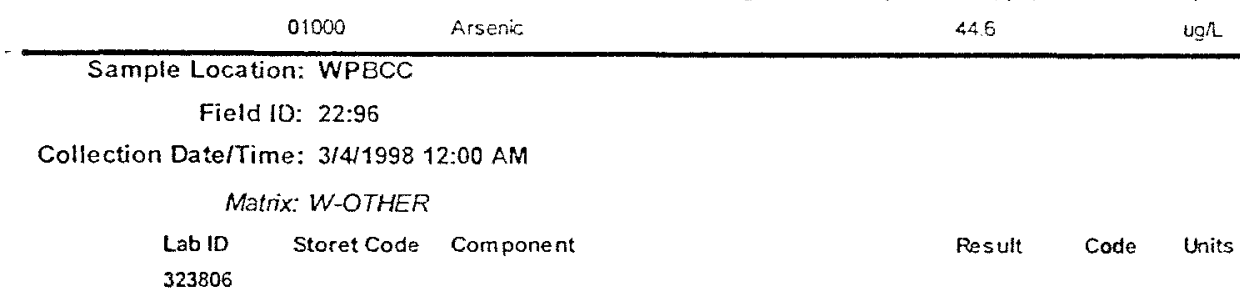

Test: Metals, dissolved, in filtered, aqueous samples using ICP mass spectros copy. (EPA 200.8 mod.)

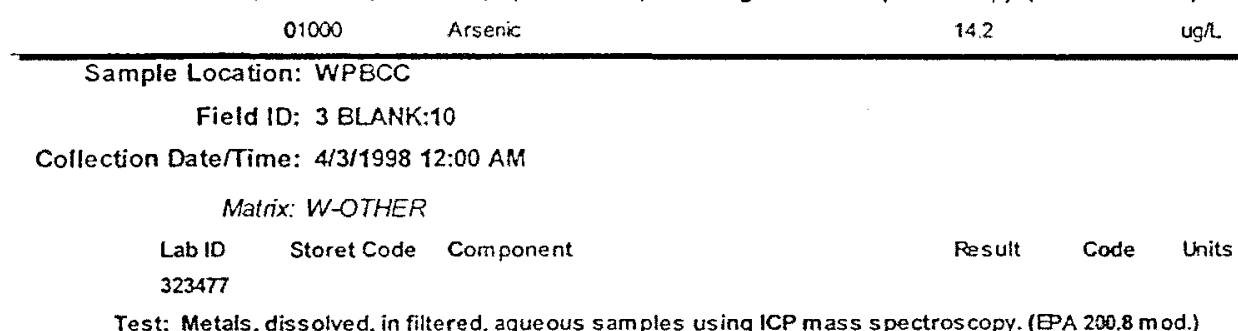

Test: Metals, dissolved, in filtered, aqueous samples using ICP mas s sectros copy. (EPA 200.8 mod.)

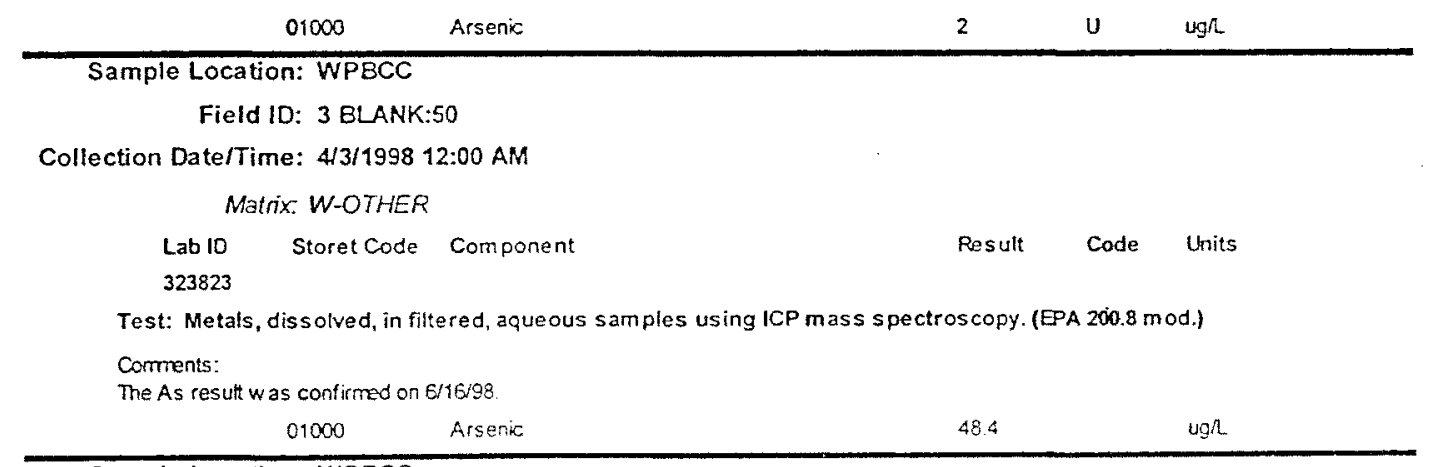

Sample Location: WPBCC

Field 10: 31:01

Collection Date/Time: 5/3/1998 12:00 AM

Matrix: W-OTHER
LabID StoretCode Component
323672
est: Metals, dissolved, in fittered, aqueous samples using ICP mass spectros COPy. (PPA 200.8 mod.)

$01000 \quad$ Arsenic $811 \quad \mathrm{ugh}$ 
Sample Location: WPBCC

Field ID: 31:05

Collection Date/Time: 5/4/1998 12:00 AM

Matrix: W-OTHER
Lablo Storetcode Component Result Code Units.
323496

Test: Metals, dissolved, in filtered, aqueous samples using ICP mass spectros copy. ( $\odot$ A 200.8 mad.)

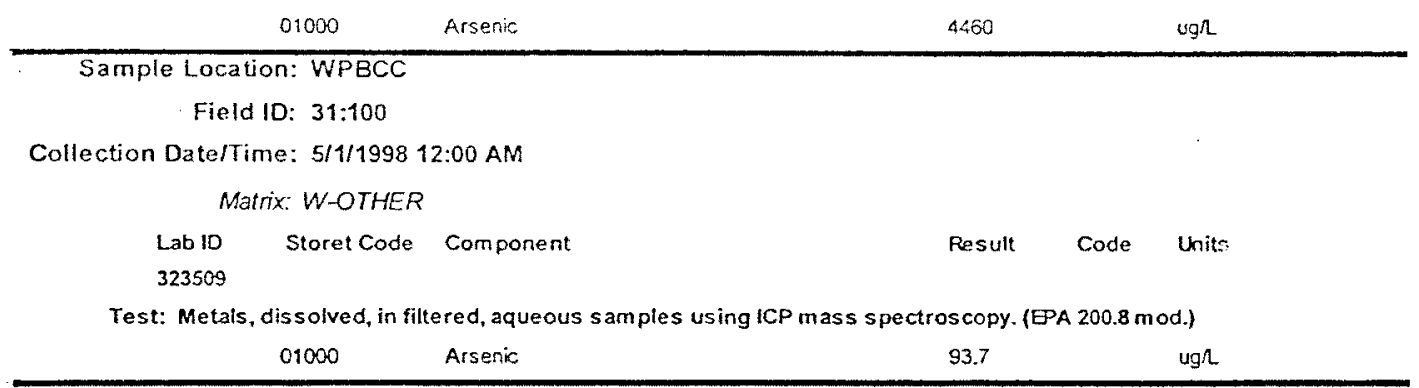

Sample Location: WPBCC

Field ID: $31: 200$

Collection Date/Time: 5/1/1998 12:00 AM

Matrix: W-OTHER

Lablo StoretCode Component Result Code inits

323818

Test: Metals, dissoived, in filtered, aqueous samples using ICP mass spectros copy. (EPA 200.8 mod.)

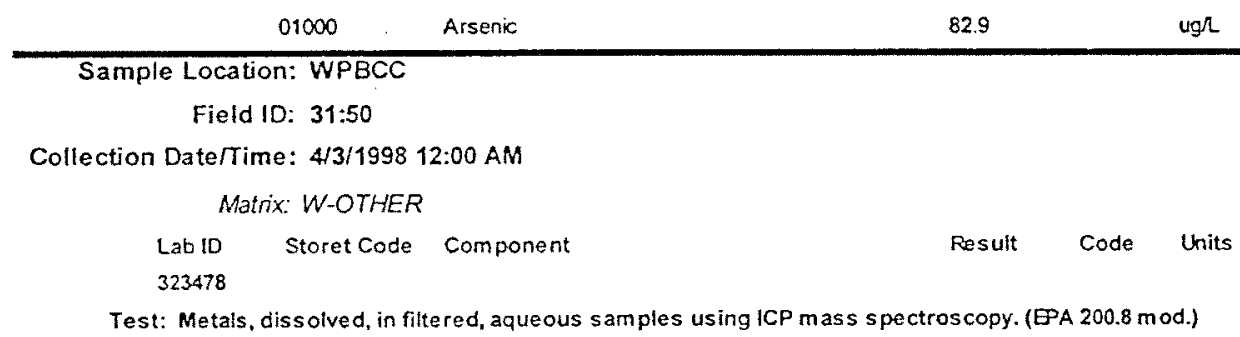

\begin{tabular}{c}
01000 \\
\hline Sample Location: WPBCC \\
Field ID: 32.05
\end{tabular}

Collection Date/Time: 5/4/1998 12:00 AM

Matrix: W-OTHER
Lab10 Storet Code Component
323677
Test: Metals, dissolved, in filtered, aqueous samples using ICP mass spectros copy. (EPA 200.8 mod.)
\[ \begin{array}{llcl}01000 & \text { Arsenic } & 4580 & \text { ugh }\end{array} \]


Sample Location: WPBCC

Field ID: $32: 10$

Collection Date/Time: 4/7/1998 12:00 AM

Matrix: W-OTHER

Labio StoretCode Component Result Code Units.

323669

Test: Metals, dissolved, in filtered, aqueous samples using ICP mass spectros copy. (EPA 200.8 mod.)

\begin{tabular}{cccc}
01000 & Arsenic & 8.4 & ug $/$ \\
\hline
\end{tabular}

Sample Location: WPBCC

Fieid ID: $32: 100$

Collection Date/Time: 5/1/1998 12:00 AM

Matrix: W-OTHER

LablD StoretCode Component .. Result Code Units

Test: Metals, dissolved, in filtered, aqueous samples using ICP mass spectros copy. (EPA 200,8 mod.)
01000
Arsenic
88.6
ugh

Sample Location: WPBCC

Field ID: $32: 200$

Collection DaterTime: 5/1/1998 12:00 AM

Matrix: W-OTHER

LabID StoretCode Component Result Code Units

323814

Test: Metals, dissolved, in filtered, aqueous samples using ICP mass spectroscopy. (EPA $200.8 \mathrm{mod}$.)

$01000 \quad$ Arsenic $142 \quad$ ugh

\section{Sample Location: WPBCC}

Field ID: $32: 50$

Collection Date/Time: 4/3/1998 12:00 AM

Matrix: W-OTHER

Lab ID StoretCode Component Result Code Units

Test: Metals, dissolved, in filtered, aqueous samples using ICP mass spectroscopy. (EPA 200.8 mod.)

\begin{tabular}{|c|c|c|c|c|c|}
\hline & 01000 & Arsenic & 40.5 & & $\operatorname{ug} h$ \\
\hline \multicolumn{6}{|c|}{ Sample Location: WPBCC } \\
\hline \multicolumn{6}{|c|}{ Field ID: $3 \mathrm{~A}: 8 \mathrm{~K}$} \\
\hline \multicolumn{6}{|c|}{ Collection Date/Time: 2/3/1998 12:00 AM } \\
\hline \multicolumn{6}{|c|}{ Matrix: W-OTHER } \\
\hline Lab 10 & Storet Code & Component & Result & Code & Units \\
\hline \multicolumn{6}{|l|}{323457} \\
\hline & & & & & Test: Metals, dis solved, in filtered, aqueous samples using ICP mass spectros copy. (EPA 200.8 mod.) \\
\hline & 01000 & Arsenic & 97.1 & & $u g h$ \\
\hline
\end{tabular}


Sample Location: WPBCC

Field 10: 3C:8K

Collection Date/Time: 2/3/1998 12:00 AM

Matrix: W-OTHER
LablD Storet Code Component Result Code Units -
323651

Test: Metals, dissolved, in fittered, aqueous samples using ICP mass spectroscopy. (EPA 200.8 mod.)
01000
Arsenic
2
U ugh

Sample Location: WPBCC

Field ID: 3D:8K

Collection Date/Time: 2/3/1998 12:00 AM

Matrix: W-OTHER

$\begin{array}{llll}\text { Lab ID } & \text {. Storet Code Component } & \text { Result Code Units }\end{array}$

Test: Metals, dissolved, in filtered, aqueous samples using ICP mass spectros copy. ( $\$ P A 200.8$ mod.)

$$
01000 \quad \text { Arsenic }
$$

100

ugh

Sample Location: WPBCC

Field ID: 3E:8K

Collection Date/Time: 2/3/1998 12:00 AM

Matrix: W-OTHER

Lab ID Storet Code Component Result Code Units
323650

Test: Metals, dissolved, in fitered, aqueous samples using ICP mass spectros copy. (EPA 200.8 mod.)
01000
Arsenic
103
$\operatorname{ug} \Omega$

Sample Location: WPBCC

Field ID: $3 F: 8 \mathrm{~K}$

Collection Date/Time: 2/3/1998 12:00 AM

Matrix: W-OTHER

Lab 10 Storet Code Component Result Code Units 323459

Test: Metals, dissolved, in filtered, aqueous samples using ICP mass spectros COpy, (EPA 200.8 mod.)

$01000 \quad$ Arsenic $\quad 2 \quad u \quad u g h$

Sample Location: WPBCC

Field ID: 4 BLANK:10

Collection Date/Time: 4/3/1998 12:00 AM

Matrix: W-OTHER
Lablo Storet Code Component Result Code Units
323476
st: Metals, dissolved, in filtered, aqueous samples using ICP mass spectros COPy. (EPA 200.8 mod.)
01000
Arsenic
2
$u \quad$ ug $h$ 
Sample Location: WPBCC

Field ID: 4 BLANK:50

Collection DatelTime: 4/3/1998 12:00 AM

Matrix: W-OTHER

LabID Storet Code Component Pesult Code Units.

323816

Test: Metals, dissolved, in filtered, aqueous samples using ICP mass spectros Copy. (EPA 200.8 mod.)
01000
Arsenic
U
ugh

Sample Location: WPBCC

Field 1D: 41:01

Collection Date/Time: 5/3/1998 12:00 AM

Matrix: W-OTHER

LabID Storet Code Component Result Code Uhits 323508

Test: Metals, dissolved, in filtered, aqueous samples using ICP mass spectros copy. (EPA 200.8 mod.)
01000
Arsenic
842
uQA

Sample Location: WPBCC

Field ID: 41:05

Collection Date/Time: 5/4/1998 12:00 AM

Matrix: W-OTHER

Lablo StoretCode Component Pesult Code Units 323502

Test: Metals, dissolved, in filtered, aque ous samples using ICP mass spectros copy. (EPA 200.8 mod.)
01000
Arsenic
6060
ugh

Sample Location: WPBCC

Field ID: 41:10

Collection DaterTime: 4/7/1998 12:00 AM

Matrix: W-OTHER
Lab ID Storet Code Component Result Code Units
323668

Test: Metals, dissolved, in filtered, aqueous samples using 1CP mass spectros copy. (EPA 200.8 mod.)
01000
Arsenic
8.8
ugh

Sample Location: WPBCC

Field 1D: $41: 200$

Collection Date/Time: 5/1/1998 12:00 AM

Matrix: W-OTHER

Lab ID Storet Code Component Result Code Units 323811

Test: Metals, dis solved, in filtered, aqueous samples using ICP mass spectros copy. (EPA 200.8 mod.)
01000
Arsenic
140
$\operatorname{ug} 1$ 
Sample Location: WPBCC

Field 10: $41: 50$

Collection Date/Time: 4/3/1998 12:00 AM

Matrix: W-OTHER
Lab10 Storet Code Component Result Code Units:
323472

Test: Metals, dissolved, in fittered, aqueous samples using ICP mass spectros copy. ( $P$ A 200.8 mod.)

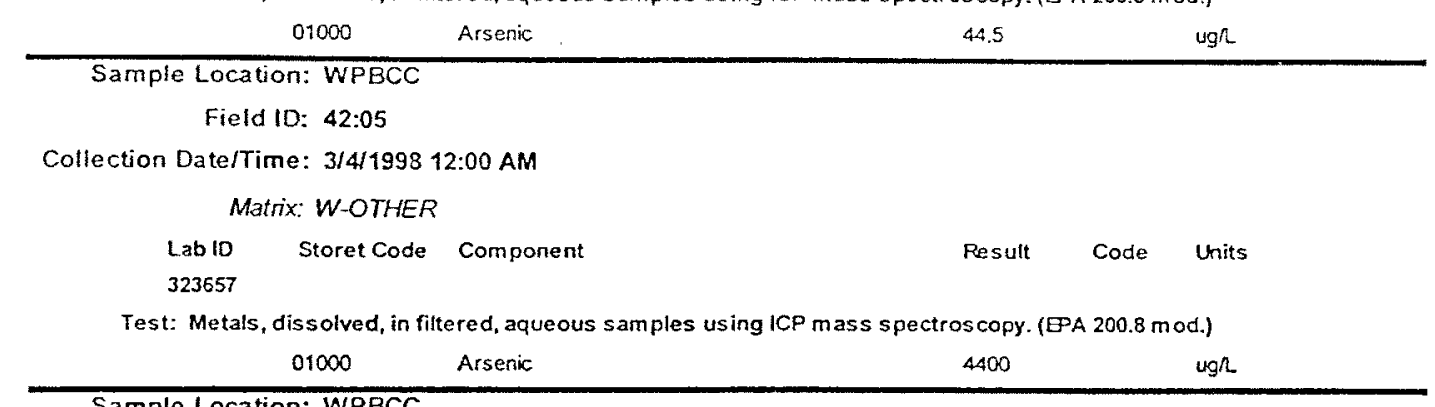

Sample Location: WPBCC

Field ID: $42: 10$

Collection Date/Time: 4/2/1998 12:00 AM

Matrix: W-OTHER

$\begin{array}{llll}\text { Lablo Storet Code Component } & \text { Result Code Units } \\ 323664 & & \end{array}$

Test: Metals, dissolved, in filtered, aqueous samples using ICP mass spectroscopy. (EPA 200.8 mod.)

\begin{tabular}{|c|c|c|c|c|c|}
\hline & 01000 & Arsenic & 9.8 & & $\operatorname{ug} \Omega$ \\
\hline \multicolumn{6}{|c|}{ Sample Location: WPBCC } \\
\hline \multicolumn{6}{|c|}{ Field ID: $42: 100$} \\
\hline \multicolumn{6}{|c|}{ Collection Date/Time: $5 / 1 / 1998$ 12:00 AM } \\
\hline \multicolumn{6}{|c|}{ Matrix: W-OTHER } \\
\hline $\operatorname{Lab} 10$ & Storet Code & Component & Result & Code & Units \\
\hline \multicolumn{6}{|l|}{323480} \\
\hline \multicolumn{6}{|c|}{ Test: Metals, dissolved, in filtered, aqueous samples using ICP mass spectroscopy. (EPA 200.8 mod.) } \\
\hline & 01000 & Arsenic & 88.3 & & ugh \\
\hline
\end{tabular}

\footnotetext{
Sample Location: WPBCC

Field ID: $42: 200$
}

Collection Date/Time: 5/1/1998 12:00 AM

Matrix: W-OTHER

Lablo Storet Code Component $\quad$ Result Code Units
323820

Test: Metals, dissolved, in fittered, aque ous samples using ICP mass s pectros copy. (EPA 200.8 mod.)

$01000 \quad$ Arsenic $\quad 92.3 \quad \mathrm{ug} / \mathrm{L}$ 
Sample Location: WPBCC

Field 1D: $42: 50$

Collection Date/Time: 4/3/1998 12:00 AM

Matrix: W-OTHER
Lablo Storet Code Component . Result Code Units.
323507

Test: Metals, dissolved, in filtered, aqueous samples using ICP mass spectroscopy. (EPA 200.8 mod.)
01000
Arsenic
46.6
ugh

Sample Location: WPBCC

Field ID: 5 BLANK:10

Collection Date/Time: 4/3/1998 12:00 AM

Matrix: W.OTHER

Lablo StoretCode Component Result Code Units

323473

Test: Metals, dissolved, in filtered, aqueous samples using ICP mass spectros copy. (EPA 200,8 mod.)
01000
Arsenic
2
4
ugh

Sample Location: WPBCC

Field ID: 50:50

Collection Date/Time: 4/3/1998 12:00 AM

Matrix: WOTHER

Lab1D Storet Code Component Result Code Units

323501

Test: Metals, dissolved, in fittered, aqueous samples using ICP mass spectros copy. (EPA 200.8 mod.) $01000 \quad$ Arsenic

46.2

$\operatorname{cog} \Omega$

Sample Location: WPBCC

Field ID: 51:01

Collection Date/Time: 5/3/1998 12:00 AM

Matrix: W-OTHER

Lab lo Storet Code Component Result Code Units

323673

Test: Metals, dissolved, in fittered, aqueous samples using ICP mass spectros copy* (EPA 200.8 mod.) $01000 \quad$ Arsenic $\quad 814 \quad$ ug/

Sample Location: WPBCC

Field ID: 51:05

Collection Date/Time: 5/4/1998 12:00 AM

Matrix: W-OTHER

LabID StoretCode Component Result Code Units

Test: Metais, dissolved, in filtered, aqueous samples using ICP mass spectros Copy. (EPA 200.8 mod.)

01000 Arsenic $\quad 4390 \quad$ ug $\pi$ 
Sample Location: WPBCC

Field 1D: 7E:96K

Collection Date/Time: 1/11/1998 2:00 PM

$$
\text { Matrix: W-GROUND }
$$

Lab10 Storetcode Component Result Code Units.

Test: Metals, dissolved, in filtered, aqueous samples using ICP mas spectroscopy. (EPA 200.8 mod.)

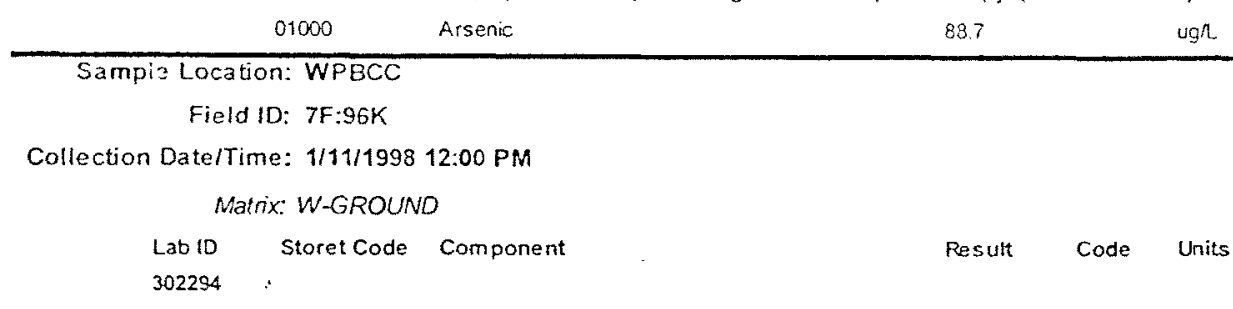

Test: Metals, dissolved, in filtered, aqueous samples using ICP mass spectros COPy. (EPA 200.8 mod.)

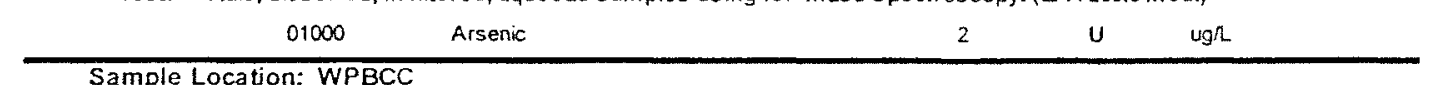

Sample Location: WPBCC

Field ID: 7G:96K

Collection Date/Time: $1 / 11 / 1998$ 12:00 PM

Matrix: W-GROUND

Labto StoretCode Component fosult Code Units
302295

Test: Metals, dis solved, in fittered, aqueous samples using ICP mass spectros copy. (EPA 200.8 mod.)

\begin{tabular}{|c|c|c|c|c|}
\hline & 01000 & Arsenic & 93.1 & $\operatorname{ug} f$ \\
\hline \multicolumn{5}{|c|}{ Sample Location: WPBCC } \\
\hline \multicolumn{5}{|c|}{ Field ID: $7 \mathrm{H}: 96 \mathrm{~K}$} \\
\hline \multicolumn{5}{|c|}{ Collection Date/Time: $1 / 11 / 1998$ 12:00 PM } \\
\hline \multicolumn{5}{|c|}{ Matrix: W-GROUNO } \\
\hline Lab 10 & Storet Code & Component & Pesult & Code \\
\hline \multicolumn{5}{|l|}{302296} \\
\hline \multicolumn{5}{|c|}{ Test: Metals, dissolved, in fittered, aqueous samples using ICP mass s pectros copy. (EPA 200,8 mod.) } \\
\hline & 01000 & Arseric & 92.4 & $\operatorname{ug} \Lambda$ \\
\hline
\end{tabular}

Sample Location: WPBCC

Field 1D: $71: 96 \mathrm{~K}$

Collection Date/Time: 1/11/1998 12:00 PM

Matrix: W-GROUND

$\begin{array}{lll}\text { Lab } 10 & \text { Storet Code Component Gesult Code Units } \\ 302297 & & \end{array}$

Test: Metals, dissolved, in filtered, aqueous samples using ICP mass spectros copy. (EPA 200.8 mod.)
01000
Arsenic
2
U ugh 
Sample Location: WPBCC

Field 10: 51:10

Collection Date/Time: 4/2/1998 12:00 AM

Matrix: W-OTHER

LabID Storetcode Component Result Code Units .
323665

Test: Metals, dissolved, in filtered, aqueous samples using ICP mass spectros Copy. ( $\boxminus P A 200.8$ mod.)
01000
Arsenic
7.0
ugh

Sample Location: WPBCC

Field 10: 51:100

Collection Date/Time: 5/1/1998 12:00 AM

Matrix: W-OTHER

$\begin{array}{lll}\text { Lab } 10 & \text { Storet Code Component Result Code Units } \\ 323481 & \end{array}$

Test: Metals, dissolved, in filtered, aqueous samples using ICP mass spectros copy. (EPA 200.8 mod.)

01000 Arsenic ugh

Sample Location: WPBCC

Field 1D: 51:16

Collection Date/Time: 3/2/1998 12:00 AM

Matrix: W-OTHER

LabID Storet Code Component Result Code Units 323460

Test: Metals, dissolved, in filtered, aque ous samples using ICP mass spectros copy. (EPA 200.8 mod.)

01000 Arsenic 18.9 ugh

Sample Location: WPBCC

Field ID: $51: 168$

Collection Date/Time: 3/3/1998 12:00 AM

Matrix: W-OTHER

Lab ID Storet Code Component Pesult Code Units 323464

Test: Metals, dissolved, in filtered, aqueous samples using ICP mass spectros copy. (EPA 200.8 mod.)

$01000 \quad$ Arsenic $18.2 \quad$ ugh

Sample Location: WPBCC

Field ID: $51: 200$

Collection Date/Time: 5/1/1998 12:00 AM

Matrix: W-OTHER

Lablo StoretCode Component Result Code Units

323804

Test: Metals, dissolved, in filtered, aqueous samples using $1 C P$ mass spectros copy. (EPA $200.8 \mathrm{mod}$.)
01000
Arsenic
132
A ugh 


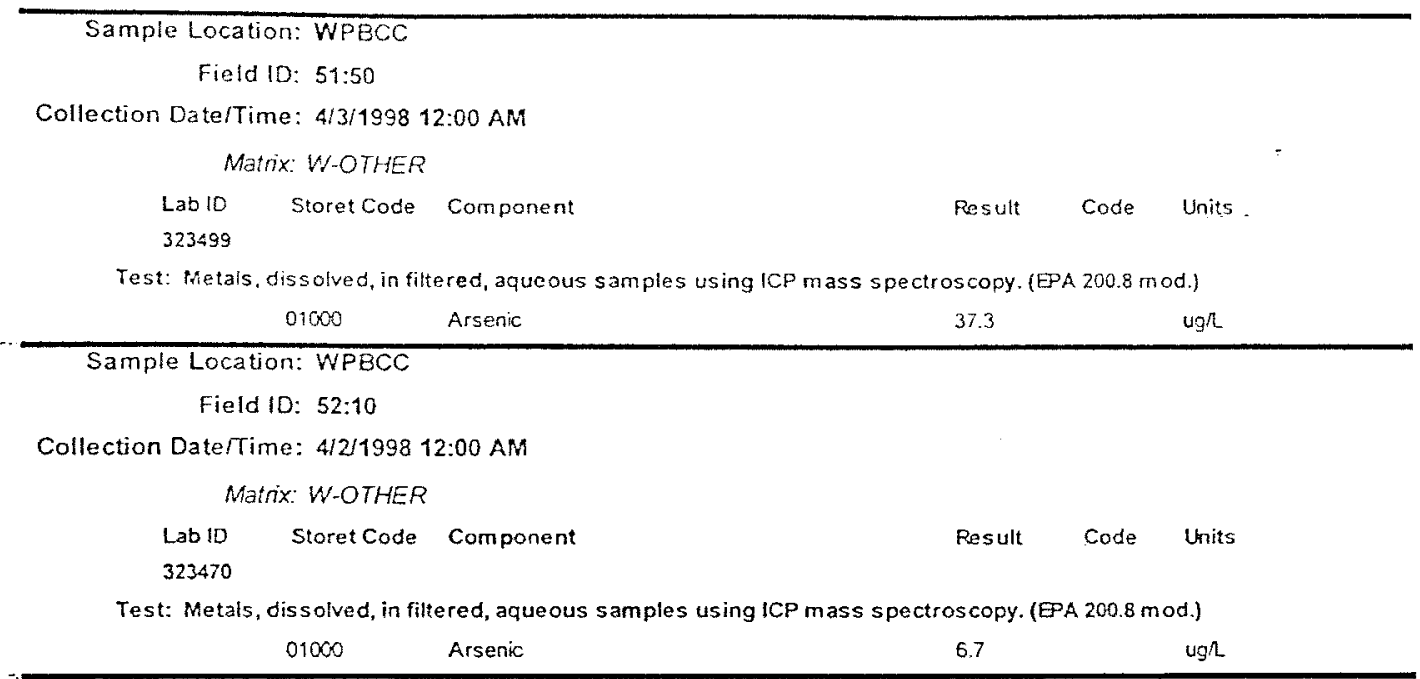

Sample Location: WPBCC

Field ID: 52:16

Collection DatelTime: 3/2/1998 12:00 AM

Matrix: W-OTHER

Lab1D Storet Code Component $\quad$ Result Code Units
323463

Test: Metals, dissolved, in filtered, aqueous samples using ICP mass s pectros copy. (EPA 200.8 mod.)
01000
Arsenic
12.0
$\operatorname{ug} h$

Sampie Location: WPBCC

Field ID: $52: 168$

Collection Date/Time: $3 / 3 / 1998$ 12:00 AM

Matrix: W-OTHER
Lablo Storet Code Component $\quad$ Result Code Units
323653

Test: Metals, dissolved, in filtered, aqueous samples using ICP mass spectros copy. (EPA 200.8 mod.)
01000
Arsenic
21.3
ugh

Sample Location: WPBCC

Field 1D: $52: 200$

Collection Date/Time: 5/1/1998 12:00 AM

Matrix: WOTHER
Lab I0 StoretCode Component Result Code Units
323670

Test: Metals, dissolved, in filtered, aqueous samples using ICP mass spectroscopy. (EPA 200.8 mod,)
01000
Arsenic
748
ugn 
Sample Location: WPBCC

Field 10: $52: 96$

Collection Date/Time: 3/4/1998 12:00 AM

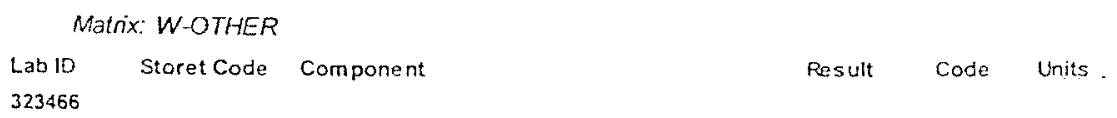

Test: Metals, dissolved, in filtered, aqueous samples using ICP mass spectros copy. (EPA 200.8 mod.)
01000
Arsenis
19.4
$\tan$

Sample Location: WPBCC

Field 10: 57:05

Collection Date/Time: 5/4/1998 12:00 AM

Matrix: W-OTHER

Lab to Storet Code Component - Result Code Units 323807

Test: Metals, dissolved, in filtered, aqueous samples using ICP mass spectros copy. (EPA 200.8 mod.)
01000
Arsenic
4610
$\operatorname{Lg} h$

Sample Location: WPBCC

Field ID: AS-100B

Collection DatefTime: 1/8/1998 12:00 AM

Matrix: W-OTHER

Lab 10 StoretCode Component Result Code Units 323453

Test: Metals, dissolved, in filtered, aqueous samples using 1CP mass spectros copy. (EPA 200.8 mod.)
01000
Arseric
433
ugh

\section{Sample Location: WPBCC}

Field ID: AS-150B

Collection Date/Time: 1/8/1998 12:00 AM

Matrix: W-OTHER

LabID Storet Code Component Result Code Units

Test: Metals, dissolved, in filtered, aque ous samples using ICP mas s pectroscopy. (EPA $200.8 \mathrm{~m}$ od.)
01000
Arsenic
657
ugh

Sample Location: WPBCC

Field 1D: AS-200B

Collection Date/Time: 1/8/4998 12:00 AM

Matrix: W-OTHER

Lablo StoretCode Component Result Code Units
323649

Test: Metals, dissolved, in fittered, aqueous samples using ICP mass spectros copy. (EPA $200.8 \mathrm{mod}$.)
01000
Arsenic
860
$u g / t$ 
Sample Location: WPBCC

Field ID: $A S-25 B$

Collection Date/Time: 1/20/1998 12:00 AM

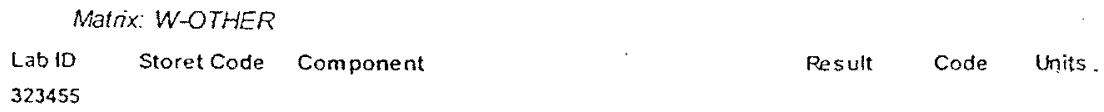

Sample Location: WPBCC

Field ID: AS-50B

Collection Date/Time: 1/8/1998 12:00 AM

Matix: W-OTHER
Lab 10 Storet Code Component $\quad$ Result Code Units
323647

Test: Metals, dissolved, in filtered, aqueous samples using ICP mass spectros copy. (EPA $200.8 \mathrm{mod}$ )
01000
Arsenic
221
ug/

\section{Sample Location: WPBCC}

Field ID: AS-OB

Collection Date/Time: 1/20/1998 12:00 AM

Matrix: W-OTHER

LablD StoretCode Component Result Code Units

323454

Test: Metals, dissolved, in filtered, aqueous samples using ICP mass spectros copy. (EPA $200.8 \mathrm{~m}$ od.)
01000
Arsenic
ugh

Sample Location: WPBCC

Field ID: CONTROL 182

Collection Date/Time: 3/2/1998 12:00 AM

Matrix: W-OTHER

LablD Storet Code Component Result Code Units
323461

Test: Metals, dissolved, in filtered, aqueous samples using ICP mass spectros copy. (GA $200.8 \mathrm{~m}$ od.)
01000
Arsenic
10.9
ugh

Sample Location: WPBCC

FIEId 10: CONTROL 5

Collection Date/Time: 3/2/1998 12:00 AM

Matrix: W-OTHER

$\begin{array}{llll}\text { Lab } 10 & \text { Storet Code Component Result Code Units } \\ 323462 & \end{array}$

Test: Metals, dissolved, in filtered, aqueous samples using ICP mas s sectros copy. (EPA. $200.8 \mathrm{mod}$ )
01000
Arsenic
19.5
ugh 
Sample Location: WPBCC

Field 10: CONTROL 5

Colfection DatefTime: 3/4/4998 12:00 AM

Matrix: W-OTHER
Lablo $\quad$ StoretCode Component
323802

Test: Metals, dissolved, in filtered, aqueous samples using ICP mass spectroscopy. (EPA 200.8 mod.)
01000
Arsenic
22.8
ugn

Sample Location: WPBCC

Field ID: CONTROL 111

Collection Date/Time: 2/3/4998 12:00 AM

MaIrix: W-OTHER

Lab tD Storet Code Component Fesult Code Units
323456

Test: Metals, dissolved, in fittered, aqueous samples using ICP mass spectros COPy. (EPA 200.8 mod.)
01000
Arsenic
2
U
$\operatorname{ug} h$

Sample Location: WPBCC

Field ID: CS-D

Collection Date/Time: 3/31/1998 12:00 AM

Matrix: W-OTHER

$\begin{array}{lll}\text { Lab ID } & \text { Storet Code Component } & \text { Result Code Units } \\ 323658 & \end{array}$

Test: Metals, dissolved, in filtered, aqueous samples using ICP mass spectros copy. (EPA 200.8 mod.)
01000
Arsenic
2
$\mathrm{U}$
ugh

Sample Location: WPBCC

Field 1D: CS-100

Collection Daterime: 3/31/1998 12:00 AM

Matrix: W-OTHER

Lab ID StoretCode Component Result Code Units

323659

Test: Metals, dissolved, in fittered, aqueous samples using ICP mass spectros copy. (EPA 200.8 mod.)

$01000 \quad$ Arsenic $\quad 94.8 \quad$ ugh

Sample Location: WPBCC

Field ID: CS-25

Collection DatelTime: 3/3/1998 12:00 AM

Matrix: W-OTHER

Lab 10 Storet Code Component Result Code Units 323656

Test: Metals, dissolved, in filtered, aqueous samples using ICP mass spectros copy. (EPA 200.8 mod.)
01000
Arsenic
23.6
wor 
Sample Location: WPBCC

Field 10: CS-5

Collection Date/Time: 3/31/1998 12:00 AM

$$
\text { Matrix: W-OTHER }
$$

Lab io Storet Code Component Result Code Units.

Test: Metals, dissolved, in filtered, aqueous samples using ICP mass spectros copy. (EPA 200.8 mod.)

\begin{tabular}{|c|c|c|c|c|c|}
\hline & 01000 & Arsenic & 4.9 & 1 & ugh \\
\hline \multicolumn{6}{|c|}{ Sample Location: WPBCC } \\
\hline \multicolumn{6}{|c|}{ Field ID: CS -50} \\
\hline \multicolumn{6}{|c|}{ Collection Date/Time: 3/31/1998 12:00 AM } \\
\hline \multicolumn{6}{|c|}{ Matrix: W-OTHER } \\
\hline Lab ID & Storet Code & Component & Result & Code & Units \\
\hline \multicolumn{6}{|l|}{323660} \\
\hline \multicolumn{6}{|c|}{ Test: Metals, dissolved, in filtered, aqueous samples using ICP mass spectroscopy. (EPA 200.8 mod.) } \\
\hline & 01000 & Arsenic & 46.6 & & $u g h$ \\
\hline
\end{tabular}

Sample Location: WPBCC

Field ID: CS:200

Collection Date/Time: 3/3/1998 12:00 AM

Matrix: W-OTHER

Lab10 Storet Code Component Result Code Units

Test: Metals, dissolved, in filtered, aqueous samples using ICP mass spectros copy. (EPA 200.8 mod.)

\begin{tabular}{|c|c|c|c|c|c|}
\hline & 01000 & Arsenic & 179 & & ugh \\
\hline \multicolumn{6}{|c|}{ Sample Location: WPBCC } \\
\hline \multicolumn{6}{|c|}{ Field ID: SOIL 1 BLANK: 100} \\
\hline \multicolumn{6}{|c|}{ Collection Date/Time: 5/1/1998 12:00 AM } \\
\hline \multicolumn{6}{|c|}{ Matrix: W-OTHER } \\
\hline Lab ID & Storet Code & Component & Result & Code & Units \\
\hline \multicolumn{6}{|l|}{323819} \\
\hline \multicolumn{6}{|c|}{ Test: Metals, dissolved, in filtered, aque ous samples using ICP mass spectroscopy. (EPA 200.8 mod.) } \\
\hline & 01000 & Arsenic & 2 & u & $\operatorname{tog} \Omega$ \\
\hline
\end{tabular}

Sample Location: WPBCC

Field ID: SOIL 1 BLANK:168

Collection DatelTime: 5/4/1998 12:00 AM

Matix: W-OTHER
Lablo StoretCode Component Result Code Units
323678

Test: Metals, dissolved, in filtered, aqueous samples using ICP mass spectros copy. (EPA 200.8 mod)
01000
Arsenic
2
y ugh 
Sample Location: WPBCC

Field ID: SOLL 2 BLANK:05

Collection Date/rime: 5/4/1998 12:00 AM

Matrix: W-OTHER

Labio Storet Code Component Result Code Units. 323576

Test: Metals, dissolved, in fittered, aque ous samples using ICP mass s pectros copy. (EPA 200.8 mod.)

$\begin{array}{ccccc}01000 & \text { Arsenic } & 2 & U & \text { ugh }\end{array}$

Sample Location: WPBCC

Field ID: SOIL 2 BLANK:200

Collection Date/Time: 5/1/1998 12:00 AM

Matrix: W-OTHER

Lab ID Storet Code Component Result Code Units 323482

Test: Metals, dissolved, in filtered, aque ous samples using ICP mass spectros copy. (EPA 200.8 mod.)

\begin{tabular}{ccccc}
01000 & Arsenic & 2 & $U$ & ugh \\
\hline Sample Location: WPBCC &
\end{tabular}

Field ID: SOIL 3 BLANK:05

Collection Date/Time: 5/4/1998 12:00 AM

Matrix: W-OTHER

Lab ID Storet Code Component Result Code Units
323495

Test: Metals, dissolved, in filtered, aqueous samples using ICP mass spectros copy. (EPA 200.8 mod.)

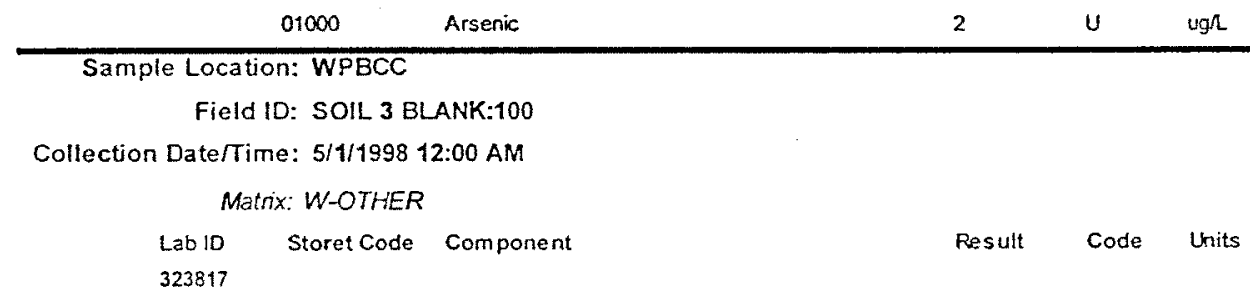

Test: Metals, dissolved, in filtered, aqueous samples using ICP mass spectroscopy. (EPA 200.8 mod.)

\begin{tabular}{ccccc}
01000 & Arsenic & 2 & ugh \\
\hline Sample & U
\end{tabular}

Sample Location: WPBCC

Field ID: SOIL 3 BLANK:200

Collection Date/Time: 5/1/1998 12:00 AM

Matrix: W-OTHER
LablD Storet Code Component $\quad$ Result Code Units
323497

Test: Metals, dissolved, in fittered, aqueous samples using ICP mass spectros copy. (EPA 200.8 mod.)
01000
Arsenic
2
U ugh 
Sample Location: WPBCC

Field ID: SOIL 4 BLANK:200

:ollection Date/Time: 5/1/1998 12:00 AM

Matrix: W-OTHER
Lab ID Storet Code Component Result Code Units -
323825

Test: Metals, dissolved, in filtered, aqueous samples using ICP mass spectros Copy. (EPA 200.8 mod.)
01000
Arsenic
2
U ugh

Sample Location: WPBCC

Field ID: SOIL 5 BLANK 96

illection Date/Time: 3/4/1998 12:00 AM

Matrix: W-OTHER

Lab ID Storet Code Component Result Code Units

323469

Test: Metals, dissolved, in filtered, aqueous samples using ICP mass spectros copy. (EA 200.8 mod.)

$$
01000 \quad \text { Arsenic }
$$

2

$\mathrm{u}$

$\lg n$

Sample Location: WPBCC

Field ID: SOIL 5 BLANK:05

ollection Date/Time: 5/4/1998 12:00 AM

Matrix: W-OTHER

Lab ID Storet Code Component Result code Units
323675

Test: Metals, dissolved, in fittered, aqueous samples using ICP mass spectros copy. (EPA 200.8 mod.)
01000
Arsenic
2
$U$
ugh

Sample Location: WPBCC

Field ID: SOIL 5 BLANK:100

Jlection Date/Time: 5/1/1998 12:00 AM

Matrix: W-OTHER

LablD Storet Code Component Result Code Units
323815

Test: Metals, dissolved, in filtered, aqueous samples using ICP mass spectros copy. (EPA 200.8 mod.)
01000
Arsenic
2
U
$4 g h$

Sample Location: WPBCC

Field ID: SOIL 5 BLANK:200

llection Date/Time: 5/1/1998 12:00 AM

Matrix: W-OTHER

$\begin{array}{lll}\text { LabiD Storet Code Component } & \text { Result Code Units } \\ 323829 & \end{array}$

Test: Metals, dissolved, in fittered, aqueous samples using 1 CP mas spectroscopy. (EPA $200.8 \mathrm{mod}$ )
01000
Arsenic
2
U ugh 
SE-OIST-1990-05-12-01

Serial Number, 000072

Section 1 of 2

Chemical Anzly sis Report Page 24 of 24

\footnotetext{
Sample Location: WPBCC

Field ID: WATER BLANK 96
}

:ollection Date/Time: 3/41998 12:00 AM

Matrix: W-OTHER

Lab 10: Storet Code Component Result Code Units.
323465

Test: Metais, dis solved, in fittered, aqueous samples using (CP mas s sectroscopy. (EPA 200.8 mod.)

$01000 \quad$ Arsenic $\quad 2 \quad$ u 
SE-OIST-19SE-05-12-01 Serial Humber: 0000721 Section 2 of 2

Ouality Control Report Page 1 of: Test Analyte
W-Coms-F Arsenic W-IOMS-F Arsenic W-KAMS-F Arsenic Test Analyte W-KFNS-F Arseric W.CAMS-F Arsenic W-KAMS-F Arsenic Test Analyte W-KAMS-F Arsenic W-CPMSF Arsenic W-OPNS-F Arsenic W-RAMS-F Arsenic Test Analyte W-OAMSF Arsenic WTANS-F Arsenic W-KAUS-F Arsenic
Quality Control Report Job ID: TLH-1998-05-12-26 LFB \%Recovery MS \%Recovery 88.2 $93.8 \quad 94.4$ $88.5 \quad 91.2$

96.598 .0 Job ID: TLH-1998-05-12-30 LFB \%Recovery MS \%Re covery $95.5 \quad 95.8$

95.3

91.192 .0

107

$93.9 \quad 96.7$ Job ID: TLH-1998-05-12-40

LFB \%Recovery MS \%Recovery 85.8 $91.8 \quad 92.7$ $95.5 \quad 95.8$ 91.192 .0 $93.9 \quad 96.1$ Job ID: TLH-1998-05-12-41

LFB \%Recovery

MS \%Recovery

107 93.996 .1

94.397 .7

$102 \quad 98.2$
Precision \%FPD Precision \%RSD

$0.6 ? 2$

3,07

7.50

Precision \%RPD Precision \%RSD

0.247

1.05

2.20

Precision \%RPD Precision \%RSD

0.981

0.247

1.06

2.20

Precision \%FPD Precision \%RSD 2.20

3.51

4.05 


\section{Chemical Analysis Report}

Florida Department of Environmental Protection

Central Laboratory

2600 Blair Stone Road

Tallahassee, FL $32399-2400$

CompQAP $870688 \mathrm{G}$

Event Description: Golf Course Arsenic Südy

Request 1D: RQ-1998-10-12-29

Customer. SE-DIST

Project ID: OTHER-WSM

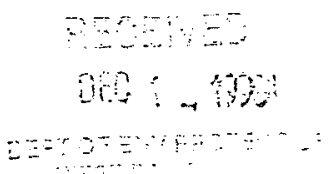

Job: TLH $-1998-10-14-22$

Group: Metals

For additional infomation please contact

Timothy W. Fitzpatrick

Yuh-Hsu Pan, Ph.D

Julio Arrecis, Ph.D.

Liang-Tsair Lin, Ph.D.

Suncom 277-2571 Phone (850) 487-2571

Certified By: 7fow

Date: $1 /-2 \nVdash-98$

Report Printed Date: Nov 23, 1998

Abbreviations and data remark codes

A - Value reported is the mean of two or more determinations

B - Results based on colony counts outside the acceptable range.

I- Value reported is less than the minimumquantitation frnit, and greater than or equal to the minimum detection linit.

J. Estimated value

$K$ - Actual value is known to be less than value given

$L$ - Actual value is known to be greater than value given

$N$ - Presumptive evidence of presence of materiat.

O- Sampled, but anatys is lost or not performed.

Q- Sample held beyond nornal holding time.

$T$ - Value reported is less than the criterion of delection.

U. Material was analyzed for but not detected, The value reported is the minirum detection limt.

$V$-Analyte $w$ as detected in both sample and method blank.

$Y$ - The laboratory anatys is $w$ as from an unpreserved or irproperly preserved sample. The data may not be accurate

$Z$ - Colonies were too numerous to count (TNTC) 
Sample Location: WPBCC

Field 10: SOIL 1\&2Z

Collection Date/Time: 10/13/1998 1:00 PM

$$
\begin{aligned}
& \text { Matrix: S-SO/L } \\
& \text { Lab ID StoretCode Component Result Code Units. } \\
& 351569
\end{aligned}
$$

rest: Metals, total recoverable, in solid sam ples using trace-lCP emission spectros copy. (EPA $6010 \mathrm{mod}$ )

\begin{tabular}{llllll}
01003 & Arsenic & 0.5 & 1 & $\mathrm{mg} / \mathrm{kg}$ \\
01170 & ton_271 & 128 & A & $\mathrm{mg} / \mathrm{kg}$ \\
\hline
\end{tabular}

Sample Location: WPBCC

Field ID: SOIL 32

Collection Date/Time: 10/13/1998 1:00 PM

Matrix: S-SOLL

Lab to Storet Code Component Result Code Units
351568

Test: Metals, total recoverable, in solid s am ples using trace-iCP emission spectroscopy. (EPA 6010 mod.)

$\begin{array}{lllll}01003 & \text { Arsenic } & 0.4 & \mathrm{U} & \mathrm{mg} / \mathrm{kg} \\ 01170 & \text { ton_271 } & 70.6 & & \mathrm{mg} / \mathrm{kg}\end{array}$

Sample Location: WPBCC

Field 1D: SOIL 42

Collection Date/Time: 10/13/1998 1:00 PM

Matrix: S-SOIL

Lab ID StoretCode Component Result Code Units 351567

Test: Metals, total recoverable, in solid sam ples using trace-ICP emission spectros copy. (EPA 6010 mod.)

$\begin{array}{lllll}01003 & \text { Arsenic } & 0.7 & 1 & \mathrm{mg} / \mathrm{kg} \\ 01170 & \text { ron_27i } & 39.2 & & \mathrm{rg} / \mathrm{kg}\end{array}$

Sample Location: WPBCC

Field ID: SOIL 52

Collection Date/Time: 10/13/1998 1:00 PM

Matrix: S-SOIL

Lab10 StoretCode Component Result Code Units
351560

Test: Metals, total recoverable, in solid samples using trace -ICP emission spectros copy. (EPA 6010 mod.)

$\begin{array}{lllll}01003 & \text { Arsenic } & 0.7 & 1 & \mathrm{mg} / \mathrm{kg} \\ 01170 & \text { tron_271 } & 1400 & \mathrm{mg} / \mathrm{kg}\end{array}$


SE-01ST-1998-10-14-02

Serial Number, 0001524

Section 2 of 2

Quality Control Report

Page 1 of 1

Quality Control Repoit

Job 1D: TLH-1998-10-14-22

Test Analyte

S-KCP-TR

Arsenic

kon_271
LFB \%Recovery

96.4

101
MS \%Re covery

$90.6 \quad 922$

99.0
Precision $\%$ RPD Precision \%RSD

173

4.57 
Login Authorisation Report for SE-DIST-1998-10-14-02 on 16-OCT-1998 15:22 Golf Course Arsenic Study

Project: OTHER-WSM

Request ID: RO-1998-10-12-29

Job ID: TLH-1998-10-14-22

\begin{tabular}{lll} 
Sample & St & Field 10 \\
\hline 351566 & $V$ & SOIL 52 \\
S-ICP-TR & & \\
351567 & $V$ & SOIL 42 \\
S-ICP-TR & & \\
351568 & $V$ & SOIL 32 \\
S-ICP-TR & & \\
351569 & $V$ & SOIL 182Z \\
S-ICP-TR & &
\end{tabular}

Job Status: V

$\frac{\text { Sampling Location }}{\text { WPBCC }}$
WPBCC
WPBCC
WPBCC


RQ ID: $1994-10-12-25$

Cooler Check

\begin{tabular}{|c|c|c|c|c|c|c|c|}
\hline Cooler ID & $\begin{array}{l}\text { Ice Present? } \\
\text { Yes LNo }\end{array}$ & $\begin{array}{l}\text { IfNo, } \\
\text { Temperature }\end{array}$ & $\begin{array}{l}\text { Evid } \\
\text { Prese } \\
\text { Yes }\end{array}$ & e Tape & $\begin{array}{l}\text { Evic } \\
\text { Tap } \\
\text { Yes }\end{array}$ & ct? & Tracking Number \\
\hline 308 & $>1$ & & & $=$ & & & 802421052017 \\
\hline & & & & & & & \\
\hline & & & & & & & \\
\hline & & & & & & & \\
\hline & & & & & & & \\
\hline & & & & & & & \\
\hline & & & & & & & \\
\hline & & & & & & & \\
\hline & & & & & & & \\
\hline
\end{tabular}

Note: If the the temperature of a cooler is above $6^{\circ} \mathrm{C}$ or an evidence seal is damaged then identify the bottles, in the affected cooler(s), on back of form.

Shipping Method: FEDEX

Acid Preserved Samples pH Checkcd: $\mathrm{pH}<=2$ ? Yes No NA If No, fill out back of form.

Base Preserved Samples pH Checked: All OK? Yes No No $N A \stackrel{2}{2}$ $(W-C N$, OV-CN $-\mathrm{pH}>1=12),(W-S U L F D E-F, \bar{W}-S U L F I D E-p H>1=9)$ If No, fill out back of form.

Evidence Tape on Bottles Present: Yes No If Yes, is it intact? Yes No

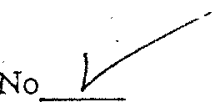

If not intact then fill out back of form.

Condition of Containers:

Loose Caps: Yes No If Yes, fill out back of form.

Broken Containers: Yes No If Yes, fill out back of form.

Chain Of Custody Form Included? Yes No If Yes verify receipt of all containers listed then sign custody form. Document discrepancies (i.e. missing containers) on $\mathrm{COC}$ form.

$\cdots$

Event Do: SE-1SSt-1998-10-14-0D

Coolers Unpacked/Checked by: Of $^{2}$ Date: $10-/ 4-98$

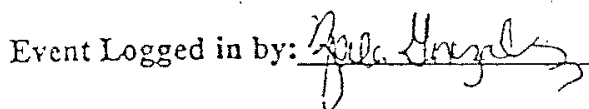

NA - Kot Applicable (i.e. sediment samples) 

Cooler Packing worksheet for Request: RQ-97-DEC-01-15 Golf Course arsenic study Ship cooler on: 24-Nov-1997

Customer: SE-WPB-WSM

Requestor: LESLIE SMTTH

Phone Number: sc 226-6704

Send kit to:Dr. Hector Fuentes, Center for Engi Dept. of Civil/Environmental Engineering/FIU 10555 west Flagler

Miami, FL 33174

Comments: Run W-ICP-23 for Fe. Run S-ICP for As and Fe. Run ICPMS fo

Comms (2): NONE

Requested Analyses:

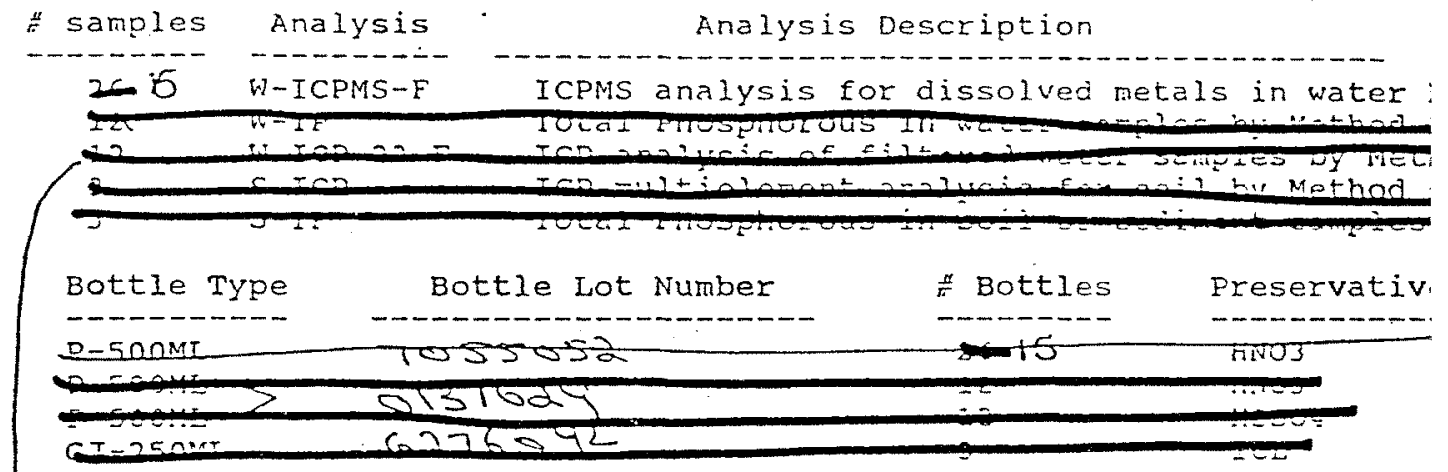

cooler Packed By: Amzed dete: $11-20-97$ DEP cooler ID PLEASE RETURN ALL COOLERS!

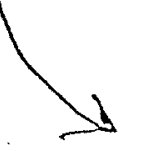

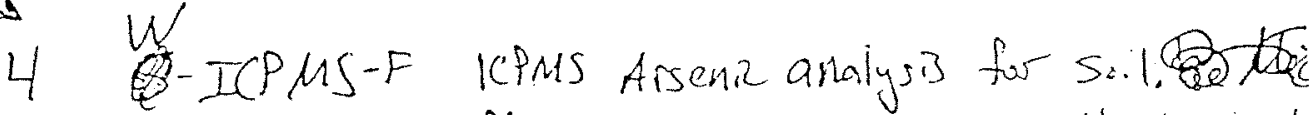
Please use extraction method possib - This is the last of the bestavaible tast samples resalts camebock With a MDL of 8-20 ing $/ \mathrm{kg}$ whith was totally useless for my work! thank Geore orcarto-PI 
FLORIDA DEPARTMENT OF ENVIRONMENTAL PROTECTION CENTRAL LABORATORY SAMPIE SUEMITTAI FORM

PMAS NO.: 1110

Lab ID:

Reyuestor: SE-HPB-HSM

Project ID: Golf Course arsenic study

$R Q-98-T R A-$

semple Location: INPBCC.

Eielo I0/Mame: Stor 52

Storet Station Number:

NPDES Number:

$=$

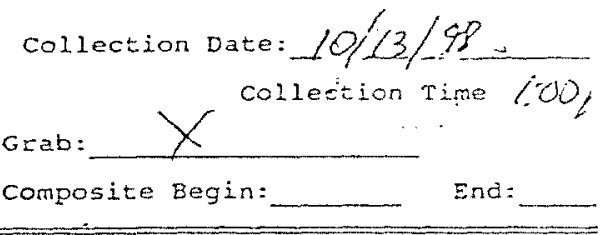

SOIL/SEDIMENT

Xsort

FRESHUATER SEDIMENT

MARINE SEDIMEHT SLUDGE
TISSUE CHEMICAL WASTI

PLANT
FISH
SHELLISISH CHEH WASTE
OTHER

\section{Signature:}

sampled by:

signature:

Field Report Prepared By:

ignature:
Field Parameters:

Depth (Feet):

Chlorine, Toral Residual - $50060(\mathrm{mg} / \mathrm{L}):$

Dissolved Oxygen(Probe) - 00299 (mg/L):

pH - 00400

(stnd. Units)

Salinity - 00680

(PPTh):

Secchi Depth - 00078

Specific Conducrance -00094

Temperature - 00010

(urto/cm)

(C):

$\Longrightarrow$

Analyses

$W-I C P Y S-E$
Bottle Type

$P-500 M L$
Bottles

1.

\section{Preservatives}

${ }^{2} \mathrm{CLC}^{-}$ 
FLORIDA DEPARTMENT OF ENVIRONMENTAL PROTECTION CENTRAL LABORATORY SAMPLE SUBMITTAL FORM

MAS NO.: 1110

Lab ID:

Requester: SE-WPB-WSM

Project ID: Golf: Course arsenic study

BO- $=8-2 \pi N-0 S$

sample Location: WABCC

:lela ro/Name: Soil 42

store Station Number:

YPDES Number: collection Date: $10 / 3 / 98$

Grab:

composite Begin:
End:
Field parameters Measured By:

ignature:

iampled By:

iignature:

Held Report Prepared By:

ignature:
Field parameters:

Depth
Chlorine, Total Residual - $50060(\mathrm{mg} / \mathrm{h})$ :

Dissolved Oxygen(Probe) - 00299 (m gL):

pH - 00400

(sind. Units):

Salinity - 00<80

(PPI):

Sech Depth - 00078

(m):

Specific conductance -00094 (unto/ $\mathrm{cm}$ ):

Temperature - 00010

(C) :

$$
\begin{array}{lccc}
\text { Analyses } & \text { Bottle Type } & \ddot{*} \text { Bottles } & \text { Preservatives } \\
\text { E-ICPMS } & \text { P-500ML } & 1 & \text { H WO } \\
\text { W } & & & \text { ICE }
\end{array}
$$

som : ina error re Leslie Smith -Waste Cleanup (SED)

366 
FLORIDA DEPARTMENT OF ENVIRONMENTAI, PROTECTION CENTRAL LABORATORY SAMPLE SUBMTTTAI FORM

PMAS NO: : 1110

Lab ID:

Requestor: $S E-$ HPB-HSM

Project ID: Gol: Course arsenic study

sample Location: WPBCC

Field ro/Name: $50, \% \div 2$

storet station Number:

vPDES Number:

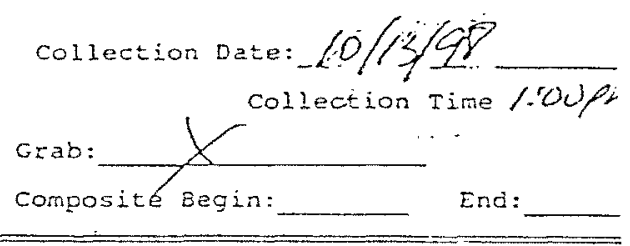
Csolt POIL PLANT FRESHUATER SEDIHEHT —FISH MARINE SEOIKEYI SHELLFISH SLUOGE OTHER BLANKS SOLL/SEDIKENT TISSUE CHEMICAL WASTE

LFACEITKCJM;
SURFACE(SALT)
GROUNO
ORINKING

ield Parameters Measured By:

ignature:

ampled $8 y$ :

ignature:

ield Report Prepared By:

ignature:
Field parameters:

Depth (Feet):
(Fhtorine.

Chtorine, Total Residual - 50050 (mg/t):

o issolved Oxysen(Probe) - 00290 (ing/h):

pH - 00600

Salinity 00480

(send. Units):

(PpTh):

Secchi Depth - 00078 (n):
Specific Conducrance -00096 (unho/cm):

temperature * 00010 (C)

$\begin{array}{lccc}\text { Analyses } & \text { Bottle Type } & \text { P Bottles } \\ \text { W-ICPMS-E } & \text { P-500ML } & 1\end{array}$


FLORIDA DEPARTMENT OF ENVIRONMENTAL PROTECTION CENTRAL LABORATORY SAMPLE SUBMITTAL FORM

PAS NO.: 1110

Lab ID:

Requestor: SE-HPB-HSM

Project ID: Golf Course arsenic study

RQ-98-JANi-OS

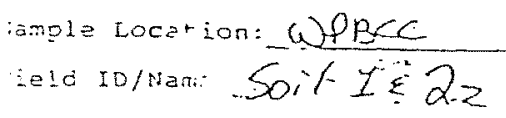

sonnet Station Number;

?OES Number:

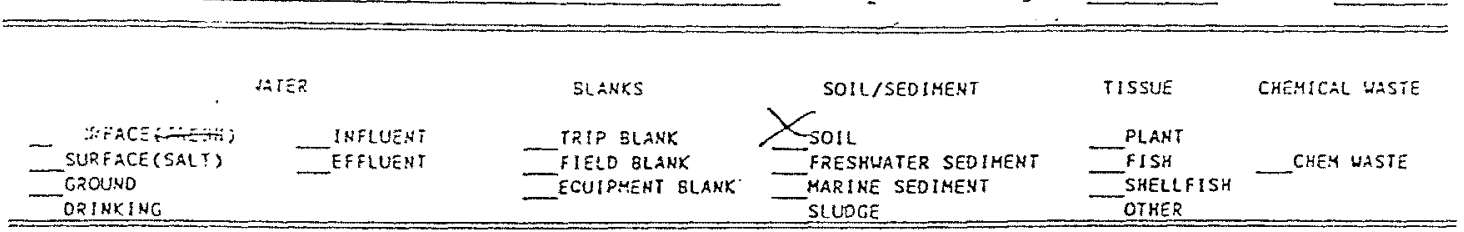

eld Parameters Measured By:

gnature:

holed By:

jnature:

Id Report Prepared By:

nature:
Field parameters:

Depth (feet):

Chlorine, Total Residual - 50060 (mg/L2:

Dissolved Oxygen(Probe) 00290 (mg/h):

Salinity - 00480

(PATh):

Sochi Depth - 00078

$(m):$

Specific Conductance -00094 (umho/cm):

Temperature - 00010

(C):
pH - 00400 (Stine. Units):

Analyses

Bottle Type

$\mathrm{P}-500 \mathrm{ML}$
F Bottles

1
Preservatives

HoS

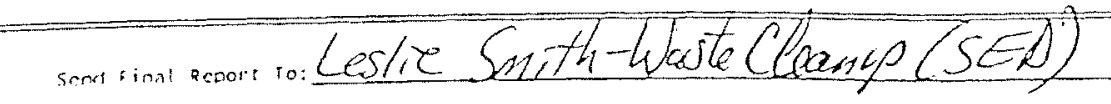

368 
CHANN OF CUSTOOY RECORD

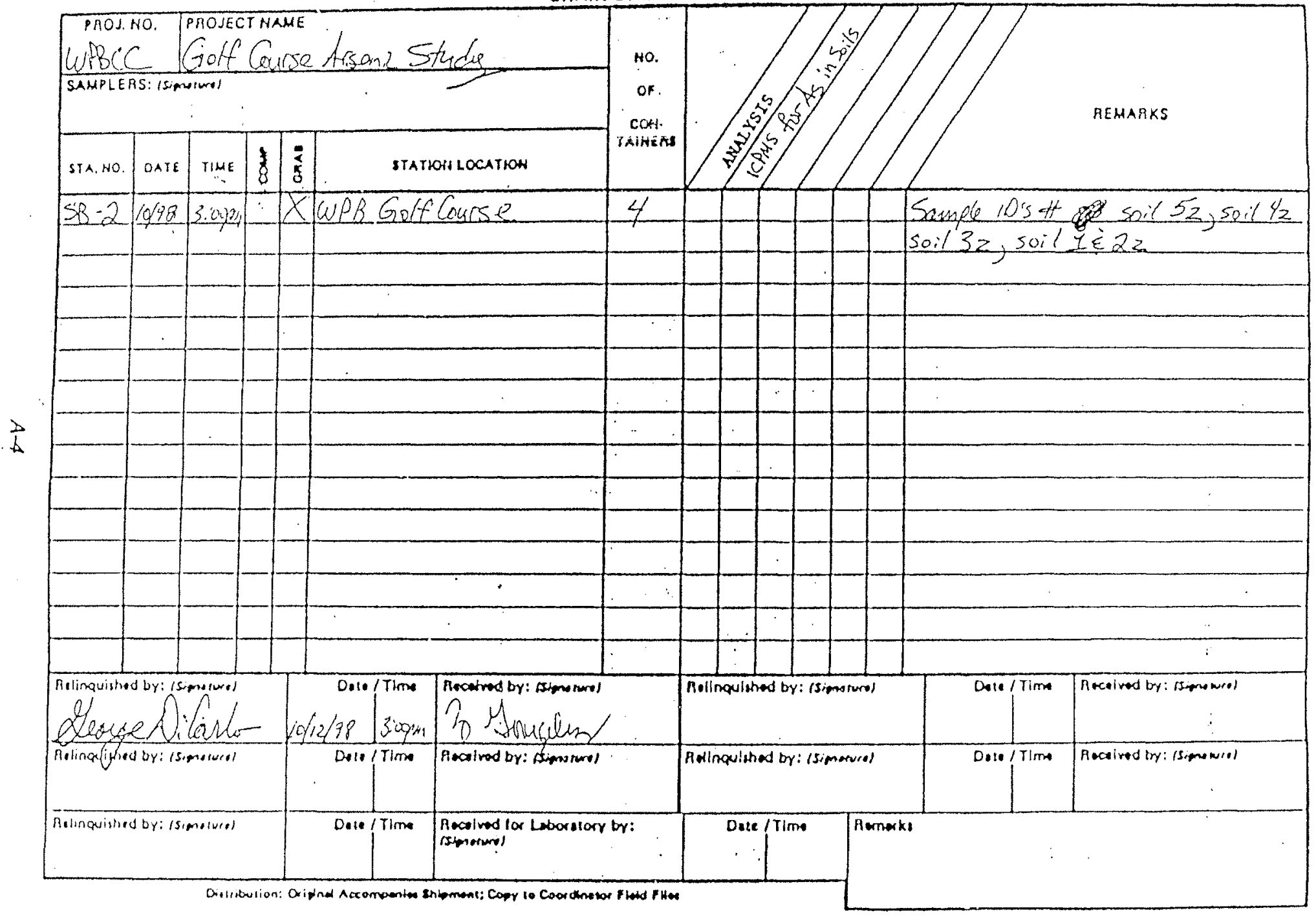

